\title{
REGULAÇÃO SISTÊMICA E PRUDENCIAL NO SETOR BANCÁRIO BRASILEIRO
}

\author{
TESE DE DOUTORADo \\ DEPARTAMENTO DE Direito ECONÔMICO, FinANCEIRo E TRIBUTÁRIO \\ Orientador: Prof. Titular Dr. Hermes MARCElo HuCK
}

FACULDADE DE DIREITO UNIVERSIDADE DE SÃO PAULO SÃO PAULO - 2011 


\section{REGULAÇÃO SISTÊMICA E PRUDENCIAL NO SETOR BANCÁRIO BRASILEIRO}

Tese de Doutorado apresentada ao Departamento de Direito Econômico, Financeiro e Tributário como exigência parcial para a obtenção do título de Doutor pela Universidade de São Paulo, sob a orientação do Professor Titular de Direito Econômico Doutor Hermes Marcelo Huck. 
Banca examinadora: 
"It ain't what you don't know that gets you into trouble. It's what you know for sure that just ain't so." MARK TWAIN, 1835-1910. 
Aos meus pais,

ALFEU $e$ MÁRCIA

Ao meu grande amor,

PATRÍCIA 


\section{AGRADECIMENTOS}

Ao meu orientador, Professor HERMES MARCELO HUCK, pela confiança que me foi depositada e orientação segura de que sempre dispus.

A todos os professores que contribuíram com valiosas sugestões ao trabalho, em especial a FÁbio Nusdeo, Haroldo Malheiros Duclerc VerÇosa, Diogo Coutinho, JAIRO SADDI, OTAVIO YAZBEK, HOWELL JACKSON e ANNA LYGIA COSTA REGO.

A Barbara Rosenberg, Caio Mário da Silva Pereira Neto e Daniel KrePel GOLDBERG, pelo apoio fundamental ao início e conclusão desta empreitada.

Aos colegas de escritório, por permitirem o encontro de tempo e tranquilidade necessários ao desenvolvimento deste trabalho.

Aos inúmeros amigos que colaboraram com comentários, revisões de capítulos e pesquisa bibliográfica. Deixo aqui registrado meu agradecimento especial a ANNA LIZA SU, CAMILA VILlaRd DURAN, DANIEL GUSTAVO FALCÃo PIMENTEl DOS REIS, LEONOR AUGUSTA Giovine Cordovil, MaIRA Yuriko Rocha MiURA, Paulo PENTEAdo De Faria e Silva NETO E RODRIGO PAGANI DE SOUZA.

Aos meus pais, ALFEU e MÁRCIA, por sempre se dedicarem à família, à educação e à felicidade de seus filhos.

Por fim, mas certamente não menos importante, à PATRÍCIA, por fazer todo o esforço valer a pena. Hoje e sempre.

Ante esse rol de amigos e colegas, cabe a ressalva de praxe, destacando que a responsabilidade pelas opiniões, imprecisões e erros no presente trabalho é exclusiva do autor. 


\section{RESUMO}

O objeto do presente trabalho é o diagnóstico do arcabouço regulatório pátrio destinado à prevenção de crises bancárias, quais sejam a regulação sistêmica e a regulação prudencial, e como as transformações ocorridas no sistema financeiro na segunda metade do século XX o afetam. A partir desse estudo, o trabalho pretende demonstrar que, embora a regulação sistêmica e a regulação prudencial no País tenham incorporado avanços notáveis nas últimas décadas, ainda há falhas significativas a serem corrigidas e desafios a serem enfrentados. Se por um lado o atual arcabouço regulatório é marcado por exigências e controles mais rigorosos que os encontrados em outros países, por outro lado, constam também inúmeros instrumentos de resgate a bancos sendo aplicados de forma desordenada, sem regras claras, com pouca ou nenhuma prestação de contas, e até mesmo desvirtuando o propósito original de alguns desses instrumentos. A presença de uma multiplicidade de mecanismos de resgate com tais características é uma preocupante fonte de risco moral no mercado. Outrossim, o exame das transformações ocorridas no Sistema Financeiro Nacional nas últimas décadas evidencia que as dificuldades enfrentadas por autoridades bancárias em outros países, como o fenômeno do "grande demais para quebrar" e o monitoramento do risco sistêmico em um contexto de conglomeração financeira, já são uma realidade no País, representando desafios para a regulação sistêmica e a regulação prudencial, e provocando a reflexão sobre as consequências desses movimentos no setor bancário nacional para o arcabouço regulatório vigente. Em conclusão, o trabalho pretende demonstrar que, apesar de seus inegáveis méritos, a exaltação ao arcabouço regulatório pátrio em face de seu desempenho considerado positivo na crise financeira recente deve ser vista com temperamentos, e que a atuação das autoridades bancárias nos próximos anos deve ser mais centrada na correção das falhas identificadas e reflexão sobre os desafios apresentados.

Palavras-Chave: risco sistêmico, regulação sistêmica, regulação prudencial, setor bancário, concentração e conglomeração financeira. 


\begin{abstract}
The study aims at evaluating the national regulatory framework designed to prevent banking crises (e.g. systemic and prudential regulation), and how the transformations that occurred in the financial services industry throughout the second half of the $20^{\text {th }}$ century affect it. Based on this analysis, the study intends to demonstrate that, albeit the systemic and prudential regulation in Brazil have incorporated important developments over the last decades, there still are significant flaws that need to be fixed and challenges to be faced. If, on the one hand, the current regulatory framework is marked by demands and controls that are more rigorous than those adopted by other countries, on the other hand, the mechanisms designed to rescue distressed banks are being applied in an unorganized manner, without clear rules, little or no accountability, and even distorting the original purpose of some of these mechanisms. The presence of this variety of rescue mechanisms with such characteristics is a concerning source of moral hazard. Furthermore, the examination of the transformations in the financial system in recent history shows that the challenges faced by banking authorities in other countries, such as the "too big to fail" phenomenon and the complexity of monitoring systemic risk in the context of financial conglomerates, are also present in Brazil, creating challenges to the current regulatory framework, and claiming a reflection on the consequences of such transformations in the national financial services industry. In conclusion, the study aims at demonstrating that, despite its unquestionable merits, the exaltation to the Brazilian systemic and prudential regulation in light of the country's performance in the recent financial crisis should be analyzed with caution, and that the role of the banking authorities over the next years should be focused in fixing the flaws identified in the analysis and reflection over the challenges discussed throughout the study.
\end{abstract}

KEYWORDS: systemic risk, systemic regulation, prudential regulation, banking sector, concentration and consolidation in the financial services industry. 


\section{RÉSUMÉ}

L'objet de cette étude est d'évaluer le cadre réglementaire national destiné à la prévention des crises bancaires, c'est-à-dire, la régulation systémique et prudentielle. L'objectif est aussi de vérifier comment les changements de ces dernières décennies dans le système financier affectent ce cadre règlementaire. Basé sur cette analyse, cette étude vise à montrer que, bien que la réglementation prudentielle et systémique du Brésil ont intégré des avancées notables durant les dernières décennies, il y a encore des imperfections importantes à résoudre et des défis à relever. Bien que d'une part, le cadre réglementaire actuel est marqué par des demandes et des contrôles plus stricts que ceux trouvés dans d'autres pays, d'autre part, de nombreux outils ont été appliqués de manière désordonnée pour sauver les banques, sans règles précises, avec peux ou sans dispositions visant à rendre des comptes, voir même en faussant l'objectif initial de ces mécanismes. La présence de cette variété de mécanismes de sauvetage avec de telles caractéristiques est une source d'aléa moral dans le marché financier. En outre, l'examen des transformations dans le système financier national dans l'histoire récente montre que les difficultés rencontrées par les autorités bancaires dans d'autres pays, tels que le «too big to fail» («trop grosse institution pour la laisser tomber») et la complexité de la surveillance du risque systémique dans le contexte des conglomérats financiers, sont également présents au Brésil. Cela pose des défis au cadre réglementaire financier actuel, et demande une réflexion sur les conséquences pour la régulation systémique et prudentielle de telles transformations dans le secteur nationale des services financiers. En conclusion, l'étude vise à démontrer que, malgré ses mérites incontestables, l'exaltation à la réglementation brésilienne systémique et prudentielle doit être analysées avec prudence compte tenu la performance du pays dans la récente crise financière. En outre, le rôle des autorités bancaires au cours des prochaines années devrait se concentrer surtout dans le traitement des défauts identifiés par cette recherche et dans la réflexion sur les défis évoqués tout au long de cette étude.

Mots-CLÉs: risque systémique, régulation systémique, régulation prudentielle, secteur bancaire, concentration et consolidation dans le secteur des services financiers. 


\section{SUMÁRIO}

INTRODUÇÃO......

DIREITO E ECONOMIA NA PREVENÇÃO A CRISES BANCÁRIAS E DELIMITAÇÕES AO PLANO DA OBRA...

1. A REGULAÇÃO FINANCEIRA E SUAS JUSTIFICATIVAS

1.1 A importância do setor bancário e de sua regulação

1.2 A economia neoclássica e seus desafios ......................................................... 24

1.3 As falhas de mercado no setor bancário .................................................... 32

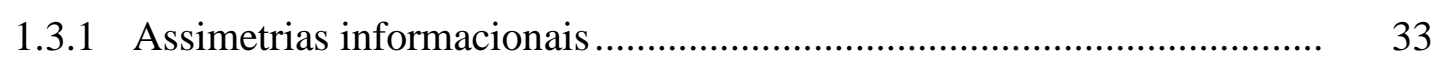

1.3.2 Concentração econômica .............................................................. 37

1.3.3 Externalidades .......................................................................... 46

1.4 Regulação financeira e falhas de mercado .................................................... 50

SÍNTESE E CONCLUSÕES DO CAPÍTULO 1 …............................................ 56

2. A ATIVIDADE BANCÁRIA NO BRASIL E SUA REGULAÇÃO........................ 58

2.1 Primórdios do setor bancário brasileiro ....................................................... 58

2.2 Reestruturação do Sistema Financeiro Nacional ............................................... 64

2.2.1 Concentração e conglomeração no Sistema Financeiro Nacional ........... 67

2.2.2 Saneamento do Sistema Financeiro Nacional - o fim do "milagre econômico" ....................................................................... 70

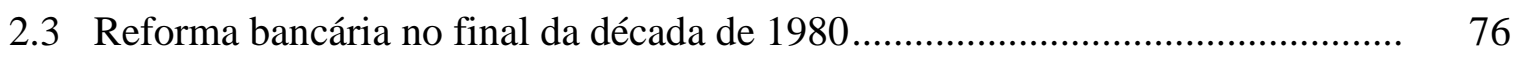

2.4 Plano Real e a abertura do setor bancário...................................................... 79

2.4.1 Saneamento do Sistema Financeiro Nacional - o Plano Real................. 80

2.4.2 Abertura do setor bancário ao capital estrangeiro ................................. 89

2.5 Desenvolvimento recente - crise financeira internacional ............................ 92

2.6 Autoridades do setor bancário ...................................................................... 94

2.6.1 Conselho Monetário Nacional.............................................................. 94

2.6.2 Banco Central do Brasil ...................................................................... 96

2.6.3 Outras autoridades do Sistema Financeiro Nacional ........................... 98

2.7 Tipos de instituição financeira......................................................................... 99 
2.7.1 Bancos múltiplos

2.7.2 Instituições financeiras públicas

3. REGULAÇÃO SISTÊMICA

3.1 Regulação sistêmica

3.1.1 Seguro de depósitos.

3.1.2 Regimes especiais aplicáveis às instituições em crise

3.1.3 Emprestador de última instância

3.1.4 Organização do sistema de pagamentos

3.1.5 Edital de Audiência Pública 34 do Banco Central

3.2 Desafios para a regulação sistêmica

3.2.1 Ampliação do conceito de risco sistêmico .

3.2.2 Grande demais para quebrar.

SÍNTESE E CONCLUSÕES DO CAPÍTULO 3

4. REGULAÇÃO PRUDENCIAL

4.1 Regulação prudencial

4.1.1 Controles de adequação patrimonial

4.1.2 Mecanismos de controle de acesso

4.1.3 Supervisão e envio de informações....

4.1.4 Instrumentos disciplinares e punitivos

4.1.5 Controle de estruturas de remuneração

4.2 Desafios para a regulação prudencial

4.2.1 Dificuldades associadas à supervisão de conglomerados financeiros.

4.2.2 Sistema bancário na "sombra"

4.2.3 Instrumentos financeiros derivativos

4.2.4 Captura regulatória

4.2.5 Papel da autorregulação

4.2.6 Instituições "auxiliares" de supervisão bancária

5. REGULAÇÃO FINANCEIRA INTERNACIONAL

5.1 Risco sistêmico internacional 
5.1.1 Internacionalização dos bancos atuantes no Sistema Financeiro Nacional 301

5.2 Arcabouço internacional de regulação e supervisão financeira......................... 304

5.2.1 Comitê de Basileia de Supervisão Bancária........................................... 304

5.2.2 Organização Internacional de Comissões de Valores Mobiliários ......... 308

5.2.3 Associação Internacional de Supervisores de Seguros .......................... 309

5.2.4 Organizações internacionais e a regulação financeira ........................... 311

5.3 Coordenação internacional para regulação e supervisão financeira ................... 315

5.3.1 Fórum de Estabilidade Financeira ....................................................... 323

5.4 Propostas de reforma e desafios ............................................................ 324

SÍNTESE E CONCLUSÕES DO CAPÍTULO 5 .............................................. 332

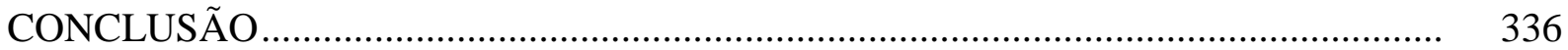

REFERÊNCIAS BIBLIOGRÁFICAS ............................................................ 346 


\section{ÍNDICE DE FIGURAS E TABELAS}

\section{Figuras}

Figura 1: Fusões e aquisições em número de operações por indústria (países G-10) .

Figura 2: Organização hierárquica do Citigroup (2004)...

Figura 3: Convênios entre autoridades do SFN

\section{Tabelas}

Tabela 1: Ativos dos maiores bancos em relação ao PIB (\%) .................................. 41

Tabela 2: Evolução de matrizes e estabelecimentos bancários (1940-1962)............... 64

Tabela 3: Crescimento do banco Itaú $(1964-1974)$.................................................... 68

Tabela 4: Participação das instituições financeiras conglomeradas nos empréstimos e captações do SFN (\%).

Tabela 5: Desempenho financeiro da reserva monetária (US\$ milhões)..................... 76

Tabela 6: Fusões e aquisições bancárias com incentivos do Proer............................. 84

Tabela 7: Privatizações de bancos públicos no âmbito do Proes................................ 87

Tabela 8: Principais mudanças institucionais no setor bancário (1994-2001)............ 91

Tabela 9: Prazo para desembolso dos recursos do FGC ........................................ 122

Tabela 10: Conselho de Administração do FGC (2008/2010) ................................... 125

Tabela 11: Capital mínimo para abertura de instituições financeiras .......................... 198

Tabela 12: Composição do PR......................................................................... 200

Tabela 13: Regras para provisionamento de créditos em atraso................................ 202

Tabela 14: Força da auditoria contábil externa - diferenças entre países .................. 280

Tabela 15: Bancos brasileiros com dependências no exterior em 31 dez. 2009......... 302

Tabela 16: Receita do Banco Itaú S.A. no Brasil e exterior (milhões de R\$) ............. 303 


\section{INTRODUÇÃO}

A maioria dos países, independentemente do seu grau de desenvolvimento, sujeita os participantes do setor bancário a algum tipo de regulação. Com efeito, embora outros setores da economia também sejam tradicionalmente regulados, possivelmente em nenhum desses casos a regulação alcança o mesmo grau e abrangência observados no setor bancário. E isso não seria uma característica dos mercados financeiros modernos. Nas palavras de Benston, "serviços financeiros são objeto de regulação estatal, de uma forma ou de outra, há séculos".

As razões para essa preocupação com o setor bancário são diversas, relacionando-se às importantes funções de intermediação financeira desempenhadas pelos bancos, consideradas estratégicas para o crescimento econômico, sua capacidade de multiplicação da moeda escritural, bem como as especificidades da atividade bancária típica, que tornariam o setor particularmente sujeito a crises, com consequências adversas para os participantes do sistema financeiro e sociedade como um todo.

O avanço da percepção econômica sobre a relevância do setor bancário acabou se refletindo no campo do direito na criação de expressivo corpo de regras voltadas à proteção desse setor e de seus participantes. A promoção desse regramento pelas autoridades responsáveis pelo setor exige a previsão de amplos poderes normativos e o desenvolvimento de vasto arcabouço regulatório destinado a garantir a estabilidade do sistema financeiro.

Embora apresentem como elemento comum a prevenção de crises bancárias, esse corpo de regras e mecanismos pode ser classificado em duas categorias distintas de acordo com seu escopo de atuação. Em primeiro lugar, tem-se a regulação sistêmica, destinada a proporcionar uma rede de segurança aos bancos para impedir que as externalidades negativas decorrentes do alto grau de integração entre eles provoquem a disseminação de crises isoladas para outros participantes do sistema financeiro. Em segundo lugar, encontra-se a regulação prudencial, que busca controlar o nível de risco assumido pelos bancos em suas atividades. A

1 BENSTON, George J. Regulating financial markets: a critique and some proposals. Washington: The AEI Press, 1999. p. 2. 
regulação prudencial possui caráter mais preventivo, procurando delinear regras que mantenham a higidez do setor bancário e do sistema financeiro como um todo, de modo que, embora seja apresentada de maneira separada, atua de forma complementar à regulação sistêmica.

Apesar dessa preocupação constante com a estabilidade do setor bancário, crises bancárias continuam a ocorrer, provocando impactos significativos nas economias de diversos países. A crise financeira recente originada no mercado hipotecário subprime norteamericano, e que se alastrou por diversos países ao redor do mundo, provocou efeitos devastadores. Segundo dados do Fundo Monetário Internacional (FMI), os custos da crise em termos de baixas em carteiras de ativos situam-se no patamar de US\$4 trilhões, dos quais US $\$ 2,8$ trilhões seriam bancados apenas por instituições financeiras. ${ }^{2}$ Nesse aspecto, talvez a única crise no século anterior que possa ser utilizada como evento comparável ao pânico que se observou seja a grande crise de 1929.

Motivados em grande medida pelos acontecimentos recentes, observam-se acalorados debates na comunidade financeira internacional sobre medidas a serem adotadas para evitar que uma crise com tais características volte a se repetir no futuro próximo. No cerne das discussões, encontram-se formas de aprimorar as regras e mecanismos voltados à prevenção de crises bancárias e de que modo enfrentar os desafios impostos às autoridades pelas transformações ocorridas no sistema financeiro - e no setor bancário em particular - nas últimas décadas. A concentração bancária crescente, a conglomeração de atividades financeiras e a formação de conglomerados financeiros internacionalmente ativos apresentam questões de difícil solução às autoridades bancárias, como a forma apropriada de lidar com entidades consideradas "grandes demais para quebrar" e técnicas de monitoramento e prevenção do risco sistêmico no caso de conglomerados financeiros de atuação transfronteiriça. Embora muitos desses pontos continuem sob discussão, já é possível observar nos Estados Unidos e na Europa as primeiras respostas em termos de reformas ao arcabouço regulatório vigente.

2 FMI. Global financial stability report: responding to the financial crisis and measuring systemic risk. Washington: International Monetary Fund, 2008. p. 30-31. 
Nos Estados Unidos, epicentro da crise financeira recente, foi promulgado em $2010 \mathrm{o}$ Dodd-Frank Wall Street Reform and Consumer Protection Act, possivelmente a maior reforma no marco regulatório do sistema financeiro norte-americano desde o Glass-Steagall Act de 1933. Igualmente, o Comitê de Basileia de Supervisão Bancária aprovou, também em 2010, um conjunto de medidas conhecidas genericamente como "Basileia III", que incluem a reformulação de parte dos acordos anteriores de Basileia e a introdução de novos mecanismos de regulação prudencial que deverão causar impactos significativos sobre as operações de instituições financeiras. Na União Europeia, o relatório Larosiére, preparado a pedido da Comissão Europeia e apresentado em fevereiro de 2009, propõe a base das reformas regulatórias destinadas às instituições financeiras atuantes nos países-membros.

Em contraste com esse cenário de intenso debate internacional e proliferação de respostas legislativas aos problemas enfrentados durante a crise, o Brasil encontra-se em situação peculiar. Com efeito, considerando-se sua intensidade e duração em comparação a outros países, pode-se dizer que as instituições financeiras do Sistema Financeiro Nacional (SFN) reagiram de forma relativamente positiva à crise financeira recente. Os efeitos desta certamente não se resumiram a uma "marolinha", como equivocadamente previsto pelo Presidente da República em outubro de $2008,{ }^{3}$ mas também não tiveram a mesma repercussão negativa constatada em outros mercados. Não se observaram ondas de quebras ou corridas bancárias, como ocorreu nos Estados Unidos e Inglaterra. Embora o Produto Interno Bruto (PIB) tenha recuado 3,2\% no quarto trimestre de 2008 e 1,6\% no primeiro trimestre de 2009, o Brasil foi um dos primeiros países a sair da recessão, apresentando resultado positivo de $1,5 \%$ já no segundo trimestre de $2009 .^{4}$

Em razão do seu desempenho considerado positivo na crise financeira recente, tendo sido um dos últimos países a sentir seus efeitos e um dos primeiros a se recuperar dela, o País, suas autoridades bancárias e seu arcabouço regulatório destinado à prevenção de crises bancárias têm angariado elogios da comunidade financeira internacional. $\mathrm{O}$ ex-presidente do Banco Central do Brasil (Bacen), Henrique Meirelles, foi convidado pela primeira vez na história em 2009 a participar do Comitê de Basileia de Supervisão Bancária, talvez o mais

3 O GLOBO. Lula: crise é tsunami nos EUA e, se chegar ao Brasil, será marolinha, 5 out. 2008, p. 42.

4 Dados disponíveis em: <seriesestatisticas.ibge.gov.br/series.aspx?vcodigo=ST16>. Acesso em: 8 dez. 2010. 
importante fórum de discussão sobre padrões mínimos de regulação do setor bancário. O FMI, acostumado a aconselhar e tutelar a implementação de reformas no País durante a década de 1990, agora muda a tônica do seu discurso, afirmando que os outros países têm muito a aprender com o Brasil no tocante à regulação financeira. ${ }^{5}$ Em 2008 o Presidente da República chegou inclusive a se oferecer para ensinar a "tecnologia" pátria de prevenção a crises bancárias aos Estados Unidos. ${ }^{6}$ Esse posicionamento não ficou restrito aos círculos políticos. Representantes de relevo da doutrina econômica nacional também parecem compartilhar desse entusiasmo com o arcabouço regulatório vigente, chegando inclusive a colocá-lo como alternativa superior aos sistemas legais existentes em vários países desenvolvidos, e que falharam em $2008 .^{7}$

É justamente a partir desse cenário que o presente trabalho apresenta seu questionamento fundamental: até que ponto a exaltação ao arcabouço regulatório pátrio destinado à prevenção de crises bancárias e a noção disseminada de que o modelo presentemente adotado é superior ao encontrado em outros países são justificadas?

A motivação para o questionamento decorre de duas constatações básicas. Em primeiro lugar, não deixa de causar estranhamento essa admiração quanto à solidez do SFN, considerando-se que a ocorrência de graves crises não é fato estranho à história do setor bancário nacional. Atendo-se apenas ao final do século passado, podem-se mencionar as crises bancárias ocorridas nas décadas de 1970 e 1980, como as quebras do Halles, Banco União Comercial, Comind e Auxiliar, entre outras, que exigiram reiteradas intervenções das autoridades voltadas ao saneamento do setor bancário. Do mesmo modo, a década de 1990 ficou marcada por crise tão ou mais severa que as verificadas nas décadas anteriores, quando a quebra de bancos como o Econômico, Nacional e Bamerindus provocou nova necessidade de saneamento das instituições financeiras atuantes no SFN. Levando em conta apenas o custo

5 VALOR ECONÔMICO. EUA têm muito a aprender com o Brasil, diz Johnson, 25 fev. 2010, p. C9.

6 O GLOBO. Lula: Bush, meu filho, resolve a sua crise, 28 mar. 2008, p. 33.

7 Nessa linha de pensamento, por exemplo, importante referir a publicação recente com coletânea de artigos de renomados economistas, incluindo Gustavo Franco, Gustavo Loyola, João Manoel Pinho de Mello, Maílson da Nóbrega, Mario Torós, Pedro Malan e Sérgio Darcy da Silva Alves, entre outros. Ver: GARCIA, Márcio; GIAMBIAGI, Fábio (orgs.). Risco e regulação: por que o Brasil enfrentou bem a crise financeira recente e como ela afetou a economia mundial. Rio de Janeiro: Elsevier, 2010. 
dos programas de saneamento nesse último caso, estima-se que estes tenham atingido valor aproximado de $8,7 \%$ do PIB à época. ${ }^{8}$

Em segundo lugar, é preciso reconhecer que algumas das principais transformações ocorridas no sistema financeiro de outros países nas últimas décadas que impuseram grandes desafios à atuação de suas autoridades bancárias também se verificam no País. A concentração bancária crescente e a conglomeração de atividades financeiras têm sido observadas historicamente no setor bancário nacional, representando inclusive importante elemento da política governamental aplicada ao setor durante o regime militar. Com efeito, ao final da década de 1980 a intermediação financeira no País já era realizada praticamente em sua integralidade por conglomerados financeiros, sendo esta ainda a matriz predominante do SFN. Outrossim, no auge da crise recente, verificou-se intenso processo de concentração de ativos bancários, com destaque para a fusão entre o Itaú e o Unibanco, criando à época o maior banco do hemisfério sul, bem como as aquisições realizadas pelo Banco do Brasil e Caixa Econômica Federal.

O evidente contraste entre a situação atual do setor bancário nacional e o seu passado não tão distante provoca a necessária reflexão sobre como os campos da regulação financeira destinados à prevenção de crises bancárias no País evoluíram nesse período, e de que forma isso pode ter contribuído para a reação favorável dos participantes do SFN durante a crise financeira recente. Igualmente, na medida em que transformações no sistema financeiro sejam parcial ou integralmente verificadas no Brasil, torna-se essencial examinar se e como tais mudanças afetam o SFN e sua regulação. A partir desse cenário os objetivos principais do presente trabalho podem ser sumarizados da seguinte forma:

(i) descrever e compreender os sistemas vigentes de regulação sistêmica e prudencial no setor bancário nacional, produzindo o diagnóstico do arcabouço regulatório voltado à prevenção de crises bancárias; e

8 GOLDFAJN, Ilan et al. Brazil's financial system: resilience to shocks, no currency substitution, but struggling to promote growth. Working Paper Series, Banco Central do Brasil, n. 75, p. 19. 
(ii) verificar como as transformações ocorridas no sistema financeiro nas últimas décadas afetam esse arcabouço regulatório.

Com relação ao primeiro objetivo, o trabalho pretende demonstrar que, embora a regulação sistêmica e a regulação prudencial no País tenham incorporado avanços notáveis nas últimas décadas, ainda subsistem relevantes falhas a serem corrigidas. $\mathrm{O}$ arcabouço regulatório atual é caracterizado por uma regulação sistêmica demasiadamente complacente com bancos em dificuldades, prevendo inúmeros instrumentos de resgate a bancos sendo aplicados de forma desordenada, sem regras claras, com pouca ou nenhuma prestação de contas, e até mesmo desvirtuando o propósito original de alguns desses instrumentos. A presença dessa multiplicidade de mecanismos de resgate com tais características é uma preocupante e significativa fonte de risco moral no mercado. Por outro lado, as regras e mecanismos de regulação prudencial presentemente adotados são marcados por exigências e controles mais rigorosos que os encontrados em outros países, já incorporando muitas das propostas de reforma atualmente sob debate na comunidade financeira internacional, colocando-se na dianteira do processo de implementação de regras mais rígidas ou mesmo recusando recomendações de Basileia que procuram diminuir o ônus regulatório no setor bancário.

A apresentação dessa combinação entre regulação sistêmica complacente com regulação prudencial rigorosa representa um importante contraponto à noção disseminada de que a atual regulação financeira no País seja adequada e sirva de modelo para outros países. O trabalho pretende demonstrar que, conquanto os avanços realizados nas últimas décadas e o tratamento mais rigoroso aplicável às instituições financeiras mereçam destaque na explicação de como o País superou a crise financeira recente, os inúmeros mecanismos de resgate presentes no modelo vigente também são relevantes na explicação de tal performance, com as consequências negativas em termos de risco moral que esse quadro acarreta. Ainda que os mecanismos voltados ao controle da higidez de instituições financeiras ajudem a mitigar esse risco, dadas as limitações inerentes à regulação prudencial que serão demonstradas ao longo do trabalho, é temerário contar apenas com esses mecanismos para compensar os efeitos deletérios decorrentes desse quadro. 
No tocante ao segundo objetivo, o trabalho pretende demonstrar que as transformações ocorridas no SFN nas últimas décadas evidenciam que muitas das dificuldades enfrentadas por autoridades bancárias em outros países, como o fenômeno do "grande demais para quebrar" e o monitoramento do risco sistêmico em um contexto de conglomeração financeira, já são uma realidade no País, representando desafios para a regulação sistêmica e, principalmente, para a regulação prudencial. O Bacen e outras autoridades do SFN sentem as pressões impostas ao arranjo institucional atual de regulação e supervisão bancária em decorrência dessas transformações e têm procurado supri-las de diversas maneiras, como a assinatura de convênios de cooperação, criação de fóruns de discussão e harmonização sobre práticas regulatórias e até mesmo apresentação de projetos de lei prevendo alterações às regras e mecanismos de regulação sistêmica e prudencial presentemente adotados. Tais constatações colocam em xeque a noção de superioridade do arcabouço regulatório vigente, tornando imperativa a reflexão sobre as consequências desses movimentos no setor bancário nacional e sua regulação.

O presente trabalho parte de um questionamento quanto à capacidade de o arcabouço regulatório pátrio destinado à prevenção de crises bancárias cumprir com seus objetivos e verificação de como as transformações ocorridas no sistema financeiro afetam-no. Com base no quadro analítico exposto, o trabalho conclui que a exaltação à regulação do SFN em face de seu desempenho considerado positivo na crise financeira recente deve ser vista com temperamentos, e que a atuação das autoridades bancárias nos próximos anos deve ser mais centrada na correção das falhas identificadas e ponderação sobre os desafios apresentados. Nesse aspecto, é importante esclarecer que a conclusão atingida não deve ser encarada como uma negação aos evidentes méritos das regras e mecanismos de regulação sistêmica e prudencial presentemente adotados no País, mas sim como um alerta aos vícios presentes na estrutura atual e desafios a serem superados.

De modo a atingir essa conclusão, o trabalho está dividido em cinco capítulos. $\mathrm{O}$ primeiro capítulo apresenta a fundamentação teórica para a regulação de instituições financeiras. Partindo-se da teoria econômica neoclássica e reconhecendo suas limitações, são 
analisadas as principais falhas de mercado presentes no setor bancário e como a regulação financeira se propõe a corrigi-las. A partir desse quadro, são apresentadas duas visões antagônicas sobre a teoria econômica da regulação e como estas influenciam a interpretação sobre o papel da regulação financeira. O capítulo aproveita também para tratar dos movimentos de concentração e conglomeração financeira observados nas últimas décadas ao redor do mundo, de modo a apoiar a exposição subsequente.

O segundo capítulo tem como objetivo contextualizar a discussão no âmbito nacional. Com o exame da evolução histórica do setor bancário pátrio, pretende-se apresentar importantes marcos regulatórios que influenciaram a estrutura atual do SFN. Nessa análise, será atribuída atenção especial à implementação e utilização pelas autoridades bancárias dos primeiros mecanismos de regulação sistêmica e prudencial no Brasil, aos movimentos de concentração bancária e conglomeração financeira observados no setor bancário nacional na segunda metade do século XX, e como eles se relacionam com a política governamental para o setor. Finalmente, o capítulo mostra a evolução recente do SFN, com destaque para os programas de saneamento na década de 1990, continuidade dos movimentos observados no setor bancário no período anterior e desdobramentos da crise financeira que atingiu o País em 2008.

O capítulo seguinte trata do conceito de regulação sistêmica, os principais mecanismos utilizados para a consecução de seus objetivos e como estes se apresentam no País. Além de ressaltar os avanços conquistados nas últimas décadas, o capítulo pretende demonstrar, por meio da apresentação de cada um desses mecanismos individualmente, que a regulação sistêmica no País é marcada atualmente pela presença de três canais independentes e alternativos de provimento de liquidez aos participantes do SFN, além da previsão de um canal adicional de acordo com projeto de lei formulado pelo Bacen. A apresentação desses mecanismos de resgate no trabalho privilegiará a análise crítica da função exercida por cada um deles e, mais importante, das situações em que devem ser aplicados, evidenciando que, da forma como se encontram presentemente estruturados, dão azo a uma preocupante ampliação do risco moral no 
mercado financeiro. Finalmente, o capítulo versa a respeito dos principais desafios às autoridades bancárias incumbidas da utilização dos mecanismos de regulação sistêmica em virtude das transformações observadas no sistema financeiro nas últimas décadas, e como essas dificuldades se relacionam ao contexto bancário nacional.

O quarto capítulo realiza exercício semelhante ao do capítulo anterior no tocante à regulação prudencial. A análise das regras e mecanismos de regulação prudencial presentes no arcabouço regulatório atual indica que o País impõe regras de higidez bancária rigorosas quando comparadas à regulação dirigida aos bancos em outros países, já incorporando regras e restrições que se encontram atualmente sob debate na comunidade financeira internacional. Nesse capítulo também é atribuído enfoque maior aos desafios e dificuldades enfrentados por autoridades bancárias no controle da higidez do sistema financeiro, seja em razão dos movimentos observados no setor bancário nas últimas décadas, ou em razão de seu relacionamento com auditores independentes e agências de rating, mostrando as preocupações inerentes à utilização das informações produzidas por tais entidades nos esforços de supervisão bancária. A análise pretende demonstrar como, a despeito de seus méritos, a regulação prudencial enfrenta limitações e desafios. Isso é particularmente relevante no contexto regulatório pátrio, em que se identifica uma regulação sistêmica conducente à ampliação demasiada do risco moral.

O quinto e último capítulo aborda o movimento de internacionalização de conglomerados financeiros e seus efeitos sobre os mecanismos de regulação sistêmica e prudencial apresentados nos capítulos anteriores, notadamente a atuação de autoridades bancárias nacionais. O capítulo descreve o atual arcabouço internacional de regulação e supervisão financeira, seus principais representantes e limitações e algumas das propostas em discussão para o seu aprimoramento. $\mathrm{O}$ capítulo procura contextualizar também o setor bancário nacional nesse movimento de internacionalização de instituições financeiras, mostrando que, embora incipiente no País, as autoridades bancárias nacionais tendem a enfrentar cada vez mais os desafios regulatórios decorrentes desse processo. 


\section{DIREITO E ECONOMIA NA PREVENÇÃO A CRISES BANCÁRIAS E DELIMITAÇÕES AO PLANO DA OBRA}

Em 1965 Fábio Konder Comparato publicou seu artigo seminal intitulado $O$ indispensável direito econômico ${ }^{9}$ - cuja importância para o direito econômico é inversamente proporcional ao seu reduzido tamanho -, no qual alertava para o processo de crise do direito e a preocupante dissociação entre um direito "nobre e oficial" e um "menos qualificado", destinado a completar e a corrigir o primeiro. ${ }^{10} \mathrm{O}$ trabalho representou um esforço de mudança do foco das normatizações encarregadas de disciplinar o funcionamento das atividades econômicas: no lugar dos direitos civil e comercial, voltados a garantir instrumentos para uma ação comercial entre agentes particulares, ganhavam centralidade os institutos e regulamentos dedicados a garantir uma intervenção pública na coordenação da economia. O direito privado cedia espaço, pois, para um direito econômico. ${ }^{11}$

Entre as relevantes provocações lançadas no artigo, houve preocupação especial com as mudanças ocorrendo no sistema financeiro e, particularmente, à estrutura do setor bancário do País. O advento do regime militar em 1964 marcou o início de uma ampla reestruturação do SFN, e o autor enfatizava a importância de os juristas não se furtarem àquele debate. ${ }^{12}$

Apesar de essas preocupações e provocações terem sido lançadas há décadas, é preciso reconhecer que, pelo menos no campo da regulação financeira, continuam sendo bastante atuais. Se outros campos do conhecimento - notadamente a economia - constataram há muito a importância do setor bancário para o desenvolvimento econômico e social, no

9 COMPARATO, Fábio Konder. O indispensável direito econômico. Revista dos Tribunais, São Paulo, v. 353, p. 14 e ss., 1965.

10 TURCZYN, Sidnei. O Sistema Financeiro Nacional e a regulação bancária. São Paulo: RT, 2005. p. 23.

11 SCHAPIRO, Mário Gomes. Novos parâmetros para a intervenção do Estado na economia. 2009. Tese (Doutoramento), FD-USP, São Paulo, p. 8. Mimeografado.

12 O eminente autor questiona se "nossos centros de cultura jurídica poderão continuar ignorando a profunda influência das instruções da extinta Sumoc, hoje Banco Central da República, sobre a vida privada, ou os problemas postos pela regulação do câmbio ou o estatuto do capital estrangeiro. [...] Será possível compreender o direito comercial de nossos dias sem conhecer a estrutura do sistema bancário do País, e as funções que nele exerce o Banco do Brasil?’. Ver: COMPARATO, Fábio Konder. O indispensável direito econômico, p. 14 e ss. 
campo do direito o tema continua sendo relegado a "injustificável plano secundário, ou mesmo silêncio completo [...]". ${ }^{13}$

Com efeito, embora se observem incursões de juristas no campo da regulação financeira em outros países, infelizmente no Brasil trata-se de campo dominado quase que exclusivamente por economistas. A produção jurídica sobre o tema é escassa, limitando-se, na maioria dos casos, a estudos na área do direito privado relativos aos aspectos jurídicos das operações bancárias, e descuidando-se da estrutura de regulação subjacente ao mercado financeiro. ${ }^{14}$ Com honrosas exceções a algumas empreitadas relativamente recentes de juristas nesse campo de estudo, praticamente não há obras jurídicas nacionais que tratem de forma aprofundada o arcabouço regulatório pátrio destinado à prevenção de crises bancárias. ${ }^{15}$

Parte desse distanciamento dos juristas em relação ao tema se deve à própria forma como o ensino jurídico ainda é conduzido no Brasil. Embora o elo entre essas áreas do conhecimento seja bastante evidente, infelizmente sua abordagem analítica tem sido estanque, com evidente prejuízo para o entendimento de fenômenos multifacetados. Isso pode ser constatado nos cursos de economia em faculdades de direito, bem como cursos de direito em faculdades de economia, que têm refletido essa visão compartimentada e pouco estimulante aos alunos. ${ }^{16}$

Contribuindo com esse quadro de distanciamento (ou como reflexo dele), devem-se mencionar também relevantes movimentos históricos no Brasil que influenciaram esse cenário de compartimentação. O advento do regime militar marcou a conformação das estruturas administrativas do Estado a uma burocracia com formação distinta, os chamados "tecnocratas", entronizando a figura do economista como elemento fundamental à

13 COMPARATO, Fábio Konder. O indispensável direito econômico, p. 14 e ss.

14 WALD, Arnoldo. O direito da regulação monetária e bancária. Revista de Direito Bancário, v. 17, p. 20 e ss., 2002.

15 A esse respeito cumpre mencionar as importantes contribuições de Jairo Saddi e Otavio Yazbek acerca da análise da regulação financeira. Ver: SADDI, Jairo. Crise e regulação bancária: navegando mares revoltos. São Paulo: Textonovo, 2001; SADDI, Jairo. Temas de regulação financeira. São Paulo: Quartier Latin, 2010; e YAZBEK, Otavio. Regulação do mercado financeiro e de capitais. São Paulo: Elsevier, 2007.

16 SZTAJN, Rachel; ZYLBERSZTAJN, Decio (Org.). Direito \& economia: análise econômica do direito e das organizações. Rio de Janeiro: Elsevier, 2005. p. XII. 
funcionalidade técnica do país, e relegando o papel dos juristas ao segundo plano. ${ }^{17}$ Assim, se no passado o País foi uma "república de bacharéis", pelo menos desde a década de 1960 ele se transformou gradualmente em uma república de economistas. ${ }^{18}$

Tais constatações não deixam de causar perplexidade, haja vista que, conforme pertinente apontamento de Nusdeo acerca do direito e economia, não existe uma relação entre as matérias; elas, na realidade, se imbricam e se integram, para formar um único campo de estudo. ${ }^{19}$ Aliás, o próprio conceito de mercado, elemento tão caro ao sistema financeiro e, consequentemente, sua regulação, já demonstra a impossibilidade de tratar as duas áreas de conhecimento separadamente. Natalino Irti chega inclusive a afirmar que o direito precede ao mercado, e não o contrário, uma vez que seria impossível a existência de qualquer mercado na ausência de mecanismos garantidores de seu funcionamento, ou seja, provedores de segurança jurídica às obrigações nele assumidas. ${ }^{20}$

Daí a intenção de procurar contribuir para a superação, no presente trabalho, da lacuna presente até os dias atuais entre juristas e o relevante tema da regulação financeira. A análise a ser empreendida busca oferecer uma visão abrangente e sistemática sobre a atuação estatal voltada à manutenção da estabilidade do setor bancário, inserindo o tema no sistema legal vigente de modo a permitir que seja examinado e avaliado quanto aos seus objetivos e aos instrumentos de atuação do Estado.

Para tentar essa aproximação entre a regulação financeira e o direito, o presente estudo parte de duas constatações elementares a respeito do papel do direito na prevenção a crises bancárias. Em primeiro lugar, cumpre destacar, conforme o valioso ensinamento de Comparato, que a unidade ou autonomia do direito econômico é trazida pela sua finalidade, qual seja: "traduzir normativamente os instrumentos de política econômica do Estado". ${ }^{21}$

\footnotetext{
17 Para uma análise conceitual da tecnocracia e do sentido político das relações de poder burocrático nesse momento histórico, ver: MARTINS, Carlos Estevam. Tecnocracia e burocracia. Estudos Cebrap, n. 2, p. 119-146, 1972.

18 YAZBEK, Otavio. Regulação do mercado financeiro e de capitais, p. 2.

19 NUSDEO, Fábio. Curso de economia: introdução ao direito econômico. 5. ed. São Paulo: RT, 2008. p. 19.

20 IRTI, Natalino. L'ordine giuridico del mercato. Bari: Laterza, 2003.

21 COMPARATO, Fábio Konder. O indispensável direito econômico, p. 14 e ss.
} 
Embora a assertiva seja válida para inúmeras atividades econômicas, é no setor bancário que possivelmente ela se manifesta com maior clareza.

É nesse sentido que se observa na atualidade um extenso corpo de regras e mecanismos voltados à preservação da estabilidade do setor bancário. As modernas técnicas regulatórias, altamente sofisticadas, representam o resultado de décadas de evolução para a criação de um corpo de regras condizente com a percepção a respeito da importância das funções desempenhadas pelos bancos. Esse corpo de regras está em constante transformação, influenciado por inúmeros fatores, como as condições políticas e correntes econômicas predominantes. Não por acaso, episódios de crises bancárias severas são seguidos pela promulgação de leis que reformam o marco regulatório vigente. Foi o crash da bolsa de Nova Iorque em 1929 que motivou o Glass Steagall Act de 1933, a crise nas sociedades de depósito e crédito (savings and loans associations) na década de 1980 motivou o Financial Institutions Reform, Recovery and Enforcement Act de 1989, e os eventos recentes culminaram na aprovação do Dodd-Frank Wall Street Reform and Consumer Protection Act de 2010. Igualmente, a grave crise bancária enfrentada pelo Brasil na década de 1990 levou à adoção de inúmeros mecanismos de regulação sistêmica e prudencial presentes até hoje no ordenamento jurídico.

É inegável, portanto, o papel do direito como instrumentalizador de políticas públicas voltadas à proteção do setor bancário. Não obstante essa consideração por si só já justificasse maior atenção da doutrina jurídica ao tema, o presente trabalho rejeita a simplificação do direito à condição de mera ferramenta a ser operada mecanicamente para atingir fins determinados. Além da preocupação específica com a criação de mecanismos para assegurar a estabilidade do setor bancário, é necessário levar em consideração as características do ordenamento jurídico em que pretendem operar. A segunda constatação de relevo a respeito do papel do direito na prevenção a crises bancárias refere-se, portanto, à reflexão sobre a viabilidade de implementação de determinadas regras e mecanismos em um determinado ordenamento jurídico, e até que ponto a forma como estes são implementados ou posteriormente transformados condiz com o objetivo que pretendem atingir.

As incursões dos tecnocratas nas oficinas de elaboração legislativa após a Revolução de 31 de Março, com a pressa e pressão que lhes eram características, dão amostra suficiente 
dos perigos associados a uma visão demasiadamente simplista sobre o papel do direito. A escalada dos economistas às fontes do direito foi criticada por alguns autores sob o aspecto técnico-jurídico, pelo fato de, no afã de se estabelecer nova ordem econômica, regras e rigores que deveriam presidir a elaboração das leis terem muitas vezes sido substituídas pela improvisação e afoiteza, viciando o processo legislativo. ${ }^{22}$ Como legado desse movimento, encontram-se leis e dispositivos legais em vigor até hoje que inundam os tribunais de processos e engessam a atuação das autoridades em razão de sua técnica jurídica deficiente, dos quais um dos exemplos notáveis é a Lei 7.492, de 16 de junho de 1986, também conhecida como "Lei do Colarinho-Branco". Tais leis e dispositivos mostram como a desatenção ao ordenamento jurídico no qual os mecanismos de prevenção a crises bancárias são empregados pode comprometer a consecução de seus objetivos.

A crise financeira recente também ajudou a enfatizar a importância de atentar ao próprio arranjo institucional de regulação e supervisão do sistema financeiro. A flexibilidade na atuação das autoridades nacionais foi determinante para o sucesso de medidas de contenção aos efeitos da crise. Em países como os Estados Unidos, a autoridade bancária não dispunha de meios legais para estender seus canais de provimento de liquidez a determinadas entidades, como bancos de investimento. Em tais casos, a autoridade precisou recorrer ao Congresso para receber a autorização legal para prestar o auxílio, tarefa que consumiu tempo precioso, comprometendo o resgate a instituições como o Lehman Brothers. Nesse aspecto, a ampla competência normativa do Conselho Monetário Nacional (CMN) revelou-se um diferencial positivo, que ajudou o Bacen a enfrentar praticamente em tempo real as demandas de liquidez do mercado. ${ }^{23}$ Os acontecimentos recentes evidenciam que fatores aparentemente externos e não relacionados ao debate de prevenção de crises bancárias, como a capacidade normativa do Executivo, podem ser determinantes no combate aos efeitos deletérios desses eventos. $^{24} \mathrm{E}$ o raciocínio contrário é igualmente verdadeiro. Ater-se demasiadamente ao formalismo jurídico também pode comprometer a atuação dos mecanismos de regulação

22 PIMENTEL, Manoel Pedro. Crimes contra o Sistema Financeiro Nacional. São Paulo: RT, 1987. p. 11.

23 Esse argumento foi levantado por Sérgio Odilon dos Anjos, chefe do Departamento de Normas do Sistema Financeiro do Banco Central, no Seminário APBC sobre Regulação Financeira, organizado pelo Insper e pela Associação dos Procuradores do Banco Central, ocorrido no dia 27.9.2010.

24 Para uma análise da capacidade normativa dos órgãos responsáveis pela regulação do setor bancário no Brasil, ver: VEIGA DA ROCHA, Jean Paul Cabral. A capacidade normativa de conjuntura no direito econômico: o déficit democrático da regulação financeira. 2004. Tese (Doutoramento), FD-USP, São Paulo. Mimeografado. 
sistêmica e prudencial. O caso da American International Group (AIG) na crise financeira recente foi emblemático nesse sentido. Pelo fato de ter a natureza jurídica de uma seguradora, era regulada e supervisionada pela autoridade encarregada de tais entidades nos Estados Unidos. Não obstante, a sua subsidiária financeira, AIG Financial Products (AIGFP), desempenhava atividades semelhantes às de um hedge fund, que acabaram se beneficiando de um vácuo regulatório. Episódios como esse mostram a necessidade de reflexão sobre critérios jurídicos para atribuição de competência regulatória adequados à nova realidade do sistema financeiro. A consideração sobre como identificar entidades consideradas "sistemicamente relevantes" certamente envolverá a contribuição e coordenação entre juristas e economistas.

Além do rigor e sensibilidade inerentes à técnica legislativa e às características do arranjo institucional de regulação e supervisão, é importante mencionar também a impossibilidade de encarar o direito como "produto" ou "tecnologia" que possa ser importado acriticamente de outros países. Isso é particularmente preocupante no contexto atual, após a ocorrência de grave crise financeira, em que órgãos e organizações internacionais apressam-se a classificar determinados modelos regulatórios como "melhores" ou "piores", servindo de exemplo para outros países, e descuidando-se da sua adequação ao contexto jurídico, econômico, social, político e ideológico daqueles. De fato, um país pode não estar aparelhado ou não possuir recursos suficientes para incorporar o aparato normativo inerente àquele modelo de forma adequada, ou então pode haver incompatibilidade do modelo com os destinatários da norma por razões diversas. Atendo-se à experiência recente da década de 1990, pode-se mencionar a malfadada tentativa de implementação de inúmeras teorias regulatórias inerentes à agenda liberalizante ditada pelo FMI e Banco Mundial, conhecidas genericamente como "Consenso de Washington", e seus resultados aquém do esperado em países em desenvolvimento e economias em transição.

Os exemplos mencionados servem apenas para ilustrar a necessidade de juristas e economistas trabalharem juntos para identificar e enfrentar brechas e limitações no arcabouço regulatório voltado à prevenção de crises bancárias. Tais exemplos serão retomados e aprofundados oportunamente ao longo do trabalho. A sua exposição nesse momento tem apenas o condão de apresentar a tônica do presente estudo, que, ao procurar conciliar fundamentos da teoria econômica moderna com o domínio da fundamentação jurídica, representa também um esforço para oferecer uma análise integrada dessas matérias. 
Além dessa explanação preliminar sobre como o direito se insere no debate a respeito da prevenção a crises bancárias, outro esclarecimento introdutório igualmente importante refere-se às limitações ao plano da obra. $\mathrm{O}$ objeto do presente trabalho é o diagnóstico do arcabouço regulatório pátrio subjacente ao setor bancário destinado a garantir sua estabilidade, e como as transformações ocorridas no sistema financeiro nas últimas décadas o afetam. Dessa forma, conquanto reconheça-se sua importância crescente na economia do País, não será analisada a regulação do mercado de capitais como prevenção às crises ou especulações bursáteis. ${ }^{25}$

25 As expressões e critérios utilizados para classificar as atividades financeiras em dois ramos distintos variam entre os autores. Turczyn, por exemplo, se refere a uma divisão entre o mercado monetário e o mercado de valores mobiliários. Segundo o autor, a distinção básica entre ambos seria a negociação do dinheiro como mercadoria no primeiro, e a negociação de títulos no segundo (TURCZYN, Sidnei. O Sistema Financeiro Nacional e a regulação bancária, p. 48). Já Mosquera apresenta distinção entre mercado financeiro e mercado de capitais, baseando sua divisão na presença da instituição financeira como parte ou mera interveniente obrigatória na operação (MOSQUERA, Roberto Quiroga. Tributação no mercado financeiro e de capitais. São Paulo: Dialética, 1999. p. 17-24). Andrezo e Lima, por sua vez, dividem o sistema financeiro em mercado de crédito ou mercado de capitais a partir do prazo típico das operações financeiras em cada um deles. No mercado de crédito as operações teriam prazo curto, médio ou aleatório (depósitos à vista), enquanto no mercado de capitais as operações teriam prazo médio, longo ou indefinido (ANDREZO, Andrea Fernandes; LIMA, Iran Siqueira. Mercado financeiro: aspectos históricos e conceituais. São Paulo: Pioneira Thomson Learning, 1999. p. 3). Por fim, seguindo na linha de Quiroga, Yazbek recorre a uma divisão entre mercado financeiro em sentido estrito, em que a mobilização e canalização dos excedentes são efetuadas por um intermediário financeiro que se coloca entre o investidor e o beneficiário do investimento, e o mercado de capitais, em que a relação de financiamento se estabelece diretamente entre o prestador de recursos e o seu beneficiário, a partir da emissão, por este último, de obrigações primárias ou diretas, como ações, debêntures ou commercial papers, adquiridas por aquele primeiro (YAZBEK, Otavio. Regulação do mercado financeiro e de capitais, p. 132). A adoção de terminologias díspares não significa que os conceitos adotados pelos autores sejam mutuamente excludentes. Pelo contrário, a eleição de diferentes classificações denota apenas a preocupação dos autores com um ou outro aspecto específico inerente aos mercados que compõem o sistema financeiro. Por meio da reunião desses aspectos, é possível adotar uma classificação funcional entre os mercados que constituem o sistema financeiro. Portanto, para fins do presente trabalho, entender-se-á o mercado financeiro como conjunto de instituições e produtos destinados a possibilitar, tipicamente, operações de prazo curto, médio ou aleatório. Nesse mercado, a mobilização e a canalização dos excedentes são efetuadas por um intermediário financeiro que se coloca entre o investidor e o beneficiário do investimento. É nele que se encontra a atividade bancária por excelência, qual seja a de intermediação financeira, cumprindo a importante função de disponibilizar recursos àqueles que necessitam, além de propiciar uma remuneração e utilização à poupança popular. É justamente em função dessa centralidade da figura do intermediário que tais atividades são consideradas um mercado de intermediação financeira. Outrossim, entender-se-á o mercado de capitais como o conjunto de instituições e instrumentos financeiros destinado a possibilitar, tipicamente, operações de médio ou longo prazo, ou de prazo indefinido, como no caso de ações, por exemplo. Nesse mercado, as operações são normalmente efetuadas diretamente entre poupadores e empresas. Assim, a relação de financiamento se estabelece diretamente entre o prestador de recursos e o seu beneficiário, a partir da emissão, por este último, de obrigações primárias ou diretas. Os intermediários são meros intervenientes (e não mais contrapartes), prestando serviços de aproximação, de representação ou de liquidação de operações para seus clientes, as partes reais. Por fim, vale mencionar que, embora a classificação supracitada represente a forma mais tradicional de divisão do sistema financeiro, reconhece-se que não é a mais abrangente, deixando de lado outras atividades que, embora não se confundam com o mercado financeiro e de capitais, com eles se relacionam, como as atividades securitárias. 
Embora esse corte metodológico seja necessário para viabilizar a análise que se pretende empreender, este deve ser relativizado em face da flexibilização das barreiras regulatórias para o exercício de atividades financeiras e do advento de novos produtos financeiros, contribuindo para a integração crescente entre o mercado financeiro e de capitais. Em determinados casos, a referência a outros setores, participantes, ou mesmo autoridades do sistema financeiro pode se fazer necessária, na medida em que sua atuação impactar a estabilidade do setor bancário. Como exemplo disso, pode-se mencionar o estudo de instituições não bancárias como fonte ou canal de propagação de risco sistêmico. É importante frisar, no entanto, que, embora a análise possa contemplar tais entidades, o foco do trabalho não será a regulação destas, mas sim como choques sistêmicos originados em tais participantes do sistema financeiro podem acabar afetando o setor bancário.

Outra importante delimitação ao plano da obra concerne aos campos da regulação financeira que serão objeto de estudo. $O$ presente trabalho pretende examinar a regulação financeira sob uma perspectiva macroscópica, baseando-se na reflexão sobre o direito como elemento de prevenção às crises bancárias. Portanto, seu foco principal será a regulação sistêmica e prudencial, avaliando as virtudes e deficiências do arcabouço regulatório pátrio e como as mudanças ocorridas no sistema financeiro nas últimas décadas afetam a eficácia dessas modalidades regulatórias. Embora se reconheça a importância da regulação de condutas como campo geral da regulação financeira, esta não será objeto de análise neste trabalho naquilo em que se referir unicamente ao regramento de práticas negociais entre agentes econômicos. Isso não implica, no entanto, a desconsideração de instrumentos que se situem na zona limítrofe entre os campos gerais de regulação financeira, como o Fundo Garantidor de Crédito, que, conforme se observará, pode ser encarado tanto como um instrumento de proteção ao consumidor de serviços bancários ou como instrumento mitigador de assimetria informacional em casos de corridas bancárias. O presente trabalho se ocupará do seu estudo apenas no tocante a esta última função.

\footnotetext{
Assim, por exemplo, Fortuna classifica as seguradoras como "instituições auxiliares do mercado financeiro", ressaltando inclusive a sua equiparação no ordenamento jurídico à instituição financeira (FORTUNA, Eduardo. Mercado financeiro: produtos e serviços. 15. ed. Rio de Janeiro: Qualitymark, 2004. p. 34). Igualmente, apesar de classificá-las como instituições "não financeiras", Assaf afirma que as companhias seguradoras estão consideradas no SFN por terem a obrigação de aplicar parte de suas reservas técnicas no mercado de capitais. Ver: ASSAF NETO, Alexandre. Mercado financeiro. 4. ed. São Paulo: Atlas, 2001. p. 84.
} 
É importante esclarecer que, embora o estudo se ocupe da análise crítica do arcabouço regulatório sistêmico e prudencial pátrio e de como as transformações no sistema financeiro nas últimas décadas o afetam, não está compreendida nos objetivos do trabalho a apresentação de soluções para as falhas e desafios identificados. Ou seja, o trabalho se preocupa com o diagnóstico, e não com a posologia às falhas ao modelo vigente. Evidentemente, um exame que, além de identificar vícios e desafios, apresentasse alternativas para sua solução seria mais completo e produtivo; no entanto, considerando tratar-se de área relativamente inexplorada na doutrina jurídica pátria, bem como a ampla evidência atribuída ao tema em razão da crise financeira recente, a análise crítica do modelo vigente já se apresenta ambiciosa o suficiente para um trabalho dessa natureza. Isso é corroborado pelo fato de este diagnóstico pretender lançar questionamentos a um modelo regulatório que goza atualmente de amplo prestígio no âmbito nacional e internacional em razão do desempenho do SFN ao longo e após a crise financeira recente.

O trabalho tampouco irá tratar da relação entre política monetária e política de regulação e supervisão bancária. Esse tem sido um debate acirrado nas últimas décadas em virtude dos possíveis conflitos de interesse inerentes à condução conjunta dessas funções pela autoridade bancária, provocando discussões sobre o arranjo institucional mais adequado para a promoção destas. Conquanto o presente trabalho reconheça a importância de considerações de ordem monetária na formulação de modelos de regulação e supervisão bancária e viceversa, esse corte metodológico torna-se necessário para viabilizar a análise pretendida. ${ }^{26} \mathrm{~A}$ crise financeira recente provocou também certo arrefecimento nessa discussão, causando inclusive o retorno de determinadas funções que haviam sido destacadas do banco central ao seu órgão de origem, como observado na Inglaterra, levando alguns economistas a declarar a discussão superada. ${ }^{27}$ Tais ponderações, no entanto, não serão objeto do presente trabalho. Igualmente, também não serão examinadas particularidades do mercado de crédito no País, ${ }^{28}$

26 A política monetária de países desenvolvidos, notadamente os Estados Unidos, tem sido apontada como uma das grandes razões para a crise financeira recente (MALAN, Pedro. Uma visão abrangente sobre a crise e o processo de sua superação. In: GARCIA, Márcio; GIAMBIAGI, Fábio (Org.). Risco e regulação, p. 50 e ss.). É importante esclarecer desde já que o presente trabalho não se ocupará da análise sobre a administração de instrumentos típicos de política monetária (taxa básica de juros e depósitos compulsórios, por exemplo), como causa ou elemento de prevenção a crises bancárias.

27 MESQUiTA, Mário M. C.; TORÓS, Mário. Gestão do Banco Central no pânico de 2008. In: GARCIA, Márcio; GIAMBIAGI, Fábio (Org.). Risco e regulação, p. 204.

28 É possível encontrar estudos que procuram atribuir o bom desempenho do SFN na crise recente ao fato de o mercado de crédito interno (baseado no indicador "crédito/PIB") ainda se encontrar em estágio incipiente, 
matérias pertinentes aos ciclos econômicos ou mesmo o estudo sobre a irracionalidade do comportamento humano em situações de crise. Ainda que todos esses temas estejam relacionados, o trabalho versa unicamente sobre a regulação pertinente a crises bancárias.

Finalmente, vale ressaltar que, embora o presente trabalho represente um esforço de balanceamento desse quadro, o fato é que a literatura sobre o tema a ser tratado ainda é dominada por estudos econômicos. Essa é uma dificuldade já reconhecida por juristas de renome em artigos sobre o tema, ${ }^{29}$ e que, inevitavelmente, afeta também esta análise. Assim sendo, haverá recurso intensivo à literatura econômica relevante ao longo do trabalho. É importante destacar, no entanto, que o recurso à teoria econômica não tem como objetivo questionar ou reformular tais preceitos, mas sim pontuar como estes podem afetar determinadas estratégias regulatórias. Assim, ainda que o trabalho se inicie com a apresentação do modelo econômico neoclássico e suas limitações, seu objetivo não é reformular paradigmas econômicos, e sim mostrar de que maneira estes afetam certos pilares do arcabouço regulatório atual, como, por exemplo, o segundo acordo de Basileia e seu foco na autorregulação e disciplina de mercado.

A título conclusivo, e seguindo em linha com algumas das delimitações previamente estabelecidas, é preciso reconhecer as dificuldades de escrever sobre regulação sistêmica e prudencial no contexto atual. Embora a pesquisa sobre a matéria tenha sido iniciada em 2006, a crise financeira recente alçou o tema a novo patamar na agenda de debates sobre regulação financeira no Brasil e no mundo. A consequência imediata e inevitável disso é a proliferação de relatórios e estudos sobre o assunto, em complemento à já extensa literatura econômica existente, cada qual com sua própria metodologia, foco de estudo e conclusão. Seria contraproducente ou mesmo inviável procurar apresentar toda a literatura que trata do tema,

em contraste com a expansão desenfreada do crédito em países desenvolvidos, causando uma deterioração geral da qualidade dos tomadores de recursos e capacidade de adimplemento de suas obrigações (GUIMARÃES, André Luiz de Souza; LIMA, Jorge Cláudio Cavalcante de Oliveira. Avaliação do risco de crédito no Brasil. In: GARCIA, Márcio; GIAMBIAGI, Fábio (Org.). Risco e regulação, p. 220). Embora não se negue a possível "contribuição" dessa característica do mercado financeiro interno ao desempenho do País na crise, o presente trabalho tratará apenas do arcabouço regulatório pátrio destinado à prevenção de crises bancárias, não se ocupando de outras razões de caráter estrutural que possam ter contribuído para esse desempenho.

29 VERÇOSA, Haroldo M. D. Considerações sobre o sistema financeiro. Crises. Regulação e re-regulação, Revista de Direito Mercantil Industrial, Econômico e Financeiro, São Paulo: Malheiros, v. 149-150, p. 30, 2008. 
de modo que o presente trabalho representa apenas um esforço de síntese das principais correntes e teorias que influenciaram a formulação do arcabouço regulatório atual e que estão hoje em discussão. Outra consequência desse quadro é que, ao longo da pesquisa, surgiram e continuarão surgindo propostas legislativas, algumas já tendo inclusive sido convertidas em lei, contendo reformulações substanciais ao arcabouço regulatório de outros países. Também estão em debate novos padrões e estratégias de regulação financeira propostos por fóruns internacionais de discussão sobre regulação financeira e organizações internacionais envolvidas no tema. Apesar de o desempenho considerado positivo do SFN durante a crise recente ter diminuído a intensidade desse movimento no País, ainda assim encontram-se atualmente em exame propostas legislativas com alterações ao arcabouço regulatório pátrio. $\mathrm{O}$ trabalho procura apresentar e contextualizar essas propostas em seu objeto de estudo, mas é impossível prever se, quando e como estas serão aprovadas, o que evidentemente influenciará a extensão da análise dedicada a elas.

A exposição desse rol de limitações ao trabalho faz-se necessária em função de seu objetivo ambicioso e atualidade do tema. Em face dos eventos recentes, talvez tivesse sido mais prudente - certamente menos árdua - a opção por maiores cortes metodológicos e foco em apenas uma modalidade regulatória, quiçá apenas um dos instrumentos de regulação que lhe são subjacentes. Ao contrário, optou-se pela manutenção do objeto de estudo conforme apresentado em virtude da ausência na doutrina jurídica nacional de um trabalho aprofundado que apresentasse, sistematizasse e avaliasse criticamente o arcabouço regulatório sistêmico e prudencial no País, bem como a crença de que as conclusões aqui atingidas contribuem para uma visão inovadora sobre o desempenho do SFN na crise recente e os perigos e desafios que cercam o modelo regulatório vigente. Se o tom inicial do trabalho é marcado pelas suas limitações, espera-se que seus méritos as compensem e tragam não apenas a contribuição original inerente a trabalhos dessa natureza, mas instiguem outros juristas a aprofundar as virtudes, vícios e desafios aqui identificados. 


\section{Capítulo 1 \\ A REGULAÇÃO FINANCEIRA \\ E SUAS JUSTIFICATIVAS}

\subsection{A importância do setor bancário e de sua regulação}

A preocupação com a estabilidade do setor bancário não é recente. Em sua leitura de A riqueza das nações, Wright argumenta que Adam Smith já considerava a presença de bancos sólidos e eficientes como algo essencial ao crescimento econômico de um país. ${ }^{30} \mathrm{Da}$ mesma forma, em seu clássico Lombard street, de 1873, Bagehot ressalta o papel fundamental dos bancos na industrialização da Inglaterra. ${ }^{31}$ Schumpeter, por sua vez, ao tratar da teoria do desenvolvimento econômico, afirma que bancos eficientes acelerariam a inovação tecnológica e, consequentemente, o crescimento econômico, ao identificar e prover fundos para empreendedores com melhores chances de desenvolver e implementar novos produtos e processos de fabricação. ${ }^{32}$ Segundo o autor, tais instituições "autorizariam o empreendedor, em nome da sociedade, a inovar". ${ }^{33}$

A racionalidade por trás dos estudos que enaltecem a importância dos bancos baseiase nas diferentes funções exercidas por tais instituições. Nesse sentido, talvez o papel mencionado com maior frequência pela doutrina jurídica e econômica seja o de canalização de recursos entre agentes econômicos superavitários e deficitários. ${ }^{34}$ Segundo Cortez, o papel primordial dos bancos seria captar a poupança individual, por meio de produtos financeiros

30 WRIGHT, Robert E. The wealth of nations rediscovered: integration and expansion in American financial markets (1780-1850). Cambridge: Cambridge University Press, 2002.

31 BAGEHOT, Walter. Lombard street: a description of the money market. Nova Iorque: John Wiley \& Sons, 1999 (ed. original, 1873).

32 SCHUMPETER, Joseph A. The theory of economic development. Cambridge: Harvard University Press, 2003 (ed. original, 1934).

33 Idem, ibidem, p. 74. Tradução livre.

34 MISHKIN, Frederic S. Prudential Supervision: why is it important and what are the issues. In: MISHKIN, Frederic S. (Org.). Prudential Supervision: what works and what doesn't. Chicago: The University of Chicago Press, 2001. p. 2. 
que geralmente são de amplo acesso popular, como contas-correntes e cadernetas de poupança, e direcionar esses recursos àqueles que deles necessitam para investir em atividades produtivas. ${ }^{35}$ Igualmente, Carvalho de Mendonça acentua a importância dos bancos em uma economia ao salientar que o objetivo principal destes consiste na "intromissão entre os que dispõem de capitais e os que precisam obtê-los; isto é, em receber e concentrar capitais para, sistematicamente, distribuí-los por meio de operações de crédito". ${ }^{36}$

Além desse papel de canalização de recursos entre agentes econômicos, autores como Bagehot enfatizam o caráter estratégico dos bancos na mobilização de recursos com alto valor agregado. Determinados projetos necessitam de uma injeção de capital de considerável porte para que sejam bem-sucedidos, e muitas vezes tais montantes não estão ao alcance de investidores individuais. Assim, sem o acesso a múltiplos investidores, muitos processos produtivos poderiam acabar não se concretizando. Nas palavras do autor: ${ }^{37}$

\begin{abstract}
Nós perdemos completamente a noção de que um empreendimento rentável deva perecer for falta de recursos; no entanto, esse era um fato bastante comum para nossos ancestrais, e ainda é comum em muitos países. Um cidadão no reinado da Rainha Elizabeth [...] poderia pensar que não havia propósito na criação de rodovias (se ele pudesse entender o que era uma rodovia), uma vez que não seria possível amealhar os recursos necessários para construí-las. Nesse momento, em colônias e países selvagens, não há grandes massas de capital transferíveis; não há recursos de monta a serem emprestados para a realização de trabalhos de grande porte.
\end{abstract}

Modernamente, novas teorias sobre a intermediação financeira passaram a focar no papel dos bancos como mitigadores dos custos de transação no mercado. ${ }^{38}$ Com efeito, em um mundo econômico ideal baseado no paradigma clássico de mercados perfeitos de ArrowDebreu, com informação e mercados completos e sem fricções, os intermediários financeiros seriam desnecessários, uma vez que ofertantes e demandantes de recursos financeiros

35 CORTEZ, Thiago Machado. O conceito de risco sistêmico e suas implicações para a defesa da concorrência no mercado bancário. In: CAMPILONGO, Celso F. et al. Concorrência e regulação no sistema financeiro. São Paulo: Max Limonad, 2002. p. 311.

36 CARVALHO DE MENDONÇA, J.X. Tratado de direito comercial brasileiro. Rio de Janeiro: Annuario do Brasil, 1947. p. 13-14.

37 BAGEHOT, Walter. Lombard street: a description of the money market, p. 3-4. Tradução livre.

38 LELAND, Hayne E.; PYLE, David H. Informational asymmetries, financial structure, and financial intermediation. Journal of Finance, 32(2), 1977; DIAMOND, Douglas W.; DYBVIG, Philip H. Bank runs, deposit insurance, and liquidity. Federal Reserve Bank of Minneapolis Quarterly Review, 24(1), 2000 (ed. original, 1983). 
transacionariam diretamente uns com os outros. ${ }^{39}$ Verificando-se o distanciamento de tais condições na realidade, bancos passam a desempenhar papel crítico na redução dos custos associados à obtenção e processamento de informações sobre agentes econômicos, facilitando a alocação de recursos na economia. ${ }^{40}$

Corroborando essas interpretações a respeito da importância do setor bancário, é possível encontrar um expressivo e crescente corpo de trabalhos indicando uma relação positiva entre crescimento econômico e o papel dos bancos. ${ }^{41}$ Esse avanço da percepção econômica sobre o impacto do sistema financeiro na economia acabou se traduzindo na criação de um conjunto de regras e instrumentos de atuação condizente com a necessidade de proteção de seus participantes e alinhamento de seus interesses com os da sociedade. Entre as regras e instrumentos aplicáveis aos participantes do setor bancário, interessam ao presente trabalho aquelas voltadas à prevenção de crises bancárias, quais sejam a regulação sistêmica e a regulação prudencial.

No entanto, antes de adentrar na análise dessas modalidades regulatórias individualmente, é preciso entender por que se considerou que a regulação de seus participantes seria a via apropriada para protegê-los. Em outras palavras, é necessário identificar qual a fundamentação para o desenvolvimento das normas que serão estudadas mais adiante como a forma indicada para assegurar a estabilidade dos bancos. A resposta para

39 LEVINE, Ross. Financial development and economic growth: views and agenda. Journal of Economic Literature, v. 35, p. 690, jun. 1997.

40 Boyd e Prescott argumentam que haveria custos substanciais envolvidos na avaliação de empresas, seus executivos e condições de mercado para fins de investimento. Considerando que poupadores individuais podem não ter a capacidade ou a expertise necessária para coletar, processar e produzir informação relativamente a tais opções de investimento e que, na ausência de intermediários financeiros, cada investidor teria de arcar individualmente com os custos de avaliação do agente econômico, esses custos elevados de produção de informação poderiam acabar limitando o fluxo de capitais na economia. No cenário apresentado pelos autores, a formação de grupos de indivíduos especializados na avaliação de firmas, gerentes e condições de mercado propiciaria economias na aquisição de informação, com ramificações positivas na alocação de recursos. Assim, em um cenário de escassez de capital, intermediários financeiros que produzem melhores informações sobre agentes econômicos poderiam financiar as empresas mais promissoras e induzir uma alocação de recursos mais eficiente. Ver: BOYD, John H.; PRESCOTT, Edward C. Financial intermediary-coalitions. Journal of Economics Theory, n. 38, 1986.

41 BECK et al. Finance and the sources of growth. Journal of Financial Economics, v. 58, n. 1-2, 2000; KING, Robert; LEVINE, Ross. Finance entrepreneurship and growth: theory and evidence. Journal of Monetary Economics, 32(3), 1993; LEVINE, Ross. Financial development and economic growth: views and agenda. Journal of Economic Literature, v. 35, jun. 1997; LEVINE, Ross. Finance and growth: theory and evidence. In: AGHION, Philippe; DURLAUF, Steven. Handbook of Economic Growth. Amsterdam: North-Holland Elsevier Publishers, 2005. 
tal indagação está relacionada às características do setor bancário e às correntes econômicas predominantes que acompanharam a sua evolução, motivo pelo qual torna-se necessário realizar uma breve apresentação destas a seguir.

\subsection{A economia neoclássica e seus desafios}

Entre as correntes econômicas predominantes no último século, merecem destaque as proposições do modelo econômico neoclássico pelo fato de estas poderem ser encontradas na raiz de praticamente todos os trabalhos essenciais sobre a regulação de atividades econômicas. ${ }^{42} \mathrm{O}$ modelo neoclássico também se apresenta como fecundo ponto de partida pelo fato de ser largamente utilizado como base para a maior parte dos debates e formulações teóricas sobre o mercado financeiro e de capitais. ${ }^{43}$ Assim, torna-se necessário relatar, ainda que de forma sucinta, os fundamentos e princípios essenciais da análise neoclássica tradicional e das principais teorias que vêm procurando aperfeiçoá-la, adaptando seus pressupostos teóricos à realidade econômica. ${ }^{44}$

As origens do modelo neoclássico podem ser traçadas aos economistas políticos do século XVIII e início do século XIX, com destaque para o trabalho de Adam Smith. A publicação de A riqueza das nações ${ }^{45}$ pelo autor em 1776 é descrita por alguns autores como o marco divisor do estudo da economia como disciplina autônoma. ${ }^{46}$ A abordagem geral que Smith ajudou a formular lançou bases para o que mais tarde viria a se chamar de economia

42 YAZBEK, Otavio. Regulação do mercado financeiro e de capitais, p. 7.

43 MERTON, Robert C.; BODIE, Zvi. Design of financial systems: towards a synthesis of function and structure. Journal of Investment Management, v. 3, n. 1, p. 2, 2005.

44 Vale salientar desde já que o presente tópico não tem nenhuma pretensão de esgotar o tema relativo à evolução da economia neoclássica desde suas origens até a atualidade, visto que uma análise dessa natureza fugiria ao escopo do trabalho. O objetivo do tópico é apenas pontuar alguns dos pilares essenciais sobre os quais a economia neoclássica se fundou, e as críticas a que está sujeita, com foco nas questões de maior impacto para a regulação bancária, considerando as limitações apresentadas no início do trabalho. É por essa razão que, apesar das inegáveis contribuições de autores como John Maynard Keynes, Douglas C. North, entre outros, para a reflexão sobre as limitações do modelo neoclássico, estes não serão objeto de análise detida neste tópico.

45 SMITH, Adam. An inquiry into the nature and causes of the wealth of nations. Chicago: University of Chicago Press, 1977 (ed. original, 1776).

46 RUBIN, Isaac I. A history of economic thought. London: Ink Links, 1979. p. 167-176. 
clássica, incluindo nomes notáveis como Thomas Malthus e David Ricardo. Segundo Smith, a economia ideal seria um sistema de mercado autorregulador que automaticamente satisfaria as necessidades econômicas da sociedade. $\mathrm{O}$ autor apresenta o mecanismo de mercado por meio da famosa analogia com uma "mão invisível", que leva todos os indivíduos, na busca de seus próprios interesses, a produzir o maior benefício para a sociedade como um todo. Portanto, cria-se a noção de que mercados competitivos tendem a satisfazer as necessidades sociais mais amplas, apesar de serem guiados por interesses individuais.

A obra de Smith apresenta importantes elementos para o desenvolvimento dos postulados clássicos e neoclássicos. Em primeiro lugar, trouxe a atuação dos agentes individuais para o centro do processo, em contraposição ao foco nos elementos naturais de correntes anteriores, como a escola fisiocrata no século XVIII. O agente racional e maximizador de seu bem-estar torna-se uma assunção-chave do sistema, o embrião do homo oeconomicus. Além disso, Smith também atribui maior atenção ao estudo do meio em que atuam tais agentes. É a busca da satisfação individual que faz funcionar as engrenagens do mercado e acaba por levar ao bem comum - ao aprimorar sua capacidade de ofertar e de adquirir bens, os agentes econômicos atuam cada vez mais especializadamente, coordenando os meios de produção. Assim, “começam a se entrelaçar, na economia clássica, a oferta e a demanda dos bens e serviços em um locus ideal". 47

Também merece destaque a teoria do valor desenvolvida pelos autores clássicos. De modo geral, tais autores, notadamente por meio dos trabalhos de David Ricardo e John Stuart Mill, reconheciam que o custo de produção de um determinado bem dependia dos custos envolvidos em sua produção. Para Smith, por exemplo, o valor do produto refletia a soma de três componentes: o salário, os lucros e os aluguéis. Observa-se que o processo de formação de preços nesse modelo teórico dava-se apenas no lado da oferta, por meio do valor do trabalho nele incorporado, e não da contraposição entre a oferta e a demanda. Essa foi justamente uma das maiores limitações encontradas na teoria clássica, o que acabou por

47 YAZBEK, Otavio. Regulação do mercado financeiro e de capitais, p. 9. 
motivar novas críticas e interpretações sobre o processo produtivo, levando à reformulação do modelo nas décadas seguintes. ${ }^{48}$

As raízes do modelo neoclássico podem ser traçadas ao final do século XIX, com a chamada "revolução marginalista", tendo William Stanley Jevons e Alfred Marshall na Inglaterra, Carl Menger na Áustria e Léon Walras na Suíça entre os seus principais idealizadores. ${ }^{49}$ Tais autores desenvolveram concomitantemente o princípio da utilidade marginal, que serviria como novo fundamento da teoria do valor. Foi por meio do conceito de utilidade marginal que esses autores demonstraram que o preço de um produto não era determinado apenas por seu custo de produção, como imaginavam os economistas clássicos, mas também pelo valor dado a ele pelo consumidor marginal, isto é, o último consumidor disposto a comprar a mercadoria. Ao explicar o preço a partir do valor dado ao bem pelo último consumidor, permitiu-se, na prática, conectar produto e consumidor, abrindo, assim, as portas para elaboração de uma teoria que tratasse do funcionamento do mercado como um todo. $^{50}$

A escola neoclássica destacou-se pela busca por maior rigor metodológico e pureza conceitual, influenciados pelo ciclo de prosperidade econômica e "cientificização" ou "matematização" da economia no século XX. A forma de garantir o progresso era fazer com que a sociedade usasse o melhor conhecimento científico disponível à época. Partia-se da premissa de que objetivos sociais poderiam ser atingidos se fosse permitido que o conhecimento científico organizasse a agenda social. Nesse sentido, a economia neoclássica conceitualizou os agentes, firmas e famílias como atores racionais maximizadores de bemestar, com ênfase nos planos de conduta formulados para esses agentes econômicos individuais. Daí o porquê de a escola neoclássica ser associada a um "individualismo metodológico", em contraste às análises historicizantes que marcaram os modelos teóricos anteriores. 51

\footnotetext{
48 YAZBEK, Otavio. Regulação do mercado financeiro e de capitais, p. 9.

49 SALOMÃO, Calixto. Regulação e concorrência (estudos e pareceres). São Paulo: Malheiros, 2002. p. 57.

50 Idem, ibidem, p. 57.

51 YAZBEK, Otavio. Regulação do mercado financeiro e de capitais, p. 10.
} 
Nesse contexto, o elemento central e bem conhecido da teoria econômica neoclássica torna-se a questão da alocação de recursos e, mais especificamente, a eficiência econômica. ${ }^{52}$ Há uma preocupação determinante com a busca da alocação de recursos mais eficiente para a sociedade. Para tal, os agentes econômicos são modelados como otimizadores que são levados ao "melhor" resultado. A referência mais comum para aferir tal eficiência foi o método do italiano Vilfredo Pareto, em que um resultado é considerado eficiente quando os bens não podem ser realocados para tornar maior o bem-estar de uma pessoa sem que haja diminuição do bem-estar de outra. ${ }^{53}$

Enquanto teoria preocupada primordialmente com a alocação eficiente de recursos, o modelo neoclássico acabou se propondo a reproduzir as condições de mercado que propiciariam aquele resultado eficiente. Para tal, era preciso prever como se comportariam os participantes de mercado e quais os resultados de seu intercâmbio econômico, o que envolvia a assunção de determinadas premissas centrais ao seu funcionamento, como a existência de mercados sem fricção e eficientes, produtos homogêneos e informação completa com agentes econômicos atomizados e racionais. ${ }^{54}$

Essa tentativa de reprodução do funcionamento do mercado como se fosse um experimento de laboratório acabou, no entanto, sujeitando o modelo neoclássico a críticas. Efetivamente, a prática econômica demonstrou que algumas de suas principais hipóteses eram absolutamente irreais, o que motivou o surgimento de novas correntes econômicas que, embora não negassem completamente o mainstream neoclássico, procuraram flexibilizar alguns de seus pilares essenciais de modo a compatibilizá-los com o "teste da realidade". 55

É nesse sentido que alguns autores passaram a se ocupar de um estudo mais institucional, econômico-jurídico, que investigasse os elementos básicos para a realização das transações no mercado. Tais críticas ganharam corpo por meio da "nova economia

\footnotetext{
52 SALOMÃO, Calixto. Regulação e concorrência, p. 56.

53 PINDYCK, Robert S.; RUBINFELD, Daniel L. Microeconomia. 4. ed. São Paulo: Makron Books, 1999. p. 637.

54 ARAÚJO, Carlos Roberto Vieira. História do pensamento econômico: uma abordagem introdutória. São Paulo: Atlas, 2008. p. 85-86.

55 SALOMÃO, Calixto. Regulação e concorrência, p. 57.
} 
institucional", termo que abrange um amplo conjunto de escolas que apresentam como ponto em comum a preocupação com as instituições, incluindo-se aí o próprio mercado e formas de organização adotadas para a realização de negócios e trocas no seu interior, em contraste com a preocupação essencial dos neoclássicos com os mecanismos microeconômicos que orientam o mercado. ${ }^{56}$

Na nova economia institucional o foco na teoria marginalista de formação dos preços é substituído pela preocupação com o funcionamento das instituições. Entre as importantes ressalvas ao modelo neoclássico, encontra-se o reconhecimento de situações em que os agentes econômicos defrontam-se com incertezas, seja quanto às condições de mercado e às relações entre oferta e demanda, ou quanto aos eventos exógenos que afetam as preferências e condições de mercado. Em sua obra Risco, incerteza e lucro, ${ }^{57}$ de 1921, Frank H. Night contesta a fragilidade e a generalidade de alguns dos pontos de partida da microeconomia então vigente e a simplificação demasiada do comportamento dos agentes econômicos nos modelos adotados. A maior falha de tais modelos, segundo o autor, residiria na indiferença a um aspecto essencial na conformação de suas ações, que seria justamente o papel da incerteza na tomada de decisões. Isto porque a incerteza estaria necessariamente vinculada à natureza antecipatória da atividade econômica empresarial, haja vista que a produção destinada ao mercado envolveria esforços de previsão em relação a diversos pontos, como os resultados do processo produtivo (quantidade produzida e preço final) e o comportamento dos demais agentes para os quais se destinam os produtos, entre outros. ${ }^{58}$ Tais críticas foram posteriormente aprofundadas por Friedrich A. Hayek, cuja obra também ficou marcada pelo questionamento a certas premissas do modelo neoclássico, destacando os problemas do conhecimento e da informação no processo econômico. ${ }^{59} \mathrm{O}$ autor ataca o modelo neoclássico de equilíbrio, voltando-se para a problemática concreta do "conhecimento econômico" e da

56 A corrente da nova economia institucional é ampla, incluindo economistas de variados matizes e tendências ideológicas. Entre os autores que traduzem em seus trabalhos preocupações relacionadas ao objeto principal de atenção da nova economia institucional, podem-se mencionar Armen Alchian, Harold Demsetz, Kenneth Arrow, Douglas North, Oliver Williamson e Friedrich Hayek, entre outros. Ver: SALOMÃO, Calixto. Regulação e concorrência, p. 57-58.

57 KNIGHT, Frank H. Risk, uncertainty and profit. Washington: Beard Group, 2002 (ed. original, 1921).

58 YAZBEK, Otavio. Regulação do mercado financeiro e de capitais, p. 18.

59 Notadamente os seguintes trabalhos: HAYEK, Friedrich A. Economics and knowledge. In: Individualism and economic order. Chicago: The University of Chicago Press, 1948 (ed. original, 1937); e HAYEK, Friedrich A. The use of knowledge in society. In: Individualism and economic order. 
distribuição das informações entre os agentes. Outrossim, o autor lança bases para o entendimento do papel das instituições como fontes de informação. ${ }^{60}$

Outra importante ressalva ao modelo neoclássico refere-se à análise da relevância das transações e a determinação dos custos envolvidos nas trocas entre os agentes econômicos. Entre os estudos sobre o tema, destaca-se o trabalho seminal de Ronald Coase, A natureza da firma, de $1937,,^{61}$ em que o autor relaciona os custos de transação àqueles custos necessários para realizar uma transação no mercado, em vez de executá-la no interior da empresa. A inovação do trabalho reside na explicação das organizações como o resultado de um comportamento minimizador de custo (incluindo custos de transação) em um mundo de informação limitada e oportunismo. Sua teoria foi posteriormente desenvolvida por Kenneth Arrow e Oliver Williamson, que sistematizaram o conceito de custos de transação e ampliaram seu campo de aplicação a outras áreas, como a teoria das organizações e o direito antitruste. $^{62}$

Além dessas críticas a dois dos pilares mais caros da escola neoclássica - agentes econômicos dotados de plena informação e a existência de mercados sem fricção -, um crescente número de autores ligados à chamada linha de economia comportamental (behavioral economics) passou a contestar a crença fundamental do modelo neoclássico na racionalidade dos agentes econômicos. O trabalho de Gary Becker, Abordagem econômica ao comportamento humano, ${ }^{63}$ de 1976 , foi um dos precursores na exploração da relação entre fatores psicológicos e comportamento econômico. Sua obra abriu portas para a proposição de modelos teóricos sensíveis a fricções de mercado e desvios de conduta racional por parte dos agentes, em contraste à robustez das assunções do modelo neoclássico. ${ }^{64} \mathrm{~A}$ aplicação dos ensinamentos da psicologia às finanças experimentou forte crescimento na última década,

60 YAZBEK, Otavio. Regulação do mercado financeiro e de capitais, p. 21.

61 COASE, Ronald $H$. The nature of the firm. In: The firm, the market and the law. Chicago: The University of Chicago Press, 1990 (ed. original, 1937).

62 ARROW, Kenneth. Limits of organization. Nova Iorque: Norton, 1974; e WILLIAMSON, Oliver. Assessing vertical market restrictions: antitrust ramifications of the transaction cost approach. University of Pennsylvania Law Review, n. 127, 1979.

63 BECKER, Gary. The economic approach to human behaviour. Chicago: University of Chicago Press, 1976.

64 SIMON, Herbert A. Models of bounded rationality. Cambridge: MIT Press, 1982; e KAHNEMAN, Daniel; SLOVIC Paul; TVERSKY, Amos. Judgment under uncertainty: heuristics and biases. Cambridge: Cambridge University Press, 1982. 
contribuindo para a explicação de como a confiança excessiva de investidores pode gerar as chamadas "bolhas no mercado". ${ }^{65}$

Evidentemente, a breve relação de economistas apresentada não pretende esgotar o valor de suas obras, ou mesmo negar as valiosas contribuições de outros autores, bastando para efeitos do presente trabalho apenas pontuar alguns dos importantes questionamentos por eles lançados. Além disso, vale ressaltar que, embora seus estudos disputem alguns dos principais pressupostos da escola neoclássica, eles não implicam necessariamente a superação desse modelo. Pelo contrário, embora tais autores visem a correção de falhas nas premissas da teoria de mercados eficientes, muitos o fazem apoiando-se na elegância e consistência formais desse mesmo aparato, notadamente o dogma neoclássico da eficiência como matriz e indicador da direção tanto da economia como do direito. É nesse sentido que Salomão considera que Coase seria melhor visto como um precursor da nova economia institucional, e não como verdadeiro construtor, na medida em que não se afasta do postulado neoclássico da maximização da eficiência. A preocupação básica que direciona sua teoria é justamente a remoção dos custos de transação para atingir o resultado eficiente. ${ }^{66}$

Tampouco foram as críticas ao paradigma neoclássico suficientes para arrefecer o entusiasmo de economistas com a teoria de mercados eficientes. Se os ataques à economia neoclássica tradicional baseiam-se nas evidências de anomalias que rejeitam seus principais postulados, os defensores do modelo neoclássico respondem que tais alegadas anomalias não existem, ou podem ser explicadas dentro do framework neoclássico, e que, em ambos os casos, as alternativas propostas não ofereceriam melhor solução. ${ }^{67}$

65 Conforme apontamento da revista The Economist: "A economia comportamental, que aplica os ensinamentos da psicologia às finanças, 'explodiu' na última década. Economistas dessa linha afirmam que os seres humanos tendem a ser muito confiantes em suas próprias habilidades, podendo extrapolar tendências recentes para o futuro, uma combinação que pode contribuir para a geração de bolhas. Há também evidências de que perdas podem tornar investidores muito avessos a risco, exagerando declínios de preços quando a bolha estoura". Ver: THE ECONOMIST. Efficiency and beyond, 18 jul. 2009, p. 71-72. Tradução livre.

66 SALOMÃO, Calixto. Regulação e concorrência, p. 59.

67 Ver, por exemplo: FAMA, Eugene. Market efficiency, long-term returns, and behavioral finance. Journal of Financial Economics, v. 49, n. 3, 1998; e RUBINSTEIN, Mark. Rational markets: yes or no? The affirmative case. Financial Analysts Journal, v. 57, n. 3, 2001. 
Mais recentemente, a eclosão da crise financeira que abalou os mercados financeiro e de capitais globais reforçou a onda de críticas a alguns postulados neoclássicos que, muito embora já tenham sido objeto de análise e temperamentos pela doutrina econômica nas últimas décadas, continuam a inspirar modelos econômicos, notadamente os voltados à área de finanças. Economistas de renome como Paul Krugman chamam a atenção para os riscos associados à confiança exagerada em modelos econômicos inspirados em mercados sem fricção, informação completa e agentes racionais e a tentativa de reprodução do mercado em laboratório. ${ }^{68}$ Mais importante, é preciso notar como tais modelos influenciaram e continuam a influenciar a política regulatória. Com efeito, um artigo da revista The Economist sintetiza bem esse quadro, ao afirmar: ${ }^{69}$

O modelo macroeconômico padrão, embora não seja descartável, sofre de evidentes
limitaçães, como a premissa de mercados completos e finanças sem fricção. Como
essas limitações são óbvias, e os economistas estão bastante cientes delas, eles
podem e distanciam-se desse modelo padrão, mas isso não reduz sua importância
[... Ele continua sendo o ponto de partida para onde economistas retornam após
seus devaneios teóricos. Poucos realmente acreditam em todas as suas premissas,
mas ainda menos ousariam adotar outro ponto de partida. Infelizmente, são esses
modelos primitivos, em vez de seus descendentes sofisticados, que acabam
exercendo maior influência no mundo da política e prática regulatória. Isso é
parcialmente devido ao fato de suas premissas perdurarem por tempo suficiente para
encontrarem seu caminho dos meios acadêmicos para a formulação de políticas
regulatórias.

A colocação é oportuna, pois mostra que, apesar de suas limitações, a teoria neoclássica continua a inspirar modelos econômicos e políticas regulatórias na atualidade. Isso também é verdadeiro no campo da regulação financeira que, conforme se observará nos próximos capítulos, também apoia-se em estratégias regulatórias de cunho neoclássico. A esse respeito, embora o presente trabalho não possua nenhuma pretensão de reformular tal paradigma econômico, é importante ter as premissas desse modelo em mente para verificar como estas podem limitar a eficácia de políticas regulatórias sistêmicas e prudenciais para o setor bancário.

68 THE NEW YORK TIMES. How did economists get it so wrong?, 2 set. 2009.

69 THE ECONOMIST. Efficiency and beyond, 18 jul. 2009, p. 71. Tradução livre. 


\subsection{As falhas de mercado no setor bancário}

O reconhecimento de que a teoria neoclássica era incapaz de lidar com a vida econômica real em toda a sua complexidade motivou o estudo dos fatores que poderiam impedir o modelo de atingir os resultados pretendidos. Nesse sentido, reconheceu-se a existência de situações em que as premissas fundamentais inerentes ao funcionamento do mercado de forma autônoma e eficiente estavam ausentes, impedindo o seu funcionamento "correto". Pelo fato de tais fatores representarem obstáculos à sua plena operacionalidade, estes receberam o nome de falhas ou imperfeições de mercado.

Pode-se atribuir a origem das discussões a respeito das falhas de mercado à obra $A$ economia do bem-estar, ${ }^{70}$ de Arthur Cecil Pigou, publicada em 1920, em que o autor desenvolveu o conceito de externalidades. Embora a identificação dessas falhas de mercado, particularmente as externalidades, já houvesse sido objeto de estudo por outros autores, como Alfred Marshall, em sua obra Princípios da economia, ${ }^{71}$ de 1890, foi Pigou quem desenvolveu o conceito e apresentou propostas concretas de solução para tais eventos. ${ }^{72}$ Com efeito, ao tratar da falha de mercado relativa à questão da poluição - que, conforme se observará, é considerada uma externalidade negativa -, o autor sugere o estabelecimento de taxas e impostos para neutralizar os danos dos custos externos, entre eles os danos ambientais de variadas origens, criando as bases para o conhecido "princípio do poluidor pagador". Da mesma forma, o autor defende o estabelecimento de subsídios para atividades que gerem efeitos positivos sobre outros agentes econômicos. ${ }^{73}$

Um aspecto de grande importância na teoria de Pigou é que a existência de falhas de mercado seria a primeira e principal justificativa para a regulação estatal destinada à sua correção. Mais importante, o direito teria um papel fundamental nesse contexto como mecanismo de correção das falhas de mercado, incentivando ou inibindo determinadas atividades conforme os efeitos por elas provocados em outros agentes econômicos.

\footnotetext{
70 PIGOU, Arthur C. The economics of welfare. Nova Iorque: Cosimo, 2005 (ed. original, 1920).

71 MARSHALL, Alfred. Principles of economics. Nova Iorque: Cosimo, 2006 (ed. original, 1890).

72 ARAÚJO, Carlos Roberto Vieira. História do pensamento econômico, p. 93-94.

73 Obviamente que essas conclusões se baseiam na premissa de que os custos dessas ferramentas de correção de incentivos não excedam os benefícios trazidos pelo ajuste das falhas de mercado.
} 
Apesar de ter experimentado larga disseminação nas primeiras décadas do século $\mathrm{XX}$, a teoria de Pigou passou a enfrentar crescentes questionamentos teóricos, principalmente a partir da publicação do aclamado artigo $O$ problema do custo social, ${ }^{74}$ por Ronald Coase em 1960. Em seu artigo, Coase refuta as conclusões de Pigou ao afirmar que taxas e subsídios não seriam necessários para resolver a questão dos custos externos, e que o desfecho eficiente poderia ser atingido por meio da negociação entre as partes afetadas pelos custos ou benefícios externos. Esse resultado, conhecido como teorema de Coase, dependeria de determinados fatores, como direitos de propriedade bem definidos, agentes econômicos racionais e custos de transação mínimos. Nesse contexto, o direito teria como função primordial a estipulação de regras voltadas a assegurar tais fatores, e o propósito da regulação estatal seria reduzido apenas à alocação inicial do direito à parte que lhe atribui maior valor. ${ }^{75}$

O mérito dessas diferentes correntes teóricas e seus efeitos para as teorias da regulação serão tratados em maior detalhe mais adiante, quando será discutida a relação entre as falhas de mercado e a regulação financeira. Para efeito do presente tópico, basta reconhecer que, empiricamente, a regulação ainda procura tratar das dificuldades para a consecução de soluções eficientes pelo sistema de mercado, legitimando-se a partir das distorções e insuficiências de tal sistema. Dessa forma, a discussão sobre a regulação financeira perpassa necessariamente pela análise das principais falhas de mercado que afetam o setor bancário. ${ }^{76}$

\subsubsection{Assimetrias informacionais}

O funcionamento eficiente do mercado pressupõe o acesso dos agentes econômicos às informações sobre ele e às características dos produtos nele negociados. As informações seriam distribuídas de maneira igualitária entre os agentes econômicos e, como resultado, o sistema de preços conteria toda a informação relevante para os participantes de mercado. ${ }^{77} \mathrm{~A}$

\footnotetext{
74 COASE, Ronald H. The problem of social cost. In: The firm, the market and the law.

75 HOVENKAMP, Herbert J. The Coase theorem and Arthur Cecil Pigou. Arizona Law Review, v. 51, 2009.

76 Há inúmeras falhas de mercado, de modo que serão tratadas aqui apenas aquelas consideradas mais relevantes para a regulação sistêmica e a regulação prudencial, que são as assimetrias informacionais, concentração econômica e externalidades. Para uma abordagem completa do tema, ver: NUSDEO, Fábio. Curso de economia, p. 138 e ss.

77 Idem, ibidem, p. 143.
} 
realidade social, no entanto, demonstrou que essa premissa não é verdadeira, havendo situações de discrepância na disponibilidade da informação em razão da existência de custos de transação que onerariam a sua obtenção por parte dos agentes econômicos interessados. ${ }^{78}$ A tais situações de discrepância de informação entre os participantes do mercado deu-se o nome de "assimetrias informacionais", havendo diversas formas como estas podem se manifestar.

Entre as assimetrias informacionais existentes no setor bancário, destacam-se as limitações inerentes à relação entre o principal e o agente, inseridas no contexto da chamada "teoria da agência". ${ }^{79}$ Segundo Saddi, o problema da agência se resume à existência de um principal e um agente que, como entidades distintas, não possuem os mesmos objetivos. $\mathrm{O}$ principal deseja induzir o agente a agir com base no seu interesse particular, mas não possui informações completas sobre as variáveis que afetam o negócio ou sobre a possibilidade real de dirigir o comportamento do agente. ${ }^{80}$ Nesse sentido, o autor sustenta que a assimetria que aflige esse relacionamento envolve a criação de um sistema de informações ao principal para monitorar as ações do agente, bem como prover também ao agente um esquema de incentivos, de modo que, ainda que seus objetivos pessoais não coincidam, haja pelo menos interesse comum na condução de suas atividades.

Nesse aspecto, Goodhart lista como consequências dessa relação entre principal e agente que representam maiores desafios para a regulação bancária a questão da seleção adversa e do risco moral. ${ }^{81}$ A seleção adversa ocorre no momento anterior à realização da

78 YAZBEK, Otavio. Regulação do mercado financeiro e de capitais, p. 42.

79 A relação de agência é aquela em que poderes são delegados a uma determinada pessoa para que esta aja em nome e benefício de seus constituintes. Um relacionamento dessa ordem pressupõe a existência de duas posições, denominadas de principal (aquele que contrata) e agente (aquele que é contratado e executa funções por conta e ordem do principal). Segundo Stone, haveria quatro aspectos característicos dessa relação, quais sejam: (i) sempre há algum valor econômico criado pelo agente, ou porque ele detém algum tipo de conhecimento técnico especial, ou porque possui mais informação, ou ainda porque conta com mais tempo, permitindo-lhe realizar a tarefa a um menor custo que o principal; (ii) os interesses do principal e os do agente são diferentes e distintos - cada um visa maximizar seus interesses próprios e recompensas, obtendo o maior retorno possível pelos seus atos; (iii) o agente pode tomar algumas medidas que desenvolvam seus interesses particulares à custa do principal; (iv) é difícil e dispendioso monitorar ou verificar o comportamento do agente. Ver: STONE, Richard. The law of agency. London: Cavendish Publishing, 1995. p. 13, apud SADDI, Jairo. Crise e regulação bancária, p. 75. SADDI, Jairo. Crise e regulação bancária, p. 74-75. GOODHART, Charles. Incentive structures for financial regulation. London: LSE, apud SADDI, Jairo. Crise e regulação bancária, p. 79. 
operação financeira, em virtude de os tomadores de pior qualidade (ou seja, maior risco de crédito) serem aqueles com maior disposição de tomar um empréstimo ou pagar uma maior taxa de juros. Isso acontece porque, caso o projeto seja malsucedido, o credor é que arcará com a maior parte, senão a totalidade do prejuízo. Além disso, como o ofertante do capital não dispõe de toda a informação necessária acerca do tomador de recursos, este último tem um estímulo para beneficiar-se de tal situação, utilizando os fundos de forma indevida, apenas para seu proveito pessoal. ${ }^{82}$

Assim, agentes econômicos com maior probabilidade de causarem um resultado indesejável são aqueles com maior interesse de serem escolhidos, inclusive concordando com maiores taxas de juros, pois sabem que dificilmente pagarão o empréstimo. Como a seleção adversa aumenta a probabilidade de que empréstimos sejam feitos a pessoas com esse perfil, os agentes econômicos com capacidade para emprestar capital podem decidir não realizar empréstimos mesmo sabendo que há tomadores com bom risco de crédito no mercado, situando os níveis de atividade econômica em patamares subótimos. Esse resultado assemelha-se àquele descrito na clássica análise de Akerlof em $O$ mercado para limões, que trata desse efeito no mercado de carros usados. ${ }^{83}$

Há evidências de que problemas informacionais seriam determinantes na aferição do grau de contestabilidade no mercado de crédito. ${ }^{84}$ A racionalidade básica é de que a seleção adversa afetaria as estratégias de precificação, uma vez que bancos concorrentes não conseguiriam fazer ofertas para atrair os melhores clientes, sem, ao mesmo tempo, atrair também os de pior qualidade. Ausubel estuda esse efeito no mercado de cartões de crédito, encontrando evidências de que a competição agressiva incentivaria o recrutamento de piores

82 MISHKIN, Frederic S. Prudential Supervision: why is it important and what are the issues, p. 5.

83 "Limão" é o termo utilizado por Akerlof para se referir àqueles veículos em má condição de conservação, com vícios ocultos. Segundo Akerlof, em razão do receio de que o carro apresente problemas, compradores irão oferecer um preço menor do que aquele indicado pelo vendedor. Isso acaba se refletindo no processo de formação de preços, e, consequentemente, os donos de carros em bom estado de conservação terão menos estímulo para ofertar seus veículos. Ver: AKERLOF, George. The market for lemons: quality uncertainty and the market mechanism. Quarterly Journal of Economics, v. 84, n. 3, 1970.

84 DELL'ARICCIA, Giovanni. Asymmetric information and the structure of the banking industry. The European Economic Review, v. 45, 2001; MARQUEZ, Robert. Competition, adverse selection and information dispersion in the banking industry. The Review of Financial Studies, v. 15, 2001. 
clientes, além de induzi-los a tomar mais empréstimos do que os bons clientes. ${ }^{85}$ Efeitos semelhantes foram encontrados no caso brasileiro, em estudo sobre apreçamento de empréstimos no cheque especial. ${ }^{86}$ Segundo Pinho de Mello, isso também poderia ser caracterizado como uma barreira à entrada no mercado bancário, uma vez que, após os bancos estabelecerem relacionamento com os tomadores, os potenciais entrantes correriam o risco de recrutar somente os piores tomadores. ${ }^{87}$

Já o estudo do risco moral, também conhecido pela expressão inglesa moral hazard, surge historicamente com a análise das relações entre seguradores e segurados, em que a proteção contra perdas para os contratantes de seguro faz com que estes tenham menos incentivos para adotarem os cuidados normais em relação ao interesse segurado. ${ }^{88}$ Em razão disso, Turczyn afirma que o risco moral consiste na tendência de comportamento dos agentes econômicos de tanto mais se arriscarem quanto maior for o aparato de proteção colocado à sua disposição. ${ }^{89}$

Os incentivos negativos decorrentes do risco moral no comportamento dos bancos são um tema de grande importância para a regulação sistêmica e prudencial. A criação de redes de segurança (safety nets) para bancos pelas autoridades reguladoras pode aumentar a propensão dessas instituições ou de seus correntistas à tomada de riscos. No caso de mecanismos de seguro de depósitos, por exemplo, isso aconteceria porque a certeza de que serão ressarcidos no caso de quebra bancária diminuiria os incentivos para os correntistas monitorarem a saúde financeira dos bancos nos quais mantêm contas, enfraquecendo um importante fator de controle à tomada excessiva de riscos pelos bancos. Da mesma forma, o auxílio indiscriminado a bancos em crise pelo governo pode também gerar incentivos à

85 AUSUBEL, Lawrence. The failure of competition in the credit card market. The American Economic Review, v. 81, n. 1, p. 50-81, 1991.

86 PINHO DE MELLO, João Manoel. Adverse selection in the market for unsecured loans: the case of overdraft loans in Brazil. 2004. Tese (Doutorado) - Department of Economics, Stanford University. Mimeografado.

87 PINHO DE MELLO, João Manoel. Proposta de delimitação do escopo de análise da SDE em atos de concentração bancárias e apurações de conduta. Seminário de Estudos e Métodos Quantitativos Aplicados à Defesa da Concorrência e à Regulação Econômica, Instituto de Pesquisas Econômicas Aplicadas (IPEA), Relatório Final, Área II.1, ANPEC/IPEA/SDE, abr. 2005, p. 27.

88 KRUGMAN, Paul. The return of depression economics and the crisis of 2008. New York: Norton, 2009. p. 63.

89 TURCZYN, Sidnei. O Sistema Financeiro Nacional e a regulação bancária, p. 73. 
tomada excessiva de risco por parte dessas instituições, devido à certeza do resgate governamental. Em razão de sua importância fundamental no presente trabalho, os efeitos do risco moral sobre a atuação dos bancos serão retomados no Capítulo 3.

\subsubsection{Concentração econômica}

A concentração econômica é considerada uma falha de mercado na medida em que nega um dos pressupostos básicos do sistema de mercado, qual seja a atomização dos agentes econômicos. Para que o mercado seja competitivo, este deve ser composto por um número razoavelmente elevado de compradores e vendedores, de modo que nenhum deles venha a deter participação ou importância excessivamente superior à de seus pares, que lhe atribua a capacidade de influenciar decisivamente o preço de um bem. Em outras palavras, um mercado perfeitamente competitivo rejeita a existência de agentes econômicos que possam exercer o chamado "poder de mercado". 90

Essa concepção de concentração econômica como falha de mercado é sujeita a críticas, haja vista a possibilidade de estruturas concentradas apresentarem eficiências. Nesse sentido, alguns autores descrevem o fenômeno da concentração crescente por meio da busca por economias de escala e escopo, ${ }^{91}$ provocando o "agigantamento do tamanho médio das unidades produtoras". 92

90 Segundo o Guia para Análise de Atos de Concentração, da Secretaria de Acompanhamento Econômico do Ministério da Fazenda (disponível em: <www.seae.fazenda.gov.br/central_documentos/legislacao〉; acesso em: 8 dez. 2010), o poder de mercado refere-se a situações em que uma empresa unilateralmente, ou um grupo de empresas agindo coordenadamente, aumenta os preços (ou reduz quantidades), diminui a qualidade ou a variedade dos produtos ou serviços, ou ainda reduz as inovações relativas aos níveis que vigorariam sob condições de concorrência irrestrita, por um período razoável de tempo, com a finalidade de aumentar seus lucros.

91 As economias de escala referem-se ao processo de redução do custo unitário de um bem na medida em que o volume produzido aumenta, em razão das chamadas indivisibilidades técnicas, ou seja, a impossibilidade ou inviabilidade econômica de se produzirem equipamentos para serem aplicados apenas a um número reduzido de peças ou unidades. As economias de escopo referem-se às reduções nos custos médios derivados da produção conjunta de bens distintos, dados os preços dos insumos. Tais reduções podem ocorrer pelo fato de insumos comuns aos distintos bens serem mais bem aproveitados por uma só empresa do que por várias, ou porque os recursos de distribuição e comercialização são mais bem aproveitados por uma só empresa do que por várias. Conforme exemplo de Fábio Nusdeo, os bancos representariam um típico caso de economias de escopo, uma vez que, além da intermediação financeira, operam sistemas de cartões de crédito ou pagamento, realizam cobranças, alugam cofres de aluguel e realizam a custódia de valores. $\mathrm{Na}$ 
Além das economias de escala e escopo, no caso das concentrações verticais, estas poderiam ser justificadas também a partir de uma análise dos custos de transação. A definição do preço relativo de cada produto, principalmente entre compradores que não se encontram em mercados concorrenciais, pode ser um elemento de difícil determinação, levando muitas vezes a impasses. Isso é um motivo de preocupação frequente para os agentes econômicos, principalmente nos casos em que fornecedores se negam a especificar as condições em que um insumo virá a ser fornecido no futuro. Tais incertezas representam uma inconveniência para compradores que querem planejar sua atividade econômica, e, justamente por isso, há um incentivo para o agente econômico organizar tais atividades internamente à empresa. ${ }^{93}$

Observa-se, portanto, que a concentração econômica pode ou não atuar como obstáculo à alocação eficiente de recursos. A resposta estatal a esse desafio consubstancia-se nas normas antitruste ou de defesa de proteção à livre concorrência, ou ainda de repressão ao abuso do poder econômico ou posição dominante, conforme a denominação escolhida pelos diferentes ordenamentos jurídicos. É justamente por isso que, na maioria dos países, incluindo o Brasil, as operações de concentração econômica são submetidas ao escrutínio de uma autoridade antitruste, que balanceará potenciais efeitos positivos decorrentes da concentração com seus possíveis efeitos deletérios. ${ }^{94}$

No caso do setor bancário, além dos efeitos sobre a livre concorrência, a concentração econômica tem implicações particularmente relevantes para a regulação financeira. Conforme se observará nos próximos capítulos, o processo de concentração e conglomeração de atividades financeiras observado nas últimas décadas no Brasil e no mundo apresenta uma série de desafios à atuação das autoridades bancárias. Em razão disso, torna-se necessário realizar um breve relato sobre a evolução recente da estrutura do setor bancário.

medida em que a segunda atividade aproveita o capital fixo da primeira, reparte entre elas os respectivos custos. Ver: NUSDEO, Fábio. Curso de economia, p. 152.

Idem, ibidem, p. 147.

SALOMÃO, Calixto. Direito concorrencial: as estruturas. 2. ed. São Paulo: Malheiros, 2002. p. 292.

NUSDEO, Ana Maria. Defesa da concorrência e globalização econômica: o controle da concentração de empresas. São Paulo: Malheiros, 2002. p. 58. 


\subsubsection{Concentração e conglomeração de atividades financeiras}

A evolução do setor bancário de diversos países ao redor do mundo na segunda metade do século XX indica uma concentração econômica crescente. Em trabalho referente ao período de 1956-1980, Rhoades analisa a concentração dos depósitos bancários entre os maiores bancos do mundo, concluindo que a participação dos 100 maiores bancos no total de ativos dos 500 maiores bancos aumentou de 63,3\%, em 1956, para 70,5\%, em 1979. ${ }^{95}$ Apesar de um leve declínio nesse nível de concentração no período de 1979 a 1989, o processo teria sido retomado e acelerado na década seguinte. ${ }^{96}$

Segundo relatório do Grupo dos 10, ao longo da década de 1990, o número anual de operações de fusões e aquisições no sistema financeiro mais do que triplicou, e o valor dessas operações aumentou mais de dez vezes. ${ }^{97} \mathrm{O}$ número de operações cresceu não apenas em valores absolutos, mas também em valores médios, passando de US\$227,6 milhões em 1990 para US\$826,6 milhões em 1999. Comparando o valor dessas operações com o PIB dos países em que ocorreram, passaram de uma média de 0,24\% em 1990 para 1,57\% em $1999 .{ }^{98}$

Apesar de o movimento ter afetado o sistema financeiro como um todo, grande parte dessa atividade de fusões e aquisições ocorreu no setor bancário. Segundo o relatório, aquisições de bancos representaram em média $60 \%$ do total de operações e $70 \%$ do valor dessas operações nos países analisados. Além disso, o relatório aponta que a maior parte das operações deu-se entre empresas atuando no mesmo segmento do sistema financeiro e de um mesmo país. ${ }^{99}$

95 RHOADES, Stephen A. Concentration of world banking and the role of US banks among the 100 largest (1956-1980). Journal of Banking and Finance, v. 7, n. 3, p. 427-437, 1983.

96 THORNTON, John. Concentration in world banking and the role of Japanese banking. Revue de La Banque, v. 1, p. 263-272, maio 1991.

97 GROUP OF 10. Report on consolidation in the financial sector. Washington: Group of 10, 2001. p. 9. A amostra considera os seguintes países: Alemanha, Austrália, Bélgica, Canadá, Espanha, Estados Unidos, França, Holanda, Inglaterra, Itália, Japão, Suécia, Suíça.

99 Idem, p. 10. 
Figura 1: Fusões e aquisições em número de operações por indústria (países G-10)

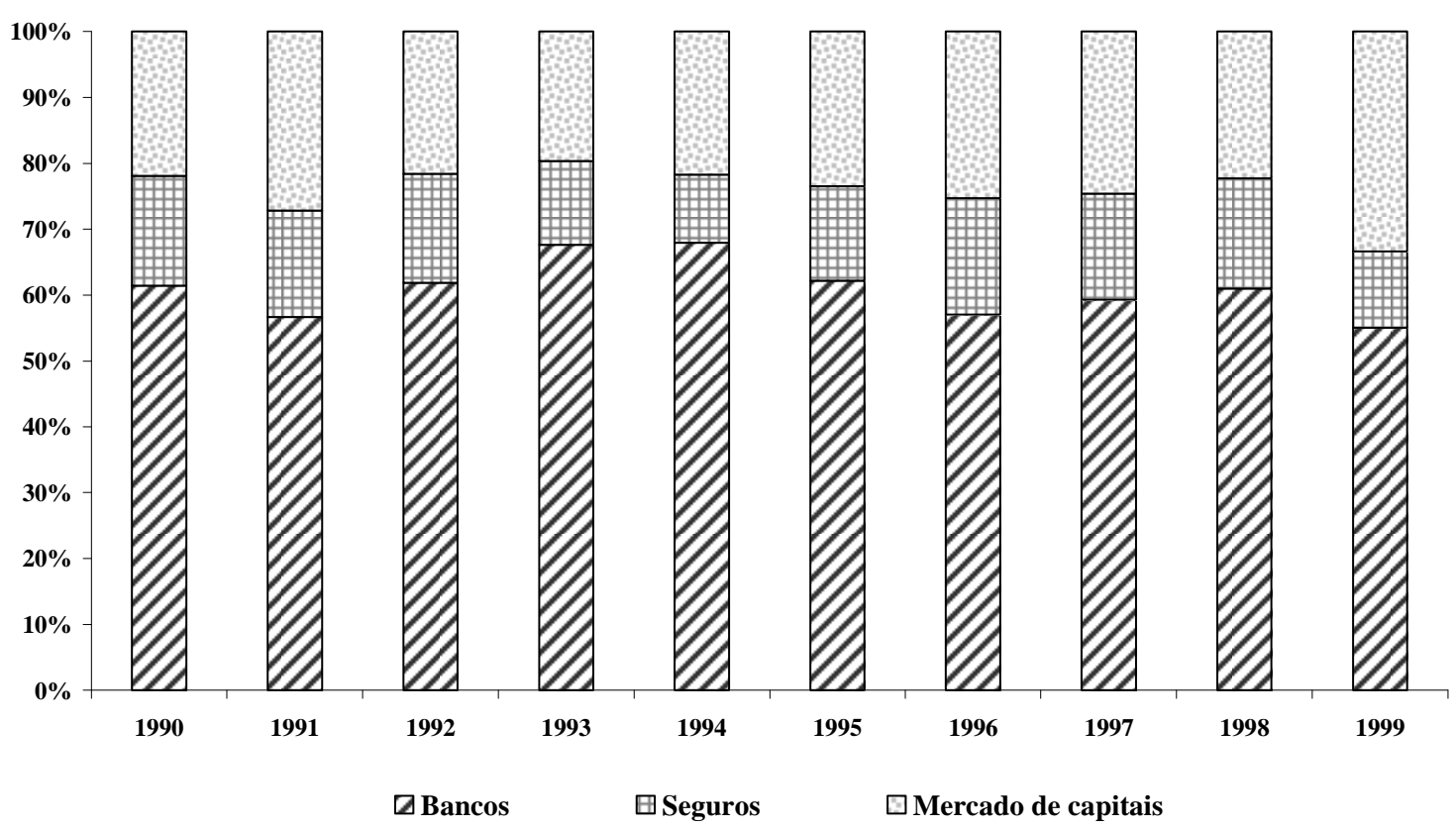

Fonte: Grupo dos 10. Report on consolidation in the financial sector, p. 335.

Em termos estruturais, observou-se uma diminuição no número de bancos em cada país $^{100}$ e um aumento na concentração do setor bancário, considerando a porcentagem dos ativos detidos pelos dez maiores bancos relativamente ao restante da economia. ${ }^{101}$ Seja utilizando a razão de concentração no setor (RC), ou o Herfindahl-Hirschman Index (HHI), ${ }^{102}$

100 A título ilustrativo da magnitude dessa diminuição, em 1984 havia 15.084 bancos nos Estados Unidos. No final do ano de 2003, esse número havia caído para 7.842, um declínio de 48\%. Ver: JONES, Kenneth; CRITCHFIELD, Tim. Consolidation in the U.S. banking industry: is the "long, strange trip" about to end? FDIC Banking Review, v. 17, n. 4, p. 33, 2005.

101 GROUP OF 10. Report on consolidation in the financial sector, p. 10.

102 Entre as diferentes medidas existentes de concentração a partir da participação de mercado das empresas, destacam-se a RC e o HHI. A RC mede a parcela de mercado das $n$ maiores firmas atuantes em um dado setor. Quanto maior o valor desse índice, maior é o poder de mercado exercido pelas $n$ maiores empresas. Até 1980, o Departamento de Justiça (Department of Justice - DOJ) e a Comissão Federal de Comércio (Federal Trade Commission - FTC) dos Estados Unidos utilizavam o RC4 (4 maiores empresas no mercado) em suas análises de concentração na indústria. Não obstante, esse índice tornou-se alvo de críticas pelo fato de não considerar fusões horizontais ou transferências de mercado entre empresas menores da indústria, e não levar em conta a participação relativa de cada empresa no grupo das $n$ maiores. As dificuldades concernentes ao índice serviram de motivação para a consideração de medidas alternativas de mensuração de concentração, e nesse contexto ganhou expressão a utilização do HHI como medida de concentração. O HHI calcula a soma do quadrado da participação das $n$ empresas atuantes no mercado. Justamente por elevar tais participações ao quadrado, o índice provoca a atribuição de um peso maior às 
observou-se sensível aumento no nível de concentração no setor, especialmente quando considerada a porcentagem dos ativos detidos pelos dez maiores bancos com relação ao restante da economia. ${ }^{103}$ Nos Estados Unidos, país que presenciou mais de 30 "megafusões" 104 na década de 1990, as dez maiores instituições detinham $26 \%$ do total de ativos bancários em 1989, e no final da década de 1990 passaram a deter 49\%. Considerando as cinquenta maiores instituições na economia, nota-se aumento de 55\% para $74 \%$ no mesmo período. ${ }^{105}$ Conforme se pode verificar abaixo, evolução semelhante foi observada ao redor do mundo:

Tabela 1: Ativos dos maiores bancos em relação ao PIB (\%)

\begin{tabular}{|l|c|c|c|c|c|c|c|c|c|c|}
\cline { 2 - 10 } \multicolumn{1}{c|}{} & $\mathbf{1 9 8 0}$ & $\mathbf{1 9 9 0}$ & $\mathbf{1 9 9 1}$ & $\mathbf{1 9 9 2}$ & $\mathbf{1 9 9 3}$ & $\mathbf{1 9 9 4}$ & $\mathbf{1 9 9 5}$ & $\mathbf{1 9 9 6}$ & $\mathbf{1 9 9 7}$ & $\mathbf{1 9 9 8}$ \\
\hline Top 20 & 19,5 & 31,6 & 35,2 & 34,2 & 36 & 36,5 & 37,5 & 36,8 & 38,1 & 39,8 \\
\hline Top 30 & 25,5 & 40,3 & 44,4 & 44,1 & 46,3 & 47 & 48,5 & 49 & 51,1 & 52,7 \\
\hline Top 40 & 30,8 & 47 & 51,5 & 51,5 & 54,1 & 55,1 & 56,8 & 56,8 & 61,4 & 63,2 \\
\hline Top 50 & 35,4 & 52,8 & 57,6 & 57,6 & 60,5 & 61,9 & 64 & 66 & 69 & 71,2 \\
\hline
\end{tabular}

Fonte: Grupo dos 10. Report on consolidation in the financial sector, p. 55.

empresas relativamente maiores. O HHI apresenta a vantagem de considerar a chamada "franja de mercado", ou seja, aquelas empresas com menor participação de mercado que não entram na composição da RC. Não obstante, nem sempre é possível computar a participação de mercado de todos os players do setor, motivo pelo qual estudos comparativos entre países geralmente se baseiam no RC dos $n$ maiores bancos. Não há unanimidade a respeito de percentuais de concentração que possam ser considerados críticos. A Portaria Conjunta SEAE/SDE 50/01 utiliza como referencial para se caracterizar um mercado como concentrado que a soma dos percentuais de participação das quatro maiores empresas atuando em um determinado mercado relevante não seja superior a $75 \%$ (disponível em: <www.seae.fazenda.gov.br/central_documentos/legislacao>; acesso em: 27 dez. 2010). Autoridades antitruste nos Estados Unidos utilizam o HHI como referencial para identificação das situações potencialmente danosas, nas avaliações das concentrações empresariais. O índice varia de 0 , indicando mercados com um número infinito de empresas com a mesma participação de mercado, até 10.000, apontando uma situação de monopólio. De acordo com as Diretrizes para Análise de Fusões Horizontais (Horizontal Merger Guidelines) publicadas pelo DOJ (disponível em: <www.ftc.gov/os/2010/08/100819hmg.pdf>; acesso em: 8 dez. 2010), mercados com HHIs inferiores a 1.500 possuem baixa concentração, os com HHI entre 1.500 e 2.500 são considerados "moderadamente concentrados", enquanto mercados com HHIs superiores a 2.500 são considerados "altamente concentrados".

103 GROUP OF 10. Report on consolidation in the financial sector, p. 10.

104 Operações em que cada uma das instituições envolvidas tinha ativos superiores a US\$10 bilhões. Ver: HANWECK, Gerald A.; SHULL, Bernard. The bank merger movement: efficiency, stability and competitive policy concerns. Antitrust Bulletin, n. 44, 1999.

105 WILMARTH, Arthur E. The transformation of the U.S. financial services industry (1975-2000): competition, consolidation, and increased risk. University of Illinois Law Review, n. 2, p. 252, 2002. 
Os acontecimentos recentes no setor indicam que o movimento tende a ganhar ainda mais força. A crise do mercado de crédito que teve início nos Estados Unidos e se espalhou pelo mundo, alcançando seu ápice em 2008 com a quebra do Lehman Brothers, atingiu de forma profunda a solvência de diversos bancos. A consequência imediata desse quadro é que, aproveitando o preço reduzido das ações de determinadas empresas, ou para evitar sua quebra, muitos bancos foram adquiridos por seus pares, ou mesmo nacionalizados. ${ }^{106}$

Além do processo de concentração no setor bancário, é importante ressaltar o movimento de conglomeração financeira ocorrido no mesmo período, em virtude da gradual desregulamentação do sistema financeiro ao redor do mundo. ${ }^{107} \mathrm{Com}$ efeito, não é possível

106 Considerando apenas o segundo semestre de 2008, podem-se mencionar a compra do Bear Sterns e Washington Mutual pelo J.P. Morgan Chase; do Merrill Lynch pelo Bank of America; do Wachovia pelo Wells Fargo; a compra parcial dos ativos do Lehman Brothers pelo Barclays; bem como as nacionalizações do Fortis e do Glitnir.

107 Considerando se tratar de um trabalho que versa sobre modalidades da regulação financeira, bem como as inúmeras referências ao movimento de desregulamentação do sistema financeiro ocorrido nas últimas décadas que serão realizadas neste e nos próximos capítulos, cumpre realizar alguns esclarecimentos a respeito do sentido com que estes termos são empregados na presente análise. Segundo a lição de Baldwin e Cave, há diversas acepções em que o termo regulação pode ser utilizado. Em primeiro lugar, pode significar o conjunto de comandos normativos editados por órgão criado para este fim. Em segundo lugar, representaria toda ação estatal deliberada, voltada a influenciar o comportamento social, econômico e político. Finalmente, pode significar uma forma de controle social, em que os mecanismos que afetam o comportamento humano são determinados por regras advindas do Estado ou dos próprios agentes econômicos, caso da chamada "autorregulação" (BALDWIN, Robert; CAVE, Martin. Understanding regulation. London: Oxford University Press, 1999. p. 2, apud SADDI, Jairo. Temas de regulação financeira, p. 17). Haveria ainda outras interpretações para o termo, como na teoria econômica, em que a regulação pode ser retratada como mecanismo de preservação de determinados interesses com objetivo de acumulação de capital. A preocupação central nesse caso não é com a definição conceitual, mas sim com suas justificativas e consequências. A regulação é tida como um produto, sendo analisada do ponto de vista da oferta e da demanda no mercado (SADDI, Jairo. Temas de regulação financeira, p. 18-19). Os sentidos apresentados não esgotam as possíveis interpretações para o termo, e tampouco são mutuamente excludentes. Cada um dos sentidos apresentados apenas procura enfatizar determinado aspecto da regulação, não raro relacionando-se à formação do interlocutor e seu propósito na abordagem do tema. Além dessas diferentes acepções para o termo regulação, é importante destacar a distinção entre regulamento e regulação. Embora sejam frequentemente utilizados como se fossem sinônimos, cada um dos termos possui sentido diverso. O primeiro diz respeito à manifestação da vontade dos governantes, expressa em atos administrativos que produzem efeitos jurídicos, ou seja, trata-se da prerrogativa legal do Poder Executivo de editar normas sobre matéria de alcance específico, enquanto que o segundo manifesta-se como preceito de autoridade, seja ela o Estado ou não. Observa-se, portanto, que a expressão regulação opera em plano mais elevado, abrangendo todas as medidas de condicionamento da atividade econômica, revestidas ou não de forma normativa, ao passo que a regulamentação se refere ao detalhamento normativo dessa intervenção (Idem, ibidem, p. 20-21). Finalmente, cabe alertar também quanto aos possíveis equívocos decorrentes da utilização do termo regulação, e sua tradução para o inglês, regulation, dependendo do local e contexto em que são usados. Em países como os Estados Unidos, o termo regulation é utilizado para se referir à presença do Estado em determinado setor da economia, enquanto que em outros países passou-se a falar em regulação com os movimentos de privatização e liberalização ocorridos a partir do final da década de 1980, sinalizando justamente a gradativa eliminação da exploração direta pelo Estado de certas atividades econômicas. No segundo contexto, regulação indica o que o Estado passa a fazer ao deixar de prover 
dissociar completamente os dois movimentos, haja vista que a desregulamentação do setor, ao

permitir a fusão entre diferentes participantes do sistema financeiro, acabou servindo também

como catalisador para o próprio processo de concentração, e as alegadas eficiências inerentes

diretamente determinados serviços (YAZBEK, Otavio. Regulação do mercado financeiro e de capitais, $\mathrm{p}$. 178). É nesse sentido que autores como Sundfeld apresentam o discurso da regulação como uma tentativa de reconstrução do debate em torno dos serviços públicos e da sua forma de prestação. Face à reestruturação dos serviços de titularidade estatal, o Estado passa a atuar de maneira diversa, regulando aqueles serviços (SUNDFELD, Carlos Ari. Introdução às agências reguladoras. In: Direito administrativo econômico. São Paulo: Malheiros, 2000. p. 32). Essa discussão, porém, perde relevo no tocante à regulação financeira, haja vista se relacionar com atividade econômica que desde sempre foi objeto de regulamentação e controle pelo Estado (BENSTON, George J. Regulating financial markets, p. 2; GOODHART, Charles A. E. Money, information, and uncertainty. 2. ed. Cambridge: The MIT Press, 1989. p. 194; e YAZBEK, Otavio. Regulação do mercado financeiro e de capitais, p. 179). Finalmente, cabe realizar um derradeiro esclarecimento quanto ao conteúdo das atividades de regulação. Para tal o trabalho se apoiará no esforço de integração desses atos em um corpo único realizado por Sundfeld, referindo-se à administração ordenadora. Segundo o autor, a administração ordenadora é a parcela da função administrativa com uso de poder de autoridade, para disciplinar, nos termos e para os fins da lei, os comportamentos dos particulares no campo de atividades que lhes é próprio (SUNDFELD, Carlos Ari. Direito administrativo ordenador. São Paulo: Malheiros, 2003. p. 20). O autor identifica as técnicas adotadas para tal, classificando-as em três campos principais de atuação, quais sejam: (i) constituição de direitos privados por ato administrativo; (ii) condicionamentos administrativos de direitos; e (iii) sacrifícios de direitos dos agentes. De forma sucinta, a primeira categoria diz respeito ao campo da administração ordenadora, que, por via de atos administrativos, cria situações jurídicas típicas da vida privada, como o direito de realizar uma atividade ou a atribuição de determinado status jurídico (essa categoria é referida por alguns autores como o campo da administração ordenadora encarregado de definir as condições de acesso ao mercado, ver: YAZBEK, Otavio. Regulação do mercado financeiro e de capitais, p. 181). A categoria seguinte refere-se à regulação administrativa do exercício dos direitos titularizados por particulares, de modo a definir-lhes o perfil. Conforme ensinamento do autor, aqui o exame da atividade administrativa deve ter duplo enfoque, de um lado tratando dos condicionamentos administrativos de direitos (incluindo limites, encargos e sujeições de direitos), e, de outro, das limitações administrativas, cuidando da definição do âmbito do exercício lícito dos direitos pela Administração. Finalmente, a última categoria trata das formas de sacrifício de direitos dos agentes privados, seja por meio de sua extinção, ou então pela restrição excessiva (SUNDFELD, Carlos Ari. Direito administrativo ordenador. São Paulo: Malheiros, 2003. p. 26-27). Conquanto a metodologia proposta pelo autor ofereça uma sistematização de todas as operações estatais de regulação do setor privado, com emprego do poder de autoridade, ela é particularmente útil à regulação financeira, que conforme se observará nos próximos capítulos, se vale extensivamente de mecanismos de constituição (caso dos mecanismos de controle de acesso que serão tratados no tópico 4.1.2) e condicionamento dos direitos dos agentes (caso das regras de adequação patrimonial que serão tratadas no tópico 4.1.1), e, em grau menor, de extinção de seus direitos (caso da indisponibilidade dos bens de administradores e controladores de instituições financeiras por conta da decretação de regimes especiais que será tratada no tópico 3.1.2). De todo o exposto, é possível obter os principais elementos do sentido de regulação que será adotado na análise a ser empreendida nos capítulos a seguir. A regulação no presente trabalho fará referência a atividades estatais e paraestatais (caso da autorregulação) voltadas à criação de regras de cunho sistêmico e prudencial, passando pela sua implementação, quando cabível, por meio de atos administrativos. Embora reconheça-se a diferença entre os termos, naquilo que se referir unicamente ao conjunto de comandos normativos editados por órgãos do Poder Executivo (CMN e Bacen, por exemplo), "regulação" e "regulamentação" serão utilizados com o mesmo significado. Quando a regulação se der por meio de atividade estatal, ou seja, como atividade exercida por órgãos públicos, ela se corporifica em um amplo conjunto de atos de regulamentação e de execução que incidem sobre a possibilidade de acesso dos agentes privados ao mercado e o regime de sua atuação, assim como sobre a própria estrutura do mercado. A desregulamentação nesse contexto se referirá ao processo de diminuição da intervenção do Estado na organização e comportamento dos participantes do setor bancário, notadamente por meio da flexibilização de mecanismos de constituição e condicionamento do direito dos agentes que nele praticam atividades. 
à concentração serviram como uma das principais justificativas para a desregulamentação do setor. $^{108}$

No período subsequente à década de 1930, o setor bancário foi marcado por intensa regulação estatal. Havia um grande temor de que crises bancárias, como a ocorrida em 1929, bem como o período de depressão econômica que se seguiu (conhecido como a Grande Depressão), voltassem a ocorrer, o que justificava a imposição de uma série de restrições às atividades bancárias, e até mesmo sobre as áreas geográficas nas quais estas poderiam ser exercidas. ${ }^{109}$ Talvez o maior exemplo dessa estratégia regulatória seja o Glass-Steagall Act de 1933, que impôs a segmentação do sistema financeiro norte-americano, proibindo a bancos comerciais exercerem atividades de bancos de investimento e vice-versa.

A partir da segunda metade do século XX, com as agruras da Grande Depressão se esvaecendo na memória da sociedade e das autoridades, o processo reverteu-se, havendo a gradativa flexibilização das barreiras legais para o exercício de atividades financeiras. Nesse período, o arcabouço regulatório em muitos países mudou de sistemas baseados no controle direto e intrusivo, com a segregação de atividades e delimitação geográfica para seu exercício, para sistemas mais flexíveis, focados em regras simples e comuns, estimulando a liberdade e competição entre instituições financeiras. ${ }^{110}$ Essa transição é bem ilustrada por Shull e Hanweck: ${ }^{111}$

108 Alguns autores criticam a menção às reformas regulatórias como um fator motivador do movimento de fusões e aquisições. Para tais autores, a desregulamentação da indústria financeira tem sido com frequência uma resposta induzida de legisladores a avanços tecnológicos e crises financeiras, e muitas vezes as reformas apenas ratificam mudanças que já haviam operado no próprio mercado (GROUP OF 10. Report on consolidation in the financial sector, p. 73). Com efeito, é difícil separar as mudanças regulatórias das outras forças mencionadas. $\mathrm{O}$ fato de que a consolidação em alguns casos precedeu a mudança na legislação pode indicar que talvez esta não seja a força determinante para o processo observado. A maior influência da desregulamentação parece ser que ela amplia o rol de manobras legais, incluindo os tipos de acordo que podem ser feitos no sistema financeiro, dando maior flexibilidade organizacional aos seus participantes. De todo modo, sendo aceita ou não como um fator motivador do movimento de concentração, é inegável sua importância como fator facilitador para o movimento, haja vista que, sem essa flexibilização regulatória, muitas dessas operações não seriam possíveis.

109 SHULL, Bernard; HANWECK, Gerald A. Bank mergers in a deregulated environment: promise and peril. Westport: Quorum Books, 2001. p. 1-2.

110 Conforme ensinamento de Krugman: “[...] na década de 1980 essas restrições foram removidas em diversos lugares. A causa principal era a desregulamentação da indústria. Bancos tradicionais eram seguros, mas também muito conservadores, supostamente falhando em direcionar capital para seu uso mais produtivo. A cura, argumentavam os reformistas, era maior liberdade e competição: deixe os bancos emprestarem para 


\begin{abstract}
Sessenta e cinco anos atrás, nas profundezas da Grande Depressão, com milhares de bancos quebrando, o caso pela regulação, compreendendo restrições extensivas na concorrência, prevaleceu sobre a presunção de livre mercado. Somente após trinta anos, no despertar do crescimento econômico pós 2. ${ }^{a}$ Guerra Mundial e com a Depressão no passado, é que o clamor pela aplicação de políticas públicas proconcorrenciais, incluindo sujeição do setor bancário às leis antitruste, ressurgiu. Na década de 1980 foram removidas não apenas restrições à concorrência originadas na Grande Depressão, como o teto para taxas de juros sobre depósitos e restrições na negociação de valores mobiliários, mas também restrições à criação de filiais originadas no século XIX.
\end{abstract}

Assim, ao longo da segunda metade do século $\mathrm{XX}$, os bancos tiveram sua área de atuação expandida para outros mercados geográficos, além de passarem a atuar em outros segmentos do mercado financeiro, como a área de corretagem de valores mobiliários e seguros. Tomando como base novamente o exemplo norte-americano, essa transição ficou particularmente evidenciada na década de 1980, quando foram removidas as limitações às taxas de juros nos depósitos de poupança (Regulation Q), e bancos foram autorizados a operar com títulos de dívida e ações, desde que as respectivas receitas não ultrapassassem $5 \%$ do total, limite posteriormente ampliado para $10 \% .{ }^{112} \mathrm{O}$ processo teve continuidade na década seguinte, com o J.P. Morgan sendo o primeiro banco a receber autorização para fazer underwriting de papéis em 1990, a eliminação das restrições geográficas às atividades bancárias em 1994 (Riegle-Neal Interstate Banking and Branching Efficiency Act), a autorização para que holding companies de bancos comerciais constituíssem subsidiárias para praticarem atividades de bancos de investimento em 1996, até que, finalmente, o GrammLeach-Bliley Act de 1999 derrubou formalmente as restrições remanescentes impostas pelo Glass-Steagall Act de 1933, ampliando consideravelmente o rol de atividades financeiras que os bancos poderiam realizar. ${ }^{113}$

Do outro lado do Atlântico, processo similar foi observado com as reformas big bang na Inglaterra, ocorridas durante o governo de Margaret Thatcher ao longo da década de

quem acharem melhor, e competirem pelos recursos dos correntistas". Ver: KRUGMAN, Paul. The return of depression economics and the crisis of 2008, p. 65. Tradução livre.

111 SHULL, Bernard; HANWECK, Gerald A. Bank mergers in a deregulated environment, p. 1-2. Tradução livre.

112 NÓBREGA, Maílson da. Origens da crise. In: GARCIA, Márcio; GIAMBIAGI, Fábio (Org.). Risco e regulação, p. 4-5.

113 Idem, ibidem, p. 5. 
1980. ${ }^{114}$ Ainda que com variada intensidade e em diferentes momentos, a segunda metade do século XX marcou movimentos semelhantes em diversos países ao redor do mundo. ${ }^{115}$

O Brasil tampouco escapou de tais transformações, e, ainda que com origens e motivações díspares, destaca-se o acelerado processo de concentração e conglomeração financeira observado no setor bancário pátrio durante o período do regime militar. Os detalhes desses movimentos no cenário nacional, bem como o contexto político que os motivaram, serão objeto de exame específico no Capítulo 2, no âmbito da discussão acerca da evolução do SFN.

\subsubsection{Externalidades}

As externalidades referem-se às situações em que os custos ou benefícios decorrentes de uma determinada atividade econômica não recaem integralmente sobre a unidade responsável pela sua condução. Nesses casos, haveria uma distorção no sistema de preços, na medida em que as externalidades corresponderiam a custos ou benefícios externos ao mercado. Segundo Nusdeo, essa distorção representaria um entrave ao funcionamento do sistema econômico, haja vista que "o cálculo econômico realizado pelos centros decisórios descentralizados passa a ser viciado por não poder incorporar todas as informações relevantes, transmitidas via sistema de preços". 116

Dependendo dos efeitos causados, as externalidades podem ser classificadas como "positivas" ou "negativas", também conhecidas, respectivamente, como economias ou deseconomias externas. As externalidades positivas surgem quando o indivíduo ou firma

114 Para um relato dessas reformas na Inglaterra, ver: NÓBREGA, Maílson da. Origens da crise, p. 5-6.

115 A título exemplificativo, podem-se mencionar a remoção das restrições a fusões entre os quatro maiores bancos e as duas maiores seguradoras (política dos "6 pilares") na Austrália (1997); a eliminação das barreiras à atuação de bancos em mercado de capitais (1987), eliminação de restrições a participações cruzadas entre instituições financeiras (1992), e a promulgação de legislação que permite a criação de holdings financeiras, relaxando regras de controle em instituições financeiras de grande porte, bem como revisão das diretrizes de avaliação de fusões e aquisições entre bancos no Canadá (2000); e as reformas promovidas no Japão (1998), inspiradas nas reformas big bang ocorridas na Inglaterra, voltadas à redução das barreiras regulatórias às atividades que poderiam ser desempenhadas pelas empresas atuantes no sistema financeiro. Ver: GROUP OF 10. Report on consolidation in the financial sector, p. 117-122.

116 NUSDEO, Fábio. Curso de economia, p. 152. 
tomando a decisão não recebe todo o benefício dela decorrente. É o caso, por exemplo, de um produtor que decide não construir uma indústria em uma região com baixos níveis de instrução, não percebendo que o valor social daquele empreendimento transcende seu valor pessoal. ${ }^{117}$ Já as externalidades negativas ocorrem quando um indivíduo ou firma, ao tomar uma decisão, não tem que arcar com o custo integral decorrente daquela decisão. O exemplo clássico de externalidade negativa é a poluição ambiental, em que o poluidor afeta toda a comunidade com os impactos adversos de sua atividade econômica. ${ }^{118}$

As externalidades negativas têm sido objeto de particular interesse acadêmico no campo das finanças em razão dos vultosos custos decorrentes de quebras bancárias. Benston afirma que a quebra de uma instituição ou mercado financeiro pode causar uma série de externalidades negativas à sociedade. Entre elas, o autor menciona a possibilidade de uma quebra gerar: (i) corridas bancárias em instituições até então solventes, ocasionando sua quebra; (ii) colapso do sistema de pagamentos, podendo afetar a solvência de outras instituições financeiras; (iii) imposição de custos a terceiros não contratantes; e (iv) custos a contribuintes no caso de resgate governamental ou seguro de depósitos patrocinado pelo governo. ${ }^{119}$ Essas externalidades negativas decorrentes de crises no setor bancário são genericamente referidas como "risco sistêmico".

\subsubsection{Conceito clássico de risco sistêmico}

A expressão "risco sistêmico" é tradicionalmente associada ao perigo de que vários bancos venham a quebrar em razão de algum acontecimento específico (o chamado "evento sistêmico"). O exemplo mais utilizado para ilustrar o risco sistêmico é o de uma corrida bancária, em que a inabilidade de um banco satisfazer demandas de retirada de seus

\footnotetext{
117 NUSDEO, Fábio. Curso de economia, p. 156.

118 Idem. Desenvolvimento e ecologia. São Paulo: Saraiva, 1975. p. 48.

119 BENSTON, George J. Regulating financial markets, p. 21.
} 
correntistas causa sua quebra, o que pode resultar na quebra de credores daquele banco, bem como de outros bancos a ele relacionados. ${ }^{120}$

Quando originado no setor bancário, o problema inicial pode se dar de duas formas. A primeira delas, chamada de exposição ou canal real de contágio, acontece quando um banco torna-se insolvente. ${ }^{121}$ A sequência de quebras subsequentes pode ocorrer porque bancos são interligados de forma muito próxima financeiramente. Eles emprestam e tomam dinheiro emprestado uns dos outros, detêm depósitos uns dos outros, e fazem pagamentos por meio do sistema interbancário de pagamentos. Em virtude dessa ligação, o inadimplemento de um banco pode afetar adversamente a capacidade de outros bancos cumprirem com suas obrigações. $^{122}$

A segunda forma refere-se ao chamado canal informacional, podendo ocorrer quando depositantes entram em pânico e dirigem-se a um banco em grandes massas para retirar seu dinheiro. ${ }^{123}$ Como bancos mantêm apenas uma pequena fração dos seus depósitos em caixa como reserva de dinheiro, podem não ter recursos suficientes para cumprir com todos os pedidos de retiradas realizados pelos correntistas, consequentemente causando seu inadimplemento e quebra. ${ }^{124}$ Esse processo é bem ilustrado por Kaufman: ${ }^{125}$

120 O modelo econômico clássico utilizado para ilustrar a ocorrência de corridas bancárias é o de DiamondDybvig, formulado pelos autores em 1983. Ver: DIAMOND, Douglas W.; DYBVIG, Philip H. Bank runs, deposit insurance, and liquidity.

121 DE BANDT, Olivier; HARTMANN, Philipp. Systemic risk: a survey. Working Paper Series, European Central Bank, n. 35, p. 18, 2000.

122 KAUFMAN, George G. Bank failures, systemic risk, and bank regulation. Cato Journal, v. 16, n. 1, p. 25, 1996.

123 DE BANDT, Olivier; HARTMANN, Philipp. Systemic risk, p. 18.

124 Observa-se, portanto, que, apesar de ser classificada como uma externalidade negativa para fins de análise de falhas de mercado, o risco sistêmico está associado também ao problema da assimetria informacional. Nas palavras de Barth et al.: "Bancos estão sujeitos a assimetrias informacionais severas porque seus administradores têm muito mais informação sobre a qualidade dos ativos bancários do que depositantes e outros credores do banco. Se depositantes e credores não podem prontamente checar a condição do banco, então quando alguém começar a sacar fundos, outros, mesmo não tendo informações sobre a condição do banco, também podem sacá-los, provocando uma corrida bancária. E se um banco está sujeito a uma corrida, a não ser que haja uma explicação para o movimento específico naquele banco, a corrida pode contaminar bancos 'vizinhos' [...] Se houvesse informação perfeita, corridas tenderiam a não ocorrer, uma vez que correntistas e credores bem informados começariam a demandar juros maiores do banco na medida em que este começasse a tomar mais risco. Consequentemente, a tomada excessiva de risco seria cortada prematuramente, antes que pudesse colocar em perigo a solvência do banco". Ver: BARTH, James R. et al. 
Um rumor de corrida bancária causa o mesmo temor que um grito de "fogo" em uma sala lotada. Imediatamente nos levantamos e progressivamente aceleramos o passo até que finalmente nos encontremos correndo em pânico para a saída mais próxima sem ao menos saber se era um alarme falso ou quão grave era o incêndio. Afinal de contas, é melhor prevenir do que remediar. De fato, o temor de uma corrida bancária pode evocar ainda mais alarde. Não apenas correntistas do banco afetado pelo rumor irão correr para sacar seus fundos, mas também clientes de outros bancos, ainda que não sujeitos ao mesmo rumor, podem correr também para sacar seus recursos, uma vez que crises bancárias são vistas como "contagiosas". Se o banco do meu vizinho está com problemas, então o meu também pode estar. Dessa forma, a corrida a um banco é capaz de causar a quebra de outros bancos no país em efeito dominó, desestabilizando o sistema financeiro, ou mesmo toda a economia.

Vale salientar que essas duas formas de risco sistêmico não são mutuamente excludentes, podendo ocorrer - e geralmente ocorrendo - ao mesmo tempo em uma situação de crise. Portanto, mesmo bancos saudáveis em termos financeiros podem acabar se tornando insolventes em resposta a uma corrida bancária, refletindo o que alguns autores vieram a chamar de profecia "autorrealizável" do risco sistêmico. ${ }^{126}$ É justamente em razão disso que se torna importante a criação de mecanismos que interrompam esse ciclo de pânico antes que ele leve instituições financeiras solventes à falência.

O exemplo histórico mais comumente citado para ilustrar as graves consequências do risco sistêmico é a Grande Depressão na década de 1930 nos Estados Unidos, quando, em resposta à queda da bolsa de valores em agosto de 1929, e posterior quebra em outubro do mesmo ano, depositantes em massa tentaram converter seus depósitos bancários em dinheiro. Muitos bancos não conseguiram satisfazer todas as demandas e acabaram quebrando, contraindo a oferta de capital no sistema. Essas quebras, por sua vez, fizeram com que muitos outros bancos solventes também se tornassem inadimplentes, e muitas empresas, sem liquidez em razão da escassez de recursos, também se viram forçadas a declarar a falência. ${ }^{127}$ Durante

Rethinking bank regulation: till angels govern. Cambridge: Cambridge University Press, 2006. p. 24. Tradução livre.

125 KAUFMAN, George G. Bank runs: causes, benefits, and costs. Cato Journal, v. 7, n. 3, p. 559, 1988. Tradução livre.

126 NATIONAL RESEARCH COUNCIL. New directions for understanding systemic risk: a report on a conference cosponsored by the Federal Reserve Bank of New York and the National Academy of Sciences. Washington: The National Academies Press, 2006. p. 85.

127 BORDO, Michael D. et al. Real versus pseudo-international systemic risk: some lessons from history. NBER Working Paper Series, n. W5371, p. 21, 1995. 
o pico da Grande Depressão, de 1930 a 1933, houve aproximadamente duas mil quebras bancárias anuais em média. ${ }^{128}$

\subsection{Regulação financeira $e$ falhas de mercado}

Uma vez analisadas as falhas de mercado presentes no setor bancário, cabe agora retomar o estudo sobre a relação entre tais falhas de mercado e a regulação financeira. Nesse sentido, observa-se que essa relação pode ser examinada no contexto de um debate mais amplo sobre o papel do governo na economia, que é marcado por duas visões contrastantes sobre a finalidade da regulação.

A primeira corrente doutrinária procura justificar a existência da regulação como um mecanismo de correção de falhas de mercado. ${ }^{129}$ Nessa perspectiva, a intervenção regulatória ocorreria para maximizar o bem-estar social, e justamente por isso ficou conhecida como "teoria do interesse público" da regulação. ${ }^{130}$ O papel do governo, segundo essa corrente, seria atuar sobre tais falhas, permitindo maior eficiência no mercado e traduzindo-se em benefícios para a sociedade.

$\mathrm{O}$ aspecto fundamental para a aplicação da teoria do interesse público reside na existência de falhas de mercado, uma vez que, na presença de produtos homogêneos, informação perfeita e agentes econômicos atomizados, os mercados tenderiam à alocação eficiente de recursos, independentemente de um papel ativo do governo. Nesse cenário ideal, a regulação do setor bancário seria quando muito irrelevante, senão prejudicial ao bem-estar social. Naturalmente, os defensores dessa corrente teórica encontram amplo espaço de trabalho no sistema financeiro, haja vista a existência de uma extensa literatura que atesta a existência de falhas de mercado significativas no setor, conforme visto nos tópicos anteriores.

128 MISHKIN, Frederic S. The economics of money, banking, and financial markets. 7. ed. Addison Wesley, 2006. p. 261.

129 KROSZNER, Randall S.; STRAHAN, Philip E. Obstacles to optimal policy - The interplay of politics and economics in shaping bank supervision and regulation reforms. In: MISHKIN, Frederic S. (Org.). Prudential Supervision, p. 234-235.

130 BARTH, James R. et al. Rethinking bank regulation, p. 21. 
Essa visão é bem representada por Goodhart ao apontar como objetivos para a regulação financeira: (i) o controle e administração das externalidades que podem decorrer das atividades financeiras (risco de contágio e outras questões de ordem sistêmica); (ii) a proteção dos clientes, dada a assimetria informacional característica de sua relação com as instituições por intermédio das quais operam; e (iii) o controle das posições de poder no mercado (das situações de monopólio ou de oligopólio, entre outras distorções). ${ }^{131}$

No entanto, apesar de sua alegada preocupação com o interesse público, essa corrente teórica está sujeita a inúmeras críticas. Conforme visto, Coase tem uma concepção distinta a respeito do papel da intervenção governamental, defendendo que esta deveria limitar-se a alocar direitos inicialmente àquele agente econômico que lhe atribui maior valor. A regulação que fosse além disso seria desnecessária ou mesmo prejudicial ao funcionamento eficiente do mercado. ${ }^{132}$

No tocante a esse aspecto, é oportuno notar que alguns autores justificam a regulação prudencial como um mecanismo de correção de incentivos negativos provocados pela regulação sistêmica. ${ }^{133}$ Isso porque, ao procurar prevenir a ocorrência de crises, a regulação sistêmica acabaria criando outros problemas, refletidos no aumento do risco moral ou na percepção de que uma instituição é grande demais para quebrar. Na medida em que a regulação prudencial procura corrigir consequências adversas de outra modalidade regulatória, questiona-se a necessidade de ambas.

Outro importante ponto de tensão com a teoria do interesse público reside na premissa de que, na presença de falhas de mercado, governos teriam incentivos e capacidade para atuar sobre elas, mitigando ou eliminando-as, o que nem sempre se verifica. É baseandose nessa fragilidade conceitual que, na segunda metade do século XX, surgem questionamentos a respeito da capacidade governamental de atuação sobre as falhas de mercado. Progressivamente, não apenas os limites do campo regulatório começaram a ser questionados, como até mesmo o sentido da regulação foi objeto de revisão crítica. Em

\footnotetext{
131 GOODHART, Charles A. E. Some regulatory concerns. In: financial regulation. London: Central Banking Publications, 1998. p. 218.

132 HOVENKAMP, Herbert J. The Coase theorem and Arthur Cecil Pigou, p. 638.

133 MISHKIN, Frederic S. Prudential Supervision: why is it important and what are the issues, p. 8.
} 
contraste à análise das falhas de mercado, a teoria econômica veio a acrescentar a análise dos grupos de interesse e falhas de governo. ${ }^{134}$

Os trabalhos de Olson, ${ }^{135}$ Stigler, ${ }^{136}$ Posner $^{137}$ e Peltzman ${ }^{138}$ permitiram que juristas e economistas passassem a encarar a regulação como um produto, e, como qualquer outro produto, pudessem analisá-la do ponto de vista das forças da oferta e demanda no mercado. É com base nesses trabalhos que surge a fundamentação para a "teoria do interesse privado" da regulação, também conhecida como "teoria econômica da regulação", que caracteriza o processo regulatório como uma competição entre grupos de interesse, em que grupos compactos e bem organizados utilizam o poder coercitivo do Estado para capturar rendas à custa de outros grupos mais dispersos.

Nessa visão de regulação, geralmente o governo é o "provedor" principal do produto, e, embora consumidores também possam demandar regulação, a indústria é considerada uma influência determinante no processo decisório, seja a favor ou contra determinados tipos de regulação. Aplicada ao sistema financeiro, essa visão afirma que governos justificariam a regulação financeira com base em uma finalidade ostensiva de interesse público, quando, na verdade, estariam verdadeiramente interessados em facilitar o financiamento de suas despesas, canalizar crédito para fins politicamente atrativos, bem como maximizar a riqueza e influência de políticos no poder. ${ }^{139}$ Nas palavras de Goodhart: ${ }^{140}$

O conceito mais antigo da regulação como um serviço público sendo introduzido para corrigir uma falha de mercado é denunciado como uma paródia da realidade, sem qualquer base teórica sólida em termos de comportamento maximizador de utilidade. Em vez disso, Stigler e Peltzman argumentam que a regulação deve ser

134 FIANNI, Ronaldo. Teoria da regulação econômica: estado atual e perspectivas futuras. Teoria política e instituições de defesa da concorrência. Grupo de Regulação da Concorrência da UFRJ, p. 12. Mimeografado.

135 OLSON, Mancur. The logic of collective action. Cambridge: Harvard University Press, 1965.

136 STIGLER, George J. The theory of economic regulation. The Bell Journal of Economics and Management Science, 2 (1), 1971.

137 POSNER, Richard A. Theories of economic regulation. The Bell Journal of Economics and Management Science, 5(2), 1975.

138 PELTZMAN, Sam. Toward a more general theory of regulation. Journal of Law and Economics, 19(2), 1976.

139 BARTH, James R. et al. Rethinking bank regulation, p. 35.

140 GOODHART, Charles A. E. Money, information, and uncertainty, p. 194. Tradução livre. 
vista como uma forma de transferência de riqueza, resultante de um processo essencialmente político. Nesses casos, um lobby bem organizado e coeso provavelmente será mais efetivo.

Esse fenômeno seria amplificado no setor bancário em virtude do papel central dos bancos na alocação de recursos, o que atrairia diversos grupos de interesse. Assim, os bancos se engajariam na busca e defesa de regulações que ampliassem o poder e bem-estar de banqueiros. Esse é um argumento suscitado com frequência para criticar as barreiras regulatórias à entrada no setor bancário como uma forma de privilegiar determinados grupos de interesse com pouco ou nenhum efeito positivo em termos de bem-estar social. ${ }^{141}$ Com efeito, a história é permeada de exemplos de trocas de privilégios entre reguladores e regulados, particularmente no setor bancário. ${ }^{142}$

Para os defensores da teoria do interesse privado da regulação, o Estado deixa de ser visto como uma entidade cuja atuação estaria fundamentalmente voltada ao bem público. Ao contrário, nesse cenário, legisladores e burocratas responsáveis pela promoção da regulação estariam sujeitos à cooptação por parte de grupos de interesse. Essas abordagens do processo regulatório ficaram conhecidas como "teorias da captura", uma vez que discutem as formas e consequências da captura dos órgãos reguladores do Estado por interesses privados. ${ }^{143}$

A apresentação das teorias do interesse público e privado da regulação é válida na medida em que mostra dois pontos de vista diametralmente opostos a respeito do papel da regulação. Realisticamente, é necessário reconhecer que não há uma opção "correta" quanto ao papel desempenhado pela regulação. Governantes e formuladores de políticas públicas podem responder a diferentes incentivos ao longo do tempo, flutuando entre os polos extremos representados pelas teorias supracitadas.

141 CHANG, Ha-Joon. Globalisation, economic development and the role of the State. Zed Books, 2003. p. 167-168.

142 O caso dos Médici com o Vaticano na Itália do século XIV é bastante ilustrativo a esse respeito. Durante o período em que foram os banqueiros oficiais do Vaticano, a Igreja nomeou Giovani Médici como Cardeal quando tinha apenas 16 anos. Este mais tarde se tornaria o Papa Leão X (1513-1521), seguido pelo seu tio dois anos depois, Giulio Médici, como Papa Clemente VII (1523-1534). Ver: BARTH, James R. et al. Rethinking bank regulation, p. 37.

143 FIANNI, Ronaldo. Teoria da regulação econômica, p. 21. 
Em estudo sobre as fundações da regulação financeira, Kane argumenta que autoridades estão sujeitas a pressões relacionadas a interesses públicos e privados ao mesmo tempo, e que a decisão regulatória não dependerá apenas das características pessoais daqueles tomando a decisão, mas também dos incentivos presentes. O autor compara o processo de decisão ao conflito dialético hegeliano, afirmando que a regulação é marcada por uma contínua oscilação entre os dois polos. ${ }^{144}$

Ademais, mesmo no âmbito do interesse privado, não é possível asseverar que o interesse de apenas um grupo específico possa prevalecer por tempo indeterminado. Os trabalhos de Kroszner, por exemplo, procuram demonstrar que o poder de cada grupo é variável, provocando diferentes resultados políticos, de modo que a transferência de poder entre os diversos grupos de interesse provocaria mudanças na orientação da regulação. ${ }^{145} \mathrm{De}$ fato, Kroszner e Strahan sustentam que a competição entre grupos de interesse ajudaria a explicar o padrão de desregulamentação do sistema financeiro nos Estados Unidos nas décadas de 1980 e $1990 .^{146}$

O balanço de poder entre o interesse público e privado também pode ser influenciado por choques exógenos. Em tempos de crise, interesses especiais podem ter menos influência, ou podem mudar sua visão. No caso norte-americano, por exemplo, após rejeitar a instituição de mecanismos de seguro de depósitos, essa resistência diminuiu durante a Grande Depressão, marcando um período de drástico aumento da regulação bancária. ${ }^{147}$ Da mesma forma, após extinguir o seguro sobre depósitos durante a década de 1980, a Argentina decidiu reintroduzir esse mecanismo em 1995 em resposta à deterioração das condições do mercado financeiro com a crise do México em 1994. ${ }^{148}$ Movimento semelhante pôde ser observado no Brasil durante a década de 1990, quando a crise no sistema financeiro brasileiro de 1994 permitiu a

144 KANE, Edward J. Interaction of financial and regulatory interaction. American Economic Review, v. 78, n. 2, p. 328-334, 1988.

145 KROSZNER, Randall S. On the political economy of banking and financial regulatory reform in emerging markets. CRSP Working Paper, n. 472, 1998; e KROSZNER, Randall S. The motivations behind banking reform. Regulation, 24(2), 2001.

146 KROSZNER, Randall S; STRAHAN, Philip E. Obstacles to optimal policy.

147 WHITE, Eugene. Deposit insurance. In: CAPRIO, Gerard; VITTAS, Dimitri (Org.). Reforming financial systems: historical implications of policy. New York: Cambridge University Press, 1997. p. 85-100.

148 Idem, ibidem, p. 85-100. 
mudança de importantes aspectos do setor bancário, como a instituição do seguro de depósitos e a entrada de instituições financeiras estrangeiras.

A mesma lógica parece se aplicar à situação atual do setor bancário, principalmente nos países mais atingidos pela crise financeira recente. Apesar de já haver deixado o cargo no momento da crise, Alan Greenspan, ex-presidente do banco central norte-americano (Federal Reserve), é considerado um dos principais culpados pelo ocorrido, justamente por um posicionamento reputado muitas vezes cético quanto ao papel da regulação financeira. ${ }^{149}$ Nesse sentido, não é de surpreender o clamor atual por uma regulação mais intensa do setor bancário. $^{150}$

Tais exemplos demonstram a impossibilidade de tratar a necessidade de regulação bancária de forma maniqueísta. Apesar de haver grande potencial de aproveitamento desse instrumental para interesses privados, é necessário reconhecer também a sua dimensão de interesse público. Não por acaso, mesmo os críticos mais ferrenhos da regulação do sistema financeiro, como Benston, acabam reconhecendo sua utilidade em certos casos. ${ }^{151}$

149 Para uma crítica concernente à postura de Alan Greenspan no comando do Federal Reserve e sua crença excessiva na capacidade de autorregulação e disciplina de mercado, ver: OVERTVELDT, Johan Van. Bernanke's test: Ben Bernanke, Alan Greenspan, and the drama of the central banker. Chicago: B2 Book, 2009.

150 Nas palavras de John H. Welch: "Mais uma vez, como já ocorreu nas diversas crises financeiras anteriores, a atual gerou um vasto e generalizado clamor para mais e nova regulamentação, quer nacional, quer mundial. E, como em tantos outros episódios, tal nova regulamentação provavelmente apresentará uma forma mais adequada para se lutar contra esta crise do que para impedir que outras ocorram". Ver: WELCH, John H. Futurologia financeira global: implicações do pós-crise. In: GIAMBIAGI, Fábio e Octavio de Barros (Org.), Brasil pós-crise: agenda para a próxima década. Rio de Janeiro: Elsevier, 2009. p. 41.

151 Segundo o autor: "De modo geral, a razão econômica, aliada a testes empíricos, me levam à conclusão de que algum grau de regulação para serviços financeiros é desejável [...]” (BENSTON, George J. Regulating financial markets, p. 2. Tradução livre). Nesse sentido, vale mencionar também o posicionamento de Verçosa, segundo o qual: “[...] as posições extremas de mercado inteiramente livre, de um lado, e de mercado estritamente regulado, do outro, revelam-se irrealistas, sabendo-se que certo nível de regulação é necessário. A sua medida adequada é um grande problema a resolver". Ver: VERÇOSA, Haroldo M. D. Considerações sobre o sistema financeiro, p. 30. 


\section{SÍNTESE E CONCLUSÕES DO CAPÍTULO 1}

1. Há um expressivo e crescente corpo de trabalhos indicando uma relação positiva entre crescimento econômico e o papel dos bancos. Além de sua clássica função como intermediador de recursos entre agentes econômicos superavitários e deficitários, teorias modernas da intermediação financeira também focam sua análise na atuação dessas instituições na redução de assimetrias informacionais entre agentes econômicos. Em razão disso, há uma preocupação especial com o bom funcionamento do sistema financeiro, o que se refletiu na criação de amplo conjunto de regras destinadas a manter sua estabilidade e alinhar os interesses de seus participantes com os da sociedade.

2. O papel da regulação financeira está intrinsecamente relacionado à própria evolução de determinadas correntes econômicas, notadamente as teorias econômicas clássica e neoclássica. A tentativa de reproduzir teoricamente o funcionamento do mercado e a busca pela alocação eficiente de recursos levaram o modelo neoclássico a assumir uma série de premissas para a sua operacionalização, como a existência de mercados sem fricção, informação completa e agentes econômicos atomizados e racionais. Verificandose a inocorrência dessas premissas na realidade, surgiram inúmeros questionamentos aos principais pilares do modelo neoclássico, destacando-se o posicionamento crítico das escolas pertencentes à nova economia institucional e, mais recentemente, os estudos ligados à linha de behavioral economics. Esses questionamentos não representam, no entanto, um afastamento por completo do modelo neoclássico, de modo que a consistência formal de seu aparato, suas premissas, e principalmente o dogma neoclássico da eficiência, continuam a influenciar a análise econômica e política regulatória.

3. A verificação de situações na vida econômica real que se afastavam das condições ideais preconizadas no modelo neoclássico levou à identificação das chamadas "falhas de mercado", referindo-se àqueles fatores que impedem o modelo de atingir os resultados pretendidos. O setor bancário tem se mostrado uma área particularmente frutífera ao estudo das falhas de mercado, principalmente em razão das assimetrias informacionais e externalidades negativas inerentes à atuação dos bancos.

4. No caso das assimetrias informacionais, destacam-se a seleção adversa e o risco moral como pontos de preocupação no funcionamento do mercado, especialmente com relação 
aos incentivos à tomada excessiva de risco pelas instituições financeiras. No tocante às externalidades, o conceito clássico de risco sistêmico baseia-se na possibilidade de ocorrência de crises bancárias em razão dos canais reais e informacionais de contágio presentes no setor. O primeiro se deve ao alto grau de integração entre os participantes do setor bancário, enquanto o segundo está relacionado às assimetrias informacionais ali presentes. Tais situações não são mutuamente excludentes, podendo e normalmente ocorrendo de forma simultânea em situações de crise bancária.

5. A concentração econômica pode ser vista como uma falha de mercado, ainda que deva ser sopesada com outras considerações de ordem econômica, como as eficiências geradas no processo. No caso bancário, chama a atenção o acelerado processo de concentração observado no setor ao redor do mundo, principalmente durante a década de 1990 e as diversas operações em 2008, motivadas pela crise financeira recente. Em paralelo a esse processo de concentração, observa-se também um movimento de desregulamentação do sistema financeiro, eliminando importantes restrições entre atividades financeiras e permitindo a formação de conglomerados financeiros.

6. As interpretações sobre as justificativas para a regulação do sistema financeiro podem ser traduzidas no contexto de um debate mais amplo sobre o papel do governo na economia. De um lado posicionam-se autores filiados à chamada corrente da teoria do "interesse público" da regulação, em que a regulação se justificaria como um mecanismo de correção de falhas de mercado procurando maximizar o bem-estar social. Do outro lado encontram-se autores filiados à chamada corrente do "interesse privado" da regulação, que rejeitam a capacidade de a regulação atuar sobre as falhas de mercado. Como reflexo da corrente do interesse privado da regulação encontra-se a teoria da captura regulatória, que vê na regulação um processo de competição entre grupos de interesse procurando utilizar o poder coercitivo do Estado para capturar rendas às custas de outros grupos mais dispersos. Tais correntes teóricas representam visões caricaturais sobre o papel da regulação, sendo que, na realidade, a regulação atende a diferentes necessidades de ordem pública e privada, podendo ser caracterizada como um processo de contínua oscilação entre os dois polos. Choques exógenos como crises bancárias também atuam sobre esse processo, geralmente justificando a imposição de regulação mais abrangente sobre as atividades financeiras. É o caso das pressões por reformas regulatórias no desenlace da crise financeira recente. 


\section{Capítulo 2 \\ A ATIVIDADE BANCÁRIA NO BRASIL E SUA REGULAÇÃO}

\subsection{Primórdios do setor bancário brasileiro}

É com a vinda da família real portuguesa para o Brasil que se inicia o desenvolvimento do setor bancário no País. ${ }^{152}$ Naquele momento é que surge o primeiro Banco do Brasil, cujos estatutos foram aprovados em 8 de outubro de 1808. À ocasião, o alvará assinado por D. João VI deixava claro que a organização de um banco emissor justificava-se pela necessidade de financiar as despesas governamentais, bem como aumentar o estoque de moeda existente. ${ }^{153}$

Além de problemas de capitalização, ${ }^{154}$ o novo banco se viu desde o início sujeito a uma forte ingerência da família real, emitindo cada vez mais para solver seus compromissos e cobrir seus gastos. Não tardou para que a constante intervenção governamental, aliada a uma política de endividamento excessivo e inadimplência com o banco, acabassem por comprometer sua situação financeira, a qual se agravou com a retirada de seus metais preciosos por ocasião do retorno de D. João VI a Portugal. ${ }^{155}$ Assim, a duração desse primeiro

152 YAZBEK, Otavio. Regulação do mercado financeiro e de capitais, p. 255.

153 MULLER, Bianca Abbot. Concorrência no setor bancário brasileiro. 2007. Dissertação (Mestrado), FDUSP, São Paulo, p. 8. Mimeografado.

154 O banco foi organizado sob a forma de sociedade anônima, com permissão para operar por um prazo de 20 anos. Ainda segundo o alvará de criação, entraria em funcionamento logo após fossem vendidas as primeiras ações de um total de 1.200, com valores de face de um conto de réis cada uma. Foi difícil a arrecadação da parcela mínima de capital para o funcionamento do banco, o que é comprovado pelo fato de ele passar a operar efetivamente apenas em 11 de dezembro de 1809, sem ter reunido capital maior que 100 contos de réis. Mesmo em 1812, quatro anos após o estabelecimento dos estatutos, o capital ainda era de apenas 126 contos de réis, correspondente a apenas 126 ações. Ver: PAULIN, Luiz Alfredo. Evolução do Sistema Financeiro Nacional. Revista de Direito Bancário, do Mercado de Capitais e da Arbitragem, São Paulo: RT, n. 17, p. 78, 2002.

155 SOUZA, Carlos Inglez de. A anarchia monetária e suas consequências. São Paulo: Monteiro Lobato \& Cia. Editores, 1924. p. 41-43. 
ensaio de instituição financeira no País foi efêmera, com a extinção do Banco do Brasil em 23 de setembro de $1829 .^{156}$

O fim do banco não causou um forte abalo na oferta de crédito ao setor privado e ao governo. O financiamento de gastos públicos ficou a cargo das emissões do Tesouro Nacional e de títulos da dívida pública. A situação do crédito à iniciativa privada também não se alterou significativamente, permanecendo nas mãos de comerciantes e prestamistas individuais, que não chegaram a ter suas atividades atingidas pelo Banco do Brasil.

A segunda metade do século XIX foi marcada por relevantes transformações econômicas, com destaque para o florescimento de uma incipiente indústria nacional e a criação de bancos de depósitos e descontos nos principais centros econômicos brasileiros, como o Banco Comercial da Bahia (1845), Banco Comercial do Maranhão (1846), Banco de Pernambuco (1851) e o Banco Comercial do Pará (1853). A criação desses bancos foi seguida da promulgação do Código Comercial (Lei 556, de 25 de junho de 1850) e da Lei de Terras (Lei 601, de 18 de setembro de 1850). Esses diplomas legais foram essenciais para o funcionamento dos estabelecimentos bancários, na medida em que reconheceram legalmente a profissão de banqueiro, regulamentaram a organização dos bancos e dos contratos de financiamento (inclusive daqueles garantidos por hipoteca), além de tornarem a terra um ativo negociável. ${ }^{157}$

É ainda nesse período que surge a Casa Mauá Mac-Gregor, uma das maiores casas bancárias do Império, com presença em Londres, Manchester, Nova Iorque, Montevidéu, Rosário, Córdoba, além do Rio de Janeiro. O banco fundado por Irineu Evangelista de Souza (o Visconde de Mauá) e outros investidores teve um papel relevante na estrutura financeira nacional ao transformar a natureza do financiamento no Rio de Janeiro. A oferta de crédito, até então baseada em relações pessoais, passa a assumir o formato da instituição financeira

\footnotetext{
156 Em 1833 houve a tentativa de criar o "segundo Banco do Brasil", mas esta fracassou pela ausência de interessados na subscrição de suas ações. Apenas em 1945 se conseguiu o intento, com a fundação de uma terceira versão do Banco do Brasil. Ver: YAZBEK, Otavio. Regulação do mercado financeiro e de capitais, p. 255-256.

157 ANDRADE, Ana Maria Ribeiro de; LEVY, Maria Bárbara. Fundamentos do sistema bancário no Brasil (1834-1860). Revista de Estudos Econômicos, v. 15, p. 20, 1985.
} 
moderna, com o empréstimo de recursos por intermédio de um banco. ${ }^{158}$ É também nesse período que se instala no Brasil o primeiro estabelecimento de capital estrangeiro, o London and Brazilian Bank, de capital inglês.

Esse cenário de crescimento do mercado financeiro é alterado com a crise da economia cafeeira no início da década de 1860. Em meio ao cenário de retração econômica, é aprovada a Lei 1.083, de 22 de agosto de 1860, conhecida como "Lei dos Entraves", que, entre outras medidas, passou a exigir aprovação governamental para o estabelecimento de sociedades anônimas, bem como a proibição à emissão de vales por bancos privados enquanto estes não se mostrassem capazes de reembolsá-los em ouro. A redução de liquidez da economia que se seguiu foi, em parte, responsável pela quebra das casas bancárias J.A. Souto \& Cia., em 1864, e Mauá Mac-Gregor, em 1866, provocando uma crise bancária no país e levando à promulgação das primeiras regras específicas para tais situações. ${ }^{159} \mathrm{O}$ Decreto 3.308, de 17 de setembro de 1864, estabeleceu uma moratória geral, ficando suspensos e prorrogados, por sessenta dias, os vencimentos das letras, notas promissórias e quaisquer outros títulos comerciais pagáveis na Corte e na Província do Rio de Janeiro, e o Decreto 3.309, de 20 de setembro de 1864, determinou que a falência de bancos não deveria se submeter à legislação das falências ordinárias. De fato, alguns autores remetem a esses diplomas a origem do caráter "especial” atribuído aos bancos na legislação pátria. ${ }^{160}$

O advento da República não representou propriamente uma mudança nos padrões de desenvolvimento do setor bancário. O novo regime nasce com uma crise haurida no período anterior - o chamado "encilhamento" -, cujas raízes encontram-se na emissão desenfreada de

158 MULLER, Bianca Abbot. Concorrência no setor bancário brasileiro, p. 14.

159 Segundo relato de George Marcondes Coelho de Souza, a crise então desencadeada levou o povo às ruas, motivando inclusive o envio de tropas do Império para guardar a casa do banqueiro Antônio José Alves Souto, com forte pressão para que o imperador tomasse medidas urgentes para evitar o pânico que se instalara nas ruas. Ver: SOUZA, George Marcondes Coelho. Da liquidação extrajudicial de bancos no direito brasileiro. 1973. Tese (Doutorado) - FD-USP, São Paulo, p. 17-18, mimeografado, apud VERÇOSA, Haroldo M. D. Considerações sobre o sistema financeiro, p. 18.

160 Paulin afirma que, pelo menos desde 1864, vem se reconhecendo a necessidade de adotar, no que se relaciona à quebra de instituições financeiras, um "regime peculiar" (PAULIN, Luiz Alfredo. Conceito de intervenção e liquidação extrajudicial - pressupostos para sua decretação. In: SADDI, Jairo (Org.). Intervenção e liquidação extrajudicial no Sistema Financeiro Nacional: 25 anos da Lei n. 6.024/74. São Paulo: Textonovo, 1999. p. 122). Já Verçosa se refere ao Decreto 3.309/1974 como o germe da futura legislação sobre a intervenção administrativa no campo das quebras bancárias. Ver: VERÇOSA, Haroldo M. D. Considerações sobre o sistema financeiro, p. 18. 
títulos e subsequente estouro da bolha especulativa que se criara. ${ }^{161} \mathrm{O}$ processo teve início com a tentativa de estimular a industrialização do Brasil por meio da concessão de crédito a investimentos industriais baseada na emissão de papel-moeda pelos bancos em todas as regiões do País. Tal mecanismo foi bem-sucedido, conforme evidenciado pelo aumento no número de registros na junta comercial do Rio de Janeiro. Em 1890, 38 bancos e 294 outras sociedades anônimas tinham estatutos arquivados junto ao órgão e, em apenas dois anos, tal número havia aumentado para 89 bancos e 549 companhias. ${ }^{162}$

O resultado das emissões, porém, foi um desastre. Em vez de financiar a industrialização, gerou um surto inflacionário no país e também um movimento de especulação desenfreada na bolsa de valores por meio de empresas fictícias. Como resultado, o Brasil passou por uma das mais graves crises econômicas de sua história, que impactou duramente os bancos, levando à quebra de diversas instituições. ${ }^{163}$ Em resposta a esse movimento, o governo promulgou a Lei 703, de 10 de outubro de 1900, que, além de promover mudanças no processo para liquidações forçadas, possibilitava aos bancos a celebração de acordos extrajudiciais com credores. ${ }^{164}$

Alguns autores apontam a década de 1920 como o período de surgimento dos primeiros instrumentos de intervenção planejada no setor bancário. Nas palavras de Paulin, “é a partir daqui que organizadamente o Estado irá regular o setor". ${ }^{165}$ É nesse período que surge a Inspetoria Geral dos Bancos, criada pela Lei 4.182, de 13 de novembro de 1920, marcando um esforço do governo de supervisão mais efetiva do setor bancário. Para efeitos de aplicação da lei, o Decreto 14.728, de 14 de março de 1921, determinou que seriam considerados bancos as pessoas físicas ou jurídicas que realizassem operações financeiras e que possuíssem capital superior a 500 contos de réis. Outro aspecto relevante do decreto é a imposição de

161 YAZBEK, Otavio. Regulação do mercado financeiro e de capitais, p. 256.

162 AZEVEDO, Francisco de Paula Vicente de. Contribuição ao estudo da reforma bancária brasileira. Separata dos Anais do $1 .^{\circ}$ Congresso Nacional de Bancos, São Paulo, 1960, p. 49, apud YAZBEK, Otavio. Regulação do mercado financeiro e de capitais, p. 257.

163 Apenas no final de 1900, 17 estabelecimentos são liquidados. Além disso, o Banco da República, o Banco Rural e Hipotecário e o Banco da Lavoura e do Comércio suspendem pagamentos.

164 MULLER, Bianca Abbot. Concorrência no setor bancário brasileiro, p. 20.

165 PAULIN, Luiz Alfredo. Evolução do Sistema Financeiro Nacional, p. 82. Igualmente, Muller considera 1920 como o marco da introdução da regulação bancária no Brasil. Ver: MULLER, Bianca Abbot. Concorrência no setor bancário brasileiro, p. 23. 
tratamento discriminatório aos bancos estrangeiros pela exigência de capital adicional de nove mil contos para sua operação no País. Essa medida estancou a entrada de novos bancos estrangeiros, fazendo com que a participação destes no total de depósitos caísse de 44,9\% em 1919 para 24,5\% em 1932. ${ }^{166}$ Também nessa época foi criada a Carteira de Emissões e Redescontos do Banco do Brasil (Cared), por meio da Lei 4.230, de 31 de dezembro de 1920, posteriormente regulamentada pelo Decreto 14.635, de 21 de janeiro de 1921. A Cared possibilitou o provimento de assistência financeira ao setor bancário pelo Banco do Brasil, aproximando as funções da instituição àquelas típicas de um banco central. ${ }^{167}$

A crise mundial de 1929 e a revolução de 1930 representam um período de elevação da intervenção governamental na economia e acirramento do viés nacionalista aplicado ao setor bancário. A título exemplificativo, pode-se mencionar o artigo 145 da Constituição de 1937, que restringe a atividade de bancos de depósitos e das empresas de seguros a instituições cujos acionistas fossem brasileiros. O reflexo de medidas como essa não tardou a ser sentido, de modo que a participação do capital estrangeiro no total de depósitos reduziu-se ainda mais, atingindo a marca de 6,6\% em 1944. ${ }^{168}$ Outro aspecto relevante desse período é o reconhecimento, em face de outra crise que se abatia sobre o país, da impraticabilidade de sujeitar bancos e casas bancárias ao procedimento falimentar ordinário. ${ }^{169}$ Desse modo, em 16 de dezembro de 1930, é promulgado o Decreto 19.479, regulamentado pelo Decreto 19.634, de 28 de janeiro do ano seguinte, que disciplinaram o processo de liquidação extrajudicial. ${ }^{170}$

A década de 1940 é marcante para o sistema bancário nacional por uma série de fatores, entre os quais se destaca o Decreto 7.293, de 2 de fevereiro de 1945, que criou a Superintendência da Moeda e do Crédito (Sumoc), refletindo a percepção crescente do governo com a necessidade de cuidado para com as empresas financeiras e do mercado de capitais. ${ }^{171}$ Subordinada ao Ministério da Fazenda, a Sumoc tinha como objetivo primordial

\footnotetext{
166 COSTA NETO, Yttrio Corrêa da. Bancos oficiais no Brasil: origem e aspectos do seu desenvolvimento. Brasília: Banco Central do Brasil, 2004. p. 48.

167 MULLER, Bianca Abbot. Concorrência no setor bancário brasileiro, p. 25.

168 Idem, ibidem, p. 32.

169 Conforme determinado pela Lei de Falências (Lei 2.024, de 17 de dezembro de 1908), que havia instaurado um regime único para todas as sociedades comerciais, não excepcionando os bancos e as casas bancárias.

170 PAULIN, Luiz Alfredo. Conceito de intervenção e liquidação extrajudicial, p. 122.

171 VERÇOSA, Haroldo M. D. Considerações sobre o sistema financeiro, p. 17.
} 
exercer o controle do mercado monetário. Para tal, tinha amplas atribuições sobre o estabelecimento de bancos, fixação de seu capital mínimo, controle das reservas compulsórias e regulamentação dos negócios bancários. A Sumoc também possuía poderes de fiscalização sobre bancos, casas bancárias e sociedades de crédito, bem como poder para neles intervir por meio do instituto da intervenção estrito senso e da liquidação extrajudicial, os quais afastavam a incidência da falência, ao menos em um primeiro momento. ${ }^{172}$ Não obstante, ressalta-se que não existia ainda uma unificação em relação à condução da política monetária, na medida em que o poder decisório continuava disperso entre a Sumoc, o Tesouro e o Banco do Brasil (por meio de suas carteiras de redesconto, de mobilização bancária e de câmbio). Genericamente, cabiam àquela superintendência a supervisão e a coordenação das políticas monetária e bancária; ao Tesouro Nacional, o poder de emissão da moeda; e ao Banco do Brasil, a atuação como agente financeiro do governo e prestador da maior parte dos serviços típicos de um banco central, tanto para o governo quanto para os bancos privados. ${ }^{173}$

Finalmente, vale ressaltar também nesse período o surgimento de alguns dos maiores bancos privados na atualidade, como o Bradesco e Itaú-Unibanco. O Unibanco, originalmente Banco Moreira Salles, surge a partir da fusão entre a Casa Bancária Moreira Salles, a Casa Bancária de Botelhos e o Banco Machadense, em 1940. O Bradesco é criado a partir da transformação da Casa Bancária Almeida no Banco Brasileiro de Descontos em 1943. O Banco Itaú foi inaugurado em São Paulo em 1944, tendo seu capital subscrito por paulistas e mineiros. As três novas instituições passaram por rápida expansão geográfica com o intuito de aumentar suas carteiras de clientes. Cinco anos após a inauguração do Banco Moreira Salles, este já servia 34 praças no País, e duas décadas depois atingia a marca de 191 agências. Em muitos casos a ampliação do número de agências se deu pela aquisição de outras instituições atuantes no mercado. O Bradesco, por exemplo, realizou diversas aquisições a partir de 1948, e em 1967 já contava com uma rede de 326 agências no País. ${ }^{174}$

\footnotetext{
172 VERÇOSA, Haroldo M. D. Considerações sobre o sistema financeiro, p. 17.

173 MULLER, Bianca Abbot. Concorrência no setor bancário brasileiro, p. 39.

174 Para um relato detalhado sobre o surgimento e evolução desses três bancos, ver: Idem, ibidem, p. 33 e ss.
} 
Tabela 2: Evolução de matrizes e estabelecimentos bancários (1940-1962)

\begin{tabular}{|l|c|c|c|c|}
\cline { 2 - 5 } \multicolumn{1}{c|}{} & $\mathbf{1 9 4 0}$ & $\mathbf{1 9 5 0}$ & $\mathbf{1 9 5 1}$ & $\mathbf{1 9 6 2}$ \\
\hline Matrizes & 354 & 413 & 404 & 336 \\
\hline Estabelecimentos Bancários $(*)$ & 1.360 & 2.596 & 3.219 & 6.124 \\
\hline
\end{tabular}

(*) Matrizes, filiais e agências

Fonte: MULLER, Bianca Abbot. Concorrência no setor bancário brasileiro, p. 39.

Esse processo de rápida expansão geográfica e proliferação do número de agências foi acompanhado por outros bancos, intensificando-se nos anos seguintes na medida em que tais instituições buscavam a escala necessária para a automação e integração nacional. Conforme se pode observar acima, o número de estabelecimentos bancários mais do que quadruplicou em cerca de duas décadas. Esse processo seria interrompido apenas em função das novas diretrizes para o setor estabelecidas a partir da Revolução de 31 de março de 1964.

\subsection{Reestruturação do Sistema Financeiro Nacional}

O golpe de 1964 marca o início de uma ampla transformação do sistema financeiro no País, com foco especial no setor bancário. Um dos pontos marcantes dessa nova política com relação ao setor é a promulgação da Lei 4.595, de 31 de dezembro de 1964, que reorganizou a estrutura de regulação e supervisão no País. A essa lei juntar-se-iam outros diplomas legais nos anos seguintes que, em conjunto, comporiam a base do Sistema Financeiro Nacional (SFN).

A Lei 4.595/1964 consolidou os poderes antes espalhados entre a Sumoc, Tesouro, e o Banco do Brasil, estabelecendo o poder normativo do Conselho Monetário Nacional (CMN) e criando o Banco Central do Brasil (Bacen). O CMN deveria formular a política monetária e creditícia e promover o progresso social e econômico. Já ao Bacen caberia a responsabilidade pela implementação das normas editadas pelo $\mathrm{CMN}{ }^{175}$

Além da criação do CMN e do Bacen, a Lei 4.595/1964 regulamentou a atuação das instituições financeiras, principalmente dos bancos comerciais. Também estavam

\footnotetext{
175 As competências específicas dessas autoridades do SFN serão objeto de tratamento detalhado mais adiante.
} 
subordinadas à lei as bolsas de valores e as corretoras e distribuidoras de títulos e valores mobiliários, as sociedades de arrendamento mercantil, as companhias de seguros e capitalização, e outras instituições. Finalmente, a lei também sujeitou à sua disciplina pessoas físicas ou jurídicas que exercessem atividade relacionada à compra e venda de ações ou títulos e operações ou serviços de natureza dos executados pelas instituições financeiras. Posteriormente, a Lei 4.728, de 14 de julho de 1965, complementou a reestruturação do SFN, permitindo a criação de novas instituições, como os bancos de investimento, bancos estaduais de desenvolvimento, distribuidoras de títulos mobiliários, sociedades de crédito imobiliário, sociedades de crédito, financiamento e investimento e as associações de poupança e empréstimo.

Paralelamente à reestruturação do sistema de crédito e financiamento, iniciou-se, também, a reorganização do sistema nacional de seguros privados, que, com o Decreto-lei 73, de 21 de novembro de 1966, passou a ser constituído pelo Conselho Nacional de Seguros Privados (CNSP), pela Superintendência de Seguros Privados (Susep), pelo Instituto de Resseguros do Brasil (IRB), pelas sociedades autorizadas a operar em seguros privados (sociedades seguradoras) e por corretores habilitados. Posteriormente, o Decreto-lei 261, de 28 de fevereiro de 1967, instituiu o sistema nacional de capitalização, seguido pela Lei 6.435, de 15 de julho de 1977, que criou as entidades abertas e fechadas de previdência privada, regulamentadas pelos Decretos 81.402, de 23 de fevereiro, e 81.240, de 20 de janeiro, ambos promulgados em 1978, estabelecendo, respectivamente, sua fiscalização pela Susep e pela Secretaria de Previdência Complementar (SPC) do Ministério da Previdência.

É também nesse período que começam a surgir esforços de organização de linhas alternativas de financiamento privado com maior maturidade. Em 7 de dezembro de 1976 é promulgada a Lei 6.385, que cria a Comissão de Valores Mobiliários (CVM), para fiscalizar e normatizar as atividades das sociedades corretoras e distribuidoras de valores mobiliários, das bolsas de valores e das companhias abertas, além de disciplinar o funcionamento dessas instituições. Em 15 de dezembro do mesmo ano é promulgada a Lei 6.404 (Lei das Sociedades por Ações), outro diploma legal de grande importância para o desenvolvimento do mercado de capitais nacional. 
A instituição do SFN, a partir da supremacia do CMN como órgão regulador de cúpula, e do Bacen na qualidade de regulador de segundo nível e executor da política determinada pelo primeiro, é considerada por alguns autores como a origem do tratamento sistêmico do mercado financeiro no País. ${ }^{176}$ Desde a promulgação da Lei 4.595/1964, observa-se a criação de importantes dispositivos voltados à supervisão e regulação bancária, alguns deles utilizados até hoje. Entre eles pode-se mencionar a promulgação da Lei 6.024, de 13 de março de 1974, com o objetivo de consolidar em um instrumento a legislação sobre intervenção e liquidação extrajudicial. Posteriormente, esses regimes especiais viriam a ser complementados pelo Regime de Administração Especial Temporária (Raet), criado pelo Decreto-lei 2.321, de 25 de fevereiro de 1987. A década seguinte também traz importantes inovações para o setor bancário nacional, como a criação, por meio do Decreto 91.152, de 15 de março de 1985, e da Resolução CMN 1.065, de 5 de dezembro de 1985, do Conselho de Recursos do Sistema Financeiro Nacional (CRSFN), que estabelece o regulamento de aplicação de penalidades às instituições financeiras, seus administradores, membros de conselhos consultivos, fiscais e semelhantes que infringissem as disposições das Leis 4.595/1964, 4.728/1965 e 4.829/1965. Finalmente, a Lei 7.492, de 16 de junho de 1986, conhecida como Lei do Colarinho-Branco, criminaliza a gestão temerária de instituições financeiras, indução da autoridade bancária a erro, falsificação de demonstrações contábeis, entre outros.

Em suma, observam-se nesse período a reformulação e criação de mecanismos de regulação e supervisão do sistema financeiro, muitos destes denotando uma preocupação específica em assegurar sua estabilidade e evitar crises sistêmicas. Essa preocupação foi reforçada com a promulgação da Constituição de 1988, que alterou parcialmente o sistema vigente, e, principalmente, pelas reformas regulatórias ao longo da década de 1990, conforme será exposto adiante.

176 Esse é o ensinamento de Verçosa, por exemplo, cabendo mencionar a ressalva do autor de que, mesmo antes da promulgação da Lei 4.595/1964, já se percebia a preocupação do legislador com o mercado financeiro e de capitais, conforme evidenciado pela criação da Sumoc em 1945 (VERÇOSA, Haroldo M. D. Considerações sobre o sistema financeiro, p. 17). O posicionamento contrasta com o de Yazbek, para quem apenas com a estabilização financeira ocorrida na década de 1990 foi possível realizar um salto qualitativo para os processos de regulação e reordenação de prioridades e de instrumentos, dotando o arcabouço regulatório de um caráter mais sistemático. Ver: YAZBEK, Otavio. Crise financeira e risco sistêmico: a evolução recente da regulação sistêmica no Brasil, p. 1-2. Mimeografado. 


\subsubsection{Concentração e conglomeração no Sistema Financeiro Nacional}

Um dos aspectos mais relevantes a respeito da política bancária do regime militar foi o estímulo declarado do governo à concentração e especialização no setor. Tais mudanças foram motivadas pela percepção de uma elevada ineficiência operacional, fruto da desordenada e excessiva proliferação de agências nos anos que precederam a revolução. ${ }^{177}$ Dessa forma, procurou-se por meio da promoção ativa e engajada da concentração e especialização das instituições financeiras em determinados tipos de operações, alcançar maior mobilização de recursos e melhores níveis de eficiência na intermediação financeira, que deveriam se traduzir em taxas de juros mais baixas. Na essência, bancos comerciais deveriam restringir sua atuação às transações de curto prazo, e os bancos de investimento deveriam dedicar-se ao financiamento de médio e longo prazo para capital fixo e de trabalho, principalmente de empresas industriais. ${ }^{178}$

Nesse sentido, observou-se no período a promulgação de uma série de regulamentos voltados à promoção dessa política setorial. Entre estes pode-se citar a Circular CMN 18, de 7 de dezembro de 1965, que suspendeu as autorizações para instalações de novas agências naquele ano e limitou a duas por ano o número de autorizações para abertura de bancos. As limitações foram reforçadas com a Resolução CMN 43 e a Circular Bacen 67, ambas de 28 de dezembro de 1966, que restringiram a duas por banco o número máximo de agências novas por ano, bem como passaram a exigir o cumprimento de vários requisitos aos bancos interessados, como aumento de capital, índice de imobilização e relação entre recursos próprios e depósitos não superior à relação de um para dez. Essa orientação restritiva prosseguiria, adquirindo um caráter absoluto a partir de 1970, com as Resoluções CMN 141, de 23 de março de 1970, 200, de 20 de dezembro de 1971, e 266 de, 15 de outubro de 1973, que suspenderam a abertura de novas agências. No bojo dessa política, vale mencionar também o Decreto-lei 1.303, de 31 de dezembro de 1973, em que o governo abre mão do imposto de renda devido por instituições consideradas "sadias" a fim de que estas incorporassem instituições em dificuldades.

177 O número total de agências cresceu de 1.565 em 1945 para 4.996 em 1959, e 7.005 em 1964. Ver: MACARINI, José Pedro. A política bancária do regime militar: o projeto do conglomerado (1967-1973). Economia e Sociedade, Campinas, v. 16, n. 3, p. 351, dez. 2007.

178 BAER, Mônica. A internacionalização financeira no Brasil. Petrópolis: Vozes, 1986. p. 14. 
Os grandes bancos de atuação nacional responderam a tais mudanças, e, em face da necessidade de ampliação de agências para viabilizar o crescimento, passaram a adotar estratégias mais agressivas de absorção de bancos menores por meio de fusões e aquisições. Nas palavras de Delfim Netto à época, "o governo tem a taxa de juros na mira e permanece muito atento aos desvios do processo. A fusão dos bancos faz parte dessa estratégia". ${ }^{179}$ Dessa forma, a política oficial veio reforçar o movimento de fusões e aquisições iniciado na década de 40. A título exemplificativo, pode-se observar o rápido crescimento do Banco Itaú no período:

Tabela 3: Crescimento do banco Itaú (1964-1974)

\begin{tabular}{|c|l|l|l|}
\hline Ano & \multicolumn{1}{|c|}{ Banco Comprador } & \multicolumn{1}{|c|}{ Banco Adquirido } & Instituição Resultante \\
\hline 1964 & Banco Federal de Crédito $\left(^{*}\right)$ & Banco Itaú & Banco Federal Itaú \\
\hline 1966 & Banco Federal Itaú & $\begin{array}{l}\text { Banco Sul Americano do } \\
\text { Brasil }\end{array}$ & $\begin{array}{l}\text { Banco Federal Itaú Sul } \\
\text { Americano }\end{array}$ \\
\hline 1969 & $\begin{array}{l}\text { Banco Federal Itaú Sul } \\
\text { Americano }\end{array}$ & Banco América & Banco Itaú América \\
\hline 1973 & Banco Itaú América & Banco Português & Banco Itaú América \\
\hline 1974 & Banco Itaú & Banco União Comercial $(* *)$ & Banco Itaú \\
\hline
\end{tabular}

(*) À época, o Banco Federal do Crédito ocupava a 32. ${ }^{a}$ posição entre os maiores bancos oficiais e privados por depósitos à vista.

(**) O Banco União Comercial era o 7. ${ }^{\circ}$ maior banco comercial privado do País por volume de depósitos à época da aquisição.

Fonte: MULLER, Bianca Abbot. Concorrência no setor bancário brasileiro, p. 36-37.

Apesar de a reforma dos anos 1964-1967 ter criado instituições financeiras especializadas e juridicamente autônomas, concretamente elas passaram a operar de maneira integrada, sob a forma de conglomerados financeiros. ${ }^{180}$ Em sua grande maioria, a instituiçãochave desses conglomerados era o banco comercial, a partir do qual se constituíam outras empresas financeiras associadas. Esse processo de agrupamento não foi uma característica exclusiva dos bancos privados nacionais, ocorrendo também entre bancos públicos e instituições financeiras estrangeiras. ${ }^{181}$

179 FOLHA DE SÃO PAULO, 16 abr. 1973, apud MACARINI, José Pedro. A política bancária do regime militar, p. 354.

180 BAER, Mônica. A internacionalização financeira no Brasil, p. 45.

181 Idem, ibidem, p. 45. 
O movimento de conglomeração foi facilitado pela gradativa flexibilização das restrições às atividades dos bancos. As Circulares CMN 126, de 20 de março de 1969, e 206, de 17 de maio de 1973, ampliaram a possibilidade de bancos terem participações em outras empresas, ainda que não financeiras. Outrossim, para instituições financeiras que integrassem um mesmo grupo econômico, foi permitido a uma delas participar do capital das demais. ${ }^{182}$ Finalmente, vale mencionar também a Resolução CMN 157, de 10 de setembro de 1970, que permitiu aos bancos comerciais atuar no mercado primário de colocação de ações. ${ }^{183}$

A evolução da captação de depósitos totais por bancos comerciais no período de 1969 a 1984 reflete bem a intensidade do processo de concentração e conglomeração no SFN. Em 1969, dezesseis bancos captavam mais da metade do total de depósitos, enquanto que, em 1984, apenas dez bancos respondiam pela mesma margem de captação. Os dados indicam também que, em 1969, os 16 maiores bancos captavam em média mais de 12 vezes o saldo médio de depósito dos 196 bancos restantes, ao passo que, em 1984, esse índice atingia, apenas para os 10 primeiros bancos, mais de 10 vezes o depósito médio dos 100 restantes. ${ }^{184}$ Evolução semelhante foi observada no tocante aos empréstimos bancários, ainda que não na mesma intensidade que a captação de depósitos totais. Em 1969 dezessete bancos respondiam por mais da metade dos empréstimos concedidos, e, por seu turno, em 1974, apenas dez bancos já somavam o mesmo montante. ${ }^{185}$ Segundo dados do Bacen, havia 336 bancos existentes no Brasil em 1964, e, quando a Constituição de 1988 foi promulgada, esse número havia se reduzido para $106 .^{186}$

182 SADDI, Jairo. Algumas propostas de mudança para a Lei n. ${ }^{\circ}$ 6.024. In: liquidação extrajudicial no Sistema Financeiro Nacional, p. 307. (Org.). Intervenção e

183 A permissão era válida apenas no regime de melhores esforços (best efforts), em que a instituição financeira assume unicamente o compromisso de tentar colocar no mercado o máximo possível de ações, não se sujeitando a qualquer obrigação ou punição em caso de fracasso da operação. Ver: MACARINI, José Pedro. A política bancária do regime militar: o projeto do conglomerado (1967-1973), p. 357.

184 TEIXEIRA, Natermes Guimarães. Origem do sistema multibancário brasileiro. Campinas: Instituto de Economia da Unicamp, 2000. p. 64-68. (Coleção Teses.)

185 Idem, ibidem, p. 64-68.

186 TROSTER, Roberto Luis. Concentração bancária. Estudos Febraban, p. 2, 2004. Disponível em: <www.febraban.org.br/Arquivo/Servicos/Imprensa/Conc0404.pdf>. Acesso em: 21 dez. 2010. 
Tabela 4: Participação das instituições financeiras conglomeradas nos empréstimos e captações do SFN (\%)

\begin{tabular}{|c|c|c|}
\hline Ano & Empréstimos & Captações \\
\hline 1979 & 86,9 & 90,0 \\
\hline 1980 & 86,5 & 90,3 \\
\hline 1981 & 85,2 & 89,4 \\
\hline 1982 & 83,1 & 87,0 \\
\hline 1983 & 84,0 & 90,6 \\
\hline 1984 & 85,1 & 91,6 \\
\hline
\end{tabular}

Fonte: TEIXEIRA, Natermes Guimarães. Origem do sistema multibancário brasileiro, p. 140.

Na década de 1980, praticamente todo o mercado bancário-creditício brasileiro já era operado predominantemente por instituições financeiras organizadas sob a forma de conglomerados. ${ }^{187}$ Essa evolução reforçou e ampliou o poder dos grandes bancos privados como estruturas bancárias, não só pelo maior peso de seu bloco de capital, mas também pela centralização operacional em termos dos diversos esquemas e possibilidades de atuação no mercado financeiro em geral. ${ }^{188}$ Essa é uma constatação relevante, na medida em que, apesar das mudanças ocorridas na década de 1990, esse quadro ainda representa, em grande medida, a matriz do atual perfil do setor bancário brasileiro.

\subsubsection{Saneamento do Sistema Financeiro Nacional - o fim do "milagre econômico"}

Além do acelerado ritmo de concentração e conglomeração, as décadas de 1970 e 1980 também foram marcadas por crises bancárias, cujas origens estão relacionadas ao esgotamento de um ciclo expansivo da economia brasileira no período de 1968-1973. Entre as principais razões para essa mudança, podem-se mencionar a crise do petróleo em 1973 e 1979, bem como a escalada das taxas de juros norte-americana na década de $1970 .{ }^{189} \mathrm{Em}$ decorrência dessas mudanças no cenário internacional, o setor bancário brasileiro sofreu uma

\footnotetext{
187 BAER, Mônica. A internacionalização financeira no Brasil, p. 45.

188 TEIXEIRA, Natermes Guimarães. Origem do sistema multibancário brasileiro, p. 68.

189 Esse movimento viria a se acentuar com a nomeação de Paul Volcker para a presidência do Federal Reserve no final da década de 1970 e o recrudescimento do combate à inflação com o aumento da fed fund rate de uma média de $11 \%$ em 1979 para $20 \%$ em junho de 1981.
} 
drástica redução de liquidez, com grande perda de reservas cambiais, o que acabou por colocar diversas instituições financeiras em dificuldades. ${ }^{190}$

Uma das primeiras quebras no período foi a do Banco Halles. Na euforia do "milagre econômico" experimentado no período de 1968-1973, o Halles passou por um processo de expansão desenfreada. $\mathrm{O}$ banco comercial do conglomerado era limitado pela capacidade de captação da rede de agências no mercado interno, de modo que a solução foi a expansão de suas atividades por meio de seu banco de investimento, contando com os generosos fundos públicos de repasse e estímulos à captação externa das chamadas "operações 63". ${ }^{191}$ A título ilustrativo, a participação dos empréstimos externos no total de recursos do banco de investimento Halles aumentou de $7 \%$ em 1969 para $29 \%$ em $1973 .{ }^{192}$ Com a crise de liquidez iniciada em 1974, o banco se viu diante de uma conjuntura oposta àquela que impulsionara seu crescimento. No mercado externo as taxas de juros subiam rapidamente, enquanto no interno a liquidez estreitava-se, com os aplicadores querendo o resgate de seus papéis. Tais fatores levaram o Halles a declarar sua insolvência em 16 de abril de 1974.

Vale ressaltar que o banco declarou sua insolvência pouco tempo após a promulgação da Lei 6.024/1974, que disciplina até hoje as intervenções e liquidações extrajudiciais em instituições financeiras. Aproveitando a situação para dar um firme exemplo de aplicação da nova lei, o governo anunciou que não iria bancar os prejuízos de ninguém, com a única exceção dos depósitos à vista até o limite de 50 vezes o salário mínimo, com base na recém-editada Resolução CMN 285, de 19 de abril de $1974 .{ }^{193}$ Nas palavras de Lundberg,

190 LUNDBERG, Eduardo Luís. Saneamento do sistema financeiro - a experiência brasileira dos últimos 25 anos. In: SADDI, Jairo (Org.). Intervenção e liquidação extrajudicial no Sistema Financeiro Nacional, p. 55.

191 O regramento da entrada de capitais estrangeiros no País no período era detalhado na Lei 4.131, de 3 de setembro de 1962; Instrução 289, de 14 de janeiro de 1965; e as Resoluções 63 e 64, de 21 e 23 de agosto de 1967, respectivamente. A Lei 4.131/1962 orienta globalmente a política sobre capital estrangeiro no Brasil, particularmente as tomadas de empréstimos diretos pelas empresas internas no mercado financeiro internacional. A Instrução 289/1965 possibilitava a contratação de empréstimos externos em moeda estrangeira diretamente entre empresas do exterior e empresas do País, enquanto as Resoluções 63 e 64 permitiam aos bancos comerciais e de investimento e ao BNDES a obtenção de empréstimos em moedas estrangeiras a serem repassados internamente às empresas. Ver: TEIXEIRA, Natermes Guimarães. Origem do sistema multibancário brasileiro, p. 43.

192 ASSIS, J. Carlos. A chave do tesouro: anatomia dos escândalos financeiros no Brasil (1974-83). Rio de Janeiro: Paz e Terra, 1983. p. 65.

193 Conforme relato de Assis, no dia seguinte à intervenção o Ministro Mário Simonsen advertia: "Eu daria um conselho a investidores para que não busquem juros acima da tabela fixada pelo Banco Central, porque 
“o resultado dessa intervenção foi o início de uma crise bancária que acabou afetando diversas instituições de menor porte". 194

Em face do clima de insegurança crescente no mercado financeiro, o governo ainda procurou aplicar a Lei 6.204/1974 enviando um grupo de interventores ao banco, mas, diante das óbvias dificuldades em assumir diretamente a administração do grupo - e considerando a própria inexperiência na aplicação do novo diploma legal -, a autoridade bancária acabou decidindo adotar uma "solução de mercado", administrando o processo de transferência da instituição sem a liquidação extrajudicial prevista na lei. Dessa forma, a instituição escolhida para receber as cartas patentes e as cem agências do Halles no Rio de Janeiro e São Paulo foi o Banco do Estado da Guanabara (BEG), presidido por Octávio Gouvêa de Bulhões, que havia sido Ministro da Fazenda de Castello Branco. Por meio de um contrato assinado com os antigos acionistas e contando com recursos do Bacen, o BEG absorveu o Halles na sua estrutura, tornando-se o 3. ${ }^{\circ}$ maior banco comercial do País. ${ }^{195}$

A operação de resgate ao Halles não impediu que outras instituições logo apresentassem sinais de dificuldade. Preocupado com a necessidade de recursos para salvar outras instituições financeiras em perigo, o governo editou o Decreto-lei 1.342, de 28 de agosto de 1974, que determinou que a receita líquida do imposto sobre operações financeiras (IOF) deveria ser destinada à formação de reservas monetárias, permitindo que tais reservas fossem aplicadas pelo Bacen para: (i) recompor o patrimônio de instituições financeiras, com o saneamento de seus ativos e passivos, podendo o Bacen deixar de decretar a intervenção e liquidação extrajudicial se entendesse que as providências a serem adotadas pudessem conduzir à completa normalidade da situação da instituição; e (ii) o pagamento total ou parcial

qualquer ganho nesse sentido será envolvido por riscos. As demais empresas que operam no setor devem observar as iniciativas excepcionais do Governo como um exemplo e evitar manobras irregulares". Ver: JORNAL DO BRASIL. Uma iniciativa inadiável, 18 abr. 1974, p. 27, apud ASSIS, J. Carlos. A chave do tesouro, p. 67.

194 LUNDBERG, Eduardo Luís. Saneamento do sistema financeiro, p. 55.

195 ASSIS, J. Carlos. A chave do tesouro, p. 68-69. 
do passivo de instituições financeiras que tivessem sofrido intervenção ou liquidação extrajudicial, mediante cessões ou transferências dos respectivos direitos. ${ }^{196}$

Conforme ensinamento de Lundberg, a autorização do uso de recursos públicos para recompor o patrimônio de instituições financeiras visava dar ao Bacen condições para promover "soluções de mercado", ou seja, assumir prejuízos de reestruturações realizadas com base no modelo da aquisição de bancos insolventes. ${ }^{197}$ Ainda segundo o autor, a autorização legal dada para assumir o passivo de instituições em regime especial sinalizava que a autoridade bancária poderia proteger com recursos públicos, a seu critério, o total de qualquer passivo ou credor de instituições financeiras inadimplentes. ${ }^{198}$

Apesar das atitudes do governo voltadas ao saneamento do setor, estas não foram suficientes para impedir a quebra do Banco União Comercial (BUC) no final de 1973, à época o $7 .^{\circ}$ maior banco comercial privado do País em termos de volume de depósitos. ${ }^{199}$ O banco comercial do conglomerado possuía uma rede de 250 agências concentradas no Rio de Janeiro e São Paulo. Sob a direção de Roberto Campos, com seu grande prestígio na comunidade bancária externa, o banco de investimentos passou rapidamente à liderança das operações do grupo. A lógica era semelhante à do Halles, amealhando uma considerável massa de recursos oriunda de operações 63 e de repasses oficiais, e concentrando-os em um número reduzido de empreendimentos, "em uma escala desproporcional aos recursos próprios do banco e à capacidade dos tomadores". 200 Os perigos desse tipo de gestão bancária evidenciaram-se quando três dos seus principais clientes, responsáveis por algumas de suas mais expressivas operações de empréstimo, entraram em regime concordatário ou falimentar. ${ }^{201}$

\footnotetext{
196 LUNDBERG, Eduardo Luís. Saneamento do sistema financeiro, p. 55. Além dessas medidas, cabe reiterar que, no ano anterior, o governo já havia renunciado, por meio do Decreto-lei 1.303/1973, ao imposto de renda devido por instituições consideradas "sadias" a fim de que estas incorporassem as instituições em dificuldades.

197 Idem, ibidem, p. 56.

198 Idem, p. 56.

199 MULLER, Bianca Abbot. Concorrência no setor bancário brasileiro, p. 37.

200 ASSIS, J. Carlos. A chave do tesouro, p. 74-76.

201 Idem, ibidem, p. 74-76.
} 
Apanhado sem lastro em meio à turbulência provocada pela quebra do Halles, o BUC passou a enfrentar crescente dificuldade de compensar os resgates de certificados e recibos de depósitos bancários (CDBs e RDBs) e outros depósitos a prazo, bem como honrar as letras de câmbio lançadas no mercado por meio do lançamento de novos títulos. O resultado foi um acúmulo crescente de débitos junto à carteira de redesconto do Bacen. Quando esses débitos acumularam Cr\$60 milhões (quase US\$9 milhões ao câmbio médio de 1974), a autoridade decidiu que era momento de agir. ${ }^{202}$

Havia um temor de que a intervenção no banco ou sua liquidação reforçasse a crise de confiança no mercado financeiro, já abalado pelo estouro do Halles. De acordo com Guido Mantega "num mercado abalado pela crise do Halles, seria fatal a mera liquidação extrajudicial do BUC. E o governo resolveu mudar de tática, assumindo todos os prejuízos e dando cobertura aos correntistas para evitar o pânico financeiro no mercado". ${ }^{203}$ Assim sendo, as autoridades decidiram adotar novamente uma "solução de mercado", e o BUC foi absorvido pelo Itaú, com a reserva monetária assumindo os prejuízos acumulados pelo banco insolvente. Como saldo da negociação, o Itaú recebeu toda a estrutura do BUC, com 250 agências, passando a deter 561 agências no território nacional. ${ }^{204}$ Além do BUC, uma série de instituições insolventes seria ainda absorvida com os recursos da reserva monetária. ${ }^{205}$

Naturalmente, em um ambiente político autoritário, com pouca transparência e escassa ou nenhuma prestação de contas, a existência de um dispositivo legal que permitia ao Bacen fazer a cobertura integral de todos os passivos de instituições financeiras em dificuldades deu azo a comportamentos inadequados. ${ }^{206}$ Não por acaso, no período que se seguiu, o órgão foi muito criticado pela mídia em razão dos "escândalos financeiros", com duras críticas de favorecimentos a grandes clientes e

\footnotetext{
202 ASSIS, J. Carlos. A chave do tesouro, p. 74-76.

203 MANTEGA, Guido. O governo Geisel, o II PND e os economistas. Relatório de Pesquisa, EAESP-FGV, Núcleo de Pesquisas e Publicações, n. 3, p. 51, 1997.

204 Informação disponível em: <www.itau.com.br/bem_vindo/conheca_emp_atual.htm>. Acesso em: 27 dez. 2010.

205 LUNDBERG, Eduardo Luís. Saneamento do sistema financeiro, p. 56.

206 Idem, ibidem, p. 56.
} 
banqueiros. ${ }^{207}$ A título exemplificativo, Assis apresenta o seguinte "padrão básico de saneamento" adotado no período: ${ }^{208}$

\begin{abstract}
A instituição ou grupo financeiro entra em crise, e o Banco Central intervém; na intervenção ele assume o passivo e paga ao aplicador com recursos da reserva monetária; da mesma fonte tira os recursos para a reconstituição do patrimônio e limpeza da contabilidade a fim de permitir a sua incorporação em outro grupo; o comprador paga com dedução do imposto de renda ou com o próprio resultado de sua futura administração da massa liquidada, quitando tempos depois os empréstimos a juros simbólicos recebidos junto com os ônus da incorporação dessas empresas.
\end{abstract}

Com as sucessivas intervenções e liquidações, o Bacen tornou-se dono de uma massa enorme de ativos de qualidade duvidosa, ${ }^{209}$ muitos dos quais jamais seriam recuperados. Com efeito, já em 1977 o Ministro da Fazenda Mário H. Simonsen admitia que o órgão considerava irrecuperáveis $\mathrm{Cr} \$ 10$ bilhões de um total de $\mathrm{Cr} \$ 18,6$ bilhões aplicados em 142 intervenções até a data. ${ }^{210}$ No final de 1979, o número de sociedades sob intervenção, em liquidação ou já liquidadas desde 1966, elevava-se a 191, das quais 126 com processos em andamento. ${ }^{211}$

A sangria de recursos da reserva monetária continuou na década de 1980, apesar das intensas críticas ao Bacen feitas pela mídia, com denúncias de favorecimento a grandes clientes e banqueiros. ${ }^{212}$ Entre os episódios mais polêmicos no período podem-se citar os casos do Sul Brasileiro, em fevereiro de 1985, que resultou na criação do Banco Meridional por meio da Lei 7.315, de 24 de maio de 1985, bem como a liquidação do Banco do Comércio e Indústria de São Paulo (Comind) e do Auxiliar, em novembro de 1985. O efeito dessas e

207 LUNDBERG, Eduardo Luís. Saneamento do sistema financeiro, p. 56.

208 ASSIS, J. Carlos. A chave do tesouro, p. 60.

209 Quanto à qualidade dos créditos, o próprio Bacen reconheceu em relatório encaminhado em 1980 à Comissão Parlamentar de Inquérito (CPI) do Mercado Financeiro no Senado que: "Como regra, a recuperação dos recursos alocados nas liquidações extrajudiciais é feita em razão direta da realização de ativos, conjugada com a Ação de Responsabilidade Civil contra os ex-administradores das instituições liquidandas, em decorrência do inquérito levado a efeito pelo Bacen. No particular, tem-se por escopo o sequestro dos bens dos ex-administradores, levados a hasta pública para que o produto reverta à massa, diminuindo, ou elidindo, o passivo a descoberto da empresa. Na prática, temos sentido que as forças da massa são, geralmente insuficientes, o que empresta a máxima importância à Ação de Responsabilidade Civil". Ver: Idem, ibidem, p. 61-62.

210 Idem, p. 61.

211 Idem, p. 61.

212 Idem, p. 78-79. 
outras operações ocorridas no período na reserva monetária pode ser constatado na tabela abaixo:

Tabela 5: Desempenho financeiro da reserva monetária (US\$ milhões)

\begin{tabular}{|c|c|c|c|}
\hline Ano & Receita de IOF & Desembolsos & Recuperações \\
\hline 1979 & 56,6 & 37,1 & 10,1 \\
\hline 1980 & 178,9 & 4,2 & 2,3 \\
\hline 1981 & 246,9 & 3,6 & 129,1 \\
\hline 1982 & $3.026,9$ & 2,7 & 5,8 \\
\hline 1983 & $1.304,4$ & 10,7 & 0,9 \\
\hline 1984 & $1.504,4$ & 1,8 & 0,8 \\
\hline 1985 & $1.042,6$ & 461,2 & 2,5 \\
\hline 1986 & $1.607,3$ & 295,5 & 78,5 \\
\hline 1987 & $1.632,6$ & $3.417,3$ & $2.404,6$ \\
\hline 1988 & 968,5 & 83,9 & 784,5 \\
\hline
\end{tabular}

Fonte: BUCCHI, Wadico. Garantia de depósitos em instituições financeiras, p. 60.

Finalmente, há que considerar nesse período os gastos decorrentes de reestruturações promovidas pelo Bacen em instituições financeiras estaduais, quadro esse agravado pelo esvaziamento dos cofres de tais instituições após as campanhas eleitorais de $1986 .{ }^{213}$ Tais fatores foram determinantes para a promulgação, em 25 de fevereiro de 1987, do Decreto-lei 2.321, que criou o Raet, logo em seguida modificado pelo Decreto-lei 2.327, de 24 de abril de 1987. Esse e outros regimes especiais aplicáveis a instituições em crise serão tratados em maiores detalhes no capítulo seguinte.

\subsection{Reforma bancária no final da década de 1980}

Apesar dos movimentos de concentração e conglomeração observados no período anterior, os bancos ainda eram obrigados a formalmente manter instituições separadas com base no formato de instituições especializadas, condicionadas pela regulamentação a praticar uma faixa restrita de operações. Isso foi modificado em 21 de setembro de 1988, quando o CMN, por meio da Resolução 1.524, introduziu uma reforma importante no sistema

213 LUNDBERG, Eduardo Luís. Saneamento do sistema financeiro, p. 58. 
financeiro, permitindo aos conglomerados financeiros a possibilidade de organizarem-se sob a forma de uma única instituição financeira, o banco múltiplo.

Na prática, a Resolução 1.524/1988 extinguiu o sistema de cartas patentes para o estabelecimento de instituição financeira, criando as chamadas "instituições universais". Segundo o Bacen, nesse modelo, as instituições, embora diferenciadas entre si na organização funcional e administrativa, na condução dos negócios e na escala de operações, apresentariam em comum o fato de, independentemente dessas diferenças, poderem oferecer todos os serviços financeiros. ${ }^{214} \mathrm{~A}$ respeito do normativo, vale mencionar o posicionamento de Andrezo e Lima: ${ }^{215}$

\begin{abstract}
O Sistema Financeiro Nacional foi concebido, em 1964, com base na ideia da especialização. Entretanto, nos anos 70 e 80, desenvolveu-se um processo de "concentração" dos bancos e conglomeração financeira. Na prática, o sistema de instituições especializadas nunca funcionou de forma perfeita. O próprio governo estimulava as fusões e incorporações, visando a redução dos custos e a ampliação dos serviços das instituições bancárias, o que nem sempre ocorre. Esta Resolução foi um mero reconhecimento da realidade existente no mercado de um sistema financeiro híbrido.
\end{abstract}

Além dessa importante Resolução, cumpre mencionar os efeitos da promulgação da Constituição de 1988 para o SFN. Com efeito, a redação original do art. 192 estabeleceu que o SFN fosse estruturado de forma a promover o desenvolvimento equilibrado do País e a servir os interesses da coletividade, remetendo sua regulamentação à legislação complementar e estabelecendo para ela um conteúdo mínimo, do qual se destacavam: (i) a autorização para funcionamento das instituições financeiras, assegurando às instituições bancárias oficiais e privadas acesso a todos os instrumentos do mercado financeiro; (ii) a organização, o funcionamento e as atribuições do Bacen e demais instituições financeiras; e (iii) a criação de fundo ou seguro com o objetivo de proteger a economia popular, garantindo créditos, aplicações e depósitos até determinado valor. ${ }^{216}$

214 BANCO CENTRAL DO BRASIL. Sistema Financeiro Nacional - 1989 a 2000. Disponível em: <www.bcb.gov.br/htms/Deorf/e88-2000/texto.asp?idpai=relsfn19882000>. Acesso em: 28 dez. 2010.

215 ANDREZO, Andrea Fernandes; LIMA, Iran Siqueira. Mercado financeiro, p. 181.

216 TURCZYN, Sidnei. O Sistema Financeiro Nacional e a regulação bancária, p. 114. 
No tocante à autorização para funcionamento das instituições financeiras, a redação original do art. 192 reafirmou o fim do sistema de cartas patentes, já previsto na Resolução 1.524/1988, estabelecendo que a autorização seria inegociável e intransferível, concedida sem ônus a pessoas com capacidade técnica, reputação ilibada e capacidade econômica compatível com o empreendimento. A superação do sistema de cartas patentes removeu a principal barreira para o ingresso de novas instituições no mercado, o que, na prática, representou a transição do sistema financeiro para um regime mais próximo do livre mercado.

Outra mudança de importância fundamental foi a transferência dos recursos captados por meio do IOF, que até então serviam para alimentar a reserva monetária, para o Tesouro Nacional. Nesse mesmo sentido, salienta-se também a vedação, prevista na redação original do art. 192, VI, à utilização de recursos da União no mecanismo de proteção aos créditos, aplicações e depósitos bancários a ser implementado. Ambas as mudanças vieram atender ao clamor por uma política de proteção aos depositantes mais transparente e sem o emprego de recursos públicos, em contraste com a política adotada nas décadas anteriores.

A eliminação da principal fonte de recursos para resgates de instituições financeiras não provocou fortes abalos no SFN. Isto porque, paralelamente às mudanças trazidas pela Constituição, o ambiente econômico também influenciou a estrutura do setor bancário naquele momento. De fato, o quadro de inflação crônica observado no período até 1994 mostrou-se favorável ao sistema bancário, que se adaptou bem a ele em seu processo de crescimento. As elevadas taxas de inflação contribuíram para alavancar a participação do setor bancário na renda nacional, permitindo aos seus participantes não apenas sobreviver, em um contexto que aparentemente seria hostil à atividade econômica e ao sistema financeiro, mas também acumular capital, desenvolver-se tecnologicamente e crescer, absorvendo parte considerável do imposto inflacionário gerado. Esse contexto de liberalização da atividade financeira e de altos ganhos decorrentes da inflação provocou uma expansão do sistema bancário, fazendo com que o número de bancos mais que dobrasse, atingindo o número de 246 participantes ao final de $1994 .^{217}$

217 BANCO CENTRAL DO BRASIL. Sistema Financeiro Nacional - 1989 a 2000. 


\subsection{Plano Real e a abertura do setor bancário}

O processo de estabilização financeira promovido pelo Plano Real afetou profundamente o setor bancário. Entre os principais impactos causados pela drástica diminuição da inflação podem-se mencionar: (i) redução da arrecadação de receitas inflacionárias; (ii) queda das oportunidades de arbitragem no mercado financeiro; e (iii) redução da demanda por serviços bancários. ${ }^{218}$ Isso atingiu duramente o desempenho de bancos que haviam se acostumado com as receitas inflacionárias auferidas no período anterior. Considerando seu peso no faturamento total dos bancos, as receitas inflacionárias, que chegaram a atingir $87,3 \%$ nos anos anteriores, caíram para 49,5\%, em 1994, e 1,6\% em 1995. ${ }^{219}$ Consequentemente, a participação do SFN no PIB do País reduziu-se de $15,61 \%$ em 1993 para $6,94 \%$ em $1995 .^{220}$

Além da perda expressiva de receita inflacionária, o novo contexto econômico afetou negativamente os bancos sob outro aspecto. Na tentativa de manter suas taxas de rentabilidade e procurando aproveitar o aumento dos depósitos bancários provocado pela estabilização da moeda, muitos bancos partiram para uma estratégia de troca de receita inflacionária pela receita de serviços. ${ }^{221}$ Essa categoria de receita, que representava apenas $8 \%$ do faturamento total dos bancos em 1990, aumentou para 10,5\% em 1993, e 21,5\% em $1995 .^{222}$ Esse crescimento da receita de serviços, no entanto, não foi realizado de forma estruturada, havendo grande aumento dos créditos de liquidação duvidosa, o que acabou por aumentar também a vulnerabilidade do setor. ${ }^{223}$

A combinação desses fatores provocou uma deterioração da condição financeira dos bancos, causando a quebra de instituições ineficientes e a deflagração de um processo de fusões e aquisições. O processo de concentração bancária observado historicamente na

\footnotetext{
218 MULLER, Bianca Abbot. Concorrência no setor bancário brasileiro, p. 50.

219 CORAZZA, Gentil. Crise e reestruturação bancária no Brasil. Universidade Federal do Rio Grande do Sul, p. 4, 2000. Disponível em: <www.ufrgs.br/ppge/pcientifica/2000_08.pdf>. Acesso em: 23 dez. 2010.

220 Idem, ibidem, p. 5.

221 Idem, p. 5.

222 Idem, p. 5.

223 Idem, p. 5.
} 
segunda metade do século XX, com uma breve interrupção no período de 1989-1994, voltou a ganhar fôlego com a implementação do Plano Real. ${ }^{224}$ A título ilustrativo, no período de 1994 a 2003, o número de bancos reduziu-se em 30\%, caindo de 246 para 164 bancos. $^{225}$

Esse processo envolveu instituições como o Banco Nacional, Banco Econômico e o Banco Bamerindus, que integravam a lista dos dez maiores bancos brasileiros em ativos bancários até então. Outro aspecto relevante quanto ao processo de concentração no setor bancário identificado na década de 1990 é que, assim como no período do regime militar, o governo desempenhou um papel fundamental nesse movimento por meio de incentivos oficiais como o Programa de Estímulo à Reestruturação e ao Fortalecimento do Sistema Financeiro Nacional (Proer) e Programa de Incentivo para a Reestruturação do Sistema Financeiro Estatal (Proes), representando um novo esforço de saneamento do SFN.

\subsubsection{Saneamento do Sistema Financeiro Nacional - o Plano Real}

O início da implementação do Plano Real, em julho de 1994, logo evidenciou que o novo ambiente de estabilização monetária não seria condizente com a dimensão que o sistema bancário havia alcançado, fruto de vários anos de alta inflação e desequilíbrios macroeconômicos. ${ }^{226}$ Nesse sentido, o governo já vinha procurando preparar os bancos nacionais para a mudança de conjuntura. Por meio da Resolução CMN 2.099, de 26 de agosto de 1994, foram adotadas medidas com o objetivo de modernizar e aumentar as exigências de capitalização das instituições financeiras, em linha com as recomendações internacionais do

224 Estudos empíricos apontam um aumento da concentração bancária no Brasil ao longo da década de 90. Rocha mostra que, de forma geral, o grau de concentração bancária, tanto em termos de RC ou HHI, elevouse no período de 1994-2000 (ROCHA, Fernando A. S. Evolução da concentração bancária no Brasil (19942000). Notas Técnicas do Banco Central, n. 11, nov. 2001). Paula e Marques encontram evidências semelhantes, apontando que a RC dos ativos totais dos cinco maiores bancos aumentou de $50,51 \%$ para $59,75 \%$ entre o primeiro semestre de 1997 e o segundo semestre de 2004. No mesmo período, a RC 10 elevou-se de 61,12\% para 79,16\%. Ver: PAULA, Luis Fernando; MARQUES, Maria Beatriz L. Tendências recentes da consolidação bancária no Brasil. Revista Análise Econômica, ano 24, n. 45, 2006.

225 Dados extraídos dos relatórios Sistema Financeiro Nacional 1989-2000, Sistema Financeiro Nacional 2001 e Sistema Financeiro Nacional 2002, do Bacen. Disponíveis em: 〈www.bcb.gov.br/?SFNCOMPEV〉. Acesso em: 28 dez. 2010.

${ }^{226}$ ALMEIDA JR., Mansueto; BARROS, José Roberto Mendonça de. Análise do ajuste do Sistema Financeiro no Brasil. Revista de Política Comparada, Brasília, v. 1, n. 2, p. 4, 1997. 
Acordo de Basileia. Desse modo, o Bacen sinalizava às instituições financeiras que deveriam se ajustar aos novos tempos de moeda estável. ${ }^{227}$

Apesar dos esforços do governo, isso não impediu a quebra em 1995 de dois dos maiores bancos do Brasil, iniciando novo processo de saneamento com vastas implicações para a estrutura do setor bancário, bem como sua regulação e supervisão. A primeira delas foi a quebra do Banco Econômico, o 4..$^{\circ}$ maior banco do País em depósitos à época, em agosto de 1995. ${ }^{228}$ Documentos do Bacen indicam que o Econômico vinha enfrentando grandes dificuldades desde dezembro de $1994 .{ }^{229}$ Não obstante, em razão do temor provocado pelas crises bancárias no México e Argentina no início do ano, a autarquia preferiu evitar a intervenção e adotar uma "solução de mercado" para o banco. ${ }^{230}$

O Bacen passou a financiar o Econômico, procurando mantê-lo em funcionamento até que fosse encontrado um comprador. Conforme relato da mídia, em 6 de março de 1995, a sua necessidade de crédito era de $\mathrm{R} \$ 664$ milhões, elevando-se para $\mathrm{R} \$ 1,467$ bilhão em 2 de maio do mesmo ano, valor este que saltaria para cerca de $\mathrm{R} \$ 3$ bilhões às vésperas da intervenção. ${ }^{231}$ Além do recurso reiterado ao redesconto do Bacen, dados do Instituto Brasileiro de Geografia e Estatística (IBGE) mostram que instituições oficiais também desempenharam papel fundamental no apoio ao banco com a concessão de financiamentos de valores significativos. ${ }^{232}$

227 LUNDBERG, Eduardo Luís. Saneamento do sistema financeiro, p. 60.

228 CORAZZA, Gentil. Crise e reestruturação bancária no Brasil, p. 5.

229 Conforme relato da Isto É, em reportagem que lhe rendeu o Prêmio Esso de jornalismo em 1998 na categoria "informação econômica": "Segundo documentos do BC, foi a partir de dezembro de 1994 que o Econômico mergulhou, sem volta, num cipoal de dificuldades. No sexto mês de vida do Plano Real, constatou-se uma maior retração do mercado em relação ao Banco Econômico nas diversas linhas de financiamento - CDI, CDB, RDB - especialmente em relação aos investidores de grande porte, instituições financeiras e investidores institucionais. O banco precisou recorrer sucessivamente, e de forma crescente, à assistência financeira do Bacen para suprir suas dificuldades de caixa”. Ver: ISTO É. A conta do Proer, n. 1.504, 29 jul. 1998, p. 108 e ss.

230 CARVALHO, Carlos Eduardo. Ocultamento e mistificação nas relações do Banco Central com os bancos: notas sobre a experiência brasileira. Política\&Sociedade, n. 6, p. 206-207, abr. 2005.

231 ISTO É. A conta do Proer, 29 jul. 1998, p. 108 e ss.

232 IBGE. Sistema financeiro: uma análise a partir das contas nacionais, p. 164, apud CARVALHO, Carlos Eduardo. Ocultamento e mistificação nas relações do Banco Central com os bancos, p. 209. 
O tortuoso processo negocial para salvar o grupo baiano passou a ser tema frequente na imprensa, com detalhes sobre a gravidade dos problemas e as dificuldades para se chegar a um acordo. A iminência da intervenção estava insinuada na imprensa dois dias antes de sua decretação, ao lado de declarações oficiosas das autoridades de que os depositantes não sofreriam prejuízos. ${ }^{233}$ Nesse ínterim, grandes aplicadores empreendiam uma debandada final, causando expressivo rombo nas contas do banco. ${ }^{234}$ Apesar de todos os esforços do Bacen, as tentativas de achar um comprador restaram infrutíferas, e a autarquia decidiu decretar a intervenção no Econômico em 11 de agosto de 1995.

A intervenção demonstrou ser apenas o início de uma grave crise bancária. Em um intervalo de meses após a sua quebra, as atenções voltaram-se ao Nacional, o 3. ${ }^{\circ}$ maior banco do País em depósitos à época. ${ }^{235}$ Existem relatos de que as primeiras irregularidades no Nacional já haviam sido detectadas pelo Departamento de Fiscalização do Bacen, em 3 de setembro de 1987, quando foi concluído o primeiro relatório detalhando operações ilegais, ${ }^{236}$ havendo inclusive alegações de que o banco estaria quebrado desde 1986, sobrevivendo desde então graças a fraudes contábeis e conivência da autoridade bancária. ${ }^{237}$ Independentemente da raiz exata do problema, entre março e abril de 1995, a fragilidade do Nacional já era de conhecimento da maioria dos participantes do mercado, que passaram a lhe negar crédito, ${ }^{238}$ fazendo com que este dependesse do redesconto do Bacen para continuar operando. Além do redesconto, o banco também contou com o auxílio da Caixa Econômica Federal (CEF) e do Banco do Brasil mediante a concessão de financiamentos. ${ }^{239}$ Influenciados pelo clima de

233 IBGE. Sistema financeiro: uma análise a partir das contas nacionais, p. 164, apud CARVALHO, Carlos Eduardo. Ocultamento e mistificação nas relações do Banco Central com os bancos, p. 207.

234 Conforme relato da revista Veja, "Só neste ano, o Econômico perdeu 880 milhões de reais em depósitos. O Bradesco tirou os 50 milhões de reais que mantinha ali aplicados. O mesmo fizeram o Real, o Lloyds e o Banco do Brasil. 'Quando vimos que podíamos perder dinheiro, sacamos tudo', diz um operador do 1313. Até o Banespa, que também está sob intervenção do BC, sacou os 247 milhões de reais que tinha investidos no Econômico. Dos grandes fundos de pensão, dez sacaram 160 milhões só neste ano. O campeão foi o Previ, dos funcionários do Banco do Brasil, que tirou 87 milhões de reais”. Ver: VEJA. O Barão da Bahia beija a lona, n. $1.405,16$ ago. 1995 , p. 85 .

235 CORAZZA, Gentil. Crise e reestruturação bancária no Brasil, p. 5.

236 ISTO É. A conta do Proer, 29 jul. 1998.

237 VEJA. O golpe do balanço fraudado, n. 1.433, 28 fev. 1996, p. 82 e ss.

238 Idem, ibidem, p. 82 e ss.

239 "Nesse caso, quem socorreu o Nacional foi o BB e a CEF, esta com uma operação pequena - de R\$230 milhões - no dia 16 de outubro de 1995. 'O Bacen encarregava-se de falar com cada um dos maiores 
insegurança provocado pela quebra do Econômico, que deixou cerca de 800.000 clientes repentinamente com o dinheiro preso no banco, correntistas de grande e pequeno porte apressaram-se para retirar suas economias da instituição. ${ }^{240}$

A gravidade da situação levou o governo a adotar uma série de medidas - conhecidas como Proer - voltadas à contenção da crise. O programa foi instituído pela Resolução CMN 2.208, de 3 de novembro de 1995, e pelas Circulares Bacen 2.636, de 17 de novembro de 1995, 2.672, de 6 de março, 2.681, de 19 de abril, e 2.713, de 28 de agosto, todas editadas em 1996, que tratam de fusões, transferência de controle acionário e modificação do objeto social das instituições financeiras. Além destas, merece destaque a Medida Provisória 1.182, de 17 de novembro de 1995, posteriormente convertida na Lei 9.447, de 14 de março de 1997, que, além de uniformizar o tratamento de determinadas matérias no âmbito da Lei 6.024/1974 e do Decreto-lei 2.321/1987, ampliou os poderes atribuídos à autoridade bancária para intervenções em instituições em crise. As medidas abarcadas pelo Proer previam, basicamente: (i) a criação de linhas especiais de crédito para equilibrar a estrutura de ativos e passivos da instituição beneficiária, concedendo-lhe liquidez; (ii) a liberação de recursos da reserva monetária para aquisição, pela instituição que pretendesse absorver outra, de títulos emitidos pela instituição a ser absorvida; (iii) a flexibilização de limites operacionais das instituições financeiras; e (iv) tratamento fiscal diferenciado e mais benéfico para as despesas decorrentes da reestruturação e para as perdas dela resultantes. ${ }^{241}$

É importante notar que o acesso às linhas de crédito do Proer foi condicionado à expressa autorização pelo Bacen, concedida caso a caso, tendo como pré-requisito básico a

parceiros, com os maiores agentes financeiros do mercado naqueles dias, e o Banco do Brasil foi um desses parceiros', confirmou o presidente do BB, Paulo César Ximenes, durante depoimento em comissão especial da Câmara, em junho de 1996. A Austin Asis, empresa especializada em balancetes de instituições financeiras, analisou os resultados do Banco do Brasil em 1995 e 1996 [...] Nos dois anos, o total de recursos provisionado pelo Banco do Brasil foi de $\mathrm{R}$ \$ 8,9 bilhões, dinheiro equivalente aos patrimônios do Bradesco e do Unibanco somados. 'Esses números todos significam que o banco teve seus custos de funcionamento elevados, queda nas receitas e provisionamento muito forte', diz um dos analistas da Austin. Para ele, o Banco do Brasil andou investindo mal nesse período. 'Aplicou dinheiro em ativos que não renderam.' A maior prova é que o percentual de inadimplência sobre as operações de intermediação financeira foi de $18 \%$ em 1995 e 22,4\% no ano seguinte, o maior índice dos últimos cinco anos." Ver: ISTO É. A conta do Proer, 29 jul. 1998, p. 108 e ss.

240 Idem, ibidem, p. 108 e ss.

241 Para um relato detalhado das medidas do Proer, ver: TURCZYN, Sidnei. O Sistema Financeiro Nacional e a regulação bancária, p. 221 e ss.; e VERÇOSA, Haroldo M. D. Bancos centrais no direito comparado: o Sistema Financeiro Nacional e o Banco Central do Brasil. São Paulo: Malheiros, 2005. p. 171 e ss. 
mudança de controlador da instituição pleiteando os recursos. Para tal, foi adotado o modelo de "banco bom - banco ruim" (good bank - bad bank), em que uma instituição adquire a parte saudável da estrutura de ativos e passivos (banco bom), sendo a carteira de créditos duvidosos e de ativos de menor liquidez (banco ruim) submetida à gestão pública, de acordo com as leis específicas relativas à insolvência das instituições financeiras. Observa-se, portanto, que algumas das medidas de saneamento aplicadas pelo Proer guardam semelhança com aquelas adotadas nas décadas de 70 e 80 . Considerando estes e outros requisitos, o Proer concedeu recursos para a realização de fusões e aquisições que contemplaram sete bancos, incluindo o Econômico e o Nacional, conforme a tabela abaixo:

Tabela 6: Fusões e aquisições bancárias com incentivos do Proer

\begin{tabular}{|l|l|c|}
\hline \multicolumn{1}{|c|}{ Instituição } & \multicolumn{1}{|c|}{ Comprador } & $\begin{array}{c}\text { Publicação no } \\
\text { D.o.U. }\end{array}$ \\
\hline Banco Nacional & Unibanco & 18.11 .1995 \\
\hline Banco Econômico & Banco Excel & 30.4 .1996 \\
\hline Banco Mercantil & Banco Rural & 31.5 .1996 \\
\hline Banco Banorte & Banco Bandeirantes & 17.6 .1996 \\
\hline Banco Martinelli & Banco Pontual & 28.8 .1996 \\
\hline Banco United & Banco Antônio Queiroz & 30.8 .1996 \\
\hline Banco Bamerindus & HSBC & 2.4 .1997 \\
\hline
\end{tabular}

Fonte: MULLER, Bianca Abbot. Concorrência no setor bancário brasileiro, p. 52 .

O volume financeiro das operações do Proer somou cerca de R $\$ 20$ bilhões, representando aproximadamente 2,7\% do PIB médio do triênio $1995-1997,{ }^{242}$ sendo que grande parte desses créditos ainda não foi recuperada. Conforme dados do próprio Bacen, a dívida junto ao Proer somava aproximadamente $\mathrm{R} \$ 13,1$ bilhões em dezembro de 2002, e o saldo devedor das reservas bancárias dos bancos que participaram do programa, $\mathrm{R} \$ 14,6$ bilhões. ${ }^{243} \mathrm{~A}$ dívida total junto à autarquia, portanto, era de $\mathrm{R} \$ 27,7$ bilhões. $\mathrm{O}$ valor da massa liquidanda dos bancos participantes do programa totalizava $\mathrm{R} \$ 25,9$ bilhões, sendo $\mathrm{R} \$ 6,8$

\footnotetext{
242 MAIA, Geraldo Villar Sampaio. Reestruturação bancária no Brasil: o caso do Proer. Notas Técnicas do Bacen, n. 38, p. 7, jun. 2003.

243 Idem, ibidem, p. 8-9.
} 
bilhões destinados a outros credores que não o Bacen. Logo, a perspectiva de recebimento era da ordem de $\mathrm{R} \$ 19,2$ bilhões ao final de $2002 .^{244}$

Outra importante medida adotada no combate à crise bancária de 1995 foi a criação do Fundo Garantidor de Crédito (FGC), um mecanismo de seguro de depósitos privado. O FGC teve sua criação autorizada pela Resolução 2.197, de 31 de agosto de 1995, seguindo-se a aprovação de seus estatutos e regulamento por meio da Resolução 2.211, de 16 de agosto de 1995, ambas do CMN. Vale mencionar que essas resoluções foram objeto de questionamento quanto à sua constitucionalidade, sob a alegação de que o regramento do FGC era matéria de Lei Complementar, nos termos da antiga redação do art. 192 da Constituição Federal. Embora reconhecendo a inconstitucionalidade dos normativos do CMN sobre o tema, ${ }^{245}$ o relator do caso no Supremo Tribunal Federal (STF), Ministro Francisco Rezek, entendeu que não poderia determinar a imediata suspensão da eficácia das Resoluções "sob pena de gerar tumulto, desordem e insegurança na comunidade dos correntistas e poupadores". 246

A implementação do FGC foi de grande relevância no contexto da reestruturação do setor bancário. Segundo Saddi, durante o período de 1997-1998, desembolsou-se um total de quase $\mathrm{R} \$ 3,3$ bilhões a aproximadamente 4 milhões de credores de onze instituições, dos quais cerca de $\mathrm{R} \$ 3$ bilhões corresponderam a pagamentos aos depositantes do Banco Bamerindus, após sua intervenção em março de 1997. ${ }^{247}$ À ocasião, como o FGC não tinha acumulado ainda recursos para honrar um crédito de tal monta, a cobertura aos depositantes do

244 MAIA, Geraldo Villar Sampaio. Reestruturação bancária no Brasil: o caso do Proer. Notas Técnicas do Bacen, n. 38, p. 8-9, jun. 2003.

245 O relator do caso no STF, Ministro Francisco Rezek, ao analisar os referidos normativos no julgamento da medida cautelar, entendeu que o CMN teria editado os atos normativos "com a evidente finalidade de suprir a exigência constitucional de lei complementar", transformando-se "em verdadeiro sucedâneo, constitucionalmente não autorizado, da lei complementar exigida pelo art. 192, VI, da Carta Política" (ADIn MC 1398: 91). Ainda, segundo o tribunal, a disciplina da matéria é de "reserva absoluta de lei em sentido formal", de "expressa reserva constitucional (que) só pode derivar de fonte parlamentar" (ADIn MC 1398: 94 e 96). O CMN teria transgredido o "princípio nuclear da separação dos poderes” (ADIn MC 1398: 96). Ver: ADIn MC 1398/DF, Rel. Min. Francisco Rezek, j. 13.03.1996.

246 O Ministro Mauricio Corrêa sustentou a decisão do relator, "tendo-se em vista que as medidas preconizadas nas normas questionadas, objeto desses atos do Banco Central do Brasil, visam exatamente à proteção do pequeno poupador" (ADIn MC 1398: 103). No entanto, o STF entendeu que os recursos públicos, relativos à incorporação do Fundo de Garantia dos Depósitos e Letras Imobiliárias (FGDLI) e da Reserva para Promoção da Estabilidade da Moeda e do Uso do Cheque (Recheque) ao fundo garantidor, por serem de improvável recuperação, deveriam ser retirados da composição do patrimônio do FGC. Ver: ADIn MC 1398/DF, Rel. Min. Francisco Rezek, j. 13.03.1996.

247 SADDI, Jairo. Crise e regulação bancária, p. 139. 
Bamerindus foi possível em larga medida por meio de um financiamento de $\mathrm{R} \$ 2,5$ bilhões do Bacen via Proer, mediante garantia dos créditos a receber do FGC, uma operação que foi objeto de questionamentos em razão da vedação constitucional vigente à época à utilização de recursos públicos no financiamento do FGC (art. 192, VI). ${ }^{248} \mathrm{O}$ restante do valor foi viabilizado pelas dezenove maiores instituições financeiras do setor, que concordaram em antecipar suas contribuições para possibilitar ao fundo honrar o pagamento dos depósitos segurados. $^{249}$

Além dos bancos privados, a reestruturação do SFN também envolveria os bancos estaduais. Desde o final de 1994 já se havia decretado o Raet em uma série desses bancos, incluindo o Banco Nacional do Estado de São Paulo (Banespa) e o Banco Nacional do Estado do Rio de Janeiro (Banerj). ${ }^{250}$ Procurando uma solução definitiva para a situação, foi baixada em 7 de agosto de 1996 a MP 1.514, que criou o Proes, com o objetivo de sanear o sistema financeiro público estadual. A medida autorizou o governo federal a financiar a privatização, extinção ou transformação dos bancos estaduais, além de permitir a aquisição dos créditos de governos estaduais e de suas empresas junto a seus bancos. Na data do estabelecimento do Proes, o sistema financeiro público estadual era composto por 35 instituições, sendo 23 bancos comerciais (ou múltiplos). ${ }^{251}$

Aspecto interessante do Proes a ser ressaltado refere-se à ajuda federal condicionada à privatização ou transformação dessas instituições em agências de fomento. Em casos em que não houvesse a transferência do controle acionário ou a transformação em agências de fomento, a ajuda federal ficaria limitada a 50\% dos recursos necessários, e o restante deveria ser arcado pelos governos estaduais. Entre os resultados mais significativos do Proes, podemse mencionar as privatizações do Banerj, do Credireal (pertencente ao governo de Minas Gerais) e a viabilização da renegociação das dívidas do Estado de São Paulo junto ao Banespa

\footnotetext{
248 ISTO É. A conta do Proer, 29 jul. 1998, p. 108 e ss.

249 SADDI, Jairo. Crise e regulação bancária, p. 139.

250 LUNDBERG, Eduardo Luís. Saneamento do sistema financeiro, p. 58.

251 Para um relato detalhado das medidas do Proes, ver: VERÇOSA, Haroldo M. D. Bancos centrais no direito comparado, p. 202 e ss.
} 
(com sua posterior privatização). ${ }^{252} \mathrm{O}$ socorro aos bancos estaduais no âmbito do Proes foi de cerca de R \$37 bilhões, baseando-se em valores de janeiro de $1998 .^{253}$

Tabela 7: Privatizações de bancos públicos no âmbito do Proes

\begin{tabular}{|c|c|c|c|c|}
\hline Data & Instituição & Comprador & $\begin{array}{c}\text { Valor } \\
(\mathbf{R} \$ \text { milhões })\end{array}$ & Ágio (\%) \\
\hline 26.6 .1997 & Banerj & Itaú & 311 & 0,4 \\
\hline 7.8 .1997 & Credireal & BCN & 121 & 0 \\
\hline 4.12 .1997 & Meridional & $\begin{array}{c}\text { Bozano, } \\
\text { Simonsen }\end{array}$ & 266 & 55 \\
\hline 14.9 .1998 & Bemge & Itaú & 583 & 85,7 \\
\hline 17.11 .1998 & Bandepe & ABN Amro & 183 & 3,2 \\
\hline 22.6 .1999 & Baneb & Bradesco & 260 & 303,2 \\
\hline 17.10 .2000 & Banestado & Itaú & 1.625 & 281,1 \\
\hline 20.11 .000 & Banespa & Santander & 7.050 & 0 \\
\hline
\end{tabular}

Fonte: MULLER, Bianca Abbot. Concorrência no setor bancário brasileiro, p. 52.

Apesar da larga reestruturação promovida pelo Proer e pelo Proes, ${ }^{254}$ o papel do Bacen no combate a crises bancárias ainda ficaria marcado por mais uma intervenção realizada na década de 1990, naquele que ficou conhecido como o caso ou escândalo Marka e FonteCindam. Embora essa intervenção não tenha se realizado necessariamente no contexto

252 PUGA, Fernando Pimentel. Sistema financeiro brasileiro: reestruturação recente, comparações internacionais e vulnerabilidades à crise cambial. Textos para Discussão BNDES, n. 68, p. 16, 1999.

253 VERÇOSA, Haroldo M. D. Bancos centrais no direito comparado, p. 174.

254 Além do Proer e do Proes, vale mencionar o Programa de Fortalecimento das Instituições Financeiras Federais (Proef), criado pela MP 2.196, de 28 de junho de 2001. Em complemento aos programas anteriores, o Proef focou nas instituições financeiras federais, procurando adequá-las à regulamentação bancária aplicável aos bancos privados (principalmente a incorporação das regras de adequação patrimonial do primeiro acordo de Basileia). Nesse sentido, o programa se valeu de três instrumentos básicos: (i) a transferência do risco de créditos de difícil recuperação no balanço dessas instituições para o Tesouro Nacional ou para empresa não financeira denominada Empresa Gestora de Ativos (Emgea), criada no âmbito do programa; (ii) a troca de ativos de pouca liquidez e baixa remuneração por ativos líquidos remunerados à taxa de mercado; e (iii) em menor grau, o aumento de capital de três instituições (Caixa Econômica Federal, Banco do Nordeste e Banco da Amazônia). Além dessas medidas, o Proef se valeu também de medidas que visavam pôr fim à longa e recorrente história de desequilíbrios nas instituições públicas federais, incluindo regras de governança corporativa voltadas à verificação da qualidade do processo decisório no que tange às rotinas de controle e de concessão de crédito. Para um relato detalhado das medidas do Proef, ver: MINISTÉRIO DA FAZENDA. Fortalecimento das instituições financeiras federais. Nota oficial divulgada em 22 de junho de 2001. Disponível em: <www.fazenda.gov.br/portugues/releases/2001/r010622.asp>. Acesso em: 27 dez. 2010. 
de saneamento do setor em virtude da queda da inflação, também está intrinsecamente ligado ao Plano Real; nesse caso, à desvalorização cambial ocorrida em 1999.

Em 13 de janeiro de 1999 o governo decidiu eliminar o sistema de bandas cambiais utilizado até então para orientar o valor da moeda. À ocasião, os Bancos Marka e FonteCindam haviam apostado na estabilidade do real, enquanto as demais instituições financeiras prepararam-se para a alta do dólar. Quando a desvalorização da moeda ocorreu, os bancos não tiveram como honrar seus compromissos, voltando-se então ao Bacen para auxílio financeiro.

Com a justificativa de que a quebra dos bancos poderia provocar pânico no sistema financeiro, a autarquia socorreu o Marka e o FonteCindam vendendo dólares com cotação abaixo do mercado. O episódio causou comoção pelas acusações de tráfico de influência de Luís Augusto Gonçalves a pedido de Salvatore Alberto Cacciola, então proprietário do Banco Marka, junto ao presidente do BACEN na ocasião, Francisco Lopes, gerando a abertura de uma Comissão Parlamentar de Inquérito (CPI), que concluiu que a operação de ajuda aos dois bancos causou prejuízo de $\mathrm{R} \$ 1,6$ bilhão aos cofres públicos. ${ }^{255}$ Além de questionamentos à legalidade da operação, houve críticas à atuação da autoridade bancária, haja vista que o sistema de garantias da BM\&F suportaria as perdas ocasionadas pelas quebras dos bancos, conforme atestado pelo superintendente-geral da BM\&F em depoimento à referida $\mathrm{CPI},{ }^{256}$ bem como pelo fato de as instituições financeiras envolvidas serem de pequeno porte, não apresentando risco de desencadear choques sistêmicos. ${ }^{257}$

\footnotetext{
255 VEJA. Perguntas que não calam, n. 1.704, 13 jun. 2001, p. 46.

256 Relatório final da "CPI dos bancos". Disponível em: <www.senado.gov.br/atividade/materia/detalhes.asp? tab=t\&p_cod_mate=1906>. Acesso em: 23 dez. 2010.

257 Idem, ibidem.
} 


\subsubsection{Abertura do setor bancário ao capital estrangeiro}

Além das diversas mudanças institucionais mencionadas nos tópicos anteriores, outro acontecimento de importância nesse período foi a abertura do setor bancário ao capital estrangeiro. $\mathrm{O}$ art. 52 do Ato das Disposições Constitucionais Transitórias (ADCT) restringiu a entrada de instituições financeiras estrangeiras no País até que fossem fixadas as condições previstas no art. 192, III, da Constituição Federal, ${ }^{258}$ que permitia a participação de capital estrangeiro em instituições financeiras se esta fosse considerada de interesse nacional ou em função de acordos internacionais.

Segundo Carvalho e Vidotto, o registro mais importante das razões do governo para a abertura do setor bancário é a Exposição de Motivos 311 (EM 311), de 24 de agosto de 1995, em que o Ministro da Fazenda propõe ao Presidente da República que utilize as prerrogativas constitucionais para reconhecer, como de interesse do governo, a participação ou o aumento do percentual de participação de pessoas físicas ou jurídicas, residentes ou domiciliadas no exterior, no capital de instituições financeiras nacionais. A EM 311 não fazia a defesa de uma abertura ampla e generalizada do setor bancário, e sim de um aumento da participação do capital estrangeiro, com base em um conjunto de contribuições esperadas. ${ }^{259}$

As justificativas apresentadas pela EM 311 combinam questões referentes aos bancos brasileiros e suas formas de atuação, notadamente as condições patrimoniais e de concorrência no setor, com a reiteração de orientações gerais da política econômica do período em termos de abertura externa e captação de recursos para financiar a balança de pagamentos. O diagnóstico inicial apresentado pela EM 311 é de que as instituições financeiras brasileiras eram "ineficientes administrativamente" e compensavam sua

258 Posteriormente revogado pela Emenda Constitucional 40, de 29 de maio de 2003.

259 CARVALHO, Carlos Eduardo; VIDOTTO, Carlos Augusto. Abertura do setor bancário ao capital estrangeiro nos anos 1990: os objetivos e o discurso do governo e dos banqueiros. Nova Economia, Belo Horizonte, v. 17(3), p. 403, 2007. 
fragilidade com ganhos permitidos pela inflação alta. Assim, no contexto de baixa inflação que passou a vigorar após o Plano Real, a fragilização dos bancos nacionais teria evidenciado a "escassez de capitais nacionais". Portanto, concluía que, no nível microeconômico, a presença estrangeira aumentaria a solidez e a eficiência do setor bancário por meio da capitalização e modernização técnica das instituições, resultando em menores custos de serviços. $^{260}$

O processo de entrada dos estrangeiros teve início em 1995, com destaque para as operações de aquisição do Banco Geral de Comércio, Banco Noroeste, Grupo Meridional e Banespa pelo Santander, fazendo com que este se tornasse o $3 .^{\circ}$ banco em ativos e maior estrangeiro no País à época. ${ }^{261}$ Além dessas, também podem ser mencionadas as aquisições do Bamerindus pelo HSBC, Banco América do Sul pelo Sudameris, Excel-Econômico pelo Bilbao Vizcaya e Banco Real pelo ABN Amro Bank. Por razões diversas que não caberia se aprofundar neste trabalho, os anos seguintes marcaram a gradativa saída de muitas dessas instituições do mercado brasileiro, de modo que, segundo dados do Bacen, a participação estrangeira no patrimônio líquido do SFN somava $17,4 \%$ ao final de $2009 .{ }^{262}$

Observa-se, portanto, que o período pós-plano Real ficou marcado pelo saneamento promovido no setor bancário, que acabou causando uma significativa mudança na estrutura regulatória do setor. É nesse período que surgem muitas das regras e mecanismos que serão objeto de estudo nos próximos capítulos. Embora algumas dessas medidas já tenham sido mencionadas, o quadro da página a seguir é ilustrativo sobre a quantidade e profundidade das mudanças ocorridas nesse período:

260 CARVALHO, Carlos Eduardo; VIDOTTO, Carlos Augusto. Abertura do setor bancário ao capital estrangeiro nos anos 1990, p. 404.

261 Idem, ibidem, p. 411.

262 Dados disponíveis em: <www.bacen.gov.br/?REVSFN>. Acesso em: 20 dez. 2010. 
Tabela 8: Principais mudanças institucionais no setor bancário (1994-2001)

\begin{tabular}{|c|c|c|}
\hline Data & Medida & Descrição \\
\hline Ago/94 & Res. CMN 2.099 & $\begin{array}{l}\text { Estabelece o limite mínimo de capital para constituir banco, bem } \\
\text { como limites adicionais conforme o grau de risco de ativos. }\end{array}$ \\
\hline Nov/95 & MP 1.179 & $\begin{array}{l}\text { Cria incentivos fiscais para a incorporação de instituições } \\
\text { financeiras. }\end{array}$ \\
\hline Nov/95 & MP 1.182 & $\begin{array}{l}\text { Amplia os poderes do Bacen, visando a realização de ações } \\
\text { preventivas saneadoras no sistema financeiro. }\end{array}$ \\
\hline Nov/95 & Resolução CMN 2.208 & Institui o Proer, para assegurar a liquidez e a solvência do sistema. \\
\hline Ago/95 & Resolução CMN 2.211 & Regulamenta o FGC. \\
\hline Nov/95 & Resolução CMN 2.212 & $\begin{array}{l}\text { Dificulta a constituição de novas instituições financeiras e cria } \\
\text { incentivos para a fusão, incorporação e transferência do controle } \\
\text { acionário. }\end{array}$ \\
\hline Mar/96 & MP 1.334 & $\begin{array}{l}\text { Institui a responsabilidade das empresas de auditoria contábil, em } \\
\text { caso de irregularidades na instituição financeira. }\end{array}$ \\
\hline $\mathrm{Jul} / 96$ & Resolução CMN 2.302 & $\begin{array}{l}\text { Obriga os bancos com dependência ou participação em instituições } \\
\text { financeiras no exterior a apurar os limites operacionais com base } \\
\text { em dados financeiros consolidados e aumenta o limite de capital } \\
\text { mínimo para a constituição destes bancos. }\end{array}$ \\
\hline $\mathrm{Jul} / 96$ & Resolução CMN 2.303 & $\begin{array}{l}\text { Permite às instituições financeiras cobrar tarifas pela prestação de } \\
\text { serviços. }\end{array}$ \\
\hline Ago/96 & MP 1.514 & $\begin{array}{l}\text { Cria o Proes, com a finalidade de sanear o sistema financeiro } \\
\text { público estadual. }\end{array}$ \\
\hline Maio/97 & Resolução CMN 2.390 & $\begin{array}{l}\text { Cria o Sistema Central de Risco de Crédito, obrigando as } \\
\text { instituições financeiras a identificar e informar o Bacen sobre } \\
\text { clientes que possuem saldo devedor superior a R\$50.000. }\end{array}$ \\
\hline Jun/97 & Resolução CMN 2.399 & $\begin{array}{l}\text { Aumenta o capital mínimo das instituições financeiras elevando de } \\
8 \% \text { para } 10 \% \text { dos ativos ponderados pelo risco. }\end{array}$ \\
\hline Nov/97 & Circular Bacen 2.784 & $\begin{array}{l}\text { Aumenta o capital mínimo das instituições financeiras elevando de } \\
10 \% \text { para } 11 \% \text { dos ativos ponderados pelo risco. }\end{array}$ \\
\hline Maio/98 & Resolução CMN 2.493 & $\begin{array}{l}\text { Possibilita aos bancos vender parte ou toda a carteira de crédito a } \\
\text { sociedades anônimas de objeto exclusivo (companhias } \\
\text { securitizadoras de créditos financeiros). }\end{array}$ \\
\hline Set/98 & Resolução CMN 2.554 & $\begin{array}{l}\text { Obriga as instituições financeiras a apresentar ao Bacen programa } \\
\text { para a implantação de sistemas de controles internos, de acordo } \\
\text { com orientações do Comitê de Basileia. }\end{array}$ \\
\hline Mar/01 & Lei $10.214 / 01$ & Reformulação do Sistema de Pagamentos Brasileiro. \\
\hline
\end{tabular}

Fonte: Adaptado de OLIVEIRA, Gesner. Defesa da concorrência e regulação no setor bancário. In: CAMPILONGO, Celso F. et al. Concorrência e regulação no sistema financeiro, p. 164-165. 


\subsection{Desenvolvimento recente - crise financeira internacional}

Se os primeiros anos do século XXI foram de relativa tranquilidade no setor bancário brasileiro - especialmente em contraste com a década passada -, o mesmo não se aplica ao período mais recente. Com efeito, a crise financeira que eclodiu no mercado hipotecário subprime norte-americano acabou contaminando sistemas financeiros ao redor do mundo, incluindo o brasileiro. Como reflexo dessa crise, observou-se, a partir de 2008, uma intensificação do processo de mudança da estrutura e arcabouço regulatório do setor.

Em especial, deve-se atentar à forte atuação do Bacen procurando conter os efeitos da crise no País a partir de agosto de 2008. A autoridade adotou uma série de medidas voltadas à flexibilização e redução dos depósitos compulsórios, visando aumentar a disponibilidade de recursos para empréstimos. ${ }^{263}$ Além do compulsório, o Bacen também tomou outras medidas para injetar recursos na economia, como a ampliação da garantia do FGC para certos depósitos a prazo (CDBs e RDBs) até o limite de $\mathrm{R} \$ 20$ milhões por correntista, a destinação de parte dos recursos do FGC para estimular o mercado de crédito, e a mudança na contabilidade de instituições financeiras, permitindo que créditos tributários oriundos de "diferenças temporárias" não fossem mais deduzidos de seu patrimônio. ${ }^{264}$

Além dessas medidas, o governo adotou outros mecanismos de caráter estrutural visando injetar recursos em instituições em dificuldades. Nesse sentido, podem-se mencionar as Circulares Bacen 3.407, de 2 de outubro de 2008, e 3.411, de 13 de outubro de 2008, que permitiram às instituições de grande porte comprar carteiras de crédito de bancos menores. As transações geraram abatimento do recolhimento compulsório feito sobre depósitos a prazo, valendo apenas para operações com instituições com patrimônio de até R \$7 bilhões. Esses regulamentos foram posteriormente modificados pela Circular Bacen 3.414, de 15 de outubro de 2008, que ampliou o rol de ativos que poderiam ser comprados de instituições de pequeno e médio porte.

263 Para um exame abrangente das medidas do Bacen, incluindo sua atuação no auxílio a instituições não bancárias, ver: VERÇOSA, Haroldo M. D. Considerações sobre o sistema financeiro, p. 27 e ss.; e MESQUITA, Mário; TORÓS, Mário. Gestão do Banco Central no pânico de 2008.

264 Essas e outras mudanças de relevo serão objeto de análise detida mais adiante. 
Em resposta à crise, a estrutura do setor bancário também passou por significativas transformações. No setor privado, destaca-se a fusão entre o Itaú e o Unibanco, respectivamente o segundo e quarto maiores bancos privados do País à época, criando o maior banco nacional, com R $\$ 575$ bilhões em ativos combinados, e o $16 .^{\circ}$ maior do mundo, à frente do espanhol BBVA e do suíço Credit Suisse. ${ }^{265}$ Embora as discussões sobre uma possível fusão já viessem ocorrendo há algum tempo, foi o efeito adverso da crise no Unibanco, especialmente o ataque especulativo sofrido em outubro de 2008, que acabou acelerando a união entre os bancos. ${ }^{266}$

No entanto, a liderança do Itaú-Unibanco no ranking nacional durou pouco, haja vista que o Banco do Brasil anunciou em novembro de 2008 a compra de 71,2\% do capital social (e capital votante na mesma proporção) da Nossa Caixa por cerca de $\mathrm{R} \$ 5,4$ bilhões e, em janeiro de 2009, anunciou a compra de 50\% do capital social (49\% do capital votante) do Banco Votorantim por cerca de $\mathrm{R} \$ 4,2$ bilhões. ${ }^{267}$ Além dessas operações, vale mencionar também a atuação da CEF durante a crise, que além de comprar carteiras de crédito de instituições financeiras em dificuldade, adquiriu 35\% do capital social (49\% do capital votante) do Banco Panamericano por cerca de $\mathrm{R} \$ 740$ milhões. ${ }^{268}$ Essas operações só foram possíveis devido ao apoio do governo por meio da edição da MP 443, de 21 de outubro de 2008, convertida na Lei 11.908 de, 3 de março de 2009, que autorizou o Banco do Brasil e a $\mathrm{CEF}$ a adquirir participações, inclusive controle acionário, de outras instituições financeiras.

Embora as operações observadas no setor sigam em linha com o movimento observado em outros países do mundo no mesmo período, é necessário ressaltar que, pelo menos no caso brasileiro, estas refletem a continuidade de um processo de concentração dos anos anteriores. Com efeito, em 2006, o Itaú havia comprado os ativos do BankBoston no país e o UBS havia comprado o Banco Pactual. Conforme apontamento de Pinto, dados do Bacen à época mostravam que o total de bancos múltiplos e comerciais no país havia recuado de 191 em 2000 para 159 ao final de 2005, e que, no período de 1996 a 2004, os dez maiores bancos

\footnotetext{
265 EXAME. O Brasil na era dos megabancos, ano 42, n. 22, 13 out. 2008, p. 23.

266 Para um relato detalhado dos episódios que aceleraram a fusão entre o Itaú e o Unibanco, ver: VALOR INVESTE. A história não contada do ataque especulativo ao Unibanco, ano 7, n. 34, nov. 2009.

267 Fatos relevantes referentes às operações disponíveis em: <www.bb.com.br>. Acesso em: 8 dez. 2010.

268 Fato relevante referente à operação disponível em: <www.panamericano.com.br>. Acesso em: 8 dez. 2010.
} 
haviam elevado sua participação no total de ativos bancários de $60,1 \%$ para $68 \%{ }^{269}$ Além dessas operações, também deve-se mencionar a aquisição em 2008 do ABN pelo Santander que, segundo declaração do presidente do Itaú, Roberto Setúbal, foi um dos fatores que motivou a fusão com o Unibanco. ${ }^{270}$

\subsection{Autoridades do setor bancário}

\subsubsection{Conselho Monetário Nacional}

Conforme visto, o CMN foi criado em substituição ao conselho da antiga Sumoc, passando a ser a autoridade máxima do SFN. ${ }^{271} \mathrm{O}$ art. $2 .^{\circ}$ da Lei 4.595/1964 atribuiu ao CMN a incumbência de formular a política da moeda e do crédito objetivando o progresso econômico e social do País. Nesse sentido, o órgão ficou investido das mais amplas atribuições de caráter normativo sobre as principais diretrizes do sistema financeiro. ${ }^{272}$

Inicialmente o CMN era composto pelo Ministro da Fazenda, na qualidade de presidente, o presidente do Banco do Brasil, o presidente do Banco Nacional de Desenvolvimento Econômico, e seis membros nomeados pelo Presidente da República, após aprovação do Senado Federal. ${ }^{273}$ Contudo, a composição do CMN já foi alterada 16 vezes,

269 PINTO, Gustavo Mathias Alves. Concorrência em risco: Banco Central deve ficar mais atento à concentração bancária. Consultor Jurídico, 29 jun. 2006. Disponível em: <www.conjur.com.br/2006-jun29/bc_ficar_atento_concentracao_bancaria>. Acesso em: 28 dez. 2010.

270 FOLHA DE SÃO PAULO. Fusão Itaú-Unibanco foi acelerada por compra do ABN pelo Santander, 3 nov. 2008.

271 Para uma exposição detalhada da composição, autonomia e competências do CMN, ver: TURCZYN, Sidnei. O Sistema Financeiro Nacional e a regulação bancária, p. 132-138.

272 ANDREZO, Andrea Fernandes; LIMA, Iran Siqueira. Mercado financeiro, p. 38.

273 Observa-se que, embora seis membros fossem indicados pelo Presidente, as decisões do órgão eram tomadas por maioria de votos, o que daria, em tese, autonomia decisória relativa ao Executivo. Apesar de a sistemática do órgão possuir como pressuposto um regime político democrático, a realidade encontrada no País a partir de 1964 era muito diferente. Portanto, a regulação pretendida foi muitas vezes substituída pela atuação direta e exclusiva do Estado por seus Ministérios. Conforme relato de Turczyn, "tornaram-se famosas as reuniões 'telefônicas' para justificar as decisões governamentais tomadas autoritariamente e comunicadas 'telefonicamente' aos conselheiros que, teoricamente, deveriam ter participado do processo decisório". Ver: TURCZYN, Sidnei. O Sistema Financeiro Nacional e a regulação bancária, p. 137-138. 
chegando a ter 24 membros. ${ }^{274}$ Atualmente, de acordo com o art. 8. ${ }^{\circ}$, caput, da Lei 9.069, de 29 de junho de 1995, o CMN é integrado pelo Ministro da Fazenda, na qualidade de presidente, pelo Ministro de Estado do Planejamento, Orçamento e Gestão, e pelo presidente do Bacen. O regimento interno do CMN em vigor foi aprovado pelo Decreto 1.307, de 9 de novembro de 1994, e alterado pelo Decreto 1.649, de 7 de setembro de 1995.

$\mathrm{O}$ art. $3 .^{\circ}$ da Lei 4.595/1964 traça os amplos objetivos da política a ser formulada pelo CMN, entre os quais se inclui o zelo pela liquidez e solvência das instituições financeiras (art. 3. $\left.{ }^{\circ}, \mathrm{VI}\right)$. A fim de possibilitar ao CMN a consecução de tais objetivos, o art. $4 .^{\circ}$ da lei outorgou-lhe diversas competências, que devem ser exercidas, segundo o caput do artigo, de acordo com diretrizes estabelecidas pelo Presidente da República. Entre estas, vale mencionar as atribuições do CMN no campo fiscalizatório, quais sejam: (i) regular a constituição, funcionamento e fiscalização dos que exercerem atividades subordinadas à Lei 4.595/1964 e a aplicação das penalidades previstas; (ii) determinar a percentagem máxima de recursos que as instituições financeiras poderão emprestar a um mesmo cliente ou grupo de empresas; (iii) estipular índices e outras condições técnicas sobre encaixes, mobilizações e outras relações patrimoniais a serem observadas; (iv) expedir normas gerais de contabilidade e de estatística obrigatórias para as instituições financeiras; (v) delimitar, no máximo a cada dois anos, o capital mínimo das instituições financeiras; (vi) regulamentar, fixando limites, prazos e outras condições, as operações de redesconto e de empréstimos, efetuadas com quaisquer instituições financeiras públicas e privadas; (vii) estabelecer normas a serem observadas pelo Bacen na negociação com títulos públicos e de emissão de entidades de que participe o Estado; (viii) autorizar o Bacen e as instituições financeiras públicas federais a efetuar a subscrição, compra e venda de ações e outros papéis emitidos por sociedades de economia mista e empresas do Estado; (ix) disciplinar as atividades das bolsas de valores e de corretores de fundos públicos; (x) estatuir normas para as operações das instituições financeiras públicas, para preservar sua liquidez, e fixar limites a partir dos quais devem ser recolhidos os excedentes de depósitos ao Bacen; (xi) fixar as condições para operações de bancos estrangeiros; e (xii) determinar ao Bacen que recuse autorizações para o funcionamento de novas instituições financeiras. ${ }^{275}$

\footnotetext{
274 ANDREZO, Andrea Fernandes; LIMA, Iran Siqueira. Mercado financeiro, p. 38.

275 TURCZYN, Sidnei. O Sistema Financeiro Nacional e a regulação bancária, p. 134.
} 
Finalmente, desde a promulgação da Lei 9.649, de 27 de maio de 1998, que dispõe sobre a organização da Presidência da República e dos Ministérios, o CMN foi integrado à estrutura básica do Ministério da Fazenda, ao qual, por disposição do art. 14, IX, $a$, da mesma lei, foram atribuídos os assuntos relativos à moeda, crédito, instituições financeiras, capitalização, poupança popular, seguros privados e previdência privada aberta, entre outros. $^{276}$

\subsubsection{Banco Central do Brasil}

De acordo com o art. 56 da Lei 4.595/1964, o Bacen assumiu funções que eram executadas por outros órgãos até 1964, como a Cared e a Caixa de Mobilização Bancária (Camob). ${ }^{277}$ Além dessas, foram transferidas à autarquia outras funções previamente exercidas pelo Banco do Brasil, como a fiscalização bancária (art. 57, parágrafo único), incluindo a aplicação de penalidades (art. 10, IX). Com a reforma promovida pela Lei 4.595/1964, o órgão tornou-se o principal executor das políticas traçadas pelo CMN, atuando também como fiscalizador do SFN.

Em sua versão original, a diretoria do Bacen era composta por quatro membros nomeados pelo CMN entre seus componentes (art. 14). Essa composição foi alterada pelo Decreto 91.961, de 19 de novembro de 1985, sendo a diretoria atualmente composta por nove membros nomeados pelo Presidente da República, sendo um deles o presidente do órgão, que devem ser aprovados pelo Senado Federal, de acordo com os arts. 52, III, $d$, e 84, XIV, da Constituição Federal. O presidente do Bacen goza de status de Ministro de Estado (art. 1. ${ }^{\circ}$ da Lei 11.036, de 22 dezembro de 2004), cabendo a ele definir a competência e as atribuições dos demais diretores. Tanto o presidente da autarquia como os demais diretores são demissíveis a qualquer momento. ${ }^{278}$

As competências do órgão são arroladas ao longo da Lei 4.595/1964. No campo da regulação e supervisão financeira, cabe ao Bacen: (i) fiscalizar as instituições financeiras e

\footnotetext{
276 TURCZYN, Sidnei. O Sistema Financeiro Nacional e a regulação bancária, p. 138.

277 Para uma exposição detalhada das competências do Bacen, ver: Idem, ibidem, p. 138-148.

278 Idem, p. 144.
} 
aplicar as penalidades; (ii) conceder autorização de instalação e funcionamento às instituições financeiras; (iii) estabelecer condições para a posse e para o exercício de cargos de gestão ou exercício de funções em órgãos consultivos, fiscais e semelhantes das instituições; (iv) regular a execução dos serviços de compensação de cheques e de outros papéis; (v) exercer permanente vigilância nos mercados financeiro e de capitais, bem como empresas que, direta ou indiretamente, interfiram nesses mercados; (vi) aplicar penalidades dentro de uma gradação que vai da simples advertência até a cassação da autorização de funcionamento das instituições infratoras das normas; e (vii) efetuar o controle dos capitais estrangeiros. ${ }^{279}$

Além dessas funções, cabe também à autarquia autorizar a transformação, fusão, incorporação e encampação de instituições financeiras (art. 10, X,c) e de regular as condições de concorrência entre instituições financeiras, coibindo-lhes os abusos com a aplicação de penas (art. 18, § 2. ${ }^{\circ}$ ). Com o advento da Lei 8.884, de 11 de junho de 1994, no entanto, essa atribuição do Bacen tornou-se objeto de divergências com o Conselho Administrativo de Defesa Econômica (Cade), dirimidas em decisão recente do Superior Tribunal de Justiça $(\mathrm{STJ}){ }^{280}$

279 TURCZYN, Sidnei. O Sistema Financeiro Nacional e a regulação bancária, p. 140.

280 O conflito de competência entre o Cade e o Bacen tem origem na interpretação da Lei 4.595/1964 e da Lei 8.884/1994. Por um lado, a Lei 4.595/1964, em seu art. 18, estabelece que o Bacen regulará as condições de concorrência entre instituições financeiras no País. Por outro lado, a Lei 8.884/1994 não excetua a competência do Cade para tratar da concorrência no setor bancário. A tentativa de solução para a controvérsia veio por meio do Parecer GM-020, de 5 de abril de 2001, da Advocacia Geral da União (AGU), que determinou a competência do Bacen concernente ao tema. No entanto, o parecer não encerrou a questão. Ao contrário, o embate ganhou relevo no bojo do Ato de Concentração (AC) 08012.006762/2000-09, envolvendo o Banco Finasa de Investimento S.A., a Brasmetal Indústria S.A. e a Zurich Participações e Representações (conhecido como "Caso Finasa"). Embora o mérito do caso não trouxesse nenhuma dificuldade, a grande questão que teve de ser tratada pelo Cade foi o suposto conflito de competências entre as autarquias. Na ocasião, o Cade determinou por maioria de votos que tinha competência para julgar atos de concentração entre instituições financeiras. A discussão voltou à tona quando o Cade impôs multa por intempestividade na apresentação do AC envolvendo o Bradesco e o Banco de Crédito Nacional (AC 08012.002381/2001-23). A questão foi levada ao Judiciário, com o Tribunal Regional Federal da 1. ${ }^{\mathrm{a}}$ Região (TRF1) afirmando, por maioria de votos, a competência concorrente do Cade e Bacen para julgar atos de concentração envolvendo instituições financeiras. Dessa decisão houve recurso para o STJ, em que, por maioria de votos, decidiu-se pela competência exclusiva do Bacen (REsp 1094218/DF, Rel. Min. Eliana Calmon, Recorrente: Banco de Crédito Nacional S.A.; Recorrido: Conselho Administrativo de Defesa Econômica, j. 25.08.2010). Para um relato detalhado da cronologia e tópicos centrais da argumentação quanto ao conflito de competência entre as autoridades, ver: SUNDFELD, Carlos Ari. Concorrência e regulação no sistema financeiro. In: CAMPILONGO, Celso F. et al. Concorrência e regulação no sistema financeiro, p. 29 e ss. 


\subsubsection{Outras autoridades do Sistema Financeiro Nacional}

Além do CMN e Bacen, há outras autoridades responsáveis pela regulação e fiscalização de atividades financeiras no País. Ainda que não sejam objeto específico deste trabalho, a menção sucinta a essas autoridades torna-se necessária em face do contexto de conglomeração de atividades financeiras observado nas últimas décadas que, conforme se observará nos capítulos a seguir, afeta diretamente a eficácia da regulação sistêmica e prudencial.

A CVM é uma autarquia federal vinculada ao Ministério da Fazenda, criada pela Lei 6.385/1976, com o propósito de disciplinar o funcionamento do mercado de valores mobiliários e a atuação de seus participantes. Como o Bacen, a CVM está sujeita ao CMN, cabendo ao órgão a execução das regras e políticas definidas pela autoridade máxima do SFN. Dessa forma, a CVM disciplina, entre outras matérias: (i) o registro de companhias abertas; (ii) o registro de distribuições de valores mobiliários; (iii) o credenciamento de auditores independentes e administradores de carteiras de valores mobiliários; (iv) a organização, funcionamento e operações das bolsas de valores; e (v) a suspensão do registro, emissão, distribuição ou negociação de valores mobiliários.

Os mercados de seguros, capitalização e previdência aberta são regulados pelo CNSP e pela Susep. O CNSP é vinculado ao Ministério da Fazenda e atua como órgão normativo das atividades de seguros no Brasil, em posição similar à do CMN para as atividades bancárias e de mercado de capitais. O CNSP foi criado pelo Decreto-lei 73/1966, diploma que institucionalizou, também, o Sistema Nacional de Seguros Privados (SNSP). A principal atribuição do conselho, na época da sua criação, era fixar as diretrizes e normas da política governamental para os segmentos de seguros privados e capitalização. Posteriormente, com o advento da Lei 6.435/1977, as suas atribuições estenderam-se à previdência privada, no âmbito das entidades abertas. Com a edição da MP 1940-17, de 6 de janeiro de 2000, o CNSP teve sua composição alterada, passando a ser presidido pelo Ministro da Fazenda e constituído, também, por representantes do Ministério da Justiça, Ministério da Previdência Social, Susep, Bacen e CVM. 
A Susep é uma autarquia federal também criada pelo Decreto-lei 73/1966, que possui competência executiva e fiscalizatória em relação às atividades de seguros privados. Cabem à autarquia, fundamentalmente, a regulamentação do setor conforme orientação do CNSP e a supervisão das atividades exercidas. Recentemente, com a promulgação das Leis 9.932, de 20 de dezembro de 1999, e 10.190, de 14 de fevereiro de 2001, a Susep assumiu novas competências, sobretudo no que tange à regulação das atividades de resseguro e à competência para atuar nos procedimentos de intervenção e de liquidação extrajudicial das sociedades seguradoras.

\subsection{Tipos de instituição financeira}

É possível encontrar na atualidade uma variedade de formas de classificação das instituições financeiras atuantes no SFN nas obras dedicadas ao tema. Essas diferentes formas de classificação estão relacionadas ao conceito de instituição financeira presente em certos diplomas legais ${ }^{281}$ - notadamente a Lei $4.595 / 1964$-, bem como a análise de aspectos

281 Os primeiros diplomas legais a versarem sobre o conceito de instituição financeira no Brasil centravam-se no ato individual. O Código Comercial brasileiro de 1850 definia os banqueiros como "os comerciantes que têm por profissão habitual de seu comércio as operações chamadas de Banco". Embora o dispositivo apresentasse a virtude de indicar que a qualificação de empresário financeiro exigiria algo mais do que a simples prática isolada das operações típicas do ramo, devendo tal prática ser habitual, pouco contribuiu ao entendimento da matéria, haja vista sua manifesta circularidade. Essa orientação legislativa foi revisitada em 1860, com a promulgação do Decreto 2.711, e em 1921, com o Decreto 14.728, que procuraram listar as atividades típicas de bancos, seguindo a lógica de reiteração da prática de atos para o enquadramento no conceito de banco (SALOMÃO, Eduardo. Direito bancário. São Paulo: Jurídico Atlas, 2007. p. 13-14). O art. 17 da Lei 4.595/1964 representou um esforço de definição mais abrangente das atividades de intermediação financeira, estipulando que seriam consideradas instituições financeiras as pessoas jurídicas públicas ou privadas, que tivessem como atividade principal ou acessória a coleta, intermediação ou aplicação de recursos financeiros próprios ou de terceiros, em moeda nacional ou estrangeira, e a custódia de valor de propriedade de terceiros. Acrescentou, ainda, em seu parágrafo único, a equiparação às instituições financeiras para as pessoas físicas que exercessem quaisquer das atividades referidas naquele artigo, de forma permanente ou eventual. Esse conceito, no entanto, foi objeto de críticas em virtude de seu escopo, considerado "desmesuradamente amplo" por alguns autores, bem como as dificuldades impostas para sua adequada interpretação em razão de sua generalidade (Idem, ibidem, p. 15). Considerando a quantidade de atividades que envolvem coleta, intermediação ou aplicação de recursos financeiros próprios ou de terceiros, uma interpretação puramente gramatical do artigo faria com que poucas atividades escapassem do enquadramento como instituições financeiras. Mesmo em face das dificuldades práticas de aplicação do dispositivo, estrutura semelhante foi adotada na Lei 7.492/1986, que classificou como instituição financeira em seu art. $1 .^{\circ}$ as pessoas jurídicas de direito público ou privado, que tivessem como atividade principal ou acessória, cumulativamente ou não, a captação, intermediação, ou aplicação de recursos financeiros de terceiros, em moeda nacional ou estrangeira, ou a custódia, emissão, distribuição, negociação, intermediação ou administração de valores mobiliários. O dispositivo equiparou, também, a instituição financeira, pessoas jurídicas que captassem ou administrassem seguros, câmbio, consórcio, capitalização ou qualquer tipo de 
poupança, ou recursos de terceiros, bem como pessoas naturais que exercessem quaisquer das atividades referidas no artigo, ainda que de forma eventual. Segundo lição de Pimentel, originariamente o dispositivo era ainda mais extenso, uma vez que aludia também a "recursos financeiros próprios ou de terceiros". A palavra "próprios" foi vetada pelo Presidente da República, com a justificativa de que seria demasiadamente abrangente, atingindo o mero investidor individual, o que obviamente não era o propósito do legislador. Conforme a Mensagem de Veto 252, "na aplicação de recursos próprios, se prejuízo houver, não será para a coletividade, nem para o sistema financeiro [...]" (PIMENTEL, Manoel Pedro. Crimes contra o Sistema Financeiro Nacional, p. 29). Entre as principais diferenças sobre os dois conceitos destacam-se a menção expressa ao fato de a "captação, intermediação ou aplicação de recursos financeiros" poderem se dar de forma cumulativa ou não; só gerar o enquadramento como instituição financeira caso se referissem a recursos de terceiros; bem como a disposição expressa de que não apenas a custódia de valores mobiliários, mas também sua emissão, distribuição, negociação, intermediação ou administração, geram enquadramento como instituição financeira (SALOMÃO, Eduardo. Direito bancário, p. 477-478). Apesar disso, constata-se que a definição apresentada na lei padece da mesma linguagem excessivamente ampla do art. 17 da Lei 4.595/1964, de sorte que sua interpretação literal conduz a situações práticas incompatíveis com os fins pretendidos pela legislação bancária. Em face da falta de um critério mais preciso apresentado pelo legislador, tribunais têm historicamente empreendido esforços de interpretação dos referidos dispositivos para melhor delinear o conceito de atividade financeira. A respeito dessa evolução jurisprudencial, Arnoldo Wald destaca dois momentos principais de discussão do conceito (WALD, Arnoldo. A evolução do conceito de instituição financeira. Revista de Direito Bancário e do Mercado de Capitais, n. 28, p. 224, 2005). No primeiro, relativo ao período de 1970-1980, haver-se-ia consolidado o entendimento do antigo Tribunal Federal de Recursos, por meio do posicionamento do Ministro Godoy Ilha, exigindo que houvesse, sucessivamente, a captação de recursos de terceiros, a intermediação e a aplicação destes também em favor de terceiros, para que se caracterizasse a operação bancária. Conforme o extrato do acórdão do Tribunal: "Ora, a realização de empréstimos, com meios próprios e sem captação de recursos de terceiros, não se pode equiparar às atividades específicas das instituições financeiras, que consistem, como expresso no texto legal, na 'coleta, intermediação ou aplicação de recursos financeiros próprios ou de terceiros'. O traço característico das chamadas 'financeiras' é a captação de recursos do público em geral para investimentos financeiros, cujos resultados são atribuídos aos respectivos subscritores" (Acórdão do Tribunal Federal de Recursos, 2. ${ }^{a}$ Turma, HC 2.555/ES, Rel. Min. Godoy Ilha, j. 09.08.1971). Mais recentemente, a discussão nos tribunais teria se voltado à qualificação das operações de factoring e cartões de crédito como atividades privativas de instituição financeira. No caso das operações de factoring, o Ministério Público assumiu a posição de que estas corresponderiam a atividades de atribuição exclusiva das instituições financeiras. No entanto, o posicionamento majoritário dos Tribunais seguiu o entendimento de que as cessões de crédito, assunções de débito, mútuos de ações e operações de factoring em geral poderiam ser realizadas por empresas que não fossem instituições financeiras, com destaque para o voto vencedor do Desembargador Newton de Lucca no HC 96.03.046651-4, e sua análise aprofundada do conceito de instituição financeira (TRF 3. ${ }^{a}$ Reg., HC 96.03.046651-4/SP, Rel. Min. Aricê Amaral, j. 12.08.1997). No caso das operadoras de cartões de crédito, o STJ entendeu, em julgamento unânime de habeas corpus, que a intermediação financeira feita por empresa administradora de cartão de crédito não constitui ato privativo de instituição financeira (RHC 4.783, 5. ${ }^{\mathrm{a}}$ Turma, Rel. Min. Cid Flaquer Scartezzini, j. 26.05.1997). Arnoldo Wald assevera, no entanto, que no campo cível a mesma matéria foi julgada pela 3. . Turma do STJ (REsp 450453, Rel. Min. Carlos Alberto Menezes Direito, j. 12.03.2003), que, por maioria, "entendeu que a administradora de cartões de crédito devia ser considerada instituição financeira, mas tão somente para o fim de poder cobrar juros acima da taxa fixada pela Lei de Usura, havendo, todavia, votos minoritários divergentes" (WALD, Arnoldo. A evolução do conceito de instituição financeira, p. 224). Da evolução jurisprudencial pode-se concluir que, se não houver operação com terceiros, tanto na captação como na aplicação dos recursos, não se caracteriza a operação financeira para o fim de aplicação da legislação bancária (Idem, ibidem, p. 225). De fato, pode-se dizer que essa posição foi acompanhada pelo próprio Bacen, ao reconhecer que: "O empréstimo de dinheiro só se caracteriza como operação privativa das instituições financeiras quando o emprestador se situar na posição de intermediário recolhendo recursos de uns para emprestar a outros. Nestas condições, o empréstimo de recursos financeiros próprios, por ser matéria ligada à livre disposição de bens, que se atribui a todo homem civilmente capaz, não constitui atividade sob controle do Banco" (Informações da Diretoria de Normas da Organização do Sistema Financeiro Nacional - Deorg, que consta no voto do relator do RHC 4.783/SP). Ainda, nesse sentido: "Vigora no seio deste Bacen o entendimento de que a atividade financeira, tal como concebida nos arts. 17 e 18 da Lei 4.595/1964 e art. $1 .^{\circ}$ 
determinantes nas atividades desempenhadas por tais entidades, tarefa esta não raro influenciada pela formação jurídica ou econômica daquele que pretende apresentar o esquema de classificação. Dessa forma, é possível encontrar juristas que partem de uma interpretação literal dos dispositivos legais para classificar os tipos de instituição financeira, enquanto economistas tendem a privilegiar aspectos comuns às atividades desempenhadas por cada qual delas. $^{282}$

Para efeitos deste trabalho, será utilizado um esquema de classificação simplificado, baseado na diferenciação entre as instituições que captam depósitos à vista, gerando efeito multiplicador da moeda (chamadas de instituições financeiras monetárias), aquelas que captam recursos por meio da emissão de títulos para posteriores empréstimos (instituições

da Lei 7.492/1986, exige que a sua captação, intermediação ou aplicação de recursos a que aludem tais dispositivos implique intromissão especulativa nos mercados financeiro e de capitais, isto é, exploração do dinheiro com mercadoria, visando a obtenção de lucro" (Informação da Deorg que consta no voto do relator do RHC 4.783).

282 Com base na redação do $\S 11^{\circ}$ do art. 18 da Lei 4.595/1964, Salomão realiza uma diferenciação entre instituições financeiras e entidades equiparadas a instituições financeiras. As instituições financeiras seriam aquelas enunciadas no início do $\S 1 .^{\circ}$, quais sejam os estabelecimentos bancários oficiais ou privados, as sociedades de crédito, financiamento e investimentos, caixas econômicas e cooperativas de crédito. A estas o autor acrescenta os Bancos de Investimento e Desenvolvimento e as Sociedades de Crédito Imobiliário e Companhias Hipotecárias. A segunda categoria corresponderia ao restante do $\S 1 .^{\circ}$, ou seja, as bolsas de valores, companhias de seguros e de capitalização, as sociedades que efetuam distribuição de prêmios em imóveis, mercadorias ou dinheiro, mediante sorteio de títulos de sua emissão ou por qualquer forma, e as pessoas físicas ou jurídicas que exerçam, por conta própria ou de terceiros, atividade relacionada com a compra e venda de ações e outros quaisquer títulos, realizando nos mercados financeiro e de capitais operações ou serviços de natureza dos executados pelas instituições financeiras (SALOMÃO, Eduardo. Direito bancário, p. 72). Paulin parte de lógica semelhante para, a partir do mesmo dispositivo, diferenciar entre as instituições financeiras stricto sensu, as instituições auxiliares e as instituições equiparadas. $\mathrm{Na}$ primeira categoria se encontrariam aquelas relacionadas na parte inicial do $\S 1 .^{\circ}$ ("estabelecimentos bancários oficiais ou privados, as sociedades de crédito, financiamento e investimentos, caixas econômicas e cooperativas de crédito ou a seção de crédito das cooperativas que a tenham"); seriam instituições auxiliares aquelas outras relacionadas no mesmo dispositivo; e seriam instituições equiparadas todas as instituições enquadradas, em razão de suas atividades, no sentido amplo de instituição financeira, constante do caput do art. 17, ainda que não expressamente mencionadas naquela lei, como as sociedades de leasing (PAULIN, Luiz Alfredo. Das instituições financeiras de fato ou irregulares - análise com base na Lei n. ${ }^{\circ}$ 4.595/64. Revista de Direito Mercantil, Industrial, Econômico e Financeiro, São Paulo: Malheiros, v. 110, p. 202, 1998, apud YAZBEK, Otavio. Regulação do mercado financeiro e de capitais, p. 159). Em contraste com o recurso ao texto legal, o economista Alexandre Assaf Neto classifica os participantes do sistema financeiro em instituições bancárias, instituições não bancárias, o sistema brasileiro de poupança e empréstimo, instituições auxiliares e instituições não financeiras. A classificação baseia-se em características comuns das atividades exercidas por diferentes tipos de instituições, como a capacidade ou não de emitir moeda ou meios de pagamento, a captação de recursos via cadernetas de poupança e fundos provenientes do Fundo de Garantia por Tempo de Serviço (FGTS), a atuação no mercado de capitais, entre outros (ASSAF NETO, Alexandre. Mercado financeiro, p. 78-84). Fortuna segue um esquema semelhante, porém mais simples, classificando as instituições em monetárias, não monetárias e auxiliares. Esse será o esquema adotado para fins do presente trabalho, conforme os critérios que serão apresentados a seguir. 
financeiras não monetárias) e, finalmente, aquelas instituições que não se enquadram em nenhuma dessas categorias (instituições auxiliares). ${ }^{283} \mathrm{~A}$ adoção do esquema proposto justifica-se pelo fato de seguir em linha com os elementos clássicos de caracterização do risco sistêmico apresentados no capítulo anterior, bem como pelo fato de esse critério direcionar a aplicação de alguns mecanismos de regulação sistêmica e prudencial que serão observados nos capítulos seguintes. Evidentemente, o trabalho terá como foco apenas os principais tipos de instituições financeiras, não pretendendo esgotar o rol de participantes do SFN.

Os bancos comerciais são o mais típico exemplo de instituição financeira monetária, razão pela qual são chamados de "bancos por excelência" por alguns autores. ${ }^{284}$ Suas atividades consistem principalmente na captação de recursos à vista, por meio de depósitos bancários, para proporcionar o suprimento oportuno e adequado de recursos necessários para financiar, a curto e médio prazos, o comércio, a indústria, as empresas prestadoras de serviço e as pessoas físicas. ${ }^{285}$ Além desses depósitos, os bancos comerciais também captam recursos por meio da contratação de empréstimos no exterior para repasse a tomadores no País, bem como o recebimento de depósitos interbancários. Observa-se, portanto, o típico binômio captação-concessão com recursos de terceiros caracterizador da intermediação financeira.

Outro tipo de instituição monetária são as caixas econômicas. Elas podem ser estaduais ou federais, embora não haja na atualidade Caixas Econômicas Estaduais em funcionamento no País. ${ }^{286}$ Suas funções equiparam-se às dos bancos comerciais, na medida em que também podem captar depósitos à vista, realizar operações ativas e efetuar prestação de serviços, embora suas atividades sejam dirigidas primordialmente às pessoas físicas. ${ }^{287} \mathrm{Um}$ de seus diferenciais em relação aos bancos comerciais é sua principal fonte de recursos, decorrente dos depósitos em caderneta de poupança. Estes são instrumentos de captação privativos de entidades financiadoras ligadas ao Sistema Financeiro da Habitação (SFH). Complementarmente, recebem depósitos do FGTS e o produto da arrecadação de concursos lotéricos.

\footnotetext{
283 FORTUNA, Eduardo. Mercado financeiro, p. 26 e ss.

284 TURCZYN, Sidnei. O Sistema Financeiro Nacional e a regulação bancária, p. 178.

285 FORTUNA, Eduardo. Mercado financeiro, p. 27.

286 Dados disponíveis em: <www.bcb.gov.br/pre/composicao/ifcdv.asp>. Acesso em: 8 dez. 2010.

287 FORTUNA, Eduardo. Mercado financeiro, p. 28.
} 
No tocante às instituições financeiras não monetárias, merecem destaque os bancos de investimento. Conforme a Resolução CMN 18, de 18 de fevereiro de 1966, os bancos de investimento são instituições que têm por objetivo a captação de recursos para a prática de operações de investimento, participação ou de financiamento a prazos médio e longo, para suprimento de capital fixo ou de movimento de empresas do setor privado. Essas entidades podem captar recursos de diversas formas, como depósitos a prazo fixo, empréstimos contraídos no País e no exterior, venda de quotas de fundos de investimento, depósitos interfinanceiros, entre outros. Tais instituições desempenham uma ampla gama de atividades, destacando-se a administração de fundos de investimento, aquisição de ações, obrigações ou quaisquer outros títulos e valores mobiliários para investimento ou revenda no mercado de capitais (operações de underwriting) e atividades de private equity ou de venture capital, que envolvem a aquisição de participações em companhias fechadas, de modo a promover a sua modernização e profissionalização, preparando-as para uma futura venda ou emissão de títulos. $^{288}$

Além dos bancos de investimento, encontram-se nessa categoria as sociedades de crédito, financiamento e investimento (também chamadas de financeiras), bem como as sociedades de crédito imobiliário e companhias hipotecárias. As primeiras têm por objetivo a captação de recursos para a realização de financiamentos para capital de giro e aquisição de bens e serviços, enquanto as outras captam recursos para aplicação em financiamentos de operações imobiliárias, como a compra e venda de imóveis, loteamentos, incorporações de prédios, entre outros. ${ }^{289}$

Entre as instituições auxiliares do mercado financeiro vale mencionar o papel das sociedades corretoras e distribuidoras de títulos e valores mobiliários, bem como os chamados investidores institucionais. As sociedades corretoras e distribuidoras são instituições que atuam no mercado de capitais, dependendo de prévia autorização da CVM para funcionar. Elas operam com a compra, venda e distribuição de títulos e valores mobiliários, seja para a sua carteira própria, ou para seus clientes. Segundo Yazbek, embora corretoras e distribuidoras sejam autorizadas a realizar o mesmo tipo de atividade, as distribuidoras de

\footnotetext{
288 YAZBEK, Otavio. Regulação do mercado financeiro e de capitais, p. 161.

289 SALOMÃO, Eduardo. Direito bancário, p. 65; e ASSAF NETO, Alexandre. Mercado financeiro, p. 80.
} 
títulos e valores mobiliários têm uma faixa operacional mais restrita do que as corretoras, uma vez que não têm acesso às bolsas de valores e mercadorias. Portanto, não têm acesso direto ao pregão ou ao sistema de negociação das bolsas, não podendo intermediar operações de câmbio e prestar outros serviços típicos da atividade de intermediação. ${ }^{290}$

Os investidores institucionais mais relevantes são os fundos mútuos de investimento, as entidades fechadas e abertas de previdência privada e as seguradoras. ${ }^{291}$ Os fundos mútuos de investimento são constituídos sob a forma de condomínio aberto ou fechado, representando a reunião de recursos de cada investidor, destinados à aplicação em carteira diversificada de títulos e valores mobiliários, com o objetivo de propiciar aos seus condôminos a valorização de suas quotas. ${ }^{292}$ Os fundos não possuem personalidade jurídica, sendo administrados pelas instituições autorizadas a realizar esse tipo de atividade. Eles podem ser abertos ou fechados, conforme permitam ou não o resgate antecipado das quotas pelos seus detentores. As entidades de previdência complementar também podem ser abertas ou fechadas. As entidades abertas são acessíveis ao público em geral, mediante o pagamento de contribuições, devendo adotar a forma de sociedades anônimas. As entidades fechadas limitam o acesso a um público restrito (geralmente funcionários de empresas), e suas atividades devem ser desenvolvidas por associações ou fundações civis (os chamados "fundos de pensão"). Elas se qualificam como investidores institucionais, na medida em que aplicam parte de suas reservas técnicas nos mercados financeiro e de capitais com o objetivo de valorização do patrimônio, para garantir a complementação da aposentadoria, nos termos da Lei Complementar 109, de 29 de maio de 2001.

$\mathrm{O} \S 1 .^{\circ}$ do art. 18 da Lei 4.595/1964 equiparou as seguradoras a instituições financeiras, tendo a matéria recebido tratamento mais detalhado no Decreto-lei 73/1966, que criou o SNSP. A equiparação dá-se pelo fato de tais entidades administrarem a massa dos prêmios por elas recebidos (constituindo suas reservas técnicas), com aplicações nos mercados financeiro e de capitais. As seguradoras devem organizar-se sob a forma de sociedades anônimas ou de sociedades cooperativas, estando sujeitas a critérios e limitações operacionais próprias de cada forma. Tais sociedades devem limitar-se a operar nos ramos de

\footnotetext{
290 YAZBEK, Otavio. Regulação do mercado financeiro e de capitais, p. 167.

291 LAMEIRA, Valdir Jesus. Mercado de capitais. Rio de Janeiro: Forense Universitária, 2001. p. 24.

292 FORTUNA, Eduardo. Mercado financeiro, p. 36.
} 
seguros para os quais foram autorizadas, não desenvolvendo atividades de outra natureza. As reservas técnicas das sociedades seguradoras devem ser destinadas a modalidades operacionais, de renda fixa e variável, respeitando-se determinados limites de aplicação, conforme a regulamentação aplicável à matéria. ${ }^{293}$

\subsubsection{Bancos múltiplos}

Os bancos múltiplos, também chamados de bancos universais ou bancos multifuncionais, surgiram com a Resolução 1.524/1988, complementada pela Circular 1.364, de 4 de outubro de 1988, ambas do Bacen. Esses diplomas legais provocaram uma importante alteração no SFN ao eliminar a segregação formal das atividades financeiras presente na época, permitindo, assim, a reunião de diversas dessas atividades em uma única instituição financeira com personalidade jurídica própria.

Aos bancos múltiplos é permitido manter, por meio de uma única instituição, carteira comercial, atuar como banco de investimentos, operar com captação de poupança e operar com crédito ao consumidor, além de exercer outras atividades de banco comercial. Para se caracterizar a existência do banco múltiplo, a instituição deve possuir pelo menos duas das carteiras mencionadas, sendo uma delas, obrigatoriamente, comercial ou de investimento.

\subsubsection{Instituições financeiras públicas}

As instituições financeiras públicas são órgãos auxiliares da execução da política de crédito do Governo Federal, e sua ação deve pautar-se no sentido de complementar as atividades bancárias privadas, almejando o pleno atendimento das necessidades da economia. ${ }^{294}$ De acordo com o $§ 1 .^{\circ}$ do art. 22 da Lei 4.595/1964, as instituições financeiras públicas federais têm suas atividades, capacidade e modalidades operacionais reguladas pelo CMN. Já as instituições financeiras públicas não federais ficam sujeitas às disposições

\footnotetext{
293 YAZBEK, Otavio. Regulação do mercado financeiro e de capitais, p. 169-170.

294 ANDREZO, Andrea Fernandes; LIMA, Iran Siqueira. Mercado financeiro, p. 47.
} 
relativas às instituições financeiras privadas, de acordo com o art. 24 do mesmo diploma legal.

Importante diferença das instituições financeiras públicas federais é o fato de estas não se sujeitarem aos regimes especiais de intervenção e liquidação extrajudicial, nem ao Raet, nos termos do art. $1 .^{\circ}$ da Lei 6.024/1974 e do art. $1 .^{\circ}$ do Decreto-lei 2.321/1987. No caso das instituições financeiras públicas não federais, pelo fato de se sujeitarem ao mesmo regime das instituições financeiras privadas, estão subordinadas à fiscalização do Bacen, com possibilidade de aplicação de regimes especiais em tais instituições.

O exemplo mais notório de instituição financeira pública é o Banco do Brasil, uma sociedade de economia mista que possui diversas atribuições de interesse público, como receber, a crédito do Tesouro Nacional, as importâncias provenientes da arrecadação de tributos ou rendas federais. Outros exemplos de instituições financeiras públicas são o Banco Nacional do Desenvolvimento Econômico e Social (BNDES) e a CEF. 


\section{SÍNTESE E CONCLUSÕES DO CAPÍTULO 2}

1. As raízes do setor bancário brasileiro remontam a 1808, com a fundação do primeiro Banco do Brasil. Apesar disso, durante o século XIX até o início do século XX, o setor não foi objeto de nenhum planejamento específico pelo governo, passando por períodos alternados de crescimento e retração como reflexo das crises econômicas ocorridas no País, notadamente a crise cafeeira da década de 1860 e a crise do encilhamento no início da República.

2. É na década de 1920 que surgem os primeiros instrumentos de intervenção pública planejada no setor bancário. A criação da Inspetoria Geral dos Bancos e da Cared marcam um esforço do governo de exercer uma supervisão mais efetiva do setor bancário. Essa tendência foi reforçada nas décadas seguintes, com destaque para a criação da Sumoc em 1945, com funções análogas às de um banco central, ainda que tivesse que compartilhar o controle da política monetária com outros órgãos. Esse período indica também o surgimento de alguns dos maiores bancos nacionais e de uma rápida proliferação de agências em busca da escala necessária para financiar sua automação e expansão geográfica.

3. A Revolução de 31 de março de 1964 marca o início de uma ampla transformação não apenas do setor bancário brasileiro, como do próprio sistema financeiro como um todo. A Lei 4.595/1964 reformulou a estrutura de regulação e supervisão do setor bancário no País, com a criação do CMN e Bacen, estabelecendo as bases do arranjo institucional adotado até hoje. A Revolução marca também o início da aplicação de uma política governamental clara para o setor bancário. A percepção de uma elevada ineficiência operacional, fruto de uma proliferação desordenada de agências, levou o governo a promover de forma ativa e engajada a concentração e especialização das instituições financeiras, procurando alcançar maior mobilização de recursos e melhores níveis de eficiência na intermediação financeira, sob a expectativa de que tais medidas se traduziriam em uma redução das taxas bancárias de juros.

4. Em resposta à política estabelecida pelo governo, especialmente às limitações impostas à abertura de novas agências, observou-se intenso processo de fusões e aquisições de modo a viabilizar os projetos de expansão geográfica dos principais bancos atuantes no setor, 
refletindo-se em acelerado movimento de concentração no setor bancário durante o regime militar. Concomitantemente a esse movimento, apesar de a reforma de 1964 ter estimulado a criação de instituições financeiras especializadas e juridicamente autônomas, concretamente elas passaram a operar de maneira integrada sob a forma de conglomerados financeiros, geralmente tendo o banco comercial como instituição-chave do grupo econômico. Esses conglomerados financeiros experimentaram um rápido crescimento, facilitado pela gradativa diluição das barreiras regulatórias às atividades dos bancos e outras atividades financeiras, de modo que, na década de 1980, essas instituições já dominavam o mercado financeiro do País. Reconhecendo a realidade existente, a Resolução 1.524/1988 permitiu aos conglomerados financeiros a possibilidade de organizarem-se sob a forma de uma única instituição financeira, o banco múltiplo. Apesar das mudanças nos anos que se seguiram, esse quadro de conglomeração financeira ainda representa, em grande medida, a matriz atual do setor bancário brasileiro.

5. As décadas de 1970 e 1980 ficaram marcadas pela ocorrência de crises bancárias severas, com a quebra de instituições de porte, como o Halles, BUC, Comind e Auxiliar. É nesse período que se observa a criação de alguns dos mecanismos de regulação sistêmica adotados na atualidade, como a Lei 6.024/1974, para disciplinar a intervenção e liquidação extrajudicial de instituições financeiras. Apesar disso, a atuação da autoridade bancária no período se pautou na busca por "soluções de mercado" para as instituições em crise, com o Bacen assumindo ativos "podres" e vendendo a parte "sadia" dos bancos a outros participantes do mercado. As reestruturações no setor bancário foram financiadas com recursos da reserva monetária, que, aliadas ao ambiente político autoritário e escassa ou nenhuma prestação de contas pelo Bacen, fizeram com que esse esforço de saneamento do SFN ficasse marcado por denúncias de favorecimento a grandes clientes e banqueiros.

6. Na segunda metade da década de 1980, observa-se um esforço para reverter a sistemática adotada no resgate a instituições em crise nos anos anteriores. Dessa forma, é promulgada em 1986 a Lei 7.492 para tratar dos chamados "crimes do colarinho-branco". Além disso, a Constituição de 1988 transferiu os recursos captados pelo IOF da reserva monetária para o Tesouro Nacional, esvaziando a principal fonte de recursos para os resgates efetuados até então, além de prever a criação de um sistema de seguro de créditos, aplicações e depósitos, proibindo a utilização de recursos da União nesse mecanismo. A Constituição também introduz outras importantes alterações na regulação do setor bancário, como a 
ampliação do acesso ao sistema financeiro, garantindo a autorização para funcionamento a todas as instituições financeiras que cumprissem com os requisitos necessários.

7. Após período de relativa estabilidade no setor bancário, graças às receitas inflacionárias auferidas pelas instituições financeiras, a implementação do Plano Real em 1994 alterou drasticamente esse cenário. Além de eliminar uma importante fonte de receitas, o fim do quadro de inflação crônica expôs as ineficiências dos bancos atuando no setor. Em resposta, observou-se a quebra de algumas das principais instituições financeiras do País no período que se seguiu. Nesse contexto, o governo adotou uma série de medidas, conhecidas como Proer e Proes, voltadas à contenção da crise e à promoção de um novo ciclo de saneamento do SFN. Importante componente desses programas é promoção ativa e engajada da concentração bancária no setor novamente pelo governo. Algumas das estratégias de saneamento adotadas no período guardam similaridade com as medidas empregadas nas décadas de 1970 e 1980. O auxílio a bancos estaduais no âmbito do Proes foi condicionado à privatização ou transformação dessas instituições em agências de fomento, o que resultou na transferência do controle acionário da maioria delas para o setor privado. Finalmente, observa-se também nesse período o recurso reiterado a bancos oficiais para auxiliar instituições em crise.

8. É durante a década de 1990 que surgem alguns dos mais importantes mecanismos de regulação sistêmica e prudencial utilizados na atualidade, como a implementação das diretrizes do Acordo de Basileia, a criação do FGC, e a promulgação da Lei 9.447/1997, que ampliou os poderes atribuídos à autoridade bancária para intervenções em instituições em crise. É nesse período também que se iniciam as discussões para a reformulação do Sistema de Pagamentos Brasileiro, que resultariam na Lei 10.214/2001.

9. O início do século XX é marcado por uma aparente estabilidade no SFN, em contraste com a turbulência observada no setor bancário nas décadas anteriores. Isso é alterado, no entanto, em 2008, na medida em que os efeitos da crise financeira internacional originada no mercado subprime dos Estados Unidos contaminaram os mercados mundiais. Nesse sentido, observa-se novamente a atuação engajada do Bacen no combate aos efeitos da crise no País, promovendo importantes alterações no regramento de mecanismos de regulação sistêmica, como o redesconto bancário e o FGC. Muito embora o processo não tenha se interrompido desde a década de 1990, o período que se seguiu também marca 
uma aceleração do processo de concentração bancária, com o governo novamente desempenhando um papel relevante nesse movimento, dessa vez com a promulgação de medidas que permitiram a aquisição por bancos públicos de participação acionária em outras instituições financeiras.

10. A estrutura de regulação e supervisão do setor bancário estabelecida pela Lei 4.595/1964 prevalece em larga medida até hoje, com o CMN desempenhando o papel de formulador da política da moeda e do crédito e incumbido de amplas atribuições de caráter normativo sobre as principais diretrizes do SFN. Ao Bacen cabe o papel de executor das políticas traçadas pelo CMN, sendo responsável também pela supervisão do SFN. Há na atualidade uma variedade de instituições financeiras atuando no SFN, sujeitas a diferentes classificações de acordo com suas características e atividades desempenhadas. 


\section{Capítulo 3 \\ REGULAÇÃO SISTÊMICA}

\subsection{Regulação sistêmica}

Diversos campos da engenharia e da ciência dividem com a economia a preocupação com o risco sistêmico. ${ }^{295}$ De fato, esse tipo de risco pode manifestar-se nas mais diversas áreas, como as pragas que assolaram a Europa na Idade Média, cuja contaminação desenfreada eliminou parcela significativa da população, ou mesmo no uso abusivo de antibióticos para combater pequenos focos de doença, podendo ocasionar surtos de enfermidades resistentes a tais medicamentos. No entanto, embora os campos de aplicação do risco sistêmico sejam vastos, considera-se que a probabilidade e a severidade de sua ocorrência no setor bancário são mais graves. ${ }^{296} \mathrm{Em}$ razão disso, há uma percepção disseminada de que o bem-estar dos bancos é especial.

Os defensores desse caráter "especial" dos bancos alegam que as instituições financeiras são importantes fontes de capital, e que sua quebra, principalmente em grandes números, aumentaria o custo, ou mesmo eliminaria canais de acesso a capital para a sociedade. ${ }^{297}$ Esse argumento poderia ainda ser estendido a outras funções de relevo

295 Conforme a descrição do National Research Council: "O risco sistêmico se manifesta em acidentes com ônibus espaciais, acidentes de avião, o colapso dos diques de Nova Orleans, apagões elétricos, colapsos de edifícios, pontes e outras obras de engenharia. Em razão desses desastres ocasionais, engenheiros possuem dados mais relevantes para o estudo do risco sistêmico do que economistas. Usando esses dados para conduzir análises retrospectivas dos problemas sistêmicos, engenheiros conseguiram identificar e remover algumas raízes dos problemas (em aviação, por exemplo). De forma semelhante, epidemiologistas e especialistas em saúde pública preocupam-se com surtos contagiosos, que ocasionalmente alcançam níveis sistêmicos, aprendendo a administrar esse risco pelo estudo de epidemias passadas. Ecologistas estudam mudanças no estado dos ecossistemas, que mesmo recebendo menos atenção da imprensa, podem claramente se qualificar como eventos sistêmicos [...]". Ver: NATIONAL RESEARCH COUNCIL. New directions for understanding systemic risk, p. 29. Tradução livre.

297 Para uma revisão das teorias e autores que apoiam o caráter especial dos bancos, ver: KAUFMAN, George. Bank contagion: a review of theory and evidence. Journal of Financial Services Research, v. 8, n. 2, 1994. 
desempenhadas pelos bancos, conforme visto no início deste trabalho. Nas palavras de Bernanke e Gertler: ${ }^{298}$

Quebras bancárias são consideradas mais graves do que quebras de firmas não bancárias, porque tais instituições são vistas como os mais eficientes provedores de serviços de intermediação financeira, de modo que disrupções temporárias ou colapsos permanentes no relacionamento entre bancos e tomadores de empréstimos pode reduzir a quantidade e aumentar o custo de crédito na economia, ou seja, causar uma crise de crédito.

Outro argumento suscitado para diferenciar os bancos de outras empresas apoia-se na noção de que o contágio ocorreria de forma mais rápida no setor bancário, em comparação com os demais setores da economia. ${ }^{299}$ Isso aconteceria pelo fato de os bancos concentrarem ativos de alto valor agregado e pronta exigibilidade, além de estarem expostos a um grande número de credores sensíveis a mudanças de mercado. Para satisfazer súbitos incrementos de retiradas de seus clientes, bancos podem precisar vender ativos ou tomar empréstimos rapidamente, talvez em condições não atrativas (fire-sales). Nesse contexto, problemas de liquidez podem transformar-se rapidamente em problemas de solvência. ${ }^{300}$ Em contraste, instituições não bancárias possuem um número de credores menor, e sua dívida não é tipicamente exigível a qualquer momento, de modo que quedas temporárias no faturamento dificilmente provocam uma situação de insolvência imediata.

Alega-se também que quebras bancárias teriam efeitos mais danosos do que em outros setores da economia em virtude do mencionado "canal informacional" de contágio sistêmico. Em momentos de crise, correntistas podem ter dificuldade para avaliar a situação financeira de seus bancos, decidindo resgatar seus ativos apenas por precaução. Segundo a oportuna colocação de Kaufman, "a visão de longas filas em frente a bancos para sacar seus depósitos e a rápida velocidade com que estes podem ser retirados têm o potencial de causar pânico mesmo nos clientes mais fiéis". ${ }^{301}$ A possibilidade de os depositantes exigirem seus ativos prontamente e o receio de que uma reação tardia cause perda de capital facilitam o pânico e a disseminação da crise sistêmica. Caso depósitos tivessem prazos de vencimento

\footnotetext{
298 BERNANKE, Ben; GERTLER, Mark. Agency costs, net worth, and business fluctuations. American Economic Review, v. 79, n. 1, p. 14, mar. 1989. Tradução livre.

299 KAUFMAN, George. Bank contagion, p. 124.

300 Idem, ibidem, p. 124.

301 Idem, p. 127. Tradução livre.
} 
maiores, haveria tempo para diferenciação entre os bancos e a crise poderia não se propagar. No entanto, esse não é o caso do típico depósito em bancos comerciais, e isto é um importante diferencial para outros setores da economia.

A contundência dos argumentos apresentados não significa, no entanto, que a discussão sobre o caráter "especial” dos bancos seja um ponto pacífico na doutrina jurídica e econômica. Autores como Benston e Kaufman disputam a ideia de que crises bancárias possam ter efeitos catastróficos, afirmando que a quebra de um banco não deveria ser tratada de forma mais ou menos importante do que a quebra de qualquer outra empresa de tamanho comparável na sociedade. As intervenções governamentais no setor bancário, na opinião dos autores, teriam maior propensão para causar choques sistêmicos do que preveni-los. ${ }^{302}$

A respeito dos argumentos supracitados, tais autores sustentam, por exemplo, que, mesmo que um banco tenha de realizar fire sales para acomodar a demanda adicional provocada por uma corrida bancária, seria pouco provável que tais vendas provocassem uma situação de insolvência. ${ }^{303}$ Os efeitos de uma corrida bancária dependeriam da percepção dos correntistas a respeito da solvência das instituições financeiras. Se eles perceberem que alguns bancos continuarão solventes, irão apenas transferir suas economias do banco sob desconfiança para bancos de melhor reputação. ${ }^{304}$

Esse ponto de tensão na doutrina jurídica e econômica é bem ilustrado no estudo empírico sobre a quebra do Continental Illinois Bank em 1984, à época o 7. maior banco dos Estados Unidos, com ativos superiores a US\$32 bilhões. ${ }^{305}$ Em junho de 1984, cerca de 2.300 bancos figuravam como credores da instituição em crise. Justamente em razão do tamanho de sua exposição bancária, o governo norte-americano, por intermédio de seu mecanismo de seguro de depósitos, o Federal Deposit Insurance Corporation (FDIC), decidiu cobrir as

302 BENSTON, George J. et al. Perspectives on safe and sound banking. Cambridge: MIT Press, 1986; e KAUFMAN, George G. Bank failures, systemic risk, and bank regulation.

303 KAUFMAN, George. Bank contagion, p. 123-150, 140-141. Para o argumento contrário de que fire sales podem ter custos substanciais, ver: SHLEIFER, Andrei; VISHNY, Robert W. Liquidation values and debt capacity: a market equilibrium approach, p. 1364.

304 BENSTON, George J. et al. Perspectives on safe and sound banking, p. 63 e ss.

305 SPRAGUE, Irvine H. Bailout: an insider's account of bank failures and rescues. Washington: Beard Books, 1986. p. 150. 
perdas de todos os credores do banco. À ocasião, embora o FDIC segurasse apenas depósitos bancários até US\$100 mil, o governo decidiu pagar o valor integral de todos os depósitos e empréstimos em razão do temor de uma crise sistêmica. ${ }^{306}$

Pela relevância do tema, após o resgate de 1984, um estudo do Congresso norteamericano ocupou-se da análise sobre os possíveis efeitos na economia caso o banco não tivesse sido resgatado. ${ }^{307}$ Surpreendentemente, os resultados indicaram que, na ausência do auxílio, o desfecho não teria sido muito diferente. Dos 2.300 bancos expostos ao Continental, 1.325 tinham créditos de até US\$100 mil, e estariam segurados pelo FDIC de qualquer maneira. Do restante, o estudo indicou que, caso os credores conseguissem recuperar apenas $40 \%$ dos ativos, somente 27 bancos sofreriam perdas em excesso do seu capital, tornando-se insolventes, totalizando perdas de cerca de US\$137 milhões. Outros 56 bancos sofreriam perdas entre $50 \%$ e $99 \%$ do seu capital, totalizando US\$237 milhões. Caso os credores recuperassem $90 \%$ dos ativos, nenhum outro banco teria sofrido perdas maiores do que seus capitais, e apenas dois bancos teriam sofrido perdas em excesso de $50 \%$ de seu capital. ${ }^{308}$

Embora a conclusão do relatório preparado pelo Congresso possa ser utilizada como “munição" por autores críticos quanto ao caráter especial dos bancos, a extensão desses achados ao campo da regulação sistêmica deve ser analisada com temperamentos. Não entrando no mérito dos cálculos efetuados, o fato de quebras como a do Continental Illinois Bank supostamente não terem o condão de causar crises sistêmicas não significa que a potencial quebra de outros bancos não possa causar tal efeito. Com isso em mente, é preciso contextualizar a aplicabilidade dos dados encontrados, reconhecendo que, em eventos de crise, as autoridades bancárias podem não dispor - e na maioria das vezes não dispõem - de tempo hábil para realizar aprofundados estudos econômicos e avaliar de forma exaustiva os

\footnotetext{
306 Para uma narrativa detalhada a respeito do resgate ao Continental Illinois Bank, ver: SPRAGUE, Irvine H. Bailout, p. 149 e ss.

307 U.S. CONGRESS. Inquiry into the Continental Illinois Corp. and Continental Illinois National Bank (9811), House of Representatives, Subcommittee on Financial Institutions, Supervision, Regulation, and Insurance, $98^{\text {th }}$ Cong., $2^{\text {nd }}$ session, 1984.

308 Idem, ibidem.
} 
riscos inerentes a tal quebra. Como um dos maiores críticos ao resgate a bancos reconhece, no setor bancário o contágio e quebras subsequentes podem acontecer em uma questão de dias. ${ }^{309}$

Além disso, é preciso atentar para a força dos exemplos históricos de crises bancárias e dos graves riscos associados a quebras generalizadas no setor. Conforme o ensinamento de Krugman a respeito da Grande Depressão: ${ }^{310}$

\begin{abstract}
Uma visão amplamente disseminada sobre a Grande Depressão é de que ela perdurou por tanto tempo porque a crise bancária de 1930-1931 provocou um dano de longo prazo nos mercados de crédito. De acordo com essa visão, havia empreendedores com condições de tomar recursos e dispostos a gastar mais, porém não tinham acesso a crédito. Os banqueiros que poderiam realizar esses empréstimos haviam quebrado ou não conseguiam levantar recursos para os empréstimos, uma vez que a confiança do público nos bancos havia se estremecido de tamanha forma.
\end{abstract}

Se não bastasse a lição da década de 1930, a crise financeira recente também ilustra bem o potencial destrutivo de quebras bancárias. O exemplo oferecido pelo caso do Lehman Brothers em setembro de 2008 apenas corrobora a noção de que crises bancárias podem, de fato, ter efeitos catastróficos. A quebra do banco gerou tamanha crise de confiança, que acabou praticamente paralisando o mercado interbancário de crédito, afetando o estado de solvência de outras instituições financeiras e potencializando ainda mais os efeitos da crise. Em razão disso, o episódio com o Lehman Brothers é considerado por alguns como o catalisador do pânico nos mercados que se seguiu. ${ }^{311}$

É importante ressaltar, no entanto, que tais constatações não implicam a rejeição por completo dos argumentos apresentados por autores contrários ao caráter especial de bancos, especialmente no tocante aos efeitos deletérios em termos de risco moral provocados pelo resgate indiscriminado de instituições financeiras. Apesar de o presente trabalho apoiar-se na premissa de que bancos são, de fato, especiais, justificando-se a sua regulação por meio de uma rede de proteção que será examinada a seguir, é preciso ter em mente que nem toda quebra bancária representa risco sistêmico. Aliás, conforme se observará ao longo do capítulo, a associação impensada de quebras bancárias a risco sistêmico pode inclusive comprometer a própria finalidade da regulação sistêmica. Justamente em razão disso, a preocupação em

\footnotetext{
309 KAUFMAN, George. Bank contagion, p. 125.

310 KRUGMAN, Paul. The return of depression economics and the crisis of 2008, p. 73. Tradução livre.

311 FINANCIAL TIMES. The Lehman legacy: catalyst of the crisis, 12 out. 2008.
} 
evitar o uso indevido dessa rede de proteção aos bancos deve estar sempre presente no emprego de seus mecanismos.

\subsubsection{Seguro de depósitos}

O primeiro país a adotar o seguro de depósitos formalmente e em escala nacional foram os Estados Unidos, com a promulgação do Banking Act em 1933, em resposta à onda de quebras bancárias que ocorreu na década de 1920 e 1930. Inicialmente, poucos países aderiram ao sistema de seguro de depósitos, com apenas seis sistemas sendo estabelecidos até 1963. A partir de então o ritmo de adoção intensificou-se, com 20 sistemas formalmente estabelecidos até 1973, e cerca de 78 sistemas até 2004, com uma série de países estudando a adoção desse mecanismo na atualidade. ${ }^{312}$

A racionalidade básica para o seguro de depósitos está intrinsecamente ligada às falhas de mercado estudadas no Capítulo 1. Assim, diversos autores justificam a necessidade desse mecanismo com base na suscetibilidade do setor a corridas bancárias devido à presença de assimetrias informacionais, bem como o fato de os ativos bancários serem em sua maioria exigíveis de imediato. ${ }^{313}$ Portanto, ao propiciar segurança aos correntistas de que, independentemente da quebra da instituição financeira, suas economias estarão asseguradas, o seguro de depósitos procura reduzir a possibilidade de ocorrência de corridas bancárias.

Apesar de suas inegáveis virtudes, o seguro de depósitos também é objeto de críticas em razão da diminuição dos incentivos aos correntistas para monitorar a saúde financeira de seus bancos, enfraquecendo importante fator de controle à tomada excessiva de riscos por parte deles. Não por acaso, o seguro de depósitos é considerado uma das principais fontes de risco moral no setor bancário. ${ }^{314}$ Kaufman, por exemplo, chega a afirmar que, na ausência desse mecanismo, efeitos adversos à sociedade seriam minimizados, visto que bancos

\footnotetext{
312 BARTH, James R. et al. Rethinking bank regulation, p. 57.

313 BHATTACHARYA, Sudipo et al. The economics of bank regulation. Journal of Money Credit and Banking, 30(4), 1998; CALOMIRIS, Charles W.; KAHN, Charles. The role of demandable debt in structuring optimal banking arrangements. American Economic Review, 81(3), 1991; e DIAMOND, Douglas. Financial intermediation and delegated monitoring. Review of Economic Studies, 51 (3), 1984.

314 BARTH, James R. et al. Rethinking bank regulation, p. 58.
} 
insolventes seriam eliminados mais rapidamente e outros bancos teriam incentivos para deter mais capital, o que evitaria a propagação de crises. ${ }^{315}$ Mais recentemente, pode-se encontrar um corpo expressivo de estudos reforçando a noção de que o seguro de depósitos pode realmente diminuir os incentivos para correntistas monitorarem os bancos. ${ }^{316}$ Nessa mesma linha, outros estudos encontram uma correlação positiva e significativa entre a existência do seguro de depósitos e a possibilidade de crises bancárias. ${ }^{317}$

Considerando seus possíveis efeitos deletérios, há uma preocupação especial com a minimização do risco moral decorrente de sua utilização na estruturação dos mecanismos de seguro de depósitos. Entre as medidas adotadas para mitigar tais efeitos, merecem destaque as seguintes: ${ }^{318}$

1. Financiamento privado: Em primeiro lugar, sugere-se que o financiamento do seguro de depósitos deve ter natureza privada. Preferencialmente, os bancos cujos depósitos serão cobertos pelo mecanismo é que deverão financiá-lo. A lógica do argumento é que, se os bancos tiverem de financiar o mecanismo, terão menos incentivos para se engajar em atividades que tornem seu uso necessário;

2. Limite e valor do seguro: É importante que o seguro de depósitos tenha um limite e que este não seja muito alto. $\mathrm{O}$ valor da garantia oferecida é relevante, pois apenas os clientes com valores acima daquela quantia continuarão tendo incentivos para fiscalizar os

315 KAUFMAN, George G. Bank failures, systemic risk, and bank regulation, p. 26.

316 DEMIRGUÇ-KUNT, Asli; DETRAGIACHE, Enrica. The determinants of banking crises in developed and developing countries. IMF Staff Papers, n. 45, 1998; DEMIRGUÇ-KUNT, Asli; HUIZINGA, Harry. Market discipline and deposit insurance. Journal of Monetary Economics, 51(2), 2004; e KANE, Edward J. The S\&L insurance mess: how did it happen? Washington: Urban Institute Press, 1989.

317 BARTH, James R. et al. Bank regulation and supervision: what works best? Journal of Financial Intermediation, 13(2), 2004; BARTH, James R. et al. Rethinking bank regulation; e DEMIRGUÇ-KUNT, Asli; DETRAGIACHE, Enrica. Does deposit insurance increase banking system stability? An empirical investigation. Journal of Monetary Economics, 49(7), 2002.

318 CAMARGO SILVA, Antonio Carlos Bueno. Estratégias para combater o risco moral. Palestra proferida no seminário "El seguro de depósitos em Latinoamérica, retos y perspectivas", em 25 de agosto de 2004. Disponível em: 〈www.fgc.org.br/libs/download_arquivo.php?ci_arquivo=6>. Acesso em: 28 dez. 2010. 
bancos. Evidentemente, o que é considerado um valor razoável para o seguro variará de acordo com as características do setor bancário de cada país; e

3. Contribuição ponderada pelo risco: $\mathrm{O}$ risco moral criado por esse mecanismo poderia ser mitigado se as contribuições para o seguro de depósitos fossem financiadas pelos próprios bancos e calculadas de maneira a refletir o tamanho do risco tomado por cada um deles. Idealmente, quanto pior o rating da instituição, maior a contribuição. Não obstante, reconhece-se que esta é uma medida de difícil implementação. ${ }^{319}$

Além dessas recomendações gerais sobre a estrutura do seguro de depósitos, vale mencionar os trabalhos da Associação Internacional de Seguradores de Depósito (International Association of Deposit Insurers - Iadi) nessa área. Criada em 2002, a Iadi tem como missão institucional contribuir para o fortalecimento e a efetividade dos sistemas de seguro de depósitos, oferecendo orientações e incentivando a cooperação internacional. Entre os trabalhos de relevo promovidos pela associação, destacam-se os Princípios Fundamentais para Sistemas Efetivos de Seguro de Depósitos (Core Principles for Effective Deposit Insurance Systems), criados em junho de 2009 em conjunto com o Comitê de Basileia de Supervisão Bancária. ${ }^{320} \mathrm{O}$ documento procura apresentar princípios básicos que possam ser

319 Saddi chega inclusive a mencionar essa alternativa como um dos possíveis caminhos para o FGC no Brasil. Segundo o autor, poder-se-ia cogitar, no que se refere à composição do prêmio e aos critérios adotados para sua cobrança, uma quantia fixa e outra variável, sujeita ao rating obtido pela instituição, de acordo com seu perfil de risco (SADDI, Jairo. Crise e regulação bancária, p. 149). Os EUA tentaram fazer isso por meio do Federal Deposit Insurance Corporation Act de 1991, que determinou a implementação de um sistema de seguro de depósitos proporcional ao risco de cada instituição. Assim, foi criado um sistema de classificação de risco baseado nas operações realizadas pelos bancos, no nível de capital disponível e no seu rating. Segundo esse sistema, o risco da instituição poderia variar entre níveis, e o valor da contribuição de cada banco seria proporcional à sua classificação de risco. Embora atrativo em teoria, na prática o sistema não funcionou tão bem. O problema básico para o funcionamento do sistema é a determinação correta do tamanho do risco tomado pelos bancos. A título exemplificativo, Mishkin menciona que, no início de 1999, 95\% dos bancos participantes, representando 98\% dos depósitos bancários, foram colocados na categoria de menor risco, não precisando pagar nada de contribuição ao sistema. Segundo o autor, "o sistema de seguro de depósitos baseado em risco nos Estados Unidos claramente não discrimina de forma adequada entre bancos, e não conseguiu prover os incentivos para reduzir a tomada de risco". Ver: MISHKIN, Frederic S. Prudential Supervision: why is it important and what are the issues, p. 11-12. Tradução livre.

320 COMITÊ DE BASILEIA E IADI. Core principles for effective deposit insurance systems, Basileia, jun. 2009. O papel do Comitê de Basileia na regulação e supervisão bancária será objeto de maior detalhamento 
redesenhados e adaptados aos sistemas nacionais, variando entre temas diversos como objetivos institucionais, governança corporativa e funding, entre outros.

Dos casos recentes de recurso ao seguro de depósitos, deve-se mencionar a corrida bancária ao Northern Rock na Inglaterra em 2008. Esse episódio chamou atenção porque o banco era protegido pelo sistema de seguro de depósitos inglês. No entanto, isso não impediu uma corrida bancária, que acabou contribuindo significativamente para o fechamento da instituição. ${ }^{321} \mathrm{O}$ caso provocou um amplo estudo sobre o sistema vigente de seguro de depósitos preparado pelo Parlamento inglês. ${ }^{322}$ Entre as principais lições proporcionadas pelo evento, o estudo ressaltou a importância de o seguro de depósitos assegurar o acesso rápido aos fundos pelo correntista. A confiança é fundamental para o funcionamento do sistema. Se este for visto como lento ou burocrático, a efetividade da garantia perde sua força. Além disso, o sistema deve ser claro e transparente. Comentadores do caso acreditam que, entre as razões pelas quais o mecanismo falhou na Inglaterra, encontra-se a complexidade da sua aplicação, que envolvia um esquema de cobertura decrescente conforme o valor depositado. ${ }^{323}$ Alguns correntistas não conseguiram entender o mecanismo, o que os incentivou a retirar todo o dinheiro. Finalmente, o estudo ressaltou a importância de haver coerência no discurso das autoridades do setor. No caso inglês, a situação agravou-se em razão do embate entre Mervyn King, presidente do banco central inglês (Bank of England), expressando forte oposição às operações de resgate ao Northern Rock, e Alistair Darling, Secretário do Tesouro (Her Majesty's Treasury), que declarou publicamente o apoio incondicional do governo aos correntistas do banco. ${ }^{324}$

nos capítulos 4 e 5 . Este e os demais relatórios do Comitê de Basileia mencionados neste trabalho podem ser encontrados em: <www.bis.org/bcbs/index.htm〉. Acesso em: 23 dez. 2010.

321 GROUP OF 30. The structure of financial supervision: approaches and challenges in a global marketplace. Washington: Group of 30, 2008. p. 176 e ss.

322 HOUSE OF COMMONS. The run on the Rock, 24 jan. 2008. Disponível em: <www.publications. parliament.uk/pa/cm200708/cmselect/cmtreasy/56/5602.htm>. Acesso em: 23 dez. 2010.

323 GROUP OF 30. The structure of financial supervision, p. 42.

324 Idem, ibidem, p. 42. 


\subsubsection{O Fundo Garantidor de Crédito}

Conforme visto no capítulo anterior, até a promulgação da Constituição de 1988, os recursos acumulados na reserva monetária foram largamente utilizados para cobrir depositantes de bancos quebrados. Esses recursos eram provenientes da captação do IOF, sendo cobrados e empregados segundo critérios estabelecidos pelo CMN. Em virtude dos evidentes vícios desse sistema, constatados por meio da intensa sangria na conta de reserva monetária ao longo das décadas de 1970 e 1980, ele foi alterado a partir da Constituição de 1998, que, na redação original de seu art. 192, VI, estabeleceu a criação de fundo ou seguro para garantir créditos, aplicações e depósitos, vedando a participação de recursos da União no mecanismo. Apesar dessa previsão constitucional, apenas em 1995 houve a adoção do seguro de depósitos no Brasil, por meio da Resolução CMN 2.197/1995, regulamentada pela Resolução CMN 2.211/1995, que instituiu o FGC.

O FGC tem natureza privada, sendo constituído sob a forma de associação civil e custeado pelas próprias instituições aderentes. De acordo com os $\S \S 1 .^{\circ}$ e $2 .^{\circ}$ da Resolução CMN 2.197/1995, a adesão ao FGC é compulsória para as instituições financeiras que recebem depósitos à vista, a prazo, em contas de poupança, e às associações de poupança e empréstimo, com exceção das cooperativas de crédito e seções de crédito das cooperativas. ${ }^{325}$ O art. 13 da Resolução CMN 2.212, de 20 de novembro de 1995, também condicionou as autorizações para funcionamento de instituições financeiras à adesão ao FGC. Inicialmente, o financiamento do mecanismo dava-se por meio da contribuição de $0,025 \%$ do valor mensal escriturado dos saldos das contas correspondentes à cobertura do fundo. Não obstante, a Resolução CMN 3.400, de 6 de setembro de 2006, determinou em seu art. 2. ${ }^{\circ}$ a redução do percentual da contribuição mensal ordinária devida pelas instituições associadas ao FGC a 0,0125\%. A Resolução CMN 2.211/1995 também estabelece que, quando os recursos disponíveis no FGC atingirem 5\% do total dos saldos das contas sujeitas ao fundo, o CMN poderá reduzir ou suspender as contribuições dos participantes.

Estão cobertos pelo FGC os depósitos à vista, depósitos de poupança, letras de câmbio, letras imobiliárias e letras hipotecárias, emitidas ou aceitas pela instituição financeira.

\footnotetext{
325 Para uma lista das instituições participantes do FGC, ver: <www.fgc.org.br/?conteudo=1\&ci_menu=18>.
} Acesso em: 12 dez. 2010. 
Inicialmente o FGC previa cobertura até o limite global, por depositante, de $\mathrm{R} \$ 20.000,00$. Esse valor sofreu alterações posteriores, situando-se atualmente no patamar de $\mathrm{R} \$ 70.000,00$, nos termos da Resolução CMN 3.931, de 3 de dezembro de 2010. De acordo com dados do FGC de dezembro de 2008, a garantia oferecida pelo fundo atingia 98,81\% dos credores das operações cobertas pelo mecanismo, representando 140.559.284 clientes e correspondendo a $25,38 \%$ do valor total dos depósitos no SFN. ${ }^{326}$

Mais recentemente, deve-se mencionar a Resolução CMN 3.692, de 26 de março de 2009, que dispõe sobre a captação de depósitos a prazo, com garantia especial proporcionada pelo FGC. A medida foi implementada pelo governo com o objetivo de facilitar a captação de recursos dos bancos de médio e pequeno porte para empréstimos no segmento de médias empresas. De acordo com o regulamento, tais depósitos são denominados “depósitos a prazo com garantia especial do FGC", e devem ter prazo mínimo de 6 e máximo de 60 meses, sendo a contribuição para tal garantia de $0,0833 \%$ ao mês sobre o saldo dos depósitos captados sob a nova sistemática. Além disso, o valor máximo dos depósitos a prazo cobertos pelo FGC por pessoa é de R $\$ 20$ milhões. ${ }^{327}$

A garantia do FGC é vinculada à decretação de intervenção ou liquidação da instituição financeira. No que concerne aos depósitos com garantia especial do FGC, conforme trata a Resolução CMN 3.692/2009, o pagamento da garantia será efetuado em até três dias úteis após a decretação de regime especial, independentemente de ação do liquidante ou interventor, em razão de o FGC possuir o registro de todas essas operações. No tocante aos depositantes cobertos apenas pelo limite de $\mathrm{R} \$ 70.000,00$, não há prazo legal específico para pagamento do seguro, havendo grande variação nesse sentido, como é possível observar na página a seguir:

326 Dados disponíveis em: <www.fgc.org.br/libs/download_arquivo.php?ci_arquivo=105>. Acesso em: 12 dez. 2010. Em 2008 a garantia oferecida pelo fundo era de $\mathrm{R} \$ 60.000,00$ por depositante, nos termos da Resolução CMN 3.400/2006.

327 A Resolução CMN 3.931/2010 determina que o volume de depósitos que as instituições financeiras podem emitir com a garantia especial concedida pelo FGC deve ser reduzido de acordo com cronograma estabelecido pela autoridade bancária. Segundo o normativo, a redução terá início em janeiro de 2012, ao ritmo de $20 \%$ ao ano, até janeiro de 2016, quando será extinta a possibilidade de realização de captações com essa modalidade de garantia. 
Tabela 9: Prazo para desembolso dos recursos do FGC

\begin{tabular}{|c|c|c|c|}
\hline Instituição Financeira & $\begin{array}{c}\text { Data da } \\
\text { Decretação do } \\
\text { Regime }\end{array}$ & $\begin{array}{l}\text { Data de Início } \\
\text { do Pagamento }\end{array}$ & $\begin{array}{c}\text { Intervalo entre } \\
\text { Decretação do } \\
\text { Regime e } \\
\text { Pagamento }\end{array}$ \\
\hline Banco Dracma S.A. & 21.3 .1996 & 15.4 .1996 & 25 dias \\
\hline Banco de Financiamento Internacional S.A. & 17.4.1996 & 15.12 .1999 & 1.337 dias $(*)$ \\
\hline Banco Banorte S.A. & 24.5 .1996 & 24.5 .1996 & Mesmo dia \\
\hline Banco Universal S.A. & 20.6 .1996 & 14.10 .1996 & 116 dias \\
\hline Banco Interunion S.A. & 30.12 .1996 & 21.2 .1997 & 53 dias \\
\hline Banco Progresso S.A. & 21.2 .1997 & 21.3 .1997 & 28 dias \\
\hline Banco Bamerindus do Brasil S.A. & 26.3 .1997 & 26.3 .1997 & Mesmo dia \\
\hline Banco Empresarial S.A. & 15.5.1997 & 27.6.1997 & 43 dias \\
\hline Banfort - Banco Fortaleza S.A. & 15.5.1997 & 21.7.1997 & 67 dias \\
\hline Banco Vega S.A. & 15.5.1997 & 27.11 .1997 & 196 dias \\
\hline Banco do Estado do Amapá S.A. & 03.9 .1997 & 24.9.1997 & 21 dias \\
\hline Milbanco S.A. & 16.2 .1998 & 16.4 .1998 & 59 dias \\
\hline Banco Brasileiro Comercial S.A. & 15.5 .1998 & 18.6 .1998 & 34 dias \\
\hline Banco BMD S.A. & 15.5.1998 & 18.6 .1998 & 34 dias \\
\hline Banco Pontual S.A. & 30.10 .1998 & 28.12 .1998 & 59 dias \\
\hline Banco Crefisul S.A. & 23.3 .1999 & 24.5.1999 & 62 dias \\
\hline Girobank S.A. & 10.5 .1999 & 06.7 .1999 & 57 dias \\
\hline Banco Lavra S.A. & 13.4 .2000 & 06.12 .1999 & $-129 \operatorname{dias}(* *)$ \\
\hline Banco Hexabanco S.A. & 13.7 .2000 & 31.7 .2000 & 18 dias \\
\hline Banco Interior de São Paulo S.A & 07.2 .2001 & 14.3 .2001 & 35 dias \\
\hline Banco Araucária S.A. & 27.3 .2001 & 16.5 .2001 & 50 dias \\
\hline Banco Interpart S.A. & 28.3 .2001 & 17.7.2001 & 111 dias \\
\hline Banco Santos Neves S.A. & 01.08 .2001 & 03.9 .2001 & 33 dias \\
\hline Banco Royal de Investimento S.A. & 22.5 .2003 & 28.7 .2003 & 67 dias \\
\hline Banco Santos S.A. & 12.11 .2004 & 27.12 .2004 & 45 dias \\
\hline
\end{tabular}

Fonte: FGC. Dados disponíveis em: <www.fgc.org.br/?conteudo=1\&ci_menu=726>. Acesso em: 12 dez. 2010.

(*) Pendência extrajudicial não permitiu o pagamento de imediato.

(**) Pagamento anterior à liquidação extrajudicial como política preventiva de saneamento. 
Observa-se a falta de padrão quanto ao prazo para pagamento do seguro para depositantes. Ainda que não se considere o caso do Banco de Financiamento Internacional S.A., o intervalo médio de pagamento é de 45 dias, com grande variação para mais ou para menos. Aqui vale ressaltar que, entre os princípios recomendados pela Iadi e o Comitê de Basileia para promover um sistema de seguro de depósitos eficaz, destaca-se a necessidade de assegurar o pronto acesso dos depositantes aos recursos garantidos. ${ }^{328}$ Aliando essa recomendação aos ensinamentos proporcionados pela corrida ao Northern Rock na Inglaterra, os dados do FGC chamam atenção, indicando uma possível área de aprimoramento em sua atuação.

Finalmente, deve-se ressaltar a ampliação do papel do FGC nos últimos anos, especialmente para amenizar a crise de liquidez na economia no final de 2008. Isso foi em grande parte possibilitado pela Resolução CMN 3.656, de 17 de dezembro de 2008, que promoveu alterações no estatuto do FGC de que trata o Anexo I à Resolução CMN 3.251, de 16 de dezembro de 2004. Nesse aspecto, houve duas importantes mudanças no estatuto do FGC, quais sejam: (i) permissão para que o Conselho de Administração do FGC determine a aplicação, até o limite global de 50\% do seu patrimônio líquido, na (a) aquisição de direitos creditórios de instituições financeiras e de sociedades de arrendamento mercantil, e (b) aplicação em depósito bancário com ou sem emissão de certificado, em letra de arrendamento mercantil ou em letra de câmbio de aceite de instituições associadas, desde que lastreados em direitos creditórios constituídos ou a constituir das respectivas aplicações, ou outros direitos creditórios com garantias reais ou fidejussórias, próprias ou de terceiros; e (ii) permissão para que o Conselho de Administração contrate a administração de suas aplicações, incluindo-se eventuais direitos creditórios adquiridos, com terceiros.

Segundo o diretor executivo do FGC, o fundo teve um papel importante para amenizar a crise de liquidez em 2008 e 2009, "ocupando um espaço que as grandes instituições hesitaram em assumir". ${ }^{329} \mathrm{O}$ saldo da crise para o FGC foi um giro de compras de

\footnotetext{
328 De acordo com o Princípio 17 do documento conjunto preparado pela Iadi e o Comitê de Basileia, a entidade de seguro de depósitos deve, prontamente, dar acesso aos depositantes a seus recursos garantidos. Da mesma forma, o Princípio 11 afirma que a entidade deve ter todos os mecanismos de funding necessários para assegurar o imediato reembolso dos depositantes. Ver: COMITÊ DE BASILEIA E IADI. Core principles for effective deposit insurance systems, p. 5.

329 VALOR ECONÔMICO. FGC estimula expansão do crédito, 6 mar. 2009.
} 
carteiras de crédito que superou os $\mathrm{R} \$ 10$ bilhões, em 280 operações feitas em pouco mais de seis meses, representando média de duas operações a cada três dias. ${ }^{330}$ Em janeiro de 2009 , baseando-se na Resolução CMN 3.656/2008, o FGC implementou um programa de investimento em CDBs emitidos por banco ou financeira com até $\mathrm{R} \$ 2,5$ bilhões de capital. Os recursos são utilizados em operações de crédito por tal banco ou financeira, que por sua vez servem como garantia da aplicação no CDB. Em março de 2009, o programa já contava com 28 instituições financeiras cadastradas, com 16 delas realizando operações no valor total de $\mathrm{R} \$ 985$ milhões. A expectativa do fundo era de continuar liberando de $\mathrm{R} \$ 1,2$ bilhão a $\mathrm{R} \$ 1,4$ bilhão por mês com o programa. ${ }^{331}$

Tendo em mente os objetivos da regulação sistêmica - e do mecanismo de seguro de depósitos em particular -, essas alterações no estatuto do FGC devem ser analisadas com cautela. Naturalmente, não é razoável esperar que os administradores do fundo deixem os recursos disponíveis parados, até que correntistas ou aplicadores venham necessitar de sua cobertura. Por outro lado, parece evidente que a diretriz primordial para a aplicação de tais recursos deve ser a procura de investimentos de baixo risco. Não por acaso, o $\S 1$. $^{\circ}$ do art. $3 .^{\circ}$ do regimento interno do FGC estabelece que "Os recursos do FGC devem ser aplicados, prioritariamente, em títulos públicos federais ou em operações compromissadas, que possuam lastro em títulos públicos federais".

Na medida em que o FGC começa a ampliar o seu portfólio de investimentos, devese tomar cuidado para que, em vez do baixo risco, se acabe priorizando o resgate a instituições financeiras. Com efeito, não deixa de chamar a atenção o fato de que, em meio à grave crise econômica cuja origem situa-se justamente nas carteiras de créditos "tóxicos" originadas do mercado hipotecário subprime norte-americano, o FGC tenha passado a comprar carteiras de crédito de instituições financeiras em dificuldade. Some-se a isso o fato de o FGC ter uma estrutura muito pequena quando comparada a seus pares ao redor do mundo. Em setembro de 2009 o fundo contava com apenas 14 funcionários e dois diretores para gerir um patrimônio de mais de $\mathrm{R} \$ 20$ bilhões. ${ }^{332}$ Em razão disso, precisou terceirizar a gestão das carteiras de crédito que adquiriu, utilizando para tal tarefa geralmente os serviços

\footnotetext{
330 VALOR ECONÔMICO. Crise confere novo status ao FGC, 26 out. 2009.

331 VALOR ECONÔMICO. FGC estimula expansão do crédito, 6 mar. 2009.

332 VALOR ECONÔMICO. Crise confere novo status ao FGC, 26 out. 2009.
} 
de bancos associados ao FGC, que examinam, desenvolvem os controles e cuidam das carteiras, como verdadeiros administradores dos recursos. ${ }^{333}$

A preocupação sobre possíveis conflitos de interesse na aplicação desses recursos é corroborada pela constatação de que o FGC é administrado pelas próprias instituições financeiras que, potencialmente, podem vir a necessitar do seu auxílio. Seu Conselho de Administração é constituído por cinco a nove membros efetivos e igual número de suplentes que são representantes de instituições associadas, e seu prazo de gestão é de três anos, admitida a recondução. Nesse aspecto, vale lembrar que a Iadi e o Comitê de Basileia listam como princípios inerentes a um sistema efetivo de seguro de depósitos a criação de uma estrutura isolada de indevida influência política ou de mercado e que mitigue o risco moral. ${ }^{334}$ Esse não parece ser o caso do FGC, conforme se pode observar abaixo:

Tabela 10: Conselho de Administração do FGC (2008/2010)

\begin{tabular}{|c|c|}
\hline Efetivos & Suplentes \\
\hline Gabriel Jorge Ferreira (Presidente) & Carlos Alberto Vieira \\
\hline Unibanco - União Bancos Brasileiros S.A. & Banco Safra S.A. \\
\hline Aldemir Bendine & Maria Fernanda Ramos Coelho \\
\hline Banco do Brasil S.A. & Caixa Econômica Federal \\
\hline \multicolumn{2}{|l|}{ Fabio Colletti Barbosa } \\
\hline \multicolumn{2}{|l|}{ Grupo Santander Brasil } \\
\hline Julio de Siqueira Carvalho de Araujo & José de Paiva Ferreira \\
\hline Banco Bradesco S.A. & Banco Santander S.A. \\
\hline Roberto Egydio Setúbal & Paulo Guilherme Monteiro Lobato Ribeiro \\
\hline Banco Itaú S.A. & Banco Alfa S.A. \\
\hline
\end{tabular}

Fonte: FGC. Disponível em: <www.fgc.org.br/?conteudo=1\&ci_menu=150>. Acesso em: 12 dez. 2010.

As mudanças recentes pelas quais vem passado o FGC fazem com que este gradativamente se torne garantidor não apenas dos correntistas, mas também dos próprios bancos. ${ }^{335}$ Tal fato é um ponto de preocupação, uma vez que acaba por agravar o risco moral

333 VALOR ECONÔMICO. FGC estimula expansão do crédito, 6 mar. 2009.

334 Princípios 1 e 5 dos Princípios Fundamentais para Sistemas Efetivos de Seguro de Depósitos. Ver: COMITÊ DE BASILEIA E IADI. Core principles for effective deposit insurance systems, p. 2-3.

335 Essa modificação no papel do FGC foi confirmada no evento recente de resgate ao Banco Panamericano. Em 9 de novembro de 2010 o FGC emitiu fato relevante em que informa a realização de empréstimo ao 
criado por tal mecanismo. Não se disputa aqui a relevância que as medidas adotadas pelo FGC tiveram para combater a crise financeira em 2008. Não obstante, é importante ter em mente que estas devem ser excepcionais e temporárias, com prazo específico para serem encerradas. E mesmo no breve período em que são necessárias, é preciso haver regras claras quanto aos limites de sua utilização. Nesse aspecto, causa alarde a posição do diretor executivo do FGC a respeito das inovações na sua estrutura, ao declarar que: "as instituições querem manter aberto esse canal e é bom manter todo o mecanismo funcionando. Se vier outra crise, estamos prontos para agir rapidamente. Não precisaremos criar formas novas". 336

\subsubsection{Regimes especiais aplicáveis às instituições em crise}

Conforme visto no início do capítulo, há um grande temor associado a quebras no setor bancário em contraste com outros setores da economia. Quebras bancárias podem causar um abalo na confiança do público poupador, desencadeando uma corrida aos bancos. A insolvência dessas instituições e a limitação do mercado de crédito podem abalar também o setor produtivo da economia, fazendo com que rapidamente o inadimplemento de um banco provoque dificuldades em outros agentes econômicos fora do sistema financeiro. Em suma, o inadimplemento de obrigações assumidas por instituições financeiras tem consequências que não se encerram em si mesmas. ${ }^{337}$

Grupo Silvio Santos, na qualidade de principal acionista controlador do Banco Panamericano, no valor de $\mathrm{R} \$ 2,5$ bilhões, para aporte na instituição. Conforme o comunicado, a operação foi "integralmente garantida por bens do patrimônio empresarial do Grupo Silvio Santos", e "o aporte destina-se a restabelecer o pleno equilíbrio patrimonial e ampliar a liquidez operacional da instituição, de modo a preservar o atual nível de capitalização, em virtude de terem sido constatadas inconsistências contábeis que não permitem que as demonstrações financeiras reflitam a real situação patrimonial da entidade" (disponível em: <www.fgc.org.br/upload/fato_relevante_p.pdf>; acesso em: 12 dez. 2010). Conforme noticiado nos periódicos, o crédito correspondeu a cerca de $10 \%$ do patrimônio do FGC, que somava $\mathrm{R} \$ 25,8$ bilhões ao final de setembro (O ESTADO DE SÃO PAULO. Banco Panamericano, do Grupo Silvio Santos, recebe $\mathrm{R} \$ 2,5$ bi para cobrir fraude, 10 nov. 2010, p. B1), e a operação foi realizada em termos "vantajosos", prevendo prazo de dez anos, com três de carência, e sem cobrança de juros sobre o montante emprestado (VEJA. Pagarei tudo que devo a eles, n. 2.191, 17 nov. 2010, p. 59-64). A respeito da transação, o então Presidente da República, Luis Inácio Lula da Silva, deu declaração emblemática em que afirmou: "O Panamericano recorreu a um empréstimo dos bancos, do fundo garantidor dos bancos. O fundo garantidor existe exatamente para isso" (O GLOBO. Não é assunto do presidente, 11 nov. 2010, p. 25).

336 VALOR ECONÔMICO. Crise confere novo status ao FGC, 26 out. 2009.

337 PAULIN, Luiz Alfredo. Conceito de intervenção e liquidação extrajudicial, p. 125. 
Em razão dessas peculiaridades inerentes ao setor bancário, muitos países preferem adotar vias alternativas ao regime falimentar para instituições financeiras, procurando minimizar os efeitos danosos da quebra e até, conforme o caso, reestruturar as atividades da instituição considerada insolvente. Na medida em que o regime falimentar geral é afastado, a maior parte dos sistemas jurídicos tem abordado tais situações de duas formas. A primeira refere-se a ações de cunho provisório, destinadas ao saneamento da instituição financeira, e a segunda concerne a medidas terminativas, voltadas à efetiva liquidação destas. ${ }^{338}$ Nada impede também que as duas ações sejam combinadas, geralmente em casos em que a autoridade procura recuperar o banco, mas seus esforços não atingem os resultados pretendidos.

Além de regras diferentes, em muitos casos há ainda a designação de uma autoridade específica para a condução de tais procedimentos - geralmente o banco central ou alguém de sua escolha -, partindo-se da premissa de maior especialização desse órgão e de administradores ou interventores por ele indicados em matéria financeira. ${ }^{339}$ Há também países que optaram por transferir a competência para conduzir tais regimes especiais aos responsáveis pelo mecanismo de seguro de depósitos. Além de sua expertise no assunto, a lógica aqui seria de que tais entidades teriam interesse em aproveitar ao máximo os ativos do banco em crise, seja para evitar o acesso aos seus recursos para ressarcir correntistas, ou porque, havendo pagamento do seguro de depósitos, se tornarão credores de relevo. É o caso, por exemplo, do FDIC nos Estados Unidos. ${ }^{340}$

O efeito prático do afastamento dos regimes especiais para as instituições financeiras é que estas passam a poder incorrer em comportamentos que, se adotados por empresas atuantes em outros setores da economia, provocariam a sua falência. Assim sendo, parece evidente que, ao impedir a aplicação de regras falimentares comuns, a regulação sistêmica deve se preocupar também em não insular os controladores e os administradores da instituição da responsabilidade pelos seus atos, criando incentivos para a tomada excessiva de risco. Com

\footnotetext{
338 YAZBEK, Otavio. Regulação do mercado financeiro e de capitais, p. 224-225.

339 SALOMÃO, Eduardo. Direito bancário, p. 531.

340 LASTRA, Rosa Maria. Banco Central e regulamentação bancária. Belo Horizonte: Del Rey, 2000. p. 110.
} 
efeito, nada gera maior risco moral do que não responsabilizar aqueles que originaram as dificuldades na instituição financeira. ${ }^{341}$

Outro aspecto de relevo na aplicação desses mecanismos é que, na medida em que o regime falimentar comum é afastado, a decretação dos regimes especiais acaba se sujeitando à discricionariedade da autoridade bancária. Considerando que há uma série de fatores que podem distorcer o foco de atuação dessas autoridades em tais situações, há preocupação especial em alinhar seus incentivos com os objetivos pretendidos pela regulação sistêmica. Entre os fatores que podem comprometer a atuação da autoridade bancária, um dos mais conhecidos é a chamada síndrome do "não no meu turno" (not on my watch syndromme), ${ }^{342}$ segundo a qual supervisores bancários podem hesitar em decretar o regime especial por temor de que isso prejudique a sua reputação. Esse fenômeno é bem representado na seguinte descrição de Goodhart: ${ }^{343}$

Uma vez que a medida de sucesso de reguladores é a prevenção de desastres, há uma
tendência evidente do regulador/supervisor de tentar prevenir desfechos
desagradáveis e, caso algo de ruim aconteça, evitar que aquilo seja reconhecido
como sua falha. Isso pode ser feito, por exemplo, por meio da tolerância, em que
regulador e regulado concordam em não invocar a penalidade legal pela infração a
alguma regulação, na esperança de que aquela infração seja corrigida por medidas
futuras mais bem-sucedidas do regulado [...] Um exemplo [dessa tolerância] foi a
demora e relutância em reconhecer e resolver as perdas causadas às Savings and
Loans Institutions nos Estados Unidos no curso da década de 1980 [...].

Parece natural que autoridades bancárias prefiram manter a normalidade das operações no sistema financeiro em vez de arriscar medidas drásticas como a decretação de regimes especiais. A intervenção ou a liquidação de instituições financeiras pode desestabilizar o mercado, lançando críticas de que as ações do órgão não evitaram uma crise sistêmica, mas sim a provocaram. Além disso, embora estejam no governo, seus integrantes podem vislumbrar o retorno à iniciativa privada ao fim de seu mandato - muitas vezes com rendimentos maiores em virtude de sua experiência "por dentro" da máquina pública -, e a

341 Esse argumento foi levantado por Gustavo Franco, no seminário Crise bancária e regulação: lições da experiência brasileira, organizado pela Rio Bravo Investimentos, ocorrido em 24 de novembro de 2009.

342 "Uma vez que quebras bancárias podem ser vistas (incorretamente, muitos diriam!) como falhas de supervisão, pode haver uma relutância em fechar bancos ('não no meu turno')." Ver: BARTH, James R. et al. Rethinking bank regulation, p. 60. Tradução livre.

343 GOODHART, Charles A. E. Regulating the regulator - An economist's perspective. In: FERRAN, Eilís; GOODHART, Charles. Regulating financial services and markets in the 21st century. Oxford: Hart Publishing, 2001. p. 154-155. Tradução livre. 
decretação desses regimes pode prejudicar essa possibilidade. A preocupação da autoridade bancária com os possíveis impactos reputacionais de suas ações pode acabar tornando-a conivente com práticas irregulares por instituições em dificuldade, ou mesmo postergando demasiadamente a decretação do regime especial, sob a crença de que a instituição irá se recuperar, potencializando as perdas para seus credores.

Além da questão do not on my watch syndromme, a atuação da autoridade bancária também pode ser desvirtuada em razão de outros fatores, como a possibilidade de captura regulatória ou a percepção de que instituições financeiras são grandes demais para quebrar. Esses pontos serão objeto de maior aprofundamento mais adiante e corroboram a necessidade de mecanismos voltados à correção de eventuais desvios no comportamento da autoridade bancária. $^{344}$

Uma forma de lidar com esses possíveis desvios na atuação da autoridade bancária é por meio da sua responsabilização (e de seus dirigentes) nos casos em que ocorram prejuízos em razão de sua atuação comissiva defeituosa ou tardia, ou mesmo omissiva. Isso evidentemente dependerá das características de cada país, notadamente a previsão de responsabilidade do Estado em seu ordenamento jurídico. No entanto, a responsabilização da autoridade em virtude de atos de supervisão, ou ausência destes, sobre as instituições financeiras, é sempre um assunto polêmico, pois, sem capacidade de previdência, intervenções consideradas necessárias e não realizadas, ou intervenções consideradas desnecessárias e realizadas, acabam invariavelmente tornando-a alvo de críticas. ${ }^{345}$

344 Vale ressaltar, no entanto, que em linha com as delimitações já apresentadas no início do trabalho, embora o presente estudo busque considerar os incentivos negativos que afetam a atuação da autoridade bancária na análise dos mecanismos de regulação sistêmica e prudencial, não se adentrará aqui na discussão a respeito do arranjo institucional adequado para mitigar eventuais desvios de conduta de sua parte. Notadamente, não se discutirá aqui o polêmico tema da autonomia do banco central na condução de suas atividades. O corte metodológico se faz necessário para viabilizar a análise que se pretende empreender, bem como pelo fato de se entender que a autonomia da autoridade bancária é tema mais afeito à discussão da livre condução da política monetária do que a condução da regulação e supervisão bancária de forma adequada.

345 Conforme a oportuna colocação de Saddi: “A decisão da decretação de qualquer um dos regimes especiais será sempre assim, eivada de possibilidade da crítica em função de sua oportunidade e conveniência. Jamais deixará de haver críticas pela decisão ser demasiado tardia ou precipitadamente antecipada". Ver: SADDI, Jairo. Algumas propostas de mudança para a Lei 6.024, p. 299. 
Outra possibilidade aventada pela doutrina especializada e organismos internacionais é a limitação dessa discricionariedade na decretação de regimes especiais. Autoridades como Gary Stern e Ron Feldman, do Federal Reserve Bank of Minneapolis, bem como o FMI, defendem uma abordagem denominada "intervenção e resolução estruturada antecipada" (structured early intervention and resolution), baseada na aplicação de penalidades e restrições às suas atividades em resposta à deterioração de seus indicadores financeiros, que se tornariam mais rigorosas na medida em que sua situação se agravasse. Caso a instituição não lograsse se recuperar após o disparo desses "gatilhos" anteriores, o regime especial seria decretado automaticamente. ${ }^{346}$

Em pesquisa sobre as melhores práticas internacionais de regulação sistêmica realizada com 153 autoridades bancárias questionadas ao redor do mundo, Barth et al. identificam 79 países que adotam indicadores de solvência como critério para a tomada de ações pela autoridade bancária, incluindo a decretação de regimes especiais. ${ }^{347}$ É o que os autores chamam de "ações corretivas imediatas" (prompt corrective action), que, segundo eles, seriam desejáveis no arcabouço regulatório, uma vez que ajudariam a proteger autoridades bancárias de pressões externas que geralmente surgem nesse processo. ${ }^{348} \mathrm{O}$ posicionamento dos autores é oportuno, pois mostra que o que poderia ser visto como uma interferência na liberdade de atuação da autoridade bancária pode ser interpretado também como uma forma de lhe garantir independência, dado que a decretação de regimes especiais se tornaria uma obrigação legal, resguardando-a de interesses privados e políticos.

Não obstante, a adoção de tais mecanismos é cercada de críticas, não raro relacionadas à eliminação da discricionariedade na atuação da autoridade bancária. ${ }^{349} \mathrm{~A}$ decretação automática de regimes especiais em contextos de instabilidades sistêmicas pode acabar potencializando o cenário de pânico e os efeitos deletérios da crise. Outra crítica é de que a imposição de penalidades e restrições às suas atividades aceleraria o processo de

\footnotetext{
346 STERN, Gary H.; FELDMAN, Ron J. Too big to fail: the hazards of bank bailouts. Washington: Brookings Institution Press, 2004. p. 125-126; e GARCIA, Gillian. Deposit insurance: actual and good practices. IMF Occasional Paper, Washington: International Monetary Fund, n. 197, p. 7.

347 BARTH, James R. et al. Rethinking bank regulation, p. 125.

348 Idem, ibidem, p. 124-125.

349 GOODHART, Charles A. E. Regulating the regulator, p. 160-161.
} 
deterioração financeira da instituição, tornando ainda mais difícil sua recuperação. Da mesma forma, caso tais "gatilhos" sejam de conhecimento público, a deterioração da condição de instituições financeiras poderia acelerar corridas bancárias, uma vez que a decretação do regime especial deixaria de ser uma possibilidade para se tornar uma certeza. Naturalmente, o argumento contrário poderia ser suscitado no sentido de que seria justamente a existência desses riscos que faria com que as instituições financeiras tivessem atenção redobrada para não se aproximarem dos patamares que acionariam os "gatilhos".

\subsubsection{Regimes especiais no Sistema Financeiro Nacional}

Existem na atualidade três regimes especiais para instituições financeiras no SFN. ${ }^{350}$ A Lei 6.024/1974 instituiu os regimes de intervenção e de liquidação extrajudicial, e o Decreto-lei 2.321/1987 criou o Raet. Enquanto a intervenção e o Raet são procedimentos destinados ao saneamento administrativo e financeiro das instituições a eles submetidas, a liquidação extrajudicial destina-se a casos de maior gravidade, em que resta apenas liquidar a instituição financeira. É importante mencionar que tanto o art. 1. ${ }^{\circ}$ da Lei 6.024/1974 como o art. $1 .^{\circ}$ do Decreto-lei 2.321/1987 determinam que os regimes se aplicam apenas às instituições financeiras privadas e públicas não federais. Assim, estariam excluídas as instituições públicas federais, em relação às quais existe a expectativa de ação direta do poder público em caso de verificação de irregularidades. ${ }^{351}$

O art. $2^{\circ}$ da Lei 6.024/1974 prevê o regime de intervenção quando se verificarem as seguintes "anormalidades" na instituição financeira: (i) a entidade sofrer prejuízo decorrente da má administração, sujeitando os credores a risco; (ii) forem verificadas reiteradas infrações a dispositivos da legislação bancária não regularizadas após as determinações do Bacen, no uso das suas atribuições de fiscalização, e (iii) ocorrência dos fatos justificadores de pedido de falência, desde que haja possibilidade de evitar a liquidação extrajudicial. O Raet, por outro lado, nos termos do art. 1. ${ }^{\circ}$ do Decreto 2.321/1987, pode ser decretado pelo Bacen na hipótese

350 Para uma análise histórica da origem dos regimes especiais no ordenamento jurídico pátrio, ver: VERÇOSA, Haroldo M.D. Responsabilidade civil especial nas instituições financeiras e nos consórcios em liquidação extrajudicial. São Paulo: RT, 1993. p. 17-26.

351 SALOMÃO, Eduardo. Direito bancário, p. 534-535. 
de: (i) prática reiterada de operações contrárias às diretrizes de política econômica ou financeira traçadas em lei federal; (ii) existência de passivo a descoberto; (iii) descumprimento das normas referentes à conta de reservas bancárias mantida no Bacen; (iv) gestão temerária ou fraudulenta de seus administradores; bem como (v) ocorrência de qualquer das situações supracitadas referentes ao art. 2. ${ }^{\circ}$ da Lei 6.024/1974. ${ }^{352}$

No caso da liquidação extrajudicial, a Lei 6.024/1974 estabelece regime distinto, voltado às situações que possam efetivamente comprometer a viabilidade das atividades da instituição. Assim, o art. 15 da lei relaciona as seguintes hipóteses de liquidação ex officio pelo Bacen: (i) em razão de ocorrências que comprometam sua situação econômica ou financeira, especialmente quando deixar de satisfazer, com pontualidade, seus compromissos ou quando se caracterizar qualquer dos motivos que autorizem a declaração de falência; (ii) quando a administração violar gravemente as normas legais e estatutárias que disciplinam a atividade da instituição bem como as determinações do CMN ou do Bacen, no uso de suas atribuições legais; (iii) quando a instituição sofrer prejuízo que sujeite a risco anormal seus credores quirografários; e (iv) quando, cassada a autorização para funcionar, a instituição não iniciar, nos 90 dias seguintes, sua liquidação ordinária, ou, quando iniciada esta, verificar o Bacen que a morosidade de sua administração pode acarretar prejuízos para os credores. $\mathrm{O}$ art. 15 da Lei também prevê a possibilidade de instauração da liquidação a pedido dos administradores da instituição (se o estatuto social lhes conferir esta competência), ou por proposta do interventor. Nessas situações, o Bacen decidirá sobre a gravidade dos fatos determinantes da liquidação extrajudicial, considerando as repercussões desta sobre os interesses dos mercados financeiro e de capitais e poderá, em lugar da liquidação, efetuar a intervenção, se julgar tal medida suficiente para a normalização dos negócios da instituição e preservação daqueles interesses.

352 Em razão das semelhanças entre os dois diplomas legais, disseminou-se a impressão de que o Raet havia revogado o regime de intervenção previsto na Lei 6.024/1974. Entretanto, conforme apontamento de Yazbek, essa impressão é equivocada. Os dois regimes continuam a coexistir, mas o Raet acabou sendo mais utilizado em virtude de seu caráter menos "traumático" e mais adequado à recuperação dos negócios da instituição. Enquanto a intervenção gera, nos termos do art. $6^{\circ}$ da Lei 6.024/1974, a suspensão da exigibilidade das obrigações vencidas, da fluência do prazo das obrigações vincendas anteriormente contraídas e a inexigibilidade dos depósitos existentes, o Raet representa procedimento mais simples, por acarretar, fundamentalmente, a perda do mandato de administradores e conselheiros fiscais e sua substituição por outros, nomeados pelo Bacen, sem interrupção dos negócios da instituição. Ver: YAZBEK, Otavio. Regulação do mercado financeiro e de capitais, p. 226. 
Esses três regimes foram "reforçados" com a Lei 9.447/1997, que teve origem na MP 1.182/1995, promulgada no contexto do Proer, e que deu amplos poderes ao Bacen para promover "soluções de mercado" em instituições em crise. Dessa forma, se o art. 15, § 1. ', da Lei 6.024/1974 já permitia expressamente que a autarquia, considerando a gravidade dos fatos, optasse entre a intervenção e liquidação extrajudicial, a Lei 9.447/1997 ampliou essa discricionariedade ao permitir-lhe três outras possibilidades. Segundo o art. 5. ${ }^{\circ}$ da lei, verificada a ocorrência de qualquer das hipóteses previstas nos arts. 2. ${ }^{\circ}$ e 15 da Lei 6.024/1974, e no art. 1. ${ }^{\circ}$ do Decreto-lei 2.321/1987, é facultado ao Bacen, sem prejuízo da posterior adoção dos regimes de intervenção, liquidação extrajudicial ou administração especial temporária, determinar a: (i) capitalização da sociedade, com o aporte de recursos necessários ao seu soerguimento, em montante por ele fixado; (ii) transferência do controle acionário; e (iii) reorganização societária, inclusive mediante incorporação, fusão ou cisão. Outro aspecto a se mencionar é que, além dessas três novas possibilidades, o art. $4 .^{\circ}$ da Lei 9.447/1997 estendeu ao Raet as hipóteses de aplicação de liquidação extrajudicial previstas no art. 15 da Lei 6.024/1974.

Havendo a decretação do regime especial cabível, a Lei 9.447/1997 previu ainda outras importantes medidas saneadoras, como: (i) a possibilidade de transferência para outra ou outras sociedades, isoladamente ou em conjunto, de bens, direitos e obrigações da empresa ou de seus estabelecimentos; (ii) a possibilidade de alienar ou ceder bens e direitos a terceiros e acordar a assunção de obrigações por outra sociedade; e (iii) proceder à constituição ou reorganização de sociedade ou sociedades para as quais sejam transferidos, no todo ou em parte, bens, direitos e obrigações da instituição sob intervenção, liquidação extrajudicial ou administração especial temporária, objetivando a continuação geral ou parcial de seu negócio ou atividade. Um dos subprodutos dessas novas regras foi a possibilidade de divisão da instituição financeira em duas partes (banco bom - banco ruim), separando a parte "saudável" de suas atividades daquela que se encontrava insolvente, e permitindo a transmissão da primeira a outras instituições. ${ }^{353}$

Essa ampla gama de opções atribuída à autoridade bancária brasileira para intervir em instituições em crise revela-se um aspecto positivo da legislação brasileira, uma vez que

353 YAZBEK, Otavio. Regulação do mercado financeiro e de capitais, p. 227. 
coloca uma série de medidas à disposição do Bacen para atenuar o impacto sistêmico dessas situações, ao mesmo tempo em que preserva a normalidade das funções do sistema financeiro. ${ }^{354}$ Esse ponto foi inclusive enfatizado em relatório recente do Comitê de Basileia, acentuando a necessidade de dotar autoridades bancárias nacionais de instrumentos que permitam a rápida transferência de operações, ativos, passivos e fundo de comércio de uma instituição para outra em contextos de crise. ${ }^{355} \mathrm{Na}$ medida em que o relatório procura sumarizar pontos de reforma regulatória com base em problemas enfrentados por autoridades bancárias na crise financeira recente, o Brasil pode ser considerado exemplo para outros países nesse aspecto.

Outra questão importante desses mecanismos de regulação sistêmica no Brasil refere-se à responsabilidade de administradores e controladores nos regimes especiais. Nesse ponto, a legislação brasileira se mostra bastante rigorosa, estabelecendo diferentes tipos de responsabilidade e medidas disponíveis à autoridade bancária, conforme o cargo ocupado e posição de controle da pessoa. ${ }^{356} \mathrm{O}$ art. 39 da Lei 6.024/1974 determina que os administradores e membros do Conselho Fiscal de instituições financeiras devem responder, a qualquer tempo, salvo prescrição extintiva, pelos atos que tiverem praticado ou omissões em que houverem incorrido. Já o art. 40 da Lei impõe aos administradores de instituições financeiras responsabilidade solidária pelas obrigações por ela assumidas durante sua gestão. Esse mesmo regime foi adotado pelo Raet por força do art. 19 do Decreto-lei 2.321/1987.

A leitura do art. 39 revela que a responsabilidade ali prevista enquadra-se no modelo de responsabilidade subjetiva clássica, em que há necessidade de verificação de culpa ou dolo, dano, violação de direito de terceiro e nexo de causalidade entre conduta e dano. ${ }^{357}$ Já no caso do art. 40 a responsabilidade não seria decorrente do ato praticado, mas sim das obrigações da

354 Apesar de seus evidentes méritos, a Lei 9.447/1997 também é alvo de críticas em razão do afastamento dos direitos dos acionistas minoritários. Para as polêmicas referentes a este ponto, ver: VERÇOSA, Haroldo M. D. Bancos centrais no direito comparado, p. 173 e ss.

355 COMITÊ DE BASILEIA. Report and recommendations of the cross-border bank resolution group, Basileia, mar. 2010.

356 Para uma análise histórica da responsabilidade civil especial na insolvência das instituições financeiras, ver: VERÇOSA, Haroldo M. D. A responsabilidade civil especial nas instituições financeiras insolventes. In: SADDI, Jairo (Org.). Intervenção e liquidação extrajudicial no Sistema Financeiro Nacional, p. 152-155.

357 SALOMÃO, Eduardo. Direito bancário, p. 560-561. 
instituição financeira. A responsabilidade é solidária entre os controladores ${ }^{358}$ e administradores, de forma que respondem mesmo por obrigações conferidas à esfera de atribuição de outrem. A esse respeito, Verçosa assevera que o art. 40 estabeleceu modelo de responsabilidade objetiva, ou seja, desvinculado da necessidade de prova de culpa ou dolo dos sujeitos passivos. ${ }^{359}$

A responsabilidade civil especial prevista no art. 40 tem importantes efeitos prudenciais, na medida em que cria estímulos para que os sujeitos passivos atuem com o máximo de diligência de que sejam capazes, não assumindo riscos atípicos no mercado, devido ao receio de se sujeitarem a uma responsabilidade sem culpa. ${ }^{360}$ Além disso, a responsabilidade objetiva solidária do art. 40 também cria incentivos para que haja constante fiscalização interna mútua, uma vez que o diretor de sistemas, por exemplo, responderia por prejuízos causados por operações de crédito aprovadas pelo comitê de crédito, ainda que dele não participe. ${ }^{361}$ Outrossim, haveria ainda pressão externa, pois apenas as instituições bem administradas conseguiriam contratar bons profissionais no mercado, haja vista que o risco de associar-se a uma instituição mal administrada e sofrer reflexos na esfera patrimonial própria é sempre presente. ${ }^{362}$

É importante notar, no entanto, que esses posicionamentos não são pacíficos, havendo várias correntes doutrinárias tratando da natureza da responsabilidade especial dos controladores e administradores de instituições financeiras, nem todas aceitando o

358 Embora o art. 19 do Decreto-lei 2.321/1987 tenha determinado a aplicação do regime de responsabilidade previsto na Lei 6.024/1974 para o Raet, houve até 1997 uma importante diferença entre os dois diplomas legais. Com efeito, o art. 15 do Decreto-lei 2.321/1987 prevê a responsabilidade solidária não apenas dos administradores da instituição financeira, mas também das pessoas naturais ou jurídicas que com ela mantenham vínculo de controle, independentemente da apuração de dolo ou culpa. Essa era uma distinção de relevo para os regimes de intervenção extrajudicial ou de liquidação, que previam apenas a responsabilidade dos administradores, criando assim um regime considerado "incoerente" por alguns autores (VERÇOSA, Haroldo M. D. A responsabilidade civil especial nas instituições financeiras insolventes, p. 158; e YAZBEK, Otavio. Regulação do mercado financeiro e de capitais, p. 228). Essa incompatibilidade foi sanada com o art. $1 .^{\circ}$ da Lei 9.447/1997, que estendeu o regime de responsabilidade solidária dos controladores previsto no art. 15 do Decreto-lei 2.321/1987 aos regimes de intervenção e liquidação extrajudicial da Lei 6.024/1974.

359 VERÇOSA, Haroldo M. D. A responsabilidade civil especial nas instituições financeiras insolventes, p. 155.

360 Idem, ibidem, p. 155.

361 A pertinência da aplicação do regime de responsabilidade objetiva a diretores-empregados não será objeto de análise no presente trabalho. Para uma postura crítica quanto a essa possibilidade, ver: Idem, p. 110-119.

362 SALOMÃO, Eduardo. Direito bancário, p. 561-562. 
entendimento supracitado. ${ }^{363}$ Nesse aspecto, embora haja julgados reconhecendo o caráter objetivo da responsabilidade prevista no art. 40 da Lei $6.024 / 1974,{ }^{364}$ é preciso mencionar também posicionamento recente do STJ afirmando seu caráter subjetivo, porém com presunção de culpa dos administradores pelos atos praticados durante sua gestão. ${ }^{365}$ Dessa forma, haveria inversão do ônus da prova, que passaria a ser dos administradores, aos quais competiria demonstrar que atuaram com o devido zelo, impedindo sua responsabilização pelos prejuízos causados.

A Lei 9.447/1997 trouxe ainda importantes alterações à esfera patrimonial de administradores e controladores de instituições sob regimes especiais, com destaque para a possibilidade de decretação da indisponibilidade de seus bens. Dessa forma, combinando o art. 36 da Lei 6.024/1974 com o art. 2..$^{\circ}$ da Lei 9.447/1997, o controlador e aquelas pessoas que eram administradores nos últimos 12 meses anteriores à decretação do regime especial ficam com os seus bens indisponíveis. ${ }^{366}$ Essa indisponibilidade pode ainda ser estendida por proposta do Bacen aos bens de outras pessoas, conforme o disposto no art. $36, \S 2 .^{\circ}$, $a$ e $b$, desde que aprovada pelo CMN. Além disso, o art. $2 .^{\circ}, \S 1 .^{\circ}$, da Lei 9.447/1997, outorgou ao Bacen o poder de excluir da indisponibilidade os bens das pessoas jurídicas controladoras das instituições financeiras sob regime especial, objetivando assegurar a normalidade de sua atividade econômica e os interesses dos credores. Essa possibilidade, no entanto, não foi estendida às pessoas naturais do controlador e dos ex-administradores. ${ }^{367}$

Em contraste com esses aspectos positivos dos regimes especiais existentes no Brasil, é preciso reconhecer também a existência de críticas quanto à atuação do Bacen na utilização desses mecanismos em determinadas situações. Com efeito, é importante notar que os regimes especiais mencionados não adotam nenhum dos mecanismos de "intervenção e

\footnotetext{
363 Para uma exposição das principais correntes, ver: DE LUCCA, Newton. A responsabilidade civil dos administradores de instituições financeiras. Revista de Direito Mercantil, Industrial, Econômico e Financeiro, n. 67, jul.-set. 1987; e VERÇOSA, Haroldo M.D. Responsabilidade civil especial nas instituições financeiras e nos consórcios em liquidação extrajudicial, p. 51-71.

364 REsp 21245/SP, Rel. Min. Ruy Rosado Aguiar, j. 04.10.1994; REsp 171748/RO, Rel. Min. Peçanha Martins, j. 06.05.2004; REsp 172736/RO, Rel. Min. Peçanha Martins, j. 10.06.2003; AgRg 189349/SP, Rel. Min. Ruy Rosado Aguiar, j. 14.12.1999.

365 REsp 447939/SP, Rel. Min. Nancy Andrighi, j. 04.10.2007.

366 VERÇOSA, Haroldo M. D. A responsabilidade civil especial nas instituições financeiras insolventes, p. 165.

367 Idem, ibidem, p. 165-166.
} 
resolução estruturada antecipada" ou "ações corretivas imediatas" utilizados em outros países. Pelo contrário, no sistema vigente impera a ampla discricionariedade da autoridade bancária na aplicação desses regimes. ${ }^{368}$ Se por um lado essa discricionariedade é vista como positiva por alguns autores, uma vez que permite à autoridade alguma margem de manobra, podendo postergar a decretação da intervenção e da liquidação se assim julgar necessário, ${ }^{369}$ por outro lado pode também ser objeto de críticas, dado que abre a possibilidade para que instituições que apresentem sinais claros de insolvência continuem em funcionamento. Esse é um ponto relevante, pois o atraso na decretação do regime necessário pode agravar ainda mais a situação financeira da instituição, aumentando o prejuízo para seus credores. ${ }^{370}$

Entre os casos mais notórios de críticas quanto à atuação (ou falta dela) do Bacen destaca-se a intervenção no Grupo Coroa Brastel na década de 1980. Um aspecto que chamou a atenção nesse episódio foi a existência de documentos preparados por comissão de sindicância do próprio Bacen indicando que a autarquia estava ciente desde 1979 da grave situação do Grupo Coroa Brastel, inclusive com parecer de um de seus inspetores indicando a existência de "caixa 2" na financeira e emissão de letras de câmbio em duplicidade. ${ }^{371}$ No

368 A análise dos arts. $2 .^{\circ}$ e 15 da Lei 6.024/1974 e do art. 1. ${ }^{\circ}$ do Decreto-lei 2.321/1987 mostra que, embora haja critérios objetivos para a decretação de regimes especiais, como a existência de passivo a descoberto (art. 1. ${ }^{\circ}, b$, Dec.-lei 2.321/1987) ou o descumprimento de normas referentes à conta de reservas bancárias (art. 1. ${ }^{\circ}, c$, Dec.-lei 2.321/1987), na maioria dos casos, os critérios utilizados para decretação dos regimes são subjetivos, apoiando-se largamente no juízo de valor do Bacen quanto à sua configuração. Assim, por exemplo, observa-se no art. 15 da Lei 6.024/1974 que a liquidação extrajudicial será decretada em razão de "ocorrências que comprometam sua situação econômica ou financeira" (art. 15, I, a), quando a instituição violar "gravemente" as normas legais e estatutárias que disciplinam a sua atividade (art. 15, I, b), ou então quando a instituição sofrer prejuízo que sujeite a risco "anormal” seus credores quirografários (art. 15, I, c). A determinação quanto ao que seria uma violação "grave" ou risco "anormal" a credores quirografários está sujeita à discricionariedade do Bacen. Situação semelhante é observada no tocante à intervenção e ao Raet, com critérios para sua decretação baseando-se na prática "reiterada" de operações "contrárias às diretrizes de política econômica ou financeira" (art. 1. ${ }^{\circ}, a$ ), ou então quando for constatada gestão "temerária" de seus administradores (art. 1. $\left.{ }^{\circ}, d\right)$.

369 SALOMÃO, Eduardo. Direito bancário, p. 538.

370 Idem, ibidem, p. 535.

371 A esse respeito é oportuna a transcrição de parte do relatório resultante da sindicância interna do Bacen: "Em 19.03.80 [...] o então Chefe da Refim/RJ, Sr. Devanildo de Oliveira, comunicava ao Defim a gravidade das irregularidades constatadas na Coroa S.A. Crédito, Financeiro e Investimento, ao encaminhar o relatório da inspeção realizada naquela financeira. Meses depois, um expediente datado de 28.11 .80 e dirigido à Chefia da REFIM/RJ [...] o auditor desta Autarquia, Sr. José Carlos Batista, fazia referência às mesmas irregularidades, assinalando que 'o íntimo relacionamento entre as empresas do grupo 'ignorava' os mais elementares princípios administrativos e contábeis', em razão do que firmava sua convicção de que só uma inspeção integrada poderia alcançar 'resultados mais consistentes'. Relatório de inspeção de 30.06 .81 constatou insuficiência de capital de giro para bancar o total de seu financiamento e de sua responsabilidade perante seus investidores em Letras de Câmbio. Descobriu-se, em maio/82, pela fiscalização do Bacen a 
entanto, mesmo em face de tais constatações, a autarquia ordenou a suspensão das fiscalizações e inspeções ordinárias na financeira a partir de maio de 1982. No período que se seguiu, a situação financeira da entidade se deteriorou rapidamente, tornando-se inevitável a decretação da intervenção em 1983, com sua subsequente liquidação, causando grande prejuízo para cerca de 34.000 investidores do grupo. Como resultado, o Bacen foi acionado judicialmente sob a acusação de que teria sido omisso em sua supervisão, não tendo interferido na instituição já em 1979, embora houvesse indicações dos técnicos da autoridade bancária de que seu patrimônio líquido estaria negativo.

As intervenções realizadas na década de 1990 no âmbito do Proer também deram ensejo a críticas quanto à atuação da autoridade bancária. Conforme visto no capítulo anterior, relatos indicam que o "sinal de alerta" em tais instituições já havia soado há algum tempo anos antes, no caso do Nacional - para o Bacen, mas a autoridade as manteve em funcionamento na crença de que se recuperariam, ou que poderia ser encontrada uma "solução de mercado" para a situação delas. Apenas no caso do Banco Econômico, estima-se que, se o Bacen tivesse agido com maior rapidez, o rombo do Econômico teria custado menos de R\$700 milhões no início de março de 1994, ou o dobro disso dois meses depois. O prolongamento da situação por cinco meses fez com que o rombo nas contas da instituição se elevasse para cerca de R $\$ 3$ bilhões no momento da intervenção. ${ }^{372}$ Outrossim, o episódio com o Banco Econômico foi objeto de pesadas críticas também em virtude das interferências políticas no processo, notadamente pelo então Senador Antônio Carlos Magalhães, que exigiu a reabertura do banco após o congelamento dos seus depósitos. Segundo o relato de Carvalho: "exibida para todo o país, causou grande impacto a cena de ACM e um numeroso grupo de parlamentares atravessando a Praça dos Três Poderes, com ar triunfante, para 'agradecer' ao presidente no Palácio do Planalto". ${ }^{373}$ A péssima repercussão na mídia e a forte reação de

conta bancária n. ${ }^{\circ}$ 623-160128, junto à agência 1. ${ }^{\circ}$ de março do Banco Nacional S.A., conhecida pelo codinome 'Caixa 2', por não registrada na contabilidade da empresa Coroa S.A. - Distribuidora de Títulos e

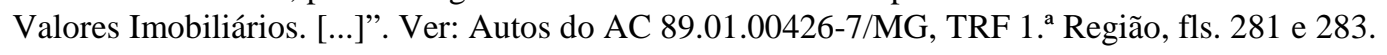

372 Os dados são de Ronaldo Brasiliense em reportagem que lhe rendeu o prêmio Esso de jornalismo em 1998, ver: ISTO É. A conta do Proer, 29 jul. 1998, p. 108 e ss.

373 CARVALHO, Carlos Eduardo. Ocultamento e mistificação nas relações do Banco Central com os bancos, p. 207. 
diretores do Bacen a esse fato fizeram o presidente recuar e romper o compromisso com o Senador da Bahia. ${ }^{374}$

Mais recentemente, crítica semelhante pôde ser observada com relação à intervenção ocorrida no Banco Santos, em novembro de 2004. O processo de degradação da saúde financeira do banco já vinha sendo noticiado na imprensa pelo menos desde 2001, com acusações de operações de "maquiagem" em suas contas. ${ }^{375}$ Documentos do Bacen também indicavam a suspeita da existência de operações consideradas "não usuais" por parte da instituição financeira desde 2002, quando enviou técnicos à sede do banco para investigar tais operações. Tais relatos foram corroborados pelo rebaixamento do rating do Banco Santos pela agência Fitch, em dezembro de 2003, em virtude da preocupação com a deterioração de sua carteira de crédito, seguido pelo rebaixamento da nota da instituição em janeiro de 2004 pela Standard\&Poors por razões semelhantes. ${ }^{376}$ Em carta enviada em 13 de abril de 2004 e um termo de comparecimento datado de 13 de maio, ${ }^{377}$ o Bacen notificava e alertava os diretores do banco da existência de irregularidades ou indícios de irregularidades, frisando que os trabalhos de fiscalização realizados no banco apontavam "o grave comprometimento da situação econômico-financeira do conglomerado financeiro Santos". ${ }^{378}$ O termo de comparecimento comparava o lucro do Banco Santos em 2001, 2002 e 2003 com os resultados "não usuais" nesse período, concluindo que, excetuando-se tais resultados suspeitos, o banco havia acumulado prejuízo de $\mathrm{R} \$ 107$ milhões naquele intervalo. Usando como referência a data de 31 de março de 2004, o Bacen apontava que o patrimônio líquido

374 Conforme relato da Revista Veja, a diretoria do Bacen teria ameaçado pedir demissão coletiva caso a intervenção no banco não fosse realizada. Ver: VEJA. O barão da Bahia beija a lona, 16 ago. 1995, p. 84-91.

375 FOLHA DE SÃO PAULO. BC via problemas no Banco Santos desde 2001, 26 dez. 2004, p. B3.

376 Idem. Banco Santos põe em dúvida agências de risco, 28 nov. 2004, p. B17.

377 Conforme o Manual de Supervisão do Bacen, o "Termo de Comparecimento é aplicado com a convocação dos representantes legais da instituição supervisionada e, caso entendido necessário, dos seus controladores, para informarem acerca das medidas que adotarão com vistas à regularização das seguintes situações: (a) descumprimento dos padrões mínimos de capital, bem como inobservância de limites operacionais, conforme disposições regulamentares vigentes; (b) crise de liquidez que, pela sua gravidade, possa colocar em risco a continuidade da instituição supervisionada; (c) grave situação dos controles internos, que comprometa ou venha a comprometer as condições indispensáveis para o funcionamento da instituição; e (d) graves deficiências ou procedimentos cuja continuidade comprometa ou venha a comprometer o regular funcionamento da instituição supervisionada, em face dos riscos legal, operacional, de reputação ou de imagem". O Manual de Supervisão do Bacen (item 4.50.40) está disponível em: <www.bcb.gov.br/?RED2MANSUP>. Acesso em: 12 dez. 2010.

378 FOLHA DE SÃO PAULO. BC via problemas no Banco Santos desde 2001, 26 dez. 2004, p. B3. 
exigido do banco acusava um déficit de $\mathrm{R} \$ 463,69$ milhões. Nos 226 dias decorridos entre o alerta da autoridade ao Banco Santos e a intervenção, o déficit na instituição teria quase dobrado, aumentando consideravelmente os prejuízos para seus investidores. ${ }^{379}$ Esse, no entanto, não foi o caso do então presidente do Senado, José Sarney, que um dia antes de o Bacen decretar a intervenção realizou saque de $\mathrm{R} \$ 2,2$ milhões de investimentos junto ao banco. $^{380}$

O reflexo imediato dessa percepção negativa dos credores quanto à atuação do Bacen pode ser observado nos tribunais, com diversas ações judiciais exigindo a sua responsabilização pelos prejuízos. No caso do Coroa Brastel, por exemplo, os investidores perderam na primeira instância, mas a decisão foi revertida pelo Tribunal Regional Federal (TRF), que condenou o Bacen por sua omissão quanto às irregularidades verificadas e ordenou o pagamento de $\mathrm{Cr} \$ 43.442 .670,00$ aos autores da ação. ${ }^{381}$ A decisão, no entanto, foi revertida pelo STJ em julgamento em que o voto da relatora, Ministra Eliana Calmon, que confirmava a decisão do TRF, foi vencido. Em voto de desempate, o Ministro Franciulli Netto decidiu contra o posicionamento da relatora, destacando que fiscalizar não significa atuar, e que não haveria nexo de causalidade entre a ação ou omissão do Estado e o dano sofrido pelo lesado. Segundo o posicionamento do Ministro: ${ }^{382}$

\begin{abstract}
A mera omissão na fiscalização, ainda que existente, não levaria ao infeliz, mas não imprevisível desate do Grupo Coroa Brastel, dado o alto risco especulativo com que atuava [...] Apenas a título de argumentação, se o fiscal oficiar como mero "dois de paus", com olhos de quem não quer enxergar e ouvidos de mercador, nem por isso, ou apesar disso, a empresa fiscalizada necessariamente irá para a bancarrota ou para o descaminho. Muito pelo contrário, empresa séria e bem estruturada atingirá plenamente seus regulares objetivos, com ou sem fiscalização.
\end{abstract}

O posicionamento de Franciulli Neto foi objeto de inúmeras críticas, inclusive por outros ministros do STJ, como Luiz Fux, que considerou que o nexo de causalidade havia sido

379 FOLHA DE SÃO PAULO. BC via problemas no Banco Santos desde 2001, 26 dez. 2004, p. B3.

380 À época o presidente do Senado soltou nota à imprensa afirmando: "Eu, como centenas de correntistas, em face dos rumores publicados na imprensa e existentes na praça sobre o Banco Santos, transferi meus depósitos, produto da venda da minha fazenda Pericumã para o Banco do Brasil, depósitos estes constantes de minha declaração de imposto de renda, há dois anos".

381 AC 95.01.26055-0/DF, TRF 1. a Região, Rel. Juiz Fernando Gonçalves, j. 25.03.1996.

382 REsp 44500/MG, Rel. Min. Eliana Calmon, j. 28.11.2000. 
muito bem destacado na sentença de $1 .^{\circ}$ grau. ${ }^{383}$ Igualmente, autores como Salomão Neto consideram a decisão do STJ "não razoável", argumentando que esta toma como base argumentos juridicamente irrelevantes, como o fato de os investidores prejudicados terem sido atraídos pelo elevado retorno das letras de câmbio - denotativo de risco - e pretenderem socializar seus prejuízos. ${ }^{384}$ Aqui vale mencionar também a jurisprudência prevalente no mesmo tribunal no sentido de que, antes de concluído o regime especial, falta interesse processual aos investidores para acionar judicialmente o Bacen para fins de indenização por danos decorrentes de deficiências na sua fiscalização. ${ }^{385}$ Embora o posicionamento jurisprudencial faça sentido na medida em que exige a avaliação da ocorrência de dano e sua precisa quantificação para analisar a responsabilidade da autoridade bancária, é preciso reconhecer também o obstáculo prático imposto a possíveis correntistas e investidores lesados, uma vez que tais regimes especiais não raro prolongam-se por anos, ou mesmo décadas, no Judiciário.

Episódios como os supracitados, aliados à jurisprudência sobre o tema, infelizmente podem acabar causando uma impressão negativa na sociedade quanto à utilização desses mecanismos pelo Bacen, quando estes na verdade possuem inúmeras virtudes em comparação com outros países. Corre-se o risco de disseminação de uma percepção quanto aos regimes especiais de que eles seriam apenas a última medida adotada pela autoridade, quando todas as outras vias (incluindo as políticas) já houvessem se esgotado, e não uma resposta lógica à debilitação das contas de uma instituição financeira. ${ }^{386} \mathrm{Na}$ medida em que participantes do

383 REsp 472735/DF, Rel. Min. Luiz Fux, j. 10.06.2003.

384 SALOMÃO, Eduardo. Direito bancário, p. 579.

385 Agravo Regimental nos Embargos de Divergência no REsp 116826/MG, Rel. Min. Luiz Fux, j. 23.08.2006.

386 A possibilidade de influência política na decretação de regimes especiais foi novamente cogitada por ocasião do resgate ao Banco Panamericano pelo FGC em 9 de novembro de 2010. A suspeita foi levantada pelo fato de Silvio Santos ter se reunido com o Presidente da República em 22 de setembro de 2010 e o resgate ter sido realizado logo após as eleições presidenciais de outubro de 2010. À ocasião, o Presidente da República afirmou que a pauta da reunião não tratou da situação do banco, mas sim de um pedido do apresentador para que o Presidente realizasse doação de $\mathrm{R} \$ 12$ mil para o programa Teleton (O GLOBO. Não é assunto do presidente, 11 nov. 2010, p. 25). O então presidente do Bacen, Henrique Meirelles, também apressou-se em esclarecer que o momento do resgate em nada se relacionou com o período eleitoral, tendo apenas seguido o rito legal de investigação desde a identificação da deficiência patrimonial no início de setembro de 2010 até o final do prazo legal de 60 dias para sua conclusão (O ESTADO DE SÃO PAULO. É o momento adequado para encerrar missão, 24 nov. 2010). A declaração do ex-presidente do Bacen contrasta com seu relato posterior, em que afirma que as dificuldades patrimoniais do Panamericano teriam influenciado a decisão sobre a taxa básica de juros em reunião do Comitê de Política Monetária (Copom) realizada em julho de 2010. Ver: O GLOBO. Meirelles: Banco Panamericano influiu na decisão de manter juros, 25 nov. 2010. 
mercado acreditem que esse processo pode ser negociado, abre-se margem para gestões temerárias ou fraudulentas capazes de colocar em risco credores e depositantes. ${ }^{387}$

\subsubsection{Emprestador de última instância}

Outro importante instrumento de prevenção de crises bancárias é o provimento de liquidez a instituições financeiras em dificuldade. Considerado o primeiro mecanismo de regulação sistêmica, suas origens confundem-se com a própria evolução da atuação dos bancos centrais na Europa. ${ }^{388}$ Justamente em função disso alguns autores o consideram uma "prerrogativa clássica" de tais órgãos. ${ }^{389}$

387 Esse é inclusive um aspecto ressaltado pelo consultor do departamento de estudos e pesquisa do Bacen, Eduardo Luís Lundberg, a respeito da política de resgate a bancos durante o regime militar. Segundo o autor, devem-se ressaltar como pontos negativos daquela política os "fortes indícios de problemas de 'moral hazard' afetando a atuação de alguns banqueiros, dada a ampla proteção governamental concedida e a própria falta de transparência da política de saneamento". LUNDBERG, Eduardo Luís. Saneamento do sistema financeiro, p. 58-59.

388 O caso do Banco da Inglaterra é ilustrativo a esse respeito. Inicialmente, em resposta a períodos de histeria financeira, o Banco da Inglaterra (bem como outros bancos europeus) iria frequentemente proteger as suas próprias reservas de ouro, recusando-se a ajudar bancos correspondentes em necessidade. Esse comportamento acabou precipitando grandes pânicos e gerando também fortes críticas ao banco, especialmente por parte de Bagehot, em sua célebre obra Lombard street, sustentando que este deveria sujeitar seu interesse privado ao interesse público do sistema bancário como um todo (conhecida como "doutrina da responsabilidade", ou, na expressão inglesa, responsibility doctrine). As proposições apresentadas por Bagehot contribuíram de forma decisiva para a modificação da conduta do Banco da Inglaterra. $\mathrm{O}$ autor reconheceu, na prática, a importância do Banco da Inglaterra e a necessidade de reformálo no sentido de torná-lo mais apto a desempenhar o papel de banco central. A partir de uma análise crítica do comportamento do banco durante os sucessivos pânicos bancários ao longo do século XIX, Bagehot formulou o que se tornou conhecido como a doutrina clássica do prestamista de última instância (FREITAS, Maria Cristina Penido. A evolução dos bancos centrais e seus desafios no contexto da globalização financeira. Revista de Estudos Econômicos, Instituto de Pesquisas Econômicas, São Paulo, v. 30, n. 3, p. 404, 2000). Gradualmente o Banco da Inglaterra passou a adotar a chamada responsibility doctrine e começou a emprestar dinheiro para bancos correspondentes em tempos de crise, desde que com uma garantia. Isso incluía também uma penalidade para compensar o risco moral. Observa-se aí a origem de uma das mais tradicionais funções de um banco central, que é justamente o seu papel de prestamista de última instância em casos de crises financeiras. De fato, alguns autores, como Capie et al., chegam inclusive a identificar o marco inicial de atuação dessas instituições como bancos centrais com base na década em que começaram a desempenhar a função de prestamistas de última instância. Ver: CAPIE, Forrest et al. The future of central banking: the tercentenary symposium of the Bank of England. Cambridge: Cambridge University Press, 1994.

389 SADDI, Jairo. Crise e regulação bancária, p. 151. 
Há dois principais contextos em que os bancos centrais são chamados a intervir no setor bancário para injeção de recursos. ${ }^{390}$ Em um primeiro momento, o banco central pode ter de prover recursos a instituições financeiras para auxiliar na superação de problemas conjunturais da economia. Esse tipo de auxílio geralmente ocorre no contexto de um evento sistêmico que afeta negativamente diversas instituições financeiras simultaneamente. Em tais casos, a atuação do banco central é direcionada principalmente a instituições ilíquidas, ou seja, aquelas que dispõem de patrimônio suficiente para garantir as suas obrigações, mas não contam, naquele momento, com caixa suficiente para liquidar suas obrigações. No segundo caso, o banco central pode ter de prover uma assistência emergencial de liquidez a um determinado banco para evitar sua quebra e uma possível contaminação de outras instituições financeiras. Nessa situação crítica, o banco que recebe o resgate tipicamente está à beira da insolvência, ou já se tornou insolvente. ${ }^{391}$

É importante ressaltar que o banco central não tem a obrigação de prover recursos às instituições financeiras e não deve oferecer auxílio de forma irrestrita. O motivo, evidentemente, é o risco moral que o provimento indiscriminado de recursos a instituições financeiras em dificuldades pode causar. Assim, a utilização de mecanismos dessa natureza deve destinar-se apenas àquelas situações em que a quebra da instituição financeira provoque riscos à estabilidade do sistema financeiro. No entanto, reconhece-se que, na prática, nem sempre é possível avaliar antecipadamente se o auxílio do banco central é imprescindível ou não. ${ }^{392}$

390 DE BANDT, Olivier; HARTMANN, Philipp. Systemic risk, p. 16. Optou-se neste tópico pela apresentação dos instrumentos típicos de provimento de liquidez, ficando de lado regras e regimes isolados, ainda que relacionados à estabilidade sistêmica. Dessa forma, fogem à exposição programas de cunho excepcional que não são passíveis de análise sob um arcabouço conceitual comum, como os já mencionados Proer, Proes e Proef, o Programa de Auxílio a Ativos Problemáticos (Troubled Asset Relief Program - Tarp) anunciado pelo Congresso norte-americano em 2008, ou o programa de recapitalização de bancos (Abbey, Barclays, HBOS, HSBC, Lloyds, Nationwide, Royal Bank of Scotland e Standard Chartered) no montante de $£ 500$ bilhões adotado na Inglaterra no mesmo ano.

391 SADDI, Jairo. Crise e regulação bancária, p. 152.

392 Conforme o pertinente ensinamento de Verçosa: “[...] se uma intervenção para correção de rumos deve ser efetuada pelo Estado, resta saber qual o nível ótimo a ser adotada: nem menos para caracterizar sua insuficiência, nem mais, para não cair no paternalismo excessivo. Essa é uma questão a ser decifrada pelos economistas, em processos de tentativa e erro". Ver: VERÇOSA, Haroldo M. D. Bancos centrais no direito comparado, p. 175. 
Entre as medidas propostas para mitigar o risco moral decorrente da adoção desse tipo de mecanismo, ressalta-se a importância de formalizar tais instrumentos no arcabouço regulatório, criando critérios delimitadores e modos de controle para o seu emprego. Conforme ensinamento de Yazbek, dada a própria evolução histórica do papel dos bancos centrais como prestamistas de última instância, em muitos países essa função não era objeto de um regramento específico, dando margem a abusos e criação de benefícios escusos para administradores e controladores das instituições resgatadas. ${ }^{393}$ Aqui vale mencionar que, como no caso da decretação de regimes especiais, o provimento de liquidez aos bancos também é área propícia ao surgimento de incentivos negativos no comportamento da autoridade bancária decorrentes da "not on my watch syndromme", captura da agência e percepção de que os agentes de mercado são grandes demais para quebrar. Em função disso, observa-se na atualidade uma tendência ao maior detalhamento desses mecanismos no arcabouço regulatório de cada país, incluindo medidas de controle para o provimento de liquidez a instituições financeiras, como limites temporais e taxas penalizantes conforme o período de utilização. ${ }^{394}$

Além dessas medidas, é importante haver a prestação de contas pela autoridade bancária em casos de operações de resgate a instituições financeiras. Essa prestação de contas pode ser feita por meio da emissão de relatório circunstanciado pela autoridade a respeito do porquê da operação de resgate, momento em que foi feita, evolução da saúde financeira da instituição no período anterior à decretação (incluindo grau de alavancagem e exposição a outras instituições financeiras) e montantes despendidos pela autoridade nesse período, entre outras questões de relevo para a avaliação da necessidade do resgate. ${ }^{395}$ Não se trataria, portanto, apenas de prestação de contas em termos quantitativos, mas sim de autoavaliação quanto à decisão tomada, esclarecendo o que foi atingido e, quando necessário, justificando aquilo em que se falhou.

393 YAZBEK, Otavio. Regulação do mercado financeiro e de capitais, p. 238.

394 HONOHAN, Patrick; KLINGEBIEL, Daniela. Controlling the fiscal costs of banking crisis. Policy Research Working Paper, The World Bank, n. 2.441, 2000.

395 BANCO MUNDIAL. Finance for growth: policy choices in a volatile world. A World Bank policy research report. Oxford: Oxford University Press, 2001. 
O principal efeito dessa medida é pressionar a autoridade bancária a dosar de forma equilibrada os possíveis benefícios da recuperação da instituição financeira em comparação com os custos caso isso não seja possível. ${ }^{396}$ Bom exemplo disso é a Autoridade de Serviços Financeiros (Financial Services Authority - FSA), responsável pela regulação e supervisão do sistema financeiro inglês, que é obrigada por lei a considerar a relação custo versus benefício em suas ações. ${ }^{397}$ Isso ajuda a evitar também que argumento do "risco sistêmico" seja invocado de forma arbitrária por autoridades bancárias para justificar resgates. Conforme o preciso apontamento de Schwarcz, "risco sistêmico é um conceito econômico, e não político, não devendo ser utilizado de forma acrítica como rótulo político ex post para quebras bancárias". 398

Além dos relatórios, há outras formas de prestação de contas pela autoridade, como a instauração de comissões pelo Poder Legislativo para investigações de grandes quebras no setor bancário, em que as autoridades bancárias são sujeitas a intenso escrutínio de suas ações. Exemplos disso são a "CPI dos bancos", realizada pelo Congresso Nacional em 1999, ${ }^{399}$ o relatório sobre a quebra do Continental Illinois Bank em $1984^{400}$ e o relatório sobre a quebra do Lincoln Savings and Loans em 1989, ${ }^{401}$ nos Estados Unidos, e, mais recentemente, a comissão instaurada pelo Parlamento inglês para averiguação da conduta da FSA na quebra do Northern Rock em 2008. ${ }^{402}$ Tais medidas, no entanto, tornam o processo sujeito a

396 Aqui é importante reconhecer que a exigência de esclarecimentos da autoridade bancária nessas situações não deve ser vista como um cerceamento à sua atuação, mas sim como uma resposta lógica ao movimento de maior autonomia e independência de tais órgãos. Segundo Daniel Lefort, ex-diretor jurídico do Bank for International Settlements, "independência requer prestação de contas, e prestação de contas requer transparência". Ver: LEFORT, Daniel. Transparency and accountability of Central Banks. Bank for International Settlement, p. 1, 2006. Tradução livre. Disponível em: <www.cemla.org/pdf/legales/leg-06lefort.pdf>. Acesso em: 26 dez. 2010.

397 Financial Services and Markets Act 2000, Seção 3.

398 SCHWARCZ, Steven L. Systemic risk. Georgetown Law Journal, v. 97, n. 1, p. 204, 2008. Tradução livre.

399 Relatório final da "CPI dos bancos". Disponível em: <www.senado.gov.br/atividade/materia/detalhes.asp? tab=t\&p_cod_mate=1906>. Acesso em: 8 dez. 2010. Vale mencionar também a convocação em novembro de 2010 do então presidente do Bacen, Henrique Meirelles e da Presidente da CEF, Maria Fernanda Ramos Coelho, para prestarem esclarecimentos à Comissão de Constituição e Justiça do Senado sobre o aporte de fundos do FGC no banco Panamericano. Ver: ESTADO DE SÃ̃O PAULO. CCJ convida Meirelles para falar sobre Panamericano, 10 nov. 2010.

400 U.S. CONGRESS. Inquiry into the Continental Illinois Corp. and Continental Illinois National Bank.

401 Idem. Investigation of Lincoln Savings and Loan Association. House of Representatives, Committe on Banking, Finance, and Urban Affairs, 1990, 100 ${ }^{\text {th }}$ Cong., $1^{\text {st }}$ session.

402 HOUSE OF COMMONS. The run on the Rock. 
conveniências políticas, que podem acabar influenciando a quantidade e qualidade das informações apresentadas.

\subsubsection{Provimento de recursos pelo Banco Central}

As operações de liquidez realizadas no âmbito do SFN encontram amparo no art. 4. ${ }^{\circ}$, XVII, da Lei 4.595/1964, que estabelece como competência privativa do CMN a atribuição da regulamentação, bem como a fixação de limites, prazos e demais condições necessárias para as operações de redesconto e de empréstimo, efetuadas com quaisquer instituições financeiras públicas e privadas de natureza bancária. Compete ao Bacen realizar as operações de redesconto e empréstimos com instituições financeiras em dificuldades (art. 10, V).

De acordo com o art. $1 .^{\circ}$ do anexo à Circular Bacen 3.105, de 5 de abril de 2002, o acesso ao redesconto é restrito às instituições financeiras titulares de contas de "reservas bancárias" junto ao órgão. ${ }^{403} \mathrm{O}$ socorro financeiro nesse caso pode ocorrer de duas formas. Em primeiro lugar, tem-se o redesconto na modalidade de compra com compromisso de revenda, em que a autoridade bancária adquire títulos públicos federais que integram a posição de custódia própria da instituição financeira, bem como outros títulos e valores mobiliários, créditos e direitos creditórios, preferencialmente com garantia real, e outros ativos. A instituição beneficiada irá posteriormente recomprar esses títulos com o acréscimo de uma remuneração financeira ao Bacen. O provimento de liquidez também pode ser realizado por meio do redesconto propriamente dito, ou redesconto em sentido estrito, como alguns autores preferem chamá-lo, ${ }^{404}$ que contempla títulos e valores mobiliários e direitos creditórios descontados integrantes do ativo da instituição financeira interessada. ${ }^{405}$

403 De acordo com o art. $1 .^{\circ}$ da Circular 3.101/2002, as disponibilidades mantidas no Bacen, em moeda nacional, pelos bancos comerciais, bancos de investimento, caixas econômicas e bancos múltiplos devem ser registradas nas chamadas contas "reservas bancárias". Segundo o art. 4. ${ }^{\circ}$ da Circular, admite-se apenas uma conta de reservas bancárias por instituição financeira. Ainda segundo o artigo, estas são de titularidade obrigatória para bancos comerciais, bancos múltiplos com carteira comercial e caixas econômicas, e de titularidade facultativa para bancos de investimento e bancos múltiplos sem carteira comercial.

404 SALOMÃO, Eduardo. Direito bancário, p. 524.

405 Para efeitos do presente trabalho, as duas modalidades serão referidas genericamente como "redesconto". 
Essas operações de liquidez podem ter diferentes prazos e finalidades. A primeira categoria é o redesconto intradiário, destinado a atender necessidades de liquidez da instituição financeira ao longo do dia. Trata-se de operação sem custo financeiro para a instituição contratante, cursada em sistemas automatizados com base em mensagens de solicitação e pagamento. $\mathrm{O}$ redesconto de um dia útil destina-se a satisfazer necessidades de liquidez decorrentes de descasamentos de curtíssimo prazo no fluxo de caixa da instituição financeira. Tais modalidades de crédito representam uma funcionalidade do Sistema de Pagamentos Brasileiro, que será objeto de análise a seguir, e que proibiu as instituições financeiras de apresentar saldos negativos na conta reservas bancárias. Essas operações podem ser realizadas apenas na forma de compra com compromisso de revenda, contemplando exclusivamente títulos públicos federais.

Além dessas, há também o redesconto de até 15 dias úteis, que pode ser recontratado até o limite de 45 dias úteis, e destina-se a satisfazer necessidades de liquidez provocadas pelo descasamento de curto prazo no fluxo de caixa da instituição financeira que não caracterizem desequilíbrio estrutural. Por fim, há o redesconto de até 90 dias corridos, que pode ser recontratado até o limite de 180 dias corridos, e destina-se a viabilizar o ajuste patrimonial da instituição financeira com desequilíbrio estrutural. As operações de até 15 dias úteis dependem de prévia anuência do Bacen, enquanto as de 90 dias corridos dependem de aprovação da Diretoria Colegiada da autarquia. O acesso ao redesconto nesses casos envolve o atendimento de determinadas condições, como a avaliação do valor dos ativos objeto de compra pelo Bacen e demonstrativo das necessidades de caixa projetadas para o período do auxílio. Tais pedidos também podem ocorrer no contexto de um programa de reestruturação firmado pelo acionista controlador visando a capitalização ou a venda do controle acionário da instituição, a ser implementado no período de vigência da operação. ${ }^{406}$

A respeito dos prazos para tais operações, cumpre ressaltar que, embora a Lei Complementar 101, de 4 de maio de 2000 (Lei de Responsabilidade Fiscal), tenha proibido em seu art. 28 a utilização de recursos públicos para socorrer instituições do SFN, as

\footnotetext{
406 A burocracia inerente a essa modalidade de redesconto é criticada por Saddi, haja vista que, na ocorrência de uma crise bancária, a necessidade de apresentação de documentos capazes de suportar o pleito para serem analisados e aprovados pelo Bacen nem sempre se coaduna com "a situação de emergência que clama por uma rápida e expedita decisão”. Ver: SADDI, Jairo. Crise e regulação bancária, p. 158.
} 
operações de redesconto e empréstimos a instituições financeiras realizadas pelo Bacen não estão sujeitas à proibição, desde que tenham prazo inferior a 360 dias (art. 28, § 2. ${ }^{\circ}$ ).

A crise financeira recente trouxe importantes alterações ao regime de redesconto no País. A primeira delas foi implementada pela MP 462, de 14 de maio de 2009, posteriormente convertida na Lei 12.058 , de 13 de outubro de 2009, determinando que os créditos do Bacen decorrentes de operações de redesconto ou de empréstimo não são alcançados pela decretação de intervenção, liquidação extrajudicial ou falência da instituição financeira. Igualmente, estabeleceu que os ativos recebidos pelo Bacen em operações de redesconto ou em garantia de operações de empréstimo não integram a massa, nem têm seu pagamento obstado pela suspensão da fluência do prazo das obrigações da instituição sob intervenção. Essas medidas visaram dar maior liberdade para a autoridade bancária injetar liquidez em instituições financeiras sem correr o risco de ter seus recursos ou garantias para tais recursos bloqueados após a decretação de um regime especial.

Não obstante, a mais importante alteração no redesconto se deu por meio da MP 442, de 6 de outubro de 2008, posteriormente convertida na Lei 11.882, de 23 de dezembro de 2008, que, entre outras disposições, permitiu ao CMN: (i) estabelecer critérios e condições especiais de avaliação e de aceitação de carteiras de crédito de instituições financeiras pelo Bacen em operações de redesconto; (ii) dar acesso às reservas internacionais para operações de empréstimo em moeda estrangeira; e (iii) afastar em situações especiais as exigências de regularidade fiscal para o acesso a tais operações. A data de edição da medida provisória que originou a lei evidencia que esta foi uma ação de caráter emergencial empregada pelo governo para dotar o CMN de meios para combater os efeitos da crise financeira que atingia o País. Não por acaso, três dias após a sua edição o CMN editou a Resolução 3.622, de 9 de outubro de 2008, que tratou das condições para a realização dessas operações.

A Resolução estipula que o redesconto com carteiras de crédito deve ser feito exclusivamente com bancos, na forma de compra de ativos com compromisso de revenda. $\mathrm{O}$ prazo máximo das operações é de 360 dias, com remuneração vinculada ao perfil e prazo das operações. Para mitigar o risco de recebimento de ativos "podres" nessas carteiras de crédito, o art. 2. ${ }^{\circ}$ da Resolução autorizou o Bacen a receber apenas créditos identificados no Sistema 
Central de Risco ${ }^{407}$ com a classificação nas categorias AA, A e B, ${ }^{408}$ observando parâmetros mínimos na relação entre ativos e o valor do redesconto. O nível de exigência varia de $120 \%$ a $170 \%$ do valor do empréstimo, ou seja, para cada $\mathrm{R} \$ 100$ emprestados, são entregues $\mathrm{R} \$ 120$ a $\mathrm{R} \$ 170$ em créditos.

No caso das operações de empréstimo em moeda estrangeira, a Resolução autorizou o Bacen a aceitar como garantia: (i) títulos soberanos denominados em dólar que possuam rating mínimo; e (ii) Adiantamentos sobre Contratos de Câmbio (ACC) e Adiantamentos sobre Cambiais Entregues (ACE) de operações de empréstimo entre residentes e não residentes. ${ }^{409}$ No caso das ACCs e ACEs, a cobertura da garantia deve de ser de $120 \%$ para os créditos classificados em risco AA; 130\% para operações com classificação A; e 140\% para aquelas com classificação B.

Finalmente, a Resolução CMN 3.622/2008 afasta, em seu art. 3. ${ }^{\circ}$, uma série de condições de regularidade fiscal para acesso às modalidades de redesconto e empréstimo ali previstas, como: (i) exigência de apresentação de certidão negativa de inscrição na dívida ativa da União (art. 62 do Decreto-lei 147, de 3 de fevereiro de 1967); (ii) prova de quitação de tributos, multas e outros encargos fiscais de administração do Ministério da Fazenda (art. $1 .^{\circ}, \S 1 .^{\circ}$, do Decreto-lei 1.715, de 22 de novembro de 1979); (iii) apresentação de Certificado de Regularidade do FGTS (art. 27, $b$, da Lei 8.036, de 11 de maio de 1990); e (iv) regularização no Cadastro Informativo de Créditos Não Quitados do Setor Público Federal (Lei 10.522, de 19 de julho de 2002). Não obstante, o afastamento das exigências de regularidade fiscal foi limitado ao prazo de um ano, a partir da data de edição da Resolução.

Observa-se, portanto, que a Lei 11.882/2008 e a Resolução 3.622/2008 proporcionaram novas formas de assistência a instituições em crise, além de flexibilizar algumas das regras para provimento de liquidez já existentes. Tais diplomas legais vieram

\footnotetext{
407 O funcionamento do Sistema Central de Risco será objeto de tratamento detalhado no tópico 4.1.3.1.

408 A Resolução CMN 2.682, de 21 de dezembro de 1999, dispõe sobre critérios de classificação das operações de crédito, e será objeto de tratamento detalhado no tópico 4.1.1.1.3.

409 Os ACCs e ACEs consistem na antecipação parcial ou total a exportadores dos reais equivalentes à quantia em moeda estrangeira comprada a termo desses exportadores pelo banco. A diferença do ACC para o ACE é que o primeiro refere-se ao momento anterior ao embarque das mercadorias, enquanto o segundo trata do momento após o embarque. Ver: FORTUNA, Eduardo. Mercado financeiro, p. 332.
} 
responder à necessidade emergencial de recursos pelos participantes do SFN em meio à escassez de crédito provocada pela crise financeira que se apresentava. Nesse contexto, é importante ter em mente que, apesar do seu inegável auxílio no combate aos efeitos da crise no País, a ampliação dos instrumentos de provimento de liquidez e a flexibilização de suas regras também dão azo ao aumento do risco moral entre os participantes do sistema financeiro. As medidas adotadas, quando consideradas em conjunto com os novos papéis assumidos pelo FGC, criam incentivos para uma maior tomada de risco pelos bancos em razão dos inúmeros canais de resgate à sua disposição.

Outro ponto de preocupação refere-se ao fato de o provimento de liquidez a instituições em crise ser mais uma área propícia ao surgimento dos incentivos negativos no comportamento da autoridade bancária mencionados no tópico anterior, de modo que o abrandamento das regras aplicáveis a esses mecanismos deve sempre ser analisado com cuidado. Com efeito, não é difícil encontrar evidências dos perigos associados ao uso displicente do redesconto bancário. Entre os grandes motivos de crítica ao Proer, cabe mencionar a utilização de créditos "podres" para garantir o acesso ao redesconto do Bacen, como o notório caso do Banco Nacional, que ofereceu bilhões de reais em títulos do Fundo de Compensação de Variações Salariais (FCVS) para receber tais recursos, bem como o acesso aos canais de provimento de liquidez a instituições financeiras em situação fiscal irregular. ${ }^{410}$

410 CARVALHO, Carlos Eduardo. Ocultamento e mistificação nas relações do Banco Central com os bancos, $p$. 207. O FCVS foi criado no SFH e tinha como objetivo cobrir possíveis resíduos nos contratos imobiliários decorrentes do descasamento entre a correção monetária da prestação e do saldo devedor. O mutuário contribuía para o FCVS, que seria responsável no final do contrato pelo pagamento de eventual saldo devedor remanescente. Como resultado de alterações feitas nos contratos durante a primeira metade da década de 1980 pela política econômica da época, que beneficiaram os mutuários, os recursos do FCVS foram insuficientes para cobrir os saldos dos financiamentos imobiliários das instituições financeiras com carteira de crédito imobiliário. À época da intervenção no Banco Nacional, constatou-se que o banco havia adquirido R $\$ 3,163$ bilhões em títulos do FCVS. Os títulos foram comprados por apenas $50 \%$ do seu valor de face, uma vez que eram considerados créditos de difícil recuperação, não podendo sequer ser utilizados em privatizações. De fato, a maioria dos bancos já havia inclusive contabilizado parte desses recursos como perda ao longo dos últimos anos. Não obstante, os FCVS foram usados como garantia para os recursos do Proer pelo seu valor integral. Ou seja, os $\mathrm{R} \$ 3,163$ bilhões acabaram garantindo dívidas de aproximadamente R\$6 bilhões (ISTO É. A conta do Proer, 29 jul. 1998, p. 108 e ss). No total, segundo dados do próprio Bacen, os títulos do FCVS constituíram aproximadamente 2/3 das garantias do Proer (MAIA, Geraldo Villar Sampaio. Reestruturação bancária no Brasil, p. 6). Nesse aspecto, conforme visto no tópico 2.4.1, a dívida total que perdura dos bancos que receberam recursos do Proer junto ao Bacen é evidência suficiente da qualidade das garantias prestadas. 
A esse respeito, poder-se-ia argumentar que a exigência de carteiras de crédito com um determinado rating pelo Bacen eliminaria o risco de acontecimentos como o supracitado. Entretanto, conforme se observará no capítulo a seguir, o fato de uma determinada carteira de crédito possuir um rating elevado está longe de ser uma segurança de recebimento dos valores envolvidos. Aliás, uma das principais lições deixadas pela crise financeira recente é a de que ratings devem ser analisados e utilizados com cautela.

Naturalmente, momentos de grave instabilidade econômica, como o ocorrido em outubro de 2008, após a quebra do banco Lehman Brothers, podem demandar medidas excepcionais para manter a viabilidade do mercado. Não obstante, é preciso ter consciência das consequências acarretadas por medidas de tal natureza, bem como a necessidade de adotálas de forma temporária e apenas em casos emergenciais. Nesse aspecto, melhor teria caminhado o legislador se tivesse imposto um prazo determinado para tais canais de auxílio, assim como o fez com o afastamento das exigências de regularidade fiscal. ${ }^{411}$

Finalmente, deve-se ressaltar que os canais de provimento de liquidez a instituições financeiras são complementados pela perigosa e recorrente prática de concessão de empréstimos por instituições oficiais a bancos em crise. Conforme visto no capítulo anterior, essas operações foram largamente utilizadas no contexto do saneamento do setor bancário promovido na década de 1990 para manter instituições em dificuldades em funcionamento. Tais empréstimos foram feitos pelo Banco do Brasil e pela CEF, geralmente ocorrendo

411 Aqui vale mencionar argumento apresentado por Antônio Gustavo Matos do Vale, Diretor de Liquidações do Bacen, no "Seminário APBC sobre Regulação Financeira", organizado pelo Insper e a Associação dos Procuradores do Banco Central, em 27 de setembro de 2010, sobre a atuação da autarquia durante a crise recente. Segundo o Diretor de Liquidações do Bacen, a disponibilização de inúmeros canais de liquidez aos bancos atuantes no SFN se justificou em razão da crença da autarquia de que a turbulência que se apresentava no setor bancário naquele momento decorria de uma crise de liquidez, e não de uma crise patrimonial, como a verificada no setor bancário na década de 1990. Em outras palavras, tratava-se de problema de iliquidez, e não de insolvência. Sem entrar no mérito da discussão sobre a origem da crise bancária que se abateu no país, é importante notar que esse argumento não justifica a manutenção de inúmeros canais de provimento de liquidez após a fase mais aguda da crise recente. Pelo contrário, se o ocorrido foi de fato apenas uma crise de liquidez, essa é mais uma razão para que as medidas adotadas tivessem caráter temporário. Da forma como foram estruturadas, tais medidas acabam perpetuando um quadro de amplo provimento de liquidez característico de uma crise de liquidez para situações de normalidade, o que pode gerar incentivos negativos em termos de criação de risco moral no mercado. Ainda que se possa argumentar que a manutenção dessas medidas se faz necessária para o caso de uma nova crise ocorrer, é importante destacar novamente a gravidade da situação verificada em 2008, cujo único paralelo na história recente foi a crise de 1929, bem como os incentivos negativos que afetam a atuação da autoridade bancária, podendo desvirtuar a utilização desses mecanismos. 
quando o acesso ao redesconto não era mais possível, ou quando este não era mais viável devido ao seu custo financeiro. O reconhecimento explícito dessas operações constou em estudo do IBGE sobre os resultados das instituições oficiais em 1995: ${ }^{412}$

[...] a CEF foi largamente acionada pelo Governo no sentido de prover recursos aos bancos privados em dificuldades, a fim de impedir que essas instituições pagassem as taxas punitivas cobradas pelo Bacen nas operações de redesconto. Esses empréstimos cresceram de $\mathrm{R} \$ 550$ milhões, em finais de 1994 , para $\mathrm{R} \$ 7,3$ bilhões em dezembro de 1995.

Mais recentemente, o Banco do Brasil e a CEF voltaram a desempenhar importante papel como provedores de liquidez no auge da crise financeira em 2008, por meio da concessão de empréstimos no montante de $\mathrm{R} \$ 5,8$ bilhões de reais aos bancos Votorantim, Safra e Alfa para ajudá-los a reforçar seu caixa durante a crise. ${ }^{413}$

A prática de tais empréstimos é preocupante, uma vez que ocorre fora do âmbito das normas de provimento de liquidez mencionadas acima, ou seja, fora do contexto de formalidade tão caro ao funcionamento correto de tais mecanismos. ${ }^{414}$ Portanto, não há regramento quanto a montantes, prazos, exigência ou qualidade dos ativos oferecidos em garantia. O resultado, em muitos casos, é que o empréstimo acaba refletindo-se em prejuízo a

412 IBGE. Sistema financeiro: uma análise a partir das contas nacionais. Rio de Janeiro: IBGE, 1997. p. 164, apud CARVALHO, Carlos Eduardo. Ocultamento e mistificação nas relações do Banco Central com os bancos, p. 209.

413 VALOR ECONÔMICO. Na crise, BB colocou R\$6,7 bilhões para socorrer bancos e Sadia, 24 nov. 2009 , p. A1.

414 É importante esclarecer que não se está questionando aqui a conveniência de manter instituições oficiais em funcionamento. Há um amplo debate na literatura econômica sobre as vantagens e desvantagens que tais instituições podem desempenhar no sistema financeiro. De um lado encontram-se autores que enaltecem o papel estratégico de bancos públicos na política de investimentos do governo, bem como sua função complementar à política monetária, ajudando a aumentar ou diminuir a liquidez na economia. De outro lado, há autores que criticam sua ineficiência em relação aos bancos atuantes no setor privado, inclusive afetando o desempenho de políticas de regulação e supervisão bancária e o nível de desenvolvimento do sistema financeiro. Para uma síntese da literatura sobre o tema, ver: BARTH, James R. et al. Rethinking bank regulation, p. 61-63. Em virtude da relação intrínseca do debate com inúmeros temas cuja análise fugiria ao escopo do presente trabalho, optou-se por não aprofundar a discussão a respeito do assunto. Igualmente, vale esclarecer que tampouco se está discutindo aqui a legalidade dessas operações de provimento de liquidez por parte das instituições oficiais. Com efeito, o art. 238 da Lei 6.404/1976 permite que o acionista controlador de sociedades de economia mista oriente as suas atividades de modo a atender ao interesse público que justificou sua criação, não sendo difícil imaginar o recurso a tal dispositivo para justificar tais operações. O que se questiona aqui é unicamente a ampliação do risco moral decorrente desses empréstimos de bancos públicos a bancos em dificuldades, pelo fato de funcionarem sem regras claras quanto a limites e garantias, em paralelo com outros mecanismos de provimento de liquidez a instituições em crise. 
tais instituições oficiais. ${ }^{415}$ Isso é bem representado no relato de Salvatore Cacciola sobre um possível empréstimo da CEF ao Banco Marka em 1999, transcrito a seguir: ${ }^{416}$

[...] O Bragança completou seu relatório dizendo que sentia que era humanamente impossível o Banco Central fazer qualquer coisa. Ele achava que o Banco Central não estava operando no mercado futuro e que o Chico Lopes não me recebia justamente porque não tinha a menor condição de me ajudar. A única sugestão, e ainda assim cercada por uma talvez, é que a Caixa Econômica me financiasse. Só que eu sabia que esse financiamento significaria literalmente pôr um pé na cova, porque, quando a Caixa financia alguém, faz isso na pré-morte, sabendo que depois você morre rapidinho e o Tesouro acaba perdendo como sempre, porque você não teria como pagar o tal empréstimo. Ou seja: é botar dinheiro antes de intervir.

A clareza do relato não deixa dúvidas sobre os perigos associados à concessão de tais empréstimos. O resgate a instituições em crise deve se dar com regras e limites de operacionalidade claros, sob o risco de ampliação do risco moral e prejuízo aos cofres públicos. O provimento de liquidez a instituições financeiras em dificuldade não deve ser visto como um imperativo, mas sim como uma ferramenta a ser utilizada em circunstâncias específicas, sob pena de desvirtuar-se o propósito desse importante mecanismo de regulação sistêmica. ${ }^{417}$

415 Conforme o oportuno posicionamento de Verçosa sobre as operações de empréstimos da CEF realizadas a instituições financeiras em crise: "Não se pode esquecer que uma parcela significativa dos problemas da Caixa Econômica Federal decorreu da existência de vultosos saldos devedores de diversas instituições financeiras liquidadas anteriormente pelo Banco Central do Brasil, quanto a recursos do Fundo de Garantia de Depósitos e Letras Imobiliárias (FGDLI) e do Fundo de Compensação de Variações Salariais (FCVS). Embora houvesse uma expectativa otimista quanto ao recebimento daqueles valores, no curso de acertos que deveriam ser feitos na ultimação de diversos processos de liquidações extrajudiciais, duvidava-se que eles viessem a ocorrer efetivamente, pois não haveria interesse de antigos controladores em arcar com tais dispêndios". Por esses e inúmeros outros problemas identificados na gestão dos bancos públicos, o autor conclui que, "após a longa dissertação que se fez sobre os problemas por eles criados, somente se pode pretender a proibição de sua permanência no sistema financeiro nacional, dando-se sua privatização" (VERÇOSA, Haroldo M. D. Bancos centrais no direito comparado, p. 201). Ainda tratando da CEF, cumpre mencionar também o considerável prejuízo sofrido pela instituição financeira no escândalo recente envolvendo o Banco Panamericano. Quando a CEF comprou sua participação no banco, em novembro de 2009, este valia cerca de R \$2,1 bilhões na bolsa de valores de São Paulo. Em 18 de novembro de 2010 o valor de mercado do banco havia diminuído para $\mathrm{R} \$ 1,2$ bilhão. Com a desvalorização das ações do Panamericano, estima-se que a perda sofrida pela CEF no período logo após o escândalo tenha sido de cerca de R $\$ 320$ milhões. Ver: O ESTADO DE SÃO PAULO. Caixa perdeu mais de R $\$ 320$ milhões no Panamericano, 21 nov. 2010.

416 CACCIOLA, Salvatore Alberto. Eu Alberto Cacciola confesso: o escândalo do Banco Marka. São Paulo: Record, 2001. p. 59.

417 LASTRA, Rosa Maria. Banco Central e regulamentação bancária, p. 105. 


\subsubsection{Organização do sistema de pagamentos}

O sistema de pagamentos compreende o conjunto de procedimentos, regras, instrumentos e sistemas operacionais integrados usados para transferir fundos do pagador para o recebedor e, com isso, encerrar uma obrigação. ${ }^{418}$ É no sistema de pagamentos que as diversas operações financeiras são processadas, por meio de transferências de fundos e recursos entre as contas bancárias dos agentes econômicos e entre as contas de reservas bancárias dos bancos junto aos bancos centrais. ${ }^{419}$

A importância do sistema de pagamentos reside no fato de as economias de mercado dependerem desses sistemas para movimentarem os fundos decorrentes da atividade econômica, tanto em moeda local como em moeda estrangeira. A regulamentação e estruturação adequadas dos sistemas de pagamentos permitem a redução dos custos de transação na economia, melhorando a liquidez do mercado financeiro e tornando a política monetária mais eficiente. ${ }^{420}$

A organização do sistema de pagamentos também guarda relevância particular para o presente trabalho pelo fato de poder ser utilizada como um instrumento de prevenção de crises. De fato, em razão do alto grau de integração entre os bancos, a insolvência ou o atraso de pagamento por parte de uma instituição pode acarretar dificuldades de liquidez nas partes beneficiárias daqueles pagamentos, disseminando o problema pelo setor. Segundo Yazbek, é nos sistemas de pagamentos que a relação entre o risco de crédito e de liquidez assume, mais flagrantemente, uma dimensão sistêmica. ${ }^{421}$

O exemplo citado com mais frequência para ilustrar esse risco é o caso do Bankhauss Herstatt, ocorrido em 26 de junho de 1974. À ocasião, alguns bancos realizaram pagamentos em marcos alemães ao Herstatt em Colônia (sede do banco) em troca de pagamentos em dólar a serem realizados em Nova Iorque. Em razão das diferenças de fuso horário, houve um

\footnotetext{
418 BANCO CENTRAL DO BRASIL. Reestruturação do Sistema de Pagamentos Brasileiro, p. 1. Disponível em: <www.bcb.gov.br/ftp/deban/deban-pdf.pdf>. Acesso em: 28 dez. 2010.

419 SADDI, Jairo. Crise e regulação bancária, p. 160.

420 BANCO CENTRAL DO BRASIL. Reestruturação do Sistema de Pagamentos Brasileiro, p. 1.

421 YAZBEK, Otavio. Regulação do mercado financeiro e de capitais, p. 232.
} 
intervalo entre as duas operações de câmbio, e, antes que os pagamentos em dólar pudessem ser realizados em Nova Iorque, o banco foi liquidado pelo banco central alemão. Por não ter recebido a contraprestação em dólares, o banco Chase Manhattan recusou-se a liquidar o câmbio com as demais contrapartes nos Estados Unidos, no que foi seguido por outras instituições financeiras, espalhando pânico no mercado. ${ }^{422}$

Esse incidente ficou conhecido como "risco Herstatt" e foi determinante para que as nações integrantes do G-10 formassem, ao final de 1974, o Comitê de Basileia de Supervisão Bancária, sob os auspícios do Banco de Pagamentos Internacionais (Bank for International Settlements - BIS), para discutir formas de mitigar tal risco. ${ }^{423}$ Ele também influenciou a promulgação do primeiro acordo de Basileia em 1988, bem como avanços subsequentes e mais recentes, como a promulgação dos Princípios Fundamentais para Sistemas de Pagamento de Relevância Sistêmica (Core Principles for Sistemically Important Payment Systems) pelo BIS. ${ }^{424}$ Esses princípios versam, de modo geral, sobre os riscos inerentes à atuação das instituições financeiras e a base legal adequada para administrá-los, como procedimentos e mecanismos para a criação e proteção de salvaguardas, regimes de contingências, entre outros. $^{425}$

\subsubsection{O Sistema de Pagamentos Brasileiro}

Até 2001 as instituições detentoras de conta de reservas bancárias no Bacen comandavam as ordens de transferências de recursos sem que houvesse checagem automática da suficiência dos saldos na conta, ficando tal conferência para o final do dia e pelo valor líquido. ${ }^{426}$ Se uma contraparte na operação não honrasse o compromisso de transferência dos fundos por motivo de falta de liquidez momentânea ou insolvência, o Bacen, desempenhando a função de mantenedor do equilíbrio do sistema financeiro, assumia o papel de fornecedor de

\footnotetext{
422 SADDI, Jairo. Crise e regulação bancária, p. 161.

423 Idem, ibidem, p. 103.

424 COMITÊ DE BASILEIA. Core principles for systemically important payment systems, Basileia, jan. 2001.

425 YAZBEK, Otavio. Regulação do mercado financeiro e de capitais, p. 232-233.

426 Para um relato detalhado sobre o funcionamento do antigo sistema de pagamentos no Brasil, ver: ARAÚJO, Maria da Glória Domingos Silva. O Sistema de Pagamentos Brasileiro e a assunção de riscos pelo Banco Central. Notas Técnicas do Banco Central, n. 23, Brasília, 2002.
} 
liquidez e crédito ao sistema. Evidentemente, esse modelo acabava criando graves problemas de risco moral, uma vez que o Bacen assumia o papel, involuntário, de garantidor das operações cursadas no âmbito do sistema. ${ }^{427}$ De fato, estima-se que, em dezembro de 2001, a concessão desse "crédito circunstancial e indesejável" pelo Bacen tenha superado a marca de R $\$ 6$ bilhões de reais. ${ }^{428}$

Essa estrutura sofreu grande transformação em 2001, quando, no bojo das medidas de reestruturação do SFN adotadas na segunda metade da década de 1990, e inspirando-se nas recomendações do BIS, foi promulgada a Lei 10.214, de 27 de março de 2001. Esse diploma legal permitiu a reorganização dos sistemas de registro, compensação e liquidação utilizados até então, criando o Sistema de Pagamentos Brasileiro (SPB).

A base do novo SPB é o Sistema de Transferências de Reservas (STR), que se tornou o único veículo para a movimentação das contas de reservas bancárias das instituições financeiras perante o Bacen. Entre as grandes inovações do STR, destaca-se a adoção do sistema de Liquidação Bruta em Tempo Real (LBTR), operação a operação. Como o próprio nome indica, no LBTR, as reservas bancárias passam a funcionar em tempo real e as movimentações correspondem aos valores brutos das operações, ou seja, só é possível a movimentação caso haja disponibilidade de valores. Esse sistema é utilizado, por exemplo, na liquidação e custódia dos títulos públicos federais pelo Sistema Especial de Liquidação e Custódia (Selic).

Além do LBTR, há também a compensação líquida de saldos, na modalidade Liquidação Defasada Líquida (LDL). Similar ao modelo anterior do sistema de pagamentos, a LDL é utilizada pelas câmaras de compensação privadas (clearings), e consiste no registro dos lançamentos entre as instituições ao longo do dia, para serem compensadas por diferença ao final do dia em um valor único. Nesse regime, a clearing torna-se a parte compradora de todos os vendedores e a parte vendedora de todos os compradores. $\mathrm{Na}$ incapacidade do cumprimento das obrigações de uma das partes, é a clearing que se responsabiliza pelo cumprimento integral de todas as obrigações pactuadas no âmbito do sistema. No caso de

\footnotetext{
427 ARAÚJO, Maria da Glória Domingos Silva. O Sistema de Pagamentos Brasileiro e a assunção de riscos pelo Banco Central, p. 12.

428 FORTUNA, Eduardo. Mercado financeiro, p. 582.
} 
inadimplemento ou de atraso por um participante na data e momento aprazados para o pagamento, a câmara recorre às garantias depositadas pelo inadimplente para cumprir as obrigações pendentes, ou mesmo a outras salvaguardas eventualmente constituídas para tal, cumprindo assim com as obrigações contratadas perante os demais participantes do sistema, sem que sintam os efeitos da falha ocorrida. ${ }^{429}$ Esse sistema é utilizado, por exemplo, na Câmara Interbancária de Pagamentos (CIP) da Federação Brasileira de Bancos (Febraban), para a liquidação de cheques e outros papéis de valor igual ou superior a $\mathrm{R} \$ 5$ mil.

Outra importante inovação do SPB foi a apresentação de novas diretrizes para o gerenciamento do risco sistêmico. Nesse sentido, o art. 5..$^{\circ}$ da Lei 10.214/2001 estabeleceu que, no caso de pessoas jurídicas que administrassem mais de um sistema de clearing considerados "sistemicamente importantes", estas deveriam constituir patrimônios segregados para cada atividade (patrimônio especial). Segundo definição apresentada no $§ 10^{\circ}$ do mesmo dispositivo, os bens e direitos integrantes do patrimônio especial não se comunicam com o patrimônio geral ou outros patrimônios especiais da mesma câmara ou prestador de serviços de compensação e de liquidação, não podendo ser utilizados para realizar ou garantir o cumprimento de qualquer obrigação assumida pela câmara ou prestador de serviços de compensação e de liquidação em sistema estranho àquele ao qual se vinculam.

$\mathrm{O}$ art. $7 .^{\circ}$ da Lei 10.214/2001 estabeleceu também que o regime falimentar ou especial a que seja submetido qualquer participante não afetará o adimplemento de suas obrigações assumidas no âmbito das câmaras ou prestadores de serviços de compensação e de liquidação, que serão liquidadas na forma de seus regulamentos. O parágrafo único do dispositivo destaca, ainda, que o produto da realização das garantias prestadas pelo participante submetido aos regimes de que trata o artigo, assim como os títulos, valores mobiliários e quaisquer outros ativos, objeto de compensação ou liquidação, serão destinados à liquidação das obrigações assumidas no âmbito das câmaras ou prestadores de serviços. ${ }^{430}$

Os dispositivos mencionados têm grande relevância sistêmica, na medida em que permitiram que os valores compensados fossem protegidos, evitando certos efeitos do

\footnotetext{
429 YAZBEK, Otavio. Regulação do mercado financeiro e de capitais, p. 235.

430 Idem, ibidem, p. 235.
} 
processo falimentar ordinário, como a obrigação de devolução das garantias à massa falida e subsequente habilitação perante esta para que, apenas em momento posterior, o crédito pudesse ser recebido. Isso favoreceu não apenas o funcionamento adequado do sistema em caso de quebra dos participantes, mas também a liquidação das operações sem maiores atrasos, paralelamente a quaisquer outras medidas de cunho concursal adotadas. ${ }^{431} \mathrm{~A}$ esse respeito, vale destacar que a Lei 11.101, de 9 de fevereiro de 2005 (Nova Lei de Falências), incorporou expressamente tais exceções ao regime concursal ordinário, reduzindo a possibilidade de questionamentos quanto a tais procedimentos (arts. 193 e 194).

\subsubsection{Edital de Audiência Pública 34 do Banco Central}

No final de 2009 o Bacen disponibilizou para audiência pública (Audiência Pública 34/2009) proposta de anteprojeto de lei a ser enviado ao Congresso Nacional com alterações aos mecanismos existentes de regulação sistêmica no Brasil. ${ }^{432}$ Embora o prazo para realização de comentários tenha se encerrado há mais de um ano, o projeto ainda não foi submetido ao Legislativo, sendo provável que, caso venha a sê-lo, ainda sofrerá alterações antes de ser aprovado. Dessa forma, para efeitos do presente trabalho, realizar-se-á apenas uma breve transcrição das principais mudanças apresentadas no projeto.

Em primeiro lugar, a proposta apresentada pelo Bacen procura reunir em um mesmo diploma legal as disposições referentes aos regimes especiais aplicáveis às instituições em crise, atualmente previstas na Lei 6.024/1974, Decreto-lei 2.321/1987 e Lei 9.447/1997. O projeto coloca também à disposição da autoridade bancária uma série de instrumentos classificados como "medidas preventivas" para serem adotados visando afastar riscos de insolvência ou iliquidez. Entre tais medidas incluem-se limites operacionais compatíveis com a exposição ao risco e a elaboração, pelos gestores da entidade supervisionada, de plano de ajuste a ser submetido à aprovação do Bacen, indicando os meios para a correção de problema identificado. Além disso, o anteprojeto prevê que a liquidação passe a ser conduzida no âmbito do Poder Judiciário, sob regime de falência, com base na Lei 11.101/2005. A intervenção do Bacen, nesse caso, teria como propósito preparar a instituição para a falência,

\footnotetext{
431 YAZBEK, Otavio. Crise financeira e risco sistêmico, p. 17.

432 Audiência Pública 34/2009. Disponível em: <www.bacen.gov.br/?AUDPUB>. Acesso em: 12 dez. 2010.
} 
mediante a prática dos atos de gestão estritamente necessários à manutenção da integridade de seu acervo, com a instituição fechada, encerrando-se com o proferimento de decisão judicial concernente ao pedido de falência apresentado pelo interventor.

Além disso, em complemento aos mecanismos de provimento de liquidez já analisados, o projeto prevê a disponibilização de outro canal de assistência às instituições financeiras. Segundo o anteprojeto, nas hipóteses que configurem "crise sistêmica ou grave ameaça à estabilidade do Sistema Financeiro Nacional”, caberia ao Bacen realizar "operações especiais de assistência financeira" com instituições financeiras (art. 55 e ss.). Tais operações seriam objeto de regulamentação e prévia autorização do $\mathrm{CMN}$, e não se sujeitariam à limitação de 360 dias prevista na Lei de Responsabilidade Fiscal para utilização de recursos públicos no socorro a instituições financeiras do SFN.

Finalmente, a proposta elaborada pelo Bacen também prevê significativas mudanças no FGC, que passaria a se chamar "Fundo de Proteção de Depositantes" (art. 49 e ss.), permitindo que este recebesse recursos decorrentes das "operações especiais de assistência financeira" para serem aplicados em instituições financeiras em crise. ${ }^{433}$ Para tal, o FGC passaria a ter natureza jurídica de instituição financeira, sujeitando-se à fiscalização direta do Bacen. Outra importante alteração é que passaria a ser vedada a participação, em sua gestão, dos controladores, administradores e demais membros dos órgãos societários das instituições financeiras que contribuem com o fundo, corroborando preocupação já levantada no tópico 3.1.1.1 quanto aos conflitos de interesse presentes em sua atual estrutura.

\subsection{Desafios para a regulação sistêmica}

\subsubsection{Ampliação do conceito de risco sistêmico}

Observou-se no primeiro capítulo deste trabalho que o conceito clássico de risco sistêmico tem como base as externalidades relacionadas ao alto grau de integração entre

433 Aqui vale ressaltar que, seguindo em linha com as diretrizes para gerenciamento do risco sistêmico do SPB, o projeto prevê também a possibilidade de realização de tais operações especiais com as clearings mencionadas no tópico anterior. 
instituições financeiras, as características da atividade bancária típica, bem como a presença de assimetrias informacionais no setor bancário. Justamente em razão disso, não causa surpresa que o conceito de risco sistêmico acabe muitas vezes sendo relacionado tão somente ao setor bancário, como se apenas nele pudesse se originar e transmitir. Embora essa concepção ainda represente importante componente da regulação sistêmica, conforme evidenciado pela rede de segurança oferecida a tais instituições que acaba de ser analisada, é preciso reconhecer sua insuficiência em face das transformações pelas quais vem passando o sistema financeiro, que provocam uma reflexão sobre a forma como o conceito de risco sistêmico é tradicionalmente pensado e aplicado. ${ }^{434}$

Com efeito, a diluição das barreiras regulatórias entre atividades financeiras observada no Brasil e no mundo nas últimas décadas torna cada vez mais difícil a precisa identificação de quais participantes do sistema financeiro devem ser considerados fontes em potencial de risco sistêmico. A crescente conglomeração das atividades de bancos comerciais, bancos de investimento, corretoras de valores mobiliários, companhias de seguro, entre outras, permite que, na atualidade, o risco sistêmico surja ou se propague por meio de outras atividades, que não a atividade de intermediação financeira típica dos bancos comerciais.

O “quase” colapso do Long-Term Capital Management (LTCM) em 1998 é um bom exemplo de como o risco sistêmico na atualidade não se restringe apenas à esfera bancária. Embora o hedge fund adotasse uma estratégia arrojada de diversificação de risco na gestão de sua carteira, contando inclusive com Myron Scholes e Robert C. Merton - ganhadores do Nobel de Economia em 1997 -, em sua administração, a irracionalidade temporária na precificação de ativos durante o mês de agosto de 1998, causada pelo default do governo russo nos seus títulos, fez com que o LTCM incorresse em perdas de bilhões de dólares, ficando à beira da falência. À ocasião, o Federal Reserve considerou que um inadimplemento do LTCM poderia afetar o estado de solvência de inúmeras instituições financeiras e causar quebra de confiança generalizada no mercado financeiro mundial, justificando-se, portanto, seu resgate. ${ }^{435}$

434 DE BANDT, Olivier; HARTMANN, Philipp. Systemic risk, p. 1.

435 Para um relato detalhado sobre a quebra do LTCM, ver: LOWENSTEIN, Roger. When genius failed: the rise and fall of Long-Term Capital Management. Nova Iorque: Random House Trade Paperbacks, 2000. 
Embora o LTCM em si não fosse uma instituição financeira, este mantinha diversas operações de derivativos com instituições financeiras, de modo que um eventual inadimplemento do fundo poderia afetá-las de forma adversa. Em 1998 o hedge fund possuía mais de 6.000 posições de derivativos em aberto, cujo grau de alavancagem em termos de dívida versus capital próprio chegou a atingir a razão de 100:1 nos meses que antecederam seu resgate. ${ }^{436}$ Sua exposição era tamanha que, em curto espaço de tempo, com a volatilidade do mercado financeiro e de capitais, acumulou prejuízo em suas operações de cerca de US\$5 bilhões. ${ }^{437}$ Segundo relato de Lowenstein, a quebra do fundo teria efeitos catastróficos para instituições financeiras constando como contrapartes em seus contratos de derivativos. Bancos como Merrill Lynch, Goldman Sachs, Morgan Stanley e Salomon Brothers, entre outros, perderiam um total de US $\$ 2,8$ bilhões. ${ }^{438}$

Além de suas contrapartes nos contratos de derivativos, havia também a preocupação de que a quebra do LTCM pudesse causar uma crise de confiança generalizada que paralisasse o sistema financeiro. Temia-se que, não sabendo como os participantes do mercado seriam afetados pela quebra do hedge fund, outros bancos pudessem hesitar em realizar operações interbancárias, o que acabaria agravando ainda mais a liquidez no mercado, gerando fundado temor de risco sistêmico. ${ }^{439}$

Além do episódio com o LTCM, outro exemplo emblemático sobre a extensão do campo de aplicação do risco sistêmico é o resgate da companhia seguradora AIG em 2008. Com efeito, a empresa, que figurava ao final de 2007 na 10. ${ }^{a}$ colocação do ranking Fortune 500 e 23. a colocação do ranking Global 500, experimentou rápida deterioração de sua saúde

436 DOWD, Kevin. Long-Term Capital Management and the Federal Reserve. Briefing Papers, Cato Institute, n. 52, 1999.

437 LOWENSTEIN, Roger. When genius failed, p. 234.

438 Idem, ibidem, p. 186.

439 A esse respeito vale transcrever a percepção de William McDonough e Peter Fisher, respectivamente presidente e vice-presidente do Federal Reserve de Nova Iorque à época, sobre os perigos inerentes à quebra do LTCM: “A preocupação de Fischer era a noção mais ampla de 'risco sistêmico'. Se o Long Term quebrasse, e se seus credores forçassem a sua liquidação apressada e desordenada, ele temia que todo o sistema financeiro fosse afetado, e não apenas seus maiores participantes [...] McDonough tinha o mesmo temor - que as perdas em tantos mercados e para tantos participantes poderia iniciar um círculo vicioso de liquidações, flutuações extremas nas taxas de juros, e ainda mais perdas: 'Mercados poderiam parar de funcionar pelo período de um ou mais dias, ou por um período de tempo ainda mais prolongado"'. Ver: Idem, p. 194-195. Tradução livre. 
financeira ao longo de 2008, encontrando-se à beira da falência em setembro do mesmo ano. ${ }^{440}$ Em resposta ao temor de sua quebra, o governo norte-americano interveio disponibilizando linhas de crédito superiores a US\$200 bilhões. $^{441}$

O resgate da companhia causou comoção por se tratar de uma seguradora, empresa que não é tradicionalmente associada ao risco sistêmico. De fato, tais empresas tipicamente não apresentam características da atividade bancária que suscitam preocupações de ordem sistêmica, como o alto grau de integração com instituições financeiras e ativos de pronta exigibilidade. Nesse caso, o socorro se deu não em razão das atividades de seguro da empresa, mas sim em função das elevadas apostas de sua subsidiária, AIGFP, atuando como contraparte de diversas instituições financeiras em contratos de derivativos denominados credit default swaps (CDS). ${ }^{442}$ Ainda de maior relevância foi a constatação de que, do outro lado de tais operações, constavam inúmeras instituições financeiras que sofreriam prejuízos de monumental proporção caso a AIGFP não viesse a cumprir com suas obrigações. De acordo com o Wall Street Journal, nessa lista figuravam bancos como Goldman Sachs, Merrill Lynch, UBS, Credit Agricole, Deutsche Bank, Barclays e Royal Bank of Scotland

440 Segundo seu balanço patrimonial em 31 de dezembro de 2007, a empresa possuía ativos no valor de US $\$ 1,06$ trilhão e patrimônio líquido no valor de US\$95,8 bilhões. Não obstante, ao longo de 2008 a empresa sofreu graves prejuízos relacionados à deterioração do mercado hipotecário nos Estados Unidos e, em agosto de 2008, encontrava-se à beira da falência. Somente sua subsidiária AIGFP sofreu prejuízos de US\$32,4 bilhões de janeiro de 2007 a setembro de 2008 (informação disponível em: <www.sec.gov/Archives/edgar/data/5272/000095012308002280/y44393e10vk.htm>; acesso em: $12 \mathrm{dez}$. 2010). A título ilustrativo do efeito devastador dos resultados negativos na capitalização da empresa, sua ação, que era negociada a US $\$ 50,15$ na bolsa de valores de Nova Iorque em 28 de fevereiro de 2008, valia US\$2,50 em 29 de setembro de 2008 (informação disponível em: <finance.yahoo.com/q/hp?s=AIG>; acesso em: 9 fev. 2009).

${ }^{441}$ Para um relato detalhado sobre o processo de deterioração da AIG e sua origem, ver: SJOSTROM, William K. The AIG bailout. Washington \& Lee Law Review, n. 66, 2009.

442 Basicamente, o CDS consiste em um contrato entre um comprador e um vendedor de proteção, no qual o comprador concorda em pagar um valor periódico (determinado a partir do valor nominal do título que detém) ao vendedor, em troca de pagamento caso aconteça determinado evento, tipicamente definido como o default do emitente ou reestruturação da dívida. $\mathrm{O}$ valor do pagamento está diretamente relacionado com a perda que o comprador vai sofrer após o evento. Um CDS pode ser realizado sobre qualquer tipo de crédito ou cesta de créditos, como uma carteira de obrigações high yield ou uma carteira de obrigações de mercados emergentes, e funciona na prática como um seguro que se paga de forma a cobrir as perdas derivadas de um determinado acontecimento. No caso da AIG, sua subsidiária AIGFP atuava como vendedora de contratos CDS cujo valor era lastreado em obrigações de crédito estruturado que, por sua vez, se baseavam em operações de securitização de diversos tipos de crédito, inclusive créditos originários de hipotecas subprime. Portanto, ao vender contratos CDS, a AIG acabava assegurando o pagamento de créditos do mercado subprime norte-americano. A título ilustrativo do grau de exposição da empresa em decorrência desse tipo de operação, ao final de 2007 esta assegurava o cumprimento de contratos com valor total de US\$527 bilhões (informação disponível em: <www.sec.gov/Archives/edgar/data/5272/000095012308 002280/y44393e10vk.htm>; acesso em: 12 dez. 2010). 
Group, entre outros. ${ }^{443}$ Apenas o Goldman Sachs, por exemplo, havia contratado mais de US\$20 bilhões em proteção por meio de contratos de CDS com a AIG. ${ }^{444}$ Justamente em virtude disso havia novamente a preocupação com a paralisação do sistema financeiro caso a seguradora viesse a quebrar. Conforme o relato de Sjostrom: ${ }^{445}$

Devido ao tamanho e interconectividade da AIG, e o fato de que mercados financeiros já estavam sob muita tensão, havia o temor de que a quebra da AIG poderia levar ao colapso de todo o sistema financeiro. O governo federal não estava disposto a assumir esse risco e por isso resgatou a AIG.

O caso da AIG também é ilustrativo para mostrar os efeitos da desregulamentação das atividades financeiras no contexto de grupos econômicos. Embora as atividades de seguro da companhia ainda apresentassem resultados positivos, foram os prejuízos ocasionados pelas atividades de sua subsidiária financeira que acabaram por comprometer a viabilidade do grupo econômico como um todo. ${ }^{446}$ Não por acaso, o comportamento da AIG tornou-se alvo de ferrenhas críticas por parte das autoridades, acusando-a de ter desempenhado atividades de um hedge fund e banco de investimento sob a forma de uma seguradora. ${ }^{447}$

Os casos supracitados servem para demonstrar que a natureza jurídica de um determinado participante do sistema financeiro deve ser relativizada na atualidade para a identificação de possíveis focos de risco sistêmico. O temor de que a quebra do LTCM (ou qualquer outro hedge fund) desencadeasse um evento sistêmico decorria não de sua caracterização como um hedge fund, mas sim da probabilidade de que sua quebra prejudicasse

443 WALL STREET JOURNAL. Behind AIG's fall, risk models failed to pass real-world test, 31 out. 2008.

444 Idem, ibidem.

445 SJOSTROM, William K. The AIG bailout, p. 32. Tradução livre.

446 Idem, ibidem.

447 Segundo depoimento do Presidente do Federal Reserve, Ben Bernanke, ao Congresso: "Se há um único episódio nesses 18 meses que mais me irritou, não consigo pensar em outro que não o caso da AIG. A AIG explorou uma brecha de supervisão enorme no sistema. Não havia supervisão da divisão de produtos financeiros. Era um hedge fund ligado a uma companhia seguradora, que acabou assumindo enormes dívidas irresponsáveis, que resultaram em grandes prejuízos. Não havia supervisão de suas atividades porque havia uma brecha no sistema [...] A AIG é uma companhia seguradora global, enorme e complexa, vinculada a um banco de investimento muito complicado, um hedge fund que pôde crescer sem nenhuma supervisão" (BLOOMBERG NEWS. Bernanke says insurer AIG operated like a hedge fund, 3 mar. 2009. Tradução livre). No mesmo sentido o posicionamento da revista The Economist, segundo a qual: "A AIG apresentava risco sistêmico em razão das suas atividades de banco de investimento, escondidas atrás do negócio de seguros, que acabaram lhe custando enormes prejuízos - e sua independência". Ver: THE ECONOMIST. AIG's rescue: size matters, 18 set. 2008. Tradução livre. 
a própria viabilidade do sistema financeiro em razão de sua estreita relação com inúmeras instituições financeiras. O mesmo é verdadeiro para o caso da AIG e as atividades de sua subsidiária financeira AIGFP. Considerando essa realidade do mercado financeiro e de capitais, autoridades responsáveis pela manutenção da estabilidade do setor bancário estão atribuindo atenção crescente ao monitoramento das chamadas entidades "sistemicamente relevantes", ainda que não bancárias.

Fugiria ao escopo deste trabalho procurar conceituar o que são entidades "sistemicamente relevantes", se é que tal definição pode ser atingida. Fatores como tamanho, conectividade com outros participantes do mercado - principalmente instituições financeiras e alavancagem certamente desempenham papel importante na identificação de possíveis focos de risco sistêmico, mas não há fórmula ou critérios claros para determinar quando e quais integrantes do sistema financeiro tornam-se "sistemicamente relevantes". ${ }^{448}$ Não por acaso, na recente reforma financeira empreendida nos Estados Unidos, o Dodd-Frank Wall Street Reform and Consumer Protection Act faz inúmeras referências a instituições consideradas "sistemicamente importantes" (systemically important), mas não chega a definir o termo. ${ }^{449} \mathrm{~A}$ consideração de quais entidades são "sistemicamente relevantes" é feita caso a caso, com base no voto afirmativo de dois terços dos seus membros, que incluem o Secretário do Tesouro, Federal Reserve, FDIC, entre outras autoridades atuantes no sistema financeiro do país.

448 Isso não impede, no entanto, que economistas se empenhem na criação de modelos econômicos voltados à identificação de entidades "sistemicamente relevantes". Nesse sentido, em apresentação realizada no "Seminário APBC sobre Regulação Financeira", organizado pelo Insper e pela Associação dos Procuradores do Banco Central, ocorrido no dia 27 de setembro de 2010, a economista Mônica Baumgarten chamou a atenção para as análises de "redes financeiras", que procuram mapear a rede de interconexões entre instituições financeiras. Essas análises focam em aspectos como a distribuição das conexões e o grau de densidade em determinados pontos da rede (clustering), bem como o padrão das interconexões e de que forma estas podem acelerar a transmissão entre instituições. Tais estudos procuram aplicar e aprofundar o conceito de redes no sistema financeiro, aprimorando o entendimento sobre o conceito de risco sistêmico e como mecanismos voltados ao controle ou mitigação desse risco devem ser estruturados. A necessidade e viabilidade de criação de meios para mensuração objetiva e monitoramento do risco sistêmico foram inclusive defendidas pelo economista Andrew Lo, professor do Massachusetts Institute of Technology, em depoimento ao Congresso norte-americano sobre alternativas para a reforma regulatória. Ver: LO, Andrew W. The feasibility of systemic risk measurement. Written Testimony of Andrew W. Lo prepared for the U.S. House of Representatives, Financial Services Committee, 19 out. 2009. Disponível em: <web.mit.edu/alo/www/>. Acesso em: 23 dez. 2010.

449 Não obstante, o Dodd-Frank Wall Street Reform and Consumer Protection Act estabelece diretrizes gerais a serem consideradas na identificação de instituições sistemicamente importantes, como: (i) o valor agregado das transações financeiras conduzidas pela entidade; (ii) a exposição agregada em termos de alavancagem; (iii) relacionamento com outros participantes do sistema financeiro; (iv) os efeitos de sua quebra no sistema financeiro; e (v) quaisquer outros fatores que a autoridade encarregada do monitoramento do risco sistêmico considerar apropriados nessa determinação (Seção 804(2)). 
Situação semelhante é encontrada no Brasil, em que, conforme visto, a Lei 10.214/2001 determina a separação de "patrimônio especial" para câmaras e prestadores de serviços de compensação e de liquidação responsáveis por ambientes "sistemicamente importantes", ou o Projeto de Lei 344, de 26 de setembro de 2002, que procurava resolver o conflito de competência entre o Cade e o Bacen em atos de concentração com base na presença de instituições que pudessem "afetar a higidez do sistema financeiro". Em ambos os casos, no entanto, não há diretrizes claras para identificação de quais entidades se enquadrariam nessas categorias. $^{450}$

Pelo contrário, em vez da delimitação taxativa das entidades que podem apresentar risco sistêmico, a crise recente trouxe a preocupação ao redor do mundo com a criação de órgãos que possam fazer um monitoramento contínuo do sistema financeiro, de modo a identificar tais ameaças com antecedência nas mais variadas formas que possam se manifestar. Exemplo disso é o recém-criado Conselho de Supervisão da Estabilidade Financeira (Financial Stability Oversight Council - FSOC) nos Estados Unidos, com a missão de aprimorar a comunicação e coordenação de atividades entre as diferentes autoridades supervisoras no país, identificar riscos à estabilidade do sistema financeiro como um todo e promover a disciplina de mercado entre seus participantes (Seção 112(a)(1)).

Iniciativa semelhante pode ser observada na União Europeia, com a recomendação de criação do Conselho Europeu de Risco Sistêmico (The European Systemic Risk Board ESRB) pelo relatório Larosiére ${ }^{451}$ que teria a função de monitorar e avaliar ameaças à estabilidade financeira na União Europeia, identificar e priorizar situações de risco sistêmico,

450 Embora a Circular Bacen 3.057, de 31 de agosto de 2001, tenha procurado estabelecer critérios objetivos para a identificação de "sistemas sistemicamente relevantes" no âmbito do SPB (art. 8. ${ }^{\circ}$ do regulamento anexo à Circular), ela acaba deixando uma cláusula genérica afirmando que, além dos requisitos mencionados, a autoridade bancária poderia, a seu exclusivo critério, em exame caso a caso e com foco no aspecto de risco, considerar outros sistemas como sistemicamente relevantes (art. $9 .^{\circ}$ do regulamento anexo à Circular). O resultado prático é que a identificação dessas entidades ainda se encontra, em grande medida, sob a ampla discricionariedade do Bacen.

451 A Comissão Europeia constituiu em 2007 um grupo de trabalho presidido por Jacques de Larosière com a missão de analisar as causas da crise financeira que despontava e de apontar soluções que permitissem garantir maior estabilidade do sistema financeiro europeu e reforçar a sua supervisão. O relatório final desse grupo foi publicado em 25 de fevereiro de 2009 e inclui 31 recomendações para a reforma da supervisão do sistema financeiro europeu, prevendo-se que, em geral, sejam acolhidas pelos órgãos de decisão da União Europeia. Ver: COMISSÃO EUROPEIA. The high level group on financial supervision in the EU, Bruxelas, 25 fev. 2009. Disponível em: <ec.europa.eu/internal_market/finances/docs/de_larosiere_ report_en.pdf>. Acesso em: 26 dez. 2010. 
além de emitir comunicados para reguladores e supervisores, quando apropriado. O ESRB também poderá fazer recomendações sobre medidas a serem adotadas para responder às ameaças identificadas. Essas recomendações podem ser genéricas ou específicas a um paísmembro, e, embora não sejam vinculantes, espera-se que elas exerçam forte influência, de modo que os países-membros deverão observar uma política de "cumprir ou explicar" (comply or explain) relativamente a elas. ${ }^{452} \mathrm{O}$ ESRB será composto por diversas autoridades, incluindo os presidentes do banco central europeu e dos bancos centrais dos 27 paísesmembros da União Europeia, entre outros membros.

Além da criação desses órgãos, cujo escopo e composição por si sós já demonstram a conscientização das autoridades quanto à necessidade de flexibilização do conceito e aplicação do risco sistêmico, é possível observar também outras medidas voltadas à extensão ou adaptação de instrumentos típicos da rede de segurança proporcionada aos bancos a outros participantes do sistema financeiro. Com efeito, em relatório preparado pelo Tesouro norteamericano (Department of Treasury) em junho de 2009, o Secretário Timothy Geithner enfatiza a necessidade de criação de regimes especiais de liquidação para os participantes do sistema financeiro considerados sistemicamente relevantes. ${ }^{453}$ Atendendo à preocupação exarada pelo Secretário do Tesouro, o Dodd-Frank Wall Street Reform and Consumer Protection Act permitiu o afastamento do regime falimentar comum para instituições não bancárias quando houver fundado receio de risco sistêmico (Seção 201). A deliberação nesses casos cabe ao Secretário do Tesouro, com base na recomendação de dois terços dos diretores (governors) do Federal Reserve e do FDIC, e o efeito prático dessa decisão é a adoção de procedimento falimentar similar ao adotado para instituições financeiras, que será administrado pelo FDIC (Seção 203). Igualmente, o Banking Act de 2009 na Inglaterra permitiu expressamente que o Tesouro estendesse as operações de resgate a instituições financeiras ali previstas para outras entidades, mesmo que não fossem bancos, conforme a necessidade específica (art. 230(1)). No entanto, a decisão do Tesouro pode ser revogada por determinação do Parlamento inglês (art. 230(2)).

${ }^{452}$ COMISSÃO EUROPEIA. The high level group on financial supervision in the EU, p. 45.

453 DEPARTMENT OF TREASURY. Financial regulatory reform - A new foundation: rebuilding financial supervision and regulation. Washington, 17 jun. 2009, p. 76. 
A esse respeito, preocupações semelhantes podem ser observadas no Brasil, como a Lei 10.190, de 14 de fevereiro de 2001, que estendeu às sociedades seguradoras, entidades abertas de previdência e sociedades de capitalização as disposições dos regimes especiais previstos na Lei 6.024/1974, Decreto-lei 2.321/1987 e Lei 9.447/1997, atribuindo à Susep a competência para cumprir as funções que, nos procedimentos acima descritos, cabem ao Bacen. Da mesma forma, a SPC é competente para instaurar procedimentos de intervenção e liquidação extrajudicial para as entidades fechadas de previdência privada, nos termos da Lei Complementar 109, de 29 de maio de $2001{ }^{454}$ Aliás, é merecedor de elogios o legislador brasileiro nesse aspecto, por antecipar-se em sete anos a um dos grandes problemas enfrentados pelas autoridades norte-americanas no auge da crise financeira em 2008.

Outra importante e recente inovação no SFN para o monitoramento da estabilidade do SFN e identificação de focos em potencial de risco sistêmico refere-se à criação do Subcomitê de Monitoramento da Estabilidade do Sistema Financeiro Nacional (Sumef), em 30 de agosto de 2010, pelo Comitê de Regulação e Fiscalização dos Mercados Financeiro, de Capitais, de Seguros, de Previdência e Capitalização (Coremec). As funções desses órgãos assemelham-se aos objetivos do ESRB na União Europeia e do FSOC nos Estados Unidos, e serão objeto de tratamento detalhado no capítulo seguinte.

Finalmente, vale mencionar novamente o anteprojeto de lei apresentado pelo Bacen em outubro de 2009, que contempla expressamente a possibilidade de realização de operações especiais de assistência financeira com câmaras e prestadores de serviços de compensação e de liquidação que atuem como contraparte central, nos termos do art. 4. ${ }^{o}$ da Lei 10.214/2001 (clearings). Nesses casos, as operações de assistência seriam realizadas pelo Fundo de Proteção de Depositantes, nova denominação do FGC, que passaria a ter natureza jurídica de instituição financeira. ${ }^{455}$

Tais constatações evidenciam que as transformações pelas quais vem passando o sistema financeiro nas últimas décadas provocam uma série de reflexões sobre a forma como a regulação sistêmica é formulada e aplicada, e o Brasil certamente não é exceção a esse

454 YAZBEK, Otavio. Regulação do mercado financeiro e de capitais, p. 229-230.

455 No entanto, cumpre reiterar que, decorrido mais de um ano do encerramento do prazo para envio de comentários ao anteprojeto de lei, este ainda aguarda envio ao Congresso Nacional. 
quadro. Essas mesmas transformações provocam desafios e reflexões ainda mais complexos para a regulação prudencial, encarregada de monitorar e prevenir o risco sistêmico. Da mesma forma como as atividades da AIGFP acabaram por comprometer a viabilidade da AIG, não é difícil imaginar o cenário contrário, em que seguradoras ou corretoras de valores pertencentes a um conglomerado financeiro possam se tornar fontes de fragilidade bancária. ${ }^{456}$ Nesse contexto, a criação de formas efetivas de monitoramento do risco sistêmico em um contexto de conglomeração financeira, bem como o arranjo institucional de regulação e supervisão apropriado para tal propósito, são alguns dos grandes desafios que se apresentam para a regulação prudencial, conforme será debatido no capítulo a seguir.

\subsubsection{Grande demais para quebrar}

O processo de concentração bancária e formação de conglomerados financeiros nas últimas décadas provocou um aumento no número de pessoas e entidades que afetam ou são afetadas pelas atividades dos bancos, com destaque especial para o aumento do número de correntistas de tais instituições. A importância desse fato pode ser mais bem ilustrada pelo exemplo do Bank of New England Corp., representando possivelmente a maior e mais complexa dissolução de uma instituição financeira na década de 1990, com ativos no valor de US\$23 bilhões em janeiro de 1991, quando tornou-se insolvente e passou ao controle do FDIC. ${ }^{457}$ Esse montante é irrisório quando comparado ao valor da quebra de bancos na atualidade, como o Lehman Brothers em 2008, com ativos da ordem de US\$700 bilhões com base no seu balanço patrimonial de 31 de dezembro de 2007 . $^{458}$

Em razão do tamanho e importância crescentes de tais instituições, há uma percepção disseminada entre autoridades e participantes do sistema financeiro de que sua eventual quebra causaria um colapso financeiro, com perdas significativas para seus credores e outras partes com quem mantêm relacionamento. A possibilidade de que tal quebra acabe por gerar efeitos negativos em outras instituições financeiras, ocasionando a subsequente quebra destas,

\footnotetext{
456 DE BANDT, Olivier; HARTMANN, Philipp. Systemic risk, p. 13-14.

457 GROUP OF 10. Report on consolidation in the financial sector, p. 15.

458 LEHMAN BROTHERS. Annual Report(10K) - 2007. Disponível em: 〈www.sec.gov>. Acesso em: 23 dez. 2010 .
} 
aumenta o temor de risco sistêmico. Defrontadas com tal possibilidade, as autoridades preferem resgatar o banco em dificuldades a arriscar que a sua quebra acabe contaminando outras instituições no mercado. Essa percepção fica clara na declaração de John P. LaWare, ex-diretor do Federal Reserve, segundo o qual "a única analogia que eu consigo pensar para a quebra de uma instituição financeira internacional de grande porte é o colapso de uma usina nuclear como Chernobyl". 459

O temor exacerbado com a quebra de uma instituição de grande porte faz com que tais instituições sejam consideradas "grandes demais para quebrar", ou, conforme a popular expressão inglesa, too big to fail. Assim, os possíveis efeitos sistêmicos decorrentes de tal evento acabam por gerar um consenso informal entre autoridades reguladoras e participantes do mercado de que, caso tal instituição sofra risco de quebra, será resgatada pelo governo. ${ }^{460}$ Essa ajuda pode vir de diversas maneiras, como a utilização do banco central para provimento de liquidez, ou mesmo com a criação de pacotes econômicos de resgate a instituições em dificuldade, conforme observado no Proer em 1995, ou no Programa de Auxílio a Ativos Problemáticos (Troubled Asset Relief Program - TARP), pacote anunciado pelo Congresso norte-americano em 2008.

Naturalmente, o grande problema com a percepção de que uma instituição é grande demais para quebrar é que isso aumenta o risco moral para controladores e administradores dessas instituições. Caso apostas arriscadas gerem retorno positivo, este será apropriado pelo banco, e, se forem malsucedidas, as perdas serão suportadas pelos contribuintes. Na oportuna analogia apresentada por Krugman, cria-se uma situação para as instituições financeiras em que "cara eu ganho, coroa os contribuintes perdem". ${ }^{461}$ Outra consequência perversa dessa percepção refere-se aos seus efeitos negativos sobre os correntistas e outros credores envolvidos no negócio, que têm seu incentivo para monitorar a saúde financeira dessas

459 LAWARE, John. Testimony in U.S. Congress, Subcommittee on Economic Stabilization of the Committee on Banking, Finance and Urban Affairs, U.S. House of Representatives, Economic implications of the "too big to fail” policy: hearings, May 9, 1991, 102 ${ }^{\text {nd }}$ Congress, 1st session, p. 34. Tradução livre.

460 Nas palavras de Alan Blinder, ex-Vice-Presidente do Federal Reserve: "Todo mundo sabe que há instituições tão grandes e interconectadas com outras que está fora de questão deixá-las quebrar". Ver: AMERICAN BANKER. "Too big to fail": deniers have a tough audience, 4 jun. 2001.

461 THE NEW YORK TIMES. Financial Russian roulette, 14 set. 2008. Tradução livre. 
instituições arrefecido devido à certeza do resgate. Os mecanismos de seguro de depósitos, aliados à garantia implícita de resgate aos bancos pelo governo, acabam por comprometer a disciplina de mercado, ampliando o risco moral. ${ }^{462}$

A respeito do tema, estudos econômicos focados nos mercados norte-americano e europeu têm examinado o comportamento das instituições financeiras, procurando encontrar relações entre seu tamanho e o grau de risco assumido em suas operações. ${ }^{463}$ A comparação entre bancos de diferente porte tem indicado evidências de que, quanto maior o tamanho da instituição, menores os níveis de capital em relação ao ativo total, maiores as porcentagens de depósitos não segurados e empréstimos de risco nas suas carteiras e menores os níveis de ativo circulante. ${ }^{464}$ Danielson, por exemplo, apresenta evidências de que em 1998 bancos com ativos superiores a US\$50 bilhões operavam com um nível médio de capital em relação aos ativos totais de 7\%, enquanto bancos com ativos em um intervalo de US\$100 milhões a US\$2 bilhões apresentavam índice de 9,43\%. ${ }^{465}$ Já Boyd e Gertler procuram demonstrar que bancos de maior porte tomam empréstimos de maior risco em comparação com bancos menores. ${ }^{466}$ Outros autores encontram uma correlação positiva entre o subsídio implícito do too big to fail e a ocorrência de crises financeiras. ${ }^{467}$

Em resposta crítica a tais achados, estudiosos do tema procuram justificar a possibilidade de instituições financeiras de grande porte operarem com índices superiores de alavancagem em razão de sua maior diversificação de ativos. ${ }^{468}$ Contudo, não há evidências

462 STERN, Gary H.; FELDMAN, Ron J. Too big to fail, p. 2.

463 Para uma revisão da literatura econômica sobre o assunto, ver: WILMARTH, Arthur E. The transformation of the U.S. financial services industry (1975-2000), p. 300 e ss.

464 Idem, ibidem.

465 DANIELSON, Arnold. Getting ready for the $21^{\text {st }}$ Century: a look at recent banking trends. Banking Policy Report, 18(1), p. 13-20, mar. 1999.

466 BOYD, John; GERTLER, Mark. U.S. commercial banking: trends, cycles, and policy. New York University Department of Economics Working Papers, n. 93-19, abr. 1993.

467 KAPLAN-APPIO, Idanna. Estimating the value of implicit government guarantees to Thai banks. Review of International Economics, 10 (1), 2002; e LAEVEN, Luc. Bank risk and deposit insurance. World Bank Economic Review, 16(1), 2002.

468 WILMARTH, Arthur E. The transformation of the U.S. financial services industry (1975-2000), p. 301. 
concretas de que a diversificação de receitas seja uma estratégia eficaz de redução da exposição ao risco no setor bancário. ${ }^{469}$

O relato de autores como Stern e Feldman, respectivamente presidente e vicepresidente da sucursal de Minneapolis do Federal Reserve, mostra que as autoridades têm ciência das consequências dos movimentos de concentração e conglomeração financeira para a regulação sistêmica, mas que esses efeitos deletérios parecem ser tolerados em razão das alegadas economias de escala e escopo produzidas nesse processo, bem como outros benefícios para depositantes e investidores. ${ }^{470}$ Segundo Meyer, outro ex-diretor do Federal Reserve: ${ }^{471}$

A escala e complexidade crescentes de nossos maiores bancos - e devo acrescentar, não apenas os nossos, mas também o de muitas outras nações - levantam mais do que nunca o potencial para o risco sistêmico decorrente da quebra de uma dessas instituições. Nesse aspecto, parece que nos defrontamos com opções indesejáveis de sujeitar nossas economias a maiores riscos para que possamos obter eficiências financeiras e mais escolhas no mercado, ou impor mais regulação com suas ineficiências e risco moral.

A esse respeito, embora não seja objeto deste trabalho, vale ressaltar que a crença exagerada nas economias de escala e de escopo decorrentes desses movimentos deve ser encarada com cautela. Inúmeros economistas já se debruçaram sobre o tema, salientando que dados da indústria não dão suporte para a visão de que a concentração e formação de conglomerados financeiros trariam eficiências significativas. ${ }^{472}$ De acordo com o relatório do Grupo dos Dez que trata do tema, "estudos que examinam mudanças ex post em termos de

469 A racionalidade por trás de tal argumento é de que um conglomerado financeiro atuante em vários segmentos do mercado está menos sujeito às variações de valor de um ativo particular, reduzindo, portanto, sua exposição global ao risco. De fato, modelos econômicos, como o conceito de diversificação eficiente da teoria de portfólio de Markowitz, demonstram que a diversificação de receitas, em teoria, não apenas minimiza a exposição do investidor ao risco, como também maximiza sua lucratividade esperada (MARKOWITZ. Harry M. Portfolio selection: efficient diversification of investments. New Haven: Yale University Press, 1970). Não obstante a solidez do modelo teórico, a prática - especialmente os acontecimentos recentes - tem demonstrado que a possibilidade de ganhos de diversificação não é garantida, ou que, quando ocorrem, são menos expressivos do que se esperava. Ver: GROUP OF 10. Report on consolidation in the financial sector, p. 14.

470 STERN, Gary H.; FELDMAN, Ron J. Too big to fail.

471 MEYER, Laurence H. Supervising large complex banking organizations - adapting to change. In: MISHKIN, Frederic S. (Org.). Prudential supervision, p. 98. Tradução livre.

472 Para uma revisão da literatura sobre o tema, ver: GROUP OF 10. Report on consolidation in the financial sector, p. 247-248. 
eficiências resultantes de fusões e aquisições falham em encontrar evidências de que ganhos de eficiência são realizados". ${ }^{473}$ Pelo contrário, há trabalhos que encontram evidências opostas à lógica das economias de escala. ${ }^{474}$ Igualmente, estudos econômicos também não apontam dados concretos sobre a presença de economias de escopo relevantes em tais operações, ${ }^{475} \mathrm{em}$ alguns casos até mesmo encontrando evidências negativas de tais economias. ${ }^{476}$ Finalmente, vale ressaltar que as economias de escala e escopo também foram objeto de estudos específicos aplicados ao contexto bancário brasileiro nas décadas de 1960 a 1980, tampouco tendo sido encontradas evidências significativas de eficiências decorrentes desse processo no período observado. ${ }^{477}$

A preocupação com o too big to fail teve sua importância revigorada no desenlace da crise financeira recente, especialmente em razão dos vultosos pacotes de resgate concedidos ao sistema financeiro em diversos países. Nesse sentido, uma das hipóteses aventadas na tentativa de mitigar o risco moral associado aos conglomerados financeiros procura atacar a raiz da questão, propondo a necessidade de limitação do tamanho de instituições financeiras,

473 GROUP OF 10. Report on consolidation in the financial sector, p. 68. Tradução livre.

474 No caso norte-americano, estudos econômicos mostram que as fusões bancárias de grande porte ocorridas ao longo das décadas de 1980 e 1990 não melhoraram a eficiência ou rentabilidade geral dos bancos resultantes. Diversos estudos encontraram também evidências de aumentos de custo após a fusão ou perdas de receita, neutralizando ganhos decorrentes da redução de funcionários ou fechamento de agências (WILMARTH, Arthur E. The transformation of the U.S. financial services industry (1975-2000), p. 272; e, Idem. Too good to be true? The unfulfilled promises behind big bank mergers. Stanford Law Journal of Business and Finance, n. 2, 1995). Os resultados desses estudos nos Estados Unidos são acompanhados por achados similares referentes ao movimento de concentração bancária na União Europeia (VENNET, Rudi Vander. The effect of mergers and acquisitions on the efficiency and profitability of EC credit institutions. Journal of Banking and Finance, n. 20, 1996; e ALTUNBAS, Yener et al. Big-bank mergers in Europe: an analysis of the cost implications. Economica, v. 64, n. 254, 1997). Para um sumário do resultado de diversos estudos no período de 1980-1993, ver: RHOADES, Stephen A. A summary of merger performance studies in banking (1980-1993). Board of Governors of the Federal Reserve System, Staff Studies, n. 167, 1994.

475 Segundo o Grupo dos Dez, ao se referir aos motivadores para fusões e aquisições entre bancos, "até agora, há pouca ou nenhuma evidência da importância das economias de escopo como fator motivador [das fusões e aquisições no setor bancário]”. Ver: GROUP OF 10. Report on consolidation in the financial sector, p. 67. Tradução livre.

476 BERGER, Allen N.; HUMPHREY, David B. Efficiency of financial institutions: international survey and directions for future research. European Journal of Operational Research, n. 98, 1997; e SAUNDERS, Anthony; WALTER, Ingo. Universal banking in the United States: what could we gain? What could we lose? Nova Iorque: Oxford University Press, 1994.

477 BOUZAN, Ary. Os bancos comerciais no Brasil: uma análise do desenvolvimento recente (1965-1971). São Paulo: Federação Brasileira das Associações de Bancos, 1972. p. 215-217; PORTOCARRERO DE CASTRO, Helio Oliveira. As causas econômicas da concentração bancária. Rio de Janeiro: IBMEC, 1981; e CARVALHEIRO, Nelson. Bancos comerciais no Brasil (1964-1976): crescimento e concentração. 1982. Dissertação (Mestrado) - FIPE-USP. Mimeografado. 
ou até mesmo a necessidade de divisão destas em determinados casos. Ironicamente, um dos defensores desse posicionamento é Alan Greenspan, durante muitos anos encarregado da supervisão do setor bancário nos Estados Unidos. Em suas palavras a respeito das instituições financeiras que estiveram no epicentro da crise financeira em 2008, "se elas são grandes demais para quebrar, elas são simplesmente grandes demais [...] quebras são uma parte integral e necessária do regime de mercado". ${ }^{478} \mathrm{O}$ posicionamento do ex-presidente do Federal Reserve encontra eco no outro lado do Atlântico, com Mervyn King, presidente do Bank of England, também chamando a atenção para a necessidade de limitação ou divisão de instituições de grande porte. ${ }^{479} \mathrm{~A}$ autoridade bancária suíça foi além, solicitando em junho de 2009 poderes legais ao parlamento para que pudesse desmembrar partes de bancos considerados grandes demais para quebrar. Nesse aspecto, a imprensa europeia não deixou de notar que dois bancos suíços, o UBS e o Credit Suisse, detinham à época mais de US\$3 trilhões em ativos bancários, cerca de seis vezes o tamanho do PIB suíço. ${ }^{480}$

A história norte-americana apresenta exemplos de empresas que, em virtude de seu porte e escala, foram segmentadas a fim de fomentar a concorrência nos seus respectivos setores, com destaque para a divisão da Standard Oil \& Co., em 1911, criando 34 novas empresas menores, das quais emergiram a Exxon, Chevron, Atlantic, Mobil e a Amoco, entre outras, bem como a divisão da AT\&T, em 1984, em que as empresas resultantes ficaram conhecidas como "baby bells". Não há, no entanto, precedente de empresas que tenham sido divididas pelo fato de serem consideradas grandes demais para quebrar. ${ }^{481}$ Essa foi uma das dificuldades encontradas pelo Congresso norte-americano na discussão de propostas para limitar o porte de empresas financeiras. ${ }^{482}$ Outro problema evidente na discussão de tais propostas é que, na medida em que tais empresas crescem de tamanho, seu lobby político também se torna mais poderoso e organizado, conforme se observará no capítulo a seguir.

\footnotetext{
478 BLOOMBERG NEWS. Greenspan says U.S. should consider breaking up large banks, 15 out. 2009.

479 BBC NEWS. Governor warns bank split needed, 20 out. 2009.

480 MALAN, Pedro. Uma visão abrangente sobre a crise e o processo de sua superação, p. 54.

481 Aqui é importante lembrar que a segmentação do sistema financeiro em bancos comerciais e de investimento realizada nos Estados Unidos na década de 1930 com o Glass-Steagall Act (1933) não teve como base a preocupação com o too big to fail, mas sim os conflitos de interesses e riscos de contágio relativos à condução conjunta dessas atividades.

482 VALOR ECONÔMICO. EUA podem limitar porte de empresas financeiras, 11 nov. 2009, p. C8.
} 
O Dodd-Frank Wall Street Reform and Consumer Protection Act procurou endereçar a questão mediante a imposição de uma limitação a fusões e aquisições no sistema financeiro em que a instituição resultante venha a deter, de forma consolidada, mais de $10 \%$ dos depósitos segurados pelo FDIC. ${ }^{483} \mathrm{O}$ novo limite para concentração, no entanto, não passa a vigorar de imediato. O FSOC tem seis meses a partir da promulgação da lei para analisar como essa medida pode afetar a estabilidade do sistema financeiro norte-americano, assim como a eficiência e competitividade das instituições que nele atuam. Com base nas recomendações do FSOC, o Federal Reserve terá então nove meses para emitir a regulamentação final sobre o tema (Seção 123). Entre as questões relevantes e ainda sem resposta que o FSOC e Federal Reserve deverão abordar, encontra-se a situação de instituições que já estejam acima desse patamar e operações entre instituições financeiras estrangeiras com operações nos Estados Unidos que venham a ultrapassar o limite estipulado.

A discussão é de grande relevância no contexto bancário brasileiro, uma vez que os movimentos que deram origem a tais preocupações no exterior também podem ser verificados historicamente no País. De fato, observou-se no capítulo anterior que a concentração bancária foi um importante pilar da política aplicada ao setor nas décadas de 1960 e 1970. Nas palavras de Delfim Netto em 1973, quando ocupava o cargo de Ministro da Fazenda: "existem realmente vantagens de escala no sistema bancário, isto é, o aumento do volume de transações concorre para a redução dos custos operacionais, e os que não entenderam isso ainda vão acabar entendendo de forma muito mais trágica". ${ }^{484}$

Embora a concentração bancária não seja mais tida como política explícita do governo, também foi possível observar que esse movimento teve continuidade nas décadas de 1990 e atual, em que tais operações contaram com incentivos do governo, quando não foram instigadas pelo próprio por meio de suas instituições oficiais. O ex-presidente do Bacen,

483 A restrição à concentração de depósitos segurados em determinado patamar por uma instituição financeira é anterior ao Dodd-Frank Wall Street Reform and Consumer Protection Act, tendo sido instituída pelo RiegleNeal Interstate Banking and Branching Efficiency Act de 1994. Não obstante, a limitação original aplicavase apenas a bank holding companies, categoria bastante específica e que não incluía, por exemplo, bancos estaduais ou bancos de investimento. Nesse sentido, a reforma recente ampliou consideravelmente o escopo da regra ao aplicá-la a qualquer financial company, termo que abrange um número consideravelmente maior de participantes do sistema financeiro nos Estados Unidos.

484 JORNAL DO BRASIL, 26 mar. 1973, p. 3, apud MACARINI, José Pedro. A política bancária do regime militar, p. 354. 
Henrique Meirelles, declarou em mais de uma ocasião que vê espaço para maior concentração bancária no País e que esse movimento ajudaria a fortalecer a solidez do sistema financeiro. ${ }^{485}$ Isso também ficou claro por ocasião do anúncio, em outubro de 2008 , da fusão entre os bancos Itaú e Unibanco, respectivamente o segundo e o quarto maiores bancos privados do País até então, que contou com o apoio imediato da autoridade bancária, havendo inclusive relatos de que seu presidente à época teria se encarregado pessoalmente de assegurar que a operação não enfrentaria resistência das autoridades antitruste. ${ }^{486}$ Parece nítido, portanto, que pelo menos no tocante à concentração no setor, a política da autoridade bancária pouco mudou em relação à mentalidade prevalente durante o regime militar.

Evidentemente, a mera constatação de que o nível de concentração vem aumentando não significa que o SFN esteja forçosamente sujeito ao problema do too big to fail. É necessário levar em consideração aspectos legais e estruturais do setor bancário brasileiro que

485 VALOR ECONÔMICO. BC vê espaço para concentração bancária ainda maior no Brasil, 15 maio 2006, B3; e, Idem. Concentração fortaleceu sistema, diz Banco Central, 19 out. 2007, C7. Fugiria ao escopo de um trabalho dessa natureza procurar provar ou refutar a relação positiva entre concentração e estabilidade suscitada pelo Bacen. Segundo Oliveira, não existe relação simples entre grau de concentração do setor bancário e risco sistêmico, sendo necessário considerar uma série de fatores nessa análise, como os índices de alavancagem, qualidade dos ativos, rentabilidade e eficiência das instituições financeiras. $\mathrm{O}$ eminente economista alerta que seria imprudente uma política de desconcentração bancária que impedisse a obtenção de ganhos de escala e pudesse fragilizar excessivamente os bancos, mas que tampouco seria aconselhável adotar uma política sistemática de estímulo à concentração bancária de forma a evitar a quebra de instituições mais frágeis, na medida em que sinaliza uma solução fora do mercado para crises de solvência, podendo, consequentemente, estimular estratégias excessivamente arriscadas, traduzindo-se em risco moral para o setor (OLIVEIRA, Gesner. Defesa da concorrência e regulação no setor bancário, 2002, p. 29 e ss.; e OLIVEIRA, Gesner de. Concorrência: panorama no Brasil e no mundo. São Paulo: Saraiva, 2001. p. 8990). Esse posicionamento é acompanhado por Pinho de Mello, que também rejeita a forma maniqueísta como a relação entre concentração e estabilidade costuma ser apresentada, mas alerta que "é provavelmente uma má ideia tentar fabricar sistemas bancários mais concentrados porque, novamente, não é claro do ponto de vista teórico que bancos maiores são mais seguros". Ver: PINHO DE MELLO, João Manoel. Estrutura, concorrência e estabilidade. In: GARCIA, Márcio; GIAMBIAGI, Fábio (Org.). Risco e regulação, p. 199200.

486 Conforme relato da Isto É Dinheiro: "Até aquele instante, já havia um entendimento entre as partes, mas o negócio não poderia ir adiante sem a anuência do Bacen. Nada estava assinado. Por isso, Setubal e Moreira Salles decidiram manter a discrição. O primeiro alugou um jato particular. O segundo voou no Legacy do Unibanco. Moreira Salles foi o primeiro a pousar em Brasília e esperou durante 30 minutos a chegada do futuro sócio. Do aeroporto, eles seguiram juntos para a casa de Meirelles, que aguardava apenas o presidente do Itaú. Meirelles, ao ver Moreira Salles, percebeu o negócio na hora. 'O que os traz aqui?', perguntou. 'Viemos anunciar a fusão entre Itaú e Unibanco', respondeu Moreira Salles. Meirelles abriu um largo sorriso, disse que a operação era boa não apenas para o sistema financeiro como também para a própria economia brasileira. Tanto que, na manhã da terça-feira 4, ele foi pessoalmente ao Ministério da Justiça argumentar com Tarso Genro que a operação será benéfica para a concorrência. Meirelles pediu que o ministro assegurasse que a Secretaria de Direito Econômico não imponha nenhum obstáculo à transação. "A fusão não prejudica a concorrência e é benéfica ao País', afirmou Meirelles. 'Concordo', respondeu Genro”. Ver: Revista Isto É Dinheiro. "Feitos um para o outro", 12 de nov. de 2008. 
podem mitigar ou mesmo evitar os efeitos deletérios dessas instituições. Nesse sentido, no tocante aos aspectos legais, autores apontam particularidades relevantes da legislação pátria em relação à americana. A primeira delas seria a previsão de responsabilidade objetiva (art. 40 da Lei 6.024/1974) e indisponibilidade dos bens de controladores e administradores nos regimes especiais aplicáveis a instituições em crise, que mitigariam os incentivos desses executivos a se engajarem em comportamentos excessivamente arriscados. ${ }^{487}$ Esse sistema seria bastante diferente daquele encontrado em outros países, como nos Estados Unidos, em que o regime de responsabilidade dos administradores não possui regras próprias, sujeitandose ao regramento aplicável às sociedades em geral, havendo apenas posicionamento jurisprudencial indicando que o dever de diligência desses administradores deve ser maior e mais estrito do que em outros casos. ${ }^{488}$

Além desse regime mais rigoroso de responsabilidade, também seria necessário considerar os amplos poderes à disposição do Bacen para vender ativos ou negociar passivos de instituições problemáticas, removendo-as do fluxo normal de atividades do setor bancário. ${ }^{489}$ Aqui vale relembrar que a Lei 9.447/1997 facilitou a cisão de instituições financeiras com problemas em duas entidades, o "banco ruim" e o "banco bom", este destinado a ter continuidade operacional, com outra gestão e controladores, resguardando depositantes e investidores, enquanto aquele permanece em liquidação e associado aos patrimônios pessoais de administradores e acionistas controladores. ${ }^{490}$

Conquanto os pontos levantados representem de fato aspectos positivos da regulação sistêmica pátria, estes devem ser relativizados em face do entendimento jurisprudencial sobre o tema, bem como a operacionalização desses instrumentos pela autoridade bancária. Com efeito, não entrando no mérito da decisão, já se observou que o STJ interpretou o disposto no art. 40 da Lei 6.024/1974 em julgamento recente como um regime de responsabilidade subjetiva, com inversão do ônus da prova para os controladores e administradores da

487 FRANCO, Gustavo H. B.; ROSMAN, Luiz Alberto C. A crise bancária norte-americana: algumas lições da experiência brasileira. In: GARCIA, Márcio; GIAMBIAGI, Fábio (Org.). Risco e regulação, p. 158.

488 FLETCHER, William Meade. Fletcher cyclopedia of the law of private corporations, Estados Unidos: Thomson-West, v. 3, 2002, apud FRANCO, Gustavo H. B.; ROSMAN, Luiz Alberto C. A crise bancária norte-americana, p. 162.

489 FRANCO, Gustavo H. B.; ROSMAN, Luiz Alberto C. A crise bancária norte-americana, p. 158.

490 Idem, ibidem, p. 158. 
instituição financeira, segundo o qual lhes caberia demonstrar que atuaram com o devido zelo, impedindo sua responsabilização pelos prejuízos causados. ${ }^{491}$ Ainda que haja inversão do ônus da prova, a prevalecer esse entendimento jurisprudencial, a interferência ex ante nos incentivos de controladores e administradores de instituições financeiras perde força.

Outrossim, no tocante ao amplo rol de opções à disposição da autoridade bancária para atuar sobre instituições em crise, é preciso ter em mente que o recurso a tais medidas depende da ocorrência das hipóteses previstas nos arts. 2..$^{\circ}$ e 15 da Lei 6.204/1974, e no art. 1. ${ }^{\circ}$ do Decreto-lei 2.321/1987. Ainda que algumas dessas hipóteses sejam bastante subjetivas, atribuindo ampla discricionariedade à autoridade bancária na decretação dos regimes especiais, nenhuma delas parece permitir, em tese, a aplicação desses regimes, ou qualquer das medidas saneadoras prevista na Lei 9.447/1997, pelo simples fato de a instituição ser considerada grande demais para quebrar. Portanto, a atuação da autoridade bancária em tais casos teria sempre um caráter remedial, e não preventivo.

Ao que parece, a autoridade bancária está ciente dessa limitação na sua capacidade de atuar, e procurou resolvê-la por meio do anteprojeto de lei apresentado em audiência pública em dezembro de 2009. Com efeito, a proposta faz referência expressa à possibilidade de aplicação de medidas preventivas em razão da exposição a risco incompatível com a natureza, atividades e, frise-se, estrutura da instituição financeira (art. 3. ${ }^{\circ}$, II), além de prever uma série de remédios de cunho estrutural que poderão ser impostos à instituição financeira antes mesmo da decretação de qualquer regime especial, como: (i) fechamento ou proibição da abertura de dependências (art. 5. ${ }^{\circ}, \mathrm{V}$ ); (ii) proibição ou redução de determinadas operações ou modalidades operacionais (art. 5. ${ }^{\circ}, \mathrm{VI}$ ); (iii) vedação à aquisição de participação, de forma direta ou indireta, no capital e outras sociedades, inclusive instituições financeiras (art. 5. ${ }^{\circ}$, XIII); (iv) vedação à exploração de nova linha de negócios (art. 5. ${ }^{\circ}$, XIV); e (v) alienação de ativos (art. 5. $\left.{ }^{\circ}, \mathrm{XVI}\right)$. Da mesma forma, dependendo da gravidade dos fatos que deram ensejo à aplicação das medidas preventivas, o Bacen poderá determinar a cisão da instituição financeira, além de outras reorganizações societárias legalmente admitidas (art. 6. ${ }^{\circ}$, III). ${ }^{492}$

491 REsp 447939/SP, Rel. Min. Nancy Andrighi, j. 04.10.2007.

492 Aqui é importante lembrar, no entanto, que, embora o anteprojeto de lei apresente medidas relevantes no tocante às preocupações decorrentes do fenômeno too big to fail, a audiência pública que tratou do tema 
Finalmente, entre os aspectos estruturais do setor bancário brasileiro, é preciso mencionar o argumento invocado com frequência pelo Bacen, segundo o qual, embora crescente, o grau de concentração no setor bancário brasileiro ainda seria baixo em comparação com outros países, o que amenizaria o impacto das fusões e aquisições recentes no setor. ${ }^{493}$ Fugiria ao escopo deste trabalho entrar no mérito dessa discussão, cabendo apenas ressaltar que o argumento da autarquia contrasta com a sua própria atuação durante a crise financeira recente. Nesse caso, talvez o relato mais contundente sobre a questão seja o de Mario Tóros, diretor de política monetária do Bacen no auge da crise, afirmando que as diversas medidas de resgate adotadas foram necessárias porque "qualquer banquinho era 'too big to fail"', 494

Declarações como as de Mario Torós evidentemente têm um reflexo negativo em termos de risco moral. Ao lado do amplo instrumental de suporte disponibilizado aos bancos, dissemina-se a percepção de que é muito difícil a autoridade bancária permitir que um banco venha a quebrar, quando não é esta a finalidade da regulação sistêmica. A concentração crescente no setor bancário impõe desafios à atuação das autoridades bancárias, e o Brasil certamente não é exceção. Se o setor bancário brasileiro ainda não apresenta níveis de concentração tão altos como o de outros países, como pretende afirmar o Bacen, esta é outra importante razão para discutir a continuidade dessa estratégia o quanto antes, uma vez que a realidade já demonstrou que, após instaurado, a solução do problema torna-se muito mais complexa.

encerrou-se há mais de um ano e este ainda não foi enviado ao Congresso Nacional, sendo provável que, caso venha a ser enviado, ainda sofra alterações antes de sua eventual aprovação.

493 VALOR ECONÔMICO. BC vê espaço para concentração bancária ainda maior no Brasil, 15 maio 2006, B3; e, Idem. Concentração fortaleceu sistema, diz Banco Central, 19 out. 2007, C7.

494 Idem. Brasil enfrentou ataque e corrida bancária na crise, 13 nov. 2009, p. A1. 


\section{SÍNTESE E CONCLUSÕES DO CAPÍTULO 3}

1. Embora o risco sistêmico se manifeste em diversas áreas, considera-se que a probabilidade e severidade de sua ocorrência no setor bancário é mais grave. As importantes funções desempenhadas pelos bancos na economia, as características do setor bancário, bem como as peculiaridades da atividade bancária típica, atribuem um caráter "especial" a tais instituições, justificando a sua proteção por meio da regulação sistêmica. Isso não significa, no entanto, que toda quebra bancária represente risco sistêmico. Pelo contrário, a associação indiscriminada de quebras bancárias a risco sistêmico tende à ampliação do risco moral e pode inclusive comprometer a própria finalidade da regulação sistêmica.

2. O Brasil adota na atualidade os principais mecanismos de regulação sistêmica existentes. Embora alguns desses mecanismos tenham sido criados ainda na década de 1970, como a Lei 6.024/1974, a maioria teve implementação mais recente, com destaque para a criação do FGC em 1995 e a reorganização do SPB em 2001. A análise da estrutura desses mecanismos revela aspectos positivos e negativos do arcabouço regulatório sistêmico no País.

3. No caso do FGC, o financiamento privado representou grande avanço quanto à sistemática adotada durante o regime militar, quando recursos acumulados na reserva monetária provenientes da captação do IOF eram utilizados para garantir depositantes de bancos quebrados, o que causava significativo risco moral. A previsão de limites de cobertura é outro importante elemento para manutenção da disciplina de mercado. A atuação do FGC foi de grande relevo no contexto da política de saneamento realizada na década de 1990, principalmente para garantir os depósitos dos 2,6 milhões de correntistas do Banco Bamerindus, bem como na crise recente, provendo liquidez a bancos em dificuldades.

4. No tocante aos regimes especiais aplicáveis a instituições em crise, destaca-se a ampla gama de medidas de saneamento à disposição do Bacen para atenuar impactos sistêmicos, ao mesmo tempo em que preserva a normalidade das funções do sistema financeiro. Entre essas medidas inclui-se a possibilidade de transferência de bens e direitos de uma instituição para outra em contextos de crise, tema que foi objeto de recomendações recentes do Comitê de Basileia quanto a melhores práticas regulatórias, e que já estão disponíveis no País desde 1997. Outrossim, vale mencionar o rigor das formas de 
responsabilidade aplicáveis a administradores e controladores de instituições financeiras sob regimes especiais, bem como a previsão de indisponibilidade de seus bens.

5. O Brasil também dispõe de um sistema de pagamentos moderno, representando grande avanço em relação ao modelo anterior, em que o Bacen bancava o risco de liquidação das operações ao final do dia, causando prejuízos à autoridade bancária e incentivando o risco moral. Outra importante inovação do SPB foi a apresentação de novas diretrizes para o gerenciamento do risco sistêmico, como o afastamento de regras do procedimento falimentar ordinário para obrigações assumidas no âmbito das câmaras ou prestadores de serviços de compensação e de liquidação, e a exigência de constituição de "patrimônio especial" segregado para entidades administrando sistemas considerados "sistemicamente relevantes".

6. Em contraste com as inúmeras virtudes dos instrumentos de regulação sistêmica adotados no País, é possível verificar aspectos que causam preocupação em termos de criação de risco moral no sistema financeiro. Algumas dessas fontes de preocupação tiveram origem em modificações recentes realizadas no regramento desses instrumentos em resposta à crise financeira internacional que atingiu o País. No que concerne ao FGC, observou-se que este passou a garantir não apenas depósitos de curto prazo, como também de longo prazo, até o limite de $\mathrm{R} \$ 20$ milhões por pessoa. Aqui vale ressaltar que a lógica de implementação do mecanismo de seguro de depósitos, que é prevenir corridas bancárias decorrentes de assimetrias informacionais presentes no setor, não se aplica aos depósitos de longo prazo. Além disso, o estatuto do FGC foi alterado para ampliar o limite e rol de ativos nos quais os recursos do fundo podem ser aplicados, com destaque para a aquisição de carteiras de crédito de instituições financeiras, bem como a delegação de sua administração para terceiros. Isso é agravado pelo fato de o FGC ser uma instituição privada administrada pelos mesmos bancos que potencialmente podem vir a necessitar desse auxílio. As transformações pelas quais vêm passando o FGC fazem com que este gradativamente se torne garantidor não apenas dos correntistas, mas, principalmente, dos próprios bancos.

7. Preocupações semelhantes são levantadas em relação às reformas recentes nos mecanismos de prestamista de última instância administrados pelo Bacen. Os canais de provimento de liquidez já existentes foram ampliados para permitir a aquisição de 
carteiras de crédito de instituições financeiras pelo Bacen na modalidade compra com compromisso de revenda, o acesso às reservas internacionais da autoridade bancária para empréstimos em moeda estrangeira, além do afastamento das exigências de regularidade fiscal para receber os recursos. Em paralelo a esses canais de provimento de liquidez, observa-se também a recorrente prática de realização de empréstimos por bancos oficiais a instituições em crise, que ocorrem fora do contexto de formalidade tão caro ao funcionamento apropriado desses mecanismos.

8. A análise dos instrumentos de regulação sistêmica no País indica que existem, na atualidade, três canais alternativos de provimento de liquidez a instituições em crise (Bacen, FGC e instituições oficiais), sendo que dois deles sofreram significativa ampliação durante a crise financeira recente (Bacen e FGC), um deles é administrado pelos próprios bancos (FGC), e um deles não está sujeito a qualquer regramento específico (instituições oficiais). O provimento de liquidez por meio dessas diferentes alternativas está sujeito a variados graus de formalidade e condições, dependendo do mecanismo utilizado. Além desses, observa-se também a intenção do Bacen de aumentar o número de canais de liquidez existentes por meio da apresentação de anteprojeto de lei que prevê a realização de "operações especiais de assistência financeira com instituições financeiras" em casos de "crise sistêmica ou grave ameaça à estabilidade do Sistema Financeiro Nacional", que não estariam sujeitas às limitações da Lei de Responsabilidade Fiscal. Esse amplo rol de canais existente pode atuar como fator de incentivo à tomada de risco por instituições financeiras, haja vista as inúmeras possibilidades de resgate à sua disposição. Alie-se a tal fato a ampla discricionariedade do Bacen na decretação de regimes especiais, que inclusive rendeu críticas e ações judiciais quanto à sua atuação omissiva ou comissiva tardia em determinadas situações, bem como um entendimento jurisprudencial que dificulta a responsabilização do órgão em tais casos. Nesse contexto, cabe questionar se o sistema financeiro reagiu tão bem à crise financeira recente porque é sólido, ou porque, no contexto atual, torna-se muito difícil um banco vir a quebrar.

9. Não se disputa aqui a relevância que as mudanças recentes no regramento desses mecanismos tiveram para debelar os efeitos da crise financeira no País, reconhecendo-se a necessidade de medidas excepcionais em momentos de grave instabilidade. Não obstante, é importante ter em mente as consequências que estas trazem em termos de aumento do 
risco moral no mercado, motivo pelo qual devem sempre ter caráter temporário e serem limitadas apenas a situações emergenciais.

10. Além dessas constatações referentes ao regramento da estrutura dos mecanismos de regulação sistêmica no País, é preciso considerar os impactos que as transformações pelas quais vem passando o sistema financeiro - e o setor bancário em particular - nas últimas décadas provocam nesse campo da regulação financeira. No caso do risco sistêmico, o movimento de conglomeração financeira provoca uma reflexão sobre a forma como seu conceito é tradicionalmente pensado e aplicado. A diluição das barreiras regulatórias entre atividades financeiras torna cada vez mais difícil a identificação de focos em potencial de risco sistêmico. Episódios como o do LTCM, em 1997, e da AIG, em 2008, evidenciam que a natureza jurídica de um determinado participante do sistema financeiro já não é tão importante na identificação de possíveis fontes desse risco, motivo pelo qual se observa na atualidade uma preocupação crescente das autoridades com as entidades consideradas "sistemicamente relevantes", ainda que sejam instituições não bancárias. Igualmente, a concentração crescente no setor bancário também gera preocupações quanto à impossibilidade de deixar uma instituição financeira quebrar. O fenômeno do too big to fail representa um grave desafio à regulação sistêmica, uma vez que fomenta o risco moral e compromete a disciplina de mercado. Esse tem sido um ponto de intenso debate no desenlace da crise financeira recente na medida em que países discutem formas de limitar o tamanho de instituições financeiras.

11. De maior relevo é a constatação de que tais preocupações também estão presentes no Brasil e que os mesmos movimentos de concentração e conglomeração que impõem esses desafios às autoridades bancárias de outros países têm sido não apenas observados, como também incentivados historicamente no País. No tocante à extensão do risco sistêmico, é possível observar avanços no marco regulatório, como a criação do Sumef em 2010, com funções análogas às do FSOC e ESRB, em implementação nos Estados Unidos e Europa, respectivamente, e a extensão das disposições dos regimes especiais aplicáveis às instituições financeiras às sociedades seguradoras e entidades abertas e fechadas de previdência e sociedades de capitalização. Da mesma forma, a proposta de anteprojeto de lei apresentada pelo Bacen em 2009 prevê a possibilidade de realização de "operações especiais de assistência financeira" com câmaras e prestadores de serviço de compensação e liquidação atuando como contrapartes centrais no SPB. 
12. Com relação ao too big to fail, há importantes diferenças a serem consideradas entre o caso brasileiro e o de outros países, como a adoção de regimes de responsabilidade para administradores e controladores mais rigorosos, e a atribuição de amplos poderes à autoridade bancária para reorganizar a estrutura de instituições em crise. Essas diferenças, no entanto, devem ser sopesadas em função de certos fatores, como os entendimentos doutrinários e jurisprudenciais divergentes sobre o tipo de responsabilidade previsto no art. 40 da Lei 6.024/1974 e, principalmente, a necessidade de verificação de uma das hipóteses de decretação de regimes especiais para que a autoridade bancária possa atuar sobre a estrutura da instituição em crise. Existe proposta de anteprojeto de lei apresentada pelo Bacen que procura modificar essa situação, atribuindo poderes mais amplos à autoridade para promover a reorganização dos ativos antes mesmo da decretação de um regime especial, mas este ainda aguarda envio ao Congresso Nacional. Finalmente, ainda que se possa argumentar que os níveis de concentração bancária observados no Brasil sejam inferiores aos observados em outros países, isso não descarta a preocupação com os efeitos deletérios desse movimento em termos de regulação sistêmica. Pelo contrário, considerando que o problema é de solução mais complexa depois de instaurado, reforça-se a necessidade de repensar os efeitos da concentração bancária crescente o quanto antes. $\mathrm{O}$ movimento de concentração bancária e as declarações do Bacen quanto ao tema contrastam com as próprias atitudes da autarquia ao longo da crise financeira recente, em que o diretor de política monetária do órgão afirmou que o resgate às instituições em crise era necessário porque "qualquer banquinho era too big to fail".

13. A análise dos mecanismos de regulação sistêmica no Brasil demonstra que, apesar de seu progresso inegável nas últimas décadas, apresentando uma série de virtudes que os destacam em relação a outros países, ainda há margem para aprimoramentos, principalmente quando considerados conjuntamente. Embora o risco moral seja uma consequência indesejável, porém inevitável, da regulação sistêmica, a dinâmica de atuação desses mecanismos no Brasil, sobretudo após as mudanças realizadas em seu regramento no âmbito da crise financeira recente, contribui para a criação de um ambiente em que o risco inerente (e necessário) à atividade bancária é diminuído em razão do extenso instrumental de suporte colocado à disposição dos bancos. Esse quadro dá azo a uma ampliação do risco moral no setor bancário brasileiro que, caso não seja devidamente controlado pela regulação prudencial, pode acabar comprometendo no médio e longo prazo os mesmos objetivos que tais instrumentos visam atingir no curto prazo. 


\section{Capítulo 4 \\ REGULAÇÃO PRUDENCIAL}

\subsection{Regulação prudencial}

A regulação prudencial procura estabelecer instrumentos voltados ao controle do risco assumido por instituições financeiras. Para tal, assenta-se na premissa de que, pelo controle do risco individual de cada uma dessas instituições, é possível manter a higidez do sistema financeiro como um todo. ${ }^{495}$ Aqui vale reiterar que, embora a busca pela higidez do sistema financeiro se apresente como um objetivo complementar à regulação sistêmica, com ela não se confunde. Enquanto a regulação sistêmica tem um caráter mais remedial, preocupando-se em criar mecanismos para conter a ocorrência das externalidades negativas relacionadas ao alto grau de integração entre instituições financeiras, a regulação prudencial possui caráter mais preventivo, procurando delinear regras que impeçam a ocorrência de crises sistêmicas a priori. De fato, Mishkin chega a afirmar que uma das motivações para a regulação prudencial surge justamente em razão da ampliação do risco moral causada pelos instrumentos utilizados na regulação sistêmica. ${ }^{496}$ Assim, a regulação prudencial desempenharia também a importante função de correção das consequências adversas da regulação sistêmica para que esta não tenha seu propósito final desvirtuado.

Embora a regulação prudencial tenha objetivos bem delineados, o mesmo não ocorre com os mecanismos adotados para atingi-los. Com efeito, as últimas décadas têm evidenciado um processo acelerado de mudança nas estratégias de regulação prudencial adotadas em muitos países. Essa mudança está intrinsecamente ligada às transformações observadas no sistema financeiro, que afetam a eficácia dos métodos empregados pelas autoridades para controlar o nível de risco assumido pelas instituições financeiras.

\footnotetext{
495 TURCZYN, Sidnei. O Sistema Financeiro Nacional e a regulação bancária, p. 368.

496 MISHKIN, Frederic S. Prudential Supervision: why is it important and what are the issues, p. 8.
} 
Segundo Carvalho, o primeiro estágio do processo evolutivo da regulação prudencial, dominante por muito tempo, pode ser caracterizado como a "regulação de balanços". ${ }^{497}$ Essa estratégia de regulação ficou marcada pelo seu conteúdo prescritivo e busca do controle direto das operações das instituições financeiras por meio da segregação estrita de suas atividades e imposição de indicadores quantitativos objetivos para o julgamento da adequação das operações permitidas. Nesse estágio, a regulação prudencial preocupava-se em garantir principalmente a liquidez dos depósitos, impondo limites à natureza das aplicações realizadas pelos bancos e estimulando (ou forçando) a constituição de reservas adequadas para enfrentar demandas de saque por parte dos depositantes. Índices de liquidez baseados na disponibilidade de reservas primárias e secundárias que permitissem honrar retiradas de depositantes, por exemplo, eram objeto de atenção especial. ${ }^{498}$

Esse sistema foi gradualmente perdendo sua importância em razão das inovações ocorridas no sistema financeiro, principalmente a partir da década de 1980. O advento de novas formas de administração de passivos baseadas na diversificação de fontes de recursos e a progressiva perda de importância das operações bancárias tradicionais em face de outras atividades bancárias provocaram uma mudança no foco das estratégias voltadas ao controle de risco das instituições financeiras. ${ }^{499}$ Nesse sentido, as autoridades passaram a atribuir atenção crescente à dinâmica de remuneração das instituições financeiras e os incentivos a correr riscos excessivos, como a propensão à realização do maior volume de negócios possível particularmente aqueles com maior risco - em virtude das maiores taxas de rentabilidade. Tais incentivos decorrem das mencionadas assimetrias informacionais presentes no setor, notadamente a relação principal-agente, permitindo que, em caso de sucesso, a instituição financeira e seus administradores aufiram grandes ganhos e, em caso de fracasso, a perda recaia sobre os poupadores cujo capital foi cedido à instituição financeira. ${ }^{500}$

Portanto, o foco da regulação prudencial passa gradativamente das operações passivas para as operações ativas das instituições financeiras e, sobretudo, para o risco de

\footnotetext{
497 CARVALHO, Fernão J. Cardim de et al. Economia monetária e financeira: teoria e política. Rio de Janeiro: Campus, 2001. p. 324.

498 Idem, ibidem, p. 324.

499 Idem, p. 325.

500 Idem, p. 325.
} 
crédito decorrente de tais operações. ${ }^{501}$ Essa abordagem seria consagrada oficialmente no Acordo de Basileia de 1988, a partir do qual os países passaram a introduzir normas regulatórias estabelecendo coeficientes de capital exigidos dos bancos em proporção aos seus ativos, ponderados de acordo com suas aplicações e grau de risco.

\section{O Acordo de Basileia de 1988}

Em 1988 o Comitê de Basileia editou um guia de recomendações intitulado Convergência Internacional para Mensuração e Adequação de Capital (International Convergence of Capital Measurement and Capital Standards), ${ }^{502}$ que ficou conhecido como o primeiro Acordo de Basileia (Basileia I). Esse acordo foi concebido originalmente para ser aplicado apenas a bancos internacionalmente ativos em países industrializados. Embora a harmonização das práticas de regulação prudencial, uniformizando critérios de avaliação e de consideração do patrimônio das instituições financeiras, fosse em si um objetivo, havia também a preocupação de nivelar as condições de competição entre bancos de diferentes países que, por estarem submetidos a marcos regulatórios distintos, competiam em condições desiguais no cenário internacional. ${ }^{503}$ Com o passar dos anos, Basileia I tornou-se importante referência regulatória, seja para países desenvolvidos ou para países em desenvolvimento, sendo aplicado por um significativo número de bancos, independentemente de seu tamanho e área de atuação.

Conforme ensinamento de Barros de Castro, a principal característica de Basileia I é sua natureza tutelar, isto é, o fato de procurar regular a atividade bancária pela imposição de um "capital regulatório" às instituições. ${ }^{504} \mathrm{~A}$ ideia-chave era que, ao forçar os bancos a comprometer seu próprio capital, os incentivos perversos à tomada excessiva de risco seriam mitigados. Assim sendo, cada banco deveria constituir capital próprio proporcional às suas aplicações, baseando-se na classificação de risco reconhecido em cada categoria de crédito,

\footnotetext{
501 YAZBEK, Otavio. Regulação do mercado financeiro e de capitais, p. 241.

502 COMITÊ DE BASILEIA. International convergence of capital measurement and capital standards, Basileia, jul. 1988.

503 BARROS DE CASTRO, Lavinia. Regulação financeira: discutindo os Acordos de Basileia. Revista do BNDES, Rio de Janeiro, v. 14, n. 28, p. 279-280, 2007.

503 Idem, ibidem, p. 279-280.

504 Idem, p. 280.
} 
adaptada às condições de cada país que aderisse ao sistema. Para tanto, foi estabelecida uma razão entre a quantidade de capital de cada banco e o "Ativo Ponderado pelo Risco" (APR), em que cada ativo de sua carteira receberia uma classificação de risco correspondente a determinado percentual de capital regulatório. ${ }^{505}$ Inicialmente, Basileia I contemplou somente o risco de crédito, e exigiu que bancos engajados ativamente em transações internacionais detivessem capital equivalente a, no mínimo, 8\% de seu APR. O capital para efeitos desse cálculo é mais amplo que o capital social e inclui ponderações entre os seguintes componentes: ${ }^{506}$

1. Capital nível I (Tier 1 ou capital nuclear) - representado pelo capital social, reservas de capital, reservas de lucros (excluídas as reservas para contingências e as reservas especiais de lucros relativas a dividendos obrigatórios não distribuídos) e lucros ou prejuízos acumulados ajustados pelo valor líquido entre receitas e despesas, deduzidos os valores referentes às ações em tesouraria, ações preferenciais cumulativas e ações preferenciais resgatáveis; e

2. Capital nível II (Tier 2 ou capital suplementar) - representado pelas reservas de reavaliação, reservas para contingências, reservas especiais de lucros relativas a dividendos obrigatórios não distribuídos, ações preferenciais cumulativas, ações preferenciais resgatáveis, dívidas subordinadas e instrumentos híbridos de capital e dívida.

505 BARROS DE CASTRO, Lavinia. Regulação financeira, p. 280.

506 GUIMARÃES, André Luiz de Souza; LIMA, Jorge Cláudio Cavalcante de Oliveira. Avaliação do risco de crédito no Brasil. In: GARCIA, Márcio; GIAMBIAGI, Fábio (Org.). Risco e regulação, p. 212. Para uma análise didática sobre o cálculo do capital regulatório em Basileia I e II, ver: TARULLO, Daniel K. Banking on Basel: the future of international financial regulation. Washington: Peterson Institute for International Economics, 2008. 
Desde o seu lançamento em 1988, algumas críticas a Basileia I tornaram-se evidentes. ${ }^{507}$ Em primeiro lugar, o acordo focou demasiadamente na defesa contra riscos de crédito, passando ao largo de outros tipos de risco (como riscos operacionais e de mercado). $\mathrm{O}$ pequeno número de categorias de risco consideradas logo se mostrou inadequado em face da diversidade de operações bancárias, e o capital exigido não refletiu adequadamente os distintos perfis de risco dos ativos das instituições. Por ironia, o próprio acordo passou a ser responsabilizado pela crescente aceitação desses outros riscos, uma vez que, ao impor coeficientes de capital sobre tipos de crédito, acabou tornando o crédito relativamente mais caro em comparação a outras formas de intermediação financeira cujos riscos não tivessem que ser compensados pela constituição de capital próprio. $\mathrm{O}$ acordo também foi objeto de críticas por não distinguir a capacidade de pagamento de diferentes tipos de emissores. Exemplos disso são a atribuição de risco "zero" a operações com títulos públicos, independentemente do país emissor, e a aplicação de fator "100\% de risco" a créditos corporativos em geral para cálculo de APR, não levando em conta a solidez de cada empresa. Assim, um empréstimo a uma empresa à beira da falência seria tratado da mesma forma que um financiamento a uma empresa com boa saúde financeira.

Por essas e outras razões, pouco tempo depois de concluído, e enquanto suas disposições sequer eram aplicadas em sua plenitude em muitos dos países aderentes, o acordo tornou-se objeto de reexame para torná-lo, ao mesmo tempo, mais eficaz e harmônico. ${ }^{508}$ Procurou-se manter a definição de coeficientes de capital como base da estratégia regulatória, mas recalculá-los de modo a abranger gama mais ampla de riscos. Ao mesmo tempo, a complexidade crescente das atividades financeiras incentivou a discussão de novas estratégias de avaliação e tratamento de riscos por meio da utilização de modelos internos pelos bancos, bem como o incentivo à prestação de informações ao mercado. Essas e outras inovações seriam reconhecidas oficialmente no segundo acordo de Basileia.

507 BARROS DE CASTRO, Lavinia. Regulação financeira, p. 281; GUIMARÃES, André Luiz de Souza; LIMA, Jorge Cláudio Cavalcante de Oliveira. Avaliação do risco de crédito no Brasil, p. 213.

508 Entre as revisões mais importantes, cabe mencionar a de janeiro de 1996, com a publicação de um adendo a Basileia I, chamado de Emenda de Risco de Mercado (Amendment to the Capital Accord to Incorporate Market Risks). Entre os aspectos relevantes da emenda, destacam-se a: (i) ampliação dos controles sobre riscos incorridos pelos bancos; (ii) extensão dos requisitos para a definição do capital regulatório, incorporando o risco de mercado; e (iii) possibilidade de utilização de modelos internos na mensuração de riscos, desde que aprovados pela autoridade nacional. Ver: COMITÊ DE BASILEIA. Amendment to the capital accord to incorporate market risks, Basileia, jan. 1996. 


\section{O Acordo de Basileia de 2004}

O segundo Acordo de Basileia (Basileia II) começou a ser discutido em junho de 1999, sendo finalizado apenas em junho de $2004 .{ }^{509} \mathrm{O}$ acordo continuou procurando estabelecer regras comuns de regulação prudencial, mantendo o foco em bancos internacionalmente ativos, embora novamente se esperasse que fosse adotado indiscriminadamente. Ainda que muitas definições de capital e técnicas para tratamento de risco tenham permanecido, Basileia II foi mais sensível a outros tipos de risco e à crescente sofisticação dos mercados financeiros. Em suma, pode-se dizer que o novo acordo ampliou o anterior, centrado na noção de capital regulatório adequado ao risco, incorporando novas dimensões de risco. 510

Entre as principais mudanças de Basileia II, encontra-se o incentivo para que os bancos melhorassem seus sistemas internos de controle, partindo do reconhecimento de que, diante do elevado grau de inovação e sofisticação financeira, tentativas de classificação de riscos tornar-se-iam rapidamente obsoletas, gerando movimentos de arbitragem regulatória. 511 Pretendeu-se, então, que cada instituição financeira utilizasse o modelo de mensuração de riscos mais compatível com seu tamanho, estrutura e grau de sofisticação. Observa-se a transição de um padrão tutelar para um modelo em que são dados incentivos às firmas para controlarem seus próprios riscos. Foi reservado, porém, à autoridade bancária de cada país, julgar as estratégias adotadas pelos bancos para controlarem cada um dos tipos de risco contemplados (risco de crédito, risco de mercado e risco operacional), bem como validar o modelo interno dos bancos, no caso de adotarem métodos próprios de avaliação e mensuração de risco. Outra importante inovação em Basileia II foi a possibilidade de utilização de ratings externos para cálculos de adequação de capital, desde que com aprovação da autoridade bancária da respectiva jurisdição.

\footnotetext{
509 COMITÊ DE BASILEIA. International convergence of capital measurement and capital standards: a revised framework, Basileia, jun. 2004.

510 BARROS DE CASTRO, Lavinia. Regulação financeira, p. 283.

511 Idem, ibidem, p. 283-284.
} 
Para introduzir tais mudanças, o novo acordo de capitais de Basileia baseou-se em três pilares fundamentais: ${ }^{512}$

1. Capital mínimo requerido: $O$ primeiro pilar busca atingir uma melhor alocação de capitais para cobrir as exposições das instituições a riscos, de modo a garantir níveis "confortáveis" de capitalização. É justamente nesse pilar que entram as novas dimensões de risco contempladas e abordagens alternativas para sua mensuração;

2. Revisão no processo de supervisão: $O$ segundo pilar incentiva as autoridades bancárias a garantir que as instituições financeiras tenham processos internos capazes de melhor identificar e gerir exposições a riscos adequadamente. A manutenção da relevância do regulador é ampliada pelo princípio da "inspeção regulatória". As autoridades devem avaliar a forma de cálculo do capital regulatório praticada por cada banco e intervir quando julgarem necessário. $\mathrm{O}$ objetivo maior é estabelecer um diálogo permanente entre o órgão supervisor e instituições supervisionadas, visando aumentar a segurança do sistema, permitir a intervenção em situações de crescimento do risco e evitar a criação de vantagens ou desvantagens entre os entes regulados; e

3. Disciplina de mercado: Por fim, o terceiro pilar estimula a transparência, procurando garantir a prudência por meio da "disciplina de mercado". Dessa forma, pretende incentivar o desenvolvimento de um conjunto de requisitos de transparência que permitam aos agentes de mercado acompanhar o comportamento das instituições financeiras. Elemento importante dessa estratégia é o fomento à padronização nos procedimentos contábeis e na divulgação das informações. Do ponto de vista analítico, incentiva

512 BARROS DE CASTRO, Lavinia. Basileia II: questões pendentes que interessam ao Brasil. Periódico Visão do Desenvolvimento, BNDES, n. 34, p. 4-5, 2007. 
o setor bancário a caminhar no sentido da autorregulação, sem prejuízo da regulação pelo governo.

Em 9 de dezembro de 2004, o Bacen, por meio do Comunicado 12.746, expressou sua intenção de adotar Basileia II no Brasil. ${ }^{513} \mathrm{O}$ comunicado indica que o Bacen pretende aderir ao acordo, incorporando gradualmente as adaptações apropriadas à realidade do setor bancário brasileiro. Em 27 de setembro de 2007, foi divulgado o Comunicado 16.137, que alterou o cronograma de implantação de Basileia II no País. ${ }^{514}$ Conforme o comunicado, a autarquia pretende concluir a adoção do acordo até o final de 2012.

\section{Basileia III}

A gravidade dos efeitos da crise financeira recente fez com que, de forma similar ao ocorrido com o primeiro acordo de Basileia, os dispositivos de Basileia II se tornassem objeto de revisão antes mesmo de sua plena incorporação. Nesse sentido, o Comitê de Basileia apresentou, em 17 de dezembro de 2009, dois documentos de consulta estabelecendo amplas propostas de reforma regulatória. ${ }^{515}$ Em 26 de julho de 2010, os países integrantes do Comitê de Basileia chegaram a um acordo preliminar sobre o conjunto de propostas a serem implementadas nos próximos anos. ${ }^{516}$ Esse conjunto de propostas ficou conhecido como "Basileia III".

Parte dos trabalhos do Comitê de Basileia apoiou-se no aperfeiçoamento de mecanismos previstos nos acordos prévios, principalmente no tocante à exigência e composição do capital regulatório mínimo. Portanto, procurou-se aumentar a qualidade, consistência e transparência da base de capital das instituições financeiras por meio da proposição de: (i) medidas mais restritivas de elegibilidade dos ativos (principalmente instrumentos financeiros derivativos) que podem ser incluídos como capital nuclear ou

\footnotetext{
513 Disponível em: <www.bcb.gov.br/?COM12746>. Acesso em: 3 jan. 2011.

514 Disponível em: <www.bcb.gov.br/?COM16137>. Acesso em: 3 jan. 2011.

515 COMITÊ DE BASILEIA. Strengthening the resilience of the banking sector, Basileia, dez. 2010; e, Idem. International framework for liquidity risk measurement, standards and monitoring, Basileia, dez. 2010.

516 Idem. The Group of Governors and Heads of Supervision reach broad agreement on Basel Committee capital and liquidity reform package, Basileia, jul. 2010.
} 
suplementar para fins de cálculo de capital ponderado pelo risco; (ii) aumento do fator de risco para determinados ativos; e (iii) aumento dos requisitos mínimos de capital para certos tipos de ativos. Para evitar que as novas exigências de capital prejudiquem a recuperação econômica de países afetados pela crise financeira recente, o cronograma de implementação dessas medidas foi alongado, com início em 2013 e aplicação gradativa até 2018.

Não obstante, Basileia III preocupou-se também em propor novos mecanismos de regulação prudencial. Esses novos mecanismos seguem em linha com preocupações levantadas por uma corrente de autores, e corroboradas na crise financeira recente, de que os acordos anteriores estariam excessivamente focados no aspecto "microprudencial", dizendo respeito à saúde de instituições financeiras consideradas individualmente, descuidando-se do aspecto "macroprudencial", em que se leva em conta a saúde do sistema financeiro como um todo. ${ }^{517}$ Isso é bem representado na seguinte passagem de Loyola: ${ }^{518}$

[...] a crise explicitou outra grave falha da regulação financeira, qual seja a pouca relevância atribuída ao risco sistêmico no desenho e na implementação das normas prudenciais e no processo de supervisão. Tipicamente, a regulação buscava limitar o risco de cada instituição vista isoladamente, sem focar no risco do sistema financeiro como um todo. Essa abordagem implicitamente assume ser suficiente que cada instituição seja segura para que a higidez de todo o sistema financeiro esteja assegurada. Há, porém, nessa hipótese uma falácia de composição, tendo em vista a possibilidade de que a gestão de risco por parte de cada banco individualmente possa levar a um comportamento que, coletivamente, aumenta o risco do sistema financeiro.

Conforme o posicionamento do autor, ainda que autoridades determinem medidas desejáveis de ajuste patrimonial para instituições financeiras isoladamente, o efeito agregado sobre o sistema financeiro pode ser indesejável. Em suma, observa-se que, em determinadas situações, a premissa de que pelo controle do risco individual das instituições financeiras seja possível manter a higidez do sistema financeiro como um todo, pode não se verificar.

517 BANK OF ENGLAND. The role of macroprudential policy: a discussion paper, 2009. Disponível em: <www.bankofengland.co.uk/publications>. Acesso em: 23 dez. 2010; BORIO, Claudio et al. Procyclicality of the financial system and financial stability: issues and policy options, marrying the macro-and microprudential dimensions of financial stability. BIS Papers, n. 1, 2001; BORIO, Claudio. Towards a macroprudential framework for financial supervision and regulation? BIS Working Paper, n. 128, 2003; HANSON, Samuel et al. A macroprudential approach to financial regulation. Paper prepared for Journal of Economic Perspectives, jul. 2010, mimeografado; e KASHYAP, Anil K.; STEIN, Jeremy C. Cyclical implications of the Basel-II capital standards. Federal Reserve Bank of Chicago Economic Perspectives, 28(1), 2008.

518 LOYOLA, Gustavo. O futuro da regulação financeira. In: GARCIA, Márcio; GIAMBIAGI, Fábio (Org.). Risco e regulação, p. 63-64. 
Um bom exemplo sobre os paradoxos inerentes ao enfoque excessivamente "microprudencial" é o componente procíclico dos requisitos de capital atualmente utilizados. ${ }^{519}$ Essa "ciclicidade" contribuiria para reforçar a expansão ou contração do crédito em diferentes momentos do ciclo econômico, bem como ampliar movimentos de ativos nas fases de alta e baixa. Com efeito, em momentos de expansão econômica, a probabilidade de default e outros parâmetros da composição do capital regulatório são calculados no ponto de menor risco, reduzindo o capital mínimo requerido e liberando limites para alavancagem adicional da instituição, enquanto que em momentos de stress, as probabilidades de default aumentam e a capacidade de recuperação dos créditos pelos bancos diminui, ao mesmo tempo em que as exigências de capital regulatório aumentam, o que pode levar a um aprofundamento da recessão. ${ }^{520}$

Com isso em mente, Basileia III procura mitigar a ciclicidade excessiva por meio do provisionamento prospectivo, que consiste basicamente em exigir que os bancos constituam reservas de capital na fase de expansão da economia para servirem de "colchão de sergurança" a ser utilizado em momentos de contração. Entre as medidas propostas nesse sentido, encontram-se restrições na distribuição de dividendos de acordo com os níveis de capitalização da instituição financeira, ou então a exigência de que o capital mínimo requerido seja calculado com base não apenas do nível total do APR, mas considerando também a velocidade de crescimento desses ativos. ${ }^{521}$

Basileia III prevê também a introdução de padrões globais de liquidez de curto e longo prazo. As propostas procuram endereçar preocupações na crise financeira recente quanto à falta de instrumentos voltados à consideração do risco de liquidez. Nesse sentido, propõe-se a adoção de um índice de cobertura de liquidez de 30 dias para assegurar a resistência a rupturas de liquidez transitórias e um índice de liquidez estrutural de longo prazo para responder a períodos prolongados de escassez de crédito. O documento promove também medidas de incentivo ao uso de fontes de financiamento estáveis.

\footnotetext{
519 KASHYAP, Anil K.; STEIN, Jeremy C. Cyclical implications of the Basel-II capital standards.

520 Idem, ibidem.

521 Para uma análise dessas e outras propostas de provisionamento cíclico, ver: LOYOLA, Gustavo. O futuro da regulação financeira, p. 68 e ss.
} 
Outra inovação de destaque em Basileia III refere-se à introdução de um índice de alavancagem não ajustado ao risco (com base nos ativos totais da instituição) para complementar os requisitos mínimos de capital. O índice procura estabelecer um nível máximo de alavancagem no setor bancário e introduzir salvaguardas adicionais contra o risco dos modelos e erros de medição por meio de um critério simples e transparente de alavancagem. Em razão disso, Loyola afirma que esse limite funcionaria como uma espécie de "seguro" para cobrir situações excepcionais não resguardadas pelas normas ordinárias de capital. $^{522}$ Naturalmente, para assegurar a comparabilidade internacional da razão de alavancagem, este deverá ser ajustado por diferenças nos padrões de contabilidade de cada país.

Finalmente, o Comitê de Basileia atenta para a questão da interconectividade dos bancos internacionais e a possibilidade de transmissão de choques negativos ao sistema financeiro e à economia em geral. Dessa forma, Basileia III propõe regras específicas de administração de riscos e provisionamento de capital no caso de instituições consideradas "sistemicamente relevantes", incluindo a possível introdução de uma "sobretaxa" de capital ou de liquidez para tais instituições.

Ainda é cedo para avaliar qual a extensão e o impacto das medidas supracitadas, uma vez que os prazos de implementação destas são bastante amplos, em alguns casos chegando até 2018. ${ }^{523}$ Além disso, a maioria das propostas, notadamente aquelas que representam inovações em relação aos acordos anteriores, depende ainda da definição de uma série de detalhes, bem como da implementação de mecanismos subjacentes ao funcionamento desses instrumentos. Justamente em razão disso, não é possível falar ainda em um novo acordo de Basileia, mas sim em audacioso plano de trabalho que ainda consumirá inúmeros meses, se não anos, antes que se traduza em medidas prudenciais concretas.

\footnotetext{
LOYOLA, Gustavo. O futuro da regulação financeira, p. 69.

523 O índice de alavancagem não ajustado ao risco será a princípio de $3 \%$ tomando como base o capital nuclear da instituição financeira (tier 1). O período de supervisão do índice de alavancagem teve início em janeiro de 2011, com o desenvolvimento de critérios para os bancos começarem a aplicá-lo. Haverá uma avaliação paralela nos anos seguintes em que o Comitê de Basileia irá fiscalizar a adequação e eficácia do índice de alavancagem, com previsão de definição do percentual final apenas em 2018.
} 


\subsubsection{Controles de adequação patrimonial}

Os controles de adequação patrimonial de instituições financeiras baseiam-se na noção de que o tamanho de capital que um banco detém em relação aos seus ativos é um dado de grande importância na análise da fragilidade do setor bancário. ${ }^{524}$ A racionalidade por trás da regulação de capital está intrinsecamente relacionada ao próprio processo de desenvolvimento da regulação prudencial descrito nos tópicos anteriores, principalmente a partir da implementação de Basileia I.

Segundo Mishkin, a adequação do nível de capital dos bancos ao seu grau de exposição a risco traz dois grandes benefícios, na medida em que cria um desincentivo à tomada excessiva de risco, bem como assegura uma margem de segurança para perdas inesperadas em operações financeiras, ajudando a proteger a higidez do setor bancário. ${ }^{525} \mathrm{~A}$ grande questão nesse ponto é saber quais riscos considerar em tal análise, e como determinar o grau adequado de capital para compensá-los. Basileia I contemplou inicialmente apenas o risco de crédito em sua estrutura, enquanto Basileia II incorporou o risco operacional, e Basileia III procura abordar o risco de liquidez. ${ }^{526}$

Apesar de sua larga disseminação como instrumento de regulação prudencial, representando na atualidade uma de suas principais ferramentas, a crise financeira recente corroborou preocupações em relação aos efeitos procíclicos desse mecanismo regulatório. Já se observou que Basileia III procurou endereçar essa questão por meio da proposição de um modelo de provisionamento com ajuste cíclico, em que os requerimentos de capital sejam maiores quando o crédito total do sistema estiver crescendo acima de sua tendência histórica,

\footnotetext{
524 BARTH, James R. et al. Rethinking bank regulation, p. 115.

525 MISHKIN, Frederic S. Prudential Supervision: why is it important and what are the issues, p. 10-11.

$526 \mathrm{O}$ risco de crédito se refere à possibilidade de inadimplemento em operações creditícias. Já o risco operacional foca na possibilidade de ocorrência de perdas resultantes de falha, deficiência ou inadequação de processos internos, pessoas e sistemas, ou mesmo eventos externos. Finalmente, o risco de liquidez se relaciona à capacidade de uma instituição financeira levantar o caixa necessário para rolar sua dívida para atender exigências de caixa, margem, garantias das contrapartes e de satisfazer retiradas de capital, ou seja, refere-se ao risco de que uma instituição não seja capaz de executar uma transação ao preço prevalente de mercado porque não há, temporariamente, qualquer interesse pelo negócio "na outra ponta" do mercado. Ver: GROUHY, Michel et al. Gerenciamento de risco: abordagem conceitual e prática. São Paulo: QualityMark, 2004.p. 34.
} 
e menores quando a situação for inversa. ${ }^{527}$ Além de atuar como um estabilizador endógeno, as sobras de capital nos momentos de alta do ciclo proporcionariam uma reserva para a fase recessiva. Naturalmente, modelos dessa natureza exigem a estimação de dados complexos, como a tendência histórica de expansão creditícia, sujeitando-o controvérsias. ${ }^{528}$ Isso não impediu, no entanto, a adoção do conceito em países como a Espanha, contando também com apoiadores de relevo nos quadros de supervisão bancária no Brasil. ${ }^{529}$

\subsubsection{Diretrizes de adequação patrimonial no Brasil ${ }^{530}$}

A implementação dos critérios estabelecidos em Basileia I iniciou-se em 17 de agosto de 1994, com a Resolução 2.099 do CMN. Até então, embora fossem adotados requisitos patrimoniais e formas de limitação de endividamento para instituições financeiras,

527 MESQUITA, Mário M. C.; TORÓS, Mário. Gestão do Banco Central no pânico de 2008, p. 200.

528 Idem, ibidem, p. 200.

529 MEIRELLES, Henrique. Reforço da regulação e supervisão e o seu papel na estabilidade do sistema financeiro. Pronunciamento do Presidente do Banco Central do Brasil na Reunião Extraordinária de Ministros Ibero-Americanos de Finanças, Porto, 2 mar. 2009. Disponível em: <www.bcb.gov.br/?PRONUNC2009008>. Acesso em: 26 dez. 2010; e MESQUITA, Mário M. C.; TORÓS, Mário. Gestão do Banco Central no pânico de 2008, p. 198.

$530 \mathrm{Na}$ esteira das considerações realizadas no início do trabalho acerca das delimitações conceituais que norteariam a análise ora empreendida, optou-se por não se tratar dos depósitos compulsórios no País como elemento de prevenção a crises bancárias. De forma sucinta, o depósito compulsório regula o multiplicador bancário, imobilizando parte maior ou menor dos depósitos bancários, restringindo ou alimentando a expansão dos meios de pagamento (FORTUNA, Eduardo. Mercado financeiro, p. 47). O regime de depósitos compulsórios no Brasil tem chamado a atenção da doutrina pela sua alegada contribuição na explicação de como bancos do SFN teriam reagido de forma positiva à crise recente. O elevado nível desses depósitos teria servido como importante limitador para o nível de alavancagem dos bancos, dificultando sua operação em larga escala em negócios de alto risco (VERÇOSA, Haroldo M. D. Considerações sobre o sistema financeiro, p. 20). Em razão disso, as autoridades bancárias pátrias têm sido inclusive "assediadas" por autoridades de outros países interessadas em "importar" aspectos do regime brasileiro de depósitos compulsórios (O ESTADO DE SÃO PAULO. Banco Central exporta tecnologia de reserva para a crise, 4 out. 2010, p. B7). Sem disputar a sua importância para evitar a manifestação dos efeitos da crise no País, o presente trabalho não tratará dessa discussão, uma vez que os depósitos compulsórios são tipicamente classificados como instrumento de política monetária, e não de regulação prudencial (FORTUNA, Eduardo. Mercado financeiro, p. 47). Com efeito, o nível de depósitos compulsórios é determinado pelo Bacen a fim de atender as metas de inflação fixadas pelo Copom. Embora não se negue aqui a relação entre instrumentos de política monetária e de regulação prudencial, este corte metodológico é necessário para viabilizar a análise que prosseguirá. 
não havia, porém, o balanceamento entre riscos assumidos e disponibilidade patrimonial para a realização de operações. ${ }^{531}$

A Resolução CMN 2.099/1994 e seus anexos I a IV provocaram mudanças significativas no arcabouço regulatório pátrio. Entre as alterações na regulação de capital, merecem destaque o aumento da exigência de capital e patrimônio líquido mínimos para o funcionamento das instituições financeiras, bem como a mudança da forma de acompanhamento dos limites de alavancagem operacional. Conforme ensinamento de Darcy e Muniz, referida Resolução modificou o enfoque em relação às regras anteriores, visto que a abordagem de supervisão baseada no patrimônio líquido das instituições como referência (i.e., no passivo) foi substituída pelo estabelecimento de limites em função do nível de risco de crédito gerado pelas operações realizadas pelas instituições. ${ }^{532}$ Além dessas mudanças, foram estabelecidas medidas de penalização para instituições que não se adequassem às novas diretrizes de adequação de capital, podendo-se chegar até mesmo à sua liquidação. ${ }^{53}$

Apesar de a Resolução e outras normas do Bacen terem incorporado a maioria das recomendações do Comitê de Basileia, cabe mencionar que alguns dos requerimentos impostos aos bancos são diferentes daqueles previstos em Basileia I, como: (i) o requisito de capital ajustado ao risco de $11 \%$, em vez dos $8 \%$ exigidos pelo acordo ${ }^{534}$ (ii) níveis de risco superiores para determinados ativos, incluindo uma ponderação pelo risco de $300 \%$ sobre créditos fiscais; ${ }^{535}$ e (iii) exigência de capital mínimo para abertura de instituições financeiras.

531 YAZBEK, Otavio. Regulação do mercado financeiro e de capitais, p. 244.

532 ALVES, Sérgio Darcy da Silva; ALVES, Tatiana Muniz Silva. A experiência brasileira de regulação: um caso de sucesso? In: GARCIA, Márcio; GIAMBIAGI, Fábio (Org.). Risco e regulação, p. 175.

533 LUNDBERG, Eduardo Luís. Rede de proteção e saneamento do sistema bancário. In: SADDI, Jairo (Org.). Intervenção e liquidação extrajudicial no Sistema Financeiro Nacional, p. 39-40.

534 Inicialmente adotou-se patamar de $8 \%$ igual ao proposto pelo Comitê de Basileia, que foi posteriormente elevado para 10\% pela Resolução CMN 2.399, de 25 de junho de 1997, e depois para 11\%, por meio da Circular Bacen 2.784, de 27 de novembro de 1997.

535 O quociente capital/APR deve ser de, no mínimo, $8 \%$, segundo Basileia I, ou 11\%, conforme adaptado pela autoridade bancária brasileira. Isso significa, por exemplo, que, para "operações de crédito em geral e outros créditos" (cujo percentual é de 100\%), deverão ser provisionados $11 \%$ de capital sobre o valor da operação, enquanto que para "créditos tributários" (com coeficiente de 300\%), é necessário provisionamento de 33\%. Ver: BARROS DE CASTRO, Lavinia. Regulação financeira, p. 280. 


\subsection{Capital mínimo}

A Resolução CMN 2.099/1994 estabeleceu em seu anexo II limites mínimos de capital realizado e patrimônio líquido para as instituições financeiras e demais instituições financeiras autorizadas a funcionar pelo Bacen. Os limites mínimos foram determinados de acordo com o tipo de instituição financeira pleiteando a autorização. Bancos comerciais, por exemplo, precisariam de $\mathrm{R} \$ 7$ milhões para operarem no País, enquanto bancos de investimento necessitariam de, no mínimo, $\mathrm{R} \$ 6$ milhões. Tratando-se de banco múltiplo, o somatório dos valores correspondentes às carteiras teria redução de $20 \%$. Os montantes de referência foram alterados posteriormente pela Resolução CMN 2.607, de 27 de maio de 1999, passando a vigorar atualmente com os seguintes valores:

Tabela 11: Capital mínimo para abertura de instituições financeiras

\begin{tabular}{|c|c|}
\hline Tipo & Capital Mínimo \\
\hline $\begin{array}{l}\text { Banco Comercial e carteira comercial de Banco } \\
\text { Múltiplo }\end{array}$ & $\mathrm{R} \$ 17.500 .000,00$ \\
\hline $\begin{array}{l}\text { Banco de Investimento, Banco de Desenvolvimento, } \\
\text { correspondentes carteiras de Banco Múltiplo e Caixa } \\
\text { Econômica }\end{array}$ & $\mathrm{R} \$ 12.500 .000,00$ \\
\hline $\begin{array}{l}\text { Sociedade de Crédito, Financiamento e Investimento, } \\
\text { Sociedade de Crédito Imobiliário, Sociedades de } \\
\text { Arrendamento Mercantil, e correspondentes carteiras de } \\
\text { Banco Múltiplo }\end{array}$ & $\mathrm{R} \$ 7.000 .000,00$ \\
\hline Companhia Hipotecária & $\mathrm{R} \$ 3.000 .000,00$ \\
\hline $\begin{array}{l}\text { Sociedade Corretora de Títulos e Valores Mobiliários e } \\
\text { Sociedade Distribuidora de Títulos e Valores } \\
\text { Mobiliários que administrem fundos de investimento } \\
\text { nas modalidades regulamentadas pelo Bacen }\end{array}$ & $\mathrm{R} \$ 1.500 .000,00$ \\
\hline $\begin{array}{l}\text { Sociedade Corretora de Títulos e Valores Mobiliários e } \\
\text { Sociedade Distribuidora de Títulos e Valores } \\
\text { Mobiliários que exerçam atividades não incluídas no } \\
\text { item anterior }\end{array}$ & $\mathrm{R} \$ 550.000,00$ \\
\hline Sociedade Corretora de Câmbio & $\mathrm{R} \$ 350.000,00$ \\
\hline
\end{tabular}


A esse respeito, vale mencionar que, até 1999, agências de instituições financeiras domiciliadas no exterior ou de bancos comerciais sob controle estrangeiro direto ou indireto, tinham um acréscimo de $100 \%$ no capital mínimo necessário para entrarem em funcionamento. Finalmente, a Resolução CMN 2.607/1999 também prevê incentivos para abertura de bancos em outras regiões do País fora dos Estados de São Paulo e Rio de Janeiro. No caso de instituição com sede de, no mínimo 90\% de suas dependências localizadas fora desses Estados, os valores de capital realizado e patrimônio líquido exigidos pelo normativo têm redução de $30 \%$.

\subsection{Patrimônio de Referência e exigências de composição de ativos}

O Patrimônio de Referência (PR) corresponde ao chamado "capital regulatório" nos acordos de Basileia, servindo como medida de capital utilizada para verificar o cumprimento dos limites operacionais das instituições autorizadas a funcionar no SFN. Nos termos da Resolução CMN 3.444, de 28 de fevereiro de 2007, o PR é composto basicamente pelo somatório do capital de nível I (correspondente ao capital tier 1, ou nuclear) e do capital de nível II (correspondente ao capital tier 2, ou suplementar), com as deduções previstas naquele instrumento normativo. A Circular Bacen 3.343, de 1. ${ }^{\circ}$ de março de 2007, dispõe sobre os procedimentos a serem adotados na solicitação ao Bacen para que instrumentos de captação integrem os níveis I e II do PR. A tabela da página a seguir apresenta a composição detalhada do PR em seus diferentes níveis: 


\section{Tabela 12: Composição do $\mathbf{P R}^{536}$}

\begin{tabular}{|c|c|}
\hline Nível I & $\begin{array}{l}\text { Corresponde à soma dos valores relativos ao patrimônio líquido, aos saldos das contas de } \\
\text { resultado credoras e ao depósito em conta vinculada para suprir deficiência de capital, } \\
\text { excluídos os valores correspondentes a: } \\
\text { (i) saldos das contas de resultado devedoras; } \\
\text { (ii) reservas de reavaliação, reservas para contingências e reservas especiais de lucros } \\
\text { relativas a dividendos obrigatórios não distribuídos; } \\
\text { (iii) ações preferenciais emitidas com cláusula de resgate e ações preferenciais com } \\
\text { cumulatividade de dividendos; } \\
\text { (iv) créditos tributários (definidos pela Resolução CMN } 3.059 \text {, de } 20 \text { de dezembro de } \\
\text { (v) ativo permanente diferido, deduzidos os ágios pagos na aquisição de investimentos; e } \\
\text { (vi) saldo dos ganhos e perdas não realizados decorrentes do ajuste ao valor de mercado } \\
\text { dos títulos de valores mobiliários classificados como "títulos disponíveis para venda" } \\
\text { e dos instrumentos financeiros derivativos utilizados para hedge de fluxo de caixa. }\end{array}$ \\
\hline Nível II & $\begin{array}{l}\text { Corresponde à soma dos valores equivalentes às reservas de reavaliação, às reservas para } \\
\text { contingências e às reservas especiais de lucros relativas a dividendos obrigatórios não } \\
\text { distribuídos, acrescida dos valores correspondentes a: } \\
\text { (i) instrumentos híbridos de capital e dívida, instrumentos de dívida subordinada, ações } \\
\text { preferenciais emitidas com cláusula de resgate e ações preferenciais com } \\
\text { cumulatividade de dividendos emitidos por instituições financeiras; e } \\
\text { (ii) saldo dos ganhos e perdas não realizados decorrentes do ajuste ao valor de mercado } \\
\text { dos títulos de valores mobiliários classificados como "títulos disponíveis para venda" } \\
\text { e dos instrumentos financeiros derivativos utilizados para hedge de fluxo de caixa. }\end{array}$ \\
\hline \multicolumn{2}{|c|}{ O valor total do Nível II não pode exceder o valor total de Nível I, sendo que: } \\
\hline $\begin{array}{l}\text { (i) } \\
\text { (ii) }\end{array}$ & $\begin{array}{l}\text { montante das reservas de reavaliação fica limitado a } 25 \% \text { do valor do Nível I; } \\
\text { vencimento inferior a dez anos, acrescido do valor dos instrumentos de dívida subordinada, fica } \\
\text { limitado a } 50 \% \text { do valor do Nível I; e } \\
\text { um redutor de } 20 \% \text { deve ser aplicado aos valores das dívidas subordinadas e ações preferenciais } \\
\text { emitidas com cláusula de resgate integrantes do Nível II a cada ano dos cinco anos imediatamente } \\
\text { anteriores ao respectivo vencimento. }\end{array}$ \\
\hline
\end{tabular}

Fonte: Resolução CMN 3.444/2007.

536 Em razão da diversidade de categorias de ativos que integram os níveis do PR, estes se encontram sujeitos a revisões periódicas quanto à sua forma de cálculo e composição, com grau de detalhamento técnico que fugiria ao escopo deste trabalho se aprofundar. Para uma revisão detalhada das normas que regulamentam o PR, as limitações operacionais decorrentes e suas modificações nos últimos anos, ver: ALVES, Sérgio Darcy da Silva; ALVES, Tatiana Muniz Silva. A experiência brasileira de regulação; e GUIMARÃES, André Luiz de Souza; LIMA, Jorge Cláudio Cavalcante de Oliveira. Avaliação do risco de crédito no Brasil. 
O PR também é utilizado como critério para estabelecer uma série de limites operacionais nas atividades das instituições financeiras. A Resolução CMN 2.844, de 29 de junho de 2001, dispõe que as instituições financeiras não podem ter mais de $25 \%$ de seu PR alocado em transações de crédito (inclusive garantias) concedidas a um mesmo cliente (inclusive do mesmo grupo econômico), não podendo também atuar como subscritores de valores mobiliários de um único emissor representando mais que 25\% de seu PR. Além disso, os ativos fixos dessas instituições não podem exceder 50\% do valor de seu PR.

Vale mencionar também que devem ser deduzidos do PR valores correspondentes a dependência ou participação em instituição financeira no exterior em relação às quais o Bacen não tenha acesso a informações, dados e documentos suficientes para fins de sua supervisão. Essas e outras limitações mencionadas seguem em linha com a publicação dos Princípios Fundamentais para uma Supervisão Bancária Efetiva do Comitê de Basileia. ${ }^{537}$ Assim, conforme a ressalva de Guimarães e Silva, enquanto no resto do mundo tais princípios eram vistos como recomendações, no Brasil foram traduzidos em determinações do órgão regulador. $^{538}$

\subsection{Classificação de crédito}

Até o final da década de 1990 as operações de crédito eram objeto de regramento pela Resolução CMN 1.784, de 30 de agosto de 1990, que classificava o risco de crédito de acordo com as garantias oferecidas e o atraso na liquidação da obrigação. ${ }^{539}$ Esse quadro foi alterado com a Resolução CMN 2.682, de 21 de dezembro de 1999, que ampliou os parâmetros existentes para considerar: (i) as características dos devedores e seus garantidores, como sua condição econômica e financeira, setor de atividade, níveis de endividamento, capacidade de gerar lucros, fluxo de caixa, administração e métodos de controle de qualidade, limites de contingenciamento de crédito e atrasos no pagamento; e (ii) as características dos

537 COMITÊ DE BASILEIA. Princípios fundamentais para uma supervisão bancária efetiva, Basileia, out. 2006.

538 GUIMARÃES, André Luiz de Souza; LIMA, Jorge Cláudio Cavalcante de Oliveira. Avaliação do risco de crédito no Brasil, p. 215.

539 SADDI, Jairo. Crise e regulação bancária, p. 119. 
termos da transação, como sua natureza e objetivo, suficiência das garantias, com atenção especial para o nível de liquidez e o valor total do crédito dessas garantias.

No modelo atual as classificações de crédito devem ser revisadas com periodicidade diversa, considerando-se diferentes elementos para a determinação do grau de risco. No caso de atraso nos pagamentos, há nove categorias de risco de acordo com o prazo decorrido do vencimento do pagamento, cada qual correspondendo a um grau de provisionamento daquele crédito, conforme se pode observar no quadro abaixo:

Tabela 13: Regras para provisionamento de créditos em atraso

\begin{tabular}{|l|c|c|}
\hline \multicolumn{1}{|c|}{ Atraso } & Nível de Risco & Provisionamento (*) \\
\hline 1 a 14 após o vencimento & A & $0,5 \%$ \\
\hline 15 a 30 dias após vencimento & B & $1,0 \%$ \\
\hline 31 a 60 dias após vencimento & C & $3,0 \%$ \\
\hline 61 a 90 dias após vencimento & D & $10,0 \%$ \\
\hline 91 a 120 dias após vencimento & E & $30,0 \%$ \\
\hline 121 a 150 dias após vencimento & F & $50,0 \%$ \\
\hline 151 a 180 dias após vencimento & G & $70,0 \%$ \\
\hline Mais de 180 dias após vencimento & H & $100,0 \%$ \\
\hline
\end{tabular}

(*) Percentual do valor total da operação de crédito que deve ser provisionado. Fonte: Resolução CMN 2.682/1999.

O nível de risco e a periodicidade de verificação e provisionamento podem, no entanto, sofrer alterações de acordo com características e contexto específico de cada caso. Operações de crédito envolvendo um mesmo cliente ou grupo econômico, por exemplo, devem ser definidas considerando aquela que representar o maior risco de crédito para as instituições financeiras. No caso de operações envolvendo o mesmo cliente ou grupo econômico cujo montante seja superior a 5\% do patrimônio líquido da instituição financeira, as classificações de crédito devem ser revisadas semestralmente. Nos outros casos, exceto quando o passivo do cliente na operação de crédito for inferior a $\mathrm{R} \$ 50 \mathrm{mil},{ }^{540}$ serão revisadas anualmente. $\mathrm{O}$ descumprimento de tais exigências estabelecidas pelo Bacen resultará na reclassificação de qualquer transação para o nível de risco $\mathrm{H}$.

540 Nesses casos a classificação é feita apenas quando ocorre um atraso no pagamento. 
Finalmente, a Resolução também determina que as instituições devem manter à disposição do Bacen sua política e seus procedimentos, devidamente documentados, para concessão e classificação de operações de crédito. A documentação deve evidenciar, no mínimo, o tipo e os níveis de risco que se dispõe a administrar, os requerimentos básicos exigidos para a concessão de empréstimos e o processo de autorização.

\subsubsection{Mecanismos de controle de acesso}

A autorização para funcionamento permite que a instituição financeira passe a integrar uma ou mais categorias de intermediários financeiros, podendo realizar as atividades a ela concernentes, conforme os regimes legais estabelecidos. ${ }^{541}$ Segundo Yazbek, trata-se de uma forma de controle de acesso ao mercado, apoiada sobre o estabelecimento de condições diversas e procedimentos específicos. ${ }^{542}$

No caso bancário, os argumentos apresentados para justificar o controle do acesso ao setor são variados. Em primeiro lugar, o controle seria necessário para evitar a entrada de bancos de "baixa qualidade", referindo-se àquelas instituições com baixo nível de capitalização, ou mesmo instituições controladas ou associadas a pessoas inidôneas, com maior tendência a praticar fraudes e sujeitar o setor a crises de confiança. Além disso, o controle de entrada dos bancos seria também uma forma de manter o número de instituições atuantes no mercado compatível com a capacidade de supervisão da autoridade bancária. ${ }^{543}$ Por fim, um argumento polêmico, porém utilizado com frequência para justificar a existência de mecanismos de controle de acesso, refere-se à necessidade de limitar a concorrência no setor para evitar a prática de taxas de juros muito agressivas que pudessem colocar em risco as operações dos bancos. ${ }^{544}$

\footnotetext{
541 YAZBEK, Otavio. Regulação do mercado financeiro e de capitais, p. 242.

542 Idem, ibidem, p. 242.

543 BARTH, James R. et al. Rethinking bank regulation, p. 111.

544 Há um acirrado debate na doutrina jurídica e econômica a respeito da interface entre regulação e concorrência no setor bancário, marcado por dois posicionamentos diametralmente opostos sobre a questão. Uma linha de estudos defende que o aumento da concorrência levaria os bancos a adotar posturas mais agressivas no tocante à sua alocação de ativos, com o objetivo de aumentar a lucratividade, consequentemente aumentando o risco de suas operações, o que poderia ocasionar o aumento da ocorrência de quebras bancárias. Segundo os defensores dessa corrente, quanto
} 
mais competitivo o setor, menor sua estabilidade (para um resumo da literatura sobre essa corrente, ver: NORTHCOTT, Carol Ann. Competition in banking: a review of the literature. Working Paper, Bank of Canada, $\mathrm{n}$. 2004-24, 2004). Os modelos que se baseiam na existência desse trade-off inevitável entre concorrência e estabilidade geralmente se apoiam na existência de assimetrias informacionais no setor bancário, o que impediria seus participantes de distinguir entre bons e maus pagadores, de modo que a concorrência excessiva entre os bancos e o incentivo para ampliar a oferta de crédito com a finalidade de conquistar mercado poderiam contaminar sua carteira de crédito, aumentando o risco de inadimplência e instabilidade no sistema. Por outro lado, a diminuição da concorrência aumentaria a estabilidade do setor, uma vez que bancos teriam lucros maiores e mais previsíveis, diminuindo o incentivo à tomada de risco excessivo. Outra corrente teórica segue em linha diametralmente oposta, afirmando que o aumento da competição no setor bancário favoreceria uma alocação de recursos mais eficiente, sem prejuízo da estabilidade para o sistema financeiro. Para Fonseca Ferreira, não haveria evidências claras de que a restrição à concorrência fomentaria a criação de bancos mais robustos a choques (FERREIRA, Caio Fonseca. Estrutura, concorrência e performance do setor bancário em um mercado heterogêneo. 2005. Tese (Doutorado) FEA-USP, São Paulo, p. 27-30. Mimeografado). Pelo contrário, um baixo grau de concorrência facilitaria a permanência de bancos ineficientes no mercado, que estariam mais propensos à quebra em momentos de instabilidade. Nas palavras de Mishkin: "Embora restringir a concorrência possa melhorar a saúde dos bancos, ela também traz sérias desvantagens: ela pode levar a tarifas mais caras para os clientes e diminuir a eficiência dos bancos, que não terão de competir como antes. Dessa forma, ainda que a existência de assimetrias informacionais possa justificar restrições à concorrência, isso não significa que elas sejam benéficas. De fato, em anos recentes, o impulso de governos em países industrializados para restringir a concorrência no setor vem se arrefecendo" (MISHKIN, Frederic S. Prudential Supervision: why is it important and what are the issues, p. 9-10. Tradução livre). Além disso, mesmo que a competição fosse considerada prejudicial à estabilidade do sistema financeiro, não se pode inferir de imediato que o sacrifício desta leve a maior bem-estar, uma vez que um sistema protegido apresenta custos, como ineficiências gerenciais. Aqui vale ressaltar que esses custos são pagos continuamente, enquanto as crises bancárias costumam ocorrer de tempos em tempos. Um corpo crescente de trabalhos empíricos tem encontrado evidências de que um maior grau de concorrência aumenta a estabilidade no setor bancário (para uma revisão da literatura sobre essa corrente, ver: BERGER, Allen N. et al. Bank concentration and competition: an evolution in the making, Wharton Financial Institutions Center, set. 2003). Levando em conta dados de 79 países, Beck et al. afirmam que a liberalização e a promoção da concorrência no setor bancário - medida indiretamente por variável que considera o grau de abertura e de independência do sistema financeiro - reduzem significativamente a probabilidade de ocorrência de crises bancárias (BECK, Thorsten et al. Bank concentration and fragility: impact and mechanics. In: CAREY, Mark; STULZ, Rene (Org.). Risks of financial institutions. Cambridge: National Bureau of Economic Research, 2006; e BECK, Thorsten et al. Bank concentration and crises. Working Paper, World Bank, n. 3.041, 2003). Em trabalho comparativo envolvendo mais de 150 países, Barth et al. também apontam evidências de que a concorrência estaria negativamente correlacionada às crises bancárias (BARTH, James R. et al. Rethinking bank regulation). Na literatura nacional, Curi e Sanches partem da mesma base de dados de Beck et al. e adicionam uma medida direta de concorrência, a "estatística H" de Panzar e Rosse, para mensurar a competitividade do setor bancário. A estatística H é um indicador comumente utilizado para medir a competitividade nesses casos, assumindo valores menores ou iguais a 0 se determinado mercado é um monopólio (cartel), valores iguais a 1 se determinado mercado encontra-se em concorrência perfeita, ou valores entre 0 e 1 se determinado mercado se encontra em concorrência monopolística ou em oligopólio. Os autores encontram evidências de que países com sistemas bancários monopolizados (estatística $\mathrm{H}$ igual a 0 ) têm aproximadamente $80 \%$ de chances de ocorrência de uma crise bancária. Por outro lado, países com estatísticas H próximas a 0,5 - o que caracteriza um sistema bancário oligopolizado ou em concorrência monopolística - apresentam probabilidade de crise bancária inferior a $10 \%$. Grosso modo, a análise dos autores aponta para uma correlação negativa e estatisticamente significativa entre o grau de concorrência e a ocorrência de crises bancárias (CURI, Andréa Zaitune; SANCHES, Fabio Miessi. Não há tradeoff inevitável entre concorrência e estabilidade bancária. Economic Toolbox, Tendências Consultoria, 2006). Vale mencionar que esse posicionamento também é acompanhado pelas experiências de autoridades concorrenciais em outras jurisdições que, contrariando a hipótese de oposição inexorável entre concorrência e estabilidade, têm demonstrado que as políticas regulatórias para o setor são compatíveis com a concorrência (OLIVEIRA, Gesner. Defesa da concorrência e regulação no setor bancário, 2002, p. 161). Nesse sentido, menciona-se o posicionamento de Guerin-Calvert, ex-economista da divisão antitruste do DOJ: "A experiência dos Estados Unidos tem demonstrado que a política antitruste, incluindo a aplicação vigorosa das leis antitruste, é compatível com o objetivo de assegurar um setor bancário sadio e seguro" (GUERIN-CALVERT, Margaret. The 1992 Agency Horizontal Merger Guidelines and the Department of Justice's approach to bank merger analyis. Antitrust Bulletin, n. 667, p. 370, 1992, apud OLIVEIRA, Gesner de. Defesa da concorrência e regulação no setor bancário. EAESP/FGV/NPP - 
A autorização para funcionamento desempenha, portanto, importante papel na redução das assimetrias informacionais presentes no setor por intermédio da definição ex ante de categorias operacionais e de padrões de qualificação, técnica e financeira, e da consequente verificação do atendimento a esses requisitos. Para os participantes do mercado - e correntistas em especial -, se determinada instituição cumpriu com os requisitos que a permitem operar no sistema financeiro, presume-se que ela ofereça um mínimo de segurança, ou então não teria recebido autorização para funcionamento do regulador. ${ }^{545}$

\subsubsection{Autorização para funcionamento pelo Banco Central}

$\mathrm{O}$ art. 4. ${ }^{\circ}$, VIII, da Lei 4.595/1964 atribui ao CMN a competência para regular a constituição, funcionamento e fiscalização das instituições que exercem atividades subordinadas à lei, enquanto o art. 10, X, estabelece a autoridade do Bacen para conceder as autorizações correspondentes. Durante muitos anos esse sistema funcionou mediante a concessão de cartas-patentes, em que o CMN fixava um número máximo de instituições (e até mesmo agências) que poderiam ser autorizadas pelo Bacen a atuar no mercado. Isso foi alterado, no entanto, com a promulgação da Constituição Federal de 1988, que na redação original de seu art. 192, § 1. ${ }^{\circ}$, estipulou que as autorizações para o funcionamento de novas instituições passariam a ter caráter inegociável e intransferível, sendo concedidas sem ônus às instituições financeiras que preenchessem os requisitos técnicos previstos em lei.

$\mathrm{O}$ acesso das instituições financeiras ao SFN na atualidade é determinado pelas disposições constantes no regulamento anexo à Resolução CMN 3.040, de 28 de novembro de 2002, que disciplina a autorização para o funcionamento, a transferência de controle acionário e a reorganização societária, bem como o cancelamento da autorização para funcionamento de

Núcleo de Pesquisas e Publicações, p. 45, 2000. Mimeografado. Tradução livre). No Brasil, o ex-Secretário de Direito Econômico Daniel Krepel Goldberg exarou posicionamento semelhante a respeito do assunto. Segundo o autor: "De qualquer forma, mesmo que tenhamos algum conflito entre concorrência e o papel do regulador, parece razoável admitir que, na presença de um regulador e um supervisor bancário atuante, há espaço, na indústria bancária, para competição bastante vibrante, sem que se coloque em risco a higidez do sistema financeiro" (GOLDBERG, Daniel K. Spread, concentração e concorrência no setor bancário. Revista do Ibrac, v. 11, n. 3, p. 6970, 2004). Vale mencionar que esse posicionamento foi reiterado recentemente por Ana Paula Martinez, ex-diretora do Departamento de Proteção e Defesa Econômica da Secretaria de Direito Econômico. Ver: VALOR ECONÔMICO. A concorrência no setor bancário no Brasil, 22 out. 2008, p. E2.

545 YAZBEK, Otavio. Regulação do mercado financeiro e de capitais, p. 242-243. 
bancos múltiplos, bancos comerciais e bancos de investimento, entre outros. Conforme o disposto no art. 2. ${ }^{\circ}$ da Resolução, os pedidos de autorização serão objeto de estudo pelo Bacen visando a sua aceitação ou recusa.

No processo de constituição deve ser indicado um responsável pela condução do pedido junto ao Bacen, bem como identificado o grupo organizador da nova instituição, do qual devem participar representantes do futuro grupo de controle e dos futuros detentores de participação qualificada. Além disso, o art. 5. ${ }^{\circ}$ do regulamento estabelece uma série de condições para a apresentação da proposta, quais sejam:

1. Apresentação de documentos diversos, levando em consideração a natureza e o porte da instituição envolvida, incluindo: (i) estudo de viabilidade com (a) análise econômica e financeira dos segmentos de mercado na região em que pretende atuar e projeção da participação nesses segmentos com indicação dos principais concorrentes em cada um, (b) expectativa de rentabilidade, com indicação de retornos esperados em cada um dos segmentos de mercado escolhidos, e (c) projeções financeiras evidenciando a evolução patrimonial no período, com a identificação das fontes de captação que viabilizem essa evolução; (ii) plano de negócios indicando (a) o detalhamento da estrutura organizacional proposta, com determinação das responsabilidades atribuídas aos diversos níveis da instituição, (b) especificação da estrutura dos controles internos, evidenciando mecanismos que garantam adequada supervisão por parte da administração e a efetiva utilização de auditoria interna e externa como instrumentos de controle, (c) estabelecimento de objetivos estratégicos, (d) definição dos principais produtos e serviços a serem operados e público-alvo, (e) tecnologias a serem utilizadas na colocação dos produtos e dimensionamento da rede de atendimento, (f) definição do prazo máximo para início das atividades após a concessão, pelo Bacen, da autorização para funcionamento, (g) descrição dos critérios empregados na escolha dos administradores, bem como 
identificação destes últimos quando solicitada pelo Bacen; e (iii) definição dos padrões de governança corporativa a serem observados, incluindo-se o detalhamento da estrutura de incentivos e da política de remuneração;

2. Indicação da composição do grupo de controle da instituição;

3. Demonstração de capacidade econômico-financeira compatível com o porte, natureza e objetivo do empreendimento, a ser atendida, a critério do Bacen, individualmente por acionista controlador ou pelo grupo de controle; e

4. Inexistência de restrições que possam, a juízo do Bacen, afetar a reputação dos controladores.

Após o início das atividades da instituição, cabe ao Bacen conceder autorização para uma série de atos societários e negociais, como a transformação, fusão ou incorporação desta. ${ }^{546}$ As instituições supervisionadas pela autarquia precisam, igualmente, de autorização para alterar seus estatutos ou, ainda, para alienar ou, por qualquer outra forma, transferir o seu controle acionário. ${ }^{547}$

Finalmente, o Bacen pode também estabelecer condições para a posse e exercício de quaisquer cargos de administração de instituições financeiras privadas, assim como para o exercício de quaisquer funções em órgãos consultivos, fiscais e semelhantes. ${ }^{548}$ Nesse sentido, em complemento à Resolução CMN 3.040/2002, a Resolução CMN 3.041, de 29 de novembro de 2002, estabeleceu novos critérios para a avaliação da qualidade técnica da administração de instituições públicas e privadas que já atuavam ou que pretendiam atuar no

\footnotetext{
546 Para uma discussão a respeito da relação entre as competências do Bacen previstas no art. 10, X, da Lei 4595/1964, com as atribuições do Cade previstas na Lei 8.884/1994, ver: SUNDFELD, Carlos Ari. Concorrência e regulação no sistema financeiro, p. 43-45.

547 JANTALIA, Fabiano. Curso de regulação do Sistema Financeiro Nacional. Brasília: Programa Saber Direito, 2009. p. 13.

548 Idem, ibidem, p. 14.
} 
SFN. Entre as condições básicas para o exercício de cargos estatutários em instituições financeiras, podem-se mencionar: (i) gozar de reputação ilibada; (ii) ser residente no País, nos casos de diretor, de sócio-gerente e de conselheiro fiscal; (iii) não estar impedido por lei especial, nem condenado por crime falimentar ou contra a economia popular, a fé pública, a propriedade ou o SFN, ou condenado a pena criminal que vede o acesso a cargos públicos; (iv) não estar declarado inabilitado ou suspenso para o exercício de cargos de conselheiro de administração, de diretor ou de sócio-gerente; (v) não responder, nem qualquer empresa da qual seja controlador ou administrador, por pendências relativas a protesto de títulos, cobranças judiciais, emissão de cheques sem fundos, inadimplemento de obrigações e outras ocorrências ou circunstâncias análogas; e (vi) não estar declarado falido ou insolvente, nem ter participado da administração ou ter controlado firma ou sociedade concordatária ou insolvente.

Observa-se, portanto, a existência de inúmeras regras que disciplinam a entrada de instituições financeiras no SFN, ou mesmo para o exercício de cargos em tais entidades. Nesse aspecto, pode-se constatar que, apesar de a Constituição Federal de 1988 ter representado um esforço para ampliar o acesso ao setor bancário, o processo ainda depende, em larga medida, do juízo discricionário do Bacen. Aqui vale notar que, segundo dados coletados da própria autarquia no ano de 2000, de 27 pedidos de autorização domésticos para ingresso no SFN, 20 foram negados. De forma semelhante, de 12 pedidos de autorização de instituições estrangeiras para operar no SFN, 9 foram negados. ${ }^{549}$ Tomando como base apenas os dados de 2000, ressalta-se que o índice de rejeição para instituições estrangeiras situa-se em patamar consideravelmente superior à média de $30 \%$ observada internacionalmente. ${ }^{550}$

549 BARTH, James R. et al. Bank regulation and supervision database (1998-2000). Disponível em: <siteresources.worldbank.org/INTRES/Resources/4692321107449512766/Caprio_2000_banking_regulatio n_database.xls>. Acesso em: 23 dez. 2010. Infelizmente não há disponibilização de dados referentes a outros anos ou apresentação da justificativa da autoridade bancária para recusar a autorização para funcionamento.

550 BARTH, James R. et al. Foreign banking: do countries' WTO commitments match actual practices? Staff Working Paper, World Trade Organization, n. ERSD-2006-11, p. 23, out. 2006. 


\subsubsection{Supervisão e envio de informações}

Para conter os incentivos à tomada excessiva de risco por instituições financeiras, não basta haver simplesmente regras voltadas à diminuição desses incentivos, ou "filtragem" dos candidatos que pretendam ingressar no setor. É preciso, também, que a autoridade bancária assuma postura ativa de supervisão e acompanhamento do perfil de risco das instituições financeiras. Ou seja, deve haver monitoramento e fiscalização contínuos das atividades desenvolvidas pelas instituições atuantes no setor.

Esse monitoramento das instituições financeiras é feito tradicionalmente de duas formas, que atuam de modo complementar. ${ }^{551}$ Em primeiro lugar, tem-se a chamada supervisão indireta, em que instituições financeiras são objeto de análise a partir de mecanismos de envio de informações e do recurso a bancos de dados de informações periodicamente encaminhadas à autoridade responsável pela supervisão do setor. Trata-se de verificação realizada a distância, em que a presença física na instituição supervisionada não é necessária. As informações solicitadas são geralmente administradas por centrais de risco de crédito, que coletam informações dos participantes do sistema financeiro periodicamente, apresentando-as de forma individual ou agregada, conforme a necessidade da autoridade bancária.

Em segundo lugar, tem-se a supervisão ou inspeção direta, representando a fiscalização propriamente dita, efetuada por meio de exames in loco e da elaboração de relatórios específicos. Trata-se de verificação realizada na própria instituição supervisionada, incluindo avaliação objetiva e profunda de sua situação e viabilidade futura. Essa inspeção é feita apenas em casos específicos, geralmente quando a supervisão indireta chamou a atenção da autoridade para algum ponto da instituição financeira que mereça análise mais atenta.

Além dessas duas formas tradicionais de monitoramento bancário, vem ganhando destaque após a crise financeira recente outra forma de supervisão prudencial, que são os chamados testes de resistência, em que se procura estimar as perdas sofridas por uma instituição financeira com determinada carteira de ativos, não apenas nas condições normais

551 JANTALIA, Fabiano. Curso de regulação do Sistema Financeiro Nacional, p. 14. 
de volatilidade de mercado, isto é, aquelas derivadas da experiência passada, mas também em circunstâncias particularmente graves concebidas pela autoridade bancária. O Brasil, conforme se observará a seguir, adota essas três modalidades de supervisão e envio de informações.

\subsubsection{Supervisão indireta pelo Banco Central}

A supervisão indireta das instituições que integram o SFN é conduzida pelo Bacen mediante o monitoramento, por meio eletrônico, da situação econômico-financeira, atendimento aos limites operacionais e riscos incorridos pelas instituições financeiras sob sua supervisão. ${ }^{552}$ Esse monitoramento é baseado na coleta e análise das informações enviadas pelas instituições e conta com o suporte de sistemas desenvolvidos pelo Bacen para o bom exercício de suas funções. Entre os instrumentos utilizados pela autarquia, destacam-se o: (i) Sistema de Informações sobre Entidades de Interesse do Bacen (Unicad) e (ii) Sistema Central de Risco (SCR).

O Unicad é o sistema que substituiu o Cadastro de Instituições Financeiras (Cadinf) e o Cadastro de Pessoas Físicas (Capef) do Bacen. Ele contém informações cadastrais das instituições supervisionadas pela autarquia e de outras entidades relacionadas a tais instituições, ou que estejam inseridas em sua área de atuação, como agências de turismo, empresas que operam no mercado de câmbio e outros. Dessa forma, ficam ali registradas informações referentes à: (i) constituição, funcionamento e cancelamento da instituição financeira (mudança de denominação social, por exemplo); (ii) capital social (aumentos ou reduções de capital, por exemplo); e (iii) composição da administração (alteração da situação de membro estatutário, por exemplo).

Além da consulta a dados cadastrais das instituições supervisionadas pelo Bacen, existem na atualidade mecanismos privados e públicos de acompanhamento de risco de crédito. Os mecanismos privados focam no chamado cadastro negativo de crédito de tomadores individuais, enquanto os mecanismos públicos se voltam para o cadastro positivo

552 JANTALIA, Fabiano. Curso de regulação do Sistema Financeiro Nacional, p. 14. 
de crédito da instituição financeira como um todo. ${ }^{553}$ A principal diferença entre ambos é que nos cadastros negativos somente há registro sobre o cliente quando ocorre algum fato desabonador, como o inadimplemento, enquanto no cadastro positivo são registradas todas as operações acima de um determinado valor, não importando se em atraso ou em dia. Os cadastros positivos apresentam a vantagem de oferecer um quadro mais abrangente do crédito de um indivíduo, tipicamente incluindo registros de todas as operações de crédito, especialmente informações referentes a todos os pagamentos honrados. Dessa forma, o sistema supre uma lacuna no mercado privado de suprimento de informações creditícias, em que tipicamente somente informação negativa é compartilhada.

Entre os principais mecanismos públicos de informação de crédito encontram-se o SCR e o Cadastro Informativo de Créditos não Quitados do Setor Público Federal (Cadin). ${ }^{554} \mathrm{O}$ propósito principal do SCR é o suporte a atividades de supervisão, enquanto o Cadin registra débitos não pagos perante o Governo Federal, incluindo aí débitos fiscais e contribuições patronais de previdência social, entre outros. ${ }^{555}$ Ambos os sistemas de informação são operados pelo Bacen e possuem amparo legal para coletar e compartilhar

553 Existem três principais mecanismos privados de informação de crédito no Brasil: a Serasa Experian (Serasa), o Serviço Central de Proteção ao Crédito (SCPC) e a Equifax. A Serasa foi criada pelos bancos domésticos brasileiros em 1968, e é atualmente o maior serviço privado de informação de crédito no País. Segundo dados de 2005, cerca de 6.000 instituições fornecem informações à Serasa, incluindo 200 bancos. O seu banco de dados contém informação sobre 65 milhões de indivíduos e cerca de 10,7 milhões de firmas, e a empresa possui mais de 300.000 clientes diretos e indiretos que realizam cerca de 2,5 milhões de consultas diárias. O SCPC é um serviço controlado e operado pela Câmara de Comércio de São Paulo, estando conectado a câmaras de comércio em centenas de cidades por todo o Brasil. Ao contrário da Serasa e Equifax, o SCPC não tem fins lucrativos. Seu foco principal é a rede varejista, contando com um banco de dados sobre 10 milhões de indivíduos e fornecendo informações para aproximadamente 100 mil usuários. A Equifax concentra seus serviços no provimento de informações de crédito empresarial. A empresa possui registros sobre 11,5 milhões de empresas e cerca de 7,5 milhões de consumidores, fornecendo tais informações para aproximadamente 25.000 usuários. Dados referentes ao ano de 2005 disponíveis em: BANCO MUNDIAL. Sistemas de informação sobre créditos e empréstimos no Brasil. Iniciativa de sistemas de informação sobre créditos e empréstimos do hemisfério ocidental, mar. 2005, p. 22-27. Disponível em: <www.whcri.org/PDF/report_brasl-pt.pdf>. Acesso em: 26 dez. 2010.

554 Há ainda outros bancos de dados operados pelo Bacen, como o Registro Comum de Operações Rurais (Recor), o Sistema de Registro de Operações de Crédito com o Setor Público (Cadip), além do Cadastro de Emitentes de Cheques sem Fundos (CCF).

555 O Cadin foi criado em 1993 com o objetivo de bloquear o acesso ao crédito público para firmas e indivíduos que se encontrassem inadimplentes com instituições oficiais ou em relação a obrigações tributárias, expandindo-se desde então para todos os órgãos públicos federais. Inicialmente somente instituições financeiras públicas podiam acessar o sistema, mas atualmente qualquer órgão público pode fazê-lo. Ver: BANCO MUNDIAL. Sistemas de informação sobre créditos e empréstimos no Brasil, p. 34. 
informações entre as instituições participantes do SFN na Lei Complementar 105, de 10 de janeiro de $2001 .^{556}$

O embrião do SCR foi a Central de Risco de Crédito (CRC), criada por meio da Resolução CMN 2.390, de 22 de maio de 1997, posteriormente substituída pela Resolução CMN 2.724, de 31 de maio de 2000. No sistema da CRC, as instituições financeiras tinham que identificar e informar à autoridade os clientes com saldo devedor igual ou superior a $\mathrm{R} \$ 50$ mil. Essas informações podiam ser disponibilizadas a outras instituições financeiras, desde que com a permissão do titular da conta, e seu principal objetivo era servir como ferramenta de auxílio na supervisão dessas instituições e prover um mecanismo público de informações creditícias, aumentando o acesso a dados relevantes para análises de crédito. ${ }^{557}$

O SCR substituiu a CRC em 2004, sendo atualmente o principal instrumento utilizado pela supervisão bancária para acompanhar as carteiras de crédito das instituições financeiras. ${ }^{558}$ Trata-se do maior cadastro brasileiro baseado em informações positivas e contém dados sobre o comportamento dos clientes no que se refere às suas obrigações contraídas no SFN. ${ }^{559}$ No novo sistema, as instituições financeiras devem fornecer informações mensalmente sobre as operações dos clientes com responsabilidade total igual ou superior a $\mathrm{R} \$ 5$ mil, a vencer ou vencidas, e os valores referentes a fianças e avais prestados pelas instituições financeiras a seus clientes, bem como dados agregados pertinentes à sua carteira de crédito. Ao diminuir o valor global das operações a serem reportadas, o SCR ampliou consideravelmente a abrangência das informações a respeito dos tomadores de crédito. Além disso, o novo sistema possui maior qualidade de informação do que o antigo CRC, facilitando a consulta e o acompanhamento da situação das instituições financeiras. ${ }^{560}$

\footnotetext{
556 A Lei Complementar 105/2001 exclui expressamente do dever de sigilo bancário "a troca de informações entre instituições financeiras, para fins cadastrais, inclusive por intermédio de centrais de crédito, observadas as normas baixadas pelo CMN e pelo Bacen” (art. 1. $\left.{ }^{\circ}, \S 3 .^{\circ}, \mathrm{I}\right)$.

557 O art. 3. ${ }^{\circ}$ da Resolução CMN 2.724/2000 afirma expressamente: "As instituições mencionadas no art. 1. poderão consultar as informações consolidadas por cliente constantes do sistema, desde que obtida autorização específica do cliente para essa finalidade".

558 BANCO CENTRAL DO BRASIL. Sistema de informações de crédito do Banco Central, 2004. Disponível em: <www.bcb.gov.br/fis/crc/ftp/cartilhascr.pdf>. Acesso em: 28 dez. 2010.

559 Idem, ibidem.

560 Aspecto importante a respeito do SRC é que devedores (tanto pessoas físicas quanto jurídicas) podem solicitar o acesso aos próprios dados, o que inclui a identificação de credores, de qualquer uma das dez
} 
De fato, o sistema é considerado parte fundamental da estratégia do Bacen para cálculo de requisitos de capital para instituições financeiras na implementação de Basileia II. ${ }^{561}$

\subsubsection{Supervisão direta pelo Banco Central}

A supervisão direta é feita pela inspeção in loco dos técnicos do Bacen. Ela normalmente ocorre em fase posterior à indireta, com base nos resultados ou suspeitas levantadas pela fiscalização da autarquia quanto às informações e dados analisados previamente. No entanto, a supervisão direta ultrapassa a mera auditoria dos registros da instituição ou a verificação e teste de suas transações, voltando-se também à análise dos riscos inerentes a cada área ou atividade e à avaliação do controle que a administração exerce sobre eles, com a identificação dos pontos fracos que possam provocar falhas. Seu objetivo é avaliar os riscos e os controles internos da instituição, bem como a atuação da alta administração na manutenção de sua solidez e regular funcionamento. ${ }^{562}$

A decisão sobre o tipo e alcance da inspeção direta a ser realizada leva em conta as características e o porte do banco, bem como sua situação econômico-financeira e perfil de risco. Nesse sentido, existem atualmente quatro tipos de trabalho que envolvem supervisão direta, contemplando graus maiores ou menores de profundidade nos exames, quais sejam: (i) Avaliação de Controles Internos e Conformidade (Acic); (ii) Inspeção Geral; (iii) Inspeção Modular; e (iv) Inspeção Global Consolidada (IGC).

A Acic, também chamada de "controles internos", refere-se à avaliação das políticas e procedimentos adotados pela administração de uma instituição financeira para assegurar que os riscos inerentes às suas atividades estão sendo reconhecidos e administrados adequadamente. Conforme ensinamento de Darcy e Muniz, historicamente os controles

Centrais de Atendimento ao Público (CAP). As CAPs estão localizadas em Brasília e em nove divisões regionais: Belém, Belo Horizonte, Curitiba, Fortaleza, Porto Alegre, Recife, Rio de Janeiro, Salvador e São Paulo. Se o devedor discordar da informação do SCR, poderá apresentar reclamação diretamente à instituição financeira que introduziu o suposto erro, a qualquer CAP ou ao Ministério da Justiça. Ver: BANCO MUNDIAL. Sistemas de informação sobre créditos e empréstimos no Brasil, p. 33.

561 Idem, ibidem, p. 28-29.

562 JANTALIA, Fabiano. Curso de regulação do Sistema Financeiro Nacional, p. 14. 
internos eram voltados à redução das possibilidades de fraude, apropriação indébita e erros. Contudo, no final da década de 1990, o escopo desses controles foi ampliado para abarcar também outros riscos com os quais as instituições financeiras se deparam (crédito, mercado, operacional, reputacional etc.), passando, então, a serem considerados elemento fundamental para o funcionamento seguro e prudente de uma instituição financeira. ${ }^{563}$

Adotando para o Brasil as recomendações do Comitê da Basileia, ${ }^{564}$ o CMN editou a Resolução 2.554, de 29 de setembro de 1998, que dispõe sobre a necessidade de implantação de sistema de controles internos. Ainda segundo os autores citados, do modelo adotado podem-se ressaltar as seguintes disposições basilares: (i) obrigatoriedade de criar canais de comunicação interna; (ii) implementação do acompanhamento sistemático do cumprimento das normas legais e regulamentares; (iii) determinação de que a auditoria interna seja considerada parte integrante do ambiente de controles internos; e (iv) imposição de limites operacionais mais restritivos para as instituições financeiras que não implantem sistemas de controles adequados. ${ }^{565}$

Além da avaliação dos controles internos adotados pela instituição financeira, o Bacen pode realizar outros tipos de inspeção direta. $\mathrm{O}$ escopo dessas inspeções é definido caso a caso, conforme os dados que tenham chamado a atenção da autarquia na supervisão indireta. Quanto à abrangência da inspeção, pode-se realizar a Inspeção Modular, voltada para atividades específicas de uma instituição, e a Inspeção Geral, que se restringe a uma única instituição. Além dessas, destaca-se a IGC, procedimento criado em 1997, voltado à análise das atividades e processos de gestão dos conglomerados financeiros de médio e grande porte,

563 ALVES, Sérgio Darcy da Silva; ALVES, Tatiana Muniz Silva. A experiência brasileira de regulação, p. 176-177.

564 Em 1998 o Comitê de Basileia divulgou sua Metodologia de Avaliação de Sistemas de Controles Internos em Bancos (Framework for Internal Control Systems in Banking Organizations), definindo os controles internos como um componente essencial na gestão de uma instituição, que favorecem a estabilidade global do sistema financeiro. COMITÊ DE BASILEIA. Framework for internal control systems in banking organizations, Basileia, set. 1998.

565 ALVES, Sérgio Darcy da Silva; ALVES, Tatiana Muniz Silva. A experiência brasileira de regulação, p. 177. 
que alcança também as empresas não financeiras que deles façam parte, assim como estabelecimentos no exterior. ${ }^{566}$

\subsubsection{Testes de resistência}

Outro importante mecanismo de supervisão bancária, principalmente no caso de conglomerados financeiros, são os chamados testes de resistência, também conhecidos como stress tests. Nesses testes, a autoridade bancária tem como foco um número restrito de instituições financeiras (as cinco maiores no ranking de ativos, por exemplo), procurando determinar de que maneira eventos específicos, como quedas abruptas no mercado de capitais, variações bruscas nas taxas de juros ou redução de liquidez no financiamento de curto prazo, podem afetar a solvência dessas instituições.

Os testes de resistência destoam da prática habitual de supervisão bancária na medida em que não esperam um "sinal de alerta" ser acionado para chamar a atenção da autoridade para instituições em dificuldade. Ademais, não se baseiam em previsões de como a economia se comportará nos próximos anos para a análise da higidez do setor. Ao contrário, envolvem um monitoramento contínuo da saúde financeira dos principais bancos, avaliando sua performance diante de cenários hipotéticos e extremos.

Embora os testes de resistência já tenham sido propostos no passado, ${ }^{567}$ ganharam destaque na crise financeira recente em razão dos estudos empreendidos pelo Federal Reserve para avaliar quais instituições financeiras precisariam de aportes adicionais de capital para ampliar o seu grau de higidez. Os stress tests foram aplicados nas 19 maiores instituições financeiras do País e seus resultados foram amplamente divulgados pelo banco central norte-

\footnotetext{
566 A IGC atende uma recomendação expressa do Comitê de Basileia contida nos Princípios Fundamentais para uma Supervisão Bancária Efetiva, cujo princípio n. 24 dispõe que: "Um elemento essencial em supervisão bancária é a supervisão consolidada do grupo bancário, monitorando adequadamente e, quando apropriado, aplicando normas prudenciais a todos os tipos de negócios conduzidos mundialmente pelo grupo". Ver: COMITÊ DE BASILEIA. Princípios fundamentais para uma supervisão bancária efetiva, p. 8 .

567 STERN, Gary H.; FELDMAN, Ron J. Too big to fail, p. 113-114.
} 
americano. ${ }^{568}$ À ocasião, constatou-se que 10 das 19 instituições analisadas precisariam de um aporte adicional total de US\$75 bilhões. ${ }^{569}$ Igualmente, testes semelhantes foram realizados na União Europeia em 2010, cujos resultados indicaram que 7 dos 91 bancos analisados (não identificados nominalmente) estavam subcapitalizados, necessitando levantar cerca de $€ 3,5$ bilhões em recursos para atingirem o nível mínimo de recursos próprios exigidos nos testes. ${ }^{570}$

A esse respeito, o Brasil encontra-se à frente de outros países, uma vez que já vem aplicando testes de resistência nas instituições financeiras mesmo antes da crise financeira internacional. Segundo o Bacen, tais testes são realizados "regularmente" com "o objetivo de verificar se as instituições possuem níveis adequados de capital para suportar perdas potenciais em situações extremas". ${ }^{571}$ Em relatório de estabilidade financeira preparado pela autoridade em maio de 2009, os testes de resistência indicaram que as instituições analisadas são resistentes a variações individuais nos fatores de risco, e que, apenas em situações extremas, superiores às variações historicamente observadas, algumas instituições se tornariam desenquadradas do índice de Basileia. O relatório aponta também que somente o cenário adverso combinado de taxas de juros, de taxas de câmbio e de elevação do risco de crédito faria com que o universo analisado apresentasse índice de Basileia inferior ao patamar exigido. ${ }^{572}$

Apesar disso, os testes aplicados no Brasil apresentam um ponto negativo, que é o fato de o Bacen não divulgar a frequência com que são realizados, a metodologia adotada na avaliação dos bancos, nem o resultado individual de cada instituição. As experiências realizadas recentemente nos Estados Unidos e União Europeia foram mais transparentes, e a

568 FEDERAL RESERVE. The supervisory capital assessment program: overview of results. Washington, 7 maio 2009. Disponível em: <www.federalreserve.gov/newsevents/press/bcreg/bcreg20090507a1.pdf〉. Acesso em: 29 dez. 2010.

569 São elas: Bank of America (US\$33,9 bilhões), Citigroup (US\$5,5 bilhões), Wells Fargo (US\$13,7 bilhões), Morgan Stanley (US\$1,8 bilhão), PNC Financial Services (US\$600 milhões), GMAC (US\$11,5 bilhões), Sun Trust Banks (US\$2,2 bilhões), Regions Financial Corporation (US\$2,5 bilhões), Fifth Third Bank (US\$1,1 bilhão) e KeyCorp (US\$1,8 bilhão). Ver: Idem, ibidem, p. 19-37.

570 FOLHA DE SÃO PAULO. Sete bancos europeus são reprovados em testes de estresse, 23 jul. 2010.

571 BANCO CENTRAL DO BRASIL. Relatório de estabilidade financeira, maio 2009, p. 95. Disponível em: <www.bcb.gov.br/?RELESTAB200905>. Acesso em: 28 dez. 2010.

572 Idem, ibidem, p. 95. 
divulgação dos procedimentos adotados pelas autoridades permitiu diálogo com participantes do sistema financeiro e doutrina especializada com intuito de tornar os testes mais precisos. Essa transparência permitiu também a contestação de algumas das premissas adotadas nos testes, como a probabilidade de default na dívida soberana da Grécia. ${ }^{573}$ A divulgação dos resultados também funciona como importante fator de incentivo para as instituições financeiras se capitalizarem. O temor de que a divulgação desses resultados pudesse causar corridas bancárias nas instituições que não tiveram bom desempenho poderia ser remediado com a imposição de um intervalo razoável entre os testes e sua divulgação, que lhes permitisse tomar as medidas necessárias para reverter sua situação.

\subsubsection{Instrumentos disciplinares e punitivos}

Outro ponto de grande importância na regulação prudencial refere-se à análise dos instrumentos disciplinares e punitivos presentes no sistema jurídico quando constatadas infrações às normas legais por parte de instituições financeiras, seus controladores e administradores. Tais instrumentos cumprem importante propósito na medida em que buscam assegurar que os deveres subjacentes ao correto funcionamento dos mecanismos prudenciais supracitados, como os controles de adequação patrimonial e o envio de informações à autoridade bancária, sejam sempre respeitados. Além disso, reconhecendo-se a impossibilidade de detectar em tempo real a prática de todos os atos passíveis de causar risco sistêmico, torna-se fundamental dotar o arcabouço regulatório de medidas que, por meio da punição exemplar aos entes supervisionados, inibam a prática de comportamentos que possam comprometer a viabilidade da instituição financeira e, potencialmente, do sistema financeiro como um todo. Bom exemplo disso é a criminalização de condutas consideradas temerárias por parte de instituições financeiras.

Naturalmente, a extensão dos poderes detidos pela autoridade bancária para recriminar tais condutas e o processo decisório para aplicação de punições são objeto de tratamento diverso em cada país. Em pesquisa recente sobre a regulação prudencial ao redor

573 VALOR ECONÔMICO. "É uma comédia grega, uma piada”, diz banqueiro, 26 jul. 2010, p. C3. 
do mundo, Barth et al. constatam que, em 127 países, a autoridade bancária não necessita de autorização judicial para impor medidas punitivas como remoção de membros da administração de instituições financeiras ou cancelamento de sua autorização para funcionamento. No entanto, na grande maioria deles há possibilidade de recurso ao Judiciário contra decisões da autoridade bancária. ${ }^{574} \mathrm{O}$ Brasil, conforme se observará, adota um sistema misto, em que determinadas condutas são processadas na esfera administrativa, e outras na esfera do Judiciário.

\subsubsection{Processo administrativo punitivo do Banco Central}

A Resolução 1.065, de 5 de dezembro de 1985, estabelece o regulamento de aplicação de penalidades às instituições financeiras, seus administradores, membros de conselhos consultivos, fiscais e semelhantes, gerentes e outras pessoas que infrinjam as disposições da Lei 4.595/1964, bem como outras normas legais ou regulamentares aplicáveis. Por força do disposto no art. $2 .^{\circ}$ da Resolução, o regulamento tornou-se parte integrante do Manual de Normas e Instruções (MNI) do Bacen.

Uma vez instaurados, os processos administrativos punitivos no âmbito do Bacen passam pelas fases de defesa do acusado e exame do processo, até a prolação da decisão administrativa pela autarquia. As penas aplicadas variam de acordo com a instituição supervisionada e com a respectiva previsão legal, indo desde a mera advertência e multa, até a suspensão ou inabilitação para o exercício de cargos (no caso de pessoa física) ou a cassação da autorização para funcionamento (pessoa jurídica), cabendo recurso de tais decisões ao CRSFN.

O CRSFN, também chamado de "Conselhinho", é um órgão colegiado integrante da estrutura do Ministério da Fazenda, cuja secretaria-executiva situa-se no edifício sede do Bacen. O Conselhinho é composto por oito conselheiros com conhecimentos especializados

574 BARTH, James R. et al. Rethinking bank regulation, p. 128. 
em assuntos relativos aos mercados financeiro, de câmbio, de capitais, de crédito rural e industrial e de consórcios, sendo quatro indicados pelo governo (Ministério da Fazenda, Bacen, CVM e Secretaria de Comércio Exterior do Ministério do Desenvolvimento, Indústria e Comércio Exterior - MDIC) e quatro indicados pelas entidades de classe ${ }^{575}$ dos mercados supervisionados. ${ }^{576}$

As decisões proferidas pelo CRSFN estão sujeitas a revisão, nos termos, limites e condições estabelecidos pela Lei 9.784, de 29 de janeiro de 1999, que regula o processo administrativo no âmbito da administração pública federal. O art. 65 da lei determina a possibilidade de revisão de processos administrativos de que resultem sanções, a qualquer tempo, a pedido ou de ofício, quando surgirem fatos novos ou circunstâncias relevantes suscetíveis de justificar a inadequação da sanção aplicada. Nesse sentido, a Portaria 10 do Ministério da Fazenda, de $1 .^{\circ}$ de novembro de 2006, estabelece o procedimento a ser seguido para recorrer das decisões do CRSFN.

Finalmente, é importante ressaltar que o CRSFN não é a única instância administrativa para a aplicação de penalidades a instituições financeiras. A Lei 9.613, de 3 de março de 1998, que trata de crimes de "lavagem" ou ocultação de bens, direitos e valores, criou, no âmbito do Ministério da Fazenda, o Conselho de Controle de Atividades Financeiras (Coaf), com a finalidade de disciplinar, aplicar penas administrativas, receber, examinar e identificar as ocorrências suspeitas de atividades ilícitas previstas na lei. O presidente do Coaf é nomeado pelo Presidente da República, por indicação do Ministro da Fazenda, e o restante dos seus membros é composto por servidores públicos designados entre os integrantes dos quadros do Bacen, da CVM, da Susep, da Procuradoria-Geral da Fazenda Nacional, da Secretaria da Receita Federal, de órgão de inteligência do Poder Executivo, do Departamento

575 Integram atualmente o CRFSN as seguintes entidades de classe: (i) Associação Brasileira das Companhias Abertas (Abrasca), (ii) Associação Brasileira das Entidades dos Mercados Financeiro e de Capitais (Anbima), (iii) Comissão de Bolsas de Valores (CNBV), (iv) Federação Brasileira das Associações de Bancos (Febraban), (v) Associação Brasileira das Empresas de Leasing (Abel), (vi) Associação das Empresas Distribuidoras de Valores (Adeval), (vii) Associação de Comércio Exterior do Brasil (AEB). Os representantes das quatro primeiras entidades têm assento no CRSFN como membros titulares e os demais, como suplentes.

576 JANTALIA, Fabiano. Curso de regulação do Sistema Financeiro Nacional, p. 15. 
de Polícia Federal, do Ministério das Relações Exteriores e da Controladoria-Geral da União. Conforme o disposto no art. 16, § 2. ${ }^{\circ}$, da Lei 9.613/1998, das decisões do Coaf relativas à aplicação de penas administrativas cabe recurso ao Ministro da Fazenda.

\subsubsection{Crimes contra o Sistema Financeiro Nacional - Lei 7.492/1986 ${ }^{577}$}

A Lei 7.492 que trata dos crimes contra o SFN (Lei do Colarinho-Branco) foi promulgada em 21 de julho de 1986, em resposta ao crescente clamor popular pela punição dos responsáveis pelos escândalos financeiros ocorridos nas décadas de 1970 e 1980. Até então, os administradores não eram sancionados penalmente porque suas condutas não se enquadravam na definição de crimes ou a responsabilidade pessoal era de difícil comprovação, dissimulada em deliberações coletivas da empresa. ${ }^{578}$

Chama a atenção na análise do diploma legal que, na própria mensagem em que apôs vetos ao texto que se transformaria na Lei 7.492, o Presidente da República já reconhecia as falhas contidas no projeto de lei. A despeito delas, o chefe do Executivo decidiu aprovar o projeto, alegando que as referidas falhas seriam corrigidas em tempo oportuno, após a

577 Embora seja apresentada no contexto de capítulo que versa sobre a regulação prudencial, a Lei 7.492/1986 não se refere a nenhum dos campos gerais da administração ordenadora referidos na nota 107. Dessa forma, não se enquadra no sentido de "regulação" apresentado no trabalho, não podendo ser classificada como mecanismo de "regulação prudencial". Apesar do exposto, decidiu-se pela manutenção do tópico por se considerar que o objetivo do diploma legal é correlato com aquele pretendido pelos mecanismos de regulação prudencial tratados neste capítulo, e, principalmente, pelo grande número de críticas à lei, conforme se observará a seguir, causando a preocupação de que a sensação de impunidade quanto a certas condutas temerárias no setor bancário possa acabar estimulando comportamentos indesejáveis, colocando em risco a estabilidade do setor.

578 Conforme apontamento de Ela Wiecko V. de Castilho, "A partir de 1974, uma sucessão de quebras e negócios mal-explicados escandalizou o país. Entre eles, tiveram grande repercussão os casos Halles, Áurea, Ipiranga, Lume, Tieppo, Delfin, Capemi, Coroa-Brastel, Haspa, Letra, Grupo Sulbrasileiro, Habitasul, Brasilinvest, Comind, Auxiliar e Maisonnave. Apesar do sentimento dos investidores de que haviam sido fraudados e de que haviam sido vítimas de crimes, os responsáveis submetiam-se apenas às regras da Lei n. ${ }^{\circ}$ 6.024, de 13 de março de 1974, que alcançavam seus bens para penhora e posterior rateio do líquido apurado entre os credores" (CASTILHO, Ela Wiecko V. de. O controle penal nos crimes contra o Sistema Financeiro Nacional. Belo Horizonte: Del Rey, 2006. p. 132). A respeito dos escândalos ocorridos nas décadas de 1970 e 1980, Lundberg afirma que "há uma ampla percepção de falta da adequada responsabilização e de impunidade quanto a irregularidades cometidas por controladores e administradores de instituições financeiras no período". Ver: LUNDBERG, Eduardo Luís. Saneamento do sistema financeiro, p. 58-59. 
aprovação da lei. ${ }^{579}$ Em face do exposto, não causa surpresa a abundância de críticas a respeito da lei, com destaque para seu recurso excessivo a tipos penais abertos e a consequente dependência de normas administrativas para sua aplicação, não raro lançando questionamentos à sua constitucionalidade. ${ }^{580}$

Isso fica bem ilustrado no caso dos crimes de gestão fraudulenta ou temerária de instituição financeira - condutas de grande relevo para a regulação prudencial - capitulados no art. $4{ }^{\circ}$ e seu parágrafo único. Considerando a ausência de definição legal do que seja a gestão fraudulenta ou temerária, bem como a subjetividade envolvida na apreciação de diversos aspectos do tipo penal, há acirrado debate nos Tribunais quanto à constitucionalidade do dispositivo. De um lado, alega-se ofensa ao princípio da reserva legal, por ser um tipo aberto, deixando leque demasiadamente amplo de condutas que poderiam caracterizá-lo com muita subjetividade. ${ }^{581}$ De outro, argumenta-se que a exigência de descrição detalhada de condutas não se sustentaria no presente caso pelo fato de a gestão temerária ou fraudulenta poder assumir um número praticamente infinito de comportamentos, de modo que a exigência da descrição de cada um deles em tipos penais fechados acabaria abrindo margem à impunidade de tais crimes. ${ }^{582}$

579 Conforme o disposto na Mensagem 252/1986 do Presidente da República: "As críticas ao resultado dos trabalhos da Comissão de Juristas, feitas por quantos desejaram trazer-lhe aperfeiçoamento, estão em fase final de catalogação e avaliação, para eventual incorporação ao anteprojeto, o qual, tão logo esteja em condições de ser apreciado pelo Congresso Nacional, encaminharei como projeto de lei à apreciação de VV. Exas. Sem embargo da providência acima referida, entendi dar sanção ao Projeto que o Congresso houve por bem aprovar”. Ver: PIMENTEL, Manoel Pedro. Crimes contra o Sistema Financeiro Nacional, p. 3031.

580 MOREIRA, Alexandre Magno Fernandes. Os crimes contra o Sistema Financeiro Nacional e o princípio da insignificância. In: JANTALIA, Fabiano (Org.). A regulação jurídica do Sistema Financeiro Nacional. Rio de Janeiro: Lumen Juris, 2009. p. 215.

581 HC 960307760-9, TRF da 3. ${ }^{a}$ R., Rel. Des. Fed. Sílvia Steiner, j. 22.04.1997; HC 03081133-9, TRF da 3. ${ }^{a}$ R., Rel. Des. Fed. Oliveira Lima, j. 04.05.1999; e HC 9603069073-2, TRF da 3. ${ }^{a}$ R., Rel. Des. Fed. Theotônio Costa, 22.10.1996.

582 HC 20000201071136-0/RJ, TRF 2. ${ }^{a}$ R., 3. ${ }^{\text {a }}$ Turma, Rel. Maria Helena Cisne, j. 03.04.2001. Nesse mesmo sentido, Fausto De Sanctis assevera: "O art. 4. ${ }^{\circ}$ e seu parágrafo único não definiram a gestão fraudulenta e a gestão temerária, levando parte da doutrina e da jurisprudência a tê-las por inconstitucionais por ofensa ao princípio da reserva legal [...] Tais dispositivos não afrontam o preceito da reserva legal, apesar de reclamarem apreciação mais acurada da conduta, por conduzir a um juízo de valor e por levar à interpretação termo jurídico ou extrajurídico, característica dos tipos anormais”. Ver: DE SANCTIS, Fausto Martin. Punibilidade no Sistema Financeiro Nacional. Campinas: Millenium, 2003. p. 66-67. 
A aplicação do dispositivo também é limitada pelo fato de os crimes previstos no art. 4. ${ }^{\circ}$ serem penalizados apenas na forma dolosa. Com efeito, o elemento subjetivo do tipo é apenas o dolo, ou seja, a vontade livre e consciente de gerir fraudulenta ou temerariamente instituição financeira, tendo conhecimento de que o faz desse modo. ${ }^{583}$ Embora tal fato seja mais evidente para o caso de gestão fraudulenta, é menos claro no tocante à gestão temerária. Com efeito, conforme indica Salomão, um dos possíveis significados para a palavra "temerário" é "imprudente", e a imprudência é uma das formas de culpa segundo o art. 18, inciso II, do Código Penal. De todo modo, não havendo previsão de modalidade culposa para tal crime, há de se concluir pela inimputabilidade do delito, a não ser quando provada a intenção de assumir riscos incompatíveis com a atividade financeira e a administração de recursos de terceiros, sendo excludente do crime a prova de errônea percepção de tais riscos por parte do agente. ${ }^{584}$

Constatações semelhantes podem ser realizadas relativamente ao tipo penal previsto no art. $3 .^{\circ}$ da lei, que trata da divulgação de "informação falsa ou prejudicialmente incompleta sobre instituição financeira". Novamente, o crime é criticado pela doutrina em razão da grande subjetividade inerente à sua aplicação, especialmente no tocante ao entendimento do que seria informação "prejudicialmente incompleta". ${ }^{585}$ Isso também é dificultado pelo fato de não haver previsão de modalidade culposa para o crime, gerando sempre a justificativa de que a eventual divulgação de informações errôneas sobre a instituição financeira, mesmo que acabe abalando a confiança do mercado perante esta ou outras instituições, não seria passível de condenação por não ser intencional.

Por fim, a Lei 7.492/1986 prevê em seu art. 30 a possibilidade de decretação da prisão preventiva do acusado da prática de algum dos crimes ali previstos em razão da magnitude da lesão causada. A respeito da questão, o STF já se posicionou no sentido de que a magnitude da lesão a que se refere o art. 30 não representa razão autônoma para decretação

583 PAULA, Áureo Natal de. Crimes contra o Sistema Financeiro Nacional e o mercado de capitais. 4. ed. Curitiba: Juruá, 2009. p. 109 e 129.

584 SALOMÃO, Eduardo. Direito bancário, p. 482-483.

585 PIMENTEL, Manoel Pedro. Crimes contra o Sistema Financeiro Nacional, p. 44; e TÓRTIMA, José Carlos. Crimes contra o Sistema Financeiro Nacional (uma contribuição ao estudo da Lei n. ${ }^{\text {o }}$ 7.492/86). 2. ed. Rio de Janeiro: Lumen Juris, 2002. p. 24, apud PAULA, Áureo Natal de. Crimes contra o Sistema Financeiro Nacional e o mercado de capitais, p. 94. 
da prisão preventiva, devendo ser considerados outros pressupostos que a autorizam, incluindo-se aí os requisitos exigidos pelo art. 312 do Código de Processo Penal (CPP). ${ }^{586}$ Assim, esse entendimento tem sido utilizado para negar a prisão preventiva em casos nos quais, a despeito da magnitude da lesão, não se apresentem as hipóteses de garantia da ordem pública, da aplicação da lei penal e da instrução processual mencionadas no CPP. ${ }^{587}$

As dificuldades cercando os dispositivos da Lei 7.492/1986 acabam por gerar uma percepção disseminada de que a aplicação da lei ficou aquém do esperado. Em um dos trabalhos mais celebrados sobre o tema, Ela Wiecko de Castilho relata a ineficácia da lei diante do poder conferido a certos grupos de definir que crimes devem ser coibidos e diante da desarticulação das instâncias formais tendentes à repressão desses tipos. A autora ressalta, também, o baixo de número de casos investigados a cada ano. ${ }^{588}$ Isso também é bem representado em pesquisa realizada com 32 professores de direito penal e criminologia de diversas universidades do País sobre sua percepção a respeito da Lei do Colarinho-Branco, na qual $84 \%$ dos entrevistados qualificam o diploma legal como falho e merecedor de reforma. ${ }^{589}$ Não por acaso, já em 1987, Manoel Pedro Pimentel asseverou em tom profético a respeito da lei que, diante “[...] dos seus evidentes defeitos e notórias imprecisões, não trará o resultado esperado, na luta contra os crimes do colarinho-branco, continuando a prevalecer a impunidade em grande escala". 590

586 HC 80.717, STF, Rel. Ministro Sepúlveda Pertence, j. 13.06.2001.

587 HC 85.615, STF, Rel. Ministro Gilmar Mendes, j. 13.12.2005.

588 Segundo Ela Wiecko V. de Castilho: “a demarcação do campo da criminalidade pelas instâncias formais segue o modelo estruturalmente seletivo do sistema penal brasileiro [...] no âmbito investigado, verifica-se que é o Bacen quem decide, fundamentalmente, quais são os fatos que geram prejuízo ao sistema financeiro e que pessoas deverão se submeter à repressão penal. [...] A quantificação e a qualificação das condutas excluídas é impossível [...] o que resta é muito pouco: uma média de 76 casos por ano em todo o Brasil”. Ver: CASTILHO, Ela Wiecko V. de. O controle penal nos crimes contra o Sistema Financeiro Nacional, p. 287.

589 DUARTE, Maria Carolina de Almeida. Crimes contra o Sistema Financeiro Nacional: uma abordagem interdisciplinar. Rio de Janeiro: Forense, 2003. p. 215.

590 PIMENTEL, Manoel Pedro. Crimes contra o Sistema Financeiro. In: MUYLAERT, Eduardo (Org.). Direito penal dos negócios: crimes do colarinho-branco. São Paulo: Associação dos Advogados de São Paulo, 1990. p. 84, apud DE SANCTIS, Fausto Martin. Punibilidade no Sistema Financeiro Nacional, p. 58. 
Essas constatações repetem-se na doutrina jurídica, ${ }^{591}$ fazendo com que alguns autores cheguem inclusive a declarar o óbito da Lei 7.492/1986. ${ }^{592}$ Radicalismos à parte, infelizmente, passados quase 25 anos de sua promulgação, é preciso reconhecer que muitos dos resultados pretendidos com a lei não foram atingidos. $\mathrm{Na}$ observação crítica de Gonçalves, "é uma lei que não se cumpriu, assertiva verdadeira, em quase todos os aspectos, quando se trata da Lei 7.492/1986".593 Não por acaso, tramitam na atualidade inúmeros projetos que procuram reformar seus dispositivos. ${ }^{594}$

Naturalmente, não se pode creditar a ausência de punições aos controladores e administradores que perpetraram os escândalos financeiros mencionados neste trabalho unicamente às deficiências da Lei do Colarinho-Branco. É preciso considerar, também, os diversos institutos de direito penal e processo penal vigentes na atualidade que permitem a protelação de feitos ad aeternum na justiça, com os réus recorrendo em liberdade, até que os crimes prescrevam. Fugiria ao escopo deste trabalho realizar análise exaustiva do tema sob a perspectiva material e processual penal, bastando pelo momento reconhecer que, seja porque os tipos previstos na lei são julgados inconstitucionais, ou porque a ineficiência do sistema jurídico permite a protelação dos feitos até que estes prescrevam; o fato é que vige na atualidade uma ampla percepção de impunidade no sistema financeiro, prejudicando a busca dos objetivos pretendidos pela regulação prudencial.

\subsubsection{Controle de estruturas de remuneração}

A discussão sobre os incentivos negativos inerentes a determinadas estruturas de remuneração insere-se no debate sobre a relação principal-agente, já tratada no

591 MACHADO, Agapito. Crimes do colarinho-branco e contrabando/descaminho. São Paulo: Malheiros, 1998. p. 82; MAIA, Rodolfo Tigre. Dos crimes contra o Sistema Financeiro Nacional: anotações à Lei Federal n. ${ }^{\circ}$ 7.492/86. São Paulo: Malheiros, 1996. p. 11; e SADDI, Jairo. Crise e regulação bancária, p. 189.

592 GONÇALVES, Luiz Carlos dos Santos. Exame necroscópico da lei do colarinho-branco. In: ROCHA, João Carlos de Carvalho et al (Org.). Crimes contra o Sistema Financeiro Nacional: 20 anos da Lei n. ${ }^{\mathbf{0}}$ 7.492/86. Belo Horizonte: Del Rey, 2006. p. 3.

593 Idem, ibidem, p. 3.

594 Para uma descrição dos projetos sobre o tema em tramitação no Congresso Nacional, ver: PAULA, Áureo Natal de. Crimes contra o Sistema Financeiro Nacional e o mercado de capitais, p. 6. 
Capítulo $1,{ }^{595}$ tendo sua importância revigorada no contexto pós-crise financeira recente. ${ }^{596} \mathrm{~A}$ estrutura de remuneração de executivos que atuam no sistema financeiro - e no setor bancário em particular - foi apontada como um dos fatores que contribuiu para a crise por criar incentivos para a tomada excessiva de risco no curto prazo, em detrimento da viabilidade das instituições financeiras no longo prazo. ${ }^{597}$ Nesse sentido, observam-se ao redor do mundo diferentes iniciativas para abordar o tema.

Alguns países europeus têm procurado enfrentar a questão por meio da política tributária. Na Inglaterra, por exemplo, foi anunciada em novembro de 2009 a imposição de um "superimposto" (super-tax) de 50\% sobre os bônus discricionários acima de $£ 25,000$ pagos a executivos do setor bancário. Em seguida, o Presidente francês Nicolas Sarkozy declarou apoio à decisão inglesa, anunciando medida semelhante aos bônus acima de $€ 27,000$ pagos naquele país. Em ambos os casos, as medidas foram divulgadas como formas de recuperar parte dos gastos incorridos no resgate a instituições financeiras, bem como uma maneira de disciplinar os executivos do setor pelas apostas arriscadas que motivaram a crise. Não obstante, tais medidas foram encaradas com ceticismo em razão de seu caráter limitado, considerado insuficiente para promover qualquer mudança duradoura no comportamento dos executivos do sistema financeiro. ${ }^{598}$

595 Conforme ensinamento de Carrasco: “A teoria econômica dos incentivos considera situações nas quais um agente econômico, o Agente, toma uma ação (potencialmente não observável) que afeta alguma medida de bem-estar de uma segunda parte, o Principal, que tem preferências distintas da dele. O problema do principal é, então, desenhar um contrato, estabelecendo formas de compensação (provisão de incentivos) de forma a alinhar os incentivos do agente aos seus. As relações entre uma companhia seguradora (principal) e um segurado (agente), emprestador (principal) e tomador do empréstimo (agente) e executivo de empresa (agente) e stakeholders (principais), entre outras, se enquadram nessa descrição". Ver: CARRASCO, Vinícius. Incentivos e crise. In: GARCIA, Márcio; GIAMBIAGI, Fábio (Org.). Risco e regulação, p. 100.

596 Isso não significa, evidentemente, que o tema não tenha sido objeto de discussão anteriormente. A esse respeito, ver: BEBCHUK, Lucian A.; FRIED, Jesse. Pay without performance: the unfulfilled promise of executive compensation. Cambridge: Harvard University Press, 2004.

597 FINANCIAL STABILITY BOARD. FSB principles for sound compensation practices - Implementation standards. Basileia, 25 set. 2009, p. 1. Este e outros documentos do Financial Stability Forum (posteriormente renomeado para Financial Stability Board) mencionados neste trabalho encontram-se disponíveis em: <www.financialstabilityboard.org/list/fsb_publications/index.htm>. Acesso em: 29 dez. 2010.

598 É preciso reconhecer o efeito pontual de tais medidas, aplicando-se apenas sobre os rendimentos do anobase de 2009, e podendo provocar apenas a migração das instituições financeiras para jurisdições menos hostis aos executivos do setor. Em razão disso, periódicos europeus alegaram um viés populista nesses "superimpostos", sugerindo que a verdadeira motivação para tais medidas seria a busca de apoio popular para as eleições para o Parlamento na Inglaterra e eleições municipais na França no 1. ${ }^{\circ}$ semestre de 2010, 
Em contraste com as medidas adotadas na Europa, observa-se nos Estados Unidos enfoque diverso à questão, em que se procura discutir as relações entre estruturas de compensação e risco sistêmico. Em depoimento ao Congresso, no bojo da discussão das reformas regulatórias nos Estados Unidos, o professor da Universidade de Harvard, Lucian Bebchuk, criticou os mecanismos tradicionais de compensação por premiarem executivos com base em resultados de curto prazo, mesmo quando esses resultados são depois revertidos. ${ }^{599}$ Embora as instituições financeiras procurem corrigir essa falha por meio da adoção de mecanismos que vinculem sua remuneração à performance de longo prazo, como opções de compra de ações (stock options), ${ }^{600}$ o professor afirma que tais mecanismos, por si sós, seriam insuficientes para solucionar o problema. Segundo o jurista, seria necessário separar o tempo em que tais opções são concedidas do momento do seu exercício. Nesse sentido, defende que estas só possam ser exercidas ao longo de um período de cinco anos ( $20 \%$ em cada ano). Como os mecanismos típicos de remuneração variável costumam prever um número crescente de opções conforme o tempo de permanência na empresa, mesmo após os cinco anos, sua remuneração continuaria efetivamente atrelada ao desempenho de longo prazo da instituição. Há também propostas mais radicais, que defendem a possibilidade de exercício de tais opções somente após a aposentadoria do executivo. ${ }^{601}$

O Dodd-Frank Wall Street Reform and Consumer Protection Act procurou endereçar algumas dessas preocupações, dedicando um subtítulo inteiro à questão das estruturas de remuneração (Seções 951 - 957). Entre as principais alterações propostas destacam-se: (i) exigência de que, pelo menos uma vez a cada três anos, os acionistas votem sobre a

especialmente em um contexto de queda de popularidade dos governos em tais países em razão da percepção disseminada da sociedade de que seus líderes não estariam sendo suficientemente rigorosos com os banqueiros. Finalmente, enquanto medidas voltadas a recuperar os gastos incorridos no resgate a instituições financeiras, destacou-se que as receitas esperadas com a imposição dos tributos é irrisória quando comparada aos valores dos pacotes de resgate nos dois países durante a crise. Ver: THE TIMES. Banks hit back at 'populist' bonus supertax, 7 dez. 2009.

599 BEBCHUK, Lucian A. Written testimony submitted to the Committee on Financial Services of the United States House of Representatives: hearing on compensation structure and systemic risk, 11 jun. 2009. Disponível em: <www.law.harvard.edu/faculty/bebchuk/Policy/FSC-written-testimony-June-11-09.pdf>. Acesso em: 26 dez. 2010.

600 As opções de compra de ações dão ao seu proprietário o direito de adquirir um pacote de ações da sociedade a um preço fixado previamente. $\mathrm{O}$ objetivo é fazer com que a gestão desses executivos se empenhe na geração do maior valor possível para a empresa de modo que o preço das ações na data de vencimento seja superior ao preço do exercício da opção. A diferença será o lucro auferido pelo executivo.

601 BEBCHUK, Lucian A. Written Testimony Submitted to Committee on Financial Services of the United States House of Representatives, p. 3. 
quantidade e estrutura de remuneração dos executivos que trabalham para a companhia, incluindo golden parachutes ${ }^{602}$ negociados no contexto de fusões, aquisições, vendas substanciais de ativos, entre outras operações; ${ }^{603}$ (ii) poderes para a Comissão de Valores Mobiliários norte-americana (Securities and Exchange Commission - SEC) criar regras que obriguem executivos a devolver parte de sua remuneração passada em determinadas circunstâncias (também chamadas de clawback policies), podendo inclusive rejeitar o registro como companhia aberta para empresas que se negarem a adotar tais regras; ${ }^{604}$ (iii) divulgação de informações relacionadas à remuneração e performance da companhia, bem como a remuneração média dos executivos por cargo; e (iv) criação de comitês de remuneração destinados a avaliar os riscos inerentes à estrutura de remuneração da companhia, bem como cuidar da implementação das regras supracitadas. Embora algumas dessas regras já tenham prazo certo para entrar em vigor, como os itens (i) e (iv), que devem ser implementados no prazo de 180 e 360 dias, respectivamente, a partir de 21 de julho de 2010, outras regras ainda dependerão de extensa regulamentação pela SEC, não havendo prazo claro para sua implementação.

A discussão não se limita apenas à Europa e Estados Unidos. Nas reuniões de 25 de abril (London Summit) e setembro (Pittsburgh Summit) de 2009, os líderes do G-20 destacaram a necessidade de implementar padrões internacionais robustos para a política de remuneração, visando desencorajar práticas que levem à assunção de riscos excessivos. Dessa forma, em comunicado de 25 de setembro de 2009, o Conselho de Estabilidade Financeira (Financial Stability Board - FSB), órgão composto por algumas das principais autoridades

602 Cláusulas que conferem indenizações substanciais para determinados executivos que deixem a companhia após a ocorrência de evento previamente estipulado contratualmente.

603 Motivo de crítica, no entanto, é o fato de esses votos não terem caráter vinculante sobre as deliberações do Conselho de Administração. Ou seja, mesmo que os acionistas rejeitem a proposta de remuneração apresentada pela companhia, esta não é obrigada a modificá-la. Evidentemente, pode-se argumentar também que a recusa reiterada do Conselho de Administração da companhia em seguir a deliberação dos acionistas pode motivar o voto destes pela troca dos diretores que pertençam ao conselho.

604 Embora a lei Sarbanes-Oxley já exigisse a criação de clawback policies pelas companhias (Seção 304), estas se limitavam a casos de conduta desonesta dos executivos (misconduct). Já as novas disposições do DoddFrank Wall Street Reform and Consumer Protection Act ampliam o escopo dessas regras, tornando-as aplicáveis mesmo em situações em que o executivo não tenha culpa. 
regulatórias internacionais, ${ }^{605}$ elencou os pontos-chave na reforma das estruturas de remuneração, propondo as seguintes medidas: ${ }^{606}$

1. Governança corporativa: Instituições financeiras devem ter comitês de remuneração como parte de sua estrutura de governança corporativa. Tais comitês devem ser organizados de forma a assegurar que as estruturas de remuneração adotadas estejam de acordo com as recomendações do FSB;

2. Estrutura de remuneração: Executivos mais seniores devem receber parte de sua remuneração em opções de ações ou opções vinculadas às ações da instituição financeira. Parte substancial dessa remuneração variável não deve ficar disponível de imediato e seu exercício deve ser distribuído ao longo de um período de tempo razoável. As proporções não disponíveis de imediato devem aumentar conforme o nível de senioridade do executivo em questão. A garantia de bônus em dinheiro no final do ano não é consistente com uma política adequada de administração de risco, devendo ser eliminada, e cláusulas contratuais com previsão de benefícios em caso de rescisão contratual, como golden parachutes, devem ser reavaliadas e mantidas apenas quando o comitê de remuneração determinar que estão alinhadas com uma política prudente de assunção de risco e crescimento no longo prazo;

3. Divulgação de informações: As práticas de remuneração adotadas em cada instituição financeira devem ser divulgadas, destacando-se: (i) o processo decisório para a estrutura de remuneração, incluindo composição e mandato do comitê de remuneração; (ii) os aspectos mais importantes da estrutura de remuneração, incluindo o critério para mensuração da performance do executivo, carência no exercício de opções e parâmetros para a determinação da parcela variável e fixa da

\footnotetext{
605 A estrutura interna e objetivos do Financial Stability Board, bem como de outros órgãos responsáveis pela elaboração de padrões mínimos de regulação e supervisão no sistema financeiro, serão tratados em detalhe no Capítulo 5.

606 FINANCIAL STABILITY BOARD. FSB principles for sound compensation practices, p. 2-5.
} 
remuneração; e (iii) informação quantitativa agregada e discriminada por presidentes, vice-presidentes, diretores e outros executivos seniores, incluindo montante fixo e variável de sua remuneração e benefícios em caso de rescisão contratual, entre outros; e

4. Supervisão oficial: Autoridades supervisoras devem: (i) assegurar a correta implementação dos princípios sugeridos pelo FSB em suas respectivas jurisdições; (ii) aprimorar a coordenação internacional para assegurar que os princípios serão adotados de forma consistente entre diferentes jurisdições (de modo a evitar arbitragem regulatória); e (iii) exigir que instituições financeiras demonstrem que os incentivos criados pela sua estrutura de remuneração levam em consideração a administração dos riscos assumidos no médio e longo prazo.

Finalmente, o relatório do FSB frisa a necessidade de que tais medidas sejam adotadas com rapidez, antes que as instituições financeiras voltem a incorrer nas práticas que contribuíram para a crise financeira recente. ${ }^{607}$ Aqui novamente o Bacen reitera sua postura rigorosa em termos de regulação prudencial, tendo disponibilizado apenas quatro meses após a reunião de 25 de setembro de 2009 proposta de Resolução que trata do tema.

\subsubsection{Política de remuneração de administradores das instituições financeiras}

Mesmo antes das reuniões do G-20, o Bacen já havia sinalizado sua disposição para interferir na estrutura de remuneração dos executivos de instituições financeiras. A Resolução CMN 3.622/2008, que alterou as regras do redesconto bancário, permitiu também que a autarquia suspendesse a distribuição de resultados em montante superior aos limites mínimos previstos em lei, nos estatutos ou no contrato social, nas situações que pudessem ameaçar o cumprimento dos padrões mínimos de capital realizado, de patrimônio líquido ou de patrimônio exigido em função do nível de risco das exposições da instituição financeira. Além disso, a Resolução permitiu que o Bacen proibisse o aumento da remuneração dos

${ }^{607}$ FINANCIAL STABILITY BOARD. FSB principles for sound compensation practices, p. 1. 
administradores ou dos demais membros de órgãos societários durante o período de acesso ao redesconto de que trata o normativo.

Seguindo nessa linha, e apoiando-se nas recomendações do FSB, em 1. ${ }^{\circ}$ de fevereiro de 2010, o Bacen disponibilizou a Audiência Pública 35, posteriormente convertida na Resolução CMN 3.921, de 25 de novembro de 2010, em que apresenta proposta de regramento para a política de remuneração de administradores das instituições financeiras. ${ }^{608}$ Conforme o normativo, a política de remuneração deve ser compatível com a política de gestão de riscos, sendo formulada de modo a não incentivar comportamentos que elevem a exposição ao risco acima dos níveis considerados prudentes nas estratégias de curto, médio e longo prazo adotadas pela instituição financeira.

Segundo o normativo, são considerados administradores os: (i) diretores estatutários e membros do Conselho de Administração das sociedades anônimas; e (ii) administradores das sociedades limitadas. ${ }^{609}$ A Resolução estipula que pelo menos $50 \%$ da remuneração variável dos administradores cujas ações tenham impacto material sobre a exposição ao risco deve ser paga em ações ou instrumentos baseados em ações. ${ }^{610}$ Além disso, no mínimo $40 \%$ da remuneração variável deve ser diferida para pagamento futuro, em período não inferior a três anos. No caso de redução significativa do lucro recorrente realizado ou da ocorrência de resultado negativo da instituição ou da unidade de negócios durante o período de diferimento, as parcelas diferidas ainda não pagas devem ser revertidas, proporcionalmente à redução no resultado. Contratos com cláusulas de pagamentos vinculados ao desligamento de administradores devem ser compatíveis com a criação de valor e com a gestão de risco de longo prazo, e a garantia de pagamento de bônus ou de outros benefícios deve ter caráter excepcional, por ocasião da contratação ou transferência de administradores para outra área,

608 Audiência Pública 35/2009. Disponível em: <www.bacen.gov.br/?AUDPUB>. Acesso em: 17 dez. 2010.

609 O escopo de aplicação da Resolução foi alterado em relação à proposta apresentada na audiência pública, que previa um leque mais abrangente de aplicação, incluindo empregados, ainda que não fossem administradores, que exercessem função gerencial ou outra função com responsabilidades ou influência na gestão equivalentes ou superiores à função gerencial, bem como empregados cujas ações tivessem impacto material sobre a exposição ao risco.

610 Para as instituições que não possuam ações negociadas no mercado e que não emitam instrumentos baseados em ações, os pagamentos devem tomar como base a variação ocorrida no valor contábil de seu patrimônio líquido, livre dos efeitos das transações realizadas com os proprietários. 
cidade ou empresa do mesmo conglomerado, e limitada ao primeiro ano após o fato que der origem à garantia. $^{611}$

As instituições financeiras constituídas sob a forma de companhia aberta ou que sejam obrigadas a constituir Comitê de Auditoria devem instituir órgão estatutário denominado "Comitê de Remuneração", composto por, no mínimo, três integrantes, e com pelo menos um membro que não seja administrador. Entre outras responsabilidades, cabe ao Comitê de Remuneração: (i) elaborar a política de remuneração da instituição, propondo ao Conselho de Administração as diversas formas de remuneração fixa e variável de administradores e empregados, como salários, benefícios, bônus, participações nos lucros e outros incentivos de desempenho, além de programas especiais de recrutamento e desligamento; (ii) supervisionar a implementação e operacionalização da política de remuneração da instituição; (iii) revisar anualmente a política de remuneração da instituição, recomendando ao Conselho de Administração a sua correção ou aprimoramento; (iv) propor ao Conselho de Administração o montante da remuneração global dos administradores a ser submetido à Assembleia Geral; (v) avaliar cenários futuros, internos e externos, e seus possíveis impactos sobre a política de remuneração; (vi) analisar a política de remuneração da instituição em relação às práticas de mercado, com intuito de identificar discrepâncias significativas em relação a empresas congêneres, propondo os ajustes necessários; e (vii) zelar para que a política de remuneração esteja permanentemente compatível com a política de gestão de riscos, com as metas e a situação financeira atual e esperada da instituição. ${ }^{612}$

Compete também ao Comitê de Remuneração elaborar, anualmente, no prazo de 90 dias relativamente à data-base de 31 de dezembro, documento próprio intitulado "Relatório do Comitê de Remuneração", descrevendo seus trabalhos. Esse relatório deve conter elementos específicos, como: (i) descrição da composição e atribuições do comitê; (ii) atividades exercidas no âmbito de suas atribuições no período; (iii) descrição do processo de decisão adotado para estabelecer a política de remuneração; (iv) principais características da política

611 Essa foi outra alteração em relação à proposta apresentada em audiência pública, que permitia tais pagamentos apenas na contratação de novos administradores e empregados, sendo limitada ao primeiro ano de trabalho.

612 A proposta apresentada em audiência pública permitia que o Comitê de Remuneração contasse com o trabalho de especialistas no âmbito de suas atribuições, restando claro, no entanto, que isso não eximiria o comitê de suas responsabilidades. Essa previsão, no entanto, foi suprimida na versão final do normativo. 
de remuneração e eventuais modificações sofridas no período; e (v) informações quantitativas consolidadas sobre a estrutura de remuneração dos administradores. Aqui vale acrescentar que a Instrução Normativa CVM 480, de 7 de dezembro de 2009, já havia tornado obrigatória a divulgação de informações relativas à remuneração máxima, média e mínima da Diretoria e Conselho de Administração de companhias de capital aberto. ${ }^{613}$

Finalmente, a Resolução permite ao Bacen solicitar, a qualquer tempo, que a instituição demonstre que os incentivos proporcionados no âmbito de seu sistema de remuneração levam em consideração a gestão de riscos, adequação de capital e liquidez. $\mathrm{O}$ Bacen pode também determinar as medidas necessárias para compensar qualquer risco adicional resultante da inadequação da política de remuneração implementada pela entidade, inclusive a revisão da referida política ou a ampliação do requerimento de capital.

A reação inicial de alguns dos maiores participantes do SFN, como Itaú-Unibanco, Bradesco e Santander, é de que o normativo não deve causar grandes impactos na governança corporativa dos bancos, uma vez que muitas dessas instituições já dispõem de Comitês de Remuneração, semelhantes ao modelo apresentado pelo Bacen. ${ }^{614}$ Além disso, a Febraban alega que as políticas de remuneração dos bancos brasileiros já são mais conservadoras em comparação com outros países, e que, na legislação brasileira, os diretores estatutários respondem com o patrimônio por quaisquer problemas que ocorram em suas instituições, o que já atuaria como forte limitação à tomada excessiva de risco. ${ }^{615}$ A esse respeito, Jairo Saddi ressalta também que a dispersão acionária dos bancos brasileiros ainda é pequena em comparação com outros países, de modo que a distribuição de bônus não é significativa e o volume de pagamento a executivos divulgados por bancos não chega a representar dois dígitos de sua receita. ${ }^{616}$ Outrossim, o autor aponta restrições do ponto de vista trabalhista na implementação das recomendações do FSB no Brasil, como a questão da irredutibilidade de vencimentos, segundo a qual ninguém pode ganhar menos na mesma função

613 Apesar disso, a validade da regra é objeto de questionamento judicial. Em março de 2010 o Instituto Brasileiro de Executivos de Finanças do Rio conseguiu liminar na 5. ${ }^{a}$ Vara Federal do Rio de Janeiro para suspender a exigência de divulgação de informações relativas à remuneração dos administradores de companhias abertas para os membros do instituto. A liminar, no entanto, foi derrubada pela $8 .^{a}$ Turma do

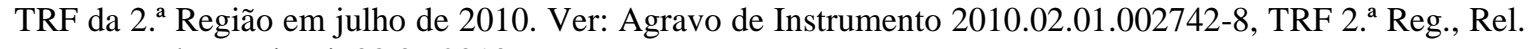
Des. Marcelo Pereira, j. 08.07.2010.

614 BRASIL ECONÔMICO. Bônus menor não assusta grandes bancos, 9 fev. 2010, p. 38.

615 Idem, ibidem, p. 38-39.

616 Idem, p. 38-39. 
ou "devolver" o que deveria receber. ${ }^{617}$ Fugiria ao escopo do trabalho, no entanto, se aprofundar nessas questões.

\subsection{Desafios para a regulação prudencial}

\subsubsection{Dificuldades associadas à supervisão de conglomerados financeiros}

O aumento do tamanho das instituições financeiras e a diversificação das suas atividades, tanto em termos de produtos como em área geográfica, causaram um inegável impacto em sua complexidade. Para possibilitar suas operações em tantos mercados, tais instituições desenvolveram uma intrincada rede societária, com centenas de subsidiárias diretas e indiretas espalhadas ao redor do mundo. O exemplo do Citigroup, um dos maiores bancos do mundo, é bastante ilustrativo a esse respeito:

\section{Figura 2: Organização hierárquica do Citigroup (2004)}

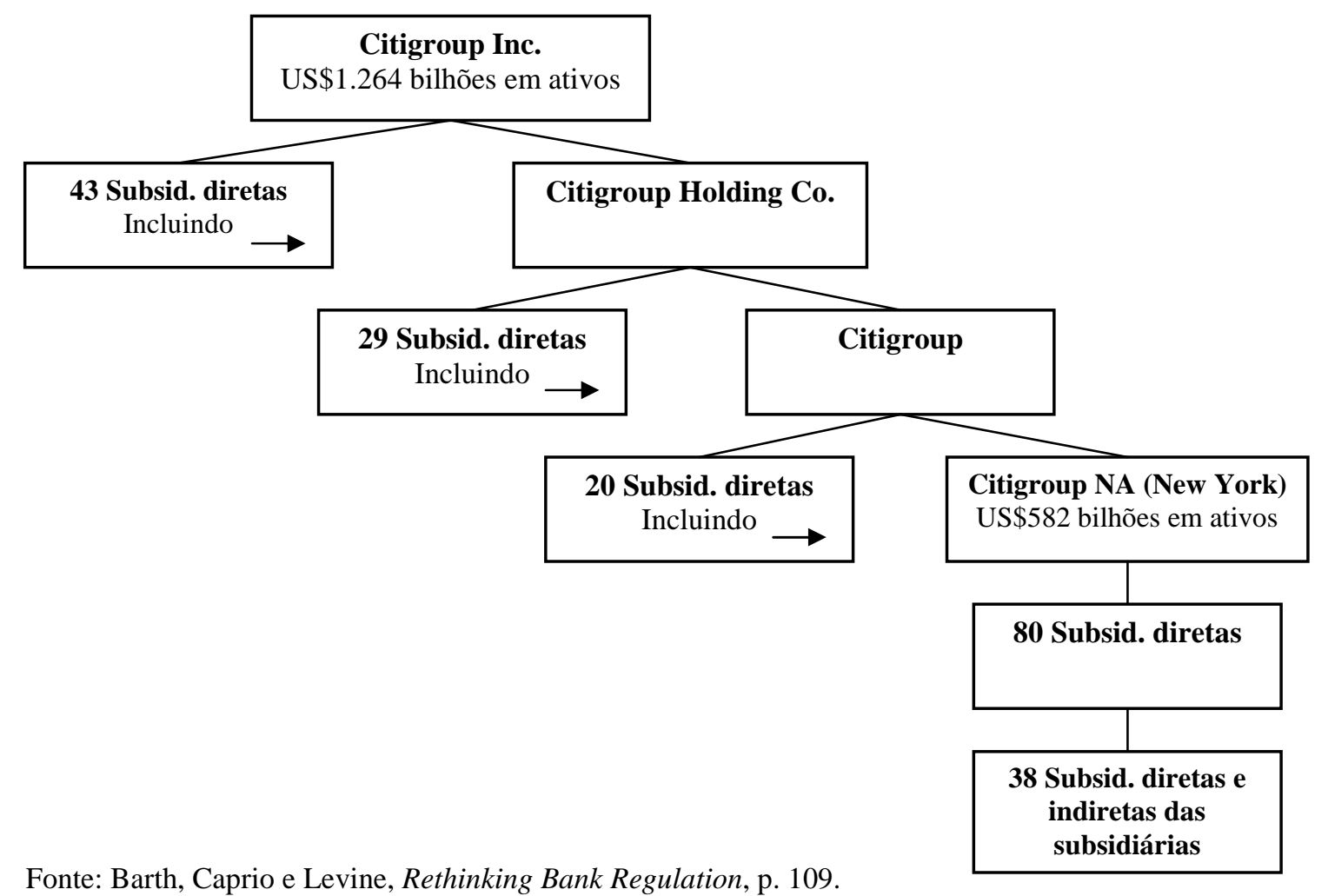

617 REVISTA CAPITAL ABERTO. É papel do Banco Central regular a remuneração dos executivos de instituições financeiras?, abr. 2010, p. 46-47. 
Essa complexidade crescente das instituições financeiras impõe uma série de desafios à sua fiscalização efetiva por parte das autoridades bancárias, principalmente no caso de instituições que atuam em diversos segmentos do sistema financeiro. Conforme visto no capítulo anterior, a ampliação do conceito de risco sistêmico demonstra que, na atualidade, a análise de risco focada apenas na atividade bancária é insuficiente, havendo necessidade de desenvolver métodos de supervisão que permitam o acompanhamento não apenas de atividades particulares da instituição, mas de sua atuação como um todo para obter melhor percepção do risco sistêmico existente.

Em face dessa conjuntura, há um amplo debate na doutrina jurídica e econômica sobre qual seria o arranjo institucional apropriado para a supervisão de diferentes atividades financeiras. A preocupação nesse caso não é com a regulação específica de um determinado segmento do mercado financeiro ou de capitais, mas sim em analisar como diferentes arranjos institucionais podem facilitar ou dificultar o monitoramento do risco sistêmico. No tocante a esses aspectos, constata-se a existência de quatro modelos teóricos contrastantes baseados nas experiências de diferentes países, quais sejam: a abordagem institucional, funcional, integrada ou por objetivos.

\subsubsection{Abordagem institucional}

A abordagem institucional é uma das formas tradicionais de organização da estrutura de regulação e supervisão de diferentes atividades financeiras. Nesse modelo, o critério para a divisão de competências entre autoridades é a natureza ou qualificação jurídica do ente supervisionado. Assim, caso este seja constituído legalmente como um banco, será supervisionado pelo banco central ou qualquer outro órgão responsável pela supervisão dos bancos. Da mesma forma, caso seja uma companhia de seguros, será supervisionado pela autoridade responsável pelas seguradoras. Os defensores desse modelo apontam como suas grandes vantagens a objetividade na determinação de competência regulatória e a possibilidade de especialização de cada autoridade em um campo específico do mercado financeiro e de capitais. ${ }^{618}$

${ }^{618}$ GROUP OF 30. The structure of financial supervision, p. 55 e ss. 
Apesar de sua larga aceitação ao redor do mundo, continuando ainda a influenciar o arcabouço regulatório de diversos países, como China e México, esse modelo passou a enfrentar crescente questionamento teórico em face das mudanças ocorridas no sistema financeiro nas últimas décadas. ${ }^{619}$ A progressiva diluição das barreiras regulatórias entre as atividades financeiras no Brasil e no mundo na segunda metade do século XX possibilitou o surgimento de participantes no mercado que desempenham outras atividades financeiras, além daquelas sugeridas pela sua natureza jurídica. Assim, por exemplo, tornou-se comum no setor bancário a prestação de atividades securitárias, além das atividades bancárias tradicionais.

Tais mudanças na estrutura do sistema financeiro provocam distorções na abordagem institucional, como a possibilidade de tratamento regulatório diverso para entidades que prestam praticamente os mesmos serviços financeiros, mas que possuem natureza jurídica diversa. É o caso de atividades de seguro prestadas por um conglomerado financeiro possuírem tratamento diverso daquelas prestadas por uma seguradora. Um efeito grave dessa distorção é a possibilidade de arbitragem regulatória, em que um agente econômico pode optar por uma determinada forma jurídica não em razão da natureza dos serviços prestados, mas em função do regime regulatório mais conveniente. ${ }^{620}$

Em certos casos, a arbitragem regulatória pode ser tamanha que algumas atividades exercidas por conglomerados financeiros acabam não sendo objeto de qualquer regulação, criando um vácuo regulatório. O já mencionado caso da AIG ilustra bem os riscos decorrentes dessa situação. Embora sua subsidiária AIGFP prestasse atividades financeiras cuja frequência e volume fizeram com que autoridades a equiparassem a um banco de investimentos ou hedge fund, esta continuou a ser supervisionada apenas pela autoridade de seguros nos Estados Unidos em razão de sua natureza jurídica. Segundo afirmação do presidente do Federal Reserve, "não havia supervisão porque havia uma brecha no sistema". 621

619 GROUP OF 30. The structure of financial supervision, p. 24.

620 CIHAK, Martin; POPDIERA, Richard. Is one watchdog better than three? International experience with integrated financial sector supervision. International Monetary Fund Working Paper, n. 06/57, p. 9, 2006.

621 BLOOMBERG NEWS. Bernanke says insurer AIG operated like a hedge fund, 3 mar. 2009. Tradução livre. 
Deficiências como essa certamente em nada contribuem com a regulação prudencial. $\mathrm{Na}$ medida em que a lógica da abordagem institucional é assentada na premissa de que a autoridade responsável pela supervisão tenha expertise no seu respectivo setor, a eliminação das barreiras regulatórias entre os setores leva tais autoridades a atuarem em casos nos quais não têm experiência, conforme se observou no exemplo supracitado. Bem a propósito, um relatório recente do Grupo dos 30 sobre a estrutura da supervisão financeira afirma que a abordagem institucional está desaparecendo porque se baseia em um modelo de negócios que não existe mais. ${ }^{622}$

\subsubsection{Abordagem funcional}

A abordagem funcional procura corrigir as deficiências da abordagem institucional ao adotar as atividades praticadas pelos agentes econômicos como critério para organizar a regulação e supervisão do sistema financeiro. Portanto, uma instituição financeira será supervisionada pelo banco central não pelo fato de possuir a natureza jurídica de um banco, mas por prestar atividades bancárias. Outrossim, caso um banco preste serviços de seguro, essas atividades não serão supervisionadas pelo banco central, e sim pela autoridade supervisora competente por aquelas atividades.

Uma alegada vantagem dessa abordagem reside na eliminação da possibilidade de arbitragem regulatória entre atividades financeiras. Todos os agentes econômicos estão sujeitos às mesmas regras de acordo com as atividades desempenhadas, e cada autoridade supervisora terá expertise em sua respectiva atividade. Outra vantagem desse modelo parece ser a eliminação do risco de vácuo regulatório, uma vez que, na medida em que um agente econômico estiver desempenhando uma atividade tipicamente regulada, deverá se reportar à autoridade cabível no tocante àquela atividade.

Apesar de representar um avanço relativamente ao modelo anterior, deve-se reconhecer que a abordagem funcional se baseia em uma premissa cuja verificação nem sempre é simples, que é a existência de funções-chave no sistema financeiro bem definidas e

622 GROUP OF 30. The structure of financial supervision, p. 34. 
com linhas divisórias claras entre elas. Com efeito, caso surjam questionamentos quanto à verdadeira natureza de uma atividade ou instrumento financeiro, abre-se margem para as deficiências encontradas na abordagem institucional. É o caso dos derivativos, por exemplo, que, conforme ensinamento de Yazbek, se desenvolveram por muito tempo sem que houvesse um regime próprio a eles aplicável ou uma estrutura regulatória especializada. ${ }^{623}$

Outra preocupação presente nessa abordagem refere-se à sobreposição de autoridades supervisoras sobre um mesmo agente econômico. Dependendo da quantidade de atividades exercidas, isso pode acabar provocando um ônus regulatório excessivo. Dessa forma, é importante que haja uma coordenação eficaz entre tais autoridades para maximizar a utilidade comum das informações requisitadas ao ente supervisionado.

No entanto, mais importante do que a preocupação com o ônus regulatório, essa abordagem gera também a necessidade de amplo esforço de coordenação entre as autoridades envolvidas para assegurar que os objetivos pretendidos por cada uma estejam alinhados. Isso porque, como as autoridades focam sua supervisão em apenas uma atividade específica, podem perder a noção do risco da instituição como um todo. Tal aspecto é preocupante porque, uma vez que nenhuma autoridade possui informação suficiente a respeito de todas as atividades desempenhadas, o monitoramento do risco sistêmico pode restar comprometido. Isso é bem representado em relatório do Tesouro norte-americano sobre a necessidade de modernizar a estrutura regulatória do país: ${ }^{624}$

\begin{abstract}
A abordagem funcional apresenta uma série de desvantagens, sendo a mais importante o fato de que nenhum regulador individual possui toda a informação e autoridade necessária para monitorar o risco sistêmico, ou o potencial de que eventos associados com instituições financeiras possam disparar consequências amplas ou séries de inadimplementos que afetem o sistema financeiro de forma tão significativa que a economia real seja afetada adversamente. Em complemento, a inabilidade de qualquer regulador para tomar ações coordenadas em todo o espectro do sistema financeiro torna mais difícil o endereçamento de problemas associados à sua estabilidade.
\end{abstract}

Embora essa deficiência possa ser trabalhada por meio de acordos que garantam trocas de informações entre as autoridades, deve-se reconhecer que tais acertos nem sempre são de fácil

623 YAZBEK, Otavio. Regulação do mercado financeiro e de capitais, p. 127.

624 DEPARTMENT OF TREASURY. Blueprint for a modernized financial regulatory structure. Washington, 31 mar. 2008, p. 4. Tradução livre. 
implementação, tampouco sendo possível assegurar que não haverá perda de informação relevante no processo. Esse é um ponto de grande importância, especialmente pelo fato de a estrutura de regulação e supervisão do SFN inspirar-se na abordagem funcional. ${ }^{625}$

Conforme visto no Capítulo 2, a Lei 4.595/1964 estabelece em seu art. 10. ${ }^{\circ}$, inciso IX, a competência do Bacen para exercer a fiscalização das instituições financeiras e aplicar as penalidades previstas, prevendo em seu art. 17 que são consideradas instituições financeiras as pessoas jurídicas que tenham como atividade principal ou acessória a coleta, intermediação ou aplicação de recursos financeiros próprios ou de terceiros e a custódia de valor de propriedade de terceiros, equiparando-se às instituições financeiras as pessoas físicas que exerçam tais atividades. Observa-se desde logo que o critério determinante para a competência do Bacen tem como base as atividades prestadas pelos entes supervisionados.

A Lei 6.385/1976 segue na mesma linha, estabelecendo em seu art. 1. ${ }^{\circ}$ quais atividades serão disciplinadas e fiscalizadas de acordo com a lei, e estipulando em seu art. $8 .^{\circ}$ a competência da CVM para "fiscalizar permanentemente as atividades e os serviços do mercado de valores mobiliários, de que trata o Art. 1. [...]". Já no caso do mercado de seguros, apesar de o Decreto-lei 73/1966 não oferecer uma orientação clara, o legislador parecer ter seguido a abordagem institucional, tomando como base para determinar a competência da Susep a qualificação da entidade como "Sociedade Seguradora" (arts. 35 e ss.).

Procurando enfrentar as limitações do modelo funcional, as autoridades do SFN vêm implementando medidas de cooperação mútua por meio da celebração de convênios. Nesse

625 Yazbek oferece uma interpretação diferente, afirmando que a evolução recente do arranjo institucional de regulação e supervisão pátrio estaria aproximando-o do modelo de regulação twin peaks, adotado na Austrália (YAZBEK, Otavio. Regulação do mercado financeiro e de capitais, 2. ed., p. 285 e ss.; e, Idem. Crise financeira e risco sistêmico, p. 8). Esse modelo é baseado na "regulação por objetivos", em que as autoridades dividem suas competências por "vocações", como a regulação prudencial, sistêmica e de condutas, tendo responsabilidade sobre todos os participantes do sistema financeiro, de acordo com o objetivo pretendido. Em que pese o papel relevante da CVM na regulação de condutas e o papel do Bacen na regulação sistêmica e prudencial, conforme enfatizado pelo autor, a análise dos principais marcos legais instituidores dessas autoridades indica que a distribuição de competências entre elas ainda se dá com base nas atividades desempenhadas e natureza jurídica dos participantes do SFN, e não o objetivo buscado por cada uma delas. Isso tem sérias implicações práticas em termos de monitoramento de risco sistêmico. Esse contraste ficará mais claro com a análise das principais características do modelo de regulação por objetivos, o que será feitos nos tópicos a seguir. 
sentido, Bacen e CVM celebraram um acordo em 5 de julho de $2002,{ }^{626}$ renovado e ampliado em 28 de outubro de 2010, ${ }^{627}$ que prevê importantes medidas de coordenação entre as autoridades, quais sejam: (i) manifestação prévia do Bacen a respeito de normas a serem editadas pela CVM que tenham reflexo na atuação das instituições financeiras e demais instituições autorizadas a funcionar pela autoridade bancária, o mesmo sendo válido para a CVM no tocante a normas a serem editadas pelo Bacen com reflexo no mercado de valores mobiliários e na atuação das instituições do sistema de distribuição de valores mobiliários; (ii) intercâmbio entre as autoridades de informações referentes às atividades desempenhadas nos mercados financeiro e de capitais, incluindo as operações realizadas nas bolsas de mercadorias e de futuros e em entidades de compensação e liquidação de operações com valores mobiliários; (iii) acesso recíproco a sistemas de informação administrados pelo Bacen e pela CVM; e (iv) cooperação nas ações de supervisão quando relacionadas aos fundos de investimento financeiro, fundos de aplicação em quotas de fundos de investimento financeiro e fundos de investimento no exterior.

Da mesma forma, o Bacen firmou convênio com a Susep, em 14 de julho de 2005, com o propósito de, entre outras providências, disciplinar o sistema de intercâmbio de informações entre as duas autoridades e elaborar uma programação coordenada de fiscalização para seguradoras que participem de conglomerados financeiros. Nesse sentido, o convênio prevê medidas voltadas à promoção de transferência mútua de tecnologia aplicada à supervisão, objetivando maior eficiência em suas respectivas áreas de competência. ${ }^{628}$ Finalmente, vale mencionar, ainda, a existência de convênio entre a CVM e a Susep, de 27 de dezembro de 2002, com o objetivo de instituir e disciplinar um sistema de intercâmbio de informações entre as duas autoridades e elaborar uma programação coordenada de supervisão das instituições sob sua responsabilidade. ${ }^{629}$ Com isso, haveria na atualidade previsão de esforços cooperativos de regulação e supervisão entre as três autoridades, conforme o esquema na página a seguir:

626 O convênio original entre o Bacen e a CVM está disponível em: <www.cvm.gov.br/port/public/publ/ convenio.asp>. Acesso em: 17 dez. 2010.

627 O novo convênio entre o Bacen e a CVM está disponível em: <www.cvm.gov.br/port/convenios/ CONV\%20BACEN.pdf>. Acesso em: 17 dez. 2010.

628 O convênio entre o Bacen e a Susep está disponível em: <www.bcb.gov.br/pre/acordos_e_convenios/ ConvenioSusep.pdf>. Acesso em: 17 dez. 2010.

629 O convênio entre a CVM e a Susep está disponível em: <www.cvm.gov.br/port/convenios/ Conv_CVM_SUSEP.asp>. Acesso em: 17 dez. 2010. 
Figura 3: Convênios entre autoridades do SFN

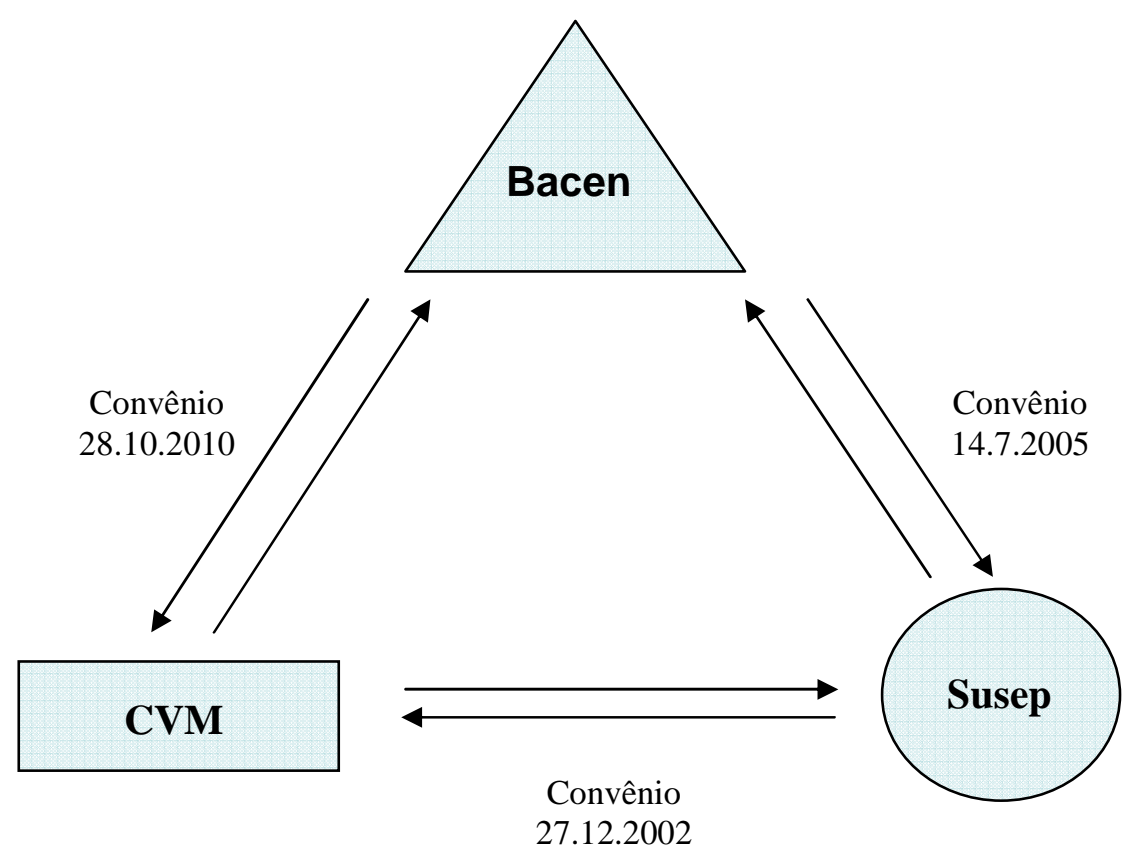

Além da troca de informações por intermédio de convênios, a coordenação da regulação e supervisão dirigida a cada atividade financeira também é facilitada pelo importante papel desempenhado pelo CMN. Conforme visto, compete ao CMN zelar pela liquidez e solvência das instituições financeiras (Lei 4.595/1964, art. 3. ${ }^{\circ}$, VI), devendo o Bacen cumprir e fazer cumprir as disposições que lhe são atribuídas pela legislação em vigor e as normas expedidas pelo CMN (Lei 4.595/1964, art. 9. ${ }^{\circ}$ ). Igualmente, compete ao CMN definir a política a ser observada na organização e no funcionamento do mercado de valores mobiliários (Lei 6.385/1976, art. 3., I), devendo a CVM regulamentar, com observância da política definida pelo órgão, as matérias previstas nas Leis 6.385/1976 e 6.404/1976.

Observa-se, assim, uma importante distinção da estrutura de regulação e supervisão pátria, que é a coordenação de políticas regulatórias para as atividades bancárias e de mercado de capitais pelo CMN. Com efeito, a Lei 6.385/1976 estabelece expressamente a competência do CMN para assegurar a coordenação de atividades entre o Bacen e a CVM nos casos de instituições financeiras e demais sociedades autorizadas a explorar simultaneamente operações ou serviços no mercado de valores mobiliários e nos mercados sujeitos à 
fiscalização do Bacen. ${ }^{630}$ Em tais casos, a lei determina também que as atribuições da CVM sejam limitadas às atividades ali previstas e exercidas sem prejuízo das atribuições do Bacen (Lei 6.385/1976, art. 15, $\S 2 .^{\circ}$ e $\left.3 .^{\circ}\right)$.

É importante notar que o papel de coordenação da atuação entre autoridades do sistema financeiro exercido pelo $\mathrm{CMN}$ não se estende às atividades de seguro e previdência. Reconhecendo essa limitação, o Decreto 5.685, de 25 de janeiro de 2006, criou o Coremec, que busca aprimorar a coordenação da política regulatória para atividades securitárias e demais atividades financeiras. Entre as suas atribuições, cabe ao Coremec: (i) propor a adoção de medidas visando o melhor funcionamento dos mercados sob a regulação e físcalização do Bacen, CVM, Susep e SPC; (ii) debater iniciativas de regulação e procedimentos de fiscalização que possam ter impacto nas atividades de mais de uma das entidades supracitadas, tendo por finalidade a harmonização de suas iniciativas e procedimentos; (iii) facilitar e coordenar o intercâmbio de informações entre tais entidades; e (iv) debater e propor ações coordenadas de regulação e fiscalização, inclusive as aplicáveis aos conglomerados financeiros.

Desde sua constituição em 2006, o Coremec já editou deliberações sobre temas diversos, como regras preventivas relacionadas à vigilância reforçada de pessoas politicamente expostas (Deliberação 2, de 1. ${ }^{\circ}$ de dezembro de 2006), iniciativas de educação financeira (Deliberação 3, de 31 de maio de 2007), verificação da adequação do produto ou serviço financeiro às necessidades, interesses e objetivos dos clientes ou participantes de planos de benefícios (Deliberação Coremec 7, de 19 de junho de 2009), entre outras. ${ }^{631}$ No

630 Exemplo dessa capacidade de harmonização do CMN é a Resolução CMN 3.427/2006, que estabelece como política a ser observada no mercado de valores mobiliários, e como orientação geral das atividades finalísticas da CVM, a adoção de um modelo de regulação e supervisão baseado em risco. Por modelo de regulação e supervisão baseado em risco deve-se entender, de acordo com a Resolução, um sistema de regulação e fiscalização do mercado de valores mobiliários que compreenda: (i) a identificação dos riscos a que está exposto o mercado de valores mobiliários; (ii) o dimensionamento e a classificação de tais riscos, inclusive segundo níveis de dano potencial ao mercado; (iii) as formas de mitigação dos riscos identificados; e (iv) o controle e o monitoramento dos eventos que possam causar dano ao mercado (cf. parágrafo único, art. 1. ${ }^{\circ}$ da Resolução). Nesse sentido, a Resolução CMN 3.427/2006 determina que a CVM adote mecanismos institucionais de organização de suas atividades e de priorização de suas ações de regulação e fiscalização, capazes de permitir a identificação, o dimensionamento, a mitigação, o controle e o monitoramento dos riscos que possam afetar a implementação de seus mandatos legais.

631 As deliberações do Coremec estão disponíveis em: <www.previdenciasocial.gov.br/conteudoDinamico. php?id=279>. Acesso em: 17 dez. 2010. 
âmbito da regulação sistêmica e prudencial, a deliberação mais importante do Coremec é a de número 12, de 30 de agosto de 2010, que instituiu o Sumef.

Compete ao Sumef manter o Coremec informado sobre a evolução dos mercados e as suas interconexões, principalmente no que se refere às relações entre os seus agentes e os papéis por eles desempenhados, apontando os riscos para o SFN. É incumbência do órgão também sinalizar situações que, em razão da integração dos mercados e de outras sobreposições, possam comprometer a estabilidade do SFN, nas quais seja necessária a atuação conjunta (ou ao menos coordenada) das entidades que compõem o Coremec. O Sumef também possui a atribuição de apresentar propostas de ações ao Coremec para reduzir o risco que situações identificadas possam gerar para a estabilidade do SFN, e coordenar ações que visem atender a demandas de informações consolidadas do SFN, principalmente as oriundas de organismos internacionais.

Infelizmente os mecanismos de coordenação entre autoridades do SFN mencionados são relativamente recentes, não havendo como afirmar de forma categórica se estão funcionando ou se funcionarão a contento. Ao contrário das deliberações do Coremec, não há divulgação ou exemplos de medidas tomadas pelas autoridades do SFN no âmbito dos convênios de cooperação. Apesar disso, guardadas as devidas diferenças, a análise da experiência de outros países que apoiam sua estrutura de regulação e supervisão na abordagem funcional, notadamente os Estados Unidos, não oferece prognóstico favorável quanto à capacidade de suprir as deficiências desse arranjo institucional mediante acordos de cooperação entre as autoridades do setor. ${ }^{632}$ Nesse aspecto, a criação do FSOC nos Estados

632 A estrutura de regulação e supervisão do sistema financeiro nos Estados Unidos apresenta elevado grau de complexidade, com instituições atuando nos mercados financeiro e de capitais sendo supervisionadas em nível federal e estadual, enquanto as seguradoras são reguladas em larga medida apenas no nível estadual. No tocante aos bancos, dependendo de seu ramo de atuação, até julho de 2010 havia cinco autoridades somente no nível federal responsáveis, direta ou indiretamente, por sua regulação e supervisão, quais sejam: Federal Reserve, FDIC, Office of Comptroller of the Currency (OCC), Office of Thrift Supervision (OTS) e National Credit Union Administration (NCUA). A divisão de competências entre tais autoridades é caracterizada predominantemente pela abordagem funcional, com resquícios da abordagem institucional (para seguradoras, por exemplo). Isso acaba gerando disputas quanto à competência para supervisionar determinadas instituições, atividades e produtos, bem como a necessidade de acordos entre as autoridades para compartilhar informações e evitar duplicação de atividades. Exemplos relevantes e recentes disso são as vendas de seguros por bancos e a caracterização de um produto financeiro como valor mobiliário ou contrato de futuro (DEPARTMENT OF TREASURY. Blueprint for a modernized financial regulatory structure, p. 5). Em virtude dessa complexidade, a estrutura regulatória norte-americana sofre críticas quanto ao ônus regulatório imposto aos entes regulados, bem como a viabilidade de realizar uma supervisão eficaz 
Unidos em 2010 assemelha-se em grande medida às razões que levaram à criação do Coremec em 2006 e do Sumef em 2010.

A evolução desses órgãos demonstrará se a solução para as deficiências da abordagem funcional de regulação e supervisão encontra-se na criação de órgãos de coordenação, ou se será necessária a reformulação estrutural do arranjo institucional de regulação e supervisão, a exemplo do ocorrido nos países que serão analisados a seguir. Independentemente disso, a preocupação do legislador pátrio em criar meios para a aplicação de uma regulação e supervisão harmônica entre as autoridades do SFN mostra que os desafios crescentes impostos à regulação prudencial em outros países também estão presentes no Brasil. Os dispositivos supracitados de coordenação entre Bacen, CVM e Susep indicam que a estrutura de regulação e supervisão do SFN, conforme concebida inicialmente nas décadas de

de entidades que desempenham atividades conjuntamente por meio de autoridades distintas (para um relato de como a estrutura regulatória norte-americana provocou a migração de negócios para a Inglaterra, ver: JACKSON, Howell. Variation in the intensity of financial regulation: preliminary evidence and potential implications. Yale Journal on Regulation, v. 24, n. 2, 2007). Isso também já foi reconhecido pelo próprio Tesouro norte-americano em relatório publicado em março de 2008, segundo o qual: "[...] a convergência de provedores de serviços e produtos financeiros aumentou na última década. Intermediários financeiros e plataformas de negociação estão convergindo. Produtos financeiros podem ter componentes relativos a atividades de seguros, bancárias, valores mobiliários e futuros [...] o sistema atual de regulação funcional é incompatível com essas mudanças no mercado, mantendo agências reguladoras separadas ao longo de linhas funcionais de serviços financeiros" (DEPARTMENT OF TREASURY. Blueprint for a modernized financial regulatory structure, p. 4. Tradução livre). No mesmo relatório, o Tesouro, à época sob a chefia de Henry M. Paulson, propõe ampla reformulação da estrutura de regulação e supervisão financeira nos Estados Unidos, defendendo a adoção de modelo mais próximo da regulação por objetivos para sanar as deficiências regulatórias presentes no modelo atual. Nessa nova estrutura proposta, três objetivos fundamentais direcionariam a regulação do sistema financeiro americano, quais sejam: (i) estabilidade do mercado; (ii) segurança e solidez por meio de supervisão prudencial; e (iii) conduta de negócios (Idem, ibidem, p. 137 e ss.). A proposta, no entanto, teve vida curta, uma vez que, após a transição da chefia do Tesouro em 2009 para Timothy F. Geithner, uma nova proposta de reforma da estrutura de regulação e supervisão financeira nos Estados Unidos foi apresentada. No tocante à regulação sistêmica, os relatórios guardam semelhanças entre si, havendo consenso quanto à necessidade de situar o Federal Reserve no centro dos esforços de atuação em casos de crises sistêmicas. No tocante à regulação prudencial, os relatórios trazem conclusões diversas. Enquanto o relatório de Paulson defende a alocação de tais atividades em autoridade separada do Federal Reserve, o documento de Geithner defende que a solução se encontra no fortalecimento das competências do banco central norte-americano, incluindo, entre outras, a ampliação do seu escopo de supervisão. Finalmente, o relatório de Geithner enfatiza a necessidade de aprimorar a coordenação entre as diferentes autoridades para o sistema financeiro, criando um conselho com representantes de sete autoridades, com o Secretário do Tesouro como seu presidente (para uma comparação detalhada dos dois relatórios, ver: MCDONALD, Gordon. Comparing the Paulson Blueprint with the Geithner White Paper, The PEW Economic Policy Group, Washington, 2009). Conforme observado, o Dodd-Frank Wall Street Reform and Consumer Protection Act segue em linha com as recomendações do relatório de Geithner, criando o FSOC, que, entre outros objetivos, procura aprimorar a comunicação e a coordenação de atividades entre as diferentes autoridades supervisoras no país. Em termos da simplificação da estrutura regulatória, pouco se progrediu. Das autoridades supracitadas, apenas o OTS foi eliminado, tendo suas atribuições divididas entre o Federal Reserve e o OCC. 
1960 e 1970, é insuficiente para responder aos desafios impostos pelo sistema financeiro na atualidade. Nesse aspecto, vale mencionar a existência de críticas abertas por parte de integrantes e ex-integrantes do Bacen quanto à estrutura de supervisão atual, defendendo a competência conjunta da autoridade bancária e CVM para determinados entes supervisionados no contexto de conglomerados financeiros, como os fundos de investimento. ${ }^{633}$ É possível e provável que, na medida em que atividades não bancárias ganhem maior representatividade nos resultados de conglomerados financeiros, o embate a respeito da extensão da competência das autoridades do SFN se torne mais frequente.

\subsubsection{Abordagem integrada}

Considerando as limitações da abordagem institucional e funcional, a solução encontrada por alguns países foi a unificação das funções de regulação e supervisão financeira em uma única autoridade. Nesse modelo, haveria apenas um responsável pela regulação e supervisão de todo o sistema financeiro, em arranjo institucional que ficou conhecido como “abordagem integrada” à regulação financeira.

Conforme indicação de Cardim de Carvalho, uma primeira vantagem a ser apontada na abordagem integrada é que esta permite a eliminação de rivalidades entre burocracias independentes, sempre zelosas quanto às suas áreas de poder. ${ }^{634} \mathrm{Com}$ efeito, mesmo na abordagem funcional, não raro observam-se autoridades divergindo quanto à natureza de uma

633 Conforme apontamento de Mario Torós, ex-diretor de Política Monetária do Bacen: "Parece pouco plausível que problemas severos em fundos associados a conglomerados financeiros não sejam transmitidos às entidades coligadas, inclusive no que se refere a instituições depositárias. Em tais circunstâncias, seria importante que o BC passasse a ter, em conjunto com a CVM, autoridade de supervisão sobre esta indústria, especificamente sobre os fundos que fazem parte de conglomerados financeiros liderados por bancos" (MESQUITA, Mário M. C.; TORÓS, Mário. Gestão do Banco Central no pânico de 2008, p. 199-200). A preocupação do ex-diretor de política monetária do Bacen parece ter sido respondida com o novo convênio de troca de informações entre a CVM e o Bacen firmado em 28 de outubro de 2010, que dá à autoridade bancária acesso a informações sobre as carteiras de fundos e sobre operações com derivativos e outras exposições relevantes.

634 CARVALHO, Fernão J. Cardim de et al. Economia monetária e financeira, p. 334. 
determinada atividade financeira e, consequentemente, quem teria competência sobre ela. ${ }^{635}$ Além disso, esse modelo garante também o tratamento isonômico a todos os entes regulados.

Outro aspecto positivo relativo à unificação das atividades de regulação e supervisão é a eliminação da necessidade de acordos para trocas de informações entre as diversas autoridades, mitigando o risco de perda de informações relevantes nesse processo de coordenação e, principalmente, permitindo uma avaliação mais completa das atividades realizadas por um determinado agente econômico e do risco sistêmico envolvido. Finalmente, argumenta-se também que a integração de atividades que normalmente seriam realizadas por diferentes autoridades traria ganhos de eficiência que se traduziriam em economias não apenas para o governo, mas, principalmente, para os entes regulados, uma vez que o processo de compliance regulatório se tornaria menos oneroso. ${ }^{636}$

Naturalmente, a abordagem integrada também apresenta desvantagens. Entre essas destaca-se o evidente perigo de concentrar tantos poderes em uma única autoridade, correndose o risco de criar um "leviatã burocrático", divorciado do setor que regula. ${ }^{637}$ Ao deixar a regulação do sistema financeiro sob a responsabilidade de apenas uma autoridade, esta pode acabar prestigiando demais um objetivo da regulação financeira em detrimento de outros. Além disso, a concentração de poderes em uma autoridade pode aumentar os riscos de uma falha de supervisão por omissão. Em contraste, a existência de diversas autoridades atuando

635 GROUP OF 30. The structure of financial supervision, p. 35. No contexto nacional, vale mencionar a consulta submetida pelo Itaú BBA S.A. à CVM em 2007 questionando se cédulas de crédito bancário (CCBs) seriam consideradas valores mobiliários e, em caso afirmativo, quais seriam as normas aplicáveis. Nesse processo a CVM decidiu que as CCBs constituem valores mobiliários, desde que sejam objeto de oferta pública, e a responsabilidade da instituição financeira por seu adimplemento tenha sido expressamente excluída do título. Ver: Processo CVM RJ2007/11.593, Registro Colegiado 5730/2007. Disponível em: <www.cvm.gov.br/Port/DesCol/respdecis.asp?File=5730-0.HTM>. Acesso em: $17 \mathrm{dez}$. 2010.

636 No entanto, deve-se ressaltar que os ganhos de escala e escopo decorrentes dessa abordagem não foram comprovados de forma inequívoca, havendo inclusive questionamentos por alguns autores quanto à sua existência. Estudos a esse respeito demonstram, por exemplo, que a integração de atividades não gera redução no número de pessoal. Ver: CIHAK, Martin; POPDIERA, Richard. Is one watchdog better than three?, p. 9; e TAFARA, Ethiopis. Remarks before the World Economic Forum Industry Agenda Meeting Regarding Finance, 21 set. 2004. Disponível em: <www.sec.gov/news/speech/spch092104et.htm>. Acesso em: 29 dez. 2010.

637 TAYLOR, Michael. Twin Peaks: a regulatory structure for the new century. London: Center for the Study of Financial Innovation, 1995. p. 15. 
sobre o setor cria maiores chances de identificação de uma falha de supervisão antes que ela atinja proporções significativas. ${ }^{638}$

Apesar dessas possíveis desvantagens, a abordagem integrada vem ganhando crescente prestígio nos últimos anos, tendo influenciado reformas regulatórias em diversos países, como a Inglaterra. As raízes do modelo inglês remetem a 1997, com a realização de uma ampla reforma no sistema regulatório do país, incluindo a criação da FSA como autoridade responsável pela regulação e supervisão do sistema financeiro. As competências da autoridade foram detalhadas em 2000, com a promulgação do Financial Services and Markets Act, que estabeleceu os quatro objetivos principais da FSA, quais sejam: (i) manter a confiança de mercado; (ii) promover consciência pública a respeito de finanças; (iii) proteger consumidores; e (iv) reduzir crimes financeiros. Para atingir seus objetivos, a FSA foi dotada de amplos poderes de investigação e aplicação de penalidades, assumindo um status "quase judicial".

Apesar de a FSA ser considerada um modelo de eficiência e efetividade regulatória, ${ }^{639}$ tendo inspirado reformas em outros países ${ }^{640}$ e sendo inclusive alardeada por autoridades inglesas como o melhor sistema de regulação e supervisão existente, ${ }^{641}$ os acontecimentos recentes envolvendo o banco Northern Rock levaram a uma reavaliação dessa

638 GROUP OF 30. The structure of financial supervision, p. 36.

639 Idem, ibidem, p. 28-29.

640 Seguindo na mesma linha do modelo inglês, pode-se mencionar o caso da Alemanha, que em 2002 promoveu reforma regulatória, criando a Bundesanstalt für Finanzdienstleistungsaufsicht (BaFin). Assim como a FSA, a BaFin tem a responsabilidade de supervisionar as atividades bancárias, de mercado de capitais e de seguros, com o objetivo de garantir a higidez do sistema financeiro do país. Não obstante, deve-se ressaltar que, apesar da separação de funções, o Bundesbank (banco central alemão) continua a desempenhar funções relativas à supervisão bancária, como a avaliação de demonstrações financeiras e informações prestadas pelas instituições financeiras referentes à utilização do sistema de pagamentos. Nesses casos, o banco central deve notificar a BaFin do resultado de sua análise. A BaFin tem o poder de conduzir investigações em instituições financeiras, bem como poderes para decretar a intervenção ou mesmo cessação de suas atividades. Para evitar duplicação de esforços de supervisão, os termos do relacionamento entre as duas autoridades estão detalhados em acordo de cooperação de 31 de outubro de 2002 (disponível em: <www.bafin.de/cln_170/nn_723146/SharedDocs/Aufsichtsrecht/DE/Richtlinien/rl__080221_ufsi chtsrichtlinie.html>; acesso em: 17 dez. 2010). Em razão dessa divisão de responsabilidades entre o Bundesbank e a BaFin, argumenta-se que o modelo alemão não pode ser considerado uma separação "pura" de funções. Ver: Idem, p. 30.

641 COLE, Margareth. The UK FSA: nobody does it better? 17 out. 2006. Disponível em: <www.fsa.gov.uk/pages/Library/Communication/Speeches/2006/1017_mc.shtml>. Acesso em: 23 dez. 2010 . 
estrutura regulatória na Inglaterra. Alguns analistas mais críticos sugerem que o modelo atual não conseguiu oferecer uma resposta suficientemente rápida para a crise de liquidez e o colapso do banco. ${ }^{642}$ Nesse aspecto, chamou atenção também o reconhecimento por parte da FSA de que não havia conduzido uma análise aprofundada da situação do Northern Rock nos 18 meses que antecederam sua liquidação. ${ }^{643}$

Em resposta a essas críticas, foi promulgado o Banking Act de 2009, que procurou esclarecer as responsabilidades das autoridades atuantes na regulação e supervisão do sistema financeiro inglês. O novo marco regulatório devolveu a responsabilidade pela estabilidade do sistema financeiro ao banco central inglês, cuja competência havia sido removida na reforma promovida em 2000. Dessa forma, o Bank of England passa a ter previsão expressa de responsabilidade pela supervisão do risco sistêmico no sistema financeiro inglês. A FSA continua exercendo importantes funções prudenciais, mas estas têm foco nas instituições financeiras consideradas individualmente, enquanto o banco central se encarregará do monitoramento do sistema financeiro como um todo, com funções análogas às exercidas pelo Sumef e FSOC. Além disso, foi instituído um sistema especial de liquidação (Special Resolution Regime - SRR), que cria amplo rol de opções a serem adotadas para lidar com instituições financeiras em crise, como a possibilidade de nacionalização temporária de bancos privados, transferência de parte ou integralidade dos ativos bancários para o setor privado ou para subsidiária do banco central inglês, substituição da administração da instituição financeira, entre outras medidas. A decisão sobre a aplicação ou não do SRR deve ser tomada conjuntamente pelo banco central, Tesouro e FSA, mas cabe ao primeiro propor quais mecanismos devem ser aplicados. Para evitar que novas divergências surjam na atuação das autoridades em momentos de crise, foi assinado um memorando de entendimento esclarecendo as responsabilidades de cada uma delas no sistema financeiro. ${ }^{644}$

642 Para um relato detalhado dos eventos que precederam a intervenção no Northern Rock, ver: BLACK, Julia. Managing the financial crisis: the constitutional dimension. LSE Law, Society and Economy Working Papers, n. 12/2010, jun. 2010.

643 THE TIMES. FSA retail chief Clive Briault leaves with $£ 380,000$ payoff after Northern Rock debacle, 20 mar. 2008.

644 Documento disponível em: <www.bankofengland.co.uk/financialstability/mou.pdf>. Acesso em: $17 \mathrm{dez}$. 2010 . 


\subsubsection{Regulação por objetivos}

O sistema de regulação por objetivos procura atingir os benefícios da abordagem integrada e corrigir suas deficiências. Como o próprio nome indica, em um sistema de regulação por objetivos, há objetivos-chave a serem perseguidos, como a regulação sistêmica, regulação prudencial e regulação de condutas. Dessa forma, as autoridades do sistema financeiro não são responsáveis por instituições ou atividades específicas, possuindo responsabilidade sobre todos os agentes econômicos atuando no setor, no limite de sua competência regulatória, que é determinada pelo objetivo perseguido.

Entre as vantagens oferecidas por esse modelo destaca-se a maior clareza e objetividade na atuação de cada autoridade. Ao permitir o tratamento separado de objetivos sistêmicos e prudenciais, mitiga-se o risco de que um deles seja prestigiado em detrimento do outro, favorecendo assim um tratamento mais equilibrado entre eles. Além disso, na medida em que diversas autoridades atuam no sistema buscando objetivos diversos, porém relacionados, mitiga-se também o risco de uma falha de supervisão passar despercebida.

Aspecto polêmico da regulação por objetivos refere-se à possibilidade de separação das funções de regulação e supervisão bancária do banco central, órgão tradicionalmente incumbido de tais tarefas. A esse respeito, há acirrado debate doutrinário quanto aos benefícios dessa divisão de funções, de um lado posicionando-se os defensores da centralização desse papel no banco central em virtude do seu profundo conhecimento sobre o setor bancário, bem como a relação intrínseca das funções de regulação e supervisão bancária com a política monetária; ${ }^{645}$ e, de outro, aqueles que

645 Aqueles que apoiam a centralização das funções de supervisão bancária no banco central afirmam que tais instituições possuem expertise sobre o setor que poderia ser comprometida se o papel fosse transferido a outro supervisor. Parte-se da premissa de que bancos centrais estariam em melhor posição para executar tal função por uma série de razões, como: (i) melhor conhecimento sobre os negócios das instituições financeiras e condições de mercado em virtude da própria natureza de suas atividades; (ii) maior conhecimento técnico de sua equipe em tais assuntos; e (iii) posição privilegiada para prover liquidez ao mercado financeiro em razão de seu conhecimento sobre os participantes de mercado e acesso a fontes de financiamento. Consequentemente, o banco central apresentaria vantagens competitivas para promover a higidez do setor bancário (GROUP OF 30. The structure of financial supervision, p. 39). Além disso, argumenta-se que a função de supervisão bancária seria inerente à própria condução da política monetária, não podendo, portanto, ser exercida de forma separada. Os mecanismos de transmissão da política monetária, como mudanças na taxa de juros e meta de inflação, fluem por meio da intermediação no setor bancário. Assim, compreender como bancos comerciais reagem a tais mudanças, e como isso afeta suas reservas, bem como suas próprias decisões relativas a crédito, pode ser crucial para que políticas macroeconômicas monetárias atinjam o resultado pretendido (GOODHART, Charles. The organizational structure of banking 
veem nessa separação uma forma de compensar a concentração excessiva de poderes no banco central e mitigar os incentivos negativos que podem comprometer a atuação do órgão no campo da regulação sistêmica e prudencial. ${ }^{646}$

supervision. In: BREALEY, Richard A. (Org.). Financial stability and Central Banks: a global perspective. London: Routledge, 2001. p. 89). Segundo os defensores da centralização das atividades de supervisão no banco central, não importa quão focado este seja em aspectos macroeconômicos de política monetária e estabilidade de preços, o sucesso dessas medidas dependerá também da manutenção de um ambiente financeiro estável. Se não houver confiança na estabilidade financeira, o ciclo de depósitos que caracteriza o mercado financeiro restará prejudicado. E o raciocínio contrário também seria válido. A higidez do sistema financeiro também depende da conjuntura macroeconômica, de modo que a função de supervisão necessitará de informações sobre o que esperar da política monetária para aprimorar sua supervisão. Nesse sentido, é oportuno o posicionamento de Ferguson, segundo o qual: "Finalmente, simplesmente não há substituto para as ligações entre supervisão, regulação, comportamento de mercado, tomada de risco, padrões prudenciais $\mathrm{e}$, não podemos nos esquecer, estabilidade macroeconômica. A inteligência e conhecimento adquirido derivados do exame e responsabilidades regulatórias desempenham papel importante, às vezes crítico, na política monetária. Não menos relevante, nossas responsabilidades pela estabilização econômica contribuem para nossa política de supervisão. Observadores e supervisores de agências com apenas um propósito frequentemente perdem noção de como uma supervisão rigorosa ou leniente pode ter sérias implicações macroeconômicas [...]". Ver: FERGUSON, Roger. Alternative approaches to financial supervision and regulation. Journal of Financial Services Research, 17(1), p. 301, 1999. Tradução livre.

${ }^{646}$ Em contraste à corrente que defende a execução de funções de regulação e supervisão bancária pelo banco central, outro corpo de estudos contesta a conveniência da integração de tais atividades, defendendo a separação e a alocação dessas funções em outra autoridade. Nesse sentido, um dos principais argumentos a favor de tal mudança fundamenta-se na preocupação com a concentração excessiva de poderes em apenas um órgão, o que seria exacerbado pelo fato de os membros do banco central tradicionalmente não serem representantes eleitos diretamente pela população, bem como pelo movimento em prol da autonomia desses órgãos observado internacionalmente nas últimas décadas. A propósito, alguns autores acreditam inclusive haver correlação entre a conquista da autonomia por bancos centrais ao redor do mundo e a atribuição da responsabilidade pela supervisão do setor para um órgão separado e especializado (GOODHART, Charles. The organizational structure of banking supervision, p. 88). No entanto, talvez o argumento mais contundente em prol da separação de funções resida na alegada existência de conflitos de interesse entre a condução da política monetária e o desempenho de atividades de regulação e supervisão. De fato, há inúmeros estudos sugerindo que a perseguição de objetivos monetários pode nem sempre ser compatível com a estabilidade do sistema financeiro (DI NOIA, Carmine; DI GIORGIO, Giorgio. Should banking supervision and monetary policy tasks be given to different agencies? International Finance, 2(3), 1999; HAUBRICH, Joseph G. Combining bank supervision and monetary policy. Federal Reserve Bank of Cleveland, Economic Commentary, v. 11, 1996; LANNOO, Karel. Challenges to the structure of financial supervision in the EU. In: BALLING, Morten et al. Adapting to financial globalization. London: Routledge, 2001). A esse respeito, vale mencionar o posicionamento de Barth et al, segundo o qual: "Aqueles que assinalam as desvantagens de atribuir a supervisão bancária ao banco central enfatizam os conflitos de interesse entre funções de supervisão e política monetária. $\mathrm{O}$ conflito pode se tornar particularmente agudo durante uma fase de recessão econômica, quando bancos centrais podem se sentir tentados a perseguir uma política monetária mais relaxada para conter efeitos adversos sobre o faturamento dos bancos e qualidade de crédito. Isso pode também encorajar bancos a estender crédito de forma mais liberal do que o desejado para acomodar a demanda em uma política monetária expansionista. Embora tal política possa ser inicialmente benéfica para o setor bancário, ela pode no final das contas ter efeitos deletérios sobre a economia" (BARTH, James R. et al. Rethinking bank regulation, p. 88. Tradução livre). A explicação de Barth et al. é oportuna porque reflete justamente um dos maiores pontos de repreensão a Alan Greenspan, apontado como um dos grandes responsáveis pela crise recente que se alastrou pelos mercados financeiros mundiais. Críticos de sua atuação enfatizam que o Federal Reserve poderia ter atuado muito antes, mas que a crença inabalável de Greenspan na sua política monetária acabou impedindo a adoção de medidas corretivas antes da eclosão da crise (OVERTVELDT, Johan Van. Bernanke's test). Outro importante aspecto do argumento 
Naturalmente, assim como na abordagem integrada, a eventual separação de funções de política monetária e supervisão bancária gera a necessidade de boa coordenação entre as respectivas autoridades para garantir atuação harmônica e sem perda de informações. O próprio Relatório Wallis (Wallis Report), que sugeriu a instituição da separação de funções de supervisão bancária na Austrália, admitiu isso ao afirmar que: "ao favorecer uma abordagem mais holística para a regulação prudencial, conduzida separadamente do banco central australiano (Reserve Bank of Australia - RBA), este relatório reconhece que há custos de transição e a necessidade de assegurar cooperação regulatória para endereçar ameaças à estabilidade sistêmica". ${ }^{647}$ Da mesma forma, há novamente a preocupação de coordenação entre as diferentes autoridades para não sobrecarregar os participantes do sistema financeiro com o ônus regulatório.

em prol da divisão de funções seria o fato de a supervisão bancária ser considerada uma "tarefa ingrata", com potencial para prejudicar a imagem do supervisor dependendo da forma como for conduzida. Os objetivos de uma política macroeconômica podem - e frequentemente são - ser determinados em termos de objetivos quantitativos para metas de inflação. Isso significa que tanto o sucesso como o fracasso de tal política são razoavelmente transparentes. Essa quantificação e transparência são mais difíceis no caso da supervisão bancária, uma vez que, na medida em que esta se preocupa com a prevenção de eventos indesejados de instabilidade sistêmica, o melhor que um supervisor pode esperar é que nada calamitoso aconteça. Um supervisor só é notado quando este perturba o regulado com alguma medida restritiva ou intrusiva, ou, pior, quando a supervisão falha. Por mais que haja argumentos para permitir a quebra de instituições financeiras (ausência de risco sistêmico, por exemplo), os responsáveis pela supervisão bancária inevitavelmente encontram-se sujeitos a críticas quando quebras ocorrem. Isso é bem ilustrado no Wallis Report, relatório que fundamentou a separação das funções de regulação e supervisão bancária do banco central na Austrália: "[...] separar as funções de regulador prudencial e prestamista de última instância para bancos em crise (esta última uma função que o relatório acredita que deva ficar com o banco central), remove um conflito de interesse potencial. A questão-chave que o prestamista de última instância enfrenta é se a instituição em crise é ilíquida ou insolvente. Na medida em que a reputação do regulador pode ser afetada por uma quebra, há um incentivo para que liquidez seja provida mais prontamente do que seria o caso se houvesse uma separação de funções" (WALLIS, Stan (Org.). Financial system inquiry final report, mar. 1997, p. 314. Disponível em: <fsi.treasury.gov.au>. Acesso em: 24 dez. 2010. Tradução livre). Entre os defensores da separação de funções de supervisão do banco central, destaca-se o posicionamento do Shadow Financial Regulatory Committee, um grupo de especialistas independentes que se reúnem periodicamente para analisar políticas regulatórias afetando o sistema financeiro. A respeito da relação entre política monetária e supervisão bancária, vale mencionar sua declaração 153, de 7 de dezembro de 1998, segundo a qual: "De fato, é a opinião do Comitê que o Fed não deveria manter ao mesmo tempo a responsabilidade pela política monetária e regulação prudencial dos bancos [...] ocorrem em certos momentos claros conflitos de interesse na condução conjunta da promoção da estabilidade no mercado financeiro doméstico e internacional, e supervisão dos bancos" (Disponível em: <www.aei.org/docLib/20051114_ShadowStatement153.pdf>. Acesso em: 17 dez. 2010. Tradução livre). Finalmente, em resposta aos críticos da separação de funções, Cardim de Carvalho ressalta que o argumento de que a supervisão bancária deva ser alocada no banco central em virtude de sua relação íntima com a política monetária não contradiz a proposta da regulação por objetivos, nem mesmo a abordagem integrada. Segundo o autor, "trata-se, na verdade, apenas de preservar os canais de informação sobre o estado do sistema bancário que o banco central pode desejar levar em conta quando decide, por exemplo, sobre variações das taxas de juros. Esses canais podem ser preservados simplesmente desenhando-se um sistema pelo qual a autoridade monetária tenha acesso, sempre que necessário, às informações relevantes coletadas pelo supervisor". Ver: CARVALHO, Fernão J. Cardim de et al. Economia monetária e financeira, p. 334.

647 WALLIS, Stan (Org.). Financial system inquiry final report, p. 314. Tradução livre. 
Entre os países que adotaram essa abordagem regulatória, o exemplo mais famoso é o da Austrália, que em 1997 promoveu uma reforma da estrutura de regulação e supervisão do seu sistema financeiro, passando a organizá-lo em duas autoridades que cuidam, respectivamente, da regulação prudencial e da conduta de negócios, em modelo que ficou conhecido como "Dois Picos" (Twin Peaks). A Autoridade Regulatória Prudencial Australiana (Australian Prudential Regulatory Authority - Apra) atua como autoridade prudencial, focando na higidez do sistema financeiro, especialmente do setor bancário. Para tal, a Apra tem ampla competência sobre os participantes do sistema financeiro australiano, funcionando de forma independente ao RBA. Nesse sentido, é ela quem autoriza o funcionamento de instituições financeiras e supervisiona seu funcionamento, contando inclusive com poderes para assumir o controle de bancos em crise ou administrar a dissolução de instituições insolventes. O RBA, por sua vez, continua responsável por algumas funções típicas de um regulador sistêmico, como a administração do sistema de pagamentos e atuação como prestamista de última instância. É importante notar, no entanto, que para o exercício dessa última função, deve atuar de forma coordenada com a Apra, contando com a sua aprovação para prestar auxílio a instituições em crise. Além da Apra, a reforma de 1997 criou a Comissão de Valores Mobiliários e Investimentos da Austrália (Australian Securities and Investments Commission - Asic), que regula a conduta de negócios no sistema financeiro, com foco específico na proteção do consumidor.

Aspecto importante a ser mencionado é que, embora a Apra seja separada do RBA, as duas autoridades devem trabalhar em regime de estrita cooperação. Nesse sentido, o Wallis Report estabeleceu no tocante à reforma regulatória que: (i) o RBA deve ter três membros na diretoria da Apra; (ii) deve haver previsão legal para plena troca de informações entre o RBA e a Apra; (iii) deve haver previsão legal para participação do RBA em equipes de inspeção da Apra; e (iv) deve ser criado um comitê bilateral de coordenação operacional, chefiado por um representante do RBA, para estabelecer como ocorrerá o intercâmbio de informações, formas de divulgação destas e quaisquer outros aspectos de cooperação operacional entre as autoridades, bem como a cooperação para estabelecer procedimentos claros para a administração de instituições financeiras em dificuldades. ${ }^{648}$

648 WALLIS, Stan (Org.). Financial system inquiry final report, p. 318. 
O modelo australiano goza de grande prestígio ao redor do mundo, tendo sido adotado na Holanda e estando em fase de implementação na Espanha. ${ }^{649}$ Em janeiro de 2006, o governo australiano preparou estudo com o objetivo de avaliar a eficácia da estrutura de regulação e supervisão do país e a percepção dos participantes do sistema financeiro quanto ao ônus regulatório imposto no modelo atual. O resultado foi positivo, sugerindo a manutenção da estrutura vigente e afirmando que o sistema conta com o apoio dos participantes do sistema financeiro, além de ser objeto de elogios na comunidade internacional. $^{650}$

\subsubsection{Sistema bancário na "sombra"}

Além das dificuldades associadas ao monitoramento do risco sistêmico em um contexto de conglomeração financeira, a regulação prudencial enfrenta outros desafios em decorrência de mudanças ocorridas no sistema financeiro nas últimas décadas. Nesse aspecto, destaca-se o surgimento de uma variedade de participantes nos mercados financeiro e de capitais que desempenham papel semelhante ao dos bancos, sem, no entanto, estarem submetidos às exigências da estrutura regulatória prudencial existente. Em segundo lugar, observa-se o surgimento de uma série de instrumentos utilizados pelas instituições financeiras para retirar ativos de risco de seus balanços e viabilizar o aumento de sua alavancagem. Justamente por funcionar à margem do arcabouço prudencial existente, esse conjunto de instituições e instrumentos financeiros recebe o nome de sistema bancário na "sombra" (shadow banking system).

No tocante ao primeiro aspecto mencionado, incluem-se no shadow banking system diversos participantes de relevo no sistema financeiro, como hedge funds, fundos de private equity, fundos de pensão e seguradoras, entre outros. ${ }^{651}$ Segundo a lição de Cintra e Farhi a

${ }^{649}$ GROUP OF 30. The structure of financial supervision, p. 38.

650 BANKS, Gary. Report of the taskforce on reducing regulatory burdens on business, 2006, p. 88. Disponível em: <www.regulationtaskforce.gov.au>. Acesso em: 23 dez. 2010.

651 Em países como os Estados Unidos, somavam-se a tais instituições até pouco tempo atrás os grandes bancos de investimento independentes (broker-dealers). Essa situação, no entanto, foi alterada durante a crise financeira de 2008, quando os últimos grandes bancos de investimento do país transformaram-se em bank holding companies para ter acesso a fundos de emergência do Federal Reserve. Ver: THE TIMES. End of Wall Street investment bank, 22 set. 2008. 
respeito da crise financeira recente, esse conjunto de instituições funcionava como banco sem sê-lo, captando recursos no curto prazo, operando de forma altamente alavancada e investindo em ativos de longo prazo e ilíquidos. ${ }^{652}$ No entanto, diferentemente dos bancos, tais instituições eram displicentemente reguladas e supervisionadas, não estando sujeitas às regras prudenciais aplicáveis aos bancos, como as determinações dos Acordos de Basileia. ${ }^{653}$ Outrossim, embora desempenhassem funções análogas às dos bancos, inclusive estando sujeitas a "corridas" por parte de investidores em alguns casos, tais instituições não possuíam acesso a instrumentos típicos da rede de segurança proporcionada aos bancos. ${ }^{654}$

Embora fuja ao escopo deste trabalho discorrer sobre se e como instituições não bancárias devem sujeitar-se à regulação sistêmica e prudencial, é importante notar como esse vácuo regulatório pode afetar as instituições bancárias. Nesse aspecto, já se observou no capítulo anterior como alguns desses participantes do shadow banking system podem se tornar fontes potenciais de risco sistêmico, comprometendo a situação financeira de bancos e outros participantes do mercado.

Outra preocupação de relevo quanto ao shadow banking system refere-se ao movimento realizado por diversas instituições financeiras para excluir determinados riscos de crédito de seus balanços. Esse processo está intrinsecamente relacionado à própria evolução da regulação prudencial, notadamente os mencionados controles de adequação patrimonial com base no nível de risco dos ativos na carteira da instituição financeira. Para procurar "aliviar" seus requisitos de capital, os bancos recorreram aos chamados "produtos estruturados", instrumentos resultantes da combinação entre um título representativo de um crédito (debêntures, bônus, títulos de crédito negociáveis, hipotecas, dívida de cartão de crédito etc.) e um leque de derivativos de crédito. Essa alquimia financeira só foi possível, por sua vez, graças às chamadas Sociedades de Propósito Específico (Special Purpose Entities SPEs) e à atuação das agências de rating, que serão objeto de análise mais adiante.

652 CINTRA, Marcos A. M.; FARHI, Maryse. A crise financeira e o global shadow banking system. Revista Novos Estudos, Cebrap, n. 82, p. 36, nov. 2008.

653 Idem, ibidem, p. 36.

654 Para um relato sobre tipos de instituições não bancárias, e como os riscos de suas atividades podem se assemelhar aos riscos apresentados por bancos, e que justificam a regulação sistêmica e prudencial que lhes é aplicada, ver: TUCKER, Paul. Shadow banking, financing markets and financial stability, Remarks at the BGC Partners Seminar, London, 21 jan. 2010. Disponível em: 〈www.bis.org/review/r100126d.pdf〉. Acesso em: 26 dez. 2010. 
As SPEs são entidades constituídas como subsidiárias ou afiliadas de outra entidade (chamada de "originadora"), geralmente um banco ou seguradora, para realizar atividades específicas e restritas, com prazo de existência determinado. Entre as atividades desempenhadas por SPEs, podem-se mencionar o financiamento de ativos por meio de securitização de recebíveis e operações estruturadas. Diversos motivos levam à criação das SPEs, como o isolamento de ativos em relação aos pertencentes à instituição financeira que os originou, favorecendo assim a emissão de títulos por parte da SPE ao diminuir a possibilidade de questionamentos por parte de credores em caso de falência da originadora. ${ }^{655}$ Além disso, as SPEs permitem a desagregação de riscos relacionados a um determinado conjunto de ativos do banco, transferindo-os para investidores que desejem assumir tais riscos por meio do investimento em títulos emitidos pela SPE.

Não obstante, a motivação para as SPEs de maior relevo para a regulação prudencial refere-se à possibilidade de retirar ativos de seus demonstrativos contábeis, diminuindo, assim, a exigência de adequação de capital para a instituição financeira. A lógica seria a de transferir aqueles ativos que exigem maior nível de capital, permanecendo no balanço apenas aqueles que possuem baixa exigência de capital, por serem considerados menos arriscados. ${ }^{656}$ Conforme o posicionamento do Comitê de Basileia sobre as SPEs: ${ }^{657}$

\begin{abstract}
Outra motivação para o uso de SPEs é a possibilidade de remover ativos do balanço patrimonial de acordo com as condições e tratamento contábil aplicáveis [...] Ao retirar determinados ativos do balanço, a instituição originadora pode se beneficiar da habilidade de demonstrar melhores condições financeiras, como um maior retorno sobre ativos [...] Além disso, o tratamento fora do balanço pode afetar os requisitos de capital em determinadas jurisdições nos quais os controles de adequação patrimonial são baseados nos ativos declarados nas demonstrações financeiras. O grau de alavancagem nos Estados Unidos é um exemplo disso.
\end{abstract}

A utilização crescente das SPEs pelas instituições financeiras apresenta obstáculos à regulação prudencial, uma vez que possibilita a transferência de riscos para entidades que não constam nos seus demonstrativos contábeis, dificultando a identificação precisa dos riscos a que tais instituições estão sujeitas. Conforme a oportuna colocação de Cardim de Carvalho

655 Naturalmente, esse não é um aspecto pacífico, estando sujeito às especificidades da legislação falimentar de cada país.

656 O tratamento contábil adotado por cada instituição financeira influenciará de forma determinante a possibilidade de atingir tal resultado, conforme se observará a seguir.

657 COMITÊ DE BASILEIA. Report on special purpose entities, Basileia, set. 2009, p. 13. Tradução livre. 
acerca das dificuldades relativas à supervisão de conglomerados financeiros, "a situação, que em si já é suficientemente difícil, se torna ainda menos tratável quando se tem em conta o crescimento da importância de operações fora de balanço, quando o balanço das instituições é o instrumento tradicional de trabalho de supervisão, da emergência de riscos ainda não mapeados, e de produtos de natureza ambígua" 658 . Outra evidente dificuldade refere-se ao fato de as SPEs, embora relacionadas a instituições financeiras, muitas vezes não terem acesso a mecanismos de regulação sistêmica e não estarem sujeitas à fiscalização da regulação prudencial, estando vulneráveis a uma série de riscos, principalmente desequilíbrios patrimoniais decorrentes da desvalorização dos ativos em face dos passivos.

A respeito da exposição das instituições financeiras a tais entidades, vale ressaltar que a diluição de valor dos ativos subjacentes a tais estruturas não afeta diretamente o originador, haja vista que estes foram repassados à SPE, o que é reforçado pelo fato de tais entidades serem estruturadas de modo a estabelecer uma "blindagem" entre ativos da originadora e da SPE. ${ }^{659}$ Isso não impede, no entanto, que o originador seja impactado indiretamente de outras formas. Em primeiro lugar, este pode deter em sua carteira de ativos títulos emitidos pela SPE pela perspectiva de maiores retornos nas emissões atreladas às tranches mais arriscadas dos produtos estruturados (junior tranches), ou mesmo como forma de garantia implícita aos investidores quanto aos ativos financiados. ${ }^{660}$ Além disso, ao

658 CARVALHO, Fernão J. Cardim de et al. Economia monetária e financeira, p. 331.

659 Esse é o chamado sistema de "originação e distribuição" (originate and distribute), que, segundo Verçosa, consiste em realizar "a securitização e venda de empréstimos no mercado financeiro, significando dizer que uma empresa ou instituição financeira concede um empréstimo e transfere o crédito correspondente a terceiros, atuando como um intermediário ativo". Ver: VERÇOSA, Haroldo M. D. Considerações sobre o sistema financeiro, p. 12.

660 O processo típico de securitização de recebíveis imobiliários tem início com uma pessoa que assume dívidas por meio de contratos de hipoteca para adquirir imóveis ou para refinanciar hipotecas já existentes. Aprovando-se a hipoteca, o emprestador de recursos vende o empréstimo - com diversas outras operações similares - para outra instituição que, por sua vez, repassará tais créditos para uma SPE. A SPE financia a aquisição de tais créditos mediante a emissão de títulos de dívida lastreados nos pagamentos das hipotecas (e outros créditos similares) contratadas inicialmente. Em razão disso, tais obrigações são chamadas de asset backed securities (ABS), uma vez que são lastreadas em um ativo financeiro, no caso, a hipoteca. A SPE utiliza o fluxo de caixa proveniente de tais contratos para remunerar os investidores que adquiriram seus títulos. Muitas vezes uma SPE divide os títulos que emite em diferentes segmentos (tranches) que refletem níveis diferentes de preferência no pagamento. Por exemplo, uma SPE pode emitir três classes diferentes de títulos de dívida: uma classe senior, uma classe intermediária, e uma classe junior. O contrato de emissão da dívida especifica os termos do pagamento da remuneração aos investidores, determinando que obrigações devidas à classe senior devem ser pagas em primeiro lugar, seguidas dos pagamentos para a classe intermediária, e, finalmente, a classe junior. Se todos os pagamentos dos contratos que originaram os créditos forem pagos regularmente, a SPE terá fundos suficientes para cumprir com suas obrigações concernentes a todas as classes. Se os fundos forem insuficientes, a classe junior será a primeira a não ser 
estimular o financiamento de ativos de alto risco, acaba aumentando também o risco de crédito no mercado na medida em que possibilita empréstimos sujeitos a maior grau de inadimplência, como os chamados ninja loans, acrônimo referente a financiamentos concedidos a pessoas sem trabalho, renda ou ativos (no job, no income and no assets). $\mathrm{O}$ Comitê de Basileia também levanta evidências de que ativos repassados às SPEs geralmente são objeto de auditoria legal mais "relaxada" do que aqueles que ficam na carteira do banco. ${ }^{661}$ Em momentos de crise, a diluição de valor desses ativos pode afetar o valor das carteiras de crédito bancárias, fato que, aliado à ausência de transparência contábil muitas vezes associada a tais estruturas, pode acabar gerando uma onda de incerteza no tocante à situação de solvência da própria instituição financeira, inclusive no próprio mercado interbancário, gerando uma crise de liquidez generalizada. Finalmente, na medida em que originadores financiam ativos de alto risco na perspectiva de repassá-los a SPEs, em momentos de crise de liquidez, pode haver dificuldade em efetuar tal repasse, fazendo com que o risco permaneça na carteira de ativos das instituições financeiras.

A crise financeira recente serviu para demonstrar como as SPEs foram utilizadas por instituições financeiras para realizar investimentos de alto risco com elevados graus de alavancagem. Segundo Overtveldt: "De repente se tornou claro que instituições financeiras vinham utilizando $\mathrm{SIVs}^{662}$ fora de seus balanços para realizar investimentos alavancados, arriscados e obscuros. Por meio de SIVs, bancos podiam ignorar requisitos de capital rígidos impostos pela regulação internacional. O Citigroup, por exemplo, havia alocado sozinho pelo menos US\$100 bilhões em SIVs"663. Com efeito, a utilização de tais estruturas na securitização de recebíveis no mercado hipotecário subprime norte-americano é associada à origem da crise financeira recente que se alastrou pelo mundo. ${ }^{664}$

paga, seguida da classe intermediária. A classe senior não será paga apenas se a inadimplência for superior aos montantes devidos à classe junior e intermediária. Tais obrigações são conhecidas como collateralized debt obligations (CDOs).

661 COMITÊ DE BASILEIA. Report on special purpose entities, p. 13.

662 Há outras denominações para as SPEs, como veículos de propósito específico (special purpose vehicles SPVs) ou veículos de investimento estruturado (structured investment vehicles - SIVs).

663 OVERTVELDT, Johan Van. Bernanke’s test, p. 163. Tradução livre.

664 LOWENSTEIN, Roger. The end of Wall Street. Nova Iorque: The Penguin Press, 2010. p. 15-27. 
Por todas essas razões, as SPEs vêm merecendo atenção cada vez maior por parte de reguladores e supervisores do sistema financeiro. Entre as principais preocupações nesse sentido, tem-se procurado atribuir maior transparência à operação dessas entidades, principalmente por meio da consolidação financeira para fins contábeis e eliminação das brechas que permitem o tratamento das SPEs fora das demonstrações financeiras. Apesar do progresso nos últimos anos, com destaque para a interpretação Fasb 46(R) para os US GAAP e a Interpretação do Comitê Permanente 12 dos IFRS, ${ }^{665}$ um relatório recente do Comitê de Basileia sobre o tema ressalta a existência de brechas nos US GAAP que ainda permitem a manipulação de demonstrativos contábeis para deixar SPEs fora do balanço patrimonial. Conforme o relatório, nesse aspecto os IFRS seriam mais transparentes do que os US GAAP. $^{666}$

Outra proposta que tem sido levantada é a de que os originadores mantenham parte dos títulos emitidos por tais entidades em sua carteira. A lógica é que, ao forçar originadores a manter tais papéis em sua própria carteira, estes assumam uma postura mais prudente relativamente aos ativos securitizados. O Dodd-Frank Wall Street Reform and Consumer Protection Act consagrou essa estratégia ao determinar a criação de regras para a retenção de ativos pelas originadoras nas operações de securitização no prazo de 270 dias a partir de 21 de julho de 2010 (Seção 941(b)). O patamar mínimo de retenção será de 5\% e a implementação das regras ficará a cargo de autoridades diversas de acordo com o mercado específico em tela. Além da retenção de ativos, a reforma regulatória nos Estados Unidos prevê também padrões mais rigorosos de diligência legal e contábil de ativos que serão securitizados (Seção 945), bem como a exigência de declarações e garantias das entidades originadoras quanto à qualidade desses ativos (Seção 943).

665 Os United States Generally Accepted Accounting Principles (US GAAP) são editados pela Financial Accounting Standards Board (Fasb), que representa o Conselho de Padrões de Contabilidade Financeira nos Estados Unidos, equivalente ao Conselho Federal de Contabilidade (CFC) no Brasil. Já os International Financial Reporting Standards (IFRS) são editados pela International Accounting Standards Board (Iasb), que representa o Conselho de Normas Internacionais de Contabilidade.

666 Conforme o relatório: "A habilidade de retirar ativos do balanço é afetada pelo tratamento contábil aplicável à instituição originadora ou patrocinadora. De modo geral, o tratamento off-balance sheet é mais fácil de ser atingido sob as regras dos US GAAP do que as regras dos IFRS. Apesar disso, as regras da US Fasb a serem emitidas em 2010 relativamente a SPEs reduzirão significativamente a possibilidade de retirar ativos de seu balanço". Para uma descrição detalhada do assunto, ver: COMITÊ DE BASILEIA. Report on special purpose entities, p. 75-80. Tradução livre. 
No Brasil a utilização das SPEs é relativamente recente, tendo se iniciado com a promulgação da Lei 9.514/1997, conhecida como a Lei de Securitização de Recebíveis, e, mais recentemente, com a Lei 11.079/2004, que tratou do regime das parcerias públicoprivadas, instituindo no ordenamento jurídico brasileiro a figura das "sociedades de propósito específico" (arts. 9. ${ }^{\circ}$ e ss.). ${ }^{667}$ A esse respeito, o Brasil encontra-se em vantagem em relação a países como os Estados Unidos, uma vez que já iniciou o processo de conversão de seus padrões contábeis para o modelo IFRS, considerado mais transparente pelo Comitê de Basileia. Isso foi possível em razão da promulgação da Lei 11.638/2007, que modificou a Lei 6.404/1976 introduzindo, entre outras alterações, o $§ 5^{\circ}$, que determina a elaboração das demonstrações financeiras das companhias abertas em consonância com os padrões internacionais de contabilidade adotados nos principais mercados de valores mobiliários. Nesse sentido, a Instrução CVM 457, de 13 de julho de 2007, estabeleceu que, a partir de 2010, as companhias brasileiras de capital aberto devem elaborar demonstrações financeiras anuais consolidadas com base nos IFRS. Vale ressaltar que o Comunicado Bacen 14.259, de 10 de março de 2006, já havia determinado a criação de grupo de trabalho no âmbito da autarquia destinado a identificar as necessidades de convergência do regramento contábil aplicável às instituições financeiras no País às normas editadas pela Iasb, entidade responsável pela elaboração dos IFRS. ${ }^{668}$ A partir desse diagnóstico, serão editados normativos objetivando a adoção de procedimentos para a elaboração e publicação de demonstrações contábeis consolidadas em consonância com os pronunciamentos da Iasb a partir de $2011 .^{669}$

\subsubsection{Instrumentos financeiros derivativos}

Os instrumentos financeiros derivativos podem ser definidos como contratos referenciados a algum ativo ou variável econômica com liquidação em data futura, cuja função consiste em administrar riscos de investimentos. ${ }^{670}$ Esses instrumentos ganharam

667 Para uma análise da figura da SPE no ordenamento jurídico brasileiro, ver: CHALHUB, Melhim Namem. Negócio fiduciário. São Paulo: Renovar, 2000. p. 331 e ss.; e GAGGINI, Fernando Schwarz. Securitização de recebíveis. São Paulo: Leud, 2003. p. 47 e ss.

668 Disponível em: <www.bcb.gov.br/?CONVINT>. Acesso em: 3 jan. 2011.

669 Além da convergência com as regras da Iasb, a autarquia também determinou a convergência com as normas editadas pela Federação Internacional de Contadores (International Federation of Accountants Ifac) no tocante à prestação de serviços de auditoria independente no âmbito do SFN.

670 SADDI, Jairo. Crise e regulação bancária, p. 190-191. 
destaque na década de 1980, com a crescente desregulamentação dos mercados financeiro e de capitais, bem como a maior volatilidade das taxas de juros e câmbio, influenciadas por causas como alta inflação. ${ }^{671}$ Exemplo típico de utilização de derivativos é o caso de empresas com passivo em moeda estrangeira que queiram proteger-se de variações cambiais.

O grande obstáculo apresentado pelos derivativos para a regulação prudencial referese à dificuldade de mensurar adequadamente os riscos apresentados por tais instrumentos financeiros e formas de evitar a alavancagem excessiva. Isso ficou evidenciado em diversos episódios na década de $1990,{ }^{672}$ corroborados pelos episódios envolvendo inúmeros bancos e outras empresas na crise financeira recente. Nesse sentido, Alexandre Lamfalussy, expresidente do BIS, considera o crescimento dos derivativos um desafio à supervisão bancária uma vez que torna cada vez mais difícil a avaliação do risco direto de crédito, de liquidez ou de juros. ${ }^{673}$

Em face das dificuldades apresentadas por tais instrumentos financeiros, é oportuna a realização de uma breve apresentação sobre algumas das principais ferramentas empregadas na tentativa de obter uma aferição mais precisa dos riscos que os derivativos apresentam às instituições financeiras.

671 Salomão afirma que, enquanto algumas formas de derivativos, como os swaps, realmente surgiram durante a década de 1980, outras modalidades já existiam de uma maneira ou outra desde época muito pregressa, tendo apenas se desenvolvido em anos recentes, como as opções e negócios a termo. $\mathrm{O}$ autor inclusive cita exemplos do uso primitivo de derivativos por Tales de Mileto. Ver: SALOMÃO, Eduardo. Direito bancário, p. 324.

672 Entre os casos ocorridos na década de 1990, pode-se mencionar o do banco alemão Metallgesellschaft, que perdeu quase $50 \%$ do seu valor de mercado por conta de suas operações com derivativos em 1993; as perdas de US\$1,5 bilhão que levaram à falência do Condado de Orange, na Califórnia, em 1994; o colapso do Barings Bank em 1995, por falta de controles internos que evitassem a excessiva alavancagem assumida por apenas um operador de derivativos em Cingapura; e a já mencionada falência do LTCM, que possuía dois ganhadores do Prêmio Nobel de Economia entre seus administradores, em 1998.

673 Segundo Lamfalussy: "Nós simplesmente não sabemos o tamanho dos riscos indiretos para instituições decorrentes dessa interdependência [...] Esses riscos não podem ser capturados com facilidade, mesmo quando técnicas sofisticadas de mensuração de risco são utilizadas”. Ver: MILLMAN, Gregory J. The vandals crown. Nova Iorque: The Free Press, 1995. p. 252, apud SADDI, Jairo. Crise e regulação bancária, p. 192. Tradução livre. 


\subsubsection{Marcação a mercado}

A marcação a mercado (mark to market) refere-se ao ajuste diário do preço de um ativo existente em determinada carteira à cotação de mercado, adequando seu valor à nova realidade. Esse procedimento é de grande importância para as autoridades na medida em que lhes permite ter conhecimento dos riscos a que as instituições financeiras estão expostas a cada momento.

A esse respeito, observou-se nos últimos anos a promulgação de inúmeras normas contábeis que disciplinam o método de contabilização do valor dos derivativos nas demonstrações financeiras das empresas. ${ }^{674}$ Tais normativos aperfeiçoam a metodologia contábil de derivativos, disciplinando situações em que a marcação a mercado é exigida, e como proceder ao adequado reconhecimento de receitas e despesas desses instrumentos. Aprimoram, também, o conceito de contabilização para operações de hedge ${ }^{675}$ destacando os instrumentos qualificados como hedge contra risco de mercado, ou fluxo de caixa, de outros instrumentos derivativos. Evidentemente, tais normativos caminham lado a lado com as preocupações levantadas no tópico anterior quanto à melhor forma de obter um tratamento contábil consolidado transparente para instituições financeiras. Ainda que as SPEs estejam sujeitas às regras de marcação a mercado, isso terá pouca utilidade às autoridades se suas operações não constarem nos balanços dos bancos.

A Circular CMN 3.082, de 30 de janeiro de 2002, estabelece os critérios contábeis a serem seguidos nas operações de instituições financeiras realizadas por conta própria com diversos tipos de instrumentos financeiros derivativos. Segundo a norma do CMN, esses instrumentos devem ser marcados a mercado, pelo menos por ocasião dos balanços mensais, tendo registros e avaliações diferentes de acordo com o seu tipo e classificação. $\mathrm{O}$ valor de referência das operações com derivativos deve ser registrado em contas de compensação, e os

674 Exemplos de tais normativos são os pronunciamentos internacionais IAS 39 - Financial Instruments: Recognition and Measurement, FAS 133 - Accounting for Derivative Financial Instruments and Hedging Activities e FAS 157 - Fair Value Measurements, promulgados, respectivamente, pela Iasb e Fasb. Os pronunciamentos estão disponíveis em: <www.ifrs.org/IFRSs/IFRS.htm> e <www.fasb.org>. Acesso em: 29 dez. 2010.

675 Operações de hedge procuram compensar, no todo ou em parte, os riscos decorrentes da exposição de variações no valor de mercado ou no fluxo de caixa de qualquer ativo, passivo, compromisso ou transação futura prevista. 
registros dos resultados devem ser lançados individualmente, sendo vedada a compensação entre receitas e despesas de contratos distintos. Para fins de avaliação, a metodologia de apuração do valor de mercado é de responsabilidade da instituição e deve ser estabelecida com base em critérios consistentes, que levem em consideração a independência na coleta de dados em relação às taxas praticadas em suas mesas de operação. Além disso, buscando aprimorar o nível de transparência das operações com tais instrumentos, tornou-se obrigatória a divulgação de informações qualitativas e quantitativas detalhadas a seu respeito em notas explicativas aos demonstrativos contábeis das instituições financeiras.

Ainda segundo o normativo, as operações com derivativos destinadas a hedge realizadas pelas instituições financeiras devem ser classificadas como hedge de risco de mercado, caso tenham como propósito compensar os riscos decorrentes da exposição à variação no valor de mercado do item objeto do hedge, ou de fluxo de caixa, quando procurarem compensar a variação no fluxo de caixa futuro estimado da instituição. Para serem classificadas como hedge, as operações devem observar algumas condições, como a devida documentação da estratégia e de sua efetividade, além de não poderem ser efetuadas com parceiros de empresa integrante do mesmo grupo econômico. Os aspectos contábeis a serem seguidos em cada caso fogem ao escopo deste trabalho, mas podem ser verificados no estudo aprofundado da referida Circular e suas atualizações.

Apesar de sua importância para a transparência e fiscalização bancária, as regras de marcação a mercado vêm sofrendo pesadas críticas nos Estados Unidos, principalmente após a crise financeira recente, de que apresentariam um acentuado componente procíclico. ${ }^{676} \mathrm{Em}$ momentos de grave instabilidade econômica, quando "não há mercado" para determinados ativos, torna-se muito difícil, senão impossível, precificá-los via marcação a mercado. Em tais situações, instituições financeiras podem ser obrigadas a dar baixa (write-offs) de parcelas substanciais de suas carteiras de ativos, potencializando a crise de confiança no mercado financeiro. Além disso, na medida em que o valor desses ativos declina no mercado, instituições financeiras podem ser obrigadas a realizar depósitos adicionais de margem para contrapartes com quem contrataram tais instrumentos financeiros derivativos. Para levantar recursos, estas podem ter de vender ativos no mercado, provocando nova onda de queda de

676 LOYOLA, Gustavo. O futuro da regulação financeira, p. 70. 
preços, pressões adicionais de vendas e sucessivos declínios de preços. Finalmente, corroborando preocupação já levantada no tópico 4.1.1, caso tais instrumentos financeiros derivativos componham a base do capital regulatório das instituições financeiras, a queda nos preços desses ativos forçará tais instituições a levantar recursos para complementar sua base de capital, o que pode ser difícil em momentos de crise de liquidez, gerando incertezas sobre a sua viabilidade futura.

Considerando essas preocupações, o Emergency Economic Stabilization Act de 2008 reiterou a autoridade da SEC para suspender a aplicação das regras de marcação a mercado caso considere que isso é no melhor interesse público e dos investidores (Seção 132). Apesar disso, a autoridade bursátil norte-americana houve por bem não suspender a aplicação da regra durante a crise recente, mas apenas sugerir-lhe aperfeiçoamentos voltados à limitação de seu componente procíclico, principalmente em períodos de grande volatilidade no mercado. Respondendo a tais sugestões, em abril de 2009, a Fasb alterou o regime de marcação a mercado nos Estados Unidos, criando regras específicas para situações em que o nível de atividade do mercado tenha decaído de forma significativa, ou quando as transações não estiverem ocorrendo de maneira "ordenada". Em tais casos, em vez de lançar os ativos por sua cotação a mercado, os bancos estão autorizados a usar um "valor justo", com base em seus critérios próprios de precificação de ativos, desde que aceitos pelas regras contábeis aplicáveis. ${ }^{677}$

\subsubsection{Operações de balcão}

O mercado de balcão (over-the-counter market - OTC) é aquele em que as instituições financeiras e demais entidades autorizadas a operar negociam instrumentos financeiros derivativos diretamente entre si, ou diretamente com seus clientes, sem um mecanismo centralizado e compulsório de formação de preços. ${ }^{678}$ A inexistência de uma

677 FASB STAFF POSITION FAS 157-4. Determining fair value when the volume and level of activity for the asset or liability have significantly decreased and identifying transactions that are not orderly. Disponível em: <www.fasb.org>. Acesso em: 23 dez. 2010.

O mercado de balcão contrasta com os chamados "derivativos de bolsa", que consistem em contratos cujas cláusulas (valor financeiro, vencimento, critérios de marcação a mercado, horários negociação, limites de oscilação de preços etc.) são definidas e publicadas pela bolsa que desenvolveu o contrato e que o oferece para negociação em ambiente de pregão (VIEIRA NETO, Cícero Augusto. Administração de risco de 
câmara de compensação, bem como a ausência de normas e especificações das operações, são características comuns dos ativos negociados no mercado de balcão. Nesse tipo de operação, normalmente apenas as partes do contrato conhecem seus termos, que podem ser completamente adequados às suas necessidades específicas. Os preços são livremente acordados entre as partes e não são transparentes, uma vez que não são tornados públicos. As particularidades de cada contrato dificultam sua negociação posterior, sendo comum que os participantes mantenham essas posições em suas carteiras até o vencimento. ${ }^{679}$

As operações de balcão são relevantes para a regulação prudencial porque o aumento do grau de interconexão entre instituições bancárias e não bancárias via operações com derivativos, notadamente aqueles negociados no mercado de balcão, tornou mais complexos e menos visíveis os vínculos entre tais instituições. Na atualidade, esses instrumentos são livremente negociados entre instituições financeiras, e entre estas e seus clientes, formando extensa e intrincada teia de créditos e débitos no sistema financeiro. A falta de transparência dos mercados de balcão, principalmente em casos de ativos com baixa liquidez, ou em estruturas contratuais intricadas, pode impedir sua avaliação no decorrer do período em que a posição é mantida. O efeito prático disso é a complexidade crescente na identificação precisa dos riscos cruzados e posições das diversas instituições financeiras, dificultando o monitoramento do nível de risco a que estão expostas.

Não por acaso, já em 1994, autoridades norte-americanas demonstravam preocupação com a ausência de regulamentação para as operações nos mercados de balcão. ${ }^{680}$

derivativos no Brasil - mercados de bolsa e de balcão. In: GARCIA, Márcio; GIAMBIAGI, Fábio (Org.). Risco e regulação, p. 276). Apesar dessa diferenciação, deve-se reconhecer o surgimento de sistemas mais ou menos centralizados também para a realização de operações de balcão, fazendo com que as tradicionais diferenças entre os dois tipos de mercado se tornem menos nítidas. A esse respeito, ver: YAZBEK, Otavio. Crise, inovação e regulação no mercado financeiro: consideraç̃os sobre a regulamentação do mercado de derivativos de balcão, p. 4. Mimeografado.

679 CINTRA, Marcos A. M.; FARHI, Maryse. A crise financeira e o global shadow banking system, p. 48.

${ }^{680}$ Em 1994 o Government Accounting Office (GAO) afirmou que mudanças legislativas eram necessárias para regular os derivativos de balcão, cujos contratos não eram padronizados e estavam fora do controle governamental. $\mathrm{O}$ relatório cita a necessidade de o Congresso colocar sob a égide regulatória tais práticas e assegurar que a regulação de derivativos seja consistente e clara entre os diversos agentes reguladores (GOVERNMENT ACCOUNTING OFFICE. US. Financial Derivatives: action needed to protect the financial system. The Journal of Derivatives, Nova Iorque, v. 2, n. 1, 1994). Tais preocupações foram retomadas em relatório recente do Departamento do Tesouro norte-americano, que indicou a criação de um marco regulatório compreensivo para os derivativos negociados nos mercados de balcão como um dos 
Tais preocupações foram retomadas e alçadas a novo patamar de evidência em razão da crise financeira recente. Entre os temas recorrentes nas propostas de reforma regulatória, destacamse: (i) maior padronização dos instrumentos financeiros derivativos negociados nos mercados de balcão; (ii) registro dessas transações em uma entidade capaz de manter, de forma centralizada, dados das operações; (iii) processo de formação de preços, com propostas visando a submissão das operações a sistemas de negociação mais ou menos centralizados; e (iv) forma de liquidação dessas operações, valorizando-se cada vez mais o papel das clearings. $^{681}$

Como reflexo dessas propostas, o Dodd-Frank Wall Street Reform and Consumer Protection Act promoveu ampla reformulação das regras aplicáveis aos agentes e ativos negociados em tais mercados. O novo marco regulatório apresenta diferentes classificações aplicáveis aos participantes do mercado de balcão (swap dealer ou major swap dealer), com base no tipo, frequência e finalidade das operações realizadas, entre outros fatores. A classificação em tais categorias sujeitará as partes envolvidas a regras mais rígidas de negociação, como: (i) adoção de cláusulas padronizadas nos contratos, incluindo exigências mais rigorosas de depósitos de margem e divulgação de informações; (ii) o registro na Comissão de Comércio de Commodities e Futuros (Commodity Futures Trading Commission - CFTC) e, possivelmente, na SEC; e (iii) a utilização de uma clearing como contraparte central em suas operações. No tocante às instituições financeiras especificamente, a lei prevê a possibilidade de obrigá-las a remover de sua estrutura operações que não sejam relacionadas exclusivamente com o hedge de determinadas atividades bancárias, transferindo-as para afiliadas caso queiram continuar tendo acesso ao redesconto do Federal Reserve e à cobertura do FDIC. As afiliadas que "abrigarem" tais operações ficarão sujeitas a requisitos de capital próprios e terão de aderir às exigências regulatórias supracitadas.

O regramento para o funcionamento dos mercados de balcão organizados no País é dado pela Instrução CVM 243, de $1 .^{\circ}$ de março de $1996,{ }^{682}$ e a realização de tais operações pelas instituições financeiras é regulamentada pela Resolução CMN 3.505, de 26 de outubro

pontos fundamentais para a reformulação do arcabouço regulatório no país. Ver: DEPARTMENT OF TREASURY. Regulatory reform over-the-counter (OTC) derivatives. Washington, 13 maio 2009.

YAZBEK, Otavio. Crise, inovação e regulação no mercado financeiro, p. 9-15.

682 Alterada pelas Instruções 250, de 14 de junho de 1996, e 343, de 11 de agosto de 2000. 
de 2007. ${ }^{683}$ A esse respeito, o Brasil encontra-se à frente de outros países, uma vez que já exerce controle mais rígido sobre as operações de balcão, inclusive contando com o registro centralizado de operações com derivativos pelas instituições financeiras nesses mercados. As entidades do mercado de balcão organizado funcionam sob a supervisão e fiscalização da CVM, dependendo, para o início de suas operações, de sua prévia autorização. ${ }^{684}$ Além disso, os regulamentos adotados pelas entidades administradoras do mercado de balcão são submetidos à aprovação da CVM, que verifica a existência de procedimentos adequados à boa formação de preços e à disseminação de informações aos participantes do mercado. Finalmente, a entidade administradora deve aprovar os modelos de contratos registrados e estabelecer determinados controles sobre o processo de registro e mesmo seu conteúdo, divulgando os detalhes das operações realizadas em seus sistemas, como ofertas de compra e venda, título negociado, preço, quantidade e última cotação. Caso a entidade calcule um índice de preços dos títulos negociados em seus mercados, também deverá divulgar a evolução desse índice, seu valor de abertura e fechamento a cada dia. ${ }^{685}$

No tocante às operações realizadas pelas instituições financeiras, a Resolução CMN 3.505/2007 exige que estas sejam registradas em mercados de balcão organizados, sistemas administrados por bolsas de valores, mercadorias e de futuros, ou entidades de registro e de liquidação financeira de ativos devidamente autorizadas pelo Bacen ou CVM. A Resolução determina também que as informações, documentação e metodologia relativas a tais operações devem permanecer à disposição do Bacen, incluindo dados concernentes ao diretor responsável pela realização de operações de derivativos em mercados de balcão. Finalmente, o normativo autoriza a autarquia a restringir os ativos subjacentes que podem ser utilizados como referenciais nas operações efetuadas pelas instituições financeiras nesses mercados.

683 Para um histórico da evolução da regulamentação dos derivativos de balcão no País, ver: YAZBEK, Otavio. Crise, inovação e regulação no mercado financeiro, p. 4.

684 Atualmente há apenas duas entidades no Brasil que oferecem plataformas para o registro de derivativos de balcão, quais sejam a BM\&FBovespa e a Cetip.

685 Apesar dos méritos da regulação pátria do mercado de balcão em contraste com outros países, é preciso reconhecer também que tais instrumentos ainda representam parcela inexpressiva do total de derivativos negociados. Segundo apontamento de Vieira Neto, os mercados de balcão representaram apenas 3\% do volume financeiro total de derivativos negociados em 2009 no País (VIEIRA NETO, Cícero Augusto. Administração de risco de derivativos no Brasil, p. 280). Essa situação contrasta com o mercado de outros países, em que as operações de balcão ultrapassam em grande medida o volume de negócios em bolsa. Segundo Yazbek, essa particularidade do mercado de balcão pátrio pode estar relacionada às regras mais rigorosas para sua operacionalização no Brasil. Ver: YAZBEK, Otavio. Crise, inovação e regulação no mercado financeiro. 
Apesar desse maior controle sobre tais operações em comparação com outros países, problemas de informação e controle por parte dos entes reguladores foram constatados nos episódios recentes de exposições corporativas exageradas a derivativos cambiais. Exemplos disso foram os "superprejuízos" da Sadia (R \$ 760 milhões), Aracruz (R \$ 1,95 bilhão) e Votorantim (R \$ 2,2 bilhões) com operações de derivativos nos mercados de balcão. ${ }^{686}$ Nesse sentido, Bacen e CVM vêm trabalhando em conjunto para tomar providências que aumentem o grau de transparência nas operações com derivativos e permitam o acompanhamento das posições consolidadas de cada contraparte nos mercados de balcão.

Considerando o maior controle já exercido nas operações realizadas por instituições financeiras no mercado doméstico, os esforços do Bacen nesse sentido tiveram como foco operações realizadas com contrapartes no exterior que não estão sujeitas à sua supervisão. A primeira medida com esse propósito foi a edição da Circular Bacen 3.474, de 11 de novembro de 2009, que determinou que as instituições financeiras devem registrar, em sistema administrado por entidades de registro e de liquidação financeira de ativos devidamente autorizado pela autarquia ou pela CVM, instrumentos financeiros derivativos que se vinculem ao custo da dívida contratada em operações de empréstimo entre residentes ou domiciliados no País e residentes ou domiciliados no exterior, inclusive pessoas naturais ou jurídicas não financeiras. A segunda, com a Resolução CMN 3.824, de 16 de dezembro de 2009, determina que as instituições financeiras devem registrar nestes mesmos sistemas as posições assumidas em instrumentos financeiros derivativos contratados no exterior, diretamente ou por meio de dependências ou empresas integrantes do conglomerado financeiro. Finalmente, em 28 de janeiro de 2010, a Resolução CMN 3.833 instituiu a obrigatoriedade de registro das operações de hedge realizadas com instituições financeiras no exterior ou em bolsas estrangeiras.

Entre as medidas adotadas pela CVM, merece menção a Instrução 475, de 17 de dezembro de 2008, que passou a exigir das companhias listadas em bolsa em seus balanços trimestrais e anuais uma exposição detalhada de tais contratos, incluindo uma análise de sensibilidade dos riscos apresentados por operações com derivativos. Além disso, com a edição da Instrução 480, de 7 de dezembro de 2009, a CVM passou a exigir que todas as empresas que emitem valores mobiliários, não só as que têm ações em bolsa, explicitem a

686 ISTO É DINHEIRO. Risco oculto, n. 579, 5 nov. 2008, p. 68. 
totalidade das operações com derivativos em seu "Formulário de Referência", documento que substituiu o "Informativo Anual". De acordo com a Instrução, as companhias devem detalhar todos os riscos que estão correndo com essas transações e os impactos que elas podem causar em seus resultados, bem como justificar a opção pela utilização de tais instrumentos e revelar quais os mecanismos usados para monitorá-los.

Além dessas ações do Bacen e da CVM, vale mencionar a recente criação da Central de Exposição de Derivativos (CED), uma empresa sem fins lucrativos que será controlada pela Febraban e que unirá em um mesmo sistema de forma consolidada as posições de empresas em instrumentos financeiros derivativos registradas na Cetip e BM\&FBovespa. $\mathrm{Na}$ CED, bancos poderão saber a exposição total em derivativos de cada empresa no fechamento do mercado do dia anterior, eliminando a necessidade de aguardar a divulgação do balanço das empresas ou pedir tais informações separadamente à Cetip ou BM\&FBovespa. O novo sistema informará também a exposição da empresa em casos desfavoráveis, em que o referencial do contrato é sujeito a grandes variações. A CED já foi reconhecida pelo CMN, que, por meio da Resolução CMN 3.908, de 30 de setembro de 2010, determinou a obrigatoriedade para bancos que quiserem fazer consultas à central de indicar ao Bacen o responsável por tais procedimentos de consulta.

\subsubsection{Captura regulatória}

Embora esse tema já tenha sido introduzido brevemente na discussão realizada no capítulo inicial deste trabalho a respeito da relação entre regulação financeira e falhas de mercado, é importante retomá-lo nesse momento por ocasião da verificação dos efeitos das transformações no sistema financeiro sobre a regulação prudencial. Conforme visto, o trabalho seminal de Olson em $1965,{ }^{687}$ posteriormente desenvolvido por Stigler, ${ }^{688}$ permitiu que a doutrina jurídica e a doutrina econômica passassem a encarar a regulação como um produto, analisando-a do ponto de vista das forças de oferta e demanda no mercado. A

\footnotetext{
687 OLSON, Mancur. The logic of collective action.

688 STIGLER, George J. The theory of economic regulation.
} 
contribuição de Olson e Stigler foi objeto de estudo por outros autores, lançando bases para o que ficou conhecido como teoria da "captura regulatória". ${ }^{689}$

De forma sucinta, a teoria da captura regulatória postula que legisladores e burocratas estão sujeitos à cooptação por parte de grupos de interesse, de modo que a implementação e a fiscalização das normas regulatórias acabam realizando-se em favor de grupos mais organizados em detrimento dos menos organizados. Segundo essa teoria, a regulação não visaria o interesse público, e sim o interesse privado, conforme a efetividade dos grupos de interesse atuantes.

O processo de concentração bancária observado nas últimas décadas é relevante para o tema, pois, entre os fatores que influenciam a efetividade dos grupos de interesse, destaca-se o número de agentes econômicos envolvidos no processo. Via de regra, a habilidade de um grupo organizar-se é inversamente proporcional ao seu tamanho. Grupos coesos teriam maior facilidade para se organizar e coordenar ações voltadas a regulações que lhe sejam mais benéficas, enquanto grupos maiores teriam dificuldade para se organizar, tanto pelos interesses divergentes que podem surgir dentro do grupo quanto pela necessidade de superar problemas de "carona" (free-riding) entre seus membros. ${ }^{690}$ Além dessa maior facilidade de organização, grupos menores também teriam mais incentivos para buscar regulações em seu favor, uma vez que seus benefícios seriam repartidos entre número menor de agentes econômicos.

No âmbito do setor bancário, estudos corroboram a noção de que bancos possuem forte influência sobre as autoridades regulatórias. ${ }^{691}$ Com efeito, em um dos trabalhos mais bem acabados sobre regulação e supervisão bancária, envolvendo análise comparativa entre mais de 150 países, Barth et al. sustentam que a regulação no setor estaria mais alinhada com

689 POSNER, Richard A. Theories of economic regulation; e PELTZMAN, Sam. Toward a more general theory of regulation.

690 Existem exceções a essa lógica, como é o caso de sindicatos e organizações de comércio, que, apesar de seu tamanho, conseguiram desenvolver mecanismos específicos e bem-sucedidos de coordenação entre seus membros, ver: OLSON, Mancur. The logic of collective action.

691 Para uma síntese de resultados, ver: KANE, Edward J. How market forces influence the structure of financial regulation. In: HARAF, William S.; KUSHMEIDER, Rose Marie. Restructuring banking and financial services in America. American Enterprise Institute, 1988. 
a teoria do interesse privado do que com a do interesse público. ${ }^{692}$ A título exemplificativo, os autores encontram evidências de que barreiras à entrada de bancos estrangeiros, embora sejam associadas a argumentos de interesse público, acabam com frequência sendo utilizadas como forma de protecionismo ao mercado local ${ }^{693}$.

Nessa mesma linha, observam-se estudos sobre as modificações da estrutura regulatória do sistema financeiro nos Estados Unidos, procurando explicar o papel que os bancos tiveram na derrocada de relevantes restrições às suas atividades durante a década de $1990{ }^{694}$ A influência política dos bancos é inclusive cogitada como possível explicação para a eliminação da mais importante barreira regulatória norte-americana no setor durante o século $\mathrm{XX}$, qual seja a separação entre atividades de bancos comerciais, investimento e seguro. ${ }^{695}$ Essa separação de atividades estava em vigor há mais de meio de século, por imposição do Glass-Steagall-Act de 1933, quando, em 1998, o banco Citigroup adquiriu a companhia de seguros Travelers Group. Embora a operação se chocasse frontalmente com a proibição legal, o Citigroup se beneficiou de uma brecha apresentada pelo Bank Holding Company Act de 1956, que lhe permitiu concluir a operação naquele momento, mas que exigiria o desinvestimento das atividades de seguro conduzidas pela Travelers Group no prazo de dois anos. ${ }^{696}$ Esse movimento ousado do banco deixou o Congresso do país na delicada situação de modificar o marco regulatório para permitir a operação e estender o benefício a outras instituições financeiras, ou manter as proibições em vigor, bloqueando uma das maiores fusões já realizadas no sistema financeiro norte-americano. O Congresso acabou optando pela primeira alternativa, de modo que, quando o prazo para o desinvestimento aproximava-se de seu fim, foi promulgado o Gramm-Leach-Bliley Act, que derrubou formalmente as disposições então existentes que impediam a consolidação de atividades financeiras em uma única instituição. Não por acaso, o marco legal também ficou conhecido como Citigroup

\footnotetext{
692 BARTH, James R. et al. Rethinking bank regulation, p. 178 e ss.

693 Idem, ibidem, p. 50; 214 e ss.

694 KROSZNER, Randall S.; STRAHAN, Philip E. Obstacles to optimal policy; KANE, Edward J. Implications of superhero metaphors for the issue of banking powers. Journal of Banking and Finance, v. 23, n. 2-4, 1999; e MACEY, Jonathan R. Regulation and disaster: some observations in the context of systemic risk. In: LITAN, Robert E.; SANTOMERO, Anthony M. (Org.). Papers on Financial Services. Washington: Brookings Institution Press, 1998.

695 BROOME, Lissa L.; MARKHAM, Jerry W. Regulation of bank financial service activities: cases and materials. West Group Publishing, 2005. p. 111.

696 Idem, ibidem, p. 111.
} 
Relief Act. ${ }^{697}$ Apesar da referência ao Citigroup, Kane afirma que esse padrão foi adotado por outras instituições financeiras durante a década de 1990 para flexibilizar restrições quanto aos seus campos de atuação, seja em termos de serviços oferecidos ou área geográfica, sempre exercendo pressão ex post para que fossem executadas alterações legais visando sua aprovação. ${ }^{698}$

Essa capacidade de organização política ficou evidenciada mais recentemente com as dificuldades enfrentadas pelo governo de Barack Obama para aprovar as propostas de reforma do sistema de regulação e supervisão bancária nos Estados Unidos. ${ }^{699}$ Cerca de um ano após a falência do Lehman Brothers e centenas de bilhões de dólares gastos no Tarp, instituições financeiras que receberam recursos do programa voltaram a apresentar resultados positivos no segundo semestre de 2009 , opondo-se de forma veemente às propostas de reforma no setor. ${ }^{700}$ Isso motivou críticas aos banqueiros por parte do presidente norte-americano, chegando a afirmar expressamente que os lobistas dos bancos em Wall Street estavam trabalhando arduamente para impedir as reformas regulatórias, esforçando-se para manter as coisas do jeito como estavam. ${ }^{701}$ Tais críticas foram reforçadas com a divulgação de dados por parte do

697 BROOME, Lissa L.; MARKHAM, Jerry W. Regulation of bank financial service activities, p. 111.

698 Conforme o apontamento de Kane: "Firmas de serviços financeiros superaram as limitações funcionais e geográficas estabelecidas pelo Congresso e legislaturas estaduais. Em vez de aguardarem pacientemente pela eliminação dessas restrições, firmas apostaram na liberalização ex post do mercado por meio de aquisições agressivas em outras indústrias e Estados”. Ver: KANE, Edward J. Implications of superhero metaphors for the issue of banking powers, p. 1. Tradução livre. BLOOMBERG NEWS. Obama administration pushes back at bank lobbying on regulation, 16 out. 2009.

700 THE NEW YORK TIMES. Goldman earns US\$3.19 billion, beating estimates, 15 out. 2009.

701 BOSTON GLOBE. Bailed out banks fight to reshape bills, 27 set. 2009. Vale ressaltar que, de acordo com dados do The Center for Responsible Politics, 509 dos 535 congressistas que votaram o Dodd-Frank Wall Street Reform and Consumer Protection Act receberam dinheiro de grupos com interesse na reforma financeira (VALOR ECONÔMICO. Dinheiro e política na reforma dos EUA, 20 ago. 2010, p. A13). Ainda é cedo para avaliar o impacto da reforma regulatória aprovada nos Estados Unidos em julho de 2010. Conforme visto ao longo deste trabalho, a maioria das mudanças aprovadas ainda dependerá da promulgação de inúmeros regramentos por autoridades diversas no país, ou mesmo do resultado de estudos sendo empreendidos pelo FSOC e Federal Reserve, entre outros. Não obstante, parece inegável que o resultado da reforma pode ser encarado de forma positiva pelas instituições financeiras norte-americanas, na medida em que rejeitou as propostas mais radicais que haviam sido originalmente cogitadas, como o retorno à segmentação das atividades financeiras instituída pelo Glass-Steagall Act de 1933. Outra importante "vitória" das instituições financeiras foi a revisão da Volcker Rule, que previa a proibição absoluta a bancos comerciais de investir, negociar ou mesmo aconselhar hedge funds e fundos de private equity, bem como o veto a realizarem operações com o próprio dinheiro para obtenção de lucros em benefício próprio, e não para os seus clientes. Às vésperas da aprovação da reforma, a regra foi modificada para permitir aos bancos comerciais investirem até 3\% do seu capital tier 1 em tais atividades. Embora pareça pequeno, analistas estimam que o limite permitirá a bancos como J.P. Morgan, Citigroup e Bank of America manterem pelo menos $70 \%$ de seus negócios de derivativos. Finalmente, o próprio fato de a implementação das reformas 
Centro para Políticas Responsáveis (The Center for Responsive Politics), organização não governamental que monitora gastos com atividades de lobby no Congresso do país, de que parcela dos recursos do Tarp foi destinada a tais atividades com o intuito de combater as propostas de reforma ali debatidas. ${ }^{702}$ A título ilustrativo da capacidade de organização política da indústria financeira, segundo dados da mesma organização, o setor bancário gastou, no período de 1998 a 2009, cerca de US\$400 milhões em atividades de lobby no Congresso. Se considerados outros participantes do sistema financeiro, como seguradoras, a cifra chega a expressivos US $\$ 3,8$ bilhões no mesmo período. $^{703}$

A esse respeito, é importante lembrar que, entre as consequências da crise financeira recente, destaca-se o aumento da concentração bancária em razão das diversas operações de fusões e aquisições entre instituições financeiras, principalmente durante $2008 .^{704}$ Nesse sentido, o economista brasileiro José Scheinkman, professor da Universidade de Princeton, demonstra preocupação com essa evolução no mercado, sustentando que a consequência nefasta desse processo é que o poder de lobby dos conglomerados financeiros resultantes de tais operações se tornará ainda mais eficiente. Segundo o economista, esse ganho de influência é muito difícil de ser combatido, uma vez que o lobby político não é ilegal, sendo muitas vezes um direito constitucionalmente assegurado. ${ }^{705}$

Por fim, é essencial ressaltar que, apesar de ser apresentada aqui como desafio à regulação prudencial, a captura regulatória não se limita de forma alguma apenas a esse campo da regulação financeira. Conforme visto no capítulo anterior, há diversas situações em que o emprego de mecanismos de regulação sistêmica pela autoridade bancária pode enfrentar interesses conflitantes do ponto de vista público e privado, notadamente nos eventos de

ainda depender do regramento por autoridades dispersas também pode ser encarado como uma oportunidade para direcionar o lobby de forma mais eficaz e longe dos "holofotes" que a discussão das propostas no Congresso inevitavelmente trazia. De certa forma, essa percepção foi corroborada pela reação positiva do mercado em termos do desempenho das ações das instituições financeiras norte-americanas que seriam mais afetadas pelas mudanças nas regras em resposta à definição do texto do projeto de reforma que seria submetido a votação no Congresso, com sua subsequente aprovação em julho de 2010. Ver: VALOR ECONÔMICO. Reforma nos EUA mais branda do que o esperado dá vigor a ações dos bancos, 28 jun. 2010, p. A2.

702 Dados disponíveis em: <www.opensecrets.org/lobby/index.php〉. Acesso em: 20 dez. 2010.

703 Idem, ibidem.

704 Ver nota 106.

705 VEJA. Vida e morte das bolhas, n. 2.081, 8 out. 2008, p. 122. 
resgate a instituições financeiras em dificuldade. Tais casos constituem situações propícias para o surgimento das preocupações a respeito da possibilidade de captura regulatória, cabendo na reflexão dos desafios à regulação sistêmica a consideração dos mesmos pontos ora expostos.

\subsubsection{Papel da autorregulação}

A autorregulação como estratégia regulatória ganhou destaque a partir da década de 1980, com os movimentos de desregulamentação observados no sistema financeiro. ${ }^{706}$ Essa transição está relacionada à percepção de que a complexidade crescente da atividade financeira impunha obstáculos significativos à supervisão de vulnerabilidades sistêmicas, o que estimulou a implementação de novos métodos de regulação e supervisão apoiados nos próprios participantes do sistema financeiro, como alternativa à regulação estatal. De acordo com a síntese de Cardim de Carvalho: ${ }^{707}$

\footnotetext{
Partindo do suposto de que seria impossível retornar a um sistema de regulação e supervisão mais detalhista, e frente à impossibilidade de desenhar um sistema de avaliação e compensação de riscos mais simples, que pudesse ser resumido em um conjunto dado de indicadores, como os coeficientes de capital fixados anteriormente pelos reguladores no Acordo de Basileia, chegou-se, de forma praticamente inevitável, à estratégia da autorregulação.
}

Conforme ensinamento de Yazbek, a autorregulação pode ser caracterizada por três aspectos: (i) trata-se de uma regulação da atividade econômica, sendo objeto de uma imposição, e não fruto de "forças equilibradoras" do mercado; (ii) resulta de uma organização coletiva que impõe uma ordem, um conjunto de regras ou procedimentos a seus membros; e (iii) possui caráter extraestatal, sendo desenvolvida por órgãos coletivos alheios às autoridades competentes pela promulgação de normas aplicáveis a determinado setor. ${ }^{708}$ Vale ressaltar, no entanto, que, apesar de sua condição extraestatal, esta pode ter caráter público ou privado. A autorregulação é privada quando os agentes a ela se submetem espontaneamente, ou pública, quando a submissão for coativa, sendo as estruturas adotadas objeto de alguma

\footnotetext{
706 YAZBEK, Otavio. Regulação do mercado financeiro e de capitais, p. 209.

707 CARVALHO, Fernão J. Cardim de et al. Economia monetária e financeira, p. 328.

708 YAZBEK, Otavio. Regulação do mercado financeiro e de capitais, p. 208-209.
} 
sanção estatal e, por isso mesmo, oficialmente tornadas obrigatórias. ${ }^{709}$ Entre os exemplos mais significativos que evidenciam essa abordagem regulatória, encontra-se o já mencionado acordo de Basileia II, que promove a definição pelos próprios bancos de formas de avaliação e tratamento de riscos, materializando-se em estratégias formais de controle, descritas em modelos quantitativos que são submetidos à autoridade supervisora para aprovação.

Embora o Brasil ainda esteja no processo de incorporação de Basileia II, a autorregulação já desempenha um papel relevante no setor bancário pátrio. A Associação Nacional dos Bancos de Investimento (Anbid) pode ser considerada a primeira entidade de classe de caráter propositivo dos bancos no País, em contraste com a prática anterior das associações de limitar sua atuação apenas à reação contra medidas governamentais. ${ }^{710}$ Embora sua fundação remonte a 1967, foi apenas em 1998 que a Anbid divulgou seu primeiro código de autorregulação, com o objetivo de estabelecer regras comuns para ofertas públicas de distribuição e aquisição de valores mobiliários, fato que também marcou a criação da primeira comissão de autorregulação que interagiu diretamente com um órgão regulador do governo, a CVM. $^{711}$ Desde então foram promulgados seis outros códigos de autorregulação sobre variados temas. $^{712}$ A título ilustrativo, no período de 1998 a 2009, a Anbid já aplicou mais de 1.000 multas, 6.000 cartas de advertência, e instaurou mais de 50 processos contra instituições

709 YAZBEK, Otavio. Regulação do mercado financeiro e de capitais, p. 209.

710 CALADO, Luiz Roberto. Regulação e autorregulação do mercado financeiro: conceito, evolução e tendências num contexto de crise. São Paulo: Saint Paul, 2009. p. 71. Inicialmente a Anbid representava e articulava os interesses apenas dos bancos de investimento existentes no País, mas posteriormente ampliou seus objetivos, passando a representar um leque maior de atividades e instituições financeiras. Em 2009 a Anbid uniu-se à Associação Nacional das Instituições do Mercado Financeiro (Andima), organização cujos objetivos e associados em larga medida coincidiam com os da Anbid. A instituição resultante foi denominada Associação Brasileira das Entidades dos Mercados Financeiro e de Capitais (Anbima), representando 325 associados, entre bancos comerciais, múltiplos e de investimento, asset managements, corretoras, distribuidoras de valores mobiliários e consultores de investimento.

711 Código de autorregulação para as afertas públicas de distribuição e aquisição de valores mobiliários (1998). Este e outros documentos da Anbid e Andima (posteriormente renomeadas para Anbima) mencionados neste trabalho encontram-se disponíveis em: <www.anbima.com.br/supervisao/codigos.asp>. Acesso em: 20 dez. 2010.

712 Código de autorregulação para os fundos de investimentos (2000), Código de autorregulação para certificação continuada (2002), Código de autorregulação para serviços de custódia qualificada (2004), Código de autorregulação para serviços qualificados ao mercado de capitais e private banking (2006) e Código de autorregulação para processos e atividades conveniadas (2008). 
financeiras. Nesse mesmo intervalo, foram também analisadas em torno de 650 ofertas públicas e 12.600 fundos de investimentos para fins de registro. ${ }^{713}$

Segundo Oliveira Filho, a autorregulação no Brasil pode ser caracterizada como um sistema mais flexível de regulação, em que parte do arcabouço regulatório é determinada por uma ação mais forte dos reguladores estatais, e parte por instituições de autorregulação de caráter privado ou público. ${ }^{714}$ Nesse quadro, a autorregulação não se propõe a buscar uma desregulamentação ou menor intervenção governamental, mas sim apoiar as iniciativas governamentais, instituindo uma regulação complementar. Igualmente, Calado afirma que a regulação estatal deve fornecer o arcabouço básico dentro do qual se dá o relacionamento entre os diversos participantes, regrando o que pode ser denominado de "macroambiente", enquanto à autorregulação caberia normatizar pormenores do processo, ou o "microambiente", partindo da premissa de que, nesse campo, os próprios participantes do mercado são os mais capacitados a interagir, discutir e propor melhores práticas. ${ }^{715}$

Como exemplos recentes de cooperação entre o regulador estatal e a Anbid, pode-se mencionar, no final de 2008, a partir de um diálogo com a CVM, a reformulação do código de ofertas públicas da Anbid para incluir uma cláusula que melhor definisse os empréstimos préaberturas de capital concedidos pelas instituições coordenadoras da oferta de valores mobiliários (também conhecidos como equity-kickers). ${ }^{716}$ Além disso, em demonstração até então inédita no País, a associação celebrou com o mesmo regulador, por meio da Instrução 471, de 8 de agosto de 2008, convênio em que se instituiu a possibilidade do registro

713 OLIVEIRA FILHO, Luiz Chrysostomo de. Autorregulação no sistema financeiro. In: BOLLE, Monica Baumgarten de; CARNEIRO, Dionísio Dias (Org.). A reforma do sistema financeiro americano: nova arquitetura internacional e o contexto regulatório brasileiro. Rio de Janeiro: Instituto de Estudos de Política Econômica - Casa das Garças, 2009. p. 2.

714 Idem, ibidem, p. 4.

715 CALADO, Luiz Roberto. Regulação e autorregulação do mercado financeiro, p. 58-59.

716 O equity kicker refere-se a cláusulas em contratos de empréstimos que permitem ao credor partilhar de benefícios provisionados aos acionistas. Um equity kicker comum é o direito que o credor tem de converter o montante do empréstimo em uma quantidade preestabelecida de ações. Isso é particularmente preocupante no contexto de ofertas públicas de ações, em que determinados empréstimos podem ser utilizados para "maquiar" o balanço patrimonial da empresa pré-abertura de capital, para depois serem pagos com os recursos da oferta ou por meio da conversão do montante devido em ações do emissor. Ver: BODIE, Zvi; MERTON, Robert C. Finanças. 2. ed. São Paulo: Bookman, 2000. p. 60. 
simplificado das ofertas públicas a partir da análise prévia pela Anbid. ${ }^{717}$ No mesmo período, vale mencionar também o lançamento do Código de Autorregulação Bancária da Febraban, que tem como foco a regulação de condutas, procurando estabelecer padronização de comportamento entre bancos e clientes, como a criação de roteiro para encerramento de contas correntes. A aderência ao código é voluntária e, em caso de descumprimento das normas ali estabelecidas, a ocorrência é encaminhada para seu comitê disciplinar, podendo inclusive provocar o descredenciamento da instituição.

Defensores da autorregulação afirmam que a elaboração e o estabelecimento pelos próprios entes regulados das normas que disciplinam sua atividade aumentariam a aceitação dessas normas, concomitantemente a uma maior responsabilidade no cumprimento e redução da necessidade de intervenção do órgão regulador. ${ }^{718}$ Conforme apontamento de Calado, a entidade autorreguladora, ao obter a adesão dos participantes do mercado, estaria mais próxima das atividades que se propõe a regular, dispondo, portanto, de maior sensibilidade para avaliar as condições e normatizá-las. Isso contribuiria também para amenizar a dissonância cognitiva entre os agentes, presente nos casos em que os destinatários da regulação não têm a adequada percepção do valor contido na informação gerada pela regulação, diminuindo a frequência com que as normas são consideradas ambíguas ou interpretadas de forma incorreta. ${ }^{719}$

Apesar de suas vantagens conceituais, a crise financeira recente serviu para lançar dúvidas quanto à capacidade não só de os governos regularem o sistema financeiro, mas, principalmente, quanto à capacidade de o próprio mercado se autorregular. $\mathrm{O}$ abalo nos mercados reforçou questionamentos concernentes às limitações e conflitos de interesse inerentes a esse processo, principalmente no tocante à credibilidade e validade da autorregulação como mecanismo capaz de vigiar e punir os excessos dos participantes do sistema financeiro. ${ }^{720}$ Ainda mais importante, lançou críticas relativamente à capacidade de os mercados se corrigirem e equilibrarem automaticamente, fundada na hipótese do mercado

\footnotetext{
717 OLIVEIRA FILHO, Luiz Chrysostomo de. Autorregulação no sistema financeiro, p. 5.

718 CALADO, Luiz Roberto. Regulação e autorregulação do mercado financeiro, p. 58.

719 Idem, ibidem, p. 58.

720 OLIVEIRA FILHO, Luiz Chrysostomo de. Autorregulação no sistema financeiro, p. 3.
} 
eficiente de inspiração neoclássica, em que o comportamento racional dos agentes levaria necessariamente a resultados benéficos e estáveis. ${ }^{721}$

Como reflexo desse quadro, observa-se na atualidade demanda generalizada da sociedade e autoridades por maiores restrições à atuação de instituições financeiras. Isso ficou evidente nos relatórios preparados pelo Tesouro norte-americano sobre a necessidade de reforma da estrutura de regulação e supervisão do país, as propostas de reforma do Relatório Larosiére na União Europeia, bem como as mudanças previstas em Basileia III. Nesse sentido, talvez a declaração mais contundente a respeito do tema tenha vindo do Presidente francês Nicolas Sarkozy, em setembro de 2008, afirmando que: "A autorregulação como forma de resolver problemas está acabada. O laissez-faire está acabado. O todo poderoso mercado que sempre sabe o que é melhor está acabado". 722

Naturalmente, essa não é uma posição pacífica, havendo autores que não concordam com a responsabilização da crise à autorregulação. Oliveira Filho, por exemplo, argumenta que a origem da crise pode ser traçada ao mercado hipotecário norte-americano, setor tradicionalmente sujeito a forte regulação estatal. Além disso, mesmo países menos dependentes da autorregulação, como Inglaterra e França, também não conseguiram evitá1a. ${ }^{723}$ De fato, parece ser ainda cedo para decretar o fim da autorregulação, como sugerido por Sarkozy, e tampouco seria o escopo deste trabalho aprofundar-se nessa questão. O propósito deste é apenas demonstrar que o monitoramento das atividades das instituições financeiras de modo mais aprofundado do que a simples aprovação de métodos de classificação interna de risco por parte de instituições financeiras, conforme sugerido em Basileia II, ainda será exigido do supervisor por algum tempo, se é que algum dia esta função poderá ser integralmente transferida ao mercado. Certamente, isso não ocorrerá enquanto externalidades importantes continuarem resultando da ação das instituições financeiras e os sistemas de administração interna de risco não forem mais confiáveis do que no presente. ${ }^{724}$

\footnotetext{
721 VERÇOSA, Haroldo M. D. Considerações sobre o sistema financeiro, p. 14.

722 TIME. Europe's conservatives sour on the free market, 26 set. 2008. Tradução livre.

723 OLIVEIRA FILHO, Luiz Chrysostomo de. Autorregulação no sistema financeiro, p. 4.

724 CARVALHO, Fernão J. Cardim de et al. Economia monetária e financeira, p. 331.
} 


\subsubsection{Instituições “auxiliares” de supervisão bancária}

O monitoramento das instituições financeiras pelo supervisor bancário conta, muitas vezes, com o produto do trabalho de agentes privados que têm por objeto a avaliação da situação econômico-financeira dessas instituições. Isso é um fato evidente, decorrente da impossibilidade de a autoridade bancária coletar em tempo real todas as informações necessárias à supervisão bancária. Além de suas próprias limitações em termos de recursos disponíveis, é preciso reconhecer, também, que esses agentes privados podem ter mais expertise na coleta e análise de informações sobre o ente supervisionado, de modo que a utilização desses dados pela autoridade faz mais sentido do que procurar desenvolver as mesmas atividades em paralelo.

Em razão disso, pode-se dizer que os referidos agentes "auxiliam" a autoridade bancária a executar suas atividades de supervisão. ${ }^{725} \mathrm{Ou}$ seja, facilitam o trabalho da autoridade, dando-lhe acesso a informações que, de outra forma, teria que coletar, processar e analisar por conta própria. Entretanto, apesar do seu caráter “auxiliar", é importante ressaltar que esses agentes não têm o mandato específico de supervisores bancários e seus objetivos destoam daqueles que cercam a atuação da autoridade bancária. A utilização dessas informações deve ser feita com cautela, uma vez que, conforme se observará, a relação entre tais agentes privados e as instituições financeiras é cercada de interesses conflitantes. Não por acaso, existem regras especiais aplicáveis a esses agentes voltadas ao alinhamento de seus objetivos com os da autoridade bancária e mitigação desses conflitos de interesse. De fato, dependendo da existência ou não e forma de implementação e aplicação dessas regras, a atuação dos agentes privados pode muito bem prejudicar a higidez do setor, motivo pelo qual se torna necessário analisar os principais aspectos do papel e atuação desses agentes "auxiliares" de supervisão bancária.

\footnotetext{
725 Estes agentes também são chamados por alguns autores de "vigias" (gatekeepers) do mercado em virtude do seu papel na vigilância das empresas e emissão de opiniões técnicas sobre suas afirmações. Ver: NOVAES, Ana. Derivativos e governança corporativa: o caso Sadia - corrigindo o que não funcionou. In: GARCIA, Márcio; GIAMBIAGI, Fábio (Org.). Risco e regulação, p. 240.
} 


\subsubsection{Auditores contábeis}

Os auditores contábeis exercem um exame cuidadoso, sistemático e independente das atividades desenvolvidas em uma determinada empresa com o objetivo de averiguar se as informações divulgadas em seus demonstrativos contábeis estão de acordo com a realidade observada na empresa durante o período compreendido pela auditoria. O papel dos auditores para a autoridade responsável pela supervisão bancária não é apenas importante, na medida em que lhe permite acompanhar a saúde financeira dos bancos, mas também necessário, haja vista que seria impraticável para a autoridade realizar a auditoria contábil de todas as instituições financeiras atuantes no setor. ${ }^{726}$

Na maioria dos casos, a autoridade bancária depende do trabalho desses profissionais como parte de seus esforços de supervisão, de modo que, após identificada alguma irregularidade ou motivo de preocupação, esta pode empreender uma análise ad hoc mais aprofundada. Mesmo nessas ocasiões, contudo, ainda depende das informações prestadas pelos auditores para investigar as contas da instituição financeira. Portanto, ao contrário de outros prestadores de serviços, no caso dos auditores, há uma preocupação especial em fazer com que tais profissionais desempenhem suas atividades a contento.

Tais preocupações são reforçadas pelos evidentes conflitos de interesse que podem surgir na prestação de serviços dessa natureza. O fato de uma mesma empresa fornecer serviços de auditoria e consultoria ao cliente é uma prática comum no mercado. A atividade de auditoria pode ceder aos imperativos dos colegas consultores, o que pode gerar um cuidado insuficiente com a análise das demonstrações financeiras. Além disso, se os auditores desabonarem as informações financeiras prestadas, poderão colocar em risco contratos significativos de consultoria com o mesmo cliente. Essa preocupação foi corroborada

726 Conforme relato do ex-presidente do Bacen, Henrique Meirelles, prestando esclarecimentos no Congresso Nacional a respeito da fiscalização do Banco Panamericano, para que a autarquia auditasse as contas de todos os participantes do SFN, seria necessária uma "super galáctica mega empresa de auditoria". Ver: ISTO É DINHEIRO. Meirelles alerta para risco caso BC fizesse auditoria, 24 nov. 2010. 
recentemente em estudo do Parlamento inglês sobre a quebra do Northern Rock na Inglaterra. $^{727}$

O caso norte-americano também é cercado de exemplos referentes às relações sensíveis entre auditores e consultores. Entre os episódios mais significativos na última década, destacam-se os casos envolvendo as empresas Worldcom e Enron e suas fraudes contábeis para acobertar prejuízos (principalmente via SPEs) e aumentar artificialmente seus resultados operacionais. Além da condenação dos responsáveis, incluindo os presidentes das empresas, esses casos levaram ainda ao fechamento da responsável por sua auditoria contábil, a Arthur Andersen, à época uma das principais empresas de auditoria do mundo, que havia recebido US\$25 milhões em honorários em 2000 para auditar os números da empresa, além de US\$27 milhões por serviços de consultoria no mesmo período. ${ }^{728} \mathrm{Na}$ esteira dos escândalos contábeis foi promulgada a Lei Sarbannes-Oxley, em 30 de julho de 2002, que, entre outras alterações, estabeleceu controles mais rigorosos para a prestação dessas atividades e penas mais severas para empresas que praticarem fraudes contábeis, bem como empresas de auditoria que sejam coniventes ou negligentes com tais práticas.

Nesse contexto, não causa surpresa a constatação em pesquisa recente sobre a qualidade da regulação prudencial ao redor do mundo, o fato de a responsabilização de empresas de auditoria ter sido levantada como um dos aspectos de grande relevância para a eficácia da regulação prudencial. ${ }^{729} \mathrm{O}$ regramento de suas atividades e a possibilidade de responsabilização dessas empresas são considerados fundamentais para alinhar seus interesses

\footnotetext{
727 Conforme relato do grupo de estudos do Parlamento inglês criado para examinar as causas da quebra do banco: "Estamos preocupados com o conflito de interesse entre a função de auditor contábil e outros trabalhos que a empresa de auditoria possa prestar a instituições financeiras. Por exemplo, a PricewaterhouseCoopers recebeu $£ 700,000$ em receitas não relacionadas a auditoria, a maioria decorrente de trabalhos realizados em conexão com emissões pelo Northern Rock. Salientamos os trabalhos sendo realizados por órgãos contábeis a respeito dessa questão e recomendamos que eles e a FSA atribuam a devida consideração a esses conflitos de interesse no contexto de instituições financeiras”. Ver: HOUSE OF COMMONS. The run on the Rock. Tradução livre.

728 HEALY, Paul M.; PALEPU, Krishna G. The fall of Enron. Journal of Economic Perspectives, 17 (2), p. 15 , 2003.

729 BARTH, James R. et al. Rethinking bank regulation, p. 142 e ss.
} 
aos das autoridades responsáveis pela supervisão bancária. Os resultados da pesquisa, da qual o Brasil também participou, podem ser observados abaixo:

Tabela 14: Força da auditoria contábil externa - diferenças entre países (*)

\begin{tabular}{|l|c|c|}
\cline { 2 - 3 } \multicolumn{1}{l|}{} & Sim & Não \\
\hline $\begin{array}{l}\text { Auditoria contábil é obrigatória para bancos? } \\
\text { negligência? }\end{array}$ & $\mathbf{1 5 1}$ & 2 \\
\hline $\begin{array}{l}\text { Auditores são obrigados por lei a comunicar aos } \\
\text { supervisores qualquer envolvimento presumido dos } \\
\text { diretores e/ou gerentes do banco em atividades ilícitas, } \\
\text { fraude ou qualquer outro tipo de abuso? }\end{array}$ & $\mathbf{1 0 7}$ & 46 \\
\hline $\begin{array}{l}\text { Supervisores têm o direito de encontrar-se com } \\
\text { auditores para discutir o resultado de seu relatório de } \\
\text { auditoria sem a aprovação do banco? }\end{array}$ & $\mathbf{1 2 3}$ & 30 \\
\hline $\begin{array}{l}\text { Critérios para realização da auditoria são determinados } \\
\text { pelos supervisores? }\end{array}$ & $\mathbf{1 2 2}$ & 31 \\
\hline
\end{tabular}

(*) Células em negrito e fundo cinza representam a resposta fornecida pelo Bacen ao Banco Mundial para a elaboração da pesquisa comparativa.

Fonte: Barth, Caprio e Levine, Rethinking Bank Regulation, p. 145.

Como é possível observar no quadro acima, no Brasil todas as instituições financeiras devem ter suas contas auditadas por auditores contábeis independentes. Além disso, as instituições financeiras somente podem contratar auditor independente devidamente registrado na CVM e com certificação de especialista em análise bancária do Bacen. Os critérios e procedimentos contábeis a serem observados pelas instituições financeiras e demais instituições autorizadas a funcionar pelo Bacen estão relacionados no Plano Contábil das Instituições do SFN (Cosif), anexo à Circular Bacen 1.273, de 29 de dezembro de 1987, que unificou os diversos planos contábeis então existentes e uniformizou os procedimentos de registro e elaboração de demonstrações financeiras com o objetivo de facilitar o acompanhamento, análise, avaliação do desempenho e controle das instituições integrantes do SFN. $^{730}$

730 O Cosif é dividido em quatro capítulos. No capítulo 1 ("Normas Básicas”) estão consolidados os princípios, critérios e procedimentos contábeis que devem ser utilizados por todas as instituições integrantes do SFN. No capítulo 2 ("Elenco de Contas") são apresentadas as contas integrantes do plano contábil e respectivas funções. No capítulo 3 ("Documentos") são apresentados os modelos de documentos de natureza contábil 
Além do regramento específico do Cosif sobre as normas contábeis a serem observadas para a elaboração das demonstrações contábeis das instituições financeiras, a Resolução CMN 3.198, de 27 de maio de 2004, estabeleceu obrigações adicionais ao relatório de auditoria. Entre elas, o auditor independente deve relatar sobre: (i) a avaliação dos controles internos e procedimentos de gerenciamento de riscos exercidos pela instituição financeira, inclusive acerca de seu sistema eletrônico de processamento de dados, descrevendo eventuais deficiências encontradas; (ii) exame circunstanciado de revisão dos critérios adotados pela instituição quanto à classificação nos níveis de risco e de avaliação do provisionamento registrado nas demonstrações financeiras; e (iii) a descrição do eventual desenquadramento da instituição financeira com a regulamentação a que está sujeita, no tocante às suas demonstrações financeiras ou atividades. ${ }^{731}$

Os auditores independentes e o comitê de auditoria também devem comunicar ao Bacen, no prazo máximo de três dias úteis da respectiva identificação, a existência ou evidências de erro ou fraude representadas por: (i) inobservância de normas legais e regulamentares, que coloquem em risco a continuidade da entidade auditada; (ii) fraudes de qualquer valor perpetradas pela administração da instituição; (iii) fraudes relevantes perpetradas por funcionários da entidade ou terceiros; e (iv) erros que resultem em incorreções relevantes nas demonstrações contábeis da entidade. Caso seja aprovada, a proposta de anteprojeto de lei apresentada pelo Bacen em dezembro de 2009 (Audiência Pública 34/2009) ampliará esse dever de informar a situações que configurem: (i) não observância dos padrões mínimos de patrimônio líquido ou de patrimônio exigido em função do nível de risco das exposições de instituições financeiras; (ii) insuficiência de liquidez; e (iii) insolvência. Finalmente, a Resolução CMN 3.606, de 11 de setembro de 2008, alterou o art. 9. ${ }^{\circ}$ da Resolução CMN 3.198/2004, determinando que todas as instituições financeiras devem substituir o responsável técnico, diretor, gerente, supervisor e qualquer outro integrante, com função de gerência, da equipe envolvida nos trabalhos de auditoria, após

que devem ser elaborados pelas instituições integrantes do SFN. No capítulo 4 (“Anexos”) são apresentadas as normas editadas por outros organismos (CPC, Ibracon etc.) que foram recepcionadas para aplicação às instituições financeiras e demais instituições autorizadas a funcionar pelo Bacen.

731 Vale destacar que a Lei 9.447/1997 promoveu alterações ao art. 26 da Lei 6.385/1976, estabelecendo expressamente a responsabilidade das empresas de auditoria contábil e auditores contábeis independentes, perante o Bacen, "pelos atos praticados ou omissões em que houverem incorrido no desempenho das atividades de auditoria de instituições financeiras e demais instituições autorizadas a funcionar pelo Banco Central do Brasil". 
emitidos pareceres relativos a, no máximo, cinco exercícios sociais completos. É vedado também o retorno desses profissionais a essa função antes de decorridos três anos da data de sua substituição. ${ }^{732}$

Apesar de o ordenamento jurídico pátrio caminhar no sentido das melhores práticas prudenciais relativamente à auditoria contábil de instituições financeiras, é preciso reconhecer que, infelizmente, a atuação do Bacen e a jurisprudência sobre o assunto parecem não seguir na mesma direção. O golpe do balanço fraudado no Banco Nacional mencionado no tópico 2.4.1 representou um dos maiores escândalos contábeis no SFN, cuja fraude consistiu no registro, ao longo de dez anos, de 652 contas-correntes negativas que somaram $\mathrm{R} \$ 5,4$ bilhões em operações de crédito fictícias. ${ }^{733} \mathrm{Na}$ esfera administrativa, o processo perdurou até fevereiro de 2008 - quase 15 anos após a identificação da fraude -, quando a KPMG, empresa responsável pela auditoria das contas do Banco Nacional, desistiu de recorrer ao CRSFN, de uma decisão do Bacen que a condenou, em primeira instância, ao pagamento de multa de R\$3.681,79 e suspendeu por dez anos o registro de Marco Aurélio Diniz Maciel, ex-sóciodiretor da KPMG, responsável pelos relatórios de auditoria do Banco Nacional por sete anos. $^{734}$

Outro caso rumoroso no SFN é o do Banco Noroeste, vendido ao Santander em 1998. Durante a auditoria realizada pelo banco espanhol, foi identificado um rombo de US\$242 milhões nas contas da agência localizada nas Ilhas Cayman. ${ }^{735}$ À ocasião, a empresa de auditoria PricewaterhouseCoopers (PWC) foi acusada de omissão e negligência ao não detectar o desvio de dinheiro que consumiu mais da metade do patrimônio do banco. O Bacen

732 Cumpre mencionar que a Resolução CMN 2.267, de 29 de março de 1996, que determinava a substituição do auditor independente após decorridos quatro exercícios sociais completos desde sua contratação, vedando sua recontratação em prazo inferior a três exercícios sociais de sua substituição, foi objeto de questionamento no STF por parte da Confederação Nacional das Profissões Liberais (CNPL). Segundo a CNPL, haveria ofensa ao princípio da legalidade, uma vez que, sem dispositivo legal, impediu-se o exercício de profissão contabilista (arts. 5. ${ }^{\circ}$, caput, XIII, 170, IV, CF), além de representar limitação incompatível com o princípio da proporcionalidade. Já o Bacen alegou que a Resolução do CMN regulava, nos limites de sua competência, o controle interno e externo das instituições integrantes do SFN. Por unanimidade, o STF indeferiu o pedido liminar pleiteado pela CNPL e não suspendeu os efeitos da Resolução do CMN. Ver: ADin MC 2.317, Rel. Min. Ilmar Galvão, j. 19.12.2000.

733 VEJA. O golpe do balanço fraudado, 28 fev. 1996, p. 82-90.

734 VALOR ECONÔMICO. KPMG desiste de recurso no caso do Banco Nacional, 22 fev. 2008.

735 O esquema de fraude é relatado em detalhes em reportagem da revista Veja que ganhou o $17 .^{\circ}$ prêmio $\mathrm{CNH}$ de jornalismo econômico em 1998. Ver: VEJA. O maior desfalque da história, n. 1.540, 1. ${ }^{\circ}$ abr. 1998 , p. 94. 
aplicou à PWC multa de R \$100 mil por irregularidades como a não apuração de discrepâncias entre os saldos dos depósitos do banco em moeda estrangeira e os saldos existentes no passivo da agência em Cayman, acrescida de $\mathrm{R} \$ 100$ mil por ter dificultado a fiscalização da autarquia. Em seu recurso ao CRSFN, a empresa de auditoria conseguiu reduzir as multas para apenas uma, no valor de R $\$ 50$ mil. A penalidade, no entanto, está suspensa desde 2004, quando a PWC recorreu ao Judiciário para anular a decisão, conseguindo uma liminar. A ação que pede a anulação da sanção aguarda julgamento na $1 .^{\text {a }}$ instância da Justiça Federal de São Paulo. ${ }^{736}$

Mais recentemente, as empresas de auditoria voltaram a ficar em evidência no SFN em razão do episódio envolvendo o banco Panamericano, quando foi identificado rombo de $\mathrm{R} \$ 2,5$ bilhões em suas contas, decorrentes de vendas de carteiras de crédito a outras instituições financeiras sem a respectiva baixa desses ativos em seu balanço patrimonial. ${ }^{737}$ Na tradicional busca por "culpados" que ocorre após os escândalos, diversas empresas de auditoria têm sido responsabilizadas pela fraude. ${ }^{738}$ No foco das atenções encontra-se a Deloitte, encarregada da verificação das contas do banco no período em que a fraude contábil supostamente se deu. Além dela, KPMG e BDO Consultores também foram alvo de críticas, pelo fato de terem sido contratadas pela CEF para prestar assessoria na diligência das contas do Panamericano por conta da aquisição da participação acionária na instituição em $2008 .^{739}$ Ainda é cedo para declarar de forma taxativa quem são os responsáveis pelo ocorrido, mas não deixa de causar perplexidade o fato de uma fraude contábil que, segundo levantamento inicial do Bacen, já era perpetrada há quatro anos, e que atingiu montante superior a duas vezes o patrimônio do banco, não ter sido detectada por nenhuma das empresas que analisou suas contas nesse período. ${ }^{740}$

\footnotetext{
736 VALOR ECONÔMICO. STJ isenta Price de culpa em ação penal, 7 jun. 2010, p. C8.

737 Ver nota 335.

738 O ESTADO DE SÃO PAULO. BC atribui responsabilidade por rombo no Panamericano a falhas de auditorias, 11 nov. 2010, p. B1

739 Idem. Deloitte, KPMG e Fator não identificaram fraude, 11 nov. 2010, p. B3.

740 O GLOBO. Quatro anos de fraudes, 11 nov. 2010, p. 25.
} 


\subsubsection{Agências de rating}

As agências de rating são responsáveis pela avaliação da condição financeira de diversos agentes econômicos, incluindo as instituições financeiras e seus clientes. O rating pode se referir a uma empresa emissora de valores mobiliários, representando uma avaliação genérica do risco de crédito associado a todas as dívidas contraídas pelo emissor e sua capacidade futura de efetuar, dentro do prazo, pagamentos do principal e dos juros de suas obrigações. Alternativamente, o rating pode se referir a um produto financeiro específico, caso em que será avaliada a capacidade de o emitente realizar os pagamentos do principal e juros daquele produto específico no prazo acordado. ${ }^{741}$ Cada agência de rating possui sua própria escala de avaliação, que utiliza notações distintas, mas com classificações semelhantes, composta por uma combinação de letras, algarismos e sinais (por exemplo: AAA, AA+, AA, pela Standard \& Poor's e Aaa, Aa1, Aa2 pela Moody's). ${ }^{742}$

A vantagem das empresas de rating reside no fato de elas atuarem como redutoras de assimetria informacional. Conforme visto no primeiro capítulo, há uma assimetria informacional entre aplicadores e tomadores de recursos com relação à sua capacidade e disposição de pagamento, que pode afetar a precificação de operações de crédito. As agências de rating ajudam a atenuar essa assimetria informacional por meio do processamento, análise e interpretação de informações que não estão disponíveis publicamente. Isso é importante para emissores porque permite maior acesso a novos mercados, maior liquidez dos papéis e, até mesmo, de acordo com a classificação obtida, redução do custo de capital. Também é relevante para investidores na medida em que lhes fornece informações comparáveis ao redor do mundo, com a consequente economia de esforços de pesquisa, além de facilitar o estabelecimento de políticas de crédito. ${ }^{743}$

As agências de rating adquirem grande relevância no contexto da regulação prudencial pelo fato de terem sido progressivamente incorporadas ao instrumental de supervisão bancária de alguns países. Essa tem sido uma prática comum em jurisdições como

\footnotetext{
741 SOARES, Carla de A. F. Da possibilidade de regulação das agências de rating no Brasil. 2005. Dissertação (Mestrado) - IE-UFRJ, Rio de Janeiro, p. 21-22. Mimeografado.

742 Idem, ibidem, p. 22.

743 SOARES, Carla de A. F. Da possibilidade de regulação das agências de rating no Brasil, p. 23-24.
} 
os Estados Unidos nas últimas décadas, principalmente com o reconhecimento das Organizações Estatísticas de Rating de Reconhecimento Nacional (Nationally Recognized Statistical Rating Organizations - NRSROs), agências de rating cujas notas são utilizadas pelas autoridades reguladoras para determinar critérios de adequação de capital, ativos restritos, ou mesmo para isentar determinadas empresas ou produtos financeiros do cumprimento de requisitos regulatórios. ${ }^{744}$ Segundo o ensinamento de Howell Jackson, professor da Universidade de Harvard: ${ }^{745}$

\begin{abstract}
Outro contexto comum para a incorporação regulatória dos trabalhos de agência de rating ocorre quando padrões de supervisão impõem restrições na estrutura do balanço patrimonial de uma entidade regulada, como um banco, companhia de seguros ou firma que atue com valores mobiliários. Às vezes a habilidade de uma entidade deter certo tipo de investimento dependerá do rating atribuído a esse investimento por determinada agência. Em outros casos, o montante que a firma poderá investir em certo ativo aumentará ou diminuirá dependendo se este tem certo rating ou não [...] Outro contexto em que agências de rating participam da atividade regulatória é na área de controles de adequação patrimonial. Em muitos casos, o montante de capital que a entidade regulada deverá manter dependerá do volume de seus ativos. Controles de adequação patrimonial mais complexos variam o montante de capital necessário para tipos de ativos, e uma forma adotada por reguladores dos Estados Unidos para diferenciar ativos é por meio da atribuição de menores requisitos de capital para ativos com maiores ratings.
\end{abstract}

Outro importante exemplo de incorporação dos ratings na supervisão bancária é o caso de Basileia II, que prevê expressamente a utilização das notas atribuídas pelas agências de rating como forma de cálculo de adequação patrimonial. ${ }^{746}$ Trata-se da abordagem-padrão para risco de crédito (standardised approach to credit risk), que permite aos bancos apoiarem-se nas notas de rating de agências privadas para realizar o provisionamento de capital associado ao risco de crédito de seus empréstimos. Assim, quanto maior o rating dos tomadores de capital, ou dos ativos financeiros incluídos na carteira da instituição, menor a necessidade de adequação de capital, e vice-versa.

744 Para uma discussão sobre as formas como as agências reguladoras dos Estados Unidos têm incorporado as notas das agências de rating em suas atividades, ver: PARTNOY, Frank. The Siskel and Ebert of financial markets: two thumbs down for the credit rating agencies. Washington Quarterly Review, v. 77, n. 3, p. 619, 1999; RHODES, Amy K. The role of the SEC in the regulation of rating agencies: well-placed reliance or free-market interference? 20 Seton Hall Legis J. 293, 1996.

745 JACKSON, Howell E. The role of credit rating agencies in the establishment of capital standards for financial institutions in a global economy. In: FERRAN, Eilís; GOODHART, Charles. Regulating financial services and markets in the 21 st century, p. 313. Tradução livre.

746 COMITE DE BASILEIA. International convergence of capital measurement and capital standards - A revised framework, p. 15. 
Apesar de suas inegáveis virtudes, as agências de rating estão sujeitas a severas críticas em razão dos conflitos de interesse presentes em sua estrutura de negócios e sua performance aquém do esperado em escândalos financeiros recentes. ${ }^{747}$ Assim como no caso da auditoria contábil, o grande conflito de interesse presente em sua atividade decorre justamente do fato de sua receita provir daqueles que contratam seus serviços para sua avaliação ou de seus produtos financeiros, o que pode acabar comprometendo a isenção da agência em sua atuação. Outro aspecto relevante sobre o relacionamento entre agências de rating e seus clientes reside no fato de os emissores poderem optar pela divulgação ou não do rating atribuído pela agência. Para que o rating se torne público, a empresa contratante deve autorizar formalmente a divulgação, criando, assim, uma tendência à sua publicação apenas quando estes lhe forem favoráveis.

Reagindo a tais críticas, defensores do papel das agências de rating procuram mitigar esses conflitos de interesse, pontuando que o "capital reputacional” é um aspecto fundamental do seu modelo de negócios. ${ }^{748}$ Caso os participantes do mercado acreditem que um emissor pode conseguir rating mais elevado de uma determinada agência pagando por isso, seus ratings perderão credibilidade, inviabilizando a atuação futura daquela agência. Desse modo, a preocupação com a reputação limitaria a possibilidade de influência dos emissores, servindo para atenuar os alegados incentivos negativos causados pelos interesses conflitantes. Segundo John Bohn Jr., ex-presidente da Moody's, a maior agência de rating do mundo: "Nós estamos no negócio da integridade: as pessoas nos pagam para sermos objetivos, para sermos independentes, e para dizer que as coisas são como elas realmente são" ${ }^{749}$

Apesar da coerência do argumento apresentado, diversos eventos envolvendo agências de rating serviram para lançar dúvidas quanto à integridade do seu trabalho. Episódios como os do LTCM, Parmalat, Enron, Worldcom e Dubai World representam casos em que as agências de rating não identificaram a deterioração da saúde financeira das empresas a tempo, causando graves prejuízos a investidores. Outro exemplo ainda mais contundente de falha de atuação das agências de rating restou evidenciado na crise do mercado hipotecário subprime norte-americano, em que muitos dos ativos "tóxicos" que

\footnotetext{
747 HILL, Claire A. Regulating the rating agencies. Washington University Law Quarterly, v. 82, p. $43,2004$.

748 SOARES, Carla de A. F. Da possibilidade de regulação das agências de rating no Brasil, p. 24.

749 HOUSE, Richard. Ratings trouble. Institutional Investor, p. 245, out. 1995. Tradução livre.
} 
contaminaram o mercado foram oferecidos a investidores por meio de operações estruturadas - principalmente os CDOs - que contavam com o beneplácito das agências de rating. ${ }^{750} \mathrm{~A}$ esse respeito, vale mencionar posicionamento do ex-presidente do Bacen, Henrique Meirelles, sobre a baixa performance das agências de risco de crédito na crise recente, afirmando que "houve excesso de confiança nessas agências, bem como falhas nos modelos e metodologias de avaliação de risco, além de desinteresse em tratar os conflitos de interesse no processo de rating". ${ }^{751}$

Acrescente-se às críticas quanto à resposta lenta ou falha em sua atuação a preocupação com a própria estrutura do mercado em que atuam. Com efeito, observa-se na atualidade que o mercado de rating é largamente dominado por apenas três participantes, quais sejam: Moody's, Standard\&Poors e Fitch. Embora todas tenham atuação global, as duas primeiras teriam atividades mais focadas nos Estados Unidos e países emergentes, enquanto a Fitch seria mais atuante na Europa. ${ }^{752}$ Naturalmente, na medida em que emissores contam com poucas opções de empresas para obterem rating, o argumento referente ao "capital reputacional" perde força, uma vez que estes podem não ter opção, independentemente da qualidade do serviço prestado. Isso seria agravado pelas evidências de significativas barreiras à entrada nesse mercado, bem como pelo fato de, em determinadas operações, ter se

750 Já se observou na nota 660 o que são CDOs e a estrutura de tranches adotada em tais operações. Tipicamente uma SPE terá todas as classes dessas obrigações (com exceção da mais junior) classificadas por uma ou mais firmas de rating. Como parte do processo de rating, a SPE normalmente procurará negociar com tais agências a divisão de classes da dívida que será emitida de modo a assegurar que a classe mais senior receberá o maior rating possível. A classe senior pode receber o rating máximo (AAA, por exemplo) mesmo que os créditos que originaram os recursos da SPE não sejam considerados "triplo-A", uma vez que são os primeiros a serem pagos e, consequentemente, os últimos a sofrerem uma perda. A qualidade do crédito da classe senior é aprimorada pelo fato de as classes mais juniores funcionarem como um "colchão de segurança" para possíveis perdas. Para melhorar o rating da tranche mais senior, não raro as SPEs realizam contratos de CDS (esse processo foi explicado na nota 442, em que se observou que esta foi a grande razão para os significativos prejuízos assumidos pela AIGFP), que garantem o pagamento de tais obrigações em casos de inadimplência (criando as chamadas super senior tranches). A vantagem da atribuição de um bom rating à tranche superior é que, dependendo da proporção desta em relação às outras tranches, o rating englobava as outras classes também, inclusive as de maior risco, de modo que, mesmo operações estruturadas envolvendo ativos tóxicos subprime, podiam receber ratings de investimento. Para uma descrição detalhada desse processo, ver: SJOSTROM, William K. The AIG bailout, p. 954 e ss.

751 MEIRELLES, Henrique. Reforço da regulação e supervisão e o seu papel na estabilidade do sistema financeiro.

752 CERVONE, Elisabetta. Credit Rating Agencies. Why might the market not work? A discussion on regulatory issues under a transatlantic perspective. The Graduate Program Visiting Scholar and Visiting Researcher Colloquium, Harvard Law School, apresentação ocorrida em 20 de março de 2008. 
desenvolvido a prática de obtenção de rating de pelos menos duas agências para emissões. ${ }^{753}$ Não por acaso, o reconhecimento dessas instituições como pilares da infraestrutura informacional dos mercados de capitais ao redor do mundo levou alguns autores a equiparar seu poder ao de superpotências mundiais. ${ }^{754}$

Reconhecendo essas limitações em sua atuação e preocupações com seu poderio crescente, observou-se nas últimas décadas movimento no sentido da regulação mais intensa das atividades dessas agências. ${ }^{755}$ Entre as iniciativas recentes nesse campo, pode-se mencionar a elaboração em 2004 de um código internacional com padrões mínimos de atuação para agências de rating, que procurou tratar de algumas das questões-chave em seu funcionamento, como: (i) qualidade e integridade do processo de rating; (ii) independência e conflitos de interesse na prestação de serviços; (iii) responsabilidade perante investidores e emissores; e (iv) criação de um código de conduta. ${ }^{756} \mathrm{Em}$ dezembro de 2005 , a União Europeia instituiu política de supervisão moderada de agências de rating por meio da exigência de aderência destas ao código de conduta mencionado, bem como pela maior regulamentação de práticas que, embora não direcionadas diretamente às suas atividades, com elas se relacionam, como a prestação de consultoria financeira (2004 Markets in Financial Instruments Directive) e punição mais rigorosa às práticas de insider dealing e manipulação de mercado (2003 Market Abuse Directive).

A Comissão Europeia promoveu importantes alterações no regramento das atividades das agências de rating em 2009, por meio do Regulamento 1.060, incluindo: (i) a obrigação de divulgação da metodologia utilizada na preparação do rating; (ii) identificação específica e

753 HILL, Claire A. Regulating the rating agencies, p. 43.

754 Nas palavras de Thomas L. Friedman, articulista do The New York Times: "Há duas superpotências no mundo atualmente em minha opinião. Há os Estados Unidos e há a Moody’s Bond Rating Service. Os Estados Unidos podem destruí-lo jogando bombas, e a Moody's pode destruí-lo rebaixando seu rating. E, acreditem em mim, não é claro às vezes quem é mais poderoso". Ver: The news hour with Jim Lehrer: Interview with Thomas L. Friedman (PBS television broadcast, Feb. 13, 1996), apud PARTNOY, Frank. The Siskel and Ebert of financial markets, p. 620. Tradução livre.

755 LANGOHR, Herwig M.; LANGOHR, Patricia T. The rating agencies and their credit ratings: what they are, how they work and why they are relevant. London: Wiley, 2008. p. 429-468.

756 IOSCO. Code of conduct fundamentals for credit rating agencies, Madrid, dez. 2004. O papel da Iosco será objeto de maior detalhamento no próximo capítulo. Este e os demais relatórios da IOSCO mencionados neste trabalho podem ser encontrados em: 〈www.iosco.org/library/index.cfm?section=pubdocs >. Acesso em: 23 dez. 2010. 
critérios mais rigorosos para rating de produtos estruturados; e (iii) requisitos organizacionais e operacionais para evitar conflitos de interesse na atuação das agências (com a exigência de divulgação de clientes que representem mais de $5 \%$ de seu faturamento, proibição à possibilidade de investimento nos ativos que serão objeto de avaliação por partes relacionadas, e restrição à prestação de serviços de consultoria para empresas que serão objeto de avaliação). As novas regras instituem também um processo unificado de registro e supervisão das agências atuantes nos países-membros, que deverá ser desempenhado por uma autoridade de valores mobiliários da União Europeia com previsão de entrada em funcionamento em 2011. Finalmente, as novas regras restringem a utilização de ratings externos por instituições financeiras para fins de composição de capital regulatório apenas àqueles preparados em conformidade com as disposições do novo regulamento.

Nos Estados Unidos foi promulgado em 2006 o Credit Rating Agency Reform Act, com o objetivo expresso de aprimorar a responsabilidade, transparência e competição na indústria de rating. Entre as principais mudanças, destaca-se a maior autoridade de supervisão das atividades das agências de rating pela SEC, que pode, inclusive, impedir a divulgação do rating, ou mesmo negar (ou suspender) o registro da agência quando entender necessário. Além disso, a reforma também procurou aumentar o número de participantes no mercado pela formalização dos critérios de licenciamento de agências cujos ratings são reconhecidos pela SEC para fins regulatórios (em substituição ao sistema de NRSROs). Mais recentemente, o Dodd-Frank Wall Street Reform and Consumer Protection Act também promoveu mudanças no regramento das atividades dessas agências, como: (i) a obrigação de descrever em seu relatório de rating preparado para ofertas de valores mobiliários as declarações e garantias prestadas pelo emissor no âmbito da operação, bem como as medidas disponíveis ao investidor contra o emissor em caso de default; (ii) obrigação de informar às autoridades práticas ilegais identificadas no escopo da auditoria preparatória ao rating; e (iii) exigência de que emissores obtenham consentimento prévio por escrito das agências de rating para mencionar as avaliações recebidas no âmbito de ofertas de valores mobiliários. Tais reformas procuram não apenas aumentar a quantidade e qualidade das informações disponíveis ao investidor, mas também atribuir maior responsabilidade às agências pelos ratings divulgados.

No campo da supervisão bancária, a mudança mais drástica promovida pelo DoddFrank Wall Street Reform and Consumer Protection Act no tocante às agências de rating foi a 
exigência de que, um ano a partir da aprovação da reforma, todas as agências federais norteamericanas removam quaisquer referências a trabalhos de agências de rating de suas regulamentações (Seção 939A). Em suma, essa modificação reverte o movimento de incorporação do trabalho dessas agências no instrumental de supervisão bancária que vinha ocorrendo nos últimos anos, impedindo que autoridades se apoiem em (e bancos utilizem) ratings externos para cálculos de adequação patrimonial, devendo os órgãos reguladores do país desenvolver seus próprios sistemas de rating para tais situações.

As origens do mercado de classificação de risco de crédito no Brasil podem ser traçadas a 1994, com a publicação do relatório de rating pela SR Rating para uma emissão estruturada envolvendo o Grupo Mesbla, em operação de financiamento de recebíveis da empresa J. C. Penney. ${ }^{757}$ Desde então diversos players entraram nesse mercado. De acordo com parecer preparado pela Secretaria de Direito Econômico (SDE) no âmbito da aquisição da Atlantic Rating pela Fitch Brasil Ltda., em 2003 a participação de mercado das agências de rating no país era liderada pela Standard\&Poors com 61,74\% do mercado, seguida pela Fitch Brasil Ltda. com 20\% (após a aquisição da Atlantic Rating), Moody's com 9,78\%, Austin Asis com $4,76 \%$ e a SR Rating com $3,12 \%$. $^{758}$

Atualmente as agências de rating brasileiras não estão submetidas a exigências legais específicas ou padrões de conduta de nenhum órgão regulador ou associação de classe. ${ }^{759}$ Evidentemente, estas podem seguir as orientações de códigos internacionais de conduta nessa área, mas não há obrigação de aderência nesse sentido, como é o caso da União Europeia. Apesar de seus produtos estarem previstos em alguns dispositivos legais, ${ }^{760}$ há pouca ou nenhuma prestação de contas concernente aos trabalhos prestados por tais agências. Ao

757 Para uma revisão da história das agências de rating no Brasil, ver: CASTRO, Paulo Rabello de. Rating agency regulation in Brazil. Notas preparadas para o Seminário "Rating agency regulation", organizado pela Bovespa em 4 de novembro de 2004. Disponível em: 〈www.cnmv.es/publicaciones/IOSCOPD177_6.pdf〉. Acesso em: 23 dez. 2010.

758 AC 08012.003203/2003-81, Rel. Cons. Roberto Augusto Castellanos Pfeiffer, j. 03.03.2004.

759 SOARES, Carla de A. F. Da possibilidade de regulação das agências de rating no Brasil, p. 31.

760 Conforme apontamento de Soares, a atuação das agências de rating já é prevista em diversos dispositivos legais, como a Instrução CVM 393, de 22 de jullho de 2003, que regula os fundos de direitos creditórios (FIDCs) e a Instrução CVM 404, de 13 de fevereiro de 2004, que dispõe sobre debêntures padronizadas. Pela Resolução CMN 2.829, de 30 de março de 2001, as entidades fechadas de previdência privada são incentivadas a utilizar a classificação de uma agência de rating em operação no Brasil para alocar em seu portfólio de renda fixa títulos de baixo risco de crédito. Ver: Idem, ibidem, p. 31. 
contrário das empresas de auditoria, não há controle sobre quem está autorizado a prestar tais atividades, exigência de rotatividade dos profissionais responsáveis pela prestação dos serviços, ou mesmo obrigação de prestar informações às autoridades caso sejam verificadas irregularidades no decorrer dos trabalhos. Isso inclusive já foi objeto de críticas, como no caso da atuação da Austin Rating em sua avaliação do Banco Santos em 2004. ${ }^{761}$

Apesar disso, deve-se ressaltar que, no tocante ao setor bancário, a preocupação quanto à falta de controle sobre as atividades de tais agências no Brasil é minimizada, em parte, pelo fato de o Bacen adotar uma abordagem conservadora relativamente aos seus trabalhos, não incorporando ratings externos ao seu instrumental de regulação e supervisão bancária. É o caso, por exemplo, do Comunicado 12.746, emitido pela autarquia em 9 de dezembro de 2004, que ao tratar do cronograma de implementação de Basileia II no País, adiantou quanto às diretrizes do acordo que a autarquia não utilizaria ratings divulgados pelas agências privadas de classificação de risco de crédito para fins de apuração do requerimento de capital. ${ }^{762}$ Pelo contrário, o Bacen possui sistemas próprios de rating baseados em fatores diversos, conforme observado no tópico 4.1.1.1.3 com relação ao tratamento atribuído pela Resolução CMN 2.682/1999 para classificação de operações de crédito. Nesse aspecto, a autarquia parece novamente colocar-se à frente das mudanças que estão sendo discutidas em outros países em decorrência da crise financeira recente. ${ }^{763}$

761 Com efeito, dois meses antes de o Bacen intervir no banco, a Austin Rating concedeu ao banco o conceito "A". No relatório em que atribuiu a nota, a agência afirmou que: "o banco apresenta solidez financeira intrínseca boa. São instituições dotadas [as classificadas com conceito A] de negócio seguro e valorizado, [com] boa situação financeira atual e histórica. O risco é muito baixo". A classificação atribuída pela Austin Rating causou estranheza, uma vez que, em dezembro de 2003, a Fitch já havia rebaixado a nota do Banco Santos em virtude da preocupação com a deterioração de sua carteira de crédito, no que foi acompanhada em janeiro de 2004 pela Standard\&Poors, que também reduziu a nota do Banco Santos em razão da piora na qualidade de seus ativos. A notícia da intervenção no banco levou o comitê de classificação de risco da Austin Rating a realizar "reunião extraordinária" para reavaliar a instituição, diminuindo sua nota de "A" para "CCC" por meio de nota divulgada em seu site na internet. Ver: FOLHA DE SÃO PAULO. Banco Santos põe em dúvida agências de risco, 28 nov. 2004, p. B17.

762 Disponível em: 〈www.bcb.gov.br/?COM12746>. Acesso em: 3 jan. 2011.

763 Evidentemente, a mitigação da preocupação quanto aos trabalhos dessas agências no campo da regulação e supervisão bancária não esvazia o debate referente à necessidade e escopo de regulação dessas atividades no tocante ao funcionamento do mercado de capitais. Essa, no entanto, é uma discussão que fugiria ao escopo do presente trabalho. 


\section{SÍNTESE E CONCLUSÕES DO CAPÍTULO 4}

1. A regulação prudencial procura implementar mecanismos voltados ao acompanhamento e controle do nível de risco assumido por instituições financeiras. Ela cumpre importante papel complementar à regulação sistêmica, na medida em que ajuda a combater os efeitos deletérios em termos de criação de risco moral decorrentes da disponibilização de uma rede de segurança aos bancos.

2. As estratégias adotadas pela regulação prudencial para atingir seus objetivos se modificaram ao longo das décadas. Inicialmente essas estratégias apoiavam-se em regras de conteúdo prescritivo e busca do controle direto das operações das instituições financeiras por meio da segregação estrita de suas atividades e imposição de indicadores quantitativos objetivos para o julgamento das operações permitidas. O foco principal da regulação prudencial nesse primeiro estágio evolutivo era assegurar a liquidez dos depósitos, permitindo que bancos honrassem demandas de retirada por depositantes. As mudanças ocorridas no sistema financeiro durante o século XX gradualmente tornaram essas estratégias obsoletas. O advento de novas formas de administração de passivos baseadas na diversificação de fontes de recursos e a progressiva perda de importância dos depósitos bancários tradicionais em face de outras atividades bancárias provocaram uma mudança no foco das estratégias de regulação prudencial. A partir da década de 1980, as autoridades passaram a atribuir atenção crescente à dinâmica de remuneração das instituições financeiras e ao incentivo à tomada excessiva de risco decorrente das assimetrias informacionais presentes no setor. Como resultado, o foco da regulação prudencial migrou das operações passivas para as operações ativas das instituições financeiras e, sobretudo, o risco de crédito decorrente de tais operações.

3. Essa mudança de foco na regulação prudencial foi consagrada em Basileia I, que procurou harmonizar práticas de regulação prudencial ao redor do mundo por meio da imposição de capital mínimo a ser observado pelas instituições financeiras, calculado de acordo com suas aplicações e baseando-se na classificação de risco reconhecido em cada categoria de crédito. Apesar de ter representado grande avanço no estabelecimento de padrões mínimos de regulação prudencial, tornando-se verdadeira referência regulatória ao redor do mundo, o acordo sofreu críticas em virtude do seu escopo limitado, voltado apenas à consideração do risco de crédito e de inconsistências na sua aplicação. Em razão disso, Basileia I 
tornou-se objeto de revisões ao longo da década seguinte, resultando em Basileia II. Além de procurar corrigir falhas do acordo anterior, Basileia II foi mais abrangente e procurou acrescentar novas categorias de risco, bem como implementar mecanismos que levassem em consideração a inovação e sofisticação crescentes no mercado financeiro. Para tal, apoiou-se no capital mínimo, supervisão bancária e disciplina de mercado como pilares fundamentais da regulação prudencial.

4. Mais recentemente, o Comitê de Basileia propôs uma série de medidas que ficaram conhecidas conjuntamente como Basileia III. Tomando como base os trabalhos realizados nos acordos prévios, Basileia III propõe ações voltadas ao aumento da qualidade, consistência e transparência da base de capital das instituições financeiras. As regras propostas também focam na chamada abordagem "macroprudencial", preocupando-se com a manutenção da higidez do sistema financeiro como um todo, em contraste com o enfoque no controle individual sobre as instituições financeiras predominante nos acordos anteriores. Nesse sentido, Basileia III procura instituir novos mecanismos de regulação prudencial em nível internacional, como a criação de um índice de alavancagem não ajustado ao risco, padrões globais de liquidez de curto e longo prazos, modelos de provisionamento de capital com ajuste cíclico, e regras especiais para instituições sistemicamente relevantes.

5. Embora o Brasil já adotasse requisitos patrimoniais e formas de limitação de endividamento anteriormente, a Resolução CMN 2.099/1994 pode ser considerada o marco inaugural do modelo de regulação prudencial atualmente adotado no País. As mudanças realizadas pela Resolução procuraram incorporar parte das recomendações de Basileia I, notadamente a transição para um sistema baseado na limitação às operações ativas, ponderadas pelo risco de crédito. O País encontra-se atualmente em processo de implementação de Basileia II, incluindo modificações próprias, com previsão de conclusão dos trabalhos até o final de 2012. Representantes do Bacen participaram das discussões referentes a Basileia III, mas como a implementação dessas propostas ocorrerá em prazos dilatados e ainda dependerá de melhor detalhamento e criação de mecanismos subjacentes ao funcionamento desses instrumentos, é cedo para avaliar se, quando e como tais medidas impactarão o regramento aplicável às instituições financeiras no País. 
6. A análise do arcabouço regulatório pátrio indica que o Brasil adota na atualidade os principais mecanismos de regulação prudencial tradicionalmente utilizados ao redor do mundo. Além disso, constatação de relevo para o presente trabalho é a de que a adoção desses mecanismos no País é marcada pela utilização de critérios e exigências mais rigorosos do que aqueles sugeridos pelos acordos de Basileia, ou mesmo em comparação com outros países. A adoção das recomendações dos acordos de Basileia não se deu de forma absoluta, incorporando importantes modificações em relação às proposições originais, como: (i) a manutenção de capital mínimo para abertura de instituições financeiras, inclusive mantendo até 1999 exigência em dobro desse capital para instituições financeiras sob controle estrangeiro direto ou indireto; (ii) níveis de risco superiores para determinados ativos, incluindo ponderação de 300\% para créditos fiscais; e (iii) requisito de capital ajustado ao risco de $11 \%$ em vez dos $8 \%$ sugeridos por Basileia I. No tocante a Basileia II, vale mencionar a proibição à utilização de agências de rating externo para cálculos de adequação de capital.

7. No que concerne aos mecanismos de regulação prudencial considerados individualmente, observou-se que o País conta com infraestrutura de supervisão bancária avançada, com mecanismos de controle de acesso austeros e sistemas de envio de informações e supervisão direta e indireta abrangentes e eficientes, em consonância com os princípios fundamentais para supervisão bancária efetiva do Comitê de Basileia. Além disso, embora por conveniência expositiva tenham sido apresentados no Capítulo 3, quando foram analisados os regimes especiais aplicáveis a instituições em crise, é inegável a dimensão prudencial que as regras rigorosas de responsabilidade e indisponibilidade dos bens de controladores e administradores em tais regimes apresentam, na medida em que criam incentivos para manutenção da higidez da instituição financeira. Outrossim, vale repisar a importância das mudanças ocorridas no SPB, passando a permitir o acompanhamento das exposições a risco de instituições financeiras praticamente em tempo real pela autoridade bancária.

8. Além da adoção das melhores práticas prudenciais, o País também se encontra à frente do debate regulatório internacional em muitas áreas da supervisão bancária. Enquanto Estados Unidos e Europa integraram apenas recentemente e de forma ad hoc os testes de resistência de instituições financeiras ao seu arcabouço regulatório, estes já são prática comum nos esforços de supervisão bancária do Bacen, conforme disposto em seus 
relatórios de estabilidade financeira. Outro importante ponto de debate internacional é o controle dos instrumentos financeiros derivativos negociados em mercados de balcão. Nesse aspecto, observou-se que o Bacen já exerce maior fiscalização sobre operações realizadas por instituições financeiras no âmbito doméstico por conta própria, inclusive exigindo que estas sejam registradas em mercados de balcão organizados (e sob supervisão da CVM), sistemas administrados por bolsas de valores, mercadorias e de futuros, ou entidades de registro e de liquidação financeira de ativos devidamente autorizadas pelo Bacen ou CVM. Esse controle foi estendido recentemente para abarcar operações realizadas por instituições financeiras com contrapartes no exterior que não estejam sujeitas à supervisão do Bacen. Com relação aos problemas apresentados pelas SPEs e os riscos causados pela transferência de riscos para fora do balanço dos bancos, vale mencionar a conversão dos padrões contábeis brasileiros para o modelo IFRS, considerado mais transparente para fins de consolidação financeira pelo Comitê de Basileia. Finalmente, o Bacen reiterou novamente sua postura rigorosa na regulação prudencial, sendo um dos primeiros países a procurar adequar a política de remuneração no setor bancário às recomendações do FSB, apresentando proposta de normativo, convertida recentemente na Resolução CMN 3.921/2010, que visa alinhar os incentivos à tomada de risco por tais executivos com o crescimento de longo prazo das instituições financeiras.

9. No tocante aos agentes "auxiliares" de supervisão bancária, o Brasil exerce controle rígido sobre os padrões contábeis aplicáveis às instituições financeiras por meio do Cosif, inclusive exigindo certificação perante o Bacen para condução de tais atividades. Há uma série de obrigações de prestação de informações por parte de auditorias independentes no caso de verificação de irregularidades na análise das contas das instituições financeiras. Quanto às agências de rating, o Brasil consegue evitar muitos dos problemas enfrentados por outros países em relação às atividades de tais entidades em razão de sua postura conservadora, não incorporando ratings externos ao instrumental de supervisão bancária.

10. Evidentemente, a constatação dessas virtudes a respeito dos instrumentos de regulação prudencial pátrios não significa que o País possa ou deva se evadir do debate a respeito de formas de aperfeiçoar tais mecanismos. A análise individual desses instrumentos indica áreas de aprimoramento, como a adoção de critérios mais transparentes para os testes de resistência administrados sobre instituições financeiras e seus resultados, ou o exame 
sobre a eficácia da Lei 7.492/1986 como forma de prevenir condutas que possam colocar em risco a viabilidade da instituição financeira e, potencialmente, do sistema financeiro como um todo. Igualmente, embora o ordenamento jurídico pátrio caminhe no sentido das melhores práticas prudenciais relativas à auditoria contábil de instituições financeiras, é preciso notar a existência de rumorosos casos no SFN envolvendo atuação com zelo questionável por parte de auditorias independentes na condução de seus trabalhos, indicando outra possível área de aprimoramento.

11. De importância ainda maior para o presente trabalho é a constatação de que, assim como observado em relação a outros campos da regulação financeira, ou mesmo a experiência de outros países, o arranjo institucional de supervisão bancária no País também sofre os efeitos das transformações observadas no sistema financeiro nas últimas décadas. A concentração crescente no setor e a diluição das barreiras regulatórias entre atividades financeiras permitem o surgimento de conglomerados financeiros de grande complexidade atuantes em diversos segmentos do sistema financeiro. Esses movimentos apresentam enormes desafios às autoridades, e o Brasil não é exceção a esse quadro.

12. O modelo de regulação e supervisão instituído por meio da reestruturação do SFN iniciada em 1964 combina elementos da abordagem funcional (atividades bancárias e bursáteis) e institucional (companhias seguradoras). Ambos os modelos apresentam limitações, uma vez que, no caso de conglomerados financeiros, nenhuma autoridade dispõe de informação suficiente a respeito de todas as atividades desempenhadas, o que pode comprometer o monitoramento do nível de risco a que a instituição está exposta. As autoridades do SFN têm procurado suprir as deficiências desse modelo por meio do estabelecimento de convênios de trocas de informação e coordenação regulatória entre si. Nesse aspecto, diferencial importante do arranjo institucional pátrio de regulação e supervisão é a presença do CMN como órgão responsável por assegurar a coordenação de atividades entre o Bacen e a CVM nos casos de instituições financeiras e demais sociedades autorizadas a explorar simultaneamente operações ou serviços nos mercados financeiro e de capitais. O mesmo não ocorre, no entanto, relativamente às atividades de seguro, razão pela qual foi instituído o Coremec, em 2006, com o propósito de aprimorar a coordenação das funções de regulação e supervisão entre as áreas de competência do Bacen, CVM, Susep e SPC. Apesar dos esforços no sentido de harmonizar a atuação entre autoridades por meio de acordos de cooperação e fóruns de discussão, é provável que, na 
medida em que atividades não bancárias ganhem maior peso nos resultados de instituições financeiras, o embate entre autoridades se torne mais frequente, como no caso do posicionamento de integrantes e ex-integrantes do Bacen quanto à extensão de sua competência sobre fundos de investimento, atualmente sob supervisão da CVM.

13. Outro desafio à regulação prudencial provocado pelos movimentos de concentração e conglomeração financeira refere-se à possibilidade de captura regulatória. A formação de conglomerados financeiros de grande porte facilita a coordenação de ações entre os participantes do setor, tornando seu lobby mais eficaz. Nesse sentido, as inúmeras operações de fusões e aquisições ocorridas no setor bancário em virtude da crise financeira recente amplificam a capacidade de organização política dessas instituições, dificultando a aprovação de medidas que restrinjam ou atribuam maior controle às suas atividades. Isso é perceptível em países nos quais o lobby se dá de forma mais institucionalizada, como nos Estados Unidos, em que os debates a respeito da reforma do sistema de regulação e supervisão financeira contaram com intensa resistência de instituições financeiras, gerando inclusive críticas abertas do presidente americano quanto ao seu comportamento.

14. É preciso ressaltar também os questionamentos levantados em relação à autorregulação e sua capacidade de conter excessos dos participantes do sistema financeiro. Esse é um ponto importante para a regulação prudencial, na medida em que Basileia II endossou essa estratégia regulatória como forma de lidar com a complexidade crescente das interações e produtos no sistema financeiro. Os eventos recentes nos mercados mundiais, no entanto, deixaram claro que o monitoramento de instituições financeiras de modo mais aprofundado do que a simples aprovação de métodos de classificação interna de risco por parte delas ainda será exigido do supervisor bancário por algum tempo, se é que algum dia esta função poderá ser integralmente transferida ao mercado.

15. Embora haja espaço para aprimoramentos, faz-se mister reconhecer os méritos inerentes ao desenvolvimento do arcabouço regulatório prudencial no País desde a década de 1990. A postura rigorosa adotada pela autoridade bancária na incorporação das recomendações de Basileia no País, bem como os méritos desses mecanismos quando considerados individualmente, ajudam a explicar como o SFN resistiu bem aos efeitos da crise 
financeira recente em comparação com outros países, colocando-o em situação privilegiada na discussão internacional sobre a necessidade de reformas regulatórias.

16. Finalmente, as conclusões do presente capítulo também são particularmente relevantes em face dos vícios identificados no quadro atual de regulação sistêmica tratados no capítulo anterior. Se a regulação sistêmica no País é tendente à geração de amplo risco moral, pelo menos ele conta com controles mais rigorosos desse risco do que os encontrados em outros países. É necessário frisar, no entanto, que isso não significa que a regulação prudencial mais exigente encontrada no Brasil possa ser vista como uma forma de compensar ou neutralizar essa situação. A análise das diferentes estratégias de regulação prudencial adotadas ao longo do tempo, aliada aos desafios e limitações enfrentados pelos supervisores bancários no monitoramento do risco sistêmico, mostra que, conquanto esta seja uma importante ferramenta para seu controle e mitigação, a regulação prudencial está fadada a procurar novas formas para administrar o risco nas atividades financeiras, mas nunca controlá-lo por completo. Isto porque, independentemente de quão rigorosas e sofisticadas sejam as regras impostas pelos reguladores, no dia seguinte à sua promulgação, participantes do mercado já estarão empregando seus melhores recursos e mentes disponíveis para encontrar formas de se evadirem de sua aplicação. Não por acaso, a regulação prudencial está em constante transformação. Desde seus primórdios, com a criação de regras voltadas à segregação estrita de suas atividades e imposição de indicadores quantitativos de liquidez, migrando para o controle das operações ativas e o risco de crédito decorrente de tais operações em Basileia I, a promessa não cumprida da autorregulação e disciplina de mercado em Basileia II, e a atenção crescente ao chamado enfoque "macroprudencial" em Basileia III; realisticamente, é preciso reconhecer que a regulação prudencial procura conter o risco moral, mas nunca neutralizá-lo por completo. Outrossim, observou-se que a regulação prudencial ainda depende do produto de entes privados para conduzir seus trabalhos. Enquanto os conflitos de interesse inerentes a esses agentes auxiliares não forem resolvidos, a supervisão bancária também será afetada adversamente por tais vícios. Em suma, embora importante e necessária, a regulação prudencial enfrenta limitações e desafios, não podendo nem devendo ser considerada a "bala de prata" contra o risco moral, motivo pelo qual as virtudes aqui identificadas não devem desviar a atenção da autoridade bancária para a correção dos vícios presentes na estrutura atual de regulação sistêmica. 


\section{Capítulo 5 \\ REGULAÇÃO FINANCEIRA INTERNACIONAL}

\subsection{Risco sistêmico internacional}

Os avanços na tecnologia da informação nas últimas décadas contribuíram de forma determinante para a crescente internacionalização dos mercados financeiro e de capitais. Como resultado do aumento da velocidade e menor custo das telecomunicações, tornou-se possível oferecer maior gama de produtos e serviços, cobrindo área geográfica mais ampla. Além disso, os aprimoramentos tecnológicos têm permitido que instituições financeiras administrem maiores carteiras de clientes e expandam suas redes de agências bancárias, facilitando a comunicação entre elas. Nesse processo, não apenas barreiras geográficas foram gradualmente sendo erodidas, como também aumentaram o volume, a velocidade e a complexidade das transações internacionais. ${ }^{764}$

Esses avanços tecnológicos possibilitaram o surgimento de instituições financeiras integradas globalmente com estruturas corporativas complexas: os chamados conglomerados financeiros internacionais. Tomando como exemplo os casos do Citigroup e Deutsche Bank, em 2003, o primeiro operava com mais de um terço dos seus ativos fora dos Estados Unidos, e auferia cerca de $40 \%$ de seu lucro líquido no exterior, enquanto o segundo operava com dois terços de seus ativos fora da Alemanha, e também recebia cerca de $40 \%$ de seu lucro líquido no exterior. Em 2005, outros cinco bancos ingressaram no "clube" de instituições financeiras com mais de um trilhão de dólares em ativos distribuídos ao redor do mundo. ${ }^{765}$

Enquanto esses conglomerados apresentam benefícios na medida em que oferecem mais serviços em mais localidades aos seus clientes, é preciso reconhecer também os imensos desafios que esse quadro de internacionalização impõe à regulação e supervisão bancária. Os

\footnotetext{
764 GROUP OF THIRTY. Global institutions, national supervision and systemic risk: a study group report. Washington: Group of 30, 1997. p. 6.

765 BARTH, James R. et al. Rethinking bank regulation, p. 109-110.
} 
capítulos anteriores apresentaram dificuldades inerentes à fiscalização de conglomerados atuantes em diversos segmentos do sistema financeiro, bem como os perigos associados à sua quebra. $\mathrm{O}$ efeito imediato da internacionalização de instituições financeiras é a transposição dessas preocupações do plano doméstico para o plano internacional. Ou seja, as transformações ocorridas no sistema financeiro mundial fazem com que autoridades bancárias passem a se preocupar não apenas com o acompanhamento do nível de risco a que a instituição está exposta no mercado doméstico, como também em outros países. Outrossim, a interdependência crescente das instituições financeiras no plano internacional aumenta o risco de que o default de uma instituição ou liquidação de uma afiliada ou subsidiária em uma determinada jurisdição acabe causando consequências negativas em outros países.

Tais preocupações são exacerbadas pela constatação de que, a despeito de suas ambições globais e da presença internacional, a regulação e a supervisão dessas instituições financeiras continuam sendo conduzidas predominantemente por autoridades nacionais, limitadas pelo domínio de suas jurisdições. ${ }^{766}$ Logo, diferenças legais, culturais ou mesmo interpretações divergentes quanto à estratégia regulatória adequada acabam afetando a regulação e supervisão que lhes são dirigidas, podendo inclusive gerar estratégias de arbitragem regulatória em busca de países com regras mais lenientes. Em decorrência desse quadro, observa-se que autoridades bancárias domésticas passam a depender cada vez mais não apenas dos resultados dos seus esforços de supervisão, mas também dos atos praticados por autoridades de outros países em que as instituições financeiras atuem.

Esse quadro de interdependência crescente entre as ações de autoridades bancárias é particularmente preocupante no caso de decisões unilaterais referentes às atividades de instituições financeiras estrangeiras em sua jurisdição. O cancelamento das operações de uma instituição financeira estrangeira pode afetar adversamente as operações desta em seu país de origem. ${ }^{767} \mathrm{O}$ cenário inverso também é possível e talvez ainda mais grave, em que uma autoridade bancária decida fechar as operações de instituição financeira constituída no país, ou negar-se a resgatá-la caso esteja em dificuldades, afetando adversamente suas operações

\footnotetext{
766 LASTRA, Rosa Maria. Banco Central e regulamentação bancária, p. 130.

767 Exemplo disso é caso da sucursal do Federal Reserve em Nova Iorque, que possui autoridade para revogar a autorização de um banco estrangeiro para operar no Estado se julgar que a instituição esteja praticando atos em outras jurisdições que, na sua interpretação, sejam perigosos ou indesejáveis. Em tais casos, não há qualquer exigência para que este consulte a autoridade bancária do país em questão para avaliar as possíveis consequências desse ato. Ver: ALEXANDER, Kern et al. Global governance of financial systems: the international regulation of systemic risk. Oxford: University Press, 2006. p. 27.
} 
em outros países. A quebra do banco Lehman Brothers nos Estados Unidos em 2008 com suas significativas repercussões ao redor do mundo é emblemática nesse sentido.

A migração da interdependência entre instituições financeiras do plano nacional para o plano internacional, aliada à incapacidade de autoridades bancárias locais lidarem unilateralmente com os riscos decorrentes desse processo, demonstram que, na atualidade, a eficácia de políticas regulatórias sistêmicas e prudenciais requer a coordenação de esforços de regulação e supervisão entre autoridades bancárias de cada país. Em outras palavras, modernamente, a manutenção da estabilidade do sistema financeiro exige a aderência a padrões de regulação e supervisão comuns às jurisdições em que as instituições financeiras atuem. Cumpre examinar, portanto, o arcabouço internacional de regulação e supervisão financeira que se desenvolveu nas últimas décadas voltado a esse propósito.

\subsubsection{Internacionalização dos bancos atuantes no Sistema Financeiro Nacional}

Antes de proceder à análise pretendida, o estudo dos impactos da internacionalização de conglomerados financeiros na regulação sistêmica e prudencial envolve necessariamente o exame de como esse fenômeno se apresenta no Brasil. Nesse aspecto, já se observou no Capítulo 2 que o art. 52 do ADCT restringiu a entrada de capital estrangeiro no setor bancário pátrio, situação que só veio se alterar com a EM 311 do Ministério da Fazenda em 1995. Desde então, apesar do rápido aumento do capital estrangeiro no SFN no final da década de 1990, muitas dessas instituições estrangeiras acabaram gradualmente saindo do País. Segundo dados do Bacen, ao final de 2009, a participação estrangeira no patrimônio líquido do SFN somava $17,4 \% .^{768}$

De acordo com o art. 39 da Lei 4.595/1964, a atuação de bancos estrangeiros no País se sujeita, basicamente, às mesmas regras aplicáveis às instituições de capital nacional. As diferenças de tratamento, quando existem, geralmente se mostram mais rigorosas ao capital estrangeiro. É o caso, por exemplo, do antigo art. 1..$^{\circ}$ § $3 .^{\circ}$, do Anexo II à Resolução CMN 2.099/1994, que determinava acréscimo de $100 \%$ ao capital mínimo exigido para autorização de funcionamento de agências de instituições financeiras domiciliadas no exterior, ou de banco comercial (ou banco múltiplo com carteira comercial) sob controle estrangeiro direto

768 Dados disponíveis em: <www.bacen.gov.br/?REVSFN>. Acesso em: 20 dez. 2009. 
ou indireto. Essa diferença de tratamento, no entanto, foi posteriormente eliminada com a Resolução CMN 2.607/1999.

Além das instituições financeiras estrangeiras atuando no País, outra questão de relevo para a análise do risco sistêmico internacional é a presença de bancos brasileiros no exterior. A esse respeito, pode-se dizer que o processo de internacionalização dos bancos nacionais ainda é incipiente. Os participantes nacionais do setor bancário com maior presença no exterior são o Banco do Brasil, o Itaú-Unibanco e o Bradesco, com, respectivamente, 24, 9 e 4 agências em outros países ao final de 2009. No total, havia 24 países com agências de bancos brasileiros no mesmo período. ${ }^{769}$ Note-se o evidente contraste com bancos como o HSBC, que, sozinho, possui operações em mais de 80 países. ${ }^{770}$

Tabela 15: Bancos brasileiros com dependências no exterior em 31 dez. 2009 (*)

\begin{tabular}{|l|c|c|c|c|}
\hline \multicolumn{1}{|c|}{ Bancos } & Agências & Escritórios & Postos & Total \\
\hline ABC Brasil & 1 & & & 1 \\
\hline Banrisul & 2 & & & 2 \\
\hline Banco do Brasil & 24 & 11 & 2 & 37 \\
\hline BBM & 1 & & & 1 \\
\hline Boavista Interatlântico & & 3 & & 3 \\
\hline Bradesco & 4 & & & 4 \\
\hline Caixa Econômica Federal & 1 & 2 & & 2 \\
\hline Daycoval & 1 & & & 1 \\
\hline Fibra & 1 & & & 1 \\
\hline Industrial e Comercial & 1 & & & 1 \\
\hline Indusval & 9 & 5 & & 14 \\
\hline Itaú Unibanco (**) & 1 & & & 1 \\
\hline Mercantil do Brasil & $\mathbf{4 7}$ & & & 2 \\
\hline Votorantim & 1 & & & \\
\hline Total & & & & \\
\hline
\end{tabular}

(*) Não considera controle de bancos estrangeiros por bancos nacionais (**) Somando Itaú, Itaú BBA, Itaú Unibanco BM e Unibanco

Fonte: Banco Central. Dados disponíveis em: <www.bacen.gov.br/?REVSFN>. Acesso em: 20 dez. 2010.

\footnotetext{
769 Dados disponíveis em: <www.bacen.gov.br/?REVSFN>. Acesso em: 20 dez. 2009.

770 BARTH, James R. et al. Rethinking bank regulation, p. 110.
} 
Apesar dessa participação internacional relativamente inexpressiva, é preciso ressaltar que esse cenário vem se alterando com relativa rapidez nos últimos anos. Um dos maiores exemplos desse movimento é o caso do antigo Banco Itaú (hoje Itaú-Unibanco), que, visando a ampliação de sua presença na América do Sul, comprou em 1998 o Banco del Buen Ayre S.A., na Argentina, criando o Banco Itaú Buen Ayre S.A., e, nos anos de 2006 e 2007, adquiriu as operações do BankBoston no Brasil, Chile e Uruguai. ${ }^{771}$ Pode-se observar abaixo o expressivo crescimento da representatividade das receitas no exterior para o faturamento do banco nessa década:

Tabela 16: Receita do Banco Itaú S.A. no Brasil e exterior (milhões de R\$)

\begin{tabular}{|l|c|c|c|c|c|}
\cline { 2 - 6 } \multicolumn{1}{c|}{} & $\mathbf{2 0 0 0}$ & $\mathbf{2 0 0 2}$ & $\mathbf{2 0 0 4}$ & $\mathbf{2 0 0 6}$ & $\mathbf{2 0 0 8}($ *) \\
\hline Receita financeira no Brasil & $\mathrm{R} \$ 7,192$ & $\mathrm{R} \$ 13,684$ & $\mathrm{R} \$ 15,543$ & $\mathrm{R} \$ 17,762$ & $\mathrm{R} \$ 25,187$ \\
\hline Receita financeira no exterior & $\mathrm{R} \$ 490$ & $\mathrm{R} \$ 872$ & $\mathrm{R} \$ 716$ & $\mathrm{R} \$ 1,584$ & $\mathrm{R} \$ 6,139$ \\
\hline Receita de prestação de serviços no Brasil & $\mathrm{R} \$ 2,585$ & $\mathrm{R} \$ 3,621$ & $\mathrm{R} \$ 4,276$ & $\mathrm{R} \$ 6,632$ & $\mathrm{R} \$ 8,337$ \\
\hline Receita de prestação de serviços no exterior & $\mathrm{R} \$ 88$ & $\mathrm{R} \$ 54$ & $\mathrm{R} \$ 67$ & $\mathrm{R} \$ 156$ & $\mathrm{R} \$ 604$ \\
\hline
\end{tabular}

(*) As demonstrações contábeis consolidadas referentes aos exercícios findos em 31de dezembro de 2008 não apresentam os efeitos da associação com o Unibanco.

Fonte: Relatórios 20-F protocolados na SEC em 2002, 2005 e 2008. Disponíveis em: 〈www.sec.gov〉. Acesso em: 20 dez. 2010.

A recente fusão do banco Itaú com o Unibanco representou mais um importante passo na concretização dessa estratégia de internacionalização. À época do anúncio da operação, os presidentes dos bancos afirmaram que, entre outros objetivos, a sua união tinha como meta criar um player global no prazo de cinco anos, e que o primeiro passo para esse processo de internacionalização seria a América Latina, na qual, além de consolidar sua presença em países em que já atuavam, como Argentina e Chile, a nova instituição visava também entrar no mercado mexicano e colombiano. ${ }^{772}$

Na esteira dessa ampliação da atuação internacional do Itaú-Unibanco, observa-se também interesse crescente do Banco do Brasil em expandir suas operações fora do país. Nesse sentido, o banco anunciou em dezembro de 2009 a aquisição do controle do Banco Patagônia, a sexta maior

771 Relatório anual 20-F do banco Itaú referente ao ano de 2007 apresentado à SEC, p. 22. Disponível em: <www.sec.gov>. Acesso em: 29 dez. 2010.

772 FOLHA DE SÃO PAULO. Itaú e Unibanco planejam ser banco internacional em cinco anos, 3 nov. 2008; e, Idem. Internacionalização de Itaú e Unibanco não seria possível sem fusão, diz banqueiro, 4 nov. 2008. 
instituição financeira de capital nacional da Argentina. ${ }^{773}$ Além disso, em abril de 2010, o Federal Reserve conferiu ao Banco do Brasil o status de Financial Holding Company, permitindo que a instituição, quando de seu interesse, de forma direta ou por intermédio de suas subsidiárias, exerça atividades bancárias nos Estados Unidos nas mesmas condições aplicáveis aos bancos locais. ${ }^{774}$ Com efeito, o ex-Presidente da República, Luís Inácio Lula da Silva, defendeu abertamente em mais de uma ocasião a necessidade de internacionalização da maior instituição financeira do País para acompanhar o crescimento das empresas nacionais no exterior. ${ }^{775}$ Finalmente, vale mencionar também as iniciativas recentes do Bradesco nesse processo, como a aquisição em junho de 2010 do controle do IBI México, ${ }^{776}$ bem como o anúncio em agosto do mesmo ano da intenção de firmar parceria com o Banco do Brasil para coordenar futuros investimentos envolvendo a aquisição de participações em outros bancos ou estabelecimento de operações próprias, no continente africano. ${ }^{777}$

\subsection{Arcabouço internacional de regulação e supervisão financeira ${ }^{778}$}

\subsubsection{Comitê de Basileia de Supervisão Bancária}

O Comitê de Basileia de Supervisão Bancária (Comitê de Basileia) foi criado no final de 1974 com o objetivo de promover melhor entendimento e qualidade da supervisão bancária

773 Ver press release do Banco do Brasil de 21 de dezembro de 2009. Disponível em: <www.bb.com.br>. Acesso em: 20 dez. 2010.

774 Ver press release do Banco do Brasil de 13 de abril de 2010. Disponível em: <www.bb.com.br〉. Acesso em: 20 dez. 2010.

775 O GLOBO. Lula defende internacionalização do Banco do Brasil, 20 jul. 2009.

776 Ver press release do Bradesco, de 2 de junho de 2010. Disponível em: <www.bradescori.com.br〉. Acesso em: 20 dez. 2010.

777 Ver press release do Banco do Brasil, de 9 de agosto de 2010. Disponível em: <www.bb.com.br〉. Acesso em: 20 dez. 2010.

778 Há uma variedade de órgãos internacionais engajados na proposição de recomendações a instituições que atuam direta ou indiretamente no sistema financeiro. A esse respeito, podem-se mencionar os trabalhos da Fasb e Iasb no campo da contabilidade, da International Swaps and Derivatives Association (ISDA) no caso de instituições que atuam com instrumentos financeiros derivativos, da Financial Action Task Force (FATF) no campo de combate à lavagem de dinheiro e terrorismo, entre outros. Considerando a impossibilidade de se apresentar todos os órgãos cujas atividades relacionam-se a temas da regulação financeira, serão objeto de análise no presente trabalho apenas aqueles cuja atuação histórica tem sido marcada pela preocupação específica com a proposição de padrões mínimos de regulação e supervisão para a prevenção do risco sistêmico, seja no contexto do setor específico nos quais atuam, ou no caso de conglomerados financeiros. 
ao redor do mundo. ${ }^{779} \mathrm{O}$ Comitê de Basileia pode ser considerado o mais importante órgão internacional definidor de padrões de conduta no setor bancário, ${ }^{780}$ exercendo influência direta e indireta no desenvolvimento do arcabouço regulatório destinado ao regramento de atividades bancárias em diversos países. Nos seus 36 anos de atuação, o órgão conduziu inúmeros trabalhos em diversas áreas da regulação bancária, com destaque para suas recomendações no tocante à coordenação de supervisão de instituições financeiras com atuação internacional e controles de adequação de capital. Esta última área foi objeto dos acordos de Basileia, já tratados no capítulo anterior.

Até 2009 o comitê era composto pelos presidentes dos bancos centrais dos paísesmembros do G-10, acrescidos de Luxemburgo e Suíça, que se reuniam periodicamente em Basileia sob os auspícios do BIS para negociar e aprovar regras referentes ao setor bancário. Seu processo decisório é informal e baseado no consenso entre seus membros. Apesar de contar com representantes do G-10, o comitê mantém grupos de trabalho com reguladores de diversos outros países. Seus esforços para a preparação de Basileia II, por exemplo, envolveram a coordenação com mais de 100 países por meio de seminários e consultas. ${ }^{781}$

Vale ressaltar que as regras do Comitê de Basileia não têm exequibilidade efetiva, sendo vinculantes apenas na medida em que incorporadas à legislação de cada país. Não há previsão de penalidades específicas no caso de descumprimento de suas recomendações, até mesmo quando referentes aos acordos de Basileia. Não obstante, apesar de o comitê agir como fórum informal e suas decisões não terem caráter coercitivo, autores como Lastra consideram que ele se tornou, de fato, verdadeira autoridade regulatória internacional. Segundo a autora, o razoável grau de despolitização e considerável experiência técnica em assuntos bancários serviram bem ao desenho das regras internacionais bancárias dentro do comitê. A estrutura de aproximação informal que permeia as relações no órgão também facilita o contato, cooperação e coordenação entre supervisores e reguladores bancários. ${ }^{782}$ Nesse sentido, um grande número de países vem incorporando as recomendações do comitê aos seus ordenamentos jurídicos com o objetivo de fortalecer seu setor bancário e melhorar

\footnotetext{
779 TARULLO, Daniel K. Banking on Basel, p. 2.

780 ALEXANDER, Kern et al. Global governance of financial systems, p. 37.

781 Idem, ibidem, p. 37.

782 LASTRA, Rosa Maria. Banco Central e regulamentação bancária, p. 134-135.
} 
sua percepção de risco nos mercados internacionais, criando assim incentivos para que outros países e instituições financeiras adiram a essas recomendações se quiserem atuar nos principais centros financeiros mundiais. Em razão desses fatores, considera-se que os poderes e influência do comitê na atualidade são bem mais abrangentes do que no momento de sua fundação. $^{783}$

O Comitê de Basileia não monitora o grau de aderência dos países às suas recomendações. Isso é tradicionalmente feito de maneira descentralizada e informal, cabendo aos países-membros avaliarem o cumprimento ou não das recomendações por seus pares, ou então por meio dos relatórios de avaliação sobre o sistema financeiro de cada país preparados pelo FMI e Banco Mundial, que serão analisados mais adiante, e que acabam funcionando também como mecanismo indireto de pressão pela adoção das orientações do Comitê de Basileia. Mesmo nos casos em que países aderem às recomendações do comitê, isso não é feito necessariamente de modo uniforme. Cada país adota as diretrizes de acordo com os seus próprios cronogramas, e muitas vezes optam por modificar parte das regras propostas nesse processo. O Brasil, particularmente, é um exemplo disso, optando pelo estabelecimento de

783 Esse status diferenciado das recomendações do Comitê de Basileia, notadamente Basileia I, II e, mais recentemente, tratativas para Basileia III, fazem com que alguns autores as classifiquem em categoria normativa diferenciada intitulada soft law (GUZMAN, Andrew T.; MEYER, Timothy L. International soft law. Journal of Legal Analysis, 2(1), p. 3, 2010). O termo soft law refere-se a instrumentos que não possuem caráter vinculante, ou cujo efeito vinculante sobre seus destinatários é considerado "mais fraco" em contraste com a força coercitiva de leis tradicionais, muitas vezes referidas como hard law. Conforme ensinamento de Salem Hikmat Nasser, o uso desses instrumentos normativos mais "flexíveis" está relacionado às dificuldades para assumir compromissos mais constringentes, seja em razão de incertezas científicas ou problemas políticos. Além disso, os custos decorrentes da adoção de certas determinações podem tornar difícil a sustentação política da aceitação de obrigações muito rígidas (NASSER, Salem Hikmat. Desenvolvimento, costume internacional e soft law. In: AMARAL JR., Alberto (Org.). Direito internacional e desenvolvimento. São Paulo: Manole, 2005. p. 215-216). Nesse aspecto, instrumentos de soft law podem ser vistos como opção flexível na medida em que evitam o compromisso imediato decorrente de tratados, mas fornecem algum grau de previsão sobre as condutas dos atores sociais e até mesmo uma expectativa em relação a seus comportamentos. Dependendo da disseminação e grau de aderência dos países a tais determinações, a soft law pode ser uma rota potencialmente mais rápida para compromissos jurídicos definitivos, em contraposição à negociação tradicional de tratados internacionais. A regulação financeira internacional tem sido uma área particularmente frutífera para a soft law, em que não apenas as recomendações do Comitê de Basileia, mas também a de outros fóruns internacionais de discussão de padrões mínimos de regulação e supervisão do sistema financeiro que serão analisados a seguir, gozam de grande disseminação e amplo grau de aderência entre seus destinatários. Fugiria ao escopo do presente trabalho, no entanto, examinar de forma aprofundada esse movimento ou mesmo realizar juízo de valor sobre a suficiência dessas categorias normativas "quase legais" para abordar os riscos apresentados pela internacionalização de conglomerados financeiros. Para um panorama geral sobre o fenômeno, ver: GIOVANOLI, Mario. Reflections on international financial standards as "soft law". In: ANDENAS, Mads; NORTON Joseph J. International monetary and financial law upon entering the new millennium: a tribute to Sir Joseph and Ruth Gold. London: The British Institute of Comparative and International Law, 2003. p. 71-98. 
requisito mais rígido de adequação patrimonial do que o original e não autorizando a utilização de ratings externos para cálculos de capital regulatório.

O aumento de influência das recomendações do Comitê de Basileia no arcabouço regulatório internacional também gera críticas quanto à legitimidade de seu processo decisório, em razão de apenas um pequeno número de países ter participado das deliberações que resultaram nos acordos. ${ }^{784}$ Nesse sentido, os esforços mais recentes de implementação de Basileia II encontraram resistência por parte de países em desenvolvimento que não concordam em adotar padrões de regulação para os quais em pouco ou nada contribuíram na discussão. $^{785}$ Isso é exacerbado pelo fato de alguns dos países-membros do G-10 não aplicarem as determinações de Basileia, enquanto países em desenvolvimento que dependem da assistência financeira de organizações internacionais muitas vezes sofrem pressão pela adoção dos acordos. É o caso dos Estados Unidos, que ainda não adotaram Basileia II, bem como do Japão, que flexibilizou os requisitos de adequação de capital para seus bancos durante a década de 90 na tentativa de estimular sua economia. ${ }^{786}$

O Comitê de Basileia procurou responder parte dessas críticas mediante a criação em 2005 do Grupo de Coordenação de Princípios Fundamentais (Core Principles Liaison Group), que inclui representantes dos bancos centrais do Brasil, China, Índia e Rússia. Outrossim, mais recentemente o comitê procurou ampliar seu grau de representatividade ao incorporar sete novos membros, incluindo o Brasil. ${ }^{787}$

784 De acordo com a definição apresentada por Julia Black e David Rouch, "legitimidade, no contexto regulatório, é a aceitação de que uma pessoa ou organização tem o direito de governar, por aqueles que ela pretende governar, bem como aqueles por conta de quem ela pretende governar. Aqueles que produzem regras podem reivindicar legitimidade, e podem se engajar em estratégias variadas numa tentativa de conquistar legitimidade, mas o seu sucesso dependerá do grau de aceitação dessas medidas por outros". Segundo os autores, mesmo que as recomendações de órgãos como o Comitê de Basileia não sejam vinculantes, a discussão sobre sua legitimidade seria importante em razão da pressão crescente pela adoção dessas regras para atuar em determinados centros financeiros, como, por exemplo, a exigência de adoção das recomendações da Iasb na União Europeia. Nesses casos os autores afirmam que a soft law passaria por um processo de "endurecimento", tornando-se hard law. Ver: BLACK, Julia; ROUCH David. The development of the global markets as rule-makers: engagement and legitimacy. Law and Financial Markets Review, 2(3), p. 225 e ss., maio 2008. Tradução livre.

785 ALEXANDER, Kern et al. Global governance of financial systems, p. 44-47.

786 Idem, ibidem, p. 44.

787 Os outros países são a Austrália, China, Índia, Rússia, Coreia e México. O aumento do número de paísesmembros no órgão é uma das formas de aumentar o grau de legitimidade de suas recomendações. Conforme 


\subsubsection{Organização Internacional de Comissões de Valores Mobiliários}

A Organização Internacional de Comissões de Valores Mobiliários (International Organization of Securities Comissions - Iosco) foi criada em 1983 com o objetivo de estabelecer um fórum em que autoridades nacionais pudessem se reunir e discutir sobre políticas e melhores práticas para a regulação dos mercados de capitais ao redor do mundo. Os membros do órgão se dividem em três categorias: (i) membros ordinários; (ii) associados; e (iii) afiliados. Os membros ordinários são geralmente representantes de autoridades nacionais e exercitam um voto cada nas reuniões e comitês nos quais servem. Os associados não têm direito a voto e não podem participar dos comitês. Os afiliados são em sua maioria bolsas de valores e entidades de autorregulação, tampouco podendo votar ou participar dos comitês. Aqui vale ressaltar que, assim como no caso do Comitê de Basileia, as recomendações da Iosco não possuem efeito vinculante sobre seus membros.

Os objetivos fundamentais da Iosco para a regulação dos mercados de capitais podem ser assim sumarizados: (i) proteger os investidores; (ii) assegurar ambientes de negociação justos, eficientes e transparentes; e (iii) reduzir o risco sistêmico. ${ }^{788}$ Para atingir tais propósitos, a Iosco conta atualmente com um Comitê Técnico (Technical Committee) e um Comitê para Mercados Emergentes (Emerging Markets Committee). O Comitê Técnico foi estabelecido em 1987 e consiste em 15 representantes de agências reguladoras com jurisdição sobre os mercados de capitais mais desenvolvidos. O Comitê de Mercados Emergentes trata basicamente das mesmas questões que o Comitê Técnico, com um enfoque maior nos mercados de economias emergentes. Os comitês da Iosco conduzem seus trabalhos em áreas diversas, algumas delas diretamente relacionadas aos interesses dos supervisores bancários, como a necessidade de uma estrutura comum relativa a exigências de capital, princípios para a supervisão de conglomerados financeiros e diretrizes sobre a administração de riscos de derivativos, entre outros. ${ }^{789}$ Nesse aspecto, vale mencionar a revisão recente dos

apontamento de Julia Black e David Rouch, no entanto, isso deve ser sopesado com a perda em termos de eficiência no processo decisório, que pode acabar ficando engessado com a presença de inúmeros países com interesses nem sempre convergentes. Para uma análise detalhada de como ampliar a legitimidade desses órgãos e os desafios à sua frente, ver: BLACK, Julia; ROUCH David. The development of the global markets as rule-makers: engagement and legitimacy.

ALEXANDER, Kern et al. Global governance of financial systems, p. 57.

789 A título exemplificativo, podem-se mencionar os seguintes trabalhos do órgão: IOSCO. Capital adequacy for securities firms, Relatório do Comitê Técnico, Madrid, 1989; Idem. Principles for the supervision of 
Princípios e Objetivos para Reguladores de Valores Mobiliários (Objectives and Principles of Securities Regulation) efetuada pelo órgão, que, seguindo em linha com as preocupações levantadas nos capítulos anteriores, afirma expressamente a responsabilidade conjunta do regulador e supervisor de valores mobiliários pelo monitoramento e prevenção do risco sistêmico. $^{790}$

A estrutura pouco formalizada da Iosco e a centralização do processo decisório nas mãos de um reduzido número de países também geram críticas quanto à legitimidade da entidade em sua atuação. ${ }^{791}$ As reuniões dos comitês não são abertas a observadores externos, ou mesmo a membros da Iosco que não sejam membros daquele comitê específico. Isso é particularmente relevante no contexto do Comitê Técnico, que acaba sendo o responsável pela maioria das recomendações. ${ }^{792}$

A CVM assinou um Memorando Multilateral de Entendimento com a Iosco em 4 de fevereiro de 2010 para regular a assistência e cooperação entre os órgãos, com previsão de intercâmbio de informações relativas a investigações e processos. Isso permite que a autarquia possa compartilhar de maneira mais ágil e segura, com um número maior de autoridades, informações sobre beneficiários finais e registros de negociação, inclusive aquelas referentes a instituições e intermediários financeiros, tendo, portanto, alcance sobre participantes de mercado com atuação global.

\subsubsection{Associação Internacional de Supervisores de Seguros}

A Associação Internacional de Supervisores de Seguros (International Association of Insurance Supervisors - Iais) foi criada em 1994 como uma organização privada sem fins lucrativos com o objetivo de promover o debate sobre melhores práticas regulatórias para o setor de seguros. Embora seu mandato original não previsse o estabelecimento de padrões

financial conglomerates, Relatório do Comitê Técnico, Madrid, 1992; e IOSCO. Coordination between cash and derivative markets - Contract design of derivative products on stock indices and measures to minimize market disruption, Relatório do Comitê Técnico, Madrid, 1992.

790 Idem. Objectives and principles of securities regulation, Madrid, jun. 2010.

791 ALEXANDER, Kern et al. Global governance of financial systems, p. 59-60.

792 Idem, ibidem, p. 59-60. 
mínimos de regulação, a Iais acabou gradativamente assumindo esse papel. O órgão conta atualmente com representantes de cerca de 160 países responsáveis pelo setor de seguros em suas respectivas jurisdições e, como nos outros órgãos, as suas disposições não possuem efeito vinculante sobre seus membros ou países que representam.

O órgão decisório máximo da Iais é sua Assembleia Geral, que acontece uma vez por ano. A Assembleia Geral é responsável pela aprovação de todos os princípios e padrões propostos. Todos os membros da Iais têm o direito de participar da Assembleia Geral e votar em todas as deliberações tomadas, inclusive recomendações sobre melhores práticas regulatórias. O Comitê Executivo da Iais é responsável pela organização interna dos grupos de trabalho estabelecidos, sendo composto por representantes de 15 países ao redor do mundo, que servem mandatos de dois anos e são eleitos na Assembleia Geral.

Um fator que diferencia a Iais de seus pares para outras atividades financeiras é o fato de ela aceitar observadores do setor privado para acompanhar ou mesmo participar das discussões sobre os temas que são levados à Assembleia Geral. O órgão conta atualmente com mais de 70 observadores, incluindo grandes companhias de seguro, escritórios de advocacia e agências governamentais com interesse em atividades de seguros, ainda que não sejam responsáveis diretamente pela sua regulação. Essas características, aliadas ao grande número de países e agências que participam da Iais, fazem com que ela seja considerada um modelo de representatividade. ${ }^{793}$

A Iais já realizou trabalhos sobre inúmeras áreas do setor de seguros e, mais recentemente, tem focado sua atuação em questões de risco sistêmico e estabilidade financeira, com a publicação de relatórios de melhores práticas em termos de administração de risco, solvência e resseguro. ${ }^{794}$ Seu primeiro relatório de princípios mínimos de regulação e supervisão no setor de seguros foi publicado em $1997,{ }^{795}$ posteriormente revisto em 2000 ,

\footnotetext{
793 ALEXANDER, Kern et al. Global governance of financial systems, p. 63.

794 A título exemplificativo, podem-se mencionar: IAIS. Principles on capital adequacy and insolvency, Basileia, jan. 2002; Idem. Principles on minimum requirements for supervision of reinsurers, Basileia, out. 2002; e Idem. Principles on group-wide supervision, Basileia, out. 2008. Estes e os demais relatórios da Iais mencionados neste trabalho podem ser encontrados em: <www.iaisweb.org/index.cfm?pageID=37>. Acesso em: 23 dez. 2010.

795 Idem. Guidance on insurance regulation and supervision for emerging market economies, Basileia, 1997.
} 
resultando nos Princípios Fundamentais de Seguros (Insurance Core Principles - ICP), que foram imediatamente adotados pelo FMI e Banco Mundial como referência para regulação das atividades de seguro. ${ }^{796}$ Mais recentemente, os ICP receberam emendas, aumentando para 28 princípios aplicáveis à supervisão de seguros. ${ }^{797}$

\subsubsection{Organizações internacionais e a regulação financeira}

Os órgãos analisados até o momento não possuem status legal de organizações internacionais, representando basicamente fóruns em que autoridades e participantes do sistema financeiro de diversos países se reúnem voluntariamente para discutir princípios mínimos de regulação e supervisão não vinculantes. Ao lado dessas entidades, encontramos verdadeiras organizações internacionais, cuja esfera de atuação é consideravelmente mais abrangente e com poder decisório mais vinculante. Embora tais organizações internacionais não se ocupem primariamente com a regulação sistêmica e prudencial, suas atividades relacionam-se em diversos aspectos com tais campos da regulação financeira. Aliás, em virtude de sua posição de destaque no sistema financeiro mundial, algumas dessas organizações internacionais são inclusive consideradas peças-chave em propostas de reforma do arcabouço internacional de regulação e supervisão financeira sob debate e que serão tratadas mais adiante, motivo pelo qual se torna necessário realizar breve apresentação a seu respeito.

\subsubsection{Fundo Monetário Internacional}

O FMI foi criado em 1945 com o objetivo básico de zelar pela estabilidade do sistema monetário internacional, notadamente por meio da promoção da cooperação e

\footnotetext{
796 ALEXANDER, Kern et al. Global governance of financial systems, p. 63-64.

797 IAIS. Insurance core principles, Basileia, out. 2003 (modificado em mar. 2007).
} 
consulta em assuntos monetários entre seus membros. Inicialmente, o FMI contava apenas com 44 países-membros e atualmente possui $187 .{ }^{798}$

A autoridade decisória máxima do FMI é sua Assembleia de Governadores, formada por um representante titular de cada país (geralmente ministros da Fazenda ou presidentes dos bancos centrais). A diretoria executiva, composta por 24 membros eleitos ou indicados pelos países ou grupos de países-membros, é responsável pelas atividades operacionais do fundo, devendo reportar-se anualmente à Assembleia de Governadores. Aspecto curioso sobre a diretoria executiva é que o cargo de diretor geral é tradicionalmente ocupado por um europeu. Desde a criação do FMI, todos os diretores gerais vieram de apenas de seis países, todos pertencentes à Europa Ocidental.

Cada país-membro detém no FMI um número de quotas determinado com base em seus indicadores econômicos e sua contribuição ao fundo. Atualmente os Estados Unidos são o país com maior poder decisório, com $16,7 \%$ dos votos na organização. ${ }^{799}$ As decisões mais importantes, como as relativas a direitos especiais de saque no fundo, valor pago para subscrição de quotas, alocação de poder de voto ou programas substanciais de assistência financeira, devem ser aprovadas por uma "supermaioria" de $85 \%$, permitindo, na prática, que os Estados Unidos possam vetar tais decisões. Embora haja uma revisão geral das quotas a cada cinco anos, esta também necessita de aprovação por $85 \%$ dos votos para ser realizada. ${ }^{800}$ Essa estrutura de votos, aliada ao critério para eleição do diretor geral, geram fortes críticas quanto à legitimidade das decisões tomadas pelo órgão. ${ }^{801}$

\footnotetext{
798 Informação disponível: 〈www.imf.org/external/np/sec/memdir/memdate.htm〉. Acesso em: 20 dez. 2010.

799 Dados disponíveis em: <www.imf.org/external/np/sec/memdir/members.htm〉. Acesso em: 20 dez. 2010.

800 A esse respeito, vale mencionar reformulação recente na distribuição do poder de voto dos países-membros da organização internacional. Em 23 de outubro de 2010, os países-membros do G-20, reunidos na Coreia do Sul, chegaram a um acordo para aumentar o poder de voto dos países emergentes, principalmente os integrantes do chamado "BRIC" (acrônimo para fazer referência ao Brasil, Rússia, Índia e China). Com as mudanças, o direito de voto do Brasil passará a $2,32 \%$, quase duplicando sua influência na organização desde o começo da crise financeira recente. Apesar disso, o poder de voto das nações em desenvolvimento como grupo aumentou pouco, de $42,1 \%$ para $44,7 \%$. Os Estados Unidos também continuam mantendo poder de veto sobre as decisões mais importantes do FMI. Ver: VALOR ECONÔMICO. Brasil é o segundo país que mais ganha com mudanças no FMI, 25 out. 2010, p. A11.
}

801 WOLF, Martin. Fixing global finance. Baltimore: The Johns Hopkins University Press, 2008. p. 187. 
A função primária do FMI conforme o seu acordo constitutivo de 1947 é a promoção da estabilidade monetária de modo a fomentar o comércio internacional e promover a reconstrução de países arrasados pela guerra. Apesar disso, nas últimas décadas, o fundo vem ampliando seu mandato original para incluir a criação de programas de assistência a economias em transição, como os países do leste europeu, incluindo o aconselhamento na estruturação de seus sistemas financeiros e boas práticas internacionais regulatórias (muitas vezes formuladas com base nos trabalhos do Comitê de Basileia, Iosco e Iais). ${ }^{802}$

O FMI também executa funções de supervisão financeira de seus membros a fim de identificar possíveis focos de distúrbios sistêmicos e avaliar se as condições assumidas para prestação de auxílio financeiro estão sendo cumpridas. Essa supervisão é tradicionalmente efetuada por meio dos Programas de Avaliação do Setor Financeiro (Financial Sector Assessment Programs - FSAPs), que são uma iniciativa conjunta do FMI e Banco Mundial com o objetivo de aumentar a higidez do sistema financeiro dos países-membros. Esses relatórios foram criados após a crise asiática na década de 1990 e visam identificar vulnerabilidades do sistema financeiro de um país, analisar como as principais fontes de risco são administradas, determinar as necessidades técnicas do setor e formular respostas em termos de política regulatória. Em setembro de 2010 o FMI anunciou que tornaria o FSAP obrigatório para 25 países, incluindo o Brasil. Segundo o comunicado da organização, esses países foram escolhidos com base no tamanho e conexões com outros países de seus sistemas financeiros. $^{803}$

O resultado das análises empreendidas no bojo dos FSAPs é utilizado na criação dos Relatórios sobre Observância de Padrões e Códigos (Reports on Observance of Standards and Codes - ROSCs), documentos que basicamente sumarizam o grau de aderência dos paísesmembros a padrões e códigos internacionalmente reconhecidos. Os FSAPs também formam a base dos relatórios de Avaliação da Estabilidade do Sistema Financeiro (Financial System Stability Assessments - FSSAs), utilizados pelo FMI para decidir quais são os riscos à

\footnotetext{
802 ALEXANDER, Kern et al. Global governance of financial systems, p. 84-97.

803 IMF. IMF expanding surveillance to require mandatory financial stability assessments of countries with systemically important financial sectors, Press Release n. 10/357, 27 set. 2010. Disponível em: <www.imf.org/external/np/sec/pr/2010/pr10357.htm>. Acesso em: 29 dez. 2010.
} 
estabilidade macroeconômica derivados do sistema financeiro, os pontos críticos de supervisão contínua, e a capacidade dos países de absorver choques macroeconômicos.

O fundo tem meios diretos e indiretos de aplicar direitos e obrigações decorrentes dos acordos assumidos com os países-membros. Em primeiro lugar, o art. XXVI(2)(a) do seu Acordo Constitutivo dá autoridade ao FMI para declarar que um membro não cumpriu com determinações do órgão, tornando-se inelegível para uso de seus recursos. Caso o descumprimento persista, o FMI pode, com uma maioria de 70\%, suspender os direitos de voto e até mesmo excluir o país do fundo (art. XXVI(2)(b)-(d)). Uma forma indireta de fazer com que países-membros cumpram com suas "recomendações" é mediante os chamados Programas de Ajustamento Estrutural (Structural Adjustment Programs - SAPs), que condicionam a utilização de recursos do fundo à adoção de reformas regulatórias. Isso ocorre geralmente no contexto de países pobres e emergentes que necessitam dos recursos do fundo, não raro sujeitando a organização a críticas de ingerência excessiva na soberania dos países. $^{804}$

\subsubsection{Banco Mundial}

O Banco Mundial foi criado em 1944 com a missão inicial de financiar a reconstrução dos países devastados durante a 2. ${ }^{a}$ Guerra Mundial, sendo composto pelo Banco Internacional para a Reconstrução e Desenvolvimento (International Bank for Reconstruction and Development - IBRD) e pela Associação Internacional para o Desenvolvimento (International Development Association - IDA). O banco pertence ao Grupo Banco Mundial que, além dos dois órgãos mencionados, inclui também a Corporação Financeira Internacional (International Finance Corporation - IFC), Agência Multilateral de Garantia de Investimentos (Multilateral Investment Guarantee Agency - Miga) e Centro Internacional de Arbitragem para Disputas sobre Investimentos (International Centre for the Settlement of Investment Disputes - ICSID). As cinco instituições estão estreitamente relacionadas e funcionam sob uma única presidência. Em contraste com o FMI, todos os presidentes do Banco Mundial até hoje tiveram origem norte-americana.

804 WOLF, Martin. Fixing global finance, p. 187. 
O Banco Mundial tem como objetivos auxiliar na reconstrução econômica, expandir o comércio internacional e promover o crescimento econômico e melhora do padrão de vida dos países que a ele recorrem. Ao contrário dos recursos do FMI, que muitas vezes têm foco no curto prazo, como sanar desequilíbrios da balança de pagamentos, os fundos do Banco Mundial são utilizados principalmente em projetos de longo prazo, tomando suas decisões com base em considerações de eficiência econômica e viabilidade dos pedidos realizados. ${ }^{805}$

A influência do Banco Mundial na regulação financeira internacional é similar à do FMI. Além de ser responsável pela elaboração dos já mencionados FASPs e ROSCs em conjunto com o fundo, o Banco Mundial também pode vincular o financiamento de projetos à adoção de pacotes de reforma regulatória.

\subsection{Coordenação internacional para regulação e supervisão financeira}

O Comitê de Basileia atraiu pouca atenção no cenário internacional até 1975, quando publicou um relatório que ficou conhecido como "Concordata de Basileia". ${ }^{806} \mathrm{O}$ documento foi elaborado em resposta às crises bancárias desencadeadas pela quebra do British-Israel Bank of London, Franklin National Bank, bem como o já mencionado caso do banco alemão Herstatt, assumindo a forma de um guia com recomendações de boas práticas para regulação e supervisão bancária de instituições financeiras operando internacionalmente por meio de agências, subsidiárias e joint ventures.

O objetivo principal do documento era impedir que bancos de atuação global escapassem a uma fiscalização adequada. Nesse sentido, o documento elencou alguns dos principais pontos a serem considerados na formulação do arcabouço regulatório destinado a tais instituições, como: (i) bancos operando em outros países deveriam ser supervisionados pelas autoridades bancárias do país da sede do banco e do seu local de atuação; (ii) as agências bancárias localizadas no exterior deveriam ser supervisionadas pela autoridade

805 ALEXANDER, Kern et al. Global governance of financial systems, p. 97-100.

806 COMITE DE BASILEIA. Report to the governors on the supervision of bank's foreign establishments, Basileia, set. 1975. 
bancária do país da sede do banco, enquanto as subsidiárias e joint ventures seriam responsabilidade da autoridade bancária do seu local de atuação; e (iii) as autoridades dos dois países deveriam cooperar para remover as restrições legais à troca de informações confidenciais sobre as operações bancárias, caso tais informações fossem reputadas necessárias para uma supervisão efetiva.

O enfoque adotado no documento de 1975 foi objeto de críticas em razão do seu caráter doméstico, uma vez que apenas estabeleceu divisões de trabalho na fiscalização dos bancos internacionais entre autoridades nacionais separadas, sem cuidar do desenho de uma estrutura superior comum a ser aplicada entre jurisdições diversas. ${ }^{807} \mathrm{O}$ comitê, em suma, apenas dava orientações relativas à delegação de responsabilidades entre autoridades com respeito a agências, subsidiárias e joint ventures.

Em 1983, reagindo ao escândalo financeiro envolvendo o Banco Ambrosiano, ${ }^{808}$ os membros do Comitê procuraram aprimorar as diretrizes do documento de $1975 .{ }^{809}$ O novo relatório apresentou avanços em relação ao anterior, na medida em que reconheceu que a adequada supervisão dos estabelecimentos estrangeiros de bancos demandava não apenas a distribuição apropriada de responsabilidades entre as autoridades da sede e local de atuação da instituição financeira, mas também o contato e cooperação entre elas. Nesse sentido, o acordo revisado enfatizou dois princípios regulatórios:

1. Supervisão dual (dual key supervision): O Comitê de Basileia enfatizou a necessidade de supervisão dual, em que as autoridades do país da sede e local de atuação examinassem de forma concorrente a qualidade de sua fiscalização, bem como a habilidade de a autoridade bancária do outro país levar a cabo suas respectivas

807 LASTRA, Rosa Maria. Banco Central e regulamentação bancária, p. 139.

808 O banco italiano Ambrosiano quebrou em 1982 em meio a acusações de um rombo de US\$1,4 bilhão em suas contas. O caso teve grande repercussão em virtude da posição do Banco do Vaticano como principal acionista do Ambrosiano, bem como pelo fato de o presidente, Roberto Calvi, chamado de "banqueiro de Deus", ter sido encontrado morto debaixo de uma ponte em Londres pouco tempo depois da intervenção no banco. Ver: BBC. God's banker found hanged, 19 jun. 1982.

809 COMITE DE BASILEIA. Principles for the supervision of bank's foreign establishments, Basileia, maio 1983. 
responsabilidades. Quando a autoridade responsável pelo banco estrangeiro determinasse que supervisão exercida pela autoridade do país da sede não era adequada, o Comitê de Basileia propunha duas opções: (i) a autoridade bancária do país em que o banco estrangeiro quisesse atuar poderia negar a sua entrada; ou (ii) poderia sujeitar a entrada do banco estrangeiro a condições específicas e diferenciadas para atuação em sua jurisdição. Caso a autoridade do país da sede considerasse que a supervisão no local de atuação não era adequada, o Comitê de Basileia sugeria que esta “desencorajasse” a expansão das atividades bancárias naquele país. O propósito aqui era evitar que países deliberadamente diminuíssem suas exigências regulatórias e arrefecessem sua supervisão de modo a estimular a entrada de bancos estrangeiros; e

2. Supervisão consolidada: A supervisão consolidada procurava assegurar que as autoridades do país da sede monitorassem o risco das instituições financeiras considerando a totalidade dos negócios conduzidos, mesmo que fora de sua jurisdição.

Além desses princípios regulatórios, o documento de 1983 indicou de modo mais preciso quais riscos na operação de estabelecimentos bancários estrangeiros (agências, subsidiárias e joint ventures) cada autoridade deveria monitorar. Assim, no tocante à adequação de capital de agências bancárias no exterior, o comitê reiterou que, apesar de esta ser uma responsabilidade da autoridade bancária da sede, a autoridade do local de atuação também poderia exigir o reforço de capital quando julgasse necessário. Já a adequação de capital de subsidiárias estrangeiras seria uma responsabilidade conjunta das autoridades do país da sede e do local de atuação. ${ }^{810}$

Apesar dos progressos no tocante à dinâmica do relacionamento entre autoridades bancárias nacionais, significativos vácuos regulatórios continuaram a existir. Isso ficou evidenciado na quebra do Bank of Credit and Commerce International (BCCI) em julho de

810 LASTRA, Rosa Maria. Banco Central e regulamentação bancária, p. 140. 
1991, que se deveu, em parte, à capacidade de a instituição se evadir da supervisão de autoridades bancárias do país da sede e do local de atuação. ${ }^{811}$ Embora o enfoque da supervisão dual procurasse reverter a tendência de os bancos gravitarem rumo à jurisdição menos regulada, o caso do BCCI demonstrou a importância da fixação de regras comuns entre jurisdições, principalmente para a determinação do que constitui uma instituição financeira ou não. Conforme apontamento de Lastra: ${ }^{812}$

O BCCI [...] não estava sujeito a uma fiscalização consolidada pelas autoridades da sede, pois sua matriz controladora - BCCI Holdings, uma empresa holding de Luxemburgo - livrava-se da regulação sob as leis de Luxemburgo por não ser classificada como banco. As duas principais subsidiárias do BCCI foram criadas em Luxemburgo e nas Ilhas Cayman, onde a fiscalização é fraca e o sigilo bancário forte; os principais acionistas estavam em Abu Dhabi, enquanto o quartel general de operações estava em Londres. As autoridades locais de onde o BCCI conduzia suas operações, como as do Reino Unido, eram freadas em seus esforços de fiscalização devido à fragmentação das responsabilidades reguladoras. A forma de concepção do BCCI claramente visava evitar a fiscalização efetiva [...] A falência do BCCI ilustrou claramente que o princípio da supervisão consolidada não deveria permitir exceções.

O escândalo financeiro provocou a preparação pelo Comitê de Basileia de novo documento com padrões mínimos de supervisão de grupos bancários internacionais e seus estabelecimentos estrangeiros, em julho de $1992 .{ }^{813}$ Os requisitos mínimos continuaram a se apoiar nas estratégias de supervisão consolidada e dual, bem como na comunicação entre autoridades bancárias, mas o documento procurou dar melhor detalhamento sobre as diretrizes para a implementação desses princípios. Os pontos principais do documento podem ser assim sumarizados: ${ }^{814}$

1. Todas as instituições financeiras ou grupos bancários com atuação em mais de uma jurisdição deveriam ser supervisionadas pela autoridade bancária de seu país de origem com base na supervisão consolidada. A ideia de um só órgão supervisor responsável pelas atividades do conglomerado foi concebida para assegurar que

811 TRUELL, Peter; GURWIN Larry. False Profits: the inside story of BCCI. The world's most corrupt financial empire. New York: Houghton Mifflin, 1992. p. 67 e ss.

812 LASTRA, Rosa Maria. Banco Central e regulamentação bancária, p. 142.

813 COMITÊ DE BASILEIA. Minimum standards for the supervision of international banking groups and their cross-border establishments, Basileia, jul. 1992.

814 LASTRA, Rosa Maria. Banco Central e regulamentação bancária, p. 143-144. 
bancos não separassem deliberadamente as funções de administração entre vários centros visando dificultar a sua fiscalização;

2. A atuação internacional de instituições financeiras ou grupos bancários deveria sujeitar-se à aprovação para entrada tanto da autoridade bancária do país em que pretendesse ingressar, como do seu país de origem. Antes de consentirem, as autoridades deveriam revisar a suficiência de capital do banco e seus procedimentos de administração de riscos. Se a autoridade local ou de origem concluísse que o deslocamento das atividades de supervisão sugerida pelo acordo não era apropriado, ou se houvesse mudança significativa nas atividades ou estrutura do grupo bancário, então tal autoridade deveria iniciar consultas com a outra para conseguir um entendimento explícito sobre qual delas estaria em melhor posição para assumir a responsabilidade principal, fosse no tocante a atividades gerais ou específicas de supervisão;

3. A autoridade bancária do país de origem deveria ter o direito de coletar informações sobre operações transfronteiriças de instituições financeiras sob sua responsabilidade; e

4. Se a autoridade bancária do local no qual a instituição pretendesse ingressar determinasse que padrões mínimos de supervisão não haviam sido atendidos de forma satisfatória, esta poderia impor medidas restritivas para satisfazer suas preocupações, incluindo a proibição para a entrada do banco estrangeiro. A autoridade local deveria considerar na sua decisão: (i) se o banco ou conglomerado bancário era autorizado a atuar em uma jurisdição da qual podia obter informação; (ii) se a autorização para a expansão internacional do banco havia sido outorgada pela autoridade competente do país de origem; e (iii) se a autoridade do país de 
origem possuía capacidade de realizar a supervisão consolidada do banco ou conglomerado bancário.

No mesmo ano em que os princípios revisados de Basileia foram divulgados, observa-se também atenção maior no tocante à necessidade de coordenação entre autoridades para além do setor bancário, principalmente no caso de conglomerados atuantes em diversos segmentos do sistema financeiro. Considerando os efeitos da quebra do BCCI, reforçou-se a preocupação de que problemas surgidos em um dos segmentos do conglomerado contagiassem outras atividades do grupo. Nesse sentido, em outubro de 1992, a Iosco divulgou seus Princípios para a Supervisão de Conglomerados Financeiros (Principles for the Supervision of Financial Conglomerates),${ }^{815}$ incluindo as seguintes recomendações: ${ }^{816}$

1. A supervisão isolada de uma entidade ou atividade regulada deveria ser complementada pela supervisão baseada no conglomerado se tal entidade ou atividade fosse vulnerável a riscos de contágio por outras áreas do conglomerado;

2. A estrutura societária de um conglomerado deveria ser entendida pelo regulador; caso contrário, os reguladores deveriam considerar se era viável e prático desmembrar estruturas que dificultassem a supervisão;

3. Nas situações em que mais de um regulador fosse responsável por uma entidade ou atividade de um conglomerado financeiro, seria desejável identificar um regulador líder com a responsabilidade principal de análise dos riscos do grupo. O principal papel do regulador líder seria garantir que as informações relevantes sobre o conglomerado fossem partilhadas rapidamente entre as autoridades envolvidas; e

\footnotetext{
${ }^{815}$ IOSCO. Principles for the supervision of financial conglomerates, Relatório do Comitê Técnico, Madrid, 1992.

816 LASTRA, Rosa Maria. Banco Central e regulamentação bancária, p. 162.
} 
4. Auditores externos deveriam ser encorajados a garantir que quaisquer preocupações graves concernentes à condição financeira e operacional do conglomerado financeiro ou de suas entidades ou atividades consideradas individualmente, fossem trazidas à atenção das autoridades responsáveis.

Outro importante passo em prol dessa cooperação entre autoridades foi dado com a divulgação conjunta pelo Comitê Técnico da Iosco e pelo Comitê de Basileia, em julho de 1994, de um guia de recomendações sobre a administração segura de riscos nas atividades de derivativos. ${ }^{817} \mathrm{O}$ documento enfatiza a importância que tanto supervisores bancários como de mercado de capitais devem dar à administração segura de riscos internos para a prudente operação de bancos e empresas no mercado de capitais e na promoção da estabilidade do sistema financeiro como um todo. Nesse sentido, os órgãos afirmam o compromisso de continuarem trabalhando conjuntamente no desenvolvimento de recomendações voltadas à regulação de derivativos e outros pontos de interesse comum.

Essa tendência de integração entre fóruns de discussão financeira foi corroborada em 1996, quando o Comitê de Basileia organizou um grupo de trabalho específico para discutir práticas de regulação e supervisão voltadas a conglomerados financeiros, contando pela primeira vez com a participação conjunta da Iosco e Iais em sua organização. O grupo tinha como objetivo propor padrões mínimos para a regulação de conglomerados financeiros que operassem em diferentes jurisdições e prestassem diferentes atividades financeiras, além de uma série de medidas almejando aprimorar a coordenação entre os reguladores dessas atividades. Em fevereiro de 1999, o grupo apresentou um relatório sumarizando os trabalhos realizados até então, que incluiu propostas para troca de informações entre autoridades e designação de um "regulador líder" para cada conglomerado, determinado com base em suas áreas predominantes de atuação (seja em termos de produtos ou área geográfica), bem como

817 COMITÊ DE BASILEIA. Risk management guidelines for derivatives, Basileia, jul. 1994; e IOSCO. Operational and financial risk management control mechanisms for over-the-counter derivatives activities of regulated securities firms, Madrid, jul. 1994. 
técnicas de mensuração e princípios para avaliação da adequação de capital no contexto de conglomerados financeiros. ${ }^{818}$

Mais recentemente, em resposta às dificuldades apresentadas na crise financeira originada nos Estados Unidos, o Comitê de Basileia apresentou relatório de recomendações às autoridades bancárias no tocante à liquidação de bancos operando internacionalmente. ${ }^{819} \mathrm{~A}$ lista de recomendações do comitê aborda o tema dos poderes das autoridades nacionais para lidar com todos os tipos de instituições financeiras em dificuldades, enfatizando a necessidade de dotá-las de poderes suficientes para atenuar o impacto sistêmico desses problemas ao mesmo tempo em que preservem a normalidade das funções do sistema financeiro. $O$ documento destaca, em particular, a necessidade de instrumentos que permitam a rápida transferência de operações, ativos, passivos e fundo de comércio da instituição em dificuldade para outros participantes do mercado. No Brasil, conforme visto, tais instrumentos já se encontram previstos na Lei 9.447/1997, tendo sido largamente utilizados nas operações do Proer. $^{820}$

Além dos poderes necessários para lidar com bancos em dificuldades, o relatório ressalta que as autoridades devem ter capacidade para estender suas ações a outras entidades pertencentes aos conglomerados. Entre os problemas encontrados para a liquidação de ativos e passivos de instituições em crise, o documento destaca os obstáculos legais para extensão dos regimes especiais a empresas não bancárias ligadas a tais instituições. Finalmente, o Comitê de Basileia reitera a necessidade de coordenação entre autoridades nacionais em casos de liquidação de bancos com operações internacionais e convergência das regras aplicáveis em tais situações.

\footnotetext{
818 COMITÊ DE BASILEIA. Joint forum on financial conglomerates: supervision of financial conglomerates, Basileia, fev. 1998.

819 Idem. Report and recommendations of the cross-border bank resolution group.

820 VALOR ECONÔMICO. Gustavo Loyola - O Brasil e as lições da crise, 5 abr. 2010, p. A13.
} 


\subsubsection{Fórum de Estabilidade Financeira}

$\mathrm{Na}$ esteira das iniciativas mencionadas no tópico anterior, e no contexto da derrubada das barreiras a atividades financeiras na maior economia do mundo por meio do GrammLeach-Bliley Act de 1999, no final da década de 1990 os países-membros do G-7 atribuíram ao presidente do banco central alemão à época, Hans Tietmeyer, a missão de consultar os órgãos apropriados e recomendar novas estruturas para melhorar a cooperação entre os vários órgãos nacionais e internacionais de regulação e supervisão financeira com intuito de promover a estabilidade do sistema financeiro global. O relatório final de Tietmeyer foi apresentado em fevereiro de 1999, com a recomendação para a criação do Fórum de Estabilidade Financeira (Financial Stability Forum - FSF). ${ }^{821}$

O FSF reuniu-se pela primeira vez em abril de 1999, apresentando três objetivos principais: (i) analisar vulnerabilidades regulatórias que afetem o sistema financeiro internacional; (ii) identificar e supervisionar ações para sanar essas vulnerabilidades; e (iii) aprimorar a coordenação e compartilhamento de informações entre as autoridades bancárias nacionais e órgãos internacionais que atuem na área de regulação e supervisão financeira. $\mathrm{O}$ fórum contava inicialmente com representantes do G-7, Austrália, Hong Kong, Holanda, Cingapura e Suíça, bem como representantes do BIS, FMI, Banco Mundial, OCDE, Comitê de Basileia, Iosco e Iais.

Desde a sua criação, o FSF publicou diversos relatórios contendo recomendações sobre melhores práticas de regulação e supervisão do sistema financeiro. Tais relatórios tratam de temas variados, como mecanismos de seguro de depósitos, administração de instituições em crise, incorporação de ratings no instrumental de supervisão bancária, controle de estruturas de remuneração, entre outros. ${ }^{822}$ Assim como no caso do Comitê de Basileia, Iosco e Iais, as suas recomendações não possuem força vinculante. Apesar disso, o FSF defende que o órgão adequado para supervisionar a aplicação dos princípios de sua recomendação seria o FMI, em razão de sua natureza de afiliação quase universal e métodos

821 BIS REVIEW. Report by the president of the Deutsche Bundesbank, 2 nov. 1999. Disponível em: <www.bis.org/review/r990225b.pdf?noframes=1>. Acesso em: 23 dez. 2010.

822 Os relatórios estão disponíveis em: <www.financialstabilityboard.org/list/fsb_publications/index.htm>. Acesso em: 20 dez. 2010. 
“indiretos" para pressionar a adoção dos princípios recomendados por países que recorrem ao fundo. ${ }^{823}$

Até 2009 a composição do FSF restringia-se ao G-7 e países e órgãos internacionais supracitados, o que acabava limitando a influência de suas recomendações. O problema foi parcialmente sanado no encontro do G-20 de 2 de abril de 2009, em que se decidiu reformular a estrutura do FSF para aumentar seu número de membros. Assim, os países pertencentes ao G-20, Espanha e a Comissão Europeia ingressaram no FSF que, a partir de então, passou a se chamar Financial Stability Board (FSB).

\subsection{Propostas de reforma e desafios}

Em outubro de 2007 o FSB (FSF naquele momento) criou um grupo de trabalho para analisar as causas da crise financeira cujos efeitos começavam a se manifestar. $\mathrm{O}$ resultado dos trabalhos foi reproduzido em relatório de abril de 2008, que estabelecia uma agenda para reforma regulatória voltada ao aprimoramento da regulação prudencial e fortalecimento da cooperação entre órgãos internacionais. ${ }^{824}$ Entre os pontos enfatizados no relatório, o FSB ressaltou a importância de haver maior complementação das atividades do órgão com o FMI. Como resultado, em abril de 2009, representantes das duas entidades publicaram carta conjunta em que esclarecem o papel de cada instituição na regulação e supervisão financeira. Os quatro pontos da carta são: $:^{825}$

1. A supervisão do sistema financeiro global é responsabilidade do FMI;

823 HALDANE, Andrew G. The Financial Stability Forum (FSF): just another acronym? In: FERRAN, Eilís; GOODHART, Charles. Regulating financial services and markets in the 21st century, p. 259.

824 FINANCIAL STABILITY FORUM. Report of the Financial Stability Forum on enhancing market and institutional resilience. Basileia, abr. 2008.

825 Ver press release do FSB de 2 abr. 2009. Disponível em: <www.financialstabilityboard.org/ press/pr_090402b.pdf>. Acesso em: 20 dez. 2010. 
2. A principal função do FSB é a coordenação com os fóruns de discussão existentes e preparação de padrões mínimos regulatórios para o sistema financeiro. O FMI participa desse trabalho e fornece inputs valiosos de informação como membro do FSB;

3. A implementação das políticas propostas pelo FSB é responsabilidade das autoridades nacionais em coordenação com os governos locais. O FMI irá avaliar a adoção das políticas propostas por meio dos FSAPs e ROSCs; e

4. O FMI e o FSB irão cooperar na condução de exercícios de aviso antecipado (early warning) de crises sistêmicas. O FMI avaliará riscos macroeconômicos e vulnerabilidades sistêmicas, enquanto o FSB avaliará as vulnerabilidades de sistemas financeiros em particular, partindo da análise de seus membros. Quando apropriado, o FMI e o FSB prepararão análises conjuntas de risco e relatórios com ações a serem tomadas para mitigar tal risco.

Segundo o modelo proposto, o FSB definiria quais são as práticas aceitáveis no âmbito da regulação e supervisão, e o FMI analisaria se os países estão cumprindo com tais determinações. Depreende-se do documento também a intenção de as partes se apoiarem no poder e abrangência do FMI no cenário financeiro internacional para promover uma ampla adesão aos princípios recomendados.

Naturalmente, a estratégia regulatória proposta levanta questionamentos quanto à possibilidade de o FSB levar a cabo a função descrita. Apesar da recente expansão para acomodar os países do G-20, o fórum continua representando pouco mais de $10 \%$ dos membros do FMI. Além disso, constam entre seus membros outros órgãos que são alvos de críticas quanto à sua representatividade, como o Comitê de Basileia e Iosco. Enquanto tais críticas persistirem, é difícil imaginar uma ampla aderência às suas recomendações.

Outra questão relevante refere-se à própria posição do FMI na estratégia proposta. Já se observou que o órgão é criticado quanto à legitimidade do seu processo decisório, que 
permite a um só país vetar suas principais decisões, bem como os critérios para eleição do seu diretor geral. No tocante à capacidade de o fundo promover a adesão de seus países-membros às recomendações do FSB, vale lembrar que tanto o FMI como o Banco Mundial sofreram pesadas críticas na década de 1990 em virtude dos resultados frustrantes decorrentes da pressão para adoção de reformas liberalizantes (o chamado "Consenso de Washington") em países em desenvolvimento e economias de transição sem levar em consideração as peculiaridades de cada país. ${ }^{826}$ Ambas as instituições já reconheceram os equívocos na promoção de uma política de "um modelo serve para todos" (one size fits all), devendo-se evitar o retorno a medidas baseadas nesse tipo de estratégia regulatória. ${ }^{827}$

Finalmente, é válida também a indagação quanto à capacidade de um órgão que depende das contribuições de seus membros para se manter em funcionamento dispor da força e determinação necessárias para assegurar o cumprimento das recomendações do FSB aos seus maiores contribuintes. Os Estados Unidos, conforme visto, detêm grande influência no FMI e ainda discutem internamente a implementação de Basileia II.

Em face das dificuldades inerentes à proposta conjunta do FMI e FSB, alguns autores defendem um modelo alternativo que propõe a criação da Organização Financeira Mundial (OFM), em formato semelhante ao da Organização Mundial do Comércio (OMC). ${ }^{828} \mathrm{Da}$ mesma forma que a $\mathrm{OMC}$ estabelece princípios para o comércio internacional (não discriminação, reciprocidade, transparência, entre outros) sem prescrever regras específicas, a

826 STIGLITZ, Joseph. Challenging the Washington consensus. The Brown Journal of World Affairs, v. 9, n. 2, 2003.

827 Esse período é bem representado na seguinte passagem de Alexander et al.: "Foi apenas no início da década de 1990 que o Banco e o Fundo passaram a coordenar seus esforços de aconselhamento a países tomadores de recursos, especialmente economias em transição recém-saídas de regimes comunistas, na implementação de programas de ajuste baseados na teoria econômica neoclássica. Essas chamadas reformas enfatizavam a privatização da maioria das empresas públicas, a adoção de códigos comerciais ocidentais, e uma diminuição do papel econômico e social do Estado. Ao final da década de 1990, tornou-se evidente que os programas do Banco e do Fundo em países pós-comunistas, como a Rússia, haviam fracassado em atingir o objetivo de desenvolvimento econômico sustentável e reforma institucional. Além disso, em muitos países em desenvolvimento da África e América Latina, os programas de ajustamento do Banco falharam em trazer crescimento econômico e desenvolvimento sustentável, e o resultado foi uma 'crise de governança' declarada em relação aos programas. Houve um reconhecimento geral de que extensas novas reformas institucionais seriam necessárias se os países quisessem atingir o desenvolvimento econômico". Ver: ALEXANDER, Kern et al. Global governance of financial systems, p. 98. Tradução livre.

828 EICHENGREEN, Barry. Out of the box thoughts about international financial structure. IMF Working Paper, n. 9, p. 116, maio 2009. 
OFM também determinaria princípios regulatórios (requisitos de capital e liquidez, limites na concentração de portfólios, adequação de sistemas de mensuração de risco e controles internos), sem procurar impor a estrutura específica desses mecanismos. A participação na organização seria obrigatória para países com instituições financeiras que quisessem obter livre acesso ao sistema financeiro de países-membros, e seus integrantes teriam o direito de restringir a atuação de bancos sediados em países que transgredissem os princípios da OFM.

Nesse modelo, as especificidades da implementação das políticas regulatórias seriam deixadas a cargo dos países-membros, que teriam liberdade para adequar a regulação e supervisão às particularidades de seus sistemas financeiros. No entanto, nesse processo, não poderiam desrespeitar os princípios gerais determinados pela OFM. Em caso de divergências, haveria um painel de experts independentes para determinar se os países estariam cumprindo com os princípios acordados, incluindo a possibilidade de imposição de sanções quando verificada a infração. A ideia básica aqui é a de que, se os países já aceitam esse modelo para o comércio internacional, não haveria razão de não o aceitarem para o sistema financeiro internacional.

As críticas ao modelo proposto atacam justamente sua premissa básica, afirmando que o comércio internacional não pode ser igualado ao sistema financeiro internacional. A intermediação financeira seria mais complexa do que o comércio de produtos e serviços não financeiros, tornando governos menos seguros sobre as consequências de delegar autoridade sobre tais assuntos. A solução de disputas por meio de painéis poderia não funcionar no contexto financeiro, haja vista que a verificação do dano nesses casos é de difícil comprovação, e na maioria das situações, de caráter difuso, em vez de concentrado em um único país. Trata-se de situação bastante diversa de uma acusação de dumping, em que o dano pode ser quantificado e as mercadorias têm procedência e destino específico. Ademais, há dúvidas quanto à eficácia de uma estratégia baseada na fixação de padrões gerais de regulação e supervisão com implementação discricionária pelos países-membros. Além de suscitar questionamentos de solução complexa, como a suficiência dos controles de adequação patrimonial adotados por cada país, esse modelo pouco agrega à dinâmica atual do arcabouço de regulação financeira internacional, que suscitou as pressões por reforma em primeiro lugar. 
Com efeito, as dificuldades inerentes à criação de tal órgão são tamanhas, que alguns autores descartam tal possibilidade de pronto, classificando-a como "inviável". 829

Em contraste com o ceticismo em torno das alternativas mencionadas, uma proposta promissora atualmente em discussão é a de estabelecer "colégios de supervisores" (supervisory colleges) para conglomerados financeiros de atuação transfronteiriça. De forma sucinta, cada um desses conglomerados teria um colégio de supervisores composto pelas autoridades responsáveis pela supervisão das atividades financeiras desempenhadas pela instituição em suas respectivas jurisdições. Essa estratégia foi endossada expressamente pelo Comitê de Basileia, ${ }^{830}$ gozando de aceitação crescente na União Europeia, principalmente após a publicação do relatório Larosière. ${ }^{831}$ De acordo com o Comitê de Supervisores Bancários Europeus (Committee of European Banking Supervisors - CEBS), que reúne autoridades bancárias dos países-membros da União Europeia e tem como missão institucional aconselhar a Comissão Europeia em assuntos relacionados à regulação e supervisão bancária, os objetivos dos colégios de supervisores podem ser sumarizados da seguinte forma: (i) facilitar a troca de informações, opiniões e análises entre supervisores comuns de um conglomerado financeiro, de modo a permitir uma supervisão conjunta e individual mais eficiente e a tomada de ações corretivas com maior rapidez; (ii) possibilitar que supervisores desenvolvam um entendimento comum sobre o perfil de risco apresentado por tais conglomerados financeiros, favorecendo a criação de estratégias de supervisão conjuntas e individuais; (iii) atingir coordenação de supervisão e análise de risco por meio da criação de planos de supervisão, divisões de tarefas e fiscalizações conjuntas nos conglomerados financeiros, diminuindo a duplicação de trabalho e o ônus regulatório; e (iv)

829 MALAN, Pedro. A coordenação internacional da regulação financeira é viável? In: BOLLE, Monica Baumgarten de; CARNEIRO, Dionísio Dias (Org.). A reforma do sistema financeiro americano, p. 4. Generalizando as considerações de Malan, o professor da Universidade de Harvard Dani Rodrik taxa como "inviável” não apenas a possibilidade de uma OFM, como de qualquer órgão supranacional que vise eliminar a autoridade dos países no tocante à regulação e supervisão de seus sistemas financeiros. Na visão do autor, a reflexão sobre a regulação financeira global deve se dar de forma pragmática, considerando o fortalecimento das estruturas dos mecanismos de coordenação já existentes, e não a criação de novos órgãos com poderes aos quais os países dificilmente concordarão em se submeter. Ver: THE ECONOMIST. A plan B for global finance, 14 mar. 2009, p. 72.

830 COMITÊ DE BASILEIA. Good practice principles on supervisory colleges, Basileia, out. 2010.

831 A Recomendação 18 do Relatório Larosière apoia expressamente a adoção de colégios supervisores como estratégia de supervisão comunitária na União Europeia. Ver: COMISSÃO EUROPEIA. The high level group on financial supervision in the EU, Bruxelas, p. 48. 
coordenar decisões tomadas por autoridades individuais e esforçar-se para atingir o consenso. $^{832}$

Para evitar que um número demasiado de países acabe dificultando o processo decisório, o CEBS sugere que tais colégios sejam organizados de duas maneiras: (i) um colégio geral com reuniões multilaterais para troca de informações e discussão de aspectos gerais da política regulatória e planejamento, ou projetos interessando a um grande número de autoridades bancárias, cuja frequência seria determinada em uma análise caso a caso; e (ii) colégios centrais, contando apenas com as autoridades responsáveis pelas atividades principais do conglomerado financeiro em questão, em que estas possam atingir convergência regulatória e estruturar uma abordagem cooperativa de supervisão. Apesar do caráter multilateral dessas reuniões, elas serviriam como plataforma também para estabelecer relacionamentos bilaterais que, além de serem o ponto de partida para estratégias conjuntas de supervisão, criariam ainda uma base de diálogo contínuo entre autoridades bancárias. Naturalmente, uma dificuldade aqui seria determinar os participantes em cada nível dos colégios. Essa organização deve levar em conta diversos fatores, como a estrutura do conglomerado financeiro supervisionado, concentração de atividades em determinadas áreas geográficas, relevância sistêmica de entidades individuais e tipos de operação, serviços e produtos do grupo. Apesar dessas dificuldades, a proposta tem progredido rapidamente na União Europeia, sendo que, em março de 2010, já haviam sido estabelecidos colégios de supervisores para 17 conglomerados financeiros, cujos trabalhos foram objeto de avaliação pela CEBS. ${ }^{833}$

832 CEBS. Range of practices on supervisory colleges and home-host cooperation, London, 27 dez. 2007 , p. 1. Este e os demais relatórios do CEBS mencionados neste trabalho podem ser encontrados em: <www.cebs.org>. Acesso em: 26 dez. 2010.

833 São eles: BNP Paribas, Commerzbank, Crédit Agricole, Deutsche Bank, Dexia, Erste Bank, ING, Intesa SanPaolo, KBC, National Bank of Greece, Nordea, RBS, RZB, Santander, SEB, Société Générale e UniCredit (CEBS. Report of the peer review on the functioning of supervisory colleges, London, 18 out. 2010). Vale ressaltar que a União Europeia apresenta vantagem aqui pelo fato de já estar trabalhando há mais tempo na determinação de critérios semelhantes entre seus membros no âmbito das discussões de implementação de Basileia II. Além disso, a entrada em funcionamento do Sistema Europeu de Supervisores Financeiros (European System of Financial Supervisors - ESFS) em 2011, formado pela Autoridade Bancária Europeia (European Banking Authority - EBA), Autoridade para Valores Mobiliários e Mercados (European Securities and Markets Authority - Esma) e a Autoridade de Seguros e Previdência Europeia (European Insurance and Occupational Pensions Authority - Eiopa), deve facilitar a coordenação entre os países-membros, haja vista que, entre os objetivos de tais autoridades, consta a missão de promover a harmonização das regras aplicáveis a entidades transfronteiriças em suas respectivas áreas de atuação. 
Obstáculo importante para o sucesso dessa estratégia é que, conforme evidenciado no capítulo anterior, antes de atingir coordenação no âmbito internacional, muitos países precisam ainda alcançar coordenação no âmbito doméstico. Em países como os Estados Unidos, por exemplo, estão envolvidos internamente nesse processo nada menos que o Federal Reserve, Tesouro, SEC, FDIC, CFTC, OCC e 50 reguladores estaduais de seguradoras, entre outros. O escrutínio a que as propostas de reforma baseadas nos relatórios do Tesouro foram submetidas no Congresso, em subcomissões distintas, várias com décadas de relacionamento com algumas das entidades mencionadas (e seus lobbies, sempre muito atuantes), mostra que o País ainda tem sérios obstáculos a enfrentar no plano interno, antes de atingir um grau de cooperação efetivo no plano internacional. ${ }^{834}$ Mesmo após pesadas críticas ao arranjo institucional de regulação e supervisão norte-americano no relatório do exSecretário do Tesouro Henry Paulson, o Dodd-Frank Wall Street Reform and Consumer Protection Act conseguiu apenas eliminar uma autoridade do sistema, dividindo suas atribuições entre outras duas. ${ }^{835}$

Igualmente, a Inglaterra ainda enfrenta dificuldades decorrentes de disputas de poder entre o Tesouro inglês, o Bank of England e a FSA sobre o escopo das atividades de cada órgão. A disputa envolve não só as autorizações legais para definir políticas, princípios e regras de regulação financeira, como também a responsabilidade pela sua aplicação. Isso é fruto do modelo de autoridade universal adotado no país, que retirou funções historicamente exercidas pelo seu banco central, transferindo-as para a FSA, tendo sido inclusive identificado como um dos fatores que contribuíram para a corrida bancária ao Northern Rock em 2008. Embora o país tenha avançado na questão com o Banking Act de 2009, que retornou a função de supervisão pela estabilidade do sistema financeiro ao banco central, bem como o memorando de entendimento firmado entre suas autoridades, não há como prever até que ponto tais medidas serão suficientes para resolver os problemas de coordenação verificados na crise recente. É importante lembrar que o Banking Act criou também novos mecanismos que deverão ser administrados conjuntamente pelas autoridades, como o SRR. Quanto mais lentamente a Inglaterra avançar na resolução doméstica dessas questões, mais complexa será a

\footnotetext{
${ }^{834}$ MALAN, Pedro. A coordenação internacional da regulação financeira é viável? p. 2.

835 Ver nota 632.
} 
tarefa de coordenação internacional na esfera regulatória, dado o peso de Londres e de suas instituições nos mercados financeiro e de capitais internacionais. ${ }^{836}$

Evidentemente, há inúmeras outras propostas de aprimoramento do arcabouço de regulação financeira internacional, cada qual com suas virtudes e críticas. Fugiria ao escopo deste trabalho procurar esgotá-las, se é que isso é possível, dada a rápida proliferação de trabalhos sobre o tema em razão dos desdobramentos da crise financeira recente. O propósito do presente tópico foi apenas apresentar algumas das imensas dificuldades que cercam as propostas sobre o tema, e assim contribuir para a reflexão sobre os desafios apresentados aos mecanismos de regulação sistêmica e prudencial analisados nos últimos capítulos.

836 MALAN, Pedro. A coordenação internacional da regulação financeira é viável? p. 2. 


\section{SÍNTESE E CONCLUSÕES DO CAPÍTULO 5}

1. As transformações ocorridas no campo da tecnologia da informação nas últimas décadas permitiram que instituições financeiras oferecessem mais produtos e serviços, para um número maior de clientes, cobrindo área geográfica mais ampla. A combinação desses avanços com os movimentos de concentração e conglomeração financeira tornou possível o surgimento de instituições financeiras de grande porte com atuação global.

2. A formação desses conglomerados financeiros internacionais impõe desafios às autoridades responsáveis pela sua regulação e supervisão, na medida em que transferem dificuldades inerentes à sua fiscalização do plano doméstico para o plano internacional. A internacionalização das instituições financeiras faz com que autoridades se preocupem não apenas com a exposição a risco dessas entidades em suas respectivas jurisdições, mas também ao redor do mundo. Igualmente, a interdependência crescente entre instituições financeiras no plano internacional aumenta o risco de que o default de uma instituição ou liquidação de uma afiliada ou subsidiária em determinado país provoque consequências negativas em outros países nos quais tenha operações.

3. Essas preocupações são exacerbadas pelo fato de, a despeito de suas ambições globais e presença internacional, tais instituições financeiras continuarem sujeitas predominantemente à regulação e supervisão de autoridades nacionais, limitadas pelo domínio de suas jurisdições domésticas. Como resultado, os esforços de supervisão bancária acabam sujeitando-se às peculiaridades do arcabouço regulatório de cada país, podendo provocar movimentos de arbitragem regulatória ou, ainda mais grave, vácuo regulatório na supervisão de determinadas atividades ou entidades do conglomerado financeiro. Outro perigo ilustrado de forma clara na crise financeira recente é de que decisões unilaterais por parte de autoridades nacionais quanto a instituições financeiras atuando em sua jurisdição possam causar efeitos negativos significativos em outros países. Realisticamente, observa-se que autoridades bancárias passam a depender cada vez mais não apenas dos resultados de seus esforços de regulação e supervisão bancária, mas também dos atos praticados por autoridades de outros países.

4. A constatação dessas limitações quanto às estratégias nacionais de regulação e supervisão de conglomerados financeiros deixa clara a necessidade de maior coordenação entre 
autoridades bancárias e a criação de padrões de regulação e supervisão comuns às jurisdições em que as instituições financeiras atuem. Nesse sentido, constatou-se nas últimas décadas o desenvolvimento de fóruns especializados em regulação financeira realizando trabalhos nessa área. Os principais representantes desse arcabouço internacional de regulação e supervisão financeira na atualidade são o Comitê de Basileia, Iosco e Iais, responsáveis, respectivamente, pelo setor bancário, bursátil e seguros.

5. A composição interna, forma e foco de trabalho desses órgãos variam entre si. A atuação do Comitê de Basileia desde sua criação tem sido mais centrada na preparação de recomendações na área de controles de adequação de capital e proposição de melhores práticas relativas à coordenação regulatória e supervisão de instituições financeiras com presença internacional. Já os trabalhos da Iosco e Iais, embora também voltados à elaboração de padrões mínimos de regulação e supervisão para os participantes dos mercados nos quais atuam, possuem enfoque mais diversificado. Ponto comum relevante com relação às recomendações desses órgãos é que elas não possuem caráter vinculante, somente tornando-se obrigatórias na medida em que incorporadas ao ordenamento jurídico de cada país. Não obstante, isso não impediu que sua atuação tivesse cada vez mais poder e influência nos mercados financeiro e de capitais mundiais, notadamente no caso do Comitê de Basileia.

6. Além desses órgãos, devem-se mencionar também os trabalhos do FMI e Banco Mundial no campo da regulação financeira. Embora suas áreas de atuação sejam consideravelmente mais abrangentes, essas organizações internacionais também realizam trabalhos relacionados ao tema. Isso é feito primordialmente por meio de programas de assistência para países em desenvolvimento e economias em transição, incluindo o aconselhamento na estruturação de seus sistemas financeiros de acordo com as melhores práticas regulatórias internacionais (muitas vezes derivadas dos trabalhos do Comitê de Basileia, Iosco e Iais). O FMI e o Banco Mundial também executam funções de supervisão financeira por meio dos FSAPs e ROSCs, programas que visam analisar o grau de aderência de países-membros a padrões e códigos de conduta internacionalmente reconhecidos, identificar vulnerabilidades no sistema financeiro de um país, verificar como as principais fontes de risco são administradas, determinar as necessidades técnicas do setor e formular respostas em termos de políticas regulatórias a serem implementadas. A grande diferença dessas organizações internacionais relativamente a outros fóruns de 
discussão sobre regulação financeira é que suas determinações têm maior vinculação sobre seus membros, especialmente quando ligadas à prestação de auxílio financeiro.

7. O primeiro trabalho realizado pelo Comitê de Basileia no campo da coordenação internacional para regulação e supervisão financeira foi o relatório que ficou conhecido como "Concordata de Basileia", preparado em 1975. Desde então, o Comitê de Basileia já realizou inúmeros estudos sobre o tema. Inicialmente seus trabalhos foram mais focados na divisão de responsabilidades entre autoridades nacionais para a supervisão de instituições financeiras de atuação internacional e as diversas formas operacionais que poderiam assumir em outros países. A preocupação central nesses relatórios era evitar que tais instituições pudessem se beneficiar de vácuos regulatórios. Essa visão logo se mostrou limitada, de modo que seus trabalhos posteriores passaram a incorporar outras dimensões de coordenação internacional de regulação financeira por meio do estímulo ao contato e cooperação contínua entre autoridades nacionais, como as estratégias de supervisão dual e consolidada. Outra preocupação levantada em relatórios posteriores foi a incorporação de definições comuns entre jurisdições quanto a quais entidades ou atividades caracterizariam uma instituição financeira. A partir da década de 1990, o Comitê de Basileia passou a focar seus trabalhos também na análise das estratégias de regulação e supervisão apropriadas para conglomerados atuantes em diversos segmentos do sistema financeiro. Nesse sentido, passou a desenvolver trabalhos com outros fóruns de discussão sobre a regulação financeira, como a Iosco e Iais, para discutir melhores práticas de regulação e supervisão no contexto desses conglomerados.

8. Corroborando a tendência de maior interação entre órgãos internacionais atuantes sobre a regulação financeira, foi criado em 1999 o FSF, com o mandato de analisar vulnerabilidades regulatórias no sistema financeiro internacional, identificar e supervisionar ações para sanar essas vulnerabilidades, bem como aprimorar a coordenação e compartilhamento de informações entre autoridades bancárias nacionais e órgãos internacionais na área de regulação e supervisão financeira. Inicialmente limitado aos países-membros do G-7 e alguns países, órgãos e organizações internacionais, o FSF passou por reformulação em 2009 para incorporar os países do G-20, entre outros membros, passando a se chamar FSB. 
9. A crise financeira recente exacerbou as preocupações quanto à necessidade de coordenação entre autoridades nacionais e elaboração de padrões comuns de regulação e supervisão mais rígidos para conglomerados financeiros de atuação internacional. Nesse sentido, inúmeras propostas têm sido apresentadas, cada qual com sua abordagem própria quanto a quem caberia assumir a liderança nesse processo e a melhor estratégia para garantir a aderência dos países a tais recomendações. O FSB apresentou proposta formulada conjuntamente com o FMI, em que o primeiro seria responsável pela definição das práticas aceitáveis no âmbito de regulação e supervisão, e o FMI se encarregaria de promover ampla adesão aos princípios recomendados. Outra proposta com aceitação crescente na União Europeia é a criação de colégios de supervisores para facilitar a cooperação e coordenação entre autoridades responsáveis pela supervisão de conglomerados financeiros com atuação transfronteiriça.

10. Apesar das propostas apresentadas, pouco se evoluiu até o presente momento na solução dessas questões. Além das dificuldades inerentes à conciliação de interesses divergentes entre países, outra possível explicação é que, antes de cooperarem no plano internacional, alguns países ainda precisam resolver desafios internamente no tocante à coordenação entre autoridades responsáveis pela regulação e supervisão do sistema financeiro.

11. O Brasil encontra-se em situação peculiar nesse debate, pois, embora já tenha sido mais expressiva no passado, a participação de bancos com capital estrangeiro no SFN atualmente é relativamente pequena, somando $17,4 \%$ de seu patrimônio líquido. A regulação aplicável a essas instituições é a mesma a que se submetem as instituições financeiras domésticas, quando não mais rigorosa, como no caso do capital mínimo para sua abertura vigente até 1999. No tocante aos bancos domésticos, seu processo de internacionalização ainda é incipiente. Não obstante, deve-se notar a rapidez com que esse quadro tem se modificado, conforme evidenciado pelas incursões recentes de instituições como o Banco do Brasil, Itaú-Unibanco e Bradesco no exterior, seja com bandeira própria, ou por meio da aquisição de operações locais de instituições financeiras estrangeiras. Caso esse movimento de internacionalização tenha continuidade, tanto o Bacen como outras autoridades responsáveis pela supervisão dos participantes do SFN deverão atribuir atenção crescente aos riscos decorrentes desse processo nos anos vindouros. 


\section{CONCLUSÃO}

O historiador financeiro Peter Bernstein relata interessante caso ocorrido na Rússia

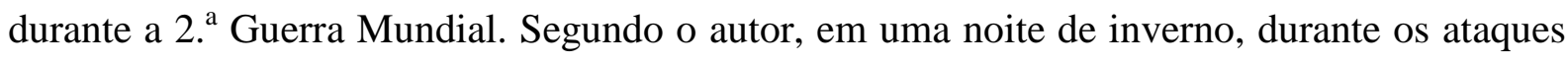
aéreos alemães contra a capital russa, os refugiados no abrigo antiaéreo local surpreenderamse ao encontrarem ali eminente professor de estatística. O motivo da surpresa se devia ao fato de aquela ser a primeira vez que o professor decidira procurar o abrigo. Colegas já haviam tentado convencê-lo inúmeras vezes a se proteger dos ataques, mas ele sempre se recusara, afirmando que, com uma população de sete milhões de habitantes na cidade, as chances de ele ser atingido eram estatisticamente insignificantes. Ao pedirem então que ele explicasse o motivo daquela súbita mudança de atitude, ele prontamente justificou-se, dizendo que havia sete milhões de habitantes na cidade e um elefante. Na noite passada haviam atingido o elefante. $^{837}$

O conto apresentado pelo autor norte-americano é um ótimo exemplo de que não é preciso aguardar catástrofes ocorrerem para se tomar precauções. A possibilidade de desastres acontecerem é possível e contínua, de modo que, independentemente da confiança em chances individuais ou conhecimento acumulado, é sempre recomendável se proteger. A história também é particularmente oportuna ao contexto atual do SFN, em que se vive momento de grande entusiasmo com o modelo regulatório brasileiro em virtude da recuperação relativamente rápida e positiva da crise financeira recente. No afã de enaltecer as virtudes do arcabouço regulatório pátrio, autoridades podem não ter percebido ou, pior, não terem dado a devida atenção ao fato de que na noite passada "o elefante foi atingido".

Sem dúvida a regulação do SFN passou por notáveis avanços nas últimas décadas. O arcabouço regulatório pátrio possui inúmeras virtudes e estas devem ser celebradas em razão de sua importância na proteção do SFN em relação aos problemas verificados em outros países na crise recente. Isso, no entanto, não deve cegar as autoridades ao fato de que ainda existem falhas a serem corrigidas. Igualmente, deve-se atentar que muitos dos graves problemas constatados no exterior e que representam verdadeiros desafios para a atuação de

837 BERNSTEIN, Peter. Against the Gods: the remarkable story of risk. Nova Iorque: John Wiley \& Sons, 1996. p. 116. 
autoridades bancárias estrangeiras também começam a se manifestar, ou então já estão presentes, no Brasil.

O presente trabalho procurou oferecer um contraponto à noção disseminada de solidez do SFN. Nesse sentido, à parte das conclusões apresentadas em cada um dos cinco capítulos, considerando os objetivos enunciados no início do trabalho - quais sejam: (i) descrever e compreender os sistemas vigentes de regulação sistêmica e prudencial no setor bancário nacional, produzindo o diagnóstico do arcabouço regulatório voltado à prevenção de crises bancárias, e (ii) verificar como as transformações ocorridas no sistema financeiro nas últimas décadas afetam esse arcabouço regulatório -, cabe realizar, à guisa de conclusão final, uma recapitulação dos principais achados do trabalho.

No tocante ao primeiro ponto, o diagnóstico do arcabouço regulatório vigente pode ser assim sumarizado:

1. O Brasil adota na atualidade os principais mecanismos de regulação sistêmica e prudencial existentes. Enquanto os mecanismos de regulação sistêmica já estão presentes há mais tempo no País, a regulação prudencial é mais recente, passando a adquirir seus contornos atuais a partir das reformas ocorridas na década de 1990, principalmente com a adoção de Basileia I em 1994.

2. Apesar dos evidentes progressos ocorridos no regramento dos mecanismos de regulação sistêmica nas últimas décadas, é preciso reconhecer que a atual configuração desses mecanismos no País é conducente ao agravamento do risco moral do mercado. Embora todos os mecanismos de regulação sistêmica tenham essa característica indesejável, no Brasil isso pode estar acontecendo de forma exagerada, em virtude da existência de inúmeros instrumentos de provimento de liquidez aos bancos operando concomitantemente e com variados graus de formalidade, exigências e transparência. Esse quadro é agravado por um contexto de grande discricionariedade na decretação de regimes especiais pela autoridade bancária e uma jurisprudência que dificulta a sua responsabilização caso venha a se omitir em sua atuação. 
3. Além dos mecanismos em existência, observa-se a intenção do Bacen de acrescentar, por meio de proposta de anteprojeto de lei, outro canal de provimento de liquidez que não se sujeitaria às restrições previstas na Lei de Responsabilidade Fiscal para operações dessa natureza. Considerando-se a ausência de definição legal ou apresentação de critérios norteadores para identificação de quais situações possam configurar "crise sistêmica ou grave ameaça à estabilidade" do SFN, sua utilização recairia sobre a discricionariedade da autoridade bancária.

4. A regulação sistêmica no País apresenta falhas individuais e conjunturais que geram preocupação sobre a geração de risco moral no SFN. Nesse contexto, é preciso questionar até que ponto o desempenho considerado positivo do SFN na crise financeira recente se deveu à solidez de suas instituições financeiras, ou à existência de inúmeros canais de provimento de liquidez que acabam garantindo o risco inerente e, frise-se, necessário à atividade bancária.

5. Em contraste com as deficiências apontadas relativas à regulação sistêmica, observa-se um quadro bastante diverso no tocante à regulação prudencial pátria. Além de adotar os principais mecanismos de regulação prudencial existentes, o regramento desses mecanismos no País é marcado por caráter mais rigoroso em relação às recomendações do Comitê de Basileia, bem como a regulação de outros países.

6. O Brasil encontra-se também na vanguarda da implementação de mecanismos de regulação prudencial, conforme evidenciado pelos testes de stress, adotados recentemente nos Estados Unidos e Europa, e que já vinham sendo utilizados pelo Bacen, assim como o controle de estruturas de remuneração, ponto enfatizado pelo FSB ao final de 2009, seguido praticamente de imediato por proposta de normativo do Bacen, convertida posteriormente em Resolução pelo CMN, regulamentando a incorporação desses princípios regulatórios no País.

7. A regulação do SFN encontra-se à frente de outros países também em pontos importantes das propostas de reformas regulatórias discutidas ao redor do 
mundo, como a maior fiscalização das operações com instrumentos financeiros derivativos realizadas nos mercados de balcão por instituições financeiras, a não incorporação de trabalhos de agências de rating no instrumental de supervisão bancária, bem como a migração para padrões contábeis considerados mais transparentes para fins de consolidação de SPEs, de acordo com as recomendações do Comitê de Basileia.

8. Se por um lado a existência de inúmeros canais de provimento de liquidez pode ter facilitado a resistência das instituições financeiras durante a crise, é preciso reconhecer também os méritos da regulação prudencial pátria, que certamente as deixou em melhor condição para enfrentar os efeitos da crise de liquidez que atingiu o País.

9. Ainda que os rigorosos mecanismos voltados ao controle da higidez de instituições financeiras ajudem a mitigar o risco moral decorrente da disponibilização de amplo instrumental de resgate aos bancos, é temerário contar apenas com esses mecanismos para compensar os efeitos deletérios decorrentes desse quadro. A regulação prudencial está em constante transformação, adaptando-se à evolução dos mercados e procurando sempre a melhor estratégia para manter a higidez do sistema financeiro. Esse quadro é agravado pelas transformações ocorridas nos mercados financeiro e de capitais nas últimas décadas e os desafios impostos às autoridades bancárias na regulação e supervisão do risco assumido por instituições financeiras. Outrossim, ainda que em diferentes intensidades, as autoridades bancárias dependem do trabalho de "agentes auxiliares" para conduzir seus trabalhos. Enquanto os conflitos de interesse inerentes a esses entes privados não forem resolvidos, a supervisão bancária também estará sujeita a esses vícios. Em suma, embora útil e necessária, a regulação prudencial enfrenta limitações, não podendo nem devendo ser considerada a "bala de prata" contra o risco moral, motivo pelo qual a autoridade bancária deve atentar para a correção dos vícios identificados na estrutura atual de regulação sistêmica. 
No tocante ao segundo objetivo do trabalho, os efeitos das transformações no sistema financeiro no arcabouço regulatório vigente podem ser assim sumarizados:

1. Foram analisadas as principais transformações pelas quais o sistema financeiro passou nas últimas décadas. Embora houvesse interesse especial na análise dessas transformações no contexto pátrio, constatou-se que esses movimentos podem ser observados com maior ou menor intensidade ao redor do mundo. Nesse sentido, foram examinados três movimentos em particular: (i) concentração crescente no setor bancário, (ii) conglomeração de atividades financeiras e (iii) internacionalização das instituições financeiras. Cada um desses movimentos, seja de forma isolada ou conjunta, apresenta desafios particulares à regulação e supervisão bancária.

2. A concentração bancária leva ao aumento de porte das instituições financeiras, fazendo com que estas assumam importância cada vez maior na economia dos países em que atuam. O porte crescente dessas instituições potencializa a importância das funções desempenhadas por elas, disseminando-se o consenso de que estas não podem vir a quebrar, sob pena de causarem efeitos devastadores na economia. Essa noção tacitamente aceita de que uma instituição é "grande demais para quebrar" provoca graves efeitos em termos de criação de risco moral, refletidos no incentivo à tomada excessiva de risco e arrefecimento da disciplina de mercado pela certeza do resgate em caso de quebra.

3. A conglomeração financeira faz com que a possibilidade de contágio sistêmico não se limite mais às atividades bancárias, podendo se originar de outras atividades, como seguros ou hedge funds. Essas atividades podem ser conduzidas de forma independente, adquirindo "relevância sistêmica" em razão de seu tamanho, alavancagem e relacionamento com instituições financeiras, entre outros, ou então no contexto de conglomerados financeiros, criando o temor de que resultados adversos de atividades não bancárias do grupo possam comprometer a viabilidade de suas atividades bancárias e viceversa. Ambos os casos ensejam a reflexão sobre a forma como o risco 
sistêmico é tradicionalmente pensado e, principalmente, prevenido. Além da preocupação com a necessidade e conveniência de estender a instituições não bancárias mecanismos típicos da rede de segurança oferecida aos bancos, outra preocupação relevante refere-se à capacidade de os arranjos institucionais tradicionais de regulação e supervisão monitorarem adequadamente o risco assumido por instituições financeiras. Formulados originalmente em um contexto em que atividades financeiras eram prestadas isoladamente, a formação de conglomerados financeiros desafia a capacidade e adequação de esses arranjos cumprirem com seu propósito, na medida em que a supervisão compartimentada de atividades que são exercidas conjuntamente faz com que nenhuma autoridade possua uma visão completa do nível de risco a que o conglomerado financeiro está exposto.

4. A internacionalização da atuação das instituições financeiras transpõe as preocupações supracitadas do plano nacional para o plano internacional, com a complexidade adicional inerente a essa transição. Atualmente autoridades bancárias devem preocupar-se com o monitoramento de risco de instituições financeiras não apenas em suas jurisdições, como também em outros países. Outrossim, nesse quadro de conglomerados financeiros integrados globalmente, os atos de autoridades bancárias em um determinado país têm reflexos diretos em outras jurisdições. Esse quadro é agravado pelo fato de a regulação financeira ainda ser conduzida, predominantemente, sob o ponto de vista doméstico. Embora se tenha observado nas últimas décadas amplo esforço para estabelecer padrões mínimos comuns de regulação e supervisão aplicáveis às diferentes jurisdições em que as instituições financeiras atuam, há ainda imensas dificuldades a serem superadas, seja no tocante ao grau de aderência a tais normas, conciliação de interesses e estratégias divergentes entre países para a regulação de seus sistemas financeiros, ou então quanto à superação de conflitos entre autoridades internas de cada país, antes de proceder à cooperação em nível internacional.

5. A concentração e conglomeração financeira não apenas estão presentes no Brasil, como têm sido historicamente incentivadas no SFN. A concentração 
bancária foi um objetivo declarado do governo durante o regime militar, sob a crença de que o processo traria economias de escala e escopo a instituições financeiras, que se traduziriam em menores taxas de juros ao mercado. Embora inicialmente a política do regime militar tenha procurado estabelecer um regime de especialização de instituições financeiras em funções-chave do sistema financeiro, na realidade observou-se o fenômeno de conglomeração, em que diversas instituições atuantes em diferentes segmentos reuniam-se sob um mesmo grupo. Ao final da década de 1980, a intermediação financeira no País era realizada praticamente em sua integralidade por conglomerados financeiros, sendo esta ainda a matriz predominante do SFN. Apesar da breve interrupção no final da década de 1980, o movimento de concentração bancária continuou na década de 1990, como parte do processo de saneamento verificado em virtude do fim das receitas inflacionárias. Ainda que em menor intensidade, o processo teve continuidade na última década, notadamente após a crise financeira recente, quando instituições financeiras privadas e oficiais efetuaram diversas aquisições no setor bancário. Embora não mais com caráter de política oficial para o setor, o governo continuou desempenhando papel relevante nesse movimento, seja por meio de programas facilitando fusões e aquisições no setor bancário na década de 1990, ou então recentemente, com a promulgação de medidas e estímulos à aquisição do controle acionário de outras instituições financeiras por bancos públicos.

6. Enquanto em países como os Estados Unidos se discute a imposição de limitação de $10 \%$ ao total de depósitos segurados pelo FDIC para o porte de instituições financeiras, no Brasil, os cinco maiores bancos já detinham ao final de 2009 cerca de $70 \%$ dos ativos totais no SFN. ${ }^{838}$ O relato do desempenho do setor bancário brasileiro na segunda metade do século XX apresentou diversos episódios em que o Bacen optou por resgatar instituições financeiras com recursos da reserva monetária por temor de que sua quebra pudesse desestabilizar o SFN, como no caso do Halles em 1974, apenas dias após a promulgação da Lei 6.024/1974, e repetindo-se no caso do BUC, Comind e

${ }^{838}$ Dados disponíveis em: <www.bcb.gov.br/htms/ deorf/r200912/index.asp>. Acesso em: 12 dez. 2010. 
Auxiliar, entre outros. Apesar da vedação à utilização desses recursos após a promulgação da Constituição de 1988, orientação semelhante foi adotada nos resgates do Econômico, Nacional, Bamerindus, entre outros, na década de 1990, com recursos do Proer e Proes. Ainda na década de 1990, é preciso mencionar o rumoroso resgate envolvendo o Marka e o FonteCindam, sob alegações semelhantes. Mais recentemente, o ex-diretor de política monetária do Bacen, encarregado dos esforços de contenção dos efeitos da crise financeira no País, declarou abertamente que tais esforços foram necessários porque "qualquer banquinho era too big to fail".

7. A preocupação com a concentração bancária crescente no País chama a atenção pela forma relativamente inconteste como é encarada pelo Bacen. Ainda que se argumente que os níveis de concentração bancária no SFN sejam menores que os encontrados em outros países, isso não justifica a ausência do debate. Pelo contrário, essa é outra razão pela qual se justifica a discussão da questão antes, e não depois de o problema ter se instaurado. A esse respeito, é preciso reconhecer que a atuação dos conglomerados financeiros no Brasil guarda importantes diferenças relativamente a outros países, com destaque para os inúmeros instrumentos à disposição da autoridade bancária para reorganizar instituições em crise, bem como a existência de regimes rigorosos de responsabilidade para administradores e controladores, incluindo a possibilidade de decretação da indisponibilidade de seus bens. Embora tais fatores certamente desempenhem um papel importante na contenção dos efeitos deletérios do status "grande demais para quebrar", devem ser analisados com temperamentos. A reorganização de instituições financeiras só é aplicável no caso de estarem presentes os pressupostos para a decretação dos regimes especiais. Não há possibilidade de limitação ex ante desses efeitos deletérios, e sim de remediação ex post de suas consequências. Ademais, embora mais rigorosa, persiste a divergência jurisprudencial quanto ao tipo de responsabilidade para administradores e controladores previsto na Lei 6.024/1974. O posicionamento mais recente do STJ é de que o regime aplicável é de responsabilidade subjetiva com inversão do ônus da prova. 
8. A conglomeração financeira também vem colocando desafios à atuação da autoridade bancária no País. O arranjo institucional de regulação e supervisão do SFN é inspirado na abordagem funcional e na abordagem institucional, que são objeto de críticas por atribuírem tratamento segregado ao risco, mesmo quando atividades financeiras são desenvolvidas conjuntamente. Para mitigar as limitações desse arranjo institucional, o Bacen firmou convênios com a CVM e Susep para troca de informações e coordenação de políticas regulatórias. É difícil precisar até que ponto a superação das limitações dessas abordagens pode ser realizada por meio de acordos entre autoridades. A experiência dos Estados Unidos, outro país cujo sistema se apoia na abordagem institucional e funcional e que procurou resolver as limitações do sistema por meio de acordos entre autoridades, não oferece prognóstico favorável a esse respeito. Evidentemente, diferenças importantes do modelo brasileiro em relação ao americano precisam ser consideradas. O Brasil possui número consideravelmente menor de autoridades com as quais a autoridade bancária deve se relacionar. Outrossim, vantagem relevante a ser enfatizada no SFN refere-se à presença do $\mathrm{CMN}$ como órgão de coordenação entre as funções de regulação e supervisão exercidas pelo Bacen e CVM. Em face da limitação em termos de coordenação com a Susep, criou-se em 2006 o Coremec, que visa estabelecer um fórum de discussão para as autoridades do SFN.

9. A formação de convênios entre autoridades do SFN, bem como a própria criação do Coremec, são relativamente recentes, não havendo como asseverar de forma categórica se estão funcionando a contento e se serão suficientes para corrigir as limitações da abordagem funcional e institucional. É possível e provável que, na medida em que atividades não bancárias ganhem maior representatividade nos resultados de conglomerados financeiros, o embate a respeito da extensão da competência das autoridades do SFN se torne mais frequente. Exemplo claro disso é a constatação de posicionamento de integrantes e ex-integrantes do Bacen invocando a autoridade de supervisão conjunta sobre fundos de investimento, atualmente sob supervisão da CVM. 
10. No tocante aos movimentos de internacionalização de instituições financeiras, o Brasil encontra-se em situação peculiar, com participação relativamente pequena de bancos com capital estrangeiro no patrimônio líquido do SFN e bancos domésticos com exposição internacional relativamente pequena. Apesar disso, ressalta-se a rapidez com que esse quadro vem se alterando, de modo que, caso esse processo tenha continuidade, a preocupação com os riscos decorrentes das operações de instituições financeiras domésticas no exterior se tornará cada vez mais recorrente na agenda de supervisão do Bacen e outras autoridades nacionais nos próximos anos.

O presente trabalho destinou-se à apresentação do diagnóstico do modelo regulatório vigente e de como as transformações no sistema financeiro o afetam. Assim, observou-se que, embora haja de fato inúmeras virtudes a serem consideradas e enaltecidas em relação a outros países, existem também falhas e desafios e serem enfrentados. Conforme alertado no início do trabalho, ainda que a análise empreendida tenha salientado áreas nas quais a autoridade bancária deverá focar sua atuação nos próximos anos, não houve o direcionamento específico do estudo para a apresentação de soluções às falhas e desafios identificados. Nesse aspecto, espera-se que, além de oferecer um contraponto à noção disseminada de que o arcabouço regulatório pátrio é adequado e superior ao modelo de outros países, as conclusões expostas também incentivem outros juristas a se engajar no campo da regulação financeira para analisar como esses pontos problemáticos podem ser superados, contribuindo para a realização de estudos que contemplem não apenas a dimensão econômica, mas também a dimensão jurídica dos instrumentos subjacentes a tais modalidades regulatórias, e do ordenamento jurídico em que se propõem a operar. 


\section{REFERÊNCIAS BIBLIOGRÁFICAS}

AKERLOF, George. The market for lemons: quality uncertainty and the market mechanism. Quarterly Journal of Economics, v. 84, n. 3, 1970.

ALEXANDER, Kern; DHUMALE, Rahul; EATWELL, John. Global governance of financial systems: the international regulation of systemic risk. Oxford: University Press, 2006.

ALMEIDA JR., Mansueto; BARROS, José Roberto Mendonça de. Análise do ajuste do Sistema Financeiro no Brasil. Revista de Política Comparada, Brasília, v. 1, n. 2, 1997.

ALTUNBAS, Yener; MOLYNEUX, Philip; THORNTON, John. Big-bank mergers in Europe: an analysis of the cost implications. Economica, v. 64, n. 254, 1997.

ALVES, Sérgio Darcy da Silva; ALVES, Tatiana Muniz Silva. A experiência brasileira de regulação: um caso de sucesso? In: GARCIA, Márcio; GIAMBIAGI, Fábio (Org.). Risco e regulação: por que o Brasil enfrentou bem a crise financeira recente e como ela afetou a economia mundial. Rio de Janeiro: Elsevier, 2010.

ANDRADE, Ana Maria Ribeiro de; LEVY, Maria Bárbara. Fundamentos do sistema bancário no Brasil (1834-1860). Revista de Estudos Econômicos, v. 15, 1985.

ANDREZO, Andrea Fernandes; LIMA, Iran Siqueira. Mercado financeiro: aspectos históricos e conceituais. São Paulo: Pioneira Thomson Learning, 1999.

ARAÚJO, Carlos Roberto Vieira. História do pensamento econômico: uma abordagem introdutória. São Paulo: Atlas, 2008.

ARAÚJO, Maria da Glória Domingos Silva. O Sistema de Pagamentos Brasileiro e a assunção de riscos pelo Banco Central. Notas Técnicas do Banco Central, n. 23, Brasília, 2002. 
ARROW, Kenneth. Limits of organization. Nova Iorque: Norton, 1974.

ASSAF NETO, Alexandre. Mercado financeiro. 4. ed. São Paulo: Atlas, 2001.

ASSIS, J. Carlos. A chave do tesouro: anatomia dos escândalos financeiros no Brasil (197483). Rio de Janeiro: Paz e Terra, 1983.

AUSUBEL, Lawrence. The failure of competition in the credit card market. The American Economic Review, v. 81, n. 1, 1991.

BAER, Mônica. A internacionalização financeira no Brasil. Petrópolis: Vozes, 1986.

BAGEHOT, Walter. Lombard street: a description of the money market. Nova Iorque: John Wiley \& Sons, 1999 (ed. original, 1873).

BALDWIN, Robert; CAVE, Martin. Understanding regulation. London: Oxford University Press, 1999.

BANCO CENTRAL DO BRASIL. Economia bancária e crédito: avaliação de 4 anos do projeto juros e spread bancário. Brasília: Banco Central do Brasil, 2003.

—. Reestruturação do Sistema de Pagamentos Brasileiro. Brasília: Banco Central do Brasil, 2002.

—. Relatório de estabilidade financeira. Brasília: Banco Central do Brasil, 2009.

—. Sistema de informações de crédito do Banco Central. Brasília: Banco Central do Brasil, 2004.

—. Sistema Financeiro Nacional - 1989 a 2000. Brasília: Banco Central do Brasil.

—. Sistema Financeiro Nacional - 2001. Brasília: Banco Central do Brasil.

_. Sistema Financeiro Nacional - 2002. Brasília: Banco Central do Brasil.

BANCO MUNDIAL. Finance for growth: policy choices in a volatile world. A World Bank policy research report. Oxford: Oxford University Press, 2001.

—. Sistemas de informação sobre créditos e empréstimos no Brasil. Iniciativa de sistemas de informação sobre créditos e empréstimos do hemisfério ocidental, mar. 2005. Disponível em: <www.whcri.org/PDF/report_brasl-pt.pdf>. Acesso em: 26 dez. 2010. 
BANK OF ENGLAND. The role of macroprudential policy: a discussion paper, 2009.

Disponível em: <www.bankofengland.co.uk/publications>. Acesso em: 23 dez. 2010.

BANKS, Gary. Report of the taskforce on reducing regulatory burdens on business, 2006. Disponível em: <www.regulationtaskforce.gov.au>. Acesso em: 23 dez. 2010.

BARTH, James R.; CAPRIO JR., Gerard; LEVINE, Ross. Rethinking bank regulation: till angels govern. Cambridge: Cambridge University Press, 2006.

- $-\frac{-}{-}-$ Bank regulation and supervision: what works best? Journal of Financial Intermediation, 13(2), 2004.

—- GAN, Jie; NOLLE, Daniel E. Global banking regulation and supervision. Nova Iorque: Nova Science Publishers, 2009.

—; MARCHETTI, Juan A.; NOLLE, Daniel E.; SAWANGNGOENYUANG,

Wanvimol. Foreign banking: do countries' WTO commitments match actual practices? Staff Working Paper, World Trade Organization, n. ERSD-2006-11, out. 2006.

BARROS DE CASTRO, Lavinia. Basileia II: questões pendentes que interessam ao Brasil. Periódico Visão do Desenvolvimento, BNDES, n. 34, 2007.

- Regulação financeira: discutindo os Acordos de Basiléia. Revista do BNDES, Rio de Janeiro, v. 14, n. 28, 2007.

BEBCHUK, Lucian A. Written testimony submitted to the Committee on Financial Services of the United States House of Representatives: hearing on compensation structure and systemic risk, 11 jun. 2009. Disponível em: <www.law.harvard.edu/faculty/ bebchuk/Policy/FSC-written-testimony-June-11-09.pdf>. Acesso em: 26 dez. 2010. _ FRIED, Jesse. Pay without performance: the unfulfilled promise of executive compensation. Cambridge: Harvard University Press, 2004.

BECK, Thorsten; DEMIRGUÇ-KUNT, Asli; LEVINE, Ross. Bank concentration and fragility: impact and mechanics. In: CAREY, Mark; STULZ, Rene (Org.). Risks of financial institutions. Cambridge: National Bureau of Economic Research, 2006.

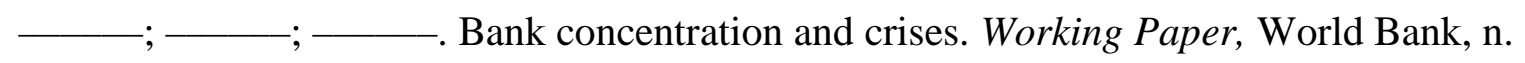
$3041,2003$. 
- ; LEVINE, Ross; LOAYZA, Norman. Finance and the sources of growth. Journal of Financial Economics, v. 58, n. 1-2, 2000.

BECKER, Gary. The economic approach to human behaviour. Chicago: University of Chicago Press, 1976.

BENSTON, George J. Regulating financial markets: a critique and some proposals. Washington: The AEI Press, 1999.

—_ EISENBEIS, Robert A.; HORVITZ, Paul M.; KANE, Edward J.; KAUFMAN, George G. (Org.). Perspectives on safe and sound banking. Cambridge: MIT Press, 1986.

BERGER, Allen N.; DEMIRGUÇ-KUNT, Asli; LEVINE, Ross; HAUBRICH, Joseph G. Bank concentration and competition: an evolution in the making. Wharton Financial Institutions Center, set. 2003.

— directions for future research. European Journal of Operational Research, n. 98, 1997.

BERNANKE, Ben; GERTLER, Mark. Agency costs, net worth, and business fluctuations. American Economic Review, v. 79, n. 1, mar. 1989.

BERNSTEIN, Peter. Against the Gods: the remarkable story of risk. Nova Iorque: John Wiley \& Sons, 1996.

BLACK, Julia. Managing the financial crisis: the constitutional dimension. LSE Law, Society and Economy Working Papers, n. 12/2010, jun. 2010.

— ROUCH, David. The development of the global markets as rule-makers: engagement and legitimacy. Law and Financial Markets Review, 2(3), maio 2008.

BODIE, Zvi; MERTON, Robert C. Finanças. 2. ed. São Paulo: Bookman, 2000.

BOLLE, Monica Baumgarten de; CARNEIRO, Dionísio Dias (Org.). A reforma do sistema financeiro americano: nova arquitetura internacional e o contexto regulatório brasileiro. Rio de Janeiro: Instituto de Estudos de Política Econômica, Casa das Garças, 2009. 
BORDO, Michael D.; MISRACH, Bruce; SCHWARTZ, Anna. Real versus pseudointernational systemic risk: some lessons from history. NBER Working Paper Series, $\mathrm{n}$. W5371, 1995.

BORIO, Claudio. Towards a macroprudential framework for financial supervision and regulation? BIS Working Paper, n. 128, 2003.

_; FURFINE, Craig; LOWE, Phillip. Procyclicality of the financial system and financial stability: issues and policy options, marrying the macro-and micro-prudential dimensions of financial stability. BIS Papers, n. 1, 2001.

BOUZAN, Ary. Os bancos comerciais no Brasil: uma análise do desenvolvimento recente (1965-1971). São Paulo: Federação Brasileira das Associações de Bancos, 1972.

BOYD, John; GERTLER, Mark. U.S. commercial banking: trends, cycles, and policy. New York University Department of Economics Working Papers, n. 93-19, abr. 1993.

—; PRESCOTT, Edward C. Financial intermediary-coalitions. Journal of Economics Theory, n. 38, 1986.

BROOME, Lissa L.; MARKHAM, Jerry W. Regulation of bank financial service activities: cases and materials. West Group Publishing, 2005.

CACCIOLA, Salvatore Alberto. Eu Alberto Cacciola confesso: o escândalo do Banco Marka. São Paulo: Record, 2001.

CALADO, Luiz Roberto. Regulação e autorregulação do mercado financeiro: conceito, evolução e tendências num contexto de crise. São Paulo: Saint Paul, 2009.

CALOMIRIS, Charles; KAHN, Charles. The role of demandable debt in structuring optimal banking arrangements. American Economic Review, 81(3), 1991.

CAMPILONGO, Celso F.; VEIGA DA ROCHA, Jean Paul Cabral; MATTOS, Paulo Todescan Lessa (Org.). Concorrência e regulação no sistema financeiro. São Paulo: Max Limonad, 2002. 
CAPIE, Forrest; FISCHER, Stanley; GOODHART, Charles; SCHNADT, Norbert (Org.). The future of central banking: the tercentenary symposium of the Bank of England. Cambridge: Cambridge University Press, 1994.

CARRASCO, Vinicius. Incentivos e crise. In: GARCIA, Márcio; GIAMBIAGI, Fábio (Org.). Risco e regulação: por que o Brasil enfrentou bem a crise financeira recente e como ela afetou a economia mundial. Rio de Janeiro: Elsevier, 2010.

CARVALHEIRO, Nelson. Bancos comerciais no Brasil (1964-1976): crescimento e concentração. 1982. Dissertação (Mestrado) - FIPE-USP. Mimeografado.

CARVALHO, Carlos Eduardo. Ocultamento e mistificação nas relações do Banco Central com os bancos: notas sobre a experiência brasileira. Política\&Sociedade, n. 6, abr. 2005. — ; VIDOTTO, Carlos Augusto. Abertura do setor bancário ao capital estrangeiro nos anos 1990: os objetivos e o discurso do governo e dos banqueiros. Nova Economia, Belo Horizonte, v. 17(3), 2007.

CARVALHO, Fernão J. Cardim de; SOUZA, Francisco E. P.; SICSÚ, João; PAULA, Luiz F. R. de; STUDART, Rogério. Economia monetária e financeira: teoria e política. Rio de Janeiro: Campus, 2001.

CARVALHO DE MENDONÇA, J.X. Tratado de direito comercial brasileiro. Rio de Janeiro: Annuario do Brasil, 1947.

CASTILHO, Ela Wiecko V. de. O controle penal nos crimes contra o Sistema Financeiro Nacional. Belo Horizonte: Del Rey, 2006.

CEBS. Range of practices on supervisory colleges and home-host cooperation, London, 27 dez. 2007.

Report of the peer review on the functioning of supervisory colleges, London, 18 out. 2010.

CHALHUB, Melhim Namem. Negócio fiduciário. São Paulo: Renovar, 2000. 
CHANG, Ha-Joon. Globalisation, economic development and the role of the State. Zed Books, 2003.

CIHAK, Martin; POPDIERA, Richard. Is one watchdog better than three? International experience with integrated financial sector supervision. International Monetary Fund Working Paper, n. 6/57, 2006.

CINTRA, Marcos A. M.; FARHI, Maryse. A crise financeira e o global shadow banking system. Revista Novos Estudos, Cebrap, n. 82, nov. 2008.

COASE, Ronald H. The nature of the firm. In: COASE, Ronald H. The firm, the market and the law. Chicago: The University of Chicago Press, 1990 (ed. original, 1937).

- The problem of social cost. In: COASE, Ronald H. The firm, the market and the law. Chicago: The University of Chicago Press, 1990 (ed. original, 1937).

COLE, Margareth. The UK FSA: Nobody does it better? 17 out. 2006. Disponível em: <www.fsa.gov.uk/pages/Library/Communication/Speeches/2006/1017_mc.shtml>. Acesso em: 23 dez. 2010.

COMISSÃO EUROPEIA. The high level group on financial supervision in the EU, Bruxelas, 25 fev. 2009.

COMITÊ DE BASILEIA. Agreement on Basel Committee capital and liquidity reform package. Basileia, jul. 2010.

—. Amendment to the capital accord to incorporate market risks. Basileia, jan. 1996.

_. Core principles for systemically important payment systems. Basileia, jan. 2001.

—. Framework for internal control systems in banking organizations. Basileia, set. 1998.

—. Good practice principles on supervisory colleges. Basileia, out. 2010.

- International convergence of capital measurement and capital standards. Basileia, jul. 1988.

- International convergence of capital measurement and capital standards: a revised framework. Basileia, jun. 2004.

- International framework for liquidity risk measurement, standards and monitoring. Basileia, dez. 2010. 
- Joint forum on financial conglomerates: supervision of financial conglomerates. Basileia, fev. 1998.

—. Minimum standards for the supervision of international banking groups and their cross-border establishments. Basileia, jul. 1992.

—. Princípios fundamentais para uma supervisão bancária efetiva. Basileia, out. 2006.

- Principles for the supervision of bank's foreign establishments. Basileia, maio 1983.

- Report and recommendations of the cross-border bank resolution group. Basileia, mar. 2010.

- Report on special purpose entities. Basileia, set. 2009.

- Report to the governors on the supervision of bank's foreign establishments. Basileia, set. 1975 .

—. Risk management guidelines for derivatives. Basileia, jul. 1994.

—. Strengthening the resilience of the banking sector. Basileia, dez. 2010.

—

COMPARATO, Fábio Konder. O indispensável direito econômico. Revista dos Tribunais, São Paulo, v. 353, 1965.

CORAZZA, Gentil. Crise e reestruturação bancária no Brasil. Universidade Federal do Rio Grande do Sul, 2000. Disponível em: <www.ufrgs.br/ppge/pcientifica/2000_08.pdf>. Acesso em: 23 dez. 2010.

CORTEZ, Thiago Machado. O conceito de risco sistêmico e suas implicações para a defesa da concorrência no mercado bancário. In: CAMPILONGO, Celso F.; VEIGA DA ROCHA, Jean Paul C.;

MATTOS, Paulo Todescan Lessa. Concorrência e regulação no sistema financeiro. São Paulo: Max Limonad, 2002.

COSTA NETO, Yttrio Corrêa da. Bancos oficiais no Brasil: origem e aspectos do seu desenvolvimento. Brasília: Banco Central do Brasil, 2004.

DANIELSON, Arnold. Getting ready for the $21^{\text {st }}$ Century: a look at recent banking trends. Banking Policy Report, 18(1), mar. 1999. 
DE BANDT, Olivier; HARTMANN, Philipp. Systemic risk: a survey. Working Paper Series, European Central Bank, n. 35, 2000.

DE LUCCA, Newton. A responsabilidade civil dos administradores de instituições financeiras. Revista de Direito Mercantil, Industrial, Econômico e Financeiro, n. 67, jul.-set. 1987.

DELL'ARICCIA, Giovanni. Asymmetric information and the structure of the banking industry. The European Economic Review, v. 45, 2001.

DEMIRGUÇ-KUNT, Asli; DETRAGIACHE, Enrica. Does deposit insurance increase banking system stability? An empirical investigation. Journal of Monetary Economics, 49(7), 2002.

— developing countries. IMF Staff Papers, n. 45, 1998.

; HUIZINGA, Harry. Market discipline and deposit insurance. Journal of Monetary Economics, 51(2), 2004.

DEPARTMENT OF TREASURY. Blueprint for a modernized financial regulatory structure. Washington, 31 mar. 2008,

- Financial regulatory reform - A new foundation: rebuilding financial supervision and regulation. Washington, 17 jun. 2009

Regulatory reform over-the-counter (OTC) derivatives. Washington, 13 maio 2009.

DE SANCTIS, Fausto Martin. Punibilidade no Sistema Financeiro Nacional. Campinas: Millenium, 2003.

DIAMOND, Douglas. Financial intermediation and delegated monitoring. Review of Economic Studies, 51 (3), 1984.

; DYBVIG, Philip H. Bank runs, deposit insurance, and liquidity. Federal Reserve Bank of Minneapolis Quarterly Review, 24(1), 2000 (ed. original, 1983). 
DI NOIA, Carmine; DI GIORGIO, Giorgio. Should banking supervision and monetary policy tasks be given to different agencies? International Finance, 2(3), 1999.

DOWD, Kevin. Too big to fail? Long-Term Capital Management and the Federal Reserve. Briefing Papers, Cato Institute, n. 52, 1999.

DUARTE, Maria Carolina de Almeida. Crimes contra o Sistema Financeiro Nacional: uma abordagem interdisciplinar. Rio de Janeiro: Forense, 2003.

EICHENGREEN, Barry. Out of the box thoughts about international financial structure. IMF Working Paper, n. 9, maio 2009.

FAMA, Eugene. Market efficiency, long-term returns, and behavioral finance. Journal of Financial Economics, v. 49, n. 3, 1998.

FEDERAL RESERVE. The supervisory capital assessment program: overview of results. Washington, 7 maio 2009.

FERGUSON, Roger. Alternative approaches to financial supervision and regulation. Journal of Financial Services Research, 17(1), 1999.

FERNANDES, Antônio Alberto Grossi. O Sistema Financeiro Nacional comentado. São Paulo: Saraiva, 2009.

FERRAN, Eilís; GOODHART, Charles A. E. (Org.). Regulating financial services and markets in the 21st century. Oxford: Hart Publishing, 2001.

FERREIRA, Caio Fonseca. Estrutura, concorrência e performance do setor bancário em um mercado heterogêneo. 2005. Tese (Doutorado) - FEA-USP, São Paulo. Mimeografado.

FIANNI, Ronaldo. Teoria da regulação econômica: estado atual e perspectivas futuras. Teoria política e instituições de defesa da concorrência. Grupo de Regulação da Concorrência da UFRJ. Mimeografado. 
FINANCIAL STABILITY BOARD. FSB principles for sound compensation practices Implementation standards. Basileia, set. 2009.

FINANCIAL STABILITY FORUM. Report of the Financial Stability Forum on enhancing market and institutional resilience. Basileia, abr. 2008.

FMI. Global financial stability report: containing systemic risks and restoring financial soundness. Washington: International Monetary Fund, abr. 2008.

- Global financial stability report: responding to the financial crisis and measuring systemic risk. Washington: International Monetary Fund, abr. 2009.

FORTUNA, Eduardo. Mercado financeiro: produtos e serviços. 15. ed. Rio de Janeiro: Qualitymark, 2004.

FRANCO, Gustavo H. B.; ROSMAN, Luiz Alberto C. A crise bancária norte-americana: algumas lições da experiência brasileira. In: GARCIA, Márcio; GIAMBIAGI, Fábio (Org.). Risco e regulação: por que o Brasil enfrentou bem a crise financeira recente e como ela afetou a economia mundial. Rio de Janeiro: Elsevier, 2010.

FREITAS, Maria Cristina Penido. A evolução dos bancos centrais e seus desafios no contexto da globalização financeira. Revista de Estudos Econômicos, Instituto de Pesquisas Econômicas, São Paulo, v. 30, n. 3, 2000.

GAGGINI, Fernando Schwarz. Securitização de recebíveis. São Paulo: Leud, 2003.

GALBRAITH, John Kenneth. A short history of financial euphoria. Nova Iorque: Penguim Books, 1990.

—. The great crash of 1929. Nova Iorque: Mariner Books, 1997.

GARCIA, Gillian. Deposit insurance: actual and good practices. IMF Occasional Paper, Washington: International Monetary Fund, n. 197. 
GARCIA, Márcio; GIAMBIAGI, Fábio (Org.). Risco e regulação: por que o Brasil enfrentou bem a crise financeira recente e como ela afetou a economia mundial. Rio de Janeiro:

Elsevier, 2010.

GIAMBIAGI, Fábio; BARROS, Octavio de (Org.). Brasil pós-crise: agenda para a próxima década. Rio de Janeiro: Elsevier, 2009.

GIOVANOLI, Mario. Reflections on international financial standards as "soft law". In: ANDENAS, Mads; NORTON Joseph J. International monetary and financial law upon entering the new millennium: a tribute to Sir Joseph and Ruth Gold. London: The British Institute of Comparative and International Law, 2003.

GOLDBERG, Daniel K. Spread, concentração e concorrência no setor bancário. Revista do Ibrac, v. 11, n. 3, 2004.

GOLDFAJN, Ilan; HENNING, Katherine; MORI, Hélio. Brazil's financial system: resilience to shocks, no currency substitution, but struggling to promote growth. Working Paper Series, Banco Central do Brasil, n. 75, 2003.

GONÇALVES, Luiz Carlos dos Santos. Exame necroscópico da lei do colarinho-branco. In: ROCHA, João Carlos de Carvalho; HENRIQUES FILHO, Tarcísio Humberto Parreiras; CAZETTA, Ubiratan (Org.). Crimes contra o Sistema Financeiro Nacional: 20 anos da Lei n. ${ }^{\circ}$ 7.492/86. Belo Horizonte: Del Rey, 2006.

GOODHART, Charles A. E. Money, information, and uncertainty. 2. ed. Cambridge: The MIT Press, 1989.

- Regulating the regulator - An economist's perspective. In: FERRAN, Eilís; GOODHART, Charles. Regulating financial services and markets in the 21st century. Oxford: Hart Publishing, 2001.

- Some regulatory concerns. In: GOODHART, Charles A. E. (Org.). The emerging framework of financial regulation. London: Central Banking Publications, 1998.

- The central bank and the financial system. Cambridge: The MIT Press, 1995.

- The organizational structure of banking supervision. In: BREALEY, Richard A.

(Org.). Financial stability and Central Banks: a global perspective. London: Routledge, 2001. 
; HARTMANN, Philipp; LLEWELLYN, David; ROJAS-SUÁREZ, Liliana;

WEISBROD, Steven. Financial Regulation: why, how and where now? London: Routledge, 1998.

GRAU, Eros Roberto. O direito posto e o direito pressuposto. São Paulo: Malheiros, 1996.

GROUHY, Michel; MARKUS, Robert. Gerenciamento de risco: abordagem conceitual e prática. São Paulo: QualityMark, 2004.

GROUP OF 10. Report on consolidation in the financial sector. Washington: Group of 10, 2001.

GROUP OF 30. Global institutions, national supervision and systemic risk: a study group report. Washington: Group of 30, 1997.

- The structure of financial supervision: approaches and challenges in a global marketplace. Washington: Group of 30, 2008.

GUIMARÃES, André Luiz de Souza; LIMA, Jorge Cláudio Cavalcante de Oliveira. Avaliação do risco de crédito no Brasil. In: GARCIA, Márcio; GIAMBIAGI, Fábio (Org.). Risco e regulação: por que o Brasil enfrentou bem a crise financeira recente e como ela afetou a economia mundial. Rio de Janeiro: Elsevier, 2010.

GUZMAN, Andrew T.; MEYER, Timothy L. International soft law. Journal of Legal Analysis, 2(1), 2010.

HALDANE, Andrew G. The Financial Stability Forum (FSF): just another acronym? In: FERRAN, Eilís; GOODHART, Charles. Regulating financial services and markets in the 21st century. Oxford: Hart Publishing, 2001.

HANSON, Samuel; KASHYAP, Anil K.; STEIN, Jeremy C. A macroprudential approach to financial regulation. Paper prepared for Journal of Economic Perspectives, jul. 2010. Mimeografado. 
HANWECK, Gerald A.; SHULL, Bernard. The bank merger movement: efficiency, stability and competitive policy concerns. Antitrust Bulletin, n. 44, 1999.

HAUBRICH, Joseph G. Combining bank supervision and monetary policy. Federal Reserve Bank of Cleveland, Economic Commentary, v. 11, 1996.

HAYEK, Friedrich A. Economics and knowledge. In: HAYEK, Friedrich A. Individualism and economic order. Chicago: The University of Chicago Press, 1948 (ed. original, 1937). —. The use of knowledge in society. In: HAYEK, Friedrich A. Individualism and economic order, Chicago: The University of Chicago Press, 1948 (ed. original, 1937).

HEALY, Paul M.; PALEPU, Krishna G. The fall of Enron. Journal of Economic Perspectives, 17 (2), 2003.

HILL, Claire A. Regulating the rating agencies. Washington University Law Quarterly, v. 82, 2004.

HONOHAN, Patrick; KLINGEBIEL, Daniela. Controlling the fiscal costs of banking crisis. Policy Research Working Paper, n. 2.441, The World Bank, 2000.

HOUSE OF COMMONS. The run on the Rock, 24 jan. 2008. Disponível em: <www.publications.parliament.uk/pa/cm200708/cmselect/cmtreasy/56/5602.htm>. Acesso em: 23 dez. 2010.

HOVENKAMP, Herbert J. The Coase theorem and Arthur Cecil Pigou. Arizona Law Review, v. 51, 2009.

HUCK, Hermes Marcelo. Aspectos jurídicos das negociações de valores mobiliários, títulos de crédito e produtos financeiros por meios digitais. Congresso Internacional de Comércio Eletrônico e Internet no Brasil, São Paulo, nov. 2002.

—. Contratos internacionais de financiamento: a lei aplicável. Revista de Direito Mercantil Industrial, Econômico e Financeiro, São Paulo, v. 53, 1984.

- Contratos com o Estado: aspectos de direito internacional. São Paulo: Aquarela, 1989. 
IAIS. Guidance on insurance regulation and supervision for emerging market economies. Basileia, set. 1997.

—. Insurance core principles. Basileia, out. 2003.

—. Principles on capital adequacy and insolvency. Basileia, jan. 2002.

- Principles on minimum requirements for supervision of reinsurers. Basileia, out. 2002.

IBGE. Sistema financeiro: uma análise a partir das contas nacionais. Rio de Janeiro: IBGE, 1997.

IOSCO. Capital adequacy for securities firms. Relatório do Comitê Técnico, Madrid, 1989.

—. Code of conduct fundamentals for credit rating agencies. Madrid, dez. 2004.

- Coordination between cash and derivative markets - Contract design of derivative products on stock indices and measures to minimize market disruption. Relatório do Comitê Técnico, Madrid, 1992.

—. Objectives and principles of securities regulation. Madrid, jun. 2010.

- Operational and financial risk management control mechanisms for over-the-counter derivatives activities of regulated securities firms. Madrid, jul. 1994.

—. Principles for the supervision of financial conglomerates. Relatório do Comitê Técnico, Madrid, 1992.

IRTI, Natalino. L'ordine giuridico del mercato. Bari: Laterza, 2003 (ed. original, 1998).

JACKSON, Howell E. The role of credit rating agencies in the establishment of capital standards for financial institutions in a global economy. In: FERRAN, Eilís; GOODHART, Charles. Regulating financial services and markets in the 21st century. Oxford: Hart Publishing, 2001.

- Variation in the intensity of financial regulation: preliminary evidence and potential implications. Yale Journal on Regulation, v. 24, n. 2, 2007.

JANTALIA, Fabiano (Org.). A regulação jurídica do Sistema Financeiro Nacional. Rio de Janeiro: Lumen Juris, 2009. 
—. Curso de regulação do Sistema Financeiro Nacional. Brasília: Programa Saber Direito, 2009.

JONES, Kenneth; CRITCHFIELD, Tim. Consolidation in the U.S. banking industry: Is the "long, strange trip" about to end? FDIC Banking Review, v. 17, n. 4, 2005.

KAHNEMAN, Daniel; SLOVIC, Paul; TVERSKY, Amos. Judgment under uncertainty: heuristics and biases. Cambridge: Cambridge University Press, 1982.

KANE, Edward J. How market forces influence the structure of financial regulation. In: HARAF, William S.; KUSHMEIDER, Rose Marie. Restructuring banking and financial services in America. American Enterprise Institute, 1988.

- Implications of superhero metaphors for the issue of banking powers. Journal of Banking and Finance, v. 23, n. 2-4, 1999.

- Interaction of financial and regulatory interaction. American Economic Review, v. 78, n. 2, 1988.

\footnotetext{
The $S \& L$ insurance mess: how did it happen? Washington: Urban Institute Press, 1989.
}

KASHYAP, Anil K.; STEIN, Jeremy C. Cyclical implications of the Basel-II capital standards. Federal Reserve Bank of Chicago Economic Perspectives, 28(1), 2008.

KAUFMAN, George. Bank contagion: a review of theory and evidence. Journal of Financial Services Research, v. 8, n. 2, 1994.

—. Bank failures, systemic risk, and bank regulation. Cato Journal, v. 16, n. 1, 1996.

—. Bank runs: causes, benefits, and costs. Cato Journal, v. 7, n. 3, 1988.

KAUFMAN, Henry. The road to financial reformation. Nova Iorque: John Wiley \& Sons, 2009.

KINDLEBERGER, Charles P. Manias, panics and crashes. 4. ed. Nova Iorque: John Wiley \& Sons, 2000. 
KING, Robert; LEVINE, Ross. Finance entrepreneurship and growth: theory and evidence. Journal of Monetary Economics, 32(3), 1993.

KNIGHT, Frank H. Risk, uncertainty and profit. Washington: Beard Group, 2002 (ed. original, 1921).

KROSZNER, Randall S. On the political economy of banking and financial regulatory reform in emerging markets. CRSP Working Paper, n. 472, 1998.

- The motivations behind banking reform. Regulation, 24(2), 2001.

— ; STRAHAN, Philip E. Obstacles to optimal policy - The interplay of politics and economics in shaping bank supervision and regulation reforms. In: MISHKIN, Frederic S. (Org.). Prudential Supervision: what works and what doesn't. Chicago: The University of Chicago Press, 2001.

KRUGMAN, Paul. The return of depression economics and the crisis of 2008. New York: Norton, 2009.

LAEVEN, Luc. Bank risk and deposit insurance. World Bank Economic Review, 16(1), 2002. ; VALENCIA, Fabian. Systemic banking crises: a new database. IMF Working Paper, n. $8 / 224$, nov. 2008.

LAMEIRA, Valdir Jesus. Mercado de capitais. Rio de Janeiro: Forense Universitária, 2001.

LANGOHR, Herwig M.; LANGOHR Patricia T. The rating agencies and their credit ratings: what they are, how they work and why they are relevant. London: Wiley, 2008.

LANNOO, Karel. Challenges to the structure of financial supervision in the EU. In: BALLING, Morten; HENNESSY, Elizabeth; HOCHREITER, Eduard H. Adapting to financial globalization. London: Routledge, 2001.

LASTRA, Rosa Maria. Banco Central e regulamentação bancária. Belo Horizonte: Del Rey, 2000. 
LAWARE, John. Testimony in U.S. Congress, Subcommittee on Economic Stabilization of the Committee on Banking, Finance and Urban Affairs, U.S. House of Representatives, Economic implications of the "too big to fail" policy: hearings, May 9, 1991, $102^{\text {nd }}$ Congress, $1^{\text {st }}$ session.

LEFORT, Daniel. Transparency and accountability of Central Banks, Bank for International Settlement, 2006. Disponível em: <www.cemla.org/pdf/legales/leg-06-lefort.pdf>. Acesso em: 26 dez. 2010.

LELAND, Hayne E.; PYLE, David H. Informational asymmetries, financial structure, and financial intermediation. Journal of Finance, 32(2), 1977.

LEVINE, Ross. Finance and growth: theory and evidence. In: AGHION, Philippe; DURLAUF, Steven. Handbook of Economic Growth. Amsterdam: North-Holland Elsevier Publishers, 2005.

- Financial development and economic growth: views and agenda. Journal of Economic Literature, v. 35, jun. 1997.

LO, Andrew W. The feasibility of systemic risk measurement. Written Testimony of Andrew W. Lo prepared for the U.S. House of Representatives, Financial Services Committee, 19 out. 2009. Disponível em: <web.mit.edu/alo/www/>. Acesso em: 23 dez. 2010.

LOUIS, Jean Victor (Org.) Banking supervision in the European Community: institutional aspects. Bruxelas: Editions de L' Université de Bruxelles, 1995.

LOWENSTEIN, Roger. The end of Wall Street. Nova Iorque: The Penguin Press, 2010. - When genius failed: the rise and fall of Long-Term Capital Management. Nova Iorque: Random House Trade Paperbacks, 2000.

LOYOLA, Gustavo. O futuro da regulação financeira. In: GARCIA, Márcio; GIAMBIAGI, Fábio (Org.). Risco e regulação: por que o Brasil enfrentou bem a crise financeira recente e como ela afetou a economia mundial. Rio de Janeiro: Elsevier, 2010. 
LUNDBERG, Eduardo Luís. Rede de proteção e saneamento do sistema bancário. In:

SADDI, Jairo (Org.). Intervenção e liquidação extrajudicial no Sistema Financeiro Nacional: 25 anos da Lei n. 6.024/74. São Paulo: Textonovo, 1999.

—. Saneamento do sistema financeiro - a experiência brasileira dos últimos 25 anos. In: SADDI, Jairo (Org.). Intervenção e liquidação extrajudicial no Sistema Financeiro Nacional: 25 anos da Lei n. ${ }^{\circ}$ 6.024/74. São Paulo: Textonovo, 1999.

MACARINI, José Pedro. A política bancária do regime militar: o projeto do conglomerado (1967-1973). Economia e Sociedade, Campinas, v. 16, n. 3, dez. 2007.

MACEY, Jonathan R. Regulation and disaster: some observations in the context of systemic risk. In: LITAN, Robert E.; SANTOMERO, Anthony M. (Org.). Papers on Financial Services. Washington: Brookings Institution Press, 1998.

MACHADO, Agapito. Crimes do colarinho-branco e contrabando/descaminho. São Paulo: Malheiros, 1998.

MACKAY, Charles. Extraordinary popular delusions and the madness of crows. Hampshire: Harriman House Classics, 2003.

MAIA, Geraldo Villar Sampaio. Reestruturação bancária no Brasil: o caso do Proer. Notas Técnicas do Bacen, n. 38, jun. 2003.

MAIA, Rodolfo Tigre. Dos crimes contra o Sistema Financeiro Nacional: anotações à Lei

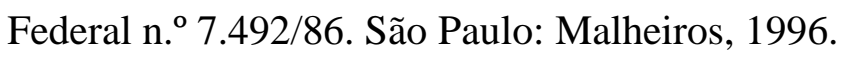

MALAN, Pedro. A coordenação internacional da regulação financeira é viável? In: BOLLE, Monica Baumgarten de; CARNEIRO, Dionísio Dias (Org.). A reforma do sistema financeiro americano: nova arquitetura internacional e o contexto regulatório brasileiro. Rio de Janeiro: Instituto de Estudos de Política Econômica - Casa das Garças, 2009.

—. Uma visão abrangente sobre a crise e o processo de sua superação. In: GARCIA, Márcio; GIAMBIAGI, Fábio (Org.). Risco e regulação: por que o Brasil enfrentou bem a crise financeira recente e como ela afetou a economia mundial. Rio de Janeiro: Elsevier, 2010. 
MANTEGA, Guido. O governo Geisel, o II PND e os economistas. Relatório de Pesquisa, EAESP-FGV, Núcleo de Pesquisas e Publicações, n. 3, 1997.

MARQUEZ, Robert. Competition, adverse selection and information dispersion in the banking industry. The Review of Financial Studies, v. 15, 2001.

MARSHALL, Alfred. Principles of economics. Nova Iorque: Cosimo, 2006 (ed. original, 1890).

MARTINS, Carlos Estevam. Tecnocracia e burocracia. Estudos Cebrap, n. 2, out. 1972.

MCDONALD, Gordon. Comparing the Paulson Blueprint with the Geithner White Paper. The PEW Economic Policy Group, Washington, 2009.

MERTON, Robert C.; BODIE, Zvi. Design of financial systems: towards a synthesis of function and structure. Journal of Investment Management, v. 3, n. 1, 2005.

MESQUITA, Mário M. C.; TORÓS, Mário. Gestão do Banco Central no pânico de 2008. In: GARCIA, Márcio; GIAMBIAGI, Fábio (Org.). Risco e regulação: por que o Brasil enfrentou bem a crise financeira recente e como ela afetou a economia mundial. Rio de Janeiro: Elsevier, 2010.

MEYER, Laurence H. Supervising large complex banking organizations - Adapting to change. In: MISHKIN, Frederic S. (Org.). Prudential supervision: what works and what doesn't. Chicago: The University of Chicago Press, 2001.

MISHKIN, Frederic S. The economics of money, banking, and financial markets. 7. ed. Addison Wesley, 2006.

- (Org.). Prudential supervision: what works and what doesn't. Chicago: The University of Chicago Press, 2001.

- Prudential Supervision: why is it important and what are the issues. In: MISHKIN, Frederic S. (Org.). Prudential supervision: what works and what doesn't. Chicago: The University of Chicago Press, 2001. 
MOREIRA, Alexandre Magno Fernandes. Os crimes contra o Sistema Financeiro Nacional e o princípio da insignificância. In: JANTALIA, Fabiano (Org.). A regulação jurídica do Sistema Financeiro Nacional. Rio de Janeiro: Lumen Juris, 2009.

MOSQUERA, Roberto Quiroga. Tributação no mercado financeiro e de capitais. São Paulo: Dialética, 1999.

MULLER, Bianca Abbot. Concorrência no setor bancário brasileiro. 2007. Dissertação (Mestrado) - FD-USP, São Paulo. Mimeografado.

NAKANE, Márcio I. Concorrência e spread bancário: uma revisão da evidência para o Brasil. In: BANCO CENTRAL DO BRASIL. Economia bancária e crédito: avaliação de 4 anos do projeto juros e spread bancário. Brasília: Banco Central do Brasil, 2003.

; WEINTRAUB, Daniela B. Banking privatization and productivity evidence for Brazil. Trabalhos para Discussão, Banco Central do Brasil, n. 90, 2004.

NASSER, Salem Hikmat. Desenvolvimento, costume internacional e soft law. In: AMARAL JR., Alberto (Org.). Direito internacional e desenvolvimento. São Paulo: Manole, 2005.

NATIONAL RESEARCH COUNCIL. New directions for understanding systemic risk: a report on a conference cosponsored by the Federal Reserve Bank of New York and the National Academy of Sciences. Washington: The National Academies Press, 2006.

NÓBREGA, Maílson da. Origens da crise. In: GARCIA, Márcio; GIAMBIAGI, Fábio (Org.). Risco e regulação: por que o Brasil enfrentou bem a crise financeira recente e como ela afetou a economia mundial. Rio de Janeiro: Elsevier, 2010.

NORTHCOTT, Carol Ann. Competition in banking: a review of the literature. Working Paper, Bank of Canada, n. 2004-24, 2004.

NOVAES, Ana. Derivativos e governança corporativa: o caso Sadia - corrigindo o que não funcionou. In: GARCIA, Márcio; GIAMBIAGI, Fábio (Org.). Risco e regulação: por que o Brasil enfrentou bem a crise financeira recente e como ela afetou a economia mundial. Rio de Janeiro: Elsevier, 2010. 
NUSDEO, Ana Maria. Defesa da concorrência e globalização econômica: o controle da concentração de empresas. São Paulo: Malheiros, 2002.

NUSDEO, Fábio. Curso de economia: introdução ao direito econômico. 5. ed. São Paulo: RT, 2008.

Desenvolvimento e ecologia. São Paulo: Saraiva, 1975.

OLIVEIRA FILHO, Luiz Chrysostomo de. Autorregulação no sistema financeiro. In:

BOLLE, Monica Baumgarten de; CARNEIRO, Dionísio Dias (Org.). A reforma do sistema financeiro americano: nova arquitetura internacional e o contexto regulatório brasileiro. Rio de Janeiro: Instituto de Estudos de Política Econômica - Casa das Garças, 2009.

OLIVEIRA, Gesner de. Concorrência: panorama no Brasil e no mundo. São Paulo: Saraiva, 2001.

. Defesa da concorrência e regulação no setor bancário. EAESP/FGV/NPP - Núcleo de Pesquisas e Publicações, 2000. Mimeografado.

. Defesa da concorrência e regulação no setor bancário. In: CAMPILONGO, Celso F.; VEIGA DA ROCHA, Jean Paul Cabral; MATTOS, Paulo Todescan Lessa (Org.).

Concorrência e regulação no sistema financeiro. São Paulo: Max Limonad, 2002.

OLSON, Mancur. The logic of collective action. Cambridge: Harvard University Press, 1965.

OVERTVELDT, Johan Van. Bernanke's test: Ben Bernanke, Alan Greenspan, and the drama of the central banker. Chicago: B2 Book, 2009.

PARTNOY, Frank. The Siskel and Ebert of financial markets: two thumbs down for the credit rating agencies. Washington Quarterly Review, v. 77, n. 3, 1999.

PAULA, Áureo Natal de. Crimes contra o Sistema Financeiro Nacional e o mercado de capitais. 4. ed. Curitiba: Juruá, 2009.

PAULA, Luis Fernando; MARQUES, Maria Beatriz L. Tendências recentes da consolidação bancária no Brasil. Revista Análise Econômica, ano 24, n. 45, 2006. 
PAULIN, Luiz Alfredo. Conceito de intervenção e liquidação extrajudicial: pressupostos para sua decretação. In: SADDI, Jairo (Org.). Intervenção e liquidação extrajudicial no Sistema Financeiro Nacional: 25 anos da Lei n. 6.024/74. São Paulo: Textonovo, 1999.

—. Evolução do Sistema Financeiro Nacional. Revista de Direito Bancário, do Mercado de Capitais e da Arbitragem, São Paulo: RT, n. 17, 2002.

PELTZMAN, Sam. Toward a more general theory of regulation. Journal of Law and Economics, 19(2), 1976.

PIGOU, Arthur C. The economics of welfare. Nova Iorque: Cosimo, 2005 (ed. original, 1920).

PIMENTEL, Manoel Pedro. Crimes contra o Sistema Financeiro Nacional. São Paulo: RT, 1987.

PINDYCK, Robert S.; RUBINFELD, Daniel L. Microeconomia. 4. ed. São Paulo: Makron Books, 1999.

PINHO DE MELLO, João Manoel. Adverse selection in the market for unsecured loans: the case of overdraft loans in Brazil. 2004. Tese (Doutorado) - Department of Economics, Stanford University. Mimeografado.

—. Estrutura, concorrência e estabilidade. In: GARCIA, Márcio; GIAMBIAGI, Fábio (Org.). Risco e regulação: por que o Brasil enfrentou bem a crise financeira recente e como ela afetou a economia mundial. Rio de Janeiro: Elsevier, 2010.

—. Proposta de delimitação do escopo de análise da SDE em atos de concentração bancárias e apurações de conduta. Seminário de Estudos e Métodos Quantitativos Aplicados à Defesa da Concorrência e à Regulação Econômica, Instituto de Pesquisas Econômicas Aplicadas (IPEA), Relatório Final, Área II.1, ANPEC/IPEA/SDE, abr. 2005.

PINTO, Gustavo Mathias Alves. Concorrência em risco: Banco Central deve ficar mais atento à concentração bancária. Consultor Jurídico, 29 jun. 2006.

- Concorrência no setor bancário - Contribuição ao estudo do caso brasileiro. Revista do Ibrac, v. 13, 2005. 
PORTOCARRERO DE CASTRO, Helio Oliveira. As causas econômicas da concentração bancária. Rio de Janeiro: IBMEC, 1981.

POSNER, Richard A. Theories of economic regulation. The Bell Journal of Economics and Management Science, 5(2), 1975.

PUGA, Fernando Pimentel. Sistema financeiro brasileiro: reestruturação recente, comparações internacionais e vulnerabilidades à crise cambial. Textos para Discussão BNDES, n. 68, 1999.

RHOADES, Stephen A. A summary of merger performance studies in banking (1980-1993). Board of Governors of the Federal Reserve System, Staff Studies, n. 167, 1994.

Concentration of world banking and the role of US banks among the 100 largest (1956-1980). Journal of Banking and Finance, v. 7, n. 3, 1983.

RHODES, Amy K. The role of the SEC in the regulation of rating agencies: well-placed reliance or free-market interference? 20 Seton Hall Legis J. 293, 1996.

ROCHA, Fernando A. S. Evolução da concentração bancária no Brasil (1994-2000). Notas Técnicas do Bacen, n. 11, nov. 2001.

ROUBINI, Nouriel; MIHM, Stephen. A economia das crises. São Paulo: Intrínseca, 2010.

RUBIN, Isaac I. A history of economic thought. London: Ink Links, 1979.

RUBINSTEIN, Mark. Rational markets: yes or no? The affirmative case. Financial Analysts Journal, v. 57, n. 3, 2001.

SADDI, Jairo. Algumas propostas de mudança para a Lei n. ${ }^{\circ}$ 6.024. In: SADDI, Jairo (Org.). Intervenção e liquidação extrajudicial no Sistema Financeiro Nacional: 25 anos da Lei n. ${ }^{\circ}$ 6.024/74. São Paulo: Textonovo, 1999.

\footnotetext{
—. Crise e regulação bancária: navegando mares revoltos. São Paulo: Textonovo, 2001. - (Org.). Intervenção e liquidação extrajudicial no Sistema Financeiro Nacional: 25
} anos da Lei n. ${ }^{\circ}$ 6.024/74. São Paulo: Textonovo, 1999. 
—. Temas de regulação financeira. São Paulo: Quartier Latin, 2010.

SALOMÃO, Calixto. Direito concorrencial: as estruturas. 2. ed. São Paulo: Malheiros, 2002. —. Regulação e concorrência (estudos e pareceres). São Paulo: Malheiros, 2002.

SALOMÃO, Eduardo. Direito bancário. São Paulo: Jurídico Atlas, 2007.

SAUNDERS, Anthony; WALTER, Ingo. Universal banking in the United States: what could we gain? What could we lose? Nova Iorque: Oxford University Press, 1994.

SCHAPIRO, Mário Gomes. Novos parâmetros para a intervenção do Estado na economia: persistência e dinâmica na atuação do BNDES em uma economia baseada no conhecimento. 2009. Tese (Doutoramento) - FD-USP, São Paulo. Mimeografado.

SCHECHTMAN, Ricardo. A central de risco de crédito no Brasil: uma análise de utilidade de informação. Trabalhos para Discussão, n. 119, Banco Central do Brasil, out. 2006.

SCHUMPETER, Joseph A. The theory of economic development. Cambridge: Harvard University Press, 2003 (ed., original 1934).

SCHWARCZ, Steven L. Systemic risk. Georgetown Law Journal, v. 97, n. 1, 2008.

SCHWERT, G. William. Anomalies and market efficiency. In: CONSTANTINIDES, George M.; HARRIS, Milton, STULZ, René M. (Org.). Handbook of the economics of finance. North Holland, 2003.

SHULL, Bernard; HANWECK, Gerald A. Bank mergers in a deregulated environment: promise and peril. Westport: Quorum Books, 2001.

SIMON, Herbert A. Models of bounded rationality. Cambridge: MIT Press, 1982.

SJOSTROM, William K. The AIG bailout. Washington \& Lee Law Review, n. 66, 2009. 
SMITH, Adam. An inquiry into the nature and causes of the wealth of nations. Chicago: University of Chicago Press, 1977 (ed. original, 1776).

SOARES, Carla de Almeida Frazão. Da possibilidade de regulação das agências de rating no Brasil. 2005. Dissertação (Mestrado) - IE-UFRJ, Rio de Janeiro. Mimeografado.

SOUZA, Carlos Inglez de. A anarchia monetária e suas conseqüências. São Paulo: Monteiro Lobato \& Cia. Editores, 1924.

SPRAGUE, Irvine H. Bailout: an insider's account of bank failures and rescues. Washington: Beard Books, 1986.

STERN, Gary H.; FELDMAN, Ron J. Too big to fail: the hazards of bank bailouts. Washington: Brookings Institution Press, 2004.

STIGLER, George J. The theory of economic regulation. The Bell Journal of Economics and Management Science, 2 (1), 1971.

STIGLITZ, Joseph E. Challenging the Washington consensus. The Brown Journal of World Affairs, v. 9, n. 2, 2003.

- O mundo em queda livre: os Estados Unidos, o mercado livre e o naufrágio da economia mundial. São Paulo: Companhia das Letras, 2010.

STONE, Mark R.; WALKER, W. Christopher; YASUI, Yosuke. From Lombard Street to Avenida Paulista: foreign exchange liquidity easing in Brazil in response to the global shock of 2008-09. Working Paper, n. 09/259, FMI, 2009.

SUNDFELD, Carlos Ari. Concorrência e regulação no sistema financeiro. In: CAMPILONGO, Celso F.; VEIGA DA ROCHA, Jean Paul Cabral; MATTOS, Paulo Todescan Lessa (Org.). Concorrência e regulação no sistema financeiro. São Paulo: Max Limonad, 2002.

—. Direito administrativo ordenador. São Paulo: Malheiros, 2003.

—. Introdução às agências reguladoras. In: SUNDFELD, Carlos Ari. Direito administrativo econômico. São Paulo: Malheiros, 2000. 
SZTAJN, Rachel; ZYLBERSZTAJN, Decio (Org.). Direito \& economia: análise econômica do direito e das organizações. Rio de Janeiro: Elsevier, 2005.

TARULLO, Daniel K. Banking on Basel: the future of international financial regulation. Washington: Peterson Institute for International Economics, 2008.

TAYLOR, Michael. Twin Peaks: a regulatory structure for the new century. London: Center for the Study of Financial Innovation, 1995.

TEIXEIRA, Natermes Guimarães. Origem do sistema multibancário brasileiro. Campinas: Instituto de Economia da Unicamp, 2000. (Coleção Teses.)

THORNTON, John. Concentration in world banking and the role of Japanese banking. Revue de La Banque, v. 1, maio 1991.

TROSTER, Roberto Luis. Concentração bancária. Estudos Febraban, 2004. Disponível em: <www.febraban.org.br/Arquivo/Servicos/Imprensa/Conc0404.pdf>. Acesso em: 21 dez. 2010.

TRUELL, Peter; GURWIN Larry. False Profits: the inside story of BCCI. The world's most corrupt financial empire. New York: Houghton Mifflin, 1992.

TURCZYN, Sidnei. O Sistema Financeiro Nacional e a regulação bancária. São Paulo: RT, 2005.

\section{U.S. CONGRESS. Inquiry into the Continental Illinois Corp. and Continental Illinois}

National Bank (98-11). House of Representatives, Subcommittee on Financial Institutions, Supervision, Regulation, and Insurance, 98 ${ }^{\text {th }}$ Cong., $2^{\text {nd }}$ session, 1984.

- Investigation of Lincoln Savings and Loan Association. House of Representatives, Committe on Banking, Finance, and Urban Affairs, 1990, 100 ${ }^{\text {th }}$ Cong., $1^{\text {st }}$ session.

VEIGA DA ROCHA, Jean Paul Cabral. A capacidade normativa de conjuntura no direito econômico: o déficit democrático da regulação financeira. 2004. Tese (Doutoramento) - FDUSP, São Paulo. Mimeografado. 
VENNET, Rudi Vander. The effect of mergers and acquisitions on the efficiency and profitability of EC credit institutions. Journal of Banking and Finance, n. 20, 1996.

VERÇOSA, Haroldo Malheiros Duclerc. A responsabilidade civil especial nas instituições financeiras insolventes. In: SADDI, Jairo (Org.). Intervenção e liquidação extrajudicial no Sistema Financeiro Nacional: 25 anos da Lei n. 6.024/74. São Paulo: Textonovo, 1999. Bancos centrais no direito comparado: o Sistema Financeiro Nacional e o Banco Central do Brasil. São Paulo: Malheiros, 2005.

. Considerações sobre o sistema financeiro. Crises. Regulação e re-regulação. Revista de Direito Mercantil Industrial, Econômico e Financeiro, São Paulo: Malheiros, v. 149/150, jan.-dez. 2008.

—. Responsabilidade civil especial nas instituições financeiras e nos consórcios em liquidação extrajudicial. São Paulo: RT, 1993.

VIEIRA NETO, Cícero Augusto. Administração de risco de derivativos no Brasil: mercados de bolsa e de balcão. In: GARCIA, Márcio; GIAMBIAGI, Fábio (Org.). Risco e regulação: por que o Brasil enfrentou bem a crise financeira recente e como ela afetou a economia mundial. Rio de Janeiro: Elsevier, 2010.

WALD, Arnoldo. A evolução do conceito de instituição financeira. Revista de Direito Bancário e do Mercado de Capitais, n. 28, 2005.

. O direito da regulação monetária e bancária. Revista de Direito Bancário, v. 17, jul.set. 2002.

WALLIS, Stan (Org.). Financial system inquiry final report, mar. 1997. Disponível em: <fsi.treasury.gov.au>. Acesso em: 24 dez. 2010.

WELCH, John H. Futurologia financeira global: implicações do pós-crise. In: GIAMBIAGI, Fábio e Octavio de Barros (Org.). Brasil pós-crise: agenda para a próxima década. Rio de Janeiro: Elsevier, 2009. 
WHITE, Eugene. Deposit insurance. In: CAPRIO, Gerard; VITTAS, Dimitri (Org.). Reforming financial systems: historical implications of policy. New York: Cambridge University Press, 1997.

WILLIAMSON, Oliver. Assessing vertical market restrictions: antitrust ramifications of the transaction cost approach. University of Pennsylvania Law Review, n. 127, 1979.

WILMARTH, Arthur E. The transformation of the U.S. financial services industry (19752000): competition, consolidation, and increased risk. University of Illinois Law Review, n. 2, 2002.

Too good to be true? The unfulfilled promises behind big bank mergers. Stanford Law Journal of Business and Finance, n. 2, 1995.

WOLF, Martin. Fixing global finance. Baltimore: The Johns Hopkins University Press, 2008.

WRIGHT, Robert E. The wealth of nations rediscovered: integration and expansion in American financial markets (1780-1850). Cambridge: Cambridge University Press, 2002.

YAZBEK, Otavio. Crise financeira e risco sistêmico: a evolução recente da regulação sistêmica no Brasil. Mimeografado.

—. Crise, inovação e regulação no mercado financeiro: considerações sobre a regulamentação do mercado de derivativos de balcão. Mimeografado.

—. Regulação do mercado financeiro e de capitais. São Paulo: Elsevier, 2007.

—. Regulação do mercado financeiro e de capitais. 2. ed. São Paulo: Elsevier, 2007.

\section{Periódicos:}

AMERICAN BANKER. "Too big to fail": Deniers have a tough audience, 4 jun. 2001. Disponível em: <www.americanbanker.com/issues/166_106/-151226-1.html>. Acesso em 28 dez. 2010.

BBC NEWS. God's banker found hanged, 19 jun. 1982. Disponível em: <news.bbc.co.uk/onthisday/hi/dates/stories/june/19/newsid_3092000/3092625.stm>. Acesso em: 24 dez. 2010. 
- Governor warns bank split needed, 20 out. 2009. Disponível em:

<news.bbc.co.uk/2/hi/business/8317200.stm>. Acesso em: 24 dez. 2010.

BLOOMBERG NEWS. Bernanke says insurer AIG operated like a hedge fund, 3 mar. 2009. Disponível em: <www.bloomberg.com/apps/news?pid=20601110\&sid=a0n7q0AGB_m4>. Acesso em: 24 dez. 2010.

—. Greenspan says U.S. should consider breaking up large banks, 15 out. 2009.

Disponível em: <www.bloomberg.com/apps/news?pid=20601087\&sid=aJ8HPmNUfchg>. Acesso em: 24 dez. 2010.

BOSTON GLOBE. Bailed out banks fight to reshape bills, 27 set. 2009. Disponível em: <www.boston.com/business/articles/2009/09/27/bailed_out_banks_battle_to_reshape_bills>. Acesso em: 24 dez. 2010.

BRASIL ECONÔMICO. Bônus menor não assusta grandes bancos, 9 fev. 2010, p. 38.

FOLHA DE SÃO PAULO. Banco Central exporta tecnologia de reserva para a crise, 4 out. 2010, p. B7.

—. Banco Santos põe em dúvida agências de risco, 28 nov. 2004, p. B17.

- BC atribui responsabilidade por rombo no Panamericano a falhas de auditorias, 11 nov. 2010, p. B1.

BC via problemas no Banco Santos desde 2001, 26 dez. 2004, p. B3.

—. Deloitte, KPMG e Fator não identificaram fraude, 11 nov. 2010, p. B3.

—. Fusão Itaú-Unibanco foi acelerada por compra do ABN pelo Santander, 3 nov. 2008. Disponível em: <www1.folha.uol.com.br/folha/dinheiro/ult91u463639.shtml>. Acesso em: 24 dez. 2010.

—. Internacionalização de Itaú e Unibanco não seria possível sem fusão, diz banqueiro, 4 nov. 2008. Disponível em: 〈www1.folha.uol.com.br/folha/dinheiro/ult91u463928.shtml〉. Acesso em: 24 dez. 2010.

—. Itaú e Unibanco planejam ser banco internacional em cinco anos, 3 nov. 2008.

Disponível em: <www1.folha.uol.com.br/folha/dinheiro/ult91u463648.shtml>. Acesso em: 24 dez. 2010. 
—. Sete bancos europeus são reprovados em testes de estresse, 23 jul. 2010. Disponível em: <www1.folha.uol.com.br/mercado/771555-sete-bancos-europeus-sao-reprovados-emteste-anticrise.shtml>. Acesso em: 24 dez. 2010.

O ESTADO DE SÃO PAULO. Banco Panamericano, do Grupo Silvio Santos, recebe R\$2,5 bi para cobrir fraude, 10 nov. 2010, p. B1.

—. Caixa perdeu mais de R \$320 milhões no Panamericano, 21 nov. 2010. Disponível em: <economia.estadao.com.br/noticias/not_44230.htm>. Acesso em: 24 dez. 2010.

. CCJ convida Meirelles para falar sobre Panamericano, 10 nov. 2010. Disponível em: <economia.estadao.com.br/noticias/not_42787.htm>. Acesso em: $21 \mathrm{dez} .2010$.

É o momento adequado para encerrar missão, 24 nov. 2010. Disponível em:

<economia.estadao.com.br/noticias/economia,e-o-momento-certo-para-encerrar-a-missao-dizmeirelles,44675,0.htm>. Acesso em: 24 dez. 2010.

O GLOBO. Lula: Bush, meu filho, resolve a sua crise, 28 mar. 2008, p. 33.

. Lula: Crise é tsunami nos EUA e, se chegar ao Brasil, será marolinha, 5 out. 2008, p. 42.

- Lula defende internacionalização do Banco do Brasil, 20 jul. 2009. Disponível em: <oglobo.globo.com/economia/mat/2009/07/20/lula-defende-internacionalizacao-do-banco-dobrasil-756902340.asp>. Acesso em: 26 dez. 2010.

—. Meirelles: Banco Panamericano influiu na decisão de manter juros, 25 nov. 2010.

Disponível em: <oglobo.globo.com/economia/mat/2010/11/25/meirelles-bancopanamericano-influiu-na-decisao-de-manter-juros-923114262.asp>. Acesso em: 24 dez. 2010.

Não é assunto do presidente, 11 nov. 2010, p. 25

Quatro anos de fraudes, 11 nov. 2010, p. 25.

REVISTA CAPITAL ABERTO. É papel do Banco Central regular a remuneração dos executivos de instituições financeiras?, ano 7, n. 80, abr. 2010.

REVISTA EXAME. O Brasil na era dos megabancos, ano 42, n. 22, 13 out. 2008.

REVISTA ISTO É. A conta do Proer, n. 1.504, 29 jul. 1998.

—. Feitos um para o outro, n. 580, 12 nov. 2008. 
—. Meirelles alerta para risco caso BC fizesse auditoria. Disponível em:

<www.istoedinheiro.com.br/noticias/42042_MEIRELLES+ALERTA+PARA+RISCO+CAS

O+BC+FIZESSE+AUDITORIA>. Acesso em: 24 nov. 2010.

. Risco oculto, n. 579, 5 nov. 2008.

THE ECONOMIST. A plan B for global finance, 14 mar. 2009, London.

Efficiency and beyond, 18 jul. 2009, London.

AIG's rescue: Size matters, 18 set. 2008, London.

THE NEW YORK TIMES. Financial Russian roulette, 14 set. 2008. Disponível em:

<www.nytimes.com/2008/09/15/opinion/15krugman.html?_r=1>. Acesso em: 24 dez. 2010.

Goldman earns US\$3.19 billion, beating estimates, 15 out. 2009. Disponível em:

<www.nytimes.com/2009/10/16/business/16goldman.html>. Acesso em: 24 dez. 2010.

. How did economists get it so wrong?, 2 set. 2009. Disponível em:

<www.nytimes.com/2009/09/06/magazine/06Economic-t.html>. Acesso em: 24 dez. 2010.

THE TIMES. Banks hit back at 'populist' bonus supertax, 7 dez. 2009. Disponível em:

<business.timesonline.co.uk/tol/business/industry_sectors/banking_and_finance/article69470 89.ece>. Acesso em: 24 dez. 2010.

—. End of Wall Street investment bank, 22 set. 2008. Disponível em:

<business.timesonline.co.uk/tol/business/industry_sectors/banking_and_finance/article48005 50.ece>. Acesso em: 24 dez. 2010.

FSA retail chief Clive Briault leaves with $£ 380,000$ payoff after Northern Rock debacle, 20 mar. 2008. Disponível em:

<business.timesonline.co.uk/tol/business/industry_sectors/banking_and_finance/article35869 50.ece>. Acesso em: 24 dez. 2010.

VALOR ECONÔMICO. A concorrência no setor bancário no Brasil, 22 out. 2008, p. E2.

—. Brasil é o segundo país que mais ganha com mudanças no FMI, 25 out. 2010, p. A11.

—. Brasil enfrentou ataque e corrida bancária na crise, 13 nov. 2009, p. A1.

- Concentração fortaleceu sistema, diz Banco Central, 19 out. 2007, p. C7.

—. Crise confere novo status ao FGC, 26 out. 2009. Disponível em:

<www.fgc.org.br/libs/download_arquivo.php?ci_arquivo=128>. Acesso em: 24 dez. 2010.

—. Dinheiro e política na reforma dos EUA, 20 ago. 2010, p. A13. 
—. Na crise, BB colocou R \$6,7 bilhões para socorrer bancos e Sadia, 24 nov. 2009, p. A1.

—. EUA podem limitar porte de empresas financeiras, 11 nov. 2009, p. C8.

—. EUA têm muito a aprender com o Brasil, diz Johnson, 25 fev. 2010, p. C9.

—. "É uma comédia grega, uma piada", diz banqueiro, 26 jul. 2010, p. C3.

—. FGC estimula expansão do crédito, 6 mar. 2009. Disponível em:

<www.fgc.org.br/libs/download_arquivo.php?ci_arquivo=90>. Acesso em: 24 dez. 2010.

—. Gustavo Loyola: O Brasil e as lições da crise, 5 abr. 2010, p. A13.

—. Reforma nos EUA mais branda do que o esperado dá vigor a ações dos bancos, 28 jun. 2010, p. A2.

- STJ isenta Price de culpa em ação penal, 7 jun. 2010, p. C8.

VALORINVESTE. A história não contada do ataque especulativo ao Unibanco, ano 7, n. 34, nov. 2009.

VEJA. O Barão da Bahia beija a lona, n. 1.405, 16 ago. 1995.

—. O golpe do balanço fraudado, n. 1.433, 28 fev. 1996.

- O maior desfalque da história, n. 1.540, 1. ${ }^{\circ}$ abr. 1998.

- Pagarei tudo que devo a eles, n. 2.191, 17 nov. 2010.

—. Vida e morte das bolhas, n. 2.081, 8 out. 2008.

—. Perguntas que não calam, n. 1.704, 13 jun. 2001.

WALL STREET JOURNAL. Behind AIG's fall, risk models failed to pass real-world test, 31 out. 2008. Disponível em: <online.wsj.com/article/SB122538449722784635.html>. Acesso em: 24 dez. 2010.

\section{Seminários:}

CAMARGO SILVA, Antonio Carlos Bueno. Estratégias para combater o risco moral. Palestra proferida no seminário "El seguro de depósitos em Latinoamérica, retos y perspectivas", em 25 de agosto de 2004. Disponível em: <www.fgc.org.br/libs/download_arquivo.php?ci_arquivo=6>. Acesso em: 28 dez. 2010. 
CASTRO, Paulo Rabello de. Rating agency regulation in Brazil. Notas preparadas para o Seminário "Rating agency regulation", organizado pela Bovespa em 4 de novembro de 2004. Disponível em: <www.cnmv.es/publicaciones/IOSCOPD177_6.pdf>. Acesso em: 23 dez. 2010.

CERVONE, Elisabetta. Credit Rating Agencies. Why might the market not work? A discussion on regulatory issues under a transatlantic perspective. The Graduate Program Visiting Scholar and Visiting Researcher Colloquium, Harvard Law School, apresentação ocorrida em 20 de março de 2008.

MEIRELLES, Henrique. Reforço da regulação e supervisão e o seu papel na estabilidade do sistema financeiro. Pronunciamento do Presidente do Banco Central do Brasil na Reunião Extraordinária de Ministros Ibero-Americanos de Finanças, Porto, 2 de março de 2009. Disponível em: <www.bcb.gov.br/?PRONUNC2009008>. Acesso em: 26 dez. 2010.

TUCKER, Paul. Shadow banking, financing markets and financial stability. Remarks at the BGC Partners Seminar, London, 21 de janeiro de 2010. Disponível em: <www.bis.org/review/r100126d.pdf>. Acesso em: 26 dez. 2010.

Seminário “APBC sobre Regulação Financeira”. Organizado pelo Insper e pela Associação dos Procuradores do Banco Central, ocorrido em 27 de setembro de 2010.

Seminário “Crise Bancária e Regulação: Lições da Experiência Brasileira”. Organizado pela Rio Bravo Investimentos, ocorrido em 24 de novembro de 2009.

Seminário "Dodd-Frank: A nova lei do setor financeiro". Organizado pelo Instituto Brasileito de Direito Empresarial (Ibrademp) e Arnold \& Porter LLP, ocorrido em 25 de agosto de 2010.

Seminário "Asset backed securities - changes in law, regulation and practice in Europe". Organizado pelo Ibrademp, ocorrido em 7 de outubro de 2010. 